


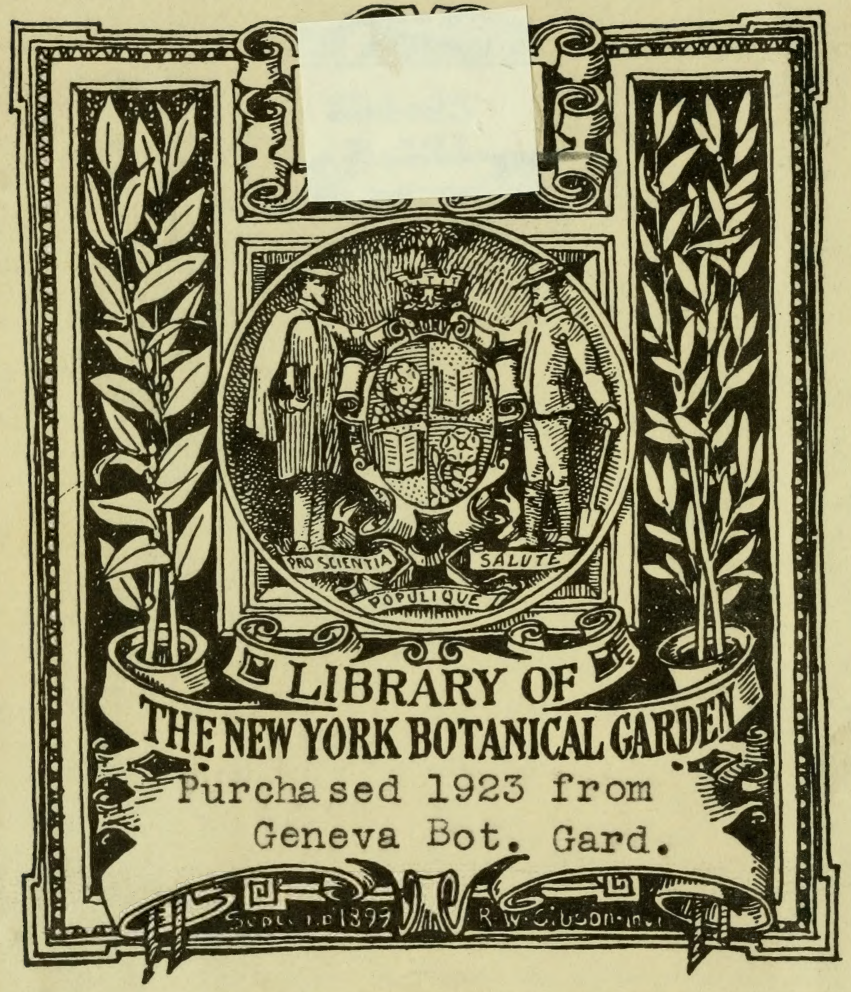






HANDBOOK OF THE AMARYLLIDE E. 
LONDON :

WEST, NEWMAN AND CO,, PRINTERS,

54, HatTon GaRden, E.c. 


\section{HANDBOOK}

OF

\section{THE AMARYLLIDE $\mathbb{E}$,}

INCLUDING THE

ALSTREMERIEE AND AGAVEE.

B Y

J. G. BAKER, F.R.S., F.L.S.,

FIRST-ASSISTANT IN THE HERBARIUM OF THE ROYAL GARDENS, KEW.

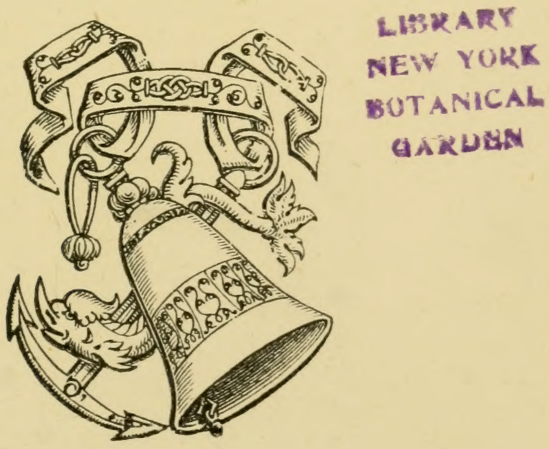

LONDON : GEORGE BELL \& SONS, YORK STREET, - COVENT GARDEN. 


$$
\text { QL55 }
$$

. Al

B29

$$
\begin{aligned}
& \text { Pen } 19 \times 3 \\
& \text { Hevern But gave. }
\end{aligned}
$$




\section{CONTENTS.}

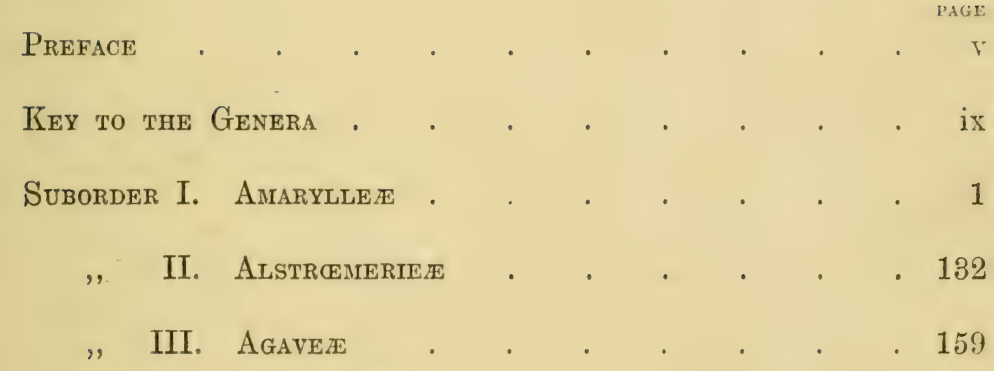

INDEX . . . . . . . . . 205 



\section{L.MYAs \\ FOE:W YONT \\ BUTANICAR \\ PREFACE. \\ that}

D) Uring the twenty-three years I have been at Kew I have made notes on the characters of all the Amaryllidece that have passed through my hands in a living state, and have had the opportunity of examining dried specimens of nearly all the species of the order. I have attempted in the present work to furnish cultivators and botanists with a compact working handbook, of which the main part consists of characters of the genera and species drawn up from actual specimens. I have not attempted to deal fully with the bibliography of the plants, or to trace out their pre-Linnean history, or to say anything about their cultivation, or to deal, except very briefly, with the garden hybrids, which are so numerous in this order. For fuller information on these points I would refer those who wish for it to Parlinson's 'Paradisus,' I unth's 'Enumeratio,' Bentham \& Hooker's 'Genera Plantar'um,' Herbert's 'Amaryllidacex' and his other writings, and the papers by Colonel Trevor Clarke in the 'Gardeners' Chronicle' for 1878. I have referred in the body of the book to various other works, such as Burbidge's 'Narcissus' and Jacobi's 'Agaver,' that deal specially with particular' tribes and genera. Two out of Bentham's five tribes of the order, Hypoxidece and V'ellosiece, have been dealt with recently elsewhere so fully that I have not thought it needful to include them here. The number of genera included is 61 , and of species admitted about 670 . 
viii

PREFACE.

I should like to take the present opportunity of thanking the numerous cultivators, whose names are mentioned in the body of the work, for the living specimens with which they have supplied me, and of expressing my obligations to Sir J. D. Hooker, Dr. Masters, Dr. Trimen, and Mr. James Britten, for the opportunity they have given me of publishing in the 'Botanical Magazine,' the 'Gardeners' Chronicle,' and the 'Journal of Botany,' what I have already written on the order.

J. G. BAKER.

Kew Herbarium,

March 20th, 1888. 


\section{KEY TO THE GENERA.}

Suborder I. Anarylle.e.-Rootstock a tunicated bulb. Leaves all radical. Peduncle a leafless scape.

Tribe 1. Cononatw.-Flower furnished with a corona between the perianth and stamens.

1. Cryptostephanus. - Perianth funnel-shaped; tube long. Corona of 12 minute linear scales.-Angola.

2. Narcissus.-Perianth hypocrateriform; tube long. Corona a distinct petaloid cup.-Europe, West Asia, North Africa.

3. Tapeinanthus. - Perianth-tube very short. Corona - of 6 minute scales._Spain, Morocco.

4. Placea.-Perianth fumnel-shaped; tube very short. Corona small, membranous, deeply 6-cleft.-Chili.

Tribe 2. Amarylle ae genunze--Corona none; filaments free.

* Anthers erect; filaments inserted at or near the base.

+ Stamens epigynous; filuments short.

5. Galantuus.-Inner segments different from the outer, permanently connivent.-South Europe, West Asia.

6. Leucosux.-Perianth-segments all alike. Filaments short. - South Furope, North Africa.

7. Lapiedra.-Perianth-segments all alike. Filaments long.Spain.

H Stamens perigynous; anthers small, globose.

8. Hessea.-Perianth-tube none or very short.-Cape.

9. Carpolyza.-Perianth-tube distinct.-Cape.

†十 Stamens perigynous; anthers oblong or linear-oblong.

Flowers solitary.

10. Gethyllis. - Peduncle short. Perianth hypocrateriform. Stamens uniseriate, often numerous.-Cape.

11. Apodolirion. - Peduncle short. Perianth fumnel-shaped. Stamens biseriate.-Cape.

12. Cooperia.-Peduncle elongated.-Texas \& North Mexico.

\section{Flowers umbellate.}

13. Axoiganthus.-Perianth-tube very short. Filaments long, filiform.-Cape.

14. Chuidanthus. - Perianth-tube long. Filaments short, dilated at the base.-Andes. 
** Anthers dorsifived, versatile.

t Ovules many, superposed; testa black. Flowers solitary; spathe tubular in the lower half.

15. Sternbergia. - Peduncle short or produced. Perianth regular, erect, bright yellow. Seeds globose.-South linrope, W'est Asia.

16. Haylockia. - Peduncle short. Perianth regular, erect, whitish. Seeds flat.-Monte Video, Buenos Ayres.

17. Zephyraxthes. - Peduncle elongated. Perianth regular, erect or suberect. Seeds flat.-America.

18. Sprekelia. - Perianth ringent, horizontal, bright red; 3 lower segments convolute; stamens and style declinate.-Mexico \& Guatemula.

Floxers umbellate. Spathe 2-4-valved, and pedicels subtended by filiform bracteoles.

19. Ungernia.- Perianth-tube short. Seeds many in a cell, flat, winged. Peduncle solid.-Asia.

20. Lycoris.-Perianth-tube short. Seeds fer in a cell, turgid. Peduncle solid.-China d Japan.

21. Hippeastrum. - Perianth-tube usually short, rarely long. Seeds many in a cell, usually flat. Peduncle hollow.-America.

22. Vallota. - Flowers erect. Perianth-tube long, broadly funnel shaped, pulvinate at the throat. Seeds winged at the base. -Cape.

23. Cyrtanthus.-Perianth-tube 2-3 times longer than the oblong segments, naked at the throat. Spathe-valves 2-4.-Cupe, Angola.

† Ovules 2, basal, collateral; testa pale.

24. Grifrinia.-Flowers lilac, umbellate. Leaves broad, thin, petioled.-Brazil.

t+t Ovules 2 or few, collateral or fascicled from the centre of the placenta.

25. Curva.-Fruit baccate. Ovules several. Bulb imperfect. - Cape.

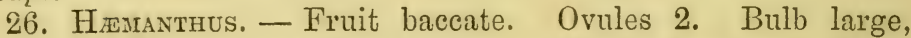
tunicated. Flowers very numerous; segments narrow. - Cape, Trop. Africa, Socotra.

27. Buphaxe.-Fruit capsular. Spathe-ralves 2.-Cape, Trop. Africa.

$+1+\dagger$ Ovules few or many, superposed. Seeds few, green, turgid.

Fruit indehiscent or bursting irregularly.

28. Crinumi-Perianth-tube long. Flower's white, sometimes flushed or keeled with red.-Cosmopolitan.

29. Arraryluis.-Perianth-tube short; segments broad.-Cape.

30. Ammocharis. - Perianth-tube short; segments narrow, acute.-Cape. 


\section{Fritit a 3-valved capsule.}

31. Brunsrara. - Style filiform. Capsule turbinate, acutely angled.-Coupe.

32. Nerine.-Style filiform. Capsule globose, obtusely angled. - Cape.

33. Strumaria. - Style swollen and triquetrous towards the base.--C'ape.

Tribe 3. Paxcratew.-Corona, none. Stamens appendiculate towards the base, often united in a distinct cup.

\section{* Covules many or few, superposed. \\ † Leaves broad, petioled.-All Andine.}

34. Eucrosia.-Perianth funnel-shaped, coloured; tube short. Stamens declinate, exserted, irregularly connate and callose at the base.

35. Strickiandia.-Perianth funnel-shaped, coloured. Stamens straight, just exserted, united in the lower half, callose at the base.

36. Calimpsyche. - Perianth funnel-shaped, coloured; tube short. Stamens declinate, much exserted, free, callose at the base.

37. Phedranassa. - Perianth coloured, subcylindrical; segments long or short. Filaments very obscurely appendiculate towards the base.

38. Urceolina.-Perianth coloured; tube cylindrical, suddenly dilated. Filaments very obscurely appendiculate towards the base.

39. Eucharis. - Perianth white, regular, subrotate; tube subcylindrical, suddenly dilated. Filaments quadrate, united in a distinct cup.

40. Plagiolirion. - Perianth white; tube short, cylindrical; limb rather irregular. Filaments united in a toothed cup.

41. Calliphruria.-Perianth white; tube fumnel-shaped; segments oblong, as long as the tube. Filaments quadrate, with a large tooth on each side of the anther.

\section{t+ Leaves linear or lorate, sessile.}

42. Eustephi.-Perianth coloured, subcylindrical; tube short. Filaments with a narrow wing on each side, ending in a tooth.Andes of Peru.

43. Stenonesson. - Perianth coloured, subeylindrical; tube long. Filaments united in an entire or toothed cup.-Anles.

44. Hyline. - Perianth white; tube none; segments linear. Staminal cup very short.-Brazil.

45. Pancratiun.-Perianth white; tube funmel-shaped. Staminal cup large. - Old World.

$$
\text { ** Ovules 2-6, busal, collateral. }
$$

46. Hynenocallis.-Perianth-tube long. Staminal cup erect. -Tropical \& Subtropical America.

47. Eusena.-Perianth-tube short. Staminal cup deflexed.Andes. 
**** Ovules 2-3, medial.

48. VAgaria. - Perianth funnel-shaped; segments narrow. Leaves lorate. Ovary 3-celled.-Syria.

49. Eurycles.-Perianth with a slender tube and broad segments. Leaves broad, petioled. Ovary 3-celled.-Malaya, Australia.

50. Calostemina. - Perianth funnel-shaped. Ovary 1-celled. Leaves various.-Australia.

Suborder II. Alstremeriex. - Root of fleshy fibres; rootstock none (except in Ixiolirion). Inflorescence a simple or compound umbel. Flowering stems leafy.

\section{* Rootstock bulbous.}

51. Ixiolirion. - Perianth-segments subequal. Stem erect.Western Asia.

\section{*** Rootstock none.}

52. Alstracieria.-Three outer segments of perianth different from three inner, and the latter unequal. Stem erect. Ovary 3-celled.-Brazil, Chiti.

53. Bonarea.-Three outer segments of perianth different from three inner, the latter equal. Stem usually elongated, sarmentose. Ovary 3-celled.-Mexico, S. America.

54. Leontochir. - Segments of perianth subequal. Ovary 1-celled.-Chili.

Suborder III. Agave..-Inflorescence racemose, spicate or panicled, not umbellate. Leaves usually rigid, fleshy, spine-edged, aggregated in a dense rosette at the base ef the peduncle.

* Leaves comparatively thin, neither spine-edged nor spine-pointed.

55. Polianthes. - Inflorescence a lax simple spike. Perianth white, with a long curved subcylindrical tube, and short segments. -Mexico.

56. Pranixhanthes. - Inflorescence a lax raceme. Perianth greenish brown, with short segments, and a tube abruptly curved and dilated at the middle.-Mexico.

57. Bravoa.- Inflorescence laxly spicate or racemose. Perianth red or white, with a curved subcylindrical tube, and very short segments.-Mexico.

58. Beschorneria.-Inflorescence a simple or panicled raceme. Perianth greenish red, with scarcely any tube, and long oblanceolate segments.-Mexico.

59. Doryanthes.-Inflorescence a capitulum or thyrsoid panicle. Flowers bright red, with scarcely any tube, and long narrow falcate segments.-E. Australia.

** Leaves thick, fleshy, usually spine-edged and spine-pointed.

60. Agave. - Perianth funnel-shaped; tube short. Filaments long, filiform.-Trop. America, especially Mexico, Southern United States.

61. Furcræa.-Perianth white, rotate. Filaments strumose at the base.-Trop. America. 


\title{
HANDBOOK OF AMARYLLIDE巴.
}

\author{
Suborder I.-AMARYLLE无. \\ Tribe 1.-Coronate.
}

1. Cryptostephanus Welw.

I'erimth narrowly fumnel-shaped; segments oblong-lanceolate, ascending, shorter than the more or less curved tube ; corona of 12 minute linear fleshy scales inserted at the throat of the tube. Anthers 6, small, oblong, nearly sessile, inserted in a single row above the middle of the tube. (Jary 3-celled; ovules several, superposed; style half as long as the tube, filiform; stigma capitate. Fruit a globose scarlet berry, with 1-2 turgid seeds in each cell.

1. C. Densiflorus Welw.; Baker in Journ. Bot. 1878, 193, t. 197. - Rootstock a compact corm. Leaves 6-8, contemporary with the flowers, lorate, glaucous, $1 \mathrm{ft}$. long, $\frac{1}{3}-\frac{1}{2}$ in. broad. Peduncle stout, 2 -edged, shorter than the leaves. Umbel dense, 20-30-flowered; pedicels short; spathe-valves many, unequal, greenish, lanceolate. Perianth dark purple, $\frac{1}{2}$ in. long. Berry $\frac{1}{3}$ in. diam.

Hab. Angola; Mountains of Huilla, 4000-5500 ft., flowering in October, Welwitsch!

\section{NARCissus $\operatorname{Linn}$ *}

Perianth hypocrateriform; tube varying from obconic to cylindrical; segments subequal, spreading, ascending or reflexing; corona gamophyllous, inserted at the throat of the tube, small or large, sancer-shaped, cup-shaped, or funnel-shaped. Stamens 6, inserted in the tube of perianth ; filaments short or long; anthers erect, basifixed. Ocary 3-celled; ovules many, superposed; style filiform ; stigma small, 3-lobed. Fruit a membranous capsule with loculicidal dehiscence. Seeds subglobose or angled by pressure;

* Reprinted, with many additions and alterations, from the 'Gardeners' Chronicle' for 1869. See 'The Narcissus; its History and Culture,' by F. W. Burbidge. London: L. Reeve \& Co. 1875. It contains figures and descriptions of all the leading types; and full details as to their history, culture, \&c. 
testa black.-Bulb with membranous tunics. Leaves linear or subulate, usually contemporary with the flowers. Flowers solitary or umbellate, erect or drooping, white or yellow, rarely green, vernal, rarely autumnal; spathe membranous, always 1 -valved.

Magnicoronati. Corona funnel-shaped or cylindrical, as long as the perianth-segments.

Corbularia. Perianth-segments lanceolate. Stamens long, declinate . . . . Sp, 1. Ajax. Perianth-segments oblong. Stamens shorter, erect : . . . . Sp. 2.

Medrocoronati. Corona cup-shaped, about half as long as the perianth-segments.

Ganymedes. Perianth-segments reflexed . Sp. 3. Queltia. Perianth-segments spreading . . Sp. 4-6.

Parvicononatr. Corona small, obconic or saucer-shaped.

Hermione. Corona uniform in texture.

Vernal .

Autuminal

Eunarcissus. Aurelia. Corona nearly obsolete
Sp. 7-10.

Sp. 11-13.

Sp. 14-15.

Sp. 16.

. 17-21.

- $22-25$.

- $26-27$.

Magnicoronate hybrids

Mediocoronate hybrids

Parvicoronate hybrids

1. N. Bulbocodrum Limn. Sp. 417 ; Bot. Mag. t. 88 ; Red. Lil. t. 24 ; Burbidge, fig. $1 \mathrm{~A}$. N. turgidus Salisb. Genus Corbularia Salisb. C. serotina Haw. - Bulb $\frac{1}{2}-\frac{3}{4}$ in. diam. Leaves usually 3-4, subterete, ascending, channelled down the face, 3-12 in. long. Peduncle slender, terete, about as long as the leaves. Flower single, ascending; pedicel $\frac{1}{2}-\frac{3}{4}$ in. long ; spathe 1-1 $\frac{1}{2}$ in. long, slit

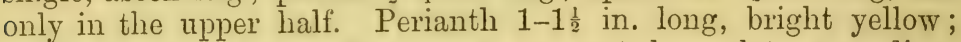
tube obconic, as long as the corona; segments lanceolate, ascending, $\frac{1}{2}-\frac{3}{4}$ in. long, broadly keeled with green, turning to brown; corona obconic, $\frac{1}{2}-\frac{3}{4}$ in. long and broad at the throat, entire or crenulate, just the same colour as the perianth in all the forms. Stamens long, declinate, inserted low down in the tube, reaching nearly to the throat of the corona. Style long, not exserted. The type flowers in May. C. lobulata Haw.; Burbidge, fig. 1 в, has a repand corona, and flowers in April. N. obesus Salisb. flowers early, and has leaves that lie flat on the ground. $N$. conspicuus (Haw.) Sweet, Brit. Flow. Gard. ii. t. 326 ; Burbidge, fig. $1 \mathrm{c}$; and $N$. aureus DC., are forms with moderately large yellow flower's, and an exserted style. N. tenuifolius Salisb.; Red. Lil. t. 486; Sweet, Brit. Flow. Gard. t. 114, is an early-flowering form, with slender erect leaves, a 6-lobed corona, and exserted style. C. Bulbocodium Haw. and C. Schultesii Roem. differ from tenuifolius by an entire corona. 
Var. N. Graellsir Webb; Bot. Mag. t. 6473 в.-Leaves generally 2, comparatively stout. Pedicel very short. Perianth about an inch long, primrose-yellow, $\frac{1}{2}$ in. long and broad. Style and often stamens exserted from the corona.--Mountains of Castille.

Var. N. nivalis Graells.-Leaves 2-3, slender, erect. Peduncle 2-4 in. long. Perianth $\frac{1}{2}-\frac{3}{4}$ in. long, orange-yellow. Style and stamens exserted.-Mountains of Central Spain and Asturias.

Var. C. hedreantha Webb \& Held. - Leaf solitary. Flower sessile, small, yellow. Corona lobed. Genitalia exserted.-Mountains of Jaen.

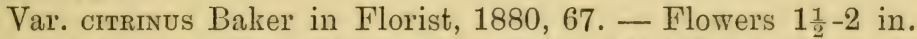
long, pale lemon-yellow. Corona $1 \mathrm{in}$. diam. at the throat, obscurely crenulate. Stamens and style included.

Var. C. моморнylla Durieu, Expl. Alger. t. 47; Bot. Mag. t. 5831; Burb. tabs. 2 \& 23в. N. Chusii Dunal. - Leaf very slender, usually solitary. Flowers nearly sessile, white, $1 \frac{1}{2}-2$ in. long. Corona crenate. Style usually exserted.-Algeria, flowering from December to February. C.. albicans and cantrabrica Haw. are white-flowered forms, known only from old figures.

Hab. South of France, Spain, Portugal, Algiers, and Morocco. We have a 2-headed form, received in May, 1873, from Mr.J. E. Daniel, of Epsom. For a full account of the forms and their distribution see a paper by Mr. G. Naw, read before the Scientific Committee of the Horticultural Society in February, 1887, printed in the 'Gardeners' Chronicle' and other journals.

2. N. Pseudo-narcissus Linn. Sp. Plant. 414; Engl. Bot. t. 17 ; Reich. Ic. Germ. t. 816 ; Burbidge, t. 3. N. festalis Salisb.

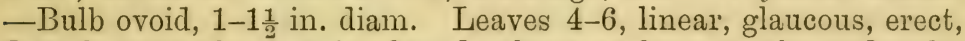
flattish upwards, $\frac{1}{3}-\frac{1}{2}$ in. broad, about as long as the peduncle. Peduncle about a foot long, with two prominent edges, flowering in March in the type; pedicel $\frac{1}{2}-\frac{3}{4}$ in. long; spathe $1 \frac{1}{2}-2$ in. long. Perianth ascending, $1 \frac{1}{2}-2$ in. long; tube obconic, $\frac{1}{2}-\frac{5}{8} \mathrm{in}$. long and broad; segments oblong, ascending, pale sulphur-yellow, 1-1 $\frac{1}{4}$ in. long, $\frac{5}{8}-\frac{3}{4} \mathrm{in}$. broad. Corona lemon-yellow, as long as the segments, 1 in. cliam. at the throat; edge erect, plicate, irregularly incisocrenate. Stamens erect, inserted low down the tube, reaching halfway up the corona. Style a little longer than the stamens. - A. serratus Haw. has segments shorter than the corona. A. nobilis Haw. (Red. Lil. t. 158) has spreading segments, and a spreading throat to the corona. A. lobularis, cambricus, and obvallaris Haw. (Bot. Mag. t. 1301, lower figure) are forms between this type and major, with shorter rather imbricated segments, and a corona with a spreading deeply 6-lobed throat. A. vugilobus Haw. has pale segments longer than the deeply 6-lobed corona, the lobes of which are very plicate. A. pullidus-precox Hort. is an early-flowering form from the Pyrenees, with very pale flowers. A. variiformis (Parkins) is a Pyrenean form between this type and moschatus. Var. Johnstoni Balier is a Portuguese form with a tube $\frac{3}{4} \mathrm{in}$. long, $\frac{1}{3} \mathrm{in}$. broad at the throat, a pale truncate corona, and style much longer than the stamens.

Subsp. A. muticus Gay. Oilens abscissus Haw. - Stature of the

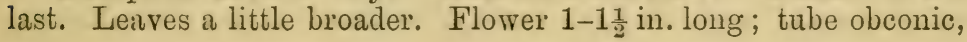




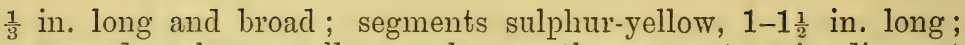
corona deep lemon-yellow, as long as the segments, $\frac{3}{4} \mathrm{in}$. diam. at the very truncate throat. - Pyrenees. Haworth's other species of Oilens, hexangularis, minor, albus, and pumilus, are known only from old figures.

Subsp. A. cyclamineus Haw. N. cyclamineus Baker in Bot. Mag. t. 6950. - Leaves narrow linear, with a deeply grooved keel. Peduncle stender, subterete. Flower very drooping; tube obconic, 1-12th in. long; segments abruptly reflexed, lemon-yellow, $\frac{1}{4}$ in. broad; corona as long as the segments, orange-yellow, crenate at the throat, under $\frac{1}{2} \mathrm{in}$. diam.-An old type, lately rediscovered near Oporto by Messr's. Johnston and Tait.

Subsp. N. MaJor Curt. in Bot. Mag. t. 51; Burbidge, tab. 4 A. N. hispanicus Gouran. - More robust than Pseudo-narcissus, and larger in all its parts. Leaves $\frac{1}{2}-\frac{3}{4} \mathrm{in}$. broad. Flower $2-2 \frac{1}{2}$ in. long; tube obconic, $\frac{3}{4} \mathrm{in}$. long and broad; segments in the type spreading, not imbricated, lemon-yellow, $1 \frac{1}{2} \mathrm{in}$. long, $\frac{1}{2} \mathrm{in}$. broad, just the same length and nearly the same shade as the corona, which has a deeply-lobed ascending much crisped margin, and a throat about an inch in diameter. A. propinquus Haw. (Bot. Mag. t. 1301, upper figure) has more ascending segments; $A$. maximus Haw. (Burbidge, tab. 4 в), a larger flower, and more spreading corona-rim; A. spurius Haw., broad imbricated perianth-segments, and a very spreading corona-rim; A. Telamonins Haw., of which the double-flowered form is very common in gardens, has the sulphur-yellow segments of Psendo-nurcissus and the large flower of major; and A. tubaflorus Herb. and A. lorifolins Haw. (Bot. Mag. t. 1187) are forms between major and bicolor. Upwards of fifty forms have garden names.

Subsp. N. mrNor Linn. Sp. Pl. 415 ; Red. Lil. t. 480 ; Burbidge, t. 5 A.-Much smaller in all its parts than Pseudo-narcissus. Leaves

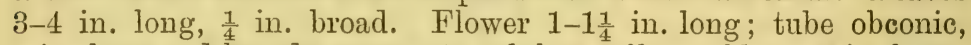
$\frac{1}{2} \mathrm{in}$. long and broad; segments sulphur-yellow, oblong, $\frac{3}{4} \mathrm{in}$. long; corona deeper yellow, with a deeply 6 -lobed spreading throat. $A$. mumilus Haw. is rather more robust, with perianth-segments cuneate at the base. A. nanus Haw. is as robust as the type, with imbricated perianth-segments longer than the coronn, the throat of which is less lobed and suberect. A. minimus Haw. (Bot. Mag. t. 6 ; Burbidge, t. 5 в ) is only $3-4$ in. high, nutant before the flower opens, with leaves $\frac{1}{6} \mathrm{in}$. broad, and flower like that of the type, but much smaller.

Subsp. N. BIColor Linn. Sp. Pl. 415. - Stature of Pseudonarcissus or major. Segments pure white, spreading, much imbricated, 1-1 $\frac{1}{2}$ in. long; corona the same length, bright lemon-yellow,

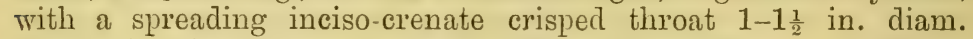
Varies in size from A. breviflos Haw. (Bot. Mag. t. 1187) to Horsfieldii and Emperor (Burbidge, t. 9A). Thirty forms have garden names.

Subsp. N. moschatus Linn. Sp. Pl. 415; Bot. Mag. t. 1300 ; Burbidge, t. 7. N. candidissimus Red. Lil. t. 188. - Stature and leaf of l'seudo-nurcissus. Perianth-tube obconic, nearly as broad as 


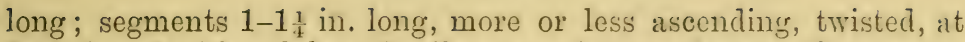
first tinged with sulphur, finally pure white, as long as the corona, which has an inciso-crenate plicate throat abont an inch across. A. albicans Haw. has a larger flower, with more imbricated segments. A. cermus Haw.; Sweet, Brit. Flow. Gard. ii. t. 101; Burbidge, t. 8, a more drooping flower, with a tube distinctly longer than broad, and segments sometimes longer than the corona. A. turtuosus Haw.; I. lomgiflorus Salisb. (Bot. Mag. t. 924), trvisted perianth-segments shorter than the corona.

Hab. Sweden and England to Portugal, Spain, Italy, and Transylvania; major, moschatus, and minor are confined to the Pyrenees and Spanish Peninsula, and bicolor is not clearly known in a wild state. Altogether between 150 and 200 forms are distinguished by name by the English cultivators.

3. N. triandrus Limn. Sp. Pl. 416; Burbidge, t. 15 A. Genela Illus and Ganymedes Haw. Illus wiandrus Haw. Ganymedes albus Haw. - Bulb $\frac{1}{2}-\frac{3}{4}$ in. diam. Leaves 2-4, very slender, subterete, channelled down the face. Pectuncle very slender, subterete, $\frac{1}{2}-1 \mathrm{ft}$.

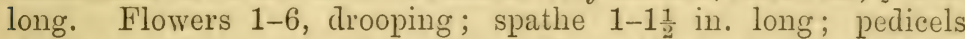
shorter or longer than the spathe. Perianth about an inch long; tube cylindrical, $\frac{1}{2}-\frac{3}{4}$ in. long; segments lanceolite, sharply reflexed, acute, as long as the tube, pure white in the type; corona cupshaped, truncate at the throat, half as long as the segments and the same colour. Stamens and style very variable in length, often exserted from the corona. G. concolor Haw. has a concolorous pale yellow flower. In N. pallidulus Graells (Bot. Mag. t. 6473A) both segments and corona are primrose-yellow. In G. pulchellus Haw. (Bot. Mag. t. 1262 ; Sweet, Brit. Flow. Gard. ser, 2, t. 99) the corona is white and the segments yellow. In G. mutans Haw. I. V. trilobus Bot. Mag. t. 945) the corona is crenulate and a deeper yellow than the segments. G. cermuns Salisb. (Bot. Mag. t. 48) is a robust many-flowered form, coloured as in the last.

Subsp. N. calathinus Red. Lil. t. 177 ; Burbidge, t. 14. Assaracus capax Haw. - Corona larger, nearly as long as the segments, both pale sulphur-yellow.-Isle of Glenans, Brittany. The Portuguese .T. reflexus Brot. Red. Lil. t. 40 ; Assaracus reflexus Haw.; connects it with the type.

Hab. The type, Spain and Portugal, flowering in April and May.

4. N. incomparabilis Miller in Gard. Dict. 1771, No. 3 ; Bot. Mag. t. 121; Reich. Ic. t. 819 ; Engl. Bot. ed. 3, t. 1502 ; Burbidge, t. $17 \mathrm{~A}$. N. Gouani Red. Lil. t. 220. Genus Queltia Salisb.

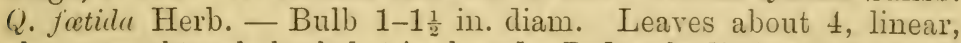
glaucous, obtusely keeled, $\frac{1}{2}$ in. broad. Peduncle distinctly 2 -edged, 1-1 $\frac{1}{2} \mathrm{ft}$. long. Flower solitary, not fragrant, ascending or horizontal; pedicel shorter than the spathe. Perianth-tube subcylindrical, green, $\frac{3}{4}$ in. long, dilated at the throat; segments spreading, ovate-oblong, imbricated, $1-1 \frac{1}{4}$ in. long, pale yellow in the type; corona obconic, $\frac{1}{2}$ in. long, lemon-yellow, $\frac{3}{4}$ in. diam. at the 6 -lobed crenulate plicate throat. Stamens and style not exserted. The form called Sir Watlin has flowers 4 in. diam. Q. cumculor Haw. (Burbidge, t. 19 A) has segments and corona both pale lemon-yellow. 
Q. semipartita Haw. is coloured like the type, but the corona is lobed more deeply.

Var. Q. aurantia Haw.; Burbidge, t. 19 c. Q. Gouani Haw.Perianth pale yellow. Corona pale yellow at the base, orange at the spreading lobed very plicate throat. Common in gardens double, called "Butter and Eggs." Var. Leedsii Hort. has a rim of orange-red to the corona.

Var. Q. AlbA Haw.; Burbidge, t. 18 в, c, 19 в.-Perianth white; corona lemon-yellow. Common double in gardens, called "Orange Phœuix." (Q. nivea Haw., dwarfer, with narrower twisted perianthsegments.

Hab. Spain and the south-west of France eastward to the Tyrol. Flowers in England late in March or early in April. About 100 forms are named by cultivators.

5. N. odorus Linn. Sp. Pl. 416; Red. Lil. t. 157 ; Reich. Ic. Germ. t. 818; Burbidge, t. 23. N. calathinus Bot. Mag. t. 934. Genus Philogyme Haw. P. odora and Campernelli Haw. - Bulb 1-1 $\frac{1}{2}$ in. diam. Leaves $3-4$, narrow, linear, bright green, deeply channelled down the face, $\frac{1}{4} \mathrm{in}$. diam. Peduncle subterete, $1-1 \frac{1}{2} \mathrm{ft}$. long. Flowers 2-4, uniform bright yellow, fragrant; pedicels shorter than the spathe. Perianth-tube subcylindrical, greenish, $\frac{3}{4}$ in. long; segments obovate-oblong, cuneate in the lower half, spreading, not imbricated, 1-1 $\frac{1}{4} \mathrm{in}$. long; corona obconic, the same colour as the segments, $\frac{1}{2}$ in. long, with a spreading throat $\frac{3}{4} \mathrm{in}$. diam., with 6 short crenate lobes. Style overtopping the anthers, reaching halfway up the corona. P. rufulosa (Burbidge, t. 25 A), calathina, and interjecta Haw. are forms with shorter oblong imbricated perianth-segments.

Var. N. trilobus Linn. Sp. Pl. 417. NT. latus Salisb.-Flowers smaller, with imbricated segments about $\frac{3}{4} \mathrm{in}$. long, not more than half as long again as the lobed corona. P. Curtisii Haw. (Bot. Mag. t. 78) and P. heminulis Haw. (Burbidge, t. 24) are smallflowered forms, with a narrow less-lobed corona.

Var. MrNor Burbidge, $25 \mathrm{~B}$, has flower's an inch in diam. and a much smaller corona than any other form. It is very likely $\mathrm{N}$. Assoanus Dufour.

Hab. Spain and France to Italy and Dalmatia. Flowers about London early in April.

6. N. Juncifolius Lagasca, Gen, et Sp. 13, non Salisb.; Burbidge, t. $37 \mathrm{~A}$. N. Requienii Roem. Queltia juncifolia Herb. Philogyne minor Haw. - Bulb $\frac{1}{2}-\frac{3}{4}$ in. diam. Leaves 3-4, terete, very slender, green, erect, 4-6 in. long, 1-12th in. diam. or less. Peduncle slender, terete, $\frac{1}{2}-1 \mathrm{ft}$. long. Umbel 1-4-flowered; pedicels $\frac{1}{2}-1 \frac{1}{2}$ in. long. Perianth-tube cylindrical, slender, about $\frac{1}{2}$ in. long; segments spreading, bright yellow, ovate, imbricated, $\frac{1}{3}-\frac{1}{2} \mathrm{in.}$ long; corona the same shade or rather darker, cup-shaped, $\frac{1}{6} \frac{1}{4} \mathrm{in}$. long, $\frac{1}{3}-\frac{1}{2} \mathrm{in}$. broad at the crenulate throat. Style reaching to the throat of the tube.

Subsp. N. gaditanus Boiss.; Burbidge, t. 27 c. - Flowers often 4-5. Pedicels longer. Perianth-segments not more than $\frac{1}{6}$ in. long, broad-ovate. Corona truncate, nearly as long as the segments. 
Subsb. N. minutiflorus Willk. Ill. Hisp. t. 74. - Flower's aloout 4. Pedicels $\frac{1}{2}-\frac{3}{4}$ in. long. Perianth-tube $\frac{1}{3}$ in. long; segments ovate, $\frac{1}{6}$ in. long; corona truncate.

Subsp. N. rupicola Dufour.; Bot. Mag. t. 6473c. N. apodanthus Boiss. et Reut. Queltia apodantha Fiunth. - Pedicel none or very short. Perianth-tube $\frac{3}{4}$ in. long; expanded limb $\frac{3}{4}$ in. diam.; corona distinctly 6 -lobed.

Hab. Spain, Portugal, and the South of France; the varieties, Spanish and Portugucse. Flowers about London in the middle of April.

7. N. tazetta Linn. Sp. Pl. 416 ; Sibth. Fl. Græca, t. 358; Moggr. Cant. Ment. t. 23 ; Burbidge, t. 29. Hermione Haw. Hermione, Pluteana, and Chione Salisb.- Bulb $1 \frac{1}{2}-2$ in. diam. Learcs 4-6, linear, glaucescent, 1-1 $\frac{1}{2} \mathrm{ft}$. long, $\frac{1}{2}-\frac{3}{4}$ in. broad, bluntly

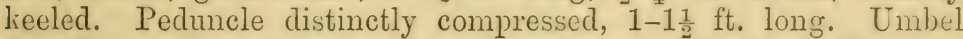
usually 4-8-flowered in the type; longer peclicels equalling or exceeding the spathe. Perianth-tube cylindrical, greenish, $\frac{3}{4}$ in. long; limb 1-1 in. diam; segments pure white, obovate, imbricated, $\frac{1}{3} \mathrm{in}$. broad; corona cup-shaped, lemon-yellow, entire, $\frac{1}{6} \mathrm{in}$. long, $\frac{1}{4}-\frac{1}{3}$ in. broad. Anthers and style just exserted from the tube.

Of the multiform Tazetta Narcissi about 100 have received specifie names.* I can here only attempt to inclicate and classify the leading types.

Series I.-Tazetrinæ Bicolores. Perianth white; corona yellow.

Snbsp. 1. H. LACTICOLOR. - From the type, as above described, the following differ but little:- N. elatus, varians, and canaliculatus Guss.; N. neglectus Ten.; N. Tenorii, spiralis, and Bicchianus Parl.; N. syriacus Boiss.; N. Biance Tod.; N. Aschersonii Bolle; H. Cypri Haw.; Sweet, Brit. Flow. Gard. ii. t. 92 ; H. citrina Haw.; Jord. Ic. t. 180 ; H. foribunda Haw.; Jord. Ic. t. 181 ; H. monspeliensis Jord. Ic. t. 186 ; H. pratensis Jord. Ic. t. 187 ; H. formosa Jord. Ic. t. 189 ; H. decora and auranticorona Haw.; H. neglecta, antipolensis, litturalis, and lobata Jord.; H. Treviana Haw. (Bot. Mag. t. 940; Jord. t. 188), flexiflora, subcrenata, and cremulata Haw., have a perianth-limb $1 \frac{1}{2}-2$ in. diam., and a corona $\frac{1}{2}$ in. diam. ; N. grandicrenutus Parl., a large deeply-lobed corona; H. crispicorona Haw. (Jord. Ic. t. 190) and corrugata Jord., a large crisped orange corona.

Subsp. 2. H. Corcyrensis Herb. - Colour of type, but flower smaller, with narrower more acute non-imbricating segments. Near this are $H$. aguilimba Herb.; $H$. mediterranea Jord. Ic. t. $185 ; H$. insolita Jord. t. 184; N. remopolensis Parl.; H. sulcicanlis Haw.; and 11 . debilis, discreta, and contorta Jord. H. yanymedoides Jord. has reflexed lanceolate segments, and a lobed orange corona.

Subsp. 3. N. patulus Lois. - Dwarfer and more slender than the type, with a pure white perianth-limb $\frac{3}{4}-\frac{7}{8}$ in. diam. and a small lemon-yellow corona. Near this are N. etruscus, ficasoliumus,

* For further details see Haworth's 'Monograph,' pp. 8-12, Kunth's 'Enumeratio,' Herbert's 'Amaryllidaceæ,' Parlatore's 'Flora Italica,' vol. iii. pp. 125 to 156, and Jordan \& Fourreau's 'Icones' and 'Breviarum Plantarum Novarum.' 
veryellensis, and siculus Parl. ; H. fistulosa, cerina, and breviflora Haw.; and $H$. jucunda and modesta Jord.

Subsp. 4. N. ochroleucus Lois. (Bot. Mag. t. 1298). H. tereticaulis Haw.; Sweet, Brit. Flow. Gard. ii. t. 179, connects Tazetta with gracilis and intermedius by its green deeply-chammelled leaves and subterete peduncle. Expanded perianth-limb 1-1 $\frac{1}{4}$ in. diam.; segments imbricated; corona lemon-yellow, $\frac{1}{4}$ in. long, $\frac{1}{2}$ in. diam. at the erect entire throat.

\section{Series II.-Tazetrinæ aLBж. Perianth and corona both white.}

Subsp. 5. N. papyraceus Ker in Bot. Mag. t. 947 ; Jord. Ic. t. 179. N. unicolor Ten. N. nivens Lois. Chione Salisb.-Peduncle acutely angled. Expanded perianth-limb about $1 \frac{1}{2}$ in. diam.; segments oblong, acute, little imbricated; corona pure white, $\frac{1}{8}$ in. long, $\frac{1}{4}$ in. diam. at the erect entire throat. Flowers more numerous and more fragrant than in the type.-Allied to this are $H$. jasmine Haw., N. Gennarii Parl., and H. virginea Jord.

Subsp. 6. N. Panizzianus Parl.; Moggr. Ment. t. 71 a; Burbidge, t. 36.-Flowers fewer than in the last; expanded limb $\frac{3}{4}-\frac{7}{8}$ in. diam.; segments oblong, acute, little imbricated. - Allied to this are $H$. virginea Jord. Ic. t. 177 ; and $H$. Sequentia Todaro.

Subsp. 7. N. Dubius Gouan; Moggr. Ment. t. 71 в, c, D ; Burbidge, t. 28. - Leaves $\frac{1}{4}$ in. broad. Flowers few. Expanded perianth-limb $\frac{1}{2}-\frac{3}{4}$ in. diam.; segments ovate, imbricated; corona pure white, half as long as the perianth-segments. - South-east of France.

Subsp. 8. N. canariensis Herb. ; Burbidge, t. 48. - Expanded limb about $\frac{1}{2}$ in. diam.; segments narrow, acute; corona small. Allied to this is H. micrantha Jord. Ic. t. 176 , from Toulon.

Sub. 9. N. Pachyвоцвоs Durieu, Expl. Alger. t. 47, fig. 1; Burbidge, t. 39 ; Bot. Mag. t. 6825. - Bulb very large. Flowers many. Expanded limb $\frac{5}{8}-\frac{3}{4}$ in. diam.; segments ovate-oblong, obtuse, much imbricated; corona small.-Algeria.

Subsp. 10. N. polyanthos Lois.; Reich. Ic. Germ. t. 367.-

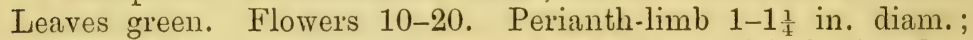
segments broad, imbricated; corona $\frac{1}{3} \mathrm{in}$. diam., faintly tinged at first with sulphur-yellow, finally mill-white. - Near this, but with smaller flowers, are H. Luna Haw., N. Barle Parl., and H. hololeuca Jord.

Series III.-Tazetrine Luteæ. Perianth and corona both yellow.

Subsp. 11. N. italicus Sims in Bot. Mag. t. 1188. N. pracox Ten. N. subalbidus Lois. - Leaves green, nearly flat. Peduncle sharply 2-edged. Flowers often 10-12; expanded limb $1 \frac{1}{2}-2$ in. diam., nearly white; segments oblong, acute, little imbricated; corona lemon-yellow, $\frac{1}{4}$ in. long, $\frac{1}{2}$ in. diam., often distinctly 6-lobed. - Allied to this are $H$. stylosa Salisb., H. temiflora Haw., and N. obliquus Guss.

Subsp. 12. H. Bertolonir Jord. Ic. t. 192. N. Bertolonii Moggr. Cont. Ment. t. 90 B. N. chrysanthus Moggr. Ment. t. $90 \mathrm{~A} .--$ Flowers 
fewer thon in the last, bright yellow, both corona and oblong acute non-imbricated segments.

Subsp. 13. N. aureus Lois.; Moggr. Ment. t. 22 ; Jord. Ic.

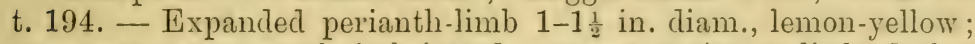
segments ovate, much imbricated; corona entire, a little darker than the segments.-Allied to this are H. xanthea Jord. Ic. t. 193; H. luteola Jord. Ic. t. 195 ; H. chlorotica Jord. Ic. t. 191 (limb sulphur-yellow); H. cheiranthea, calliopsis, amena, and sertulosa Jord. ; and $H$. sublutea, flaveola, trifida, and reflexicaulis Haw.

Subsp. 14. H. cupularis Salisb. (Red. Lil. t. 17; Bot. Mag. t. 925). - Segments broadly imbricated, lemon-ycllow; corona orange-yellow. - Allied to this are $H$. multiflora, solaris, latifolia, perlutea, and uperticorona Haw. ; and H. nobilis, splendens, cullichrou, eriodora, and fulgida Jord.

Hab. Extends from Canary Islands and Portugal through the South of Europe to Syria, Cashmere, China, and Japan. The principal concentration of various forms is in Italy and the South-east of France. Flowers from January to May.

8. N. interniedius Lois. Gall. i. 237, t. 7 ; Red. Lil. t. 427 ; Moggr. Cont. Ment. t. 41; Burbidge, t. 38 A. Hermione Herb.-

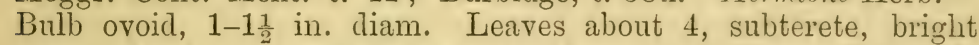
green, deeply channelled down the face, $\frac{1}{4}$ in. diam. Peduncle subterete, a foot or more long. Umbel 4-10-flowered; longer pedicels as long as the spathe. Perianth-tube subcylindrical, greenish, $\frac{5}{8}-\frac{3}{4}$ in. long; segments oblong, slightly imbricated, spreading, bright lemon-yellow, $\frac{3}{4}$ in. long; corona cup-shaped, orange-yellow, $\frac{1}{8} \mathrm{in}$. long, $\frac{1}{4} \mathrm{in}$. broad at the slightly-lobed throat. Style and anthers just exserted from the perianth-tube. $H$. bifrons Haw.; Burbidge, t. 38A, has narrower perianth-segments, and a longer corona. H. primulina Haw. (Bot. Mag. t. 1299) has imbricated segments, and a corona with a spreading 6-lobed margin. $H$. biscrenata Haw. is a robust many-flowered form, with 6 bifid plicate lobes to the corona. H. compressa Haw. (N. rucliutus Red. Lil. t. 459) has a large plane 6-lobed corona. H. alba Haw., known only from old records, has white flowers.

Hab. Spain, Balearic Isles, and South of France. Differs from the Tazettince lutece by its subeylindrical green leaves. Salisbury forms of it, with N. Jonquilla, his genus Tityrus.

9. N. gracilis Sabine in Bot. Reg. t. 816 (1824); Sweet, Brit. Flow. Gard. ii. t. 136 ; Burbidge, t. 37 A. Genus Helena Haw. Genus l'eniera Salisb. - Bulb 1 in. diam. Leaves narrow, linear, green, a foot long, $\frac{1}{8}-\frac{1}{6}$ in. broad. Peduncle weak, slender, subterete, a foot long. Umbel 1-3-flowered; pedicels long. Perianthtube cylindrical, yellowish-green, $\frac{3}{4}-1$ in. long; segments bright yellow, spreading, imbricated, oblong, acute, an inch long; corona obconic, deeper yellow, 1-6th to 1-5th in. long, $\frac{1}{3}$ in. broad at the slightly plicate erect crenulate throat. Stamens and style not exserted from the corona. N. temuior Curt. in Bot. Mag. t. 379 (1797); Burbidge, t. $37 \mathrm{~B}$, is more slender in all its parts, with smaller paler flowers, changing to white as they grow old. $H$. 
planicorona Haw. has very narrow leaves, very pale flowers, and a subentire corona.

Hab. An old garden plant, found wild, according to Salisbury, by Le Venier near Bordeaux.

10. N. Jonquilla Linn. Sp. Pl. 417 (excl. syn.); Curt. in Bot. Mag. t. 15; Red. Lil. t. 159 ; Reich. Ic. t. 811 ; Burbidge, t. 40. Queltia Herb. Jonquilla Haw. Titynus Salisb. N. juncifolius

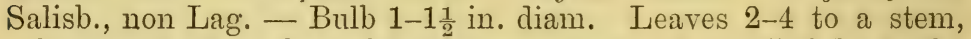
subterete, 8-12 in. long, bright green, deeply channelled down the face, $\frac{1}{8}$ in. diam. Peduncle slender, subterete. Umbels 2-6flowered; longer pedicels as long as the spathe. Perianth-tube cylindrical, greenish, $\frac{3}{4}-1 \mathrm{in}$. long ; segments bright yellow, obovate, spreading, scarcely imbricated; corona cup-shaped, the same colour as the segments, $\frac{1}{8}$ in. long, $\frac{1}{3}$ in. broad at the crenate throat. Stamens and style just imbricated from the tube. J. major and media Haw. differ a little in stature.

Var. J. mrnor Haw. N. Webbii Parl.-A dwarf form, with very slender leaves, and a perianth-limb only $\frac{1}{2} \mathrm{in}$. diam. - South of Spain and Algeria.

Var. stellaris Baker.-Segments lanceolate, reflexing; corona distinctly 6-lobed.

Subsp. N. Jonquilloides Willk. Ill. Fl. Hisp. t. 138.-Perianthtube $\frac{1}{2}$ in. long; limb $\frac{3}{4}$ in. diam.; segments obovate, imbricated; corona more than half as long as the segments; throat erect, plain, truncate.

Hab. Spain, through France and Italy to Dalmatia and Algeria. Flowers with us late in April. Very fragrant.

11. N. viridiflorus Schonsb. Maroc. fasc. i. t. 2 ; Bot. Mag. t. 1687 ; Burbidge, t. 44 . Hermione Herb. Chloraster fissus Haw. Prasiteles Salisb.-Bulb globose, 1 in. diam., with tunics produced far above its neck. Leaves 1-2, subterete, not produced with the

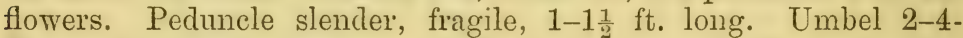
flowered; pedicels long, erect. Perianth-tube cylindrical, slender, green, $\frac{1}{2}-\frac{5}{8}$ in. long; segments green, lanceolate, acute, reflexing, shorter than the tube; corona very short, green, 6 -lobed down to the base. Anthers just exserted from the perianth-tube. C. integer Haw. is said to have an entire corona.

Hab. Morocco and Gibraltar, flowering in November.

12. N. serotinus Limn. Sp. Pl. 417 ; Burbidge, t. 46 . Hermione Haw. Aryenope Salisb.-Bulb globose, $\frac{1}{2}-1$ in. diam. Leaves very slender, subterete, not produced till after the flowers are gone. Peduncle very slender, flexuose and with 1-2 swollen joints low down, which are often hidden by the produced tunics. Flowers often solitary, sometimes 2. Perianth-tube greenish, subcylindrical, $\frac{1}{2}-\frac{5}{8}$ in. long; segments of the limb spreading, pure white, oblanceolate, obtuse, minutely cuspidate, about $\frac{1}{2}$ in. long. Corona 1-16th in. long, lemon-yellow, 6-lobed. Anthers just exserted from the perianth-tube.

Var. N. Deficiens Herb. in Bot. Reg. 1847, tab. 22, fig. 1.Corona reduced to a mere rudiment. 
Hab. Through the Mediterranean region from Spain to Greece and Palestine. Flowers in October and November. Carregnoa dubia Willk. Ic. t. $74 \mathrm{~A}$, agpears to be a form of this, with the corona slit down to the base into six square segments.

13. N. elegans Spach Veg. Phan. xii. 452 ; Burbidge, t. 45. Hermione Haw. N. autumnalis Link. N. Cupanianus Guss. N. oxypetalus Boiss. - Bulb globose, 1 in. diam. Leaves 1-4, contemporary with the flowers, subterete, green, 4-6 in. long, 1-16th in. diam. Peduncle rather shorter than in serotinus, stiffly erect, not jointed. Umbel 2-6-flowered; pedicels erect, often longer than the spathe. Perianth-tube cylindrical, greenish white, $\frac{1}{2}-\frac{5}{8} \mathrm{in.}$ long; segments pure white, spreading, lanceolate, acute, not imbricated, $\frac{1}{2}$ in. long. Corona saucer-shaped, yellow, 1-20th in. deep.

Var. H. obsoleta Haw.; Herb. Amaryll. t. 41, fig. 28. Perianth-segments rather broader; corona nearly obsolete.

Hab. Italy, Sicily, and Algeria, flowering in September and October.

14. N. BIFlorus Curt. Bot. Mag. t. 197; Engl. Bot. t. 276; Red. Lil. t. 405; Burbidge, t. 41. N. medio-lutens Miller (1771).Bulb globose, $1 \frac{1}{2}-2$ in. diam. Leaves about 4, linear, slightly glancous, broadly channelled down the face, 1-2 ft. long, $\frac{1}{2}-\frac{5}{8}$ in. broad. Peduncle sharply 2 -edged, $1-1 \frac{1}{2} \mathrm{ft}$. long. Flower's usually 2 , rarely 1 or 3 ; pedicels shorter than the spathe. Perianth-tube cylindrical, greenish white, an inch long; segments obovate, milkywhite, imbricated, obtuse, minutely cuspidate, $\frac{3}{4}-1 \mathrm{in}$. long; corona obconic, $\frac{1}{8}$ in. long, pale yellow, $\frac{1}{4}$ in. diam. at the scariose erect much-crisped edge. Stamens and style just exserted from the perianth-tube. $N$. dianthos Haw. has pure white flowers, nonimbricated perianth-segments, and an orange-yellow corona. $N$. biflorus Haw, has 2-3 flowers, pure white imbricated segments, and an orange-yellow corona. $\quad \mathrm{h}$. albus Miller has snow-white flowers, with imbricated segments, and a more spreading corona, tinged with red.

Hab. France, Switzerland, Italy, and the Tyrol, flowering in England in May. The three varieties are intermediate between the type and poeticus.

15. N. Poeticus Linn. Sp. Pl. 414 ; Red. Lil. t. 160. - Bulb 1-1 $\frac{1}{2}$ in. diam. Leaves about 4, linear, glaucous, a foot or more long, $\frac{1}{4}-\frac{1}{3}$ in. broad. Peduncle 2 -edged, as long as the leaves. Tlower solitary, ascending or horizontal, fragrant, developed in the type in May. Perianth-tube cylindrical, greenish, an inch long; segments spreading, pure white, obovate, imbricated, an inch long; corona $\frac{1}{8}-\frac{1}{6} \mathrm{in}$. long, with a scariose red much-crisped edge $\frac{1}{3} \mathrm{in}$. diam. Style and stamens just exserted from the perianth-tube. N. patellaris Haw. (Engl. Bot. t. 275) is a robust late-flowering form with imbricated perianth-segments. N. spathulatus Haw. has smaller earlier flower's. N. stellaris Haw. (Sweet, Brit. Flow. Gard. ii. t. 132 and N. recurvus Haw. (Sweet, ii. t. 188) are late-flowering forms, with scarcely imbricated perianth-segments, the latter with weak recurving leaves. N. poetarum Haw. flowers in April, and has large flowers, with imbricated segments, and a corona fulvous down to the base. N. tripodalis Salisb. (N. omatus Haw.) is an early form, with rather reflexing narrower segments. 
Subsp. N. Radifforus Salisb. N. angustifolius and majalis Curt. Bot. Mag. t. 193. - Leaves $\frac{1}{8}-\frac{1}{6}$ in. broad, shorter than the slender peduncle. Perianth-segments cuneately narrowed in the lower half, and not imbricated. N. verbanensis Haw. Amaryll. t. 37, fig. 2 ; Burbidge, t. 43, fig. в, is a dwarf form, with narrow leaves, and lanceolate acute reflexing perianth-segments.

Hab. All through the Mediterranean region from France to Greece.

16. N. Broussonetin Lag. Nov. Gen. 13; Burbidge, t. 47. Aurelia J. Gay. N. obliteratus Willd. Hermione Haw. - Bulb $1 \frac{1}{2}$ in. diam. Leaves about 4, linear, contemporary with the flowers, $\frac{1}{4} \mathrm{in}$. broad. Peduncle 2 -edged, a foot long. Umbel manyflowered; pedicels 1-2 in. long. Perianth-tube whitish, cylindrical, with a funnel-shaped apex, $\frac{3}{4}$ in. long; segments oblong, obtuse, pure white, $\frac{1}{2} \mathrm{in}$. long; corona rudimentary. Anthers exserted from the perianth-tube.

Hab. Morocco; long lost, but lately regathered by Dr. Leared and others. Flowers in April. Habit of N. italicus.

\section{HyBRID NARCISSI.*}

17. N. Bulbocodio-pseudo-narcissus Baker in Gard. Chron. 1887, i. 414. - Leaf linear, slightly glaucescent, channelled down the face, $\frac{1}{6}$ in. broad. Peduncle slender, terete, 1 -flowered; spathe an inch long, tubular in the lower half; pedicel as long as the spathe. Flower horizontal, milky-white, $1 \frac{1}{2}$ in. long ; tube narrowly funnel-shaped, much tinged with green, $\frac{5}{8}$ in. long; $\frac{1}{6} \mathrm{in}$. diam. at the throat; segments linear, ascending, rather shorter than the corona. Corona $\frac{5}{8} \mathrm{in}$. long, $\frac{1}{4} \mathrm{in}$. diam. at the base, faintly crenulate at the throat, where it is $\frac{1}{3} \mathrm{in}$. diam. Stamens inserted low down the tube; filaments straight, anthers only just protruded from the tube. Style reaching halfway up the corona.

Hab. Portugal, near Oporto, found wild by Messrs. Tait and Barr in March, 1887. This or a nearly-allied form is figured Gard. Chron. 1887, vol. i. fig. 78. $N$. triandrus also hybridises naturally both with $N$. Pseudo-narcissus and Bulbocodium.

18. N. Huner Hort. N. poculiformis lutens Herb. Leeds.Leaf $\frac{1}{3}$ in. broad. Flower solitary, cernuous; tube obconic, $\frac{1}{2}$ in. long, $\frac{1}{3}$ in. broad; segments oblong, loosely ascending, sulphuruyellow, $1 \frac{1}{2}$ in. long, $\frac{1}{2}$ in. broad; corona lemon-yellow, about an inch long and an inch broad at the erect throat, which is minutely crenulate. Var. ulbiclus Hort. has mill-white ascending segments, and a lemon-yellow corona.

Hab. A hybrid raised by Dr. Leeds, of Manchester, no doubt between poculiformis and some form of Pseudo-narcissus.

19. N. Backhousei Hort. - Stature and leaves of Pseudonarcissus. Flower solitary, horizontal; tube obconic, about $\frac{1}{2} \mathrm{in}$. long and broad; segments spreading horizontally, oblong, imbricated, sulphur-yellow. 1-1 $\frac{1}{4}$ in. long ; corona lemon-yellow, a little shorter than the segments, with a deeply-lobed plicate erect throat.

* See Herbert in Journ. Hort. Soc. ii. 21 to 28. 
Hab. An intermediate form between Pseudo-narcissus and incomparabilis. Named after IV. Backhouse, Esq., of Darlington and St. John's in Weardale, who raised many new garden forms.

20. N. Macleati Lindl. in Bot. Reg. t. 987 ; Bot. Mag. t. 2588; Burbidge, t. 17. Diomedes minor Haw. Panza bicolor Salisb.Bulb above 1 in. diam. Leaves about 6 , linear, bright green, $\frac{1}{4}-\frac{1}{3}$ in. broad. Peduncle a foot long, slightly 2 -edged, 1 -flowered. Flower horizontal, inodorous; pedicel much shorter than the spathe. Perianth-tube subcylindrical, $\frac{3}{4} \mathrm{in}$. long, white tinged with green; segments milk-white, obovate-oblong, much imbricated, $\frac{3}{4}$ in. long; corona bright yellow, $\frac{1}{2}$ in. long and broad, minutely crenate at the throat. Stamens biseriate. Style included. N. Sabini Lindl. in Bot. Reg. t. 762 (Diomedes major Haw.) is more robust, with a larger flower, and corona longer in proportion to the segments. N. Nelsoni, a garclen type with many forms, is more robust than Macleaii, with segments $1-1 \frac{1}{2}$ in. long, $\frac{3}{4}-1$ in. broad, much imbricated, with a lemon-yellow corona more than half as long as the segments. N. tridymus Hort. bears 2-3 flowers, like those of Nelsoni, but the tube is rather more obconic. N. Bernardi Henon (Diomedes Purlinsoni Haw.) has an orange or lemon-yellow more plicate corona half as long as the spreading white segments.

Hab. Macleaii was received by Alexander Macleay, Esq., from France in 1819. Bernardi is wild in the South of France, and has becn imported alive lately into English gardens by the Hon. Mrs. Barton from the Pyrenees. These forms connect incomparabilis var. albus with bicolor. A form very like Bernardi, figured Bot. Reg. vol. xxix. tab. 38, was produced by Herbert by crossing Pseudo-narcissus and poeticus.

21. N. Juncifolio-nuticus Baker. - Leaves subterete, bright green, $\frac{1}{6}$ in. broad, deeply channelled down the face. Peduncle

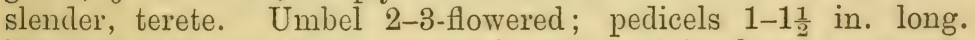
Perianth-tube cylindrical, greenish yellow, 产 in. long; segments ovate-oblong, spreading, lemon-yellow, $\frac{1}{2}-\frac{5}{8} \mathrm{in}$. long, nearly $\frac{1}{2} \mathrm{in}$. broad; corona obconic, orange-yellow, $\frac{1}{2}$ in. long, abore $\frac{1}{2}$ in. diam. at the truncate erect throat. Style reaching halfway up the corona.

Hab. Gathered in the Pyrenees, in April, 1886, by E. W. Buxton, Esq., growing with its parents. A probable hybrid between juncifolius and triandrus was exhibited by Mr. Geo. Maw at the Linnean Society in February, 1887.

22. N. poculiformis Salisb. Prodr. 224 ; Burbidge, t. $16 . \quad$ N. montunus Ker in Bot. Reg. t. 123. Genus Tros Haw. C'ydenis

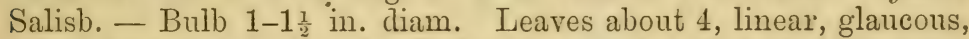
a foot long, $\frac{1}{4}-\frac{1}{3} \mathrm{in}$. broad. Peduncle angled, a foot or more long, 1-2-flowered; spathe 1-1 $\frac{1}{2}$ in. long; pedicels cernuous, shorter than the spathe. Flower fragrant, pure white; tube green, subcylindrical, $\frac{3}{4}$ in. long; segments spreading, oblong, an inch long, rather imbricated; corona cup-shaped, half as long as the segments, minutely crenulate at the throat. Stamens biseriate, inserted low down in the tube. Style reaching sometimes to the throat of the corona. T. gulunthifoliu Haw. has less imbricated perianth-segments, with inflexed edges, and a more plicate corona.

Hab. Origin uncertain. Stated by Salisbury to be a native of damp ralleys of the Pyrenees. Flowers early in April. 
23. N. Leedstr Hort. - Leaf twisted, canaliculate, glaucous, $\frac{1}{3}$ in. broad. Peduncle 2-edged, longer than the leaf. Flower single, horizontal or rather drooping. Perianth-tube subcylindrical, $\frac{3}{4}$ in. long; segments spreading, oblong, acute, milk-white, 1-1 $\frac{1}{4}$ in. long, $\frac{1}{2}-\frac{3}{4} \mathrm{in}$. broad; corona cup-shaped, sulphur-yellow, $\frac{1}{2} \mathrm{in}$. long, $\frac{1}{2}$ in. diam. at the erect irregularly crenate plicate throat. Style reaching nearly to the throat of the corona, overtopping the anthers.

Hab. Intermediate between poculiformis and incomparabilis. About fifty forms are distinguished by name by cultivators.

24. N. Barri Hort.; Burbidge, t. 22.-Leaves linear, twisted, glancous, above a foot long, $\frac{1}{4}$ in. broad. Peduncle compressed, a foot long. Flower solitary, horizontal or ascending. Perianthtube subcylindrical, $\frac{3}{4}-1$ in. long; segments spreading, oblong, acute, sulphur-yellow, slightly imbricated, $1-1 \frac{1}{4}$ in. long, $\frac{1}{2}-\frac{3}{4}$ in. broad; corona obconic, $\frac{1}{3} \mathrm{in}$. long, above $\frac{1}{2} \mathrm{in}$. broad at the erect crenulate plicate throat, lemon-yellow at the base, passing into orange-yellow upwards. Style just overtopping the anthers.

Hab. Covers a series of forms intermediate between incomparabilis and poeticus, nearer the former than the latter. About fifty forms have been named in cultivation. Burbidge t. $22 \mathrm{~A}$, is a cross between minor and poeticus; t. $22 \mathrm{~B}$, between incomparabilis and Pseudo-narcissus.

25. N. orientalis Linn. Mant. 38 ; Bot. Mag. t. 948. Queltia orientalis Herb. Hermione ambigna Salisb. Schizanthes orientalis Haw. Genus Patrocles Salisb. - Leaves green, $\frac{1}{3}$ in. broad. Peduncle much compressed. Umbel 3-4-flowered; pedicels long, erect or arcuate. Perianth-tube subcylindrical, green, $\frac{1}{2} \mathrm{in}$. long; segments spreading, sulphur-yellow, oblong, acute, 1 in. long, $\frac{1}{2} \mathrm{in}$. broad; corona cup-shaped, one-third the length of the segments, orange-yellow, deeply irregularly 3 -lobed; margin erect. Stamens and style not exserted.

Hab. Probably a hybrid between incomparabilis and Tazetta.

26. N. Burbidger Hort. - Leaves linear, glancous, twisted, above a foot long, $\frac{1}{3}-\frac{1}{2}$ in. broad. Peduncle above a foot long, 2-edged. Flower solitary, horizontal or drooping. Perianth-tube subcylindrical, green, an inch long; segments spreading horizontally, oblanceolate-oblong, acute, not imbricated, pure white, $1 \frac{1}{4} \mathrm{in}$. long, $\frac{1}{2} \mathrm{in.} \mathrm{broad;} \mathrm{corona} \mathrm{obconic,} \frac{1}{8} \mathrm{iu}$. long, $\frac{1}{3} \mathrm{in}$. broad, yellow at the base, red at the minutely crenulate plicate throat. Stamens and stigma not exserted from the corona.

Hab. Covers a series of forms between incomparabilis and poeticus, in which the characters of the latter predominate. About fifty of them are distinguished by names in Mr. Barr's catalogue.

27. N. Tazetto-poeticus Gren. \& Godr. Fl. Franc. iii. 257. N. biflonus var. hybridus DC. - Near biflorus, but flowers 2-5, smaller, with less imbricated segments. Corona sometimes larger, scarcely scariose at the edge and lobed, sometimes scariose, plicate, and tinged with red.

Hab. South of France, in meadows at Grasse and near Montpellier, growing amongst its parents. 


\section{Tapeinanthus Herb.}

\section{(Tapeinagle Herb.; Carregnoa Boiss.)}

Perianth-tube short; segments equal, narrow, spreading; corona nearly obsolete. Stumens in two rows at or a little distance below the throat of the perianth-tube; filaments filiform, longer than the versatile anthers. Oeary 3 -celled, turbinate; ovules many in a cell; style filiform, as long as the stamens; stigma capitate. Fruit a small globose capsule dehiscing loculicidally at the apex. Seeds oblong, black, shining.

1. T. Hunilis Herb. Amaryll. 190, 414. Pancratinm humile Car. Carremoa lutea Boiss. Amaryllis eximua Schousb. Lapiedra fracillima Balier. - Bulb globose, $\frac{1}{2}$ in. diam; tunics brown, membranous, produced 1-1 $\frac{1}{2}$ in. above its neck. Leaves $1-3$, filiform, 2-3 in. long, produced in November. Peduncle very slender, 2-6 in. long. Flowers 1-2, erect; spathe membranous, tubular at the base. Perianth bright yellow, $\frac{1}{2} \mathrm{in}$. long; tube very short, fumnel-shaped; segments lanceolate. Stamens nearly as long as the perianth-segments; anthers linear-oblong.

Hab. Spain and Morocco, very rare. Flowers in October. Carregnoa dubia Willk., seems to be, as pointed out by Janka, a form of Narcissus serotinus.

\section{Placea Miers.}

Perianth funnel-shaped, slightly declinate; tube scarcely any; segments oblong, acute, subequal. Corona funnel-shaped, membranous, inserted at the base of the segments, deeply cut; divisions emarginate. Stumens inserted inside the corona; filaments filiform, declinate, upper 3 shorter; anthers oblong, versatile. Orary turbinate, 3-celled; ovules many, superposed; style filiform, declinate; stigma capitate, faintly 3-lobed. Capsule unknown. - Rootstock a tunicated bulb. Lecures 2-3, linear, contemporary with the flowers in autumn. Peduncle long, hollow. Umbel many-flowered; spathevalves 2 , lanceolate; pedicels bracteolate. Flovers inodorous, white or yellow, striped with red.

1. P. onnata Mier's in Bot. Reg. xxvii. t. 50.-Bulb ovoid, $1 \mathrm{in.}$ diam. Leaves 2, linear, as long as the peduncle, $\frac{1}{4}-\frac{1}{3} \mathrm{in}$. broad. Peduncle 6-9 in. long, attenuated upwards. Umbel 4-6-flowered; spathe-valves lanceolate; pedicels slender, 1-3 in. long. Perianthlimb 1-1 in. long; segments $\frac{1}{3}$ in. broad at the middle, minutely cuspidate, white, with conspicuous stripes of red-purple, distinctly unguiculate. Corona $\frac{1}{8}-\frac{1}{6} \mathrm{in}$. long. Stamens half as long as the limb; filaments red-purple. Style nearly as long as the limb.

Hab. Chili; Valley of Aconagua, Miers! Reed! Santiago, Philippi!

2. P. grandiflora Lemaire in Ill. Hort. t. 574. - Bulb above 1 in. diam.; neek short. Leaves 3 , linear, $1 \frac{1}{2} \mathrm{ft}$. long, very acuminate. Peduncle $1 \frac{1}{2} \mathrm{ft}$. long. Umbel 6-8-flowered; spathe-valves lanceolate, $1 \frac{1}{2}$ in. long, tinged with red; pedicels $1 \frac{1}{2}-2 \mathrm{in.}$ long. Perianth-limb 2 in. long; segments oblong, acute, white, with bright red stripes, $\frac{1}{2}$ in. broad. Corona $\frac{1}{6}$ in. long, red-purple; segments emarginate. St:lmens half as long as the perianth. 
Hab. Valparaiso. Introduced into cultivation by Verschaffelt in 1867; received from M. Jules Grisar, Belgian Consul at Valparaiso.

3. P. Arze Philippi, Descr. Nuev. Plant. 1872, 65. - Bulb $2 \frac{1}{2}$ in. diam. Leaves 2 , linear, glaucous, under a foot long, $\frac{1}{6}$ in. broad. Peduncle $1 \frac{1}{2} \mathrm{ft}$. long. Umbel 3-5-flowered; spathe-valves

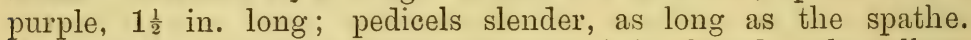
Perianth-limb $1 \frac{3}{4}-2$ in. long; segments $\frac{1}{2}$ in. broad, pale yellow, tinged and conspicuously striped with claret-purple. Corona $\frac{1}{6}$ in. long; segments quadrate, united in the lower half. Stamens half as long as the limb.

Hab. Chili; Province of Santiago, Philippi, Reed! May be the same as P. grandiflora.

4. P. Lutea Philippi in Linnæa, xxxii. 259.-Leaves 2, glaucous, as long as the peduncle, $\frac{1}{8}$ in. broad. Peduncle glaucous. Umbel 3-12-flowered. Perianth-segments bright yellow, veined with purple at the base, above an inch long. Corona cup-shaped, with 6 ribs ending in small cusps. Lower 3 stamens as long as the perianth. Style longer than the stamens.

Hab. Chili; Mount Alto de Catemn, Province of Aconagua, Philippi.

5. P. Germanni Philippi in Linnæa, xxix. 67.-Leaves unlrnown. Peduncle $1 \frac{1}{2} \mathrm{ft}$. long. Umbel 5-flowered; pedicels $1 \frac{1}{2} \mathrm{in}$. long, a little exceeding the spathe-valves. Perianth $1 \frac{1}{4}-1 \frac{1}{2}$ in. long; segments $\frac{1}{3}$ in. broad, purple at the base, yellow upwards, with purple dots. Corona one-fourth as long as the segments, 6-lobed. Stamens half as long as the perianth.

Hab. Chili; Mount Campana de Quillota, Germain.

\section{Tribe 2.-Airaryluem genuine.}

\section{Galanthus Lim.}

Perianth-tube none ; segments dimorphic ; outer oblong-spathulate; inner much shorter, obovate, emarginate, stiffly erect. Stamens epigynous; filaments very short; anthers basifixed, lanceolate, usually acuminate, hidden by the inner segments. Ovary globose, 3-celled: ovules many in a cell, superposed; style filiform, longer than the stamens; stigma capitate, minute. Fruit finally loculicidally 3-valved. Seeds ellipsoid, strophiolate; testa pale, thin. - Rootstock a tunicated bulb, one tunic wrapped tightly round the base of the stem and leaves. Leaves 2-3, lorate. Peiluncle solid. Flower solitary, cernuous; spathe usually simple.

Leaves simply channelled down the face.

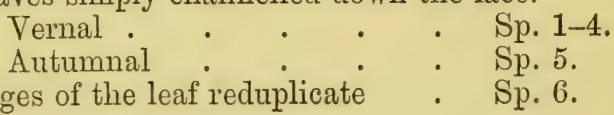

Edges of the leaf reduplicate . Sp. 6 .

1. G. Nivalis Linn. Sp. Pl. 413; Engl. Bot. t. 19 ; Red. Lil. t. 200. - Bulb globose, $\frac{1}{2}-1$ in. diam.; basal sheath truncate, 2-3 in. long, slit down one side. Leaves linear, glaucous, finally 6-9 in. long, $\frac{1}{4}-\frac{1}{3} \mathrm{in}$. broad, simply channelled down the face. 
Peduncle 3-12 in. long; spathe green, with a hyaline edge. Outer periantli-segments oblong, $\frac{1}{2}-1 \mathrm{in}$. long; inner half as long, obovatecuneate, deeply emarginate, with only a green patch round the sinus. Anthers lanceolate, $\frac{1}{4}$ in. long, gradually acuminate. $G$. reflexus Herb., from Mount Gargarus, has flower's much smaller than in the type, and inner segments reflexed at the apex. Var. lutescens Hort. has a yellowish ovary, and imner segments tipped with yellow instead of green. Var. poculiformis Hort. has the inner segments plain white, and nearly as long as the outer. $G$. Scharlolii Caspary has two long herbaceous spathe-valves, sometimes two flowers, and a green spot at the tip of each outer segment. G. corcyrensis (precorc) Hort., from Corfu, flower's in December. G. octolrensis Hort., brought by Lord Walsingham to the late Rev. Harpur Crewe, from Albania, flowers in England at the end of October.

Subsp. G. Imperati Bertol. Fl. Ital. iv. 5. G. plicatus Tenore, non M. B. G. Clusii Fisch. - Leaves broader than in the type, and flowers larger. Outer segments 1-1 $\frac{1}{4} \mathrm{in}$. long, more spathulate and narrower at the base than in the type. - Naples and Genoa. Figured by Matthiolus in 1575, and received by Clusius from Byzantium in 1582. Var. Melvillei Hort. scarcely differs.

Subsp. G. caucasicus Baker in Gard. Chron. 1887, i. 312.Leaves broader than in the type, finally $8-9 \mathrm{in}$. long, $\frac{3}{4} \mathrm{in}$. broad. Petals usually $\frac{3}{4}-1 \mathrm{in}$. long, oblong-spatlıulate, with a very narrow claw.-Caucasus only. Flowers later than the type. Includes $G$. nivalis, vars. Redontei, major, and cuspiues of Ruprecht. Often confounded with $G$. plicatus, but the edge of the leaf is not recurved. Var. virescens Hort. is apparently a form of this, with the outer segments flushed with green on the outside.

Hab. Extends through Southern and Central Europe from the Pyrenees to the Caucasus. Flowers in February and March.

2. G. Græcus Orph.; Boiss. Fl. Orient. v. 145.-Very near $G$. Elwesii, but the flower smaller, with narrower outer segments, and the apical lobes of the inner segments not spreading nor crisped.

Hab. Isle of Chios, on Mount Pellinos, alt. $3800 \mathrm{ft}$., flowering in April, Orphanides.

3. G. Elwesir Hook. fil. in Bot. Mag. t. 6166. - Bulb larger than in nivalis; sheath $1-3$ in. long. Leaves very glaucous, broader than in nivalis, simply channelled down the face. Flower more globose than in nivalis; outer segments oblong-spathulate, $\frac{3}{4}-1 \frac{1}{4}$ in. long, $\frac{1}{3}-\frac{3}{4}$ in. broad; inner dark green in the lower half and also round the sinus; lobes square, rather spreading and crisped. Anthers $\frac{1}{4}$ in. long, narrowed gradually from the base to the apex. Capsule rather turbinate.

Hab. Mountains of Asia Ninor, 2000-5000 ft., flowering with us in February. Gathered by Ba'ansa in 1854, but first individualised by Mr. Elwes in 1875. G. glolosus. Wilks in Garden, 1887, i. 393, with woodeut, from Smyrna, is a form with very broad outer segments, globose perianth-limb, and frequently two flowers.

4. G. Latifolius Ruprecht in Regel Gartenfl. 1868, 130, t. 578, fig. 1; Gard. Chron. 1879, fig. $32 \mathrm{c} ; 1881,404$, fig. 80. - Bulb 
1 in. diam.; sheath short, truncate. Leaves lorate, bright green, $\frac{3}{4}-1$ in. broad, simply chamnelled down the centre. Outer segments oblong-spathulate, $\frac{1}{2}-\frac{3}{4}$ in. long; inner with only a green patch round the sinus both inside and outside. Anthers narrowed snddenly to an acute point.

Hab. Caucasus, flowering with us in February and March, in its native home in May, alt. 6000-8000 ft.

5. G. Olg Arph. ; Boiss. Fl. Orient. v. 146. - Leaves 6-8 in. long, $\frac{1}{4}$ in. broad, simply channelled, glaucous, especially beneath. Outer segments of the perianth oblong-unguiculate, about an inch long, $\frac{1}{4}-\frac{1}{3} \mathrm{in}$. broad ; inner half as long, plain white, with rounded lobes. Anthers lanceolate-acuminate.

Hab. Greece; Mount Taygetus, flowering in October, Orphanides 4017.

6. G. plicatus M. B. Fl. Taur. Canc. iii. 255; Bot. Mag. t. 2162 ; Bot. Reg. t. 545. G. latifolins Salisb.-Bulb larger than in nivalis. Leaves very gliucous, finally a foot long, an inch broad, broadly chammelled down the face, and the edges reduplicate. Outer perianth-segments oblong from a very narrow base, very convex on the back, $\frac{3}{4}-1$ in. long, widely spreading or even reflexed; inner deeply emarginate, green in the upper lalf, with a white edge. Anthers lanceolate-acuminate, $\frac{1}{4}$ in. long.

Hab. Mountains of the Crimea and Dobruscha, flowering with us in March and April. The Caucasian plant, often called plicatus, is nivalis subsp. caucasicus.

\section{Leucojum Linn.*}

Perianth-tube none; segments uniform, ovate or oblong, spreading. Stamens epigynous; filaments filiform, shorter than the linear-oblong basifixed anthers. Orary 3-celled; ovules many in a cell, superposed; style filiform or strumose near the apex: stigma minute, capitate. Fruit finally dehiscing loculicidally into three valves from the top. Seeds subglobose; testa usually black. liootstock a bulk, with membranous tunics. Leaves slender or lorate. Flower's one or several in an umbel, white, tinged with red or green; spathe-valves usually single.

Leaves lorate. Style strumose near the tip.

Subgenus Eulencojum. Seeds with a black crustaceous testa and no strophiole . . . .

Subgenus Erinosma. Seeds with a membranous

pale testa and conspicuous strophiole . . Sp. 3 .

Leaves filiform or narrow linear. Style filiform.

Sp. 1-2.

Subgenus Acis. Epigynous disk not lobed.

Vernal
Antumnal
$\begin{gathered}\text { Subgrnus linminiu. Epigynous disk with } \\ \text { rate lobes at the edge }\end{gathered}$

Sp. 4-6.

Sp. T-8.

Sp. 9.

* See Baker in Gard. Chron. 1879, i. 399. 


\section{Subgenus Euleucojum.}

1. L. estrvuar Linn. Sp. Pl. 414 ; Engrl. Bot. t. 621 ; Bot. Mag. t. 1210 ; Red. Lil. t. 135. Virarin astiralis Mœnch.-- Bulb ovoid,

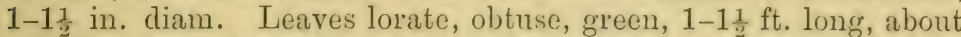
$\frac{1}{2}$ in. broad. Peduncle ancipitous, hollow, about a foot long. Umbel 4-8-flowered; spathe lanceolate, 1 -valved, $1 \frac{1}{2}-2$ in. long; pedicels long, cermuous. Perianth-segments broad-oblong, $\frac{1}{3}-\frac{3}{4}$ in. Iong, white, tipped with green. Stamens half as long as the limb; anthers longer than the filaments. Style longer than the stamens, green, and slightly strumose towards the tip. Capsule subglobose, ${ }_{4}^{3}$ in. diam. Seeds with a thick black shining crustaceous testa.

Hab. Central and Southern Europe from Britain and France to the Crimea and Armeria. Flowers with us at the end of April and beginning of May:

2. L. pulchellum Salisb. Parad. t. 74. L. Hernundezii Cambes. -Differs from the last by its smaller flowers and capsule, and narrower leaves, and flowers a fortnight earlier.

Hab. Sardinia and Balearic Isles.

\section{Subgenus Erivosira.}

3. L. vernum Limn. Sp. Pl. 414 ; Bot. Mag. t. 46 ; Jacq. Austr. t. 312. Frinosma vermum Herb. - Bulb globose, $\frac{3}{4}-1$ in. diam.; outer tunics thin, pale green. Leaves $3-4$, lorate, $\frac{1}{3}-\frac{1}{2} \mathrm{in}$. broad, finally 6-9 in. long. Peduncle 2-edged, hollow, $\frac{1}{2}-1 \mathrm{ft}$. long, usually 1-flowered; spathe single, lanceolate; pedicel cernuous, about as long as the ovary. Ovary turbinate; perianth-segments white, tipped with green, broad-oblong, $\frac{3}{4} \mathrm{in}$. long. Stamens half as long as the perianth-limb; filament much shorter than the anther. Style clavate below the apex. Capsule green, turbinate, $\frac{1}{2}$ in. diam. Seeds with a thin testa and small strophiole. E. curputhicum Herb. (Bot. Mag. t. 1993) is a form with the perianthsegments tipped with yellow instead of green. Var. Vugneri Stapf. is a tall robust form with two flowers.

Hab. Throughout Central Europe from France to Bosnia and the Tyrol. Flowers early in March.

\section{Subgenus Acis.}

4. L. trichophyludu Schonsb. Marok. 154; Reich. Ic. Crit. t. 703; Gawl. in Bot. Reg. t. 544. L. autummule Desf. in part. Acis trichophylla Herb. A. Broteri Jord. et Four. Ic. t. 64, fig. 105.-Bulb ovoid, $\frac{1}{2}-\frac{3}{4}$ in. diam. ; tunics pale brown. Leaves about 3, filiform, as long as the stem, contemporary with the flowers. Peduncle very slencier, $\frac{1}{2}-1 \mathrm{ft}$. long; flower's $2-4$; spathevalves 2 , linceolate; perlicels long, cermous. Perianth-limb white, $\frac{1}{2}-\frac{3}{4}$ in. long; segments oblanceolate-oblong, laxly 7-nerved. Stamens $\frac{1}{15}$ in. long; filaments rery short. Capsule turbinate, $\frac{1}{3}$ in. diam.

Var. L. grandiflorum DC. in Red. Lil. t. 217. Acis grandiflora Sweet.-Perianth-limb $\frac{3}{4}-1$ in. long.

Hab. Spain, Portugal, Morocco and Algiers. Flower's in April. 
5. L. tingitanum Baker in Journ. Linn. Soc. xvi. 678.-Closely allied to $L$. trichophyllum. Leaves narrow-linear, a foot long, contemporary with the flowers. Peduncle much stouter than in trichophyllum, 1-1 $\frac{1}{2} \mathrm{ft}$. long; flowers $5-6$; spathe-valves 2 , lanceolate, membranous. Perianth-limb white, $\frac{1}{2}-\frac{5}{8}$ in. long; segments oblanceolate. Stamens $\frac{1}{4} \mathrm{in}$. long; filament shorter than the anther.

Hab. Marocco, near Tangier, Blackmore! Vernal.

6. L. Longifolium J. Gay; Gren. \& Godr. Fl. France, iii. 252. Acis longifolia Roem.; Jord. et Four. Ic. t. 65, fig. 107. - Bulb ovoid, $\frac{1}{2}$ in. diam. ; tunics thin, pale brown. Leaves $2-3$, filiform, very slender, flaccid, longer than the stem, $\frac{1}{2}-1 \mathrm{ft}$. long. Peduncle very slender, $3-6$ in. long; flowers $1-3$; spathe-valves 2 , linear ; pedicels short. Perianth-limb white, $\frac{1}{4}-\frac{1}{3}$ in. long; segments oblanceolate, 5 -nerved. 'Stamens $\frac{1}{8}$ in. long; filaments very short.

Hab. Mountains of Corsica, alt. 4500-6000 ft. Flowers in April and May.

7. L. autumnale Linn. Sp. Pl. 414; Bot. Mag. t. 960 ; Salisb. Parad. t. 21. Acis autumnalis Salisb. A. oporantha and pulchella Jord. et Four. Ic. t. 64 . - Bulb globose, $\frac{1}{2}$ in. diam.; tunies thin, pale brown, produced 1-2 in. above its neck. Leaves filiform, very slender, usually produced after the flowers. Peduncle very slender, 3-9 in. long; flower's 1-3; spathe-valve linear, single; pedicels longer than the spathe, cernuous. Perianth-limb $\frac{1}{3}-\frac{1}{2}$ in. long, white, tinged with red; segments oblanceolate-oblong, laxly 5-7nerved. Stamens half as long as the limb; filaments very short. Capsule globose, $\frac{1}{6} \mathrm{in}$. diam. A. cephalonica Gay is a form with a 2-valved spathe. A. pulchellu Jord. et Four., from Algeria, has large pendulous flowers, and leaves produced with the flowers.

Hab. Portugal and Maroceo to the Ionian Islands. Flowers in autumn.

8. L. Roseum Martin in Bibl. Physic. 1804, 344 ; Reich. Ic. t. 944-946; Pl. Crit. t. 704 . Acis rosea Sweet, Brit. Flow. Gard. t. 297.-Bulb globose, $\frac{1}{4}-\frac{1}{2} \mathrm{in}$. diam.; tunics pale. Leaves filiform, produced after the flower. Peduncle very slender, 2-4 in. long; flower usually solitary, cernuous; spathe-valves 2 , small ; pedicel very short. Perianth-limb $\frac{1}{3} \mathrm{in}$. long, rose-red; segments oblanceolate. Stamens $\frac{1}{6}$ in. long; filaments very short. Capsule very small, globose.

Hab. Mountains of Corsica. Flowers in September and October.

\section{Subgenus Ruminia.}

9. L. hyenale DC. Fl. Franc. Suppl. 326 ; Baker in Bot. Mag. t. 6711. L. nicanse Ard. Acis hiemalis hoem. Ruminia hyemalis Parl. R. nicceensis Jord. et Four. Ic. t. 65, fig. 108.--Bulb globose, $\frac{1}{2}$ in. diam.; tunics brown. Leaves 2-4, narrow-linear, contemporary with the flowers, finally a foot long. Peduncle 4-6 in. long; flower usually solitary; spathe 2-valved; pedicel short, cernuous. Perianth-limb $\frac{1}{3}-\frac{1}{2}$ in. long, white, tinged with green outside; segments oblong. Anther's $\frac{1}{6} \mathrm{in}$. long; filaments scarcely any. Ovary with the dise produced into 6 minute scales. Capsule depresso-globose, $\frac{1}{3} \mathrm{in}$. diam. 
Hab. Coast-rocks at Nice, Mentone, and Villafranca. Flowers in April, hence the name hyemale is misleading.

\section{Lapiedra Lagas.}

I'erianth-tube none; segments lanceolate, subequal, spreading, persistent. Stumens epigynous; filaments filiform; anthers lanceolate, deeply sagittate at the base, erect. Orury 3-celled; ovules several in a cell, superposed; style filiform; stigma simple. Cripsule small, deeply lobed, loculicidally 3 -valved. Sceds 1-2 in a cell, turgid, with a shining black crustaccous testa.-Monotypic.

1. L. Martinezir Lag. Eleuch. 14; Boiss. Voy. t. 171. L. Placiana Herb. Crinum Martinezii Spreng. - Bulb ovoid, 2 in. diam., with a long neck. Leaves 2, lorate, developed after the flowers, keeled with white. Scape slender, ancipitous, $\frac{1}{2} \mathrm{ft}$. long. Umbel 4-8-flowered; spathe-valves 2, membranous, linear; pedicels longer than the flowers. Perianth-limb $\frac{1}{3} \mathrm{in}$. long; segments white, with a broad green keel. Stamens and style shorter than the segments. Capsule $\frac{1}{4}$ in. diam., with 3 round lobes.

Hab. South of Spain, flowering in September. Noticed by Clusius (1576) and Barrelier (1714).

\section{Hessea Herb.}

Perimnth cut down nearly or quite to the ovary; segments subequal, oblanceolate or oblong, obtuse, spreacling, 3-nerved down the keel. Stamens inserted at the base of the perianth-segments; filaments filiform or flattened towards the base; anther's small, globose, basifixed. Ovary globose, 3-celled; ovules few in a cell; style subulate throughout or dilated at the base; stigma tricuspidate. Capsule globose, membranous, deeply lobed, loculicidally 3-valved. Seels globose, green. - Rootstock a bulb, with membranous tunics. Lences generally produced after the flowers, filiform, linear or lorate. Umbels many-flowered; pedicels long; spathe-valves 2; flower's small, reddish white.

Subgenus Hessea proper. Style not dilated at the base.

Stamens much shorter than the oblong perianthsegments b i d

Stamens nearly or quite as long as the oblonglanceolate perianth-segments

Sp. 1-2.

Sp. 3-5.

Subgenus Imhofiu. Style ovoid or conic at the base.

Leaves filiform .

Leaves lorate $\quad \cdot \quad \cdot \quad \cdot \quad \cdot \quad \cdot \quad \cdot \quad$ Sp. 8.

1. H. stellaris Herb. Amaryll. 289. Amuryllis stellaris Jaeq. Hort. Schoen. t. 71. Strumaria stellaris Gawl. - Bulb globose, $\frac{3}{4}-1$ in. diam.; neck 1-2 in. long. Leares lorate, produced after the flowers, $\frac{1}{2}-1 \mathrm{ft}$. long. Peduncle $3-9 \mathrm{in}$. long. Flowers $6-30 \mathrm{in}$ an umbel; pedicels 1-2 in. long; spathe-valves lanceolate. Perianth-tube scarcely any; segments oblong, crisped, red at the 
throat. Stamens about half as long as the limb. Style subulate; stigmas recurved. Capsule $\frac{1}{4}$ in. diam.

Hab. Cape Colony; South-western provinces.

2. H. CRISPa Kunth, Enum. v. 632, ex parte. Amaryllis crispa Jacq. Hort. Schoen. t. 72 . Strumaria crispa Ker in Bot. Reg. t. 1383. Imhofia crispa Herb. Amaryllis cinnamomea L'Herit. Sert. t. 18.- Habit and flowers of $H$. stelluris, from which it only differs by its stouter rather strumose style.

Hab. Cape Colony; South-ivestern provinces. Doubtfully distinct from H. stellaris.

3. H. Dregeana Kunth, Enum. v. 633.--Bulb globose, with a mass of tunics produced $1 \frac{1}{2}$ in. above its neck. Leaves 2 , lorate, with a long truncate basal sheath. Peduncle 3-4 in. long; flowers 20-30 in an umbel; pedicels $1 \frac{1}{2} \mathrm{in.}$ long; spathe-valves 2 , green, lanceolate. Perianth-tube scarcely any; segments oblanceolate, $\frac{1}{4}$ in. long, reddish white. Stamens about as long as the limb. Style as long as the stamens, cylindrical, stouter towards the base.

Hab. Cape Colony ; Province of Clanwilliam, Drége $252 b$ !

4. H. Rehnanni Baker. - Bulb globose, under 1 in. diam.; neck an inch long. Leaves subterete, shorter than the peduncle. Peduncle slender, subterete, 4-8 in. long. Flowers 8-12 in an umbel; pedicels strongly angled, $\frac{1}{2}-\frac{3}{4} \mathrm{in}$. long; spathe-valves small, ovate or ovate-lanceolate. Perianth-tube scarcely any; segments oblanceolate, pale, much crisped. Stamens as long as the limb. Style not strumose.

Hab. Transvaal, Relmann 6:4!)!

5. H. Zeyheri Baker. - Bulb globose; neck $1 \frac{1}{2}-2$ in. long. Leaves linear, glabrous, a foot long. Peduncle stout, 4-8 in. long. Flowers 20-30 in an umbel; pedicels $2-2 \frac{1}{2} \mathrm{in}$. long; spathe-valves lanceolate, green. Perianth $\frac{1}{3} \mathrm{in}$. long, purplish white; tube short; segments oblanceolate, scarcely crisped. Stamens nearly as long as the limb. Style as long as the limb, slender down to the base.

Hab. Cape Colony ; Province of Uitenhage, Zeyher 1661 !

\section{Subgenus Iмноғiа.}

6. H. Filifolia Benth. Gen. Plant. iii. 721. Imhofu filifoliu Herb. Strumaria filifolia Jacq. Ic. t. 361 ; Bot. Reg. t. 440. Leucojum strumosum 'Thunb. Crimum tenellum Linn. fil. - Bulb globose, $\frac{1}{2}$ in. diam. ; neck slenter, an inch long. Leaves filiform, contemporary with the flower's. Peduncle very slender, not spirallytwisted, 3-6 in. long. Umbel 4-12-flowered; pedicels slender, $\frac{1}{2}-2$ in. long; spathe-valves small, linear. Perianth reddish white, $\frac{1}{4}$ in. long; tube none; segments oblanceolate, not crisped. Stamens rather shorter than the limb. Style subulate from an ovoid base. Capsule $\frac{1}{6}$ in. diam., deeply 3 -lobed.

Hab. Cape Colony; South-western provinces.

7. H. sprralis Baker. - Very near H. filifolia, from which it 
differs by its spirally-twisted stem, longer stouter pedicels, and longer spathe-valves.

Hab. Cape Colony ; Province of Uitenhage, Zeyher 1662 !

8. H. gemarata Benth. Gen. Plant. iii. 721. Strumurin yemmutu Ker in Bot. Nag. t. 1620. Imhojie gemmate and Burchelliunn Herb. 1. Bergiana Kunth.-Bulb globose, 1 in. diam.; neck 1-2 in. long. Leaves lorate, developed after the flowers, $\frac{1}{2} \mathrm{ft}$. long, eiliated with long fine hairs. Peduncle $\frac{1}{2}-1$ ft. long. Umbel 10-20-flowered; pedicels 1-3 in. long; spathe-valves lanceolate. Perianth purplish white, $\frac{1}{3}$ in. long; tube none; segments oblanceolate, crispecl. Stamens nearly as long as the limb. Style stout, cylindrical from a conical base. Capsule $\frac{1}{4}$ in. diam.

Hab. Cape Colony; South-eastern and Central provinces, ascending to $5000 \mathrm{ft}$. on the Sneewbergen.

\section{Carpolyza Salisb.}

Perianth with a short funnel-shaped tube; segments linearoblong, subequal, spreading. Stumens inserted in the perianthtube ; filaments short, filiform; anthers subglobose, minute, basifixed. Ocary globose, 3-celled; ovules few in a cell; style filiform; stigma tricuspidate. Capsule globose, membranous, loculicidally 3-valved. Seedls few in a cell, subglobose, green.-Monotypic.

1. C. Spiralis Salisb. Parad. t. 63. Strumaria spiralis Ait.; Bot. Mag. t. 1388. Hamanthus spiralis Thunb. C'rinum tenellum Jacq. Ic. t. 363. C. spirale Andr. Bot. Rep. t. 92. - Bulb oroid, $\frac{1}{4}-\frac{1}{3}$ in. diam., with a long slender neck; tunics membranous. Leaves $2-4$, contemporary with the flowers in June, subulate, very slender. Peduncle filiform, spirally-twisted, $2-4 \mathrm{in.}$ long; spathevalves 2 , linear. Perianth funnel-shaped, pinkish white; tube $\frac{1}{8}-\frac{1}{6}$ in. long; segments $\frac{1}{2}$ in. long. Capsule $\frac{1}{4}$ in. diam., with 3 rounded lobes.

Hab. Cape Colony; South-western provinces only.

\section{Gethyluis Linn.*}

Perianth hypocrateriform; tube long, cylindrical; segments subequal, oblong, acute. Stamens 6 or many in 6 cluster's inserted in a single row at the throat of the tube; filaments short; anthers linear, basifixed, soon curling up when the flower opens. (Iurry 3-celled; ovules many, superposed; style long, filiform; stigma capitate. Fruit succulent, clavate, inclehiscent. Sieds globose, immersed in pulp; testa loose, hyaline.-Rootstock a turicated bulb. Peduncle short, hypogoous. Syuthe monophyllous, membranous. Leares produced after the flowers, filiform, linear or lanceeolate. Flowers whitish, fugitive. Habit of Crocus.

Stamens six, undivided .

Stamens numerous, but arranged in six bundles . Sp. 5-9.

* See my fuller Synopsis in the 'Journal of Botany,' 188.5, p. 22.5, with two plates. Masson's drawings, recently discovered, have added very materially to our knowledge of the species. 
1. G. spilatis Limn. fil. Suppl. 198; Bot. Mag. t. 1088. Papivia spiralis Thunb. - Bulb globose, 1-1 $\frac{1}{4}$ in. diam.; neck 1-2 in. long. Leaves 4-6, subulate or linear-subulate, spirally-twisted, glabrous, produced after the flowers. Perianth-tube 2-3 in. long; limb 1-1 $\frac{1}{2} \mathrm{in}$. long, white, tinged red on the outside ; segments oblonglanceolate, $\frac{1}{4}-\frac{1}{3}$ in. broad. Stamens 6 , about $1 \frac{1}{2} \mathrm{in}$. long; filaments as long as the anthers. Style just overtopping the stamens. Fruit clavate, $2-3 \mathrm{in}$. long, under $\frac{1}{2} \mathrm{in}$. diam. G. roseu Ecklon is a form with small flowers, tinged red on the outside.

Hab. Cape Colony; South-western provinces. Flowers in December, and fruits in February.

2. G. verticillata R. Br. Prodr. 290; Baker in Journ. Bot. 1885, 226, tab. 259, fig. 2. - Bulb small, ovoid, with a purplespotted cylindrical neck $1 \frac{1}{2}-2$ in. long. Leaves $4-5$, narrow-linear, glabrous, circinate. Perianth-tube 3-4 in. long; limb white, an inch long; segments lanceolate, acute. Stamens 6; filaments filiform, as long as the anthers. Style just overtopping the stamens. Fruit yellow, clavate.

Hab. Cape Colony. Described from a drawing and specimen of a plant collected by Masson at Piquet Bay in 1790 .

3. G. villosa Linn. fil. Suppl. 198. Papiria villosa Thunb.-

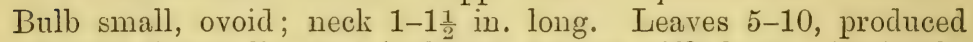
after the flower, linear, $\frac{1}{6}$ in. broad, densely stiffly hairy. Perianthtube pilose, 2-4 in. long; limb about an inch long, tinged outside with pink; segments lanceolate, $\frac{1}{6} \mathrm{in}$. broad. Stamens one-third the length of the perianth-limb. Style straight, reaching to the tip of the anthers. Fruit clavate, yellow, 2 in. long, $\frac{1}{3}$ in. diam.

Hab. Cape Colony ; South-western provinces, Thunberg! Masson!

4. G. Longistyla Bolus in Journ. Linn. Soc. xviii. 396. - Bulb ovoid or subglobose, with a long neck. Leaves 12-18, linear, 3-4 in. long, covered with linear white lacerated centrally-fixed scales. Perianth-tube $2 \mathrm{in.}$ long; limb an inch long; segments oblong-lanceolate, $\frac{1}{t} \mathrm{in}$. broad. Stamens 6 , about half as long as the limb. Style exserted $\frac{1}{2}$ in. beyond the tip of the segments, attenuated upwards.

Hab. Cape Colony; Sneewbergen range, discorered by Mr. Tyson (Bolus 842).

5. G. afra Linn. Sp. Pl. 633; Lindl. Bot. Reg. t. 1016.-Bulb globose, $1 \frac{1}{2}-2$ in. diam.; neck $2-3$ in. long. Leaves 12-20, linear, twisted, glabrous, strongly ribbed. Perianth-tube 3-4 in. long; limb whitish, $1 \frac{1}{2}-2 \mathrm{in}$. long; segments oblong or oblanceolateoblong, $\frac{1}{2}-\frac{3}{4}$ in. broad. Stamens $9-12$, about $\frac{1}{2}$ in. long; anthers as long as the filaments. Style just overtopping the anthers. Fruit yellow, clavate.

Hab. Cape Colony; Southern provinces, Burchell 7209! Zeyher 1663! A plant that flowered at Kew, August, 1887, had the 6 stamens variously broken up into 2,3 , or 4 , and the segments much flushed with red outside.

6. G. Britteniana Baker in Journ. Bot. 1885, 227, tab. 260.Bulb subglobose, 2-3 in. diam., with a purple-spotted neck $1 \frac{1}{2} \mathrm{in}$. long. Leaves 12-15, linear, glabrous, spirally-twisted. Perianthtube stout for the genus, $2-3 \mathrm{in.}$ long; limb pure white, $2 \mathrm{in.} \mathrm{long;}$ 
segments oblong-lanceolate, $\frac{3}{4} \mathrm{in}$. broad. Stamens very numerous, arranged in six clusters, $\frac{1}{2} \mathrm{in}$. long. Style not overtopping the stamens.

Hab. Cape Colony. Described from three sketches by Masson of a plant marked "Karoo, Sept. 1793." May be an extreme form of G. afra.

7. G. ciliaris Limn. fil. Suppl. 198; Jacq. Hort. Schoen. i. 41, t. 79. - Bulb globose, $1 \frac{1}{2}$ in. diam. ; neck eylindrical, sometimes 4-5 in. long. Leaves 20 or: more, produced after the flowers, linear, spirally-twisted, conspicuously ciliatcd. Perianth-tube

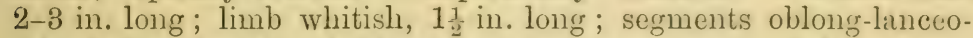
late, $\frac{1}{3}-\frac{1}{2}$ in. broad. Anthers linear, very numerous, $\frac{1}{4}-\frac{1}{3} \mathrm{in.}$ long; filaments very short. Fruit clavate, $2-3$ in. long.

Hab. Cape Colony; Southern provinces, Thunberg! MIasson! A full original description by Solander, under the name of $G$. polyunthera, is reprinted by Mr. Britten in Journ. Bot. 1884, p. 148. There is a plant in Thunberg's herbarium labelled "G. cuspidata," without leaves, in which four of the six filaments bear two anthers, and the others one each.

8. G. undulata Herb. Amaryll. 186, tab. 25, fig. 5. - Bulb globose, 2-3 in. diam.; neck cylindrical, $2-3 \mathrm{in.}$ long. Leaves 12-20, lanceolate, spreading or close, much undulated, 5-6 in. long, $\frac{1}{3}-\frac{1}{2}$ in. broad. Perianth-tube stout, $2-3 \mathrm{in.}$ long; limb pure white, $1 \frac{1}{2}$ in. long; segments oblong-lanceolate. Stamens numerous; filaments short. Style scarcely overtopping the stamens.

Hab. Cape Colony. Described from Masson's specimen and drawings marked "Zee Koe Valley, Narch, 1794."

9. G. Latifolia Masson; Baker in Journ. Bot. 1885, 228, tab. 259, fig. 1. - Bulb globose, 1슬 in. diam.; neck cylindrical, sometimes 8-9 in. long. Leares 10-12, spreading, lorate, twisted, glabrous, 4-5 in. long, $\frac{1}{2}$ in. broad. Perianth-tube stout, 2-3 in. long; limb tinged pink on the outside, 2 in. long; segments oblonglanceolate, acute, $\frac{1}{2} \mathrm{in}$. broad. Stamens about 20, all distinct, $\frac{1}{4}-\frac{1}{3}$ in. long; filaments as long as the anthers.

Hab. Cape Colony. Described from a drawing of Masson's, made Feb., 1794 , not localised.

\section{Apodolirion Baker.}

Periunth funnel-shaped, with a long cylindrical tube dilated at the apex, and 6 subequal ascending oblong-lanceolate or lanceolate segments. Stamens inserted in two rows near the throat of the tube ; filaments filiform, about as long as the linear erect basifixed anthers, which soon eurl up. (Mcury 3-celled; ovules many, superposed; style filiform; stigma capitate, obscurely lobed. Fruit and seeds unknown. - Rootstock a tunicated bulb. Peduncle short, 1-flowered, hirdden in the bulb-neck, as in C'rocus and Gethyllis. Leares narrow, not uswally produced with the flowers. Symthe membranous, cylindrical. Fluter's about as large as those of a Crocus, white or reàdish.

$\begin{array}{lll}\text { Perianth-tube comparatively short } & \text { Sp. 1-2. } \\ \text { Perianth-tube 2-4 in. long . } & \text {. } & \text { Sp. 3-5. } \\ \text { Perianth-tube 6-8 in. long . } & \text {. } & \text { Sp. 6. }\end{array}$


1. A. canceolatum Benth. Gen. Plant. iii. 722. Gethyllis lanceolata Linn. fil. Papiria lanceolata Thunb. - Bulb small,

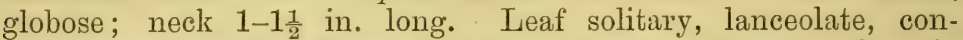
temporary with the flower, $1 \frac{1}{2}-2$ in. long, moderately firm in texture, crisped at the edge. Perianth-tube an inch long; limb whitish, $\frac{3}{4}-1$ in. long; segments lanceolate, acute, $\frac{1}{8}$ in. broad. Anther's $\frac{1}{6}$ in. long.

Hab. Cape Colony; South-western provinces, very rare, Thunberg! Harvey!

2. A. Етте Baker. - Bulb not seen; neck cylindrical, an inch long, $\frac{1}{3}$ in. diam. Leaves unknown. Peduncle and spathe hidden in the neck of the bulb. Perianth-tube cylindrical, reaching 3 in. long; limb 1-1 $\frac{1}{4}$ in. long, white, tinged with red; segments $\frac{1}{6}$ in. broad. Anthers in two superposed rows opposite the lower half of the limb, $\frac{1}{4}$ in. long.

Hab. Natal; grassy hill at Imbumbulu, Wood 3193! Received in 1855. Named, at Mr. Wood's request, after Miss Etta Stainbank.

3. A. Buchanani Balier in Journ. Bot. 1878, 75 ; Hook. Ic. t. 1388. Cyphonema Buchanani Baker.--Bulb globose, 1 in. diam.; neck 1-1 $\frac{1}{2}$ in. long. Leaves unknown. Spathe membranous, hyaline, an inch long, lacerated at the apex. Perianth-tube very slender, 2 in. long; limb whitish, $1 \frac{1}{2}$ in. long; segments oblanceolate, obtuse, cuspidate, $\frac{1}{4} \mathrm{in}$. broad above the middle. Anthers in two distinct rows opposite the lower half of the limb, $\frac{1}{4}$ in. long. 1875 .

Hab. Mountains of Natal, Krauss 449 ! Rev. J. Buchanan! Gathered in

4. A. Bolusir Balier in Journ. Bot. 1878, 75. -- Bulb not seen. Leaves 3 , contemporary with the flower, linear, firm in texture, spirally-twisted. Perianth-tube 2 in. long; limb whitish, $1 \frac{1}{2}$ in. long; segments oblong, subacute, $\frac{1}{2}$ in. broad. Stamens in two superposed rows opposite the lower half of the limb, $\frac{1}{4} \mathrm{in}$. long. in 1868.

Hab. Mountains of Graaf-Reinet, alt. 4300 ft., Bolus 717 ! Discovered

5. A. Macowani Baker.--Bulb globose, 1 in. diam.; neck 1-1 $\frac{1}{2}$ in. long. Leaves linear, firm in texture, much crisped. Spathe and peduncle hidden in the neck of the bulb. Perianth-tube 3-4 in.

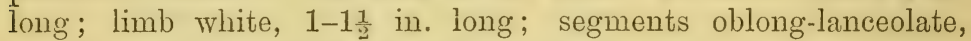
$\frac{1}{4}-\frac{1}{3}$ in. broad. Anthers in two superposed rows, $\frac{1}{6}$ in. long.

Hab. Cape Colony; sandy ground at Port Elizabeth, and on the banks of the Coega River, Mracowan 1928! Discovered in 1872.

6. A. Mackenir Baker in Journ. Bot. 1878, 75. -- Bulb globose, $\frac{1}{2} \mathrm{in.}$ diam.; neck $1 \frac{1}{2} \mathrm{in}$. long. Pecluncle and spathe hidden in the neck of the bulb. Leaves unknown. Perianth-tube very slender, 6-8 in. long; limb bright red, $2 \mathrm{in.}$ long; segments lanceolate or oblanceolate, subacute, $\frac{1}{4}-\frac{1}{3}$ in. broad. Anthers $\frac{1}{6}$ in. long, placed in two superposed rows opposite the lower quarter of the limb.

Hab. Natal, on the Great Noodsberg, alt. $2500 \mathrm{ft}$., MIacKen! (gathered in in 1869), Wood 110! Flowers in May. 


\section{Cooperia Herb.}

Perimth solitary, erect, regnlar; tube long, cylindrical; limb fummel-shaped, with subequal oblong segments. Stamens inserted at the throat of the tube; filaments very short; anthers linear, erect. Ovary 3-celled; ovules many, superposed; style about as long as the tube; stigma trifid. C'apsule membranous, loculicidally 3-valved, deeply 3-lobed. Scels many, compressed; testa black.-Liootstock a tunicated bulb. Leares linear, contemporary with the flowers in summer. Filowers whitish, fragrant; spathe single, membranous, tubular below the middle. - Habit of Zephyrunthes, from which it differs by its stamens and long perianth-tube.

1. C. Drumnondi Herb. in Bot. Reg. t. 1835. -- Bulb globose, 1 in. diam.; neck short. Leaves narrow linear, erect, a foot long. Peduncle slender, fragile, hollow, $\frac{1}{2}-1 \mathrm{ft}$. long. Spathe $1 \frac{1}{2}-2$ in. long, 2 -valved at the tip. Ovary sessile; tube very slender, $3-5$ in. long; limb $\frac{3}{4}-1$ in. long, white, tinged with red outside; segments oblong, obtuse, with a cusp, $\frac{1}{4}-\frac{1}{3}$ in. broad. Anther's $\frac{1}{4}$ in. long. Capsule $\frac{3}{4}$ in. diam., deeply lobed laterally.

Var. C. chlorosolen Herb. in Bot. Mag. t. 3482. -- Perianthtube stouter, tinged with green; limb longer, less rotate. Leaves a little broader.

Hab. Texas, New Mexico, and North Mexico. First gathered by Drummond about 1835 .

2. C. pedunculata Herb. Amaryll. 179, t. 42 ; Bot. Mag. t. 3727. Sceptranthus Drummondii Graham. Zephyranthes Drummondii Don; Sweet, Brit. Flow. Gard. ser. 2, t. 328.-- Habit more robust. Bulb with a neck 2-3 in. long. Leaves abont 6 , a foot long, $\frac{1}{4}$ in. broad. Peduncle about $\frac{1}{2} \mathrm{ft}$. above ground. Spathe 1-2-valved at the tip. Orary shortly pedicellate. Perianth-tube $1 \frac{1}{2}$ in. long; limb nearly as long as the tube, tinged red outside; segments oblong, obtuse, cuspidate.

Hab. Texas, Drummond! Lindheimer 542! Hall 652!

\section{Anoiganthus Baker.}

Periunth regular, erect; tube short, funnel-shaped; segments oblong-lanceolate, subequal. Stumiens biserial, 3 inserted in the perianth-tube and 3 at its throat; filaments filiform; anthers erect, oblong. ()ury oblong, 3-celled; ovules numerous, superposed; style filiform; stigmas 3, slender, falcate. ('upsule globose, membranous, loculicidally 3 -ralved down to the base. Seells many, flat; testa black.--Monotypic.

1. A. Breviflonus Baker in Journ. Bot. 1878, 76 . Cyrtanthus breviflorus Harv. Thesaur. Cap. t. 139. - Bulb ovoid, 1 in. diam., with a short neck. Leaves 3-4, contemporary with the flower's, lorate, a foot or more long. Peduncle $\frac{1}{2}-1 \mathrm{ft}$. long. Umbel 2-10flowered; spathe-valves 2, lanceolate; pedicels erect, slender, 1-2 in. long. Perianth bright yellow, about an inch long; tube $\frac{1}{4}-\frac{1}{3}$ as long as the segments. Stamens half as long as the perianthsegments. Capsule $\frac{1}{2}$ in. long; valves reflexing from the base. 
Var. minor Baker. A. luteus Baker, l.c., is a dwarf mountain form, with a short peduncle, and narrow perianth-segments.

Hab. Mountains of Natal and the eastern provinces of Cape Colony, ascending to $5000 \mathrm{ft}$. on the Sneewbergen. Flowers October to February.

\section{Chlidanthus Herb. \\ (Coleophyllum Klotzsch.)}

Perianth erect, regular; tube long, cylindrical; limb funnelshaped, with subequal oblong segments. Strmens inserted at the throat of the perianth-tube; filaments short, subulate from a deltoid base; anther's ligulate, erect. Oxary oblong, 3-celled; ovules very numerous; style longer than the tube; stigmas linear, recurved. Capsule loculicidally 3-valved. Seeds many, flat; testa black.-Monotypic. Habit of Crinum \& I'latycester, but flower's yellow, and stamens and seeds totally different.

1. C. fragrans Herb. App. 46 ; Lindl. Collect. t. 34 ; Bot. Mag. t. 640 ; Flore des Serres, t. 326. -- Bulb large, ovoid. Leaves about 6 , contemporary with the flowers in June, linear, obtuse, glancous, erect, $\frac{1}{4} \mathrm{in}$. broad. Peduncle solid, 2-edged. Flower's 1-4 in an umbel, fragrant, bright yellow; spathe-valves 2, large, lanceolate; pedicels 0 or very short. Perianth-tube $1 \frac{1}{4}-3 \mathrm{in}$. long, tinged with green; segments oblong, cuspidate, $1 \frac{1}{4}-1 \frac{1}{2}$ in. long. Anthers $\frac{1}{3}$ in. long.

Hab. Andes of Peru, Pavon! Matthews 3180! Quito, Lehmann 391! Catamarca, Lorentz. The living specimens I have seen were sent by Col. Trevor Clarke and Dr. Wallace, the latter from bulbs gathered by Roezl. I cannot make out from the description that the Mexican C. Ehrenbergii Kunth, is more than a mere form of the Andine species.

\section{Sternbergia $W . \& K$.}

Periunth funnel-shaped; tube short or moderately long; segments lanceolate or oblong, equal, permanently ascending. Stamens inserted at the throat of the tube; filaments long, filiform; anthers oblong, dorsifixed, versatile. ()rry 3-celled; ovules many, superposed; style filiform; stigma capitate or shortly 3-lobed. Fruit fleshy, scarcely dehiscent. Seeds subglobose, sometimes strophiolate; testa thin, blackish. - Bulb with many tunics and a long neek. Leaves lorate, vernal or antumnal. Peduncle short; spathe single, membranous, tubular below the middle. Flowers bright yellow.

Sternbergia proper. Peduncle short. Flowers autumnal. Leaves vernal. Perianth-tube long, cylindrical. .

Oporanthus. Peduncle produced. Flowers and leaves contemporary. Perianth-tube short, funnel-shaped . Sp. 3-4.

1. S. colchiciflora W. \& K. Pl. Rar. Hung. ii. 172, t. 159 ; Reich. Ic. Germ. t. 372, figs. 823-4; Lindl. in Bot. Reg. t. 2008. Amaryllis citrina Sibth. \& Sm. Fl. Græc. t. 311. A. colchiciflora Ker. S. cetnensis Schult. S. Schuberti Schenk. -- Bulb ovoid, $\frac{1}{2}-\frac{3}{4}$ in. diam. Leaves $4-6$, linear, produced in spring with the 
fruit, erect, 3-4 in. long. Peduncle not longer than the bulb-neck; spathe linear, an inch long. Flowers antumnal; perianth-tube cylindrical, $\frac{1}{2}-1 \mathrm{in}$. long; segments oblanceolate, $1-1 \frac{1}{\mathrm{i}} \mathrm{in}$. long, $\frac{1}{8}-\frac{1}{6}$ in. broad. Stamens half as long as the limb. Stigna with 3 short falcate lobes. Fruit subglobose, $\frac{1}{3}$ in. long, produced in spring. Seeds strophiolate.

Hab. Sicily, East Europe, Asia Ninor, Crimea, Caucasus. S. dalmatica Herb. (Reich. Ic. (iern. t. 372, figs. 825-7) and s. pulchellu Boiss. et Blanche, look to me mere varieties. Narcissus persicus Clus. Hist. ii. 163 (S. C'lusiana Ker) is, from the figure, evidently this species, not the next.

2. S. macrantha J. Gay in Balans. Exsicc. No. 827. S.lutifolia and stipitutu Boiss. S. C'husiunu Boiss., non Ker. -- luulb globose, 1-1 $\frac{1}{2}$ in. diam., with a neck 4-6 in. long; tunies pale or brown. Leaves lorate, obtuse, glancescent, $\frac{3}{4} \mathrm{in}$. broad, fully developed in June. Peduncle as long as the bulb-neck; spathe 3-4 in. long, membranous, eylindrical in the lower half. Flowers bright yellow, produced in autumn; tube cylindrical, 2 in. long; segments oblong, 1-1 $\frac{1}{4}$ in. broad. Stamens more than half as long as the limb. Stigma not lobed.

Hab. Asia Minor, Syria, Palestine, West Persia, and Sinaitic Peninsula.

\section{Subgenus Oporanthus.}

3. S. lutea Roem. \& Schult. Syst. viii. 795 ; Reich. Ic. Germ. tab. 373, fig. 828. Amaryllis luten L.; Bot. Mag. t. 290; Red. Lil. t. 418; Fl. Græe. t. 310. Oporanthus huteus Herb. -- Bulb ovoid, 1-2 in. diam. Leaves 5-6, lorate, $\frac{1}{2}$ in. broad, a foot long, produced with the flowers in autumn. Peduncle protruded from the bulb-neck, sometimes 6-9 in. long, rarely 2 -flowered. Spathe lanceolate, 1-1 $\frac{1}{2}$ in. long. Flowers produced in autumn, bright yellow; ovary sessile; tube funnel-shaped, $\frac{1}{4}-\frac{1}{3} \mathrm{in.}$ long; segments oblong, $1 \frac{1}{4}-1 \frac{1}{2} \mathrm{in}$. long, $\frac{1}{2} \mathrm{in}$. broad. Stamens more than half as long as the limb. Style sometimes as long as the limb; stigma not lobed. Fruit green, turbinate, developed in winter. Seeds black, shining, not strophiolate. S. sicula Tineo is a form with narrower leaves and perianth-segments. Var. freca Peich. Ic. Germ. fig. 828, from the mountains of Greece, is a form with leaves only 1-12th to $1-8$ th in. broad, and oblanceolate perianth-segments. There is a similar form in Crete with a longer peduncle.

Hab. Through the Mediterranean Region from Spain and Algeria to Syria and Persia.

4. S. Fischeriana Room. Amaryll. 46. Oporanthus Fischeriumus Herb. Habit of $S$. lute , from which it differs by flowering in spring, and by its stipitate ovary and capsule.

Hab. Caucasus.

\section{Haylockia Herb.}

Periunth solitary, erect, regular; tube long, very slender; limb fumnel-shaped, with equal obovate-oblong segments. Stamens biseriate at the throat of the perimuth-tube; filaments short, filiform; anthers linear-oblong, versatile. Ocary 3-celled; ovules many, 
superposed; style as long as the tube; stigmas linear, falcate. Capsulc membranous, loculicidally 3 -valved. Seeds many, flattened; testa black. -- Monotypic. Allied to Zephuranthes, from which it differs by its short hypogœous peduncle. Habit like Gethyllis.

1. H. pusilua Herb. in Bot. Reg. t. 1371, Zephyranthes pusilla Dietr. Sternbergia americana Hoffm.--Bulb globose, $\frac{3}{4}-1$ in. diam.; neck 1-2 in. long. Leaves developed in winter, narrow linear, spreading. Peduncle not longer than the bulb-neck. Spathe membranous, bifid, tubular in the lower half. Ovary sessile. Perianth-tube 1-2 in. long, very slender, tinged with green; limb 1-1 $\frac{1}{4}$ in. long, whitish, sometimes tinged red outside: segments $\frac{1}{4}-\frac{1}{3}$ in. broad. Filaments about as long as the anthers, which soon curl up. Capsule small, subglobose.

Hab. Buenos Ayres and Monte Video, Sello! Gibert! Flowers in March.

\section{Zephyranthes Herb.}

Perianth funnel-shaped, erect or slightly inclined; tube short or elongated, often minutely scaly at the throat; segments subequal. Stamens inserted near the throat or middle of the tube, erect or slightly declinate, more or less unequal; filaments filiform; anthers linear-oblong, versatile. Ovary 3-celled; ovules many, superposed; style filiform, more or less declinate; stigma usually trifid. Capsule subglobose, loculicidally 3 -valved. Seeds flat or compressed, with a thin black testa. -- Rootstock a tunicated bulb. Leaves narrow, usually contemporary with the flowers. Peduncle elongated, slender, hollow. Spathe membranous, tubular in the lower half, bifid at the apex. Flower white, red, or yellow. Capsule and seeds of Hippeastrum, from which it differs by its erect or suberect solitary flower and monophyllous spathe, tubular in the lower half.

Subgenus Zephyranthes proper. Flower erect; tube short. Stamens inserted near its throat.

Stigma trifid.

Ovary stalked.

Perianth 2-3 in. long . . Sp.1-3.

Perianth 1-2 in. long . . Sp.4-7.

Perianth an inch long or less Sp. 8-14.

Ovary sessile. . . . Sp. 15.

Stigma capitate, faintly 3-lobed . Sp. 16-18. (Argyropsis Herb.)

Subgenus Zephyrites (Herb.). Flower slightly inclined; tube short. Stamens inserted near its throat. Style more declinate than in the two other subgenera.

Perianth 2-3 in. long . $\quad$; $\quad$ Sp. 19-23.
Perianth 1-2 in. long : $\quad$ Sp. 24-29.

Subgenus Pyrolirion (Herb.). Flowers erect; tube longer, dilated in the upper half. Stamens inserted at the middle of the perianth-tube . . . . . Sp. 30-34. 
1. Z. Atanasco Herb. App. 36. Amaryllis Atamasco L.; Bot. Mag. t. 239; Ped. Lil. t. 31; Lodd. Bot. Cab. t. 1899.-Bull, oroid, under $1 \mathrm{in}$. diam.; neck short. Leaves $4-6$, contemporary with the flowers, bright green, narrow linear. Peduncle $\frac{1}{2}-1 \mathrm{ft}$. long. Spathe 1-1 in. long; valves lanceolate. Pelicel much shorter than the spathe. Perianth pure white, 3 in. long; tulse $\frac{1}{2} \mathrm{in.}$ long, tinged green; scgments oblanceolate-unguiculate, acute, $\frac{1}{2}$ in. lroad. Stanens more than half as long as the limb) anthers $\frac{1}{4}-\frac{1}{3} \mathrm{in}$. long. Style trifid, reaching nearly to the tip of the segments.

Hab. Southern United States. Scentless. Flowers in March. The plant that represents Amaryllis Atamasco in the Linnean herbarium is Cyrtanthus uniflorus.

2. Z. Treatiz S. Wats. Proc. Amer. Acad. xiv. 300. - Bulb ovoid, 3 in. diam.; neck short. Leaves 6-8, contemporary with the flowers, grass-green, not shining, very narrow, $\frac{1}{3}$ in. broad. Peduncle $\frac{1}{2}-1 \mathrm{ft}$. long; purple at the base. Spathe $\frac{3}{4}-1 \mathrm{in.}$ long, tubular in the lower half; ralves lanceolate. Pedicel much shorter: than the spathe. Perianth white, $3 \mathrm{in.}$ long; tube an inch long; segments lieeled with red, $\frac{1}{2} \mathrm{in}$. broad. Stamens half as long as the limb; anthers $\frac{1}{8}-\frac{1}{4} \mathrm{in}$. long. Style deeply trifid, reaching to the tip of the segments. Capsule depresso-globose, deeply lobed, $\frac{1}{2}$ in. diam.

Hab. Florida, in damp ground, Curtiss 2829*! Flowers in April and May. Described from a plant that flowered at Kew in 1880.

3. Z. carinata Herb. in Bot. Reg. t. 2594 ; Sweet, Brit. Flow. Gard. Ser. 2, t. 4 ; Bury, Hexand. t. $13 . \quad Z$. grandiflora Lindl. in Bot. Reg. t. 902. Amaryllis carinata Spreng. - Bulb ovoid, 1 in. diam.; neck short. Leaves $4-6$, contemporary with the flowers in summer, linear, $\frac{1}{3}-1 \mathrm{ft}$. long, $\frac{1}{4}-\frac{1}{3} \mathrm{in}$. broad, shallowly channelled down the face. Peduncle 6-9 in. long. Spathe $1 \frac{1}{2}-2$ in. long, tubular in the lower half; valves lanceolate. Pedicel shorter than the spathe. Perianth-limb bright rose-red, $2 \frac{1}{2}-3$ in. long; tube $\frac{1}{2}-\frac{3}{4}$ in. long; segments obovate, $\frac{1}{2}-\frac{3}{4}$ in. broad. Stamens reaching halfway up the limb; anthers above $\frac{1}{2}$ in. long. Style overtopping the stamens, deeply trifid.

Hab. Jamaica, March! Cuba, C. Wright 3246! Mexico, Duges. Native name, Muyo. Guatemala, Ortgies! The commonest species of the genus now in cultivation. I have not seen the allied $Z$. lilacina Liebm., which is said to have lilac flowers $3 \mathrm{in}$. long, a pedicel as long as the flower, and a spathe an inch long.

4. Z. тubispatha Herb. App. 96 ; Bury, Hexand. t. 25. Amuryllis tubisputha Gawl. in Bot. Mag. t. 1586. Z. nervosu Herb. Amuryllis nerrosa H. B. K. - Bulb globose, 1 in. diam.; neck short. Leares 4-5, narrow linear, flaccid, bright green, contemporary with the flower in spring or summer, sumetimes above a foot long. Peduncle

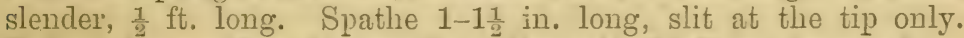

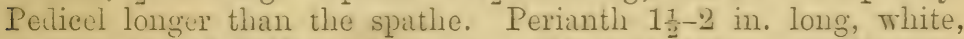
slightly tinged with green, never with red; tube scarcely any; segments obovate, $\frac{1}{2}$ in. broad. Stamens half as long as the limb. Style deeply trifil, overtopping the anthers. Capsule $\frac{1}{3}$ in. (iirum. 
Hab. West 1ndies, Venezuela, and New Granada. One of the commonest species of the genus in cultivation. Received living from Messrs. Bull, Henderson, \&c. It is in Royle's Himalayan collections as a garden plant. $Z$. Spofforthiana Herb. in Bot. Reg. t. $17 \pm 6$, is a garden hybrid between this species and carinata.

5. Z. iresochloa Herb. in Bot. Reg. t. 1361. Z. acuminata and favescens Herb.; Kunth, Enum. v. 487. Amaryllis mesochloa Seubert. -Bulb ovoid, $\frac{3}{4}-1$ in. diam.; neck $1-1 \frac{1}{2}$ in. long. Leaves narrow linear, contemporary with the flowers in spring. Peduncle

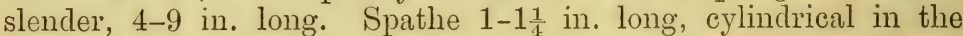
lower half. Pedicel $\frac{1}{2}-2$ in. long. Perianth-limb 1-2 in. long, white or faintly tinged outside with red, rarely yellowish; tube none; segments acute, under $\frac{1}{2}$ in. broad. Stamens half as long as the limb. Style deeply trifid. Capsule $\frac{1}{3}$ in. diam.

Hab. Buenos Ayres, Anderson, Tweedie! Cordoba, Catamarca, and Entrerios, Lorentz! Paraguay, Balansa 525! 527! Z. flavescens Herb. is a form with the flowers straw-coloured when they first open. Amaryllis entreriana O. Hoffm. in Linnæa, xliii. 137, is probably a variety.

6. Z. Lindleyana Herb. Amaryll. 174, t. 35, fig. 5. Z. nervosa Mart. et Gal. Enum. 4. -- Bulb globose, $\frac{3}{4}$ in. diam. ; neck short. Leaves narrow linear, contemporary with the flower's, 6-9 in. long. Peduncle slender, $\frac{1}{2}-1 \mathrm{ft}$. long. Spathe $1-1 \frac{1}{4} \mathrm{in}$. long, trifid only at the tip. Pedicel about as long as the spathe. Perianth bright red, $1 \frac{1}{2}-2$ in. long; tube greenish, $\frac{1}{2}-\frac{3}{4}$ in. long; segments obovatecuneate, $\frac{\sigma}{\mathrm{T}}$ in. broad. Stamens half as long as the limb; stigma trifid.

Hab. Mountains of Mexico, Galeotti 5415! Bourgeau 2273! Schafiner 541! Flowered at Kew in June, 1865.

7. Z. Wrightir Baker. -- Bulb globose, $\frac{3}{4}$ in. diam.; neck an inch long. Leaves $2-3$, narrow linear, erect, short, contemporary with the flowers. Peduncle slender, 4-5 in. long. Spathe $\frac{3}{4}$ in. long, tubular in the lower two-thirds. Pedicel nearly as long as the spathe. Perianth-limb bright red, $1 \frac{1}{4}-1 \frac{1}{2}$ in. long; tube $\frac{1}{3}-\frac{1}{6}$ in. long; segments obovate, $\frac{1}{4}$ in. broad above the middle. Stamens reaching halfway up the limb. Style trifid, overtopping the stamens.

Hab. Cuba, C. Wright 3247! Distributed as Z. Lindleyana, but, I think, distinct from the Mexican plant.

8. Z. rosea Lindl. in Bot. Reg. t. 821 ; Herb. in Bot. Mag. t. 2537 ; Bury, Hexand. t. 13. Amaryllis rosea Spreng. A. carnea Schultes fil.--Bulb globose, $\frac{3}{4}$ in. diam. ; neck scarcely any ; tunics thin, brown, shining. Leaves about 6 , spreading, linear, bright green, $\frac{1}{6}$ in. broad, contemporary with the flowers in October. Peduncle slender, 4-6 in. long. Spathe $\frac{1}{2}-\frac{3}{4}$ in. long, bifid at the tip only. Pedicel much longer than the spathe. Perianth bright red, about an inch long; tube short, greenish; segments obovate, $\frac{1}{4}-\frac{1}{3}$ in. broad. Stamens much shorter than the limb. Style trifid, nearly as long as the limb.

Hab. Cuba, C. Wright 3248! Described from a living plant from Messrs. Veitch, Oct. 1878. Probably it is identical with A. bifolia Lam., founded on an unpublished figure of Plumier. 
9. Z. Commersoniana Herb. Amaryll. 174, t. 29, fig. 3. Amuryllis Atamasco minor Red. Lil. t. 454. - Bulb globose, $\frac{1}{2}-\frac{3}{4}$ in. diam.; neck 1-1 $\frac{1}{2}$ in. long. Leaves $3-4$, contemporary with the flowers in August, narrow linear, finally 8-9 in. long. Peduncle slender, 4-6 in. long. Spathe $\frac{3}{4}-1 \mathrm{in}$. long, bifid at the tip. Pedicel a little longer than the spathe. Perianth-limb bright red, yellow at the base, 1-1 $\frac{1}{4}$ in. long; tube none; segments oblanceolate-oblong, subacute, $\frac{1}{3}$ in. broad. Stamens a little shorter than the perianth. Style deeply trifid. Capsule under $\frac{1}{2}$ in. diam.

Hab. Monte Video, Commerson! (Herb. Smith).

10. Z. Depauperata Herb. Amaryll. 171. Amaryllis depanperata Poeppig. - Leaves narrow linear, produced with the flowers in spring. Peduncle slender, 4-5 in. long. Spathe an inch long, tubular in the lower half. Pedicel $1 \frac{1}{2}$ in. long. Perianth an inch long, sulphur-yellow inside, tinged with red outside; tube very short; segments oblong, acute, under $\frac{1}{2}$ in. broad. Stamens more than half as long as the limb. Style trifid.

Hab. Sandy plains of South Chili, Poeppig. A plant gathered by Dr. Gillies on the Cerro de Portezuelo, drawn by Herbert, and called $Z$. filifolia, is either the same species or a close ally. Its leaves are filiform. There are a number of unpublished drawings of Amaryllidece by Herbert in the Lindley library. Wể have just received several specimens of a plant that only differs from Herbert's drawing by its smaller flowers, from Patagonia, from MIr. J. L. Williams Andrews.

11. Z. longifolia Hemsl. Diag. Pl. Nov. iii. 55. Z. aurea S. Wats. in Proc. Amer. Acad. xviii. 161.-Bulb ovoid, $\frac{3}{4}-1$ in. diam.; neck $1 \frac{1}{2}-2$ in. long. Leaves very narrow, contemporary with the flowers in summer, 6-9 in. long. Peduncle slender, 3-6 in. long. Spathe $\frac{3}{4}-1$ in. long, tubular in the lower half. Pedicel much shorter than the spathe. Perianth $\frac{3}{4}-1$ in. long, bright yellow, coppery outside; tube short; segments unguiculate, $\frac{1}{4}$ in. broad. Stamens much shorter than the limb. Style trifid. Capsulevalves orbicular, $\frac{1}{4}$ in. broad.

Hab. New Mexico, C. Wright 1904! Arizona, Pringle! Texas, Palmer 1363 ! Highlands of Central Mexico, Schatjiner 340! Parry \& Pulmer 870 !

12. Z. тexana Herb.; Kunth. Enum. v. 487. Habranthus Andersoni var. texanus Herb. in Bot. Mag. t. 3596. - Bulb globose,

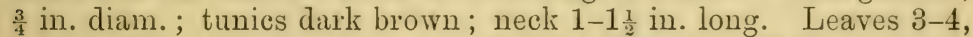
narrow linear, contemporary with the flowers. Peduncle very slender, 4-8 in. long. Spathe an inch long, bifid only at the tip. Pedicel erect, much longer than the spathe. Perianth erect, yellow inside, coppery yellow outside, an inch long; tube scarcely any; segments obovate, acute, $\frac{1}{4} \mathrm{in}$. broad. Stamens more than half as long as the perianth. Style trifid, as long as the stamens. Capsule $\frac{1}{3}$ in. diam.

Hab. Texas, first gathered by Drummond in 1835, and since by Lindheimer and Palmer.

13. Z. Gracilis Herb. Amaryll. 172, t. 29, fig. 1. - Bulb and leaves unknown. Peduncle short, slender. Spathe $\frac{5}{8}$ in. long. Pedicel shorter than the spathe. Perianth-limb above $\frac{1}{2}$ in. long; tube scarcely any; segments oblanceolate, 1-12th in. broad. 
Stamens nearly as long as the segments. Style reaching to the tip of the segments, shortly trifid.

Hab. Peru; Porto de Sta. Maria, Pavon! (Herb. Mus. Brit.).

14. Z. мinima Herb. Amaryll. 172, t. 24, fig. 3. A. parvula Seubert. A. minima Griseb. - Bulb globose, $\frac{1}{2}-\frac{3}{4}$ in. diam.; neck 1-1 $\frac{1}{2}$ in. long. Leaves filiform, contemporary with the flowers in April. Peduncle very slender, $2-4$ in. long. Spathe $\frac{1}{2}-\frac{3}{4}$ in. long, tubular in the lower half. Pedicel much shorter than the spathe. Perianth-limb about $\frac{1}{2}$ in. long, yellow, tinged outside with red; tube very short; segments obovate, acute, $\frac{1}{6}$ in. broad. Stamens more than half as long as the limb. Stigma trifid. Capsule globose, $\frac{1}{4}$ in. diam.

Hab. Buenos Ayres, Tweedie! Entre Rios and Cordoba, Lorentz! Hieronymus!

15. Z. verecunda Herb. in Bot. Mag. t. 2583 ; Baker in Ref. Bot. t. 356. Z. sessilis Herb.; Baker in Ref. Bot. t. 212. Z. striata Herb. in Bot. Mag. t. 2593. Z. Grahamiana Herb. Amaryll. 175, t. 29, fig. 2. Amaryllis verecunda and striatula Schultes fil. - Bulb ovoid, $\frac{3}{4}-1$ in. diam.; neck 1-2 in. long. Leaves $3-6$, contemporary with the flowers in spring and summer, narrow linear, green, $\frac{1}{2}-1 \mathrm{ft}$. long. Peduncle slender, 3-9 in. long. Spathe about an inch long, tubular in the lower half; segments lanceolate. Ovary sessile. Perianth-limb $1 \frac{1}{2}-2$ in. long, white, more or less tinged outside or keeled with red; tube $\frac{1}{2}-\frac{3}{4} \mathrm{in}$. long; segments obovate, $\frac{1}{4}-\frac{1}{3}$ in. broad. Stamens reaching halfway up the segments. Style trifid, reaching to the tip of the segments. Capsule-valves orbicular, $\frac{1}{4}-\frac{1}{3}$ in. broad.

Hab. Highlands of Central Mexico, Hartweg 220! Andrieux 320! Graham 358 ! Bourgeau 240! Schaffner! Received living from Mr. Wilson Saunders, Colonel Trevor Clarke, Messrs. Backhouse, \&c. The imperfectly-known $Z$. pallida Roem. (A. minuta H. B. K.) is probably a form of this species.

16. Z. candida Herb. in Bot. Mag. t. 2607 ; Lodd. Bot. Cab. t. 1419 ; Bury, Hexand. t. 25. Amaryllis candida Lindl. in Bot. Reg. t. 724. A. nivea Schultes fil.-Bulb ovoid, 1 in. diam.; neck 1-2 in. long. Leaves bright green, subterete, contemporary with the flowers in autumn and lasting through the winter, above a foot long. Peduncle slender, 6-9 in. long. Spathe an inch long, bifid halfway down. Pedicel shorter than the spathe. Perianth-limb $1 \frac{1}{2}-2 \mathrm{in}$. long, pure white or slightly tinged with red outside; tube none; segments $\frac{1}{2} \mathrm{in}$. broad. Stamens scarcely half as long as the segments. Style $\frac{1}{2}-\frac{3}{4}$ in. long; stigma minutely 3 -lobed. Capsule $\frac{1}{2}$ in. diam.

Hab. Marshes of La Plata, abundant, Tweedie! Entre Rios, Lorentz! Widely spread in cultivation. Described from specimens in the Kew herbaceous ground, Sept. 1869.

17. Z. citrina Baker in Bot. Mag. t. 6605. - Bulb globose, $1 \frac{1}{2}$ in. diam., copiously stoloniferous. Leaves $3-4$, contemporary with the flower in August, bright green, deeply channelled down the face, a foot long, $\frac{1}{6}$ in. broad. Peduncle $\frac{1}{2} \mathrm{ft}$. long, ancipitous, green, tinged with red towards the base. Spathe under an inch 
long. Pedicel shorter than the spathe. Perianth-limb bright yellow, $1 \frac{1}{2}-2$ in. long; tube $\frac{1}{3}-\frac{1}{2}$ in. long; segments obovateunguiculate, under $\frac{1}{2} \mathrm{in}$. broad. Stamens more than half as long as the limb. Style shorter than the stamens; stigma with 3 orbicular lobes.

Hab. Received alive from Messrs. Veitch, Aug. 1881. Supposed to have been imported from Demerara.

18. Z. macrosiphon Baker in Gard. Chron. n. s. xvi. 70.- Bulb ovoid, 1 in. diam.; neck 2 in. long. Leaves 3-4, contemporary with the flower's in summer, linear, bright green, a foot long. Peduncle $\frac{1}{2}-1 \mathrm{ft}$. long. Spathe $1 \frac{1}{4}-1 \frac{1}{2} \mathrm{in}$. long, tubular in the lower half. Pedicel as long as or a little longer than the spathie. Perianth bright red, 2-2 in. long; tube as long as the obovate segments, which are above $\frac{1}{2} \mathrm{in}$. broad at the middle. Stamens half an inch shorter than the limb. Stigma capitate, with 3 orbicular lobes.

Hab. Mexico. Received alive from Messrs. Veitch, May, 1881.

\section{Subgenus ZePHYrItes.}

19. Z. robusta Baker. Habranthus robustus Herb.; Sweet, Brit. Flow. Gard. ser. 2, t. 14 ; Lodd. Bot. Cab. t. 1761. Amuryllis tubispatha L'Herit. A. robusta Spach. A. Berterii Spreng.-Bulb ovoid, 1-1 $\frac{1}{2}$ in. diam. ; neck short. Leaves linear, glaucous, produced after the flower's. Peduncle slencler, 6-9 in. long. Spathe $1 \frac{1}{2}-2$ in. long, cleft only in the upper quarter. Pedicel as long as the spathe. Perianth-limb erecto-patent, $2 \frac{1}{2}-3$ in. long, rose-red; tube short, greenish ; segments subacute, $\frac{1}{2}-\frac{3}{4}$ in. broad. Stamens half as long as the limb. Stigma trifid.

Hab. Buenos Ayres, Tweedie! Introduced into cultivation in 1838. Flowers in July and August.

20. Z. verstcolor Baker. Habranthus versicolor Herbert in Bot. Mag. t. 2485. Amuryllis versicolor. Spreng. - Bulb oblong, 1 in. diam.; tunics nearly black. Leaves 3 or more, green, linear, a foot long, produced after the flower. Peduncle slender, 4-6 in. long. Spathe $1 \frac{1}{2}$ in. loug, tubular in the lower half. Pedicel a little longer than the spathe. Perianth suberect, $2-2 \frac{1}{2}$ in. long, white, flushed outside with red and green; tube very short; segments obovate-unguiculate, cuspidate, $\frac{1}{2}$ in. broad. Stamens half as long as the limb. Style deeply trifid.

Hab. Maldonado, Tweedie! Introduced in 1824. Flowering in January.

21. Z. sylvatica Baker. Amuryllis syluatica Mart. Habranthus sylvaticus Herb. - Bulb globose, $\frac{3}{4}-1$ in. diam.; tunics pale brown; neck an inch long. Leaves linear, $\frac{1}{8}$ in. broal, produced after the flowers. Peduncle weak, slender, 3-4 in. long. Spathe an inch long, tubular in the lower half. Pedicel as long as or rather shorter than the spathe. Perianth erecto-patent, bright red, 2-21 in. long ; tube greenish, $\frac{1}{2}-\frac{3}{4}$ in. long; segments subequal, $\frac{1}{3}$ in. broad. Stamens $\frac{1}{2}$ in. shorter than the limb. Style very slender, declinate, trifid, longer than the stamens.

Hab. Bahia, Martius. Ceara, in dry open woods near Crato, Gardner 1855 ! 
22. Z. concolor S. Wats. in Proc. Amer. Acad. xviii. 161. Habranthus concolor Lindl. in Bot. Reg. 1845, t. 54. - Bulb ovoid, $1 \frac{1}{2}-2$ in. diam; tunics dark brown; neck 2-3 in. long. Leaves about 4, produced with the leaves in summer, linear, glaucescent, a foot long, $\frac{1}{3}-\frac{1}{2}$ in. broad. Peduncle terete, a foot long. Spathe $1 \frac{1}{2}-2$ in. long, bifid in the upper third. Pedicel 2-3 in. long. Perianth-limb lemon-yellow, 2-21 in. long; tube short; segments obovate-unguiculate, cuspidate, $\frac{3}{4} \mathrm{in}$. broad. Stamens half as long as the limb; anthers $\frac{1}{3}$ in. long. Style overtopping the stamens, deeply trifid. Capsule nearly $1 \mathrm{in}$. diam.

Hab. Mountains of Mexico, ascending to 6000-8000 ft., Hartweg 219! Parry d: Palmer 868 ! Schaffiner 540! Sent alive by Messrs. Krelage, of Haarlem, in July, 1878.

23. Z. andrcola Baker. Habranthus andicola Herb. Amaryllis andicola Poeppig.-Leaves linear, glaucous. Peduncle 6-7 in. long. Spathe bifid, reaching halfway up the flower. Perianth-limb bright violet, $2 \mathrm{in}$. long; tube $\frac{1}{4}-\frac{1}{3} \mathrm{in.}$ long. Stamens very s̀hort, deflexed.

Hab. Chili; Andes of Antuco, Poeppig. Flowers in January. I have not seen any specimen.

24. Z. mendocensis Balier. - Bulb-neck an inch long. Leaves not seen. Peduncle slender, 5-6 in. long. Spathe an inch long, tubular in the lower half. Pedicel as long as or shorter than the spathe. Perianth-limb rather declinate, 18-21 lines long; upper segment $\frac{1}{4}$ in. broad; lower narrower. Stamens unequal; longest more than half as long as the limb. Stigma trifid. Capsule small, globose.

Hab. Argentine territory; Province of Mendoza, Reed!

25. Z. cearensis Baker. Habranthus ceurensis Herb. - Bulb ovoid, $\frac{3}{4}$ in. diam.; tunics pale brown; neck short. Leaves very narrow, produced after the flowers. Peduncle very slender, 4-5 in. long. Spathe an inch long, tubular in the lower half. Pedicel a little longer than the spathe. Perianth whitish, erecto-patent, $1 \frac{1}{2}$ in. long; tube $\frac{1}{4}-\frac{1}{3}$ in. long; segments oblanceolate, $\frac{1}{4}$ in. broad. Stamens more than half as long as the limb. Style trifid.

Hab. Brazil ; Ceara, in woods near Crato, Gardner 1858! Goyaz, Burchell 8123 ! 8124! Quite distinct from Z. Andersoni, with which Seubert has confused it.

26. Z. Franciscana Herb. MSS. - Bulb ovoid, $1 \frac{1}{2}$ in. diam.; tunics pale brown; neck $1 \frac{1}{2}-2$ in. long. Leaves very narrow, produced with the flowers. Peduncle 4-8 in. long. Spathe 1-1 $\frac{1}{4}$ in. long, tubular above the lower half. Pedicel at most as long as the spathe. Perianth-limb oblique, whitish, $1-1 \frac{1}{2} \mathrm{in}$. long; tube $\frac{1}{3}-\frac{1}{2}$ in. long; segments oblanceolate, $\frac{1}{4}$ in. broad. Stamens a little shorter than the limb. Stigma trifid.

Hab. Central Brazil; banks of the Rio St. Francisco, Gardner 1422! Flowers in March.

27. Z. gracilifolia Baker. Habranthus gracilifolius Herb. in Bot. Nag. t. 2464. Amaryllis gracilifolia Schultes fil. - Bulb 1 in. diam. ; neck short; tunies dark brown. Leaves 4-5, linear, deeply channelled down the face, 6-9 in. long. Peduncle very slender, 
4-8 in. long. Spathe $\frac{3}{4}-1 \frac{1}{4}$ in. long, tubular in the lower half. Pedicel as long as or rather longer than the spathe. Perianth-limb an inch long, suberect, pale purplish pink; tube short; segments obovate, cuspidate, $\frac{1}{3} \mathrm{in}$. broad. Stamens half as long as the limb. Style trifid.

Hab. Maldonado, Tweedie! Introduced in 1823. Monte Video, Isabelle! Flowers in September.

28. Z. Andersoni Baker. Habranthus Andersoni Herb. in Bot. Reg. t. 1345 ; Lodd. Bot. Cab. t. 1677 ; Sweet, Brit. Flow. Gard. ser. 2, t. 70. Amaryllis Andersoni Steudel. - Bulb ovoid, ${ }^{3}-1$ in. diam.; neck short. Leaves narrow linear, pale green, 5-6 in. long, produced with the flowers. Peduncle slender, 3-6 in. long. Spathe 1-1 $\frac{1}{4}$ in. long, tubular below the middle; valves lanceolate. Pedicel longer than the spathe. Perianth suberect, 1-1 $\frac{1}{2} \mathrm{in}$. long, bright yellow inside, coppery red outside; tube scarcely any; segments obovate, cuspidate, $\frac{1}{3}-\frac{1}{2} \mathrm{in}$. broud. Stamens unequal, half as long as the limb; anthers yellow, $\frac{1}{6}$ in. long. Style trifid. Capsule $\frac{1}{2}$ in. diam., deeply 3 -lobed.

Hab. Monte Video, first introduced in 1829, Anderson! Tweedie! Gibert! Entre Rios, Lorentz! Buenos Ayres, Tweedie! Araucania, Reynolds! Described from plants flowered at Kew in June and July, 1887.

29. Z. cerulea Baker. Amaryllis (Habranthus) carulea Griseb. - Bulb under 1 in. diam.; neck $1-2 \frac{1}{2} \mathrm{in.} \mathrm{long.} \mathrm{Leaves} \mathrm{unlinown.}$ Peduncle 3-4 in. long. Pedicel as long as the bifid spathe. Perianth pale blue, an inch long; tube none ; segments obovate-unguiculate, mucromate. Stamens unequal; 3 longer equalling the trifid style.

Hab. Entre Rios; Concepcion del Uraguay, flowering in March, Lorentz.

\section{Subgenus Prrolirion.}

30. Z. aurea Balier. Pyrolivion aureum Herb. Amaryllis aurea Ruiz et Pavon, Fl. Peruv. t. 286 A. A. tubiflora L'Herit. - Bulb globose, $1 \frac{1}{2}$ in. diam. Leaves about 5, linear, a foot long, $\frac{1}{4}$ in. broad, contemporary with the flowers in December and January.

- Peduncle $\frac{1}{2}-1 \mathrm{ft}$. long. Spathe membranous, $1 \frac{1}{2} \mathrm{in.} \mathrm{long,} \mathrm{cylindrical}$ in the lower half. Ovary sessile. Perianth-limb erect, bright yellow; tube fummel-shaped, longer than the segments, suclenly dilated at the middle, furnished at the throat with minute toothed scales; segments acute, equal, $1 \frac{1}{2} \mathrm{in}$. long, $\frac{1}{2} \mathrm{in.} \mathrm{broad.} \mathrm{Stamens}$ inserted at the middle of the perianth-tube; filaments erect, $1 \frac{1}{2} \mathrm{in}$. İong; anthers small, linear-oblong. Style trifid, reaching nearly to the tip of the segments.

Hab. Peru; Valley of Lima, in corn-fields, \&c., Pavon! Natthews 400 ! Nation!

31. Z. flava Baker. Pyrolirion flarum. Herb. P. aureum funce lavi Lindl. in Bot. Reg. t. 1724. - Differs from $Z$. aurea by being destitute of scales at the throat of the tube.

Hab. Peru. Known only from the plant described and figured by Lindley

32. Z. Flandea Balier. Amaryllis flammea Ruiz et Paron, F1. Penuv. t. 286в. Pyrolirion flammenm Herb. - Just like Z. anrea, 
but the colour of the flower flame-red. Segments furnished with small truncate crenate membranous scales at the base.

Hab. Peru; Valley of Lima, Pavon!

33. Z. albicans Balker. Pyrolirion albicans Herb. - Leaves linear, 7-8 in. long. Peduncle 6-8 in. long. Perianth-limb whitish, 4 in. long; tube as long as the segments.

Hab. Peru. (Lilionarcissus monanthos flore albicante tubo prælongo, Feuill. Obs. iii. 29, fig. 20).

34. Z. Boliviensis Baker. - Bulb globose, $1 \frac{1}{2}$ in. diam; neck $1 \frac{1}{2}-3$ in. long. Leaves unknown. Peduncle slender, $\frac{1}{2}-1 \mathrm{ft}$. long. Spathe an inch long. Ovary sessile, soon splitting open the spathe. Perianth-limb whitish, erect, 2 in. long; tube as long as the segments, cylindrical in the lower, funnel-shaped in the upper half; segments equal, oblong-lanceolate, $\frac{1}{4}-\frac{1}{3} \mathrm{in}$. broad. Stamens inserted halfway up the tube; anthers opposite the base of the segments. Style deeply trifid, much overtopping the stamens.

Hab. Bolivia; near Sorata, alt. 8000-9000 ft., MIandon 1194 in part! Flowers in September.

\section{Sprekelia Heist.}

Perianth ringent, horizontal; tube none; upper segment broadest; two lateral lanceolate; three lowest deflexed, rolled together to enclose the stamens and style. Stamens declinate, attached to the base of the segments, with minute scales between; filaments filiform; anthers linear-oblong, versatile. Ovary turbinate, 6 -angled, 3-celled; ovules many, superposed; style filiform; stigma trifid. Capsule globose-trigonous, loculicidally 3 -valved down to the base. Seeds many, discoid, narrowly winged; testa thin, black.Monotypic.

1. S. formosissnia Herb. App. 35 ; Sweet, Brit. Flow. Gard. ser. 2, t. 1446. S. Heisteri Trew Ehrhet, t. 24. Amaryllis formosissima L.; Bot. Mag. t. 47 ; Red. Lil. t. 5 ; Bury, Hexand. t. 6.Bulb globose, 2 in. diam.; tunics brown. Leaves 3-6, contemporary with the flowers in April, linear, green, finally 1-11 ft. long, $\frac{1}{2}-\frac{3}{4}$ in. broad. Peduncle reddish, hollow, slightly compressed, $\frac{1}{2}-1 \mathrm{ft}$. long. Spathe red-brown, $2 \mathrm{in}$. long, bifid at the tip. Pedicel about as long as the spathe, erect. Perianth bright crimson, $3 \frac{1}{2}-4$ in. long; upper segments distinctly unguiculate, upper an inch broad at the middle; sicle ones $\frac{1}{2}$ in. broad, recurved towards the tip; three lowest comnivent in the lower half. Capsule-valves orbicular, $\frac{3}{4}$ in. broad.

Var. S. Glauca Lindl. in Bot. Reg. 1841, t. 6.-Leaves glancous. Flowers smaller and paler than in the type.

Var. S. Karwinswir Roem. Amaryll. 144.-Perianth less brightly coloured.; segments keeled and bordered with white.

Var. S. RIngens Morren in Ann. Soc. Hort. Gand. ii. 133, t. 60. - Leaves glaucous. Flower cernuous; upper segment vittate at the base and middle with yellow.

Hab. Mexico and Guatemala, introduced into Europe in 1593. Flowers with the leaves in spring. We are indebted to Colonel Trevor Clarke for the capsule and ripe seeds. 


\section{Ungernia Bunge.}

Perianth regular; tube funnel-shaped, naked at the throat; segments oblong, subequal, keeled with many close green ribs. Stamens inserted into two rows near the throat of the tube; filaments filiform, nearly straight; anthers linear-oblong, versatile. Ocary 3-celled; ovules many in a cell; style filiform; stigma capitate, minutely 3-lobed. Capsule membranous, deeply lobed laterally, loculicidally 3-valved. Seeds flat; testa thin, black.Rootstock a large bulb, with a long neck. Leaves lorate, not produced with the flowers. Peduncle solid. Umbel many-flowered, with 2 spathe-valves. Differs from Lycoris by its numerous ovules and discoid seeds.

1. U. trisphera Bunge in Bull. Soc. Imp. Nat. Mosc. 1875, ii. 271. Lycoris Sever $\approx$ ovi Regel, Gartenfl. t. 914.-Bulb 3 in. diam.; tunics many, thin, bright brown, produced $\frac{1}{2} \mathrm{ft}$. above its neck. Leaves lorate. Peduncle $\frac{1}{2}-1 \mathrm{ft}$. long. Umbel 6-15-flowered; central flowers erect, outer rather inclined; pedicels $1-3 \mathrm{in}$. long, stout, stiff; spathe-valves large, lanceolate. Perianth 1-1 $\frac{1}{4} \mathrm{in}$. long; tube $\frac{1}{2}$ in. long, cylindrical in the lower half; segments reddish, acute, $\frac{1}{6}$ in. broad, lieeled with $7-9$ close ribs. Stamens shorter than the segments. Capsule nearly $1 \mathrm{in}$. diam. Seeds 10-12 in a cell.

Hab. Khorassan, Bunge! Turkestan, Sewerzow. Afghan boundary, abundant, Aitchison 714! Introduced into England alive by Dr. Aitchison in 1886.

2. U. Flava Boiss. et Haussk. Fl. Orient. v. 149. - Habit of U. trisphara, from which it differs by its yellow flowers and shorter perianth-tube, gradually dilated from the base to the apex.

Hab. South-western Persia, discovered by Dr. Hausskwecht.

3. U.? Oldhani Maxim. in Engler Jahrb. 1884, vi. 76.-Bulb and leaves unknowu. Peduncle a span long. Umbel many-flowered; spathe-valves rigid; filiform bracteoles present. Perianth with ovary $1 \frac{1}{2} \mathrm{in}$. long; limb reddish; tube half as long as the revolute linear segments. Stamens shorter than the limb. Ovules 12-15 in a cell.

Hab. Japan. Known only from a single specimen given to Dr. Maximowicz. by a nativ 6 botanist. Oldham's plant is not this, but Lycoris sanguinea.

\section{LyCoRIs Herb.}

Perianth funnel-shaped, rather irregular ; tube short, cylindrical, dilated at the apex, sometimes scaly at the throat; segments oblanceolate, subequal, unguiculate. Stumens inserted near the throat of the tube; filaments long, filiform, declinate ; anthers oblong, versatile. Ovary 3 -celled; ovules few in a cell; style long, filiform; stigma capitate, minute. Capsule membranous, loculicidally 3 -valved. Seeds few, turgid; testa black, opaque.-Rootstock a bulb with membranous tunics and a short neck. Leares linear or lorate, not usually developed with the flowers. Peduncle solid. Limbels manyflowered; spathe-valves 2, lanceolate; pedicels often bracteolate. Flowers red or yellow. 
Flowers yellow

Flowers red.

Stamens nearly as long as the limb . Sp. 3-4.

Stamens much longer than the limb . Sp. 5.

1. L. aurea Herb. App. 20. Amaryllis aurea L'Herit. Stirp. t. 16 ; Bot. Mag. t. 409 ; Red. Lil. t. 61 ; Bot. Reg.t. 611 . Nerine aurea Bury, Hexand. t. 3. - Bulb subglobose, 2 in. diam. Leaves $5-7$, ensiform, glaucous, produced in May, $\frac{1}{2}-\frac{3}{4} \mathrm{in}$. broad. Peduncle subterete, 1-2 ft. long. Flowers bright yellow, inodorous, produced in August. Umbel 5-10-flowered; spathe-valves large, lanceolate; pedicels shnrt, stout. Perianth $3 \mathrm{in}$. long; tube $\frac{1}{2}-\frac{3}{4}$ in. long, scaly at the throat; segments subringent, rather crisped, $\frac{1}{3}-\frac{1}{2}$ in. broad. Stamens declinate, rather exserted, as is also the style.

Hab. China, introduced into English gardens by Dr. Fothergill in 1777. Hort. Salisbury 1785! Formosa, Oldham 643! Hancock! Apparently only cultivated in Japan.

2. L. straminea Lindl. in Journ. Hort. Soc. iii. 76. - Allied to L. aurea, but segments pale straw-coloured, with a pink keel, and a few scattered red dots; tube very short.

Hab. China, introduced into cultivation by Fortune in $\mathbf{1 8 4 5}$.

3. L. squamigera Maxim. in Engler Jahrb. 1884, 79. - Bulb large, globose. Leaves 5-6 to a bulb, produced in spring, above a foot long, $\frac{3}{4}-1 \mathrm{in}$. broad at the middle. Peduncle stout, $2-3 \mathrm{ft}$. long. Flowers rose-lilac, fragrant, produced in July and August. Umbel 4-7-flowered; spathe-valves large, lanceolate; pedicels short, stout, bracteolate. Perianth 3 in. long; tube $\frac{1}{2}$ in. long, scaly at the throat, cylindrical below the apex; segments subringent, obtuse with a cusp, $\frac{1}{2}$ in. broad above the middle. Stamens declinate, nearly as long as the segments. Style a little exserted.

Hab. Japan, MIaximowicz! A plant from grave-yards at Ningpo, Hancock 34 ! with longer more slender pedicels, will probably prove distinct. Nearly allied to $L$. aurea ; differs by its red flowers and shorter stamens.

4. L. sanguinea Maxim. in Engler Jahrb. 1884, 80. - Bulb ovoid, 1 in. diam.; neck 1-2 in. long. Leaves $3-7$, produced after the flowers, linear, obtuse, $\frac{1}{6}$ in. broad. Peduncle slender, 1-1 $\frac{1}{2} \mathrm{ft}$. long. Umbel 4-6-flowered; spathe-valves lanceolate; pedicels slender, generally 1-2 in. long. Perianth erect, bright red, $1 \frac{1}{2}-2 \frac{3}{4}$ in. long; tube $\frac{1}{2} \mathrm{in}$. long, cylindrical below the apex, not scaly at the throat; segments erect, oblanceolate, $\frac{1}{6}$ in. broad, neither crisped nor reflexing. Stamens shorter than the limb. Style finally exserted.

Hab. Japan, Oldham 188! Buerger! Maximowicz! Dickins! Has the most nearly regular flowers of any species of the genus.

5. L. Radiata Herb. App. 20. Amaryllis radiata L'Herit.; Andr. Bot. Rep. t. 25 ; Bot. Reg. t. 596. A. samiensis Thunb., non Linn. Nerine japonica Miquel. Genus Orexis Salisb.-Bulb globose, $1 \frac{1}{2}$ in. diam.; neck short. Leaves 5-6, produced in winter, linear, obtuse, glaucous, $\frac{1}{2} \mathrm{ft}$. long, $\frac{1}{4}$ in. broad. Peduncle slender, 1-11 ft. long. Flowers bright red, inodorous, produced in autumn. Umbel 4-12- 
flowered; spathe-valves lanceolate; pedicels short, slender. Perianth $1 \frac{1}{2}$ in. long; tube very short; segments oblanceolate, crisped, spreading more widely than in the other species and more recurved, $\frac{1}{6}$ in. broad. Stamens declinate, nearly twice as long as the segments. Style $2 \frac{1}{2}-3 \mathrm{in}$. long.

Hab. China and Japan, widely spread and long cultivated. Introduced into English gardens in 1750. Noticed by Kompfer in 1712.

\section{Hippeastrum Herb.*}

Perianth funnel-shaped, usually more or less declinate; tube usually short, rarely long, often furnished with minuce scales or a distinct neck at the throat; segments nearly equal or the lowest of the inner row narrower. Stamens inserted at the throat of the tube, more or less declinate; filaments filiform; anthers linear or linearoblong, versatile. Ovary 3-celled; ovules many, superposed; style long, declinate; stigma capitate or trifid. C'alsule globose, loculicidally 3 -valved. Seeds usually flattened, with a thin black testa.Rootstock a bulb with membranous tunics. Leaves linear or lorate. Peduncle hollow. Flowers usually 2 or more in an umbel, rarely solitary, but, if so, the spathe is bifid down to the base, and the pedicel furnished at the base with a linear bracteole. Flowers usually bright red or whitish.

\section{* Leaves linear.}

Subgenus 1. Habranthus (Herb.).--Periantil openly funnel-shaped; tube short. Stigma trifid.

$\begin{array}{ll}\text { Umbel 1-2-flowered } & \text { Sp. 1-5. } \\ \text { Umbel 3-6-flowered } \quad \text { Sp.6-10. }\end{array}$

Subgenus 2. Phycella (Lindl.).-Perianth narrowly fumnel-shaped; tube short. . . . . Sp.11-13.

Subgenus 3. Rhodophiala (Presl).-Perianth openly funnel-shaped; tube short. Stigma capitate.

Umbel 1-flowered . Sp. 14-16.

Umbel 2-6-flowered . Sp. 17-18.

** Leaves lorate.

Subgenus 4. Macropodastruar.-Perianth with a long tube. Stigma capitate . . . . Sp. 19.

Subgenus 5. Oмrphadissa (Salish).). - Perianth with a short tube, closed in by a distinct neck at the throat.

Stigma trifid . . Sp. 20-23.

Stigma capitate . . Sp. 24-26.

Subgenus 6. Aschanria (Salisb.). - Perianth with a short tube, not closed in at the throat. Stigma capitate.

Perianth-tube very short Sp. 26-32.

Perianth-tube $\frac{1}{2}-1$ in. long Sp. 33-35.

Subgenus 7. LaIs (Salisb.). - Periauth-tube short, not closed in at the throat. Stigma trifid . . Sp.36-38.

* See Baker in Journ. Bot. 1879, 79. 


\section{Subgenus Habranthus.}

1. H. soratense Baker.-Bulb ovoid, under 1 in. diam. Leaves about 4, narrow linear, 1-12th in. long, contemporary with the flowers in September. Peduncle slender, 4 in. long. Umbel 2 -flowered; spathe-valves 2 , linear, $3 \mathrm{in}$. long; pedicels $\frac{3}{4}-1 \mathrm{in}$. long. Perianth-limb erect, $4-4 \frac{1}{2} \mathrm{in}$. long; tube $3 \mathrm{in.} \mathrm{long,} \mathrm{funnel-}$ shaped at the apex, cylindrical below it; segments oblong-lanceolate, $1 \frac{1}{4}$ in. long, $\frac{1}{4}$ in. broad at the middle. Stamens as long as the segments; anthers $\frac{1}{4}$ in. long. Style deeply trifid.

Hab. Andes of Bolivia; Sorata, alt. 8000-9000 ft., Mrandon!

2. H. ChILense Baker in Journ. Bot. 1878, 82. Habranthus chilensis Herb. Amaryllis chilensis R. \& P.-Bulb globose, 1-1 $\frac{1}{2}$ in. diam.; neck 1-3 in. long; tunics dull brown. Leaves about 2, narrow linear, contemporary with the flowers, 6-9 in. long. Peduncle 6-9 in. long. Umbel mostly 2-flowered; spathe-valves linear, $1 \frac{1}{2} \mathrm{in.} \mathrm{long;} \mathrm{pedicels} \frac{1}{2}-1$ in. long. Perianth-limb erect or ascending, $1 \frac{1}{2}-2$ in. long; tube very short; segments bright red or yellow, oblong, acute, $\frac{1}{3}$ in. broad at the middle. Stamens shorter than the perianth-segments: anthers oblong, $\frac{1}{8}$ in. long. Style reaching to the tip of the segments; stigma trifid.

Hab. Sandy plains of South Chili, Pavon! Lesson! Reed! Flowers in spring.

3. H. Roseun Baker in Journ. Bot. 1878, 82. Habranthus roseus Herb. ; Sweet, Brit. Flow. Gard. ser. 2, t. 107. H. pumilus Lodd. Bot. Cab. t. 1771. Zephyranthes purpurea Philippi. - Bulb ovoid, under $1 \mathrm{in}$. diam.; neck short; tunics dark brown. Leaves about 3 , contemporary with the flowers in summer, narrow linear, glaucous, a foot long. Peduncle slender, $\frac{1}{2} \mathrm{ft}$. long. Flower usually solitary, nearly horizontal; spathe 2 -valved, 1-1 $\frac{1}{2}$ in. long; pedicel shorter than the spathe. Perianth-limb 2 in. long, bright red; tube very short, greenish; segments oblong-lanceolate, acute. Stamens shorter than the segments; anther's $\frac{1}{8}$ in. long. Style longer than the stamens; stigma trifid.

Hab. Chili, Reed! Introduced into cultivation from the Island of Chiloe by Lieut. Barlow in 1831, but now lost.

4. H. Linfatum Baker in Journ. Bot. 1878, 82. Habranthus lineutus Philippi. - Bulb and leaves unknown. Peduncle slender, $\frac{1}{2} \mathrm{ft}$. long. Unbel 2 -flowered; spathe-valves linear, above 2 in. long; pedicels half as long as the spathe-valves. Flowers cernuous, yellow, marked with red lines, $1 \frac{1}{2}-2$ in. long; tube $\frac{1}{4}$ in. long; segments oblanceolate, $\frac{1}{3} \mathrm{in}$. broad. Stamens much shorter than the segments. Style shorter than the segments; stigma trifid.

Hab. Chili, near Santiago, Philippi. Flowers in September.

5. H. Brachyandrum Baker. - Bulb and leaves not seen. Peduncle slender, a foot long. Umbel 1 -flowered; spathe-valves linear, 2 in. long; pedicel as long as the spathe. Flower nearly erect, bright red, $3 \frac{1}{2}$ in. long; tube short, funnel-shaped; segments oblong-lanceolate, acute, $\frac{1}{2} \mathrm{in}$. broad. Stamens under an inch long. Style reaching halfway up the flower; stigma deeply trifid. 
Hab. On the Parana, lat. $26-27^{\circ}$ S., Parodi! Received at Kew in 1883 , a dried specimen.

6. H. advenum Herb. App. 31. Amaryllis adrena Gawl. in Bot. Reg. t. 849 ; Bot. Mag. t. 1125. Habranthus hesperius Herb. II. mendocinus Philippi. Éustephic Macleanica Baker in Ref. Bot. t. 332, non Herb. Chlidanthus Cuminuii Presl. - Bulb ovoid, $1 \frac{1}{2}$ in. diam.; neck short; tunics dark brown. Leaves linear, a foot long, glancous green. Peduncle $\frac{1}{2}-1 \mathrm{ft}$. long. Umbel 2-6flowered; spathe-valves lanceolate, $1 \frac{1}{2}-2 \mathrm{in}$. long; pedicels $1-3 \mathrm{in}$. long. Flowers horizontal or ascending, openly fummel-shaper, $1 \frac{1}{2}-2$ in. long, yellow or red; tube very short, greenish, crenulate at the throat; segments oblong-lanceolate, acute, 1 in. broad. Stamens declinate, much shorter than the perianth; anthers $\frac{1}{13}$ in. long. Style exceeding the stamens; stigma trific. Tar. pallidus Herb. ; Lodd. Bot. Cab. t. 1760, has pale yellow flowers. Habranthus miniatus D. Don in Sweet Brit. Flow. Gard. ser. 2, t. 213, has large bright red flowers.

Hab. Chili, about Valparaiso, Santiago, dc., flowering in December and January. First figured by Feuillée in 1714.

7. H. BIFIdum Baker in Journ. Bot. 1878, 83. Habranthus

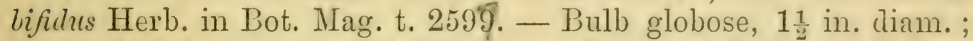
tunics dark brown; neck $2-3$ in. long. Leaves $2-3$, linear, slightly glancous, a foot long, produced after the flower's. Pertuncle slightly compressed, a foot long. Umbel 3-6-flowered; spathe-valves lanceolate, 2-3 in. long; pedicels slender, 1-2 in. long. Flowers bright red, erect or suberect, about 2 in. long; tube very short, coronulate at the throat; segments oblanceolate-unguiculate, obtuse, cuspidate, $\frac{1}{4}-\frac{1}{3}$ in. lroad. Stamens declinate, unequal, about half as long as the limb; anthers $\frac{1}{8} \mathrm{in.} \mathrm{long.} \mathrm{Style} \mathrm{longer}$ than the stamens; stigma trifid.

Hab. Plains of Buenos Ayres and Monte Video. Introduced by Lord Carnarvon about 1825. Flowers in March. I camnot separate as species Habranthus kermesimus Herb. (Bot. Reg. t. 1638), H. intermedius Herb. (Bot. Reg. t. 1148), H. nobilis, nemoralis, spathaceus, angustus (Bot. Mag. t. 2639), pulcher, and pedunculosus Herb. Received alive lately from Colonel Trevor Clarke and Miss F. Hall, of Paddington. A closely allied plant gathered by Jameson and Colonel Hall in the Andes of Ecuador will probably prove a distinet species.

8. H. Bagnoldi Baker in Journ. Bot. 1878, 83. Habranthus Ba!moldi Herb. in Bot. Reg. t. 1396. - Bulb globose, 2 in. diam. ; tunics nearly black. Leares linear, glaucous, a foot long. Peduncle slender, a foot long. Umbel 4-6-flowered; spathe-ralves lanceolate, $2 \mathrm{in.} \mathrm{long}$; pedicels finally 2-3 in. long. Flowers erect or suberect, openly funnel-shaped, $1 \frac{1}{2}-2 \mathrm{in}$. long, yellow, tinged with red; tube very short, funnel-shaped, coronulate at the throat; segments oblong, $\frac{1}{3}-\frac{1}{2}$ in. broad. Stamens rather shorter than the perianthlimb; anthers $\frac{1}{6}$ in. long. Style as long as the perianth; stigma trifid.

Hab. Chili, near Coquimbo, Cuming 865! Var. Gilliesianus Herb., from Melocoton, has smaller flowers than the type, pale yellow, with shorter pedicels. $H$. punctatus Herb., collected by Reynolds in South Chili, has copious small reduish dots on the flower-segments. 
9. H. Berteroanum Baker in Journ. Bot. 1878, 83. Hippeastrum Berterounum Philippi.-Leaves and bulb unknown. Peduncle 9-12 in. long. Umbel 5-6-flowered; spathe-valves lanceolate, $1 \frac{1}{2}-2$ in. long; pedicels sometimes as long. Flowers purple, unspotted, openly funnel-shaped, $2 \frac{1}{4}$ in. long; tube very short, minutely squamulose at the throat; segments oblanceolate, $\frac{1}{3} \mathrm{in}$. broad. Stamens much shorter than the flower.

Hab. Chili; Rancagua, flowering in January, Bertero.

10. H. Jamesoni Baker in Journ. Bot. 1878, 83. - Bulb and leaves not seen. Peduncle slender, $\frac{1}{2} \mathrm{ft}$. long. Umbel 2-4-flowered; spathe-valves lanceolate, $1 \frac{1}{2}-2 \frac{1}{2}$ in. long; pedicels shorter than the spathe. Flowers horizontal, ascending or cernuous, red, $2-2 \frac{1}{2}$ in. long; tube very short, funnel-shaped; segments oblong, acute, $\frac{1}{2}$ in. broad at the middle; lower inner narrower. Stamens declinate, unequal, about half as long as the segments. Style rather longer than the stamens; stigma trifid.

Hab. Argentine Republic; ravines near Jachal, flowering in February, Jameson!

\section{Subgenus Phycella.}

11. H. PHycelloides Baker in Journ. Bot. 1878, 83. Habranthus

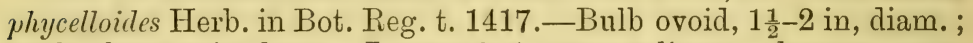
neck about $2 \mathrm{in}$. long. Leaves 3-4, narrow linear, glancous, contemporary with the flowers. Peduncle $\frac{1}{2}-1 \mathrm{ft}$. long. Umbel 3-6flowered; spathe-valves linear, $2-3 \mathrm{in}$. long; pedicels $1 \frac{1}{2}-2 \mathrm{in}$. long. Flowers erect or ascending, bright red, yellowish inwards; tube $\frac{1}{3} \mathrm{in}$. long, with a minute ciliated corona at the throat; segments oblanceolate, $\frac{1}{3}$ in. broad, connivent except at the tip. Stamens as long as the perianth; anthers $\frac{1}{6}$ in. long. Style exserted; stigma minutely tricuspidate.

Hab. Andes of Chili, Macrae! Reed! Introduced into cultivation in 1830. Connects the subgenera Habranthus and Phycella.

12. H. BIColor Baker in Journ. Bot. 1878, 83. Amaryllis bicolor R. \& P. A. cyrtanthoides Sims in Bot. Mag. t. 2399. A. iynea Lindl. Bot. Reg. t. 809. Phycella ignea, cyrtanthoides, magnifica, graciliflora, attemuata, brevituba, bicolor, and biflora Herb. (Bot. Reg. t. 1943). P. angustifolia Philippi. - Bulb globose, 2 in. diam.; tunics dark brown; neck 1-2 in. long. Leaves about 4 , contemporary with the flowers, linear, obtuse, $1 \frac{1}{2}-2 \mathrm{ft}$. long, about $\frac{1}{2} \mathrm{in}$. broad, narrowed to

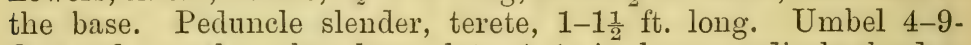
flowered; spathe-valves lanceolate, 1-1 $\frac{1}{2}$ in. long; pedicels slender, as long as the spathe. Flowers ascending, narrowly funnel-shaped, $1 \frac{1}{2}-2$ in. long, bright red, passing into yellowish green towards the base; tube short, funnel-shaped, appendiculate with 6 minute teeth at the throat; segments oblanceolate, with a long claw, connivent, $\frac{1}{3}$ in. broad near the tip. Stamens unequal, declinate, nearly as long as the segments. Style exserted; stigma capitate.

Hab. Frequent in Chili, about Valparaiso, \&c., flowering in October. I cannot make out any specific characters to separate the synonyms above cited. The finest variety is $P$. magnifica Herb., which has a perianth-limb 3 in. long. 
13. H. Herbertinum Baker in Joum. Bot. 1878, 83. 11. andinum Baker. L'hycella /lerbertiana Lindl. in Bot. Keg. t. 1341. Lihodophiula? andina Philippi.-Bulb globose, $1 \frac{1}{2}$ in. dian. Leaves 3-4, contemporary with the flowers, $1-1 \frac{1}{2}$ in. long, $\frac{1}{2} \mathrm{in}$. broad. Peduncle slender, a foot long. Umbel 4-6-flowered; spathe-valves lanceolate, 2 in. long; pedicels slender, 1-1 $\frac{1}{2}$ in. long. Flowers bright red, suberect, narrowly fumnel-shaped, above 2 in. long; tube very short; segments oblanceolate, acute, $\frac{1}{4}$ in. broad above the midalle. Stamens as long as the segments; anthers $\frac{1}{6}-\frac{1}{4} \mathrm{in}$. long. Style exterted; stigma capitate.

Hab. Chili ; Cordilleras of Santiago, Philippi! Introduced into cultivation by Macrae in 1825 , but now lost.

\section{Subgenus RHodophiala.}

14. H. nodestun Baker in Journ. Bot. 1878, 83. Lihendophliala modesta Philippi. - Bulb ovoid, $\frac{1}{2}$ in. diam.; tunics grey; neck 1-2 in. long. Leaves 2-3, narrow linear, developed after the flowers. Peduncle very slender, 1-flowered, protruded only about an inch from the neck of the bulb, Spathe of 2 linear valves $\frac{1}{2}$ in. long. Pedicel erect, $\frac{1}{4}$ in. long. Flower erect; tube very short; segments oblanceolate, acute, under 1-12ti in. broad, white, with a broad red keel. Stamens rather shorter than the segments. Style as long as the limb; stigma capitate.

Hab. Andes of Chili; Cuerta de los Molles, Philippi !

15. H. Rhodolinion Baker in Journ. Bot. 1878, 84. Rhodolivion andinum Philippi.-Bulb and leaves unknown. Peduncle 1-flowered, $1 \frac{1}{2} \mathrm{ft}$. long. Spathe-valves lanceolate, $1 \frac{1}{2}-2$ in. long; pecticel $\frac{3}{4}$ in. long. Perianth bright red, openly fumnel-shaped, 3 in. long; tube greenish, $\frac{3}{4} \mathrm{in}$. long. Stamens half as long as the limb. Style overtopping the stamens; stigma capitate.

Hab. Chili; Andes of the Province of St. Fernando, Bustillos.

16. H. uniflorum Baker in Journ. Bot. 1878, 83. Fihodulirion montanum. Philippi.-Bulb globose, $1 \frac{1}{2}$ in. diam. ; neck 2-3 in. long. Leaves linear, developed after the flowers. Peduncle 1-flowered, 2-4 in. long; spathe-valves linear, an inch long; pedicel very short. Flower erect, red, about 2 in. long; tube funnel-shaped, above $\frac{1}{2}$ in. long; segments oblong, acute, $\frac{1}{2}$ in. broad at the middle. Stamens half as long as the limb. Style erect, overtopping the stamens; stigma capitate.

Hab. Chili; Cordilleras of Santiago, Philippi! Judging from the description, Rhodophiala uniflora Philippi, from the Province of Atacama, differs from this by its shorter tube, which is only as long as the ovary.

17. H. moxtanum Balier in Journ. Bot. 1878, 83. Habranthus montanus Philippi.-Leaves linear, $\frac{1}{6}$ in. broad. Peduncle 9-12 in. long. Umbel 2-4-flowered: spathe-valves lanceolate, $1 \frac{1}{2}$ in. long; pedicels rather shorter. Perianth an inch long, openly funnelshaped, yellow; segments reflexing towards the tip. Stamens straight, slightly shorter than the perianth. Style just exserted; stigma faintly 3 -lobed.

Hab. Chili ; Province of Talca ; Cordillera of St. Francisco, Philippi. 
18. H. PRAtense Baker in Journ. Bot. 1878, 84. Habranthus pratensis Herb.; Bot. Reg. 1842, t. 35. Rhodophiala amarylloides Presl. Placea pratensis Poepp. Stephanoma elegans Kunze. Habranthus speciosus Herb.-Bulb ovoid, $1 \frac{1}{4}-1 \frac{1}{2}$ in. diam. ; neck short; tunics dark brown. Leaves linear, contemporary with the flowers in spring, 1-1 $\frac{1}{2} \mathrm{ft}$. long, $\frac{1}{4}-\frac{1}{2}$ in. broad. Peduncle moderately stout, 1-2 ft. long. Umbel 2-4-flowered; spathe-valves lanceolate, 2 in. long; pedicels $1-1 \frac{1}{2}$ in. long. Flowers bright red, ascending or horizontal; tube very short, appendiculate at the throat with minute linear scales; segments $2 \frac{1}{2}$ in. long, oblanceolate, $\frac{1}{2}$ in. broarl above the middle, subobtuse. Stamens declinate, more than half as long as the limb; anthers linear-oblong. Style declinate, as long as the limb; stigma capitate.

Hab. Hills and plains of Chili, introduced into cultivation about 1840. Received in 1872 alive from Mr. Tyerman. I cannot separate specifically Rhodophiola Volckmanni and R. leta Philippi, the latter a plant of the hills of Atacama.

\section{Subgenus Macropodastrum.}

19. H. solandriflorum Herb. App. 31 ; Bot. Mag. t. 2573 \& 3771; Lindl. Collect. t. 11; Lodd. Bot. Cab. t. 1200.-Bulb ovoid, 3-4 in. diam.; neck short. Leaves lorate, $1 \frac{1}{2} \mathrm{ft}$. long, above an inch broad. Peduncle slightly 2 -edged, $1 \frac{1}{2}-2 \mathrm{ft}$. long, Umbel 2-4flowered; spathe-valves lanceolate, $2-3 \mathrm{in}$. long; pedicels $1-1 \frac{1}{2}$ in. long. Perianth-limb funnel-shaped, 7-10 in. long; tube greenishcylindrical, 4-5 in. long; segments greenish white, obovate, 4-5 in. long, 1-1 $\frac{1}{2}$ in. broad. Stamens shorter than the segments; anthers linear-oblong. Style as long as the segments; stigma capitate.

Hab. North Brazil, Burchell! Gardner 3477! Guiana, Schomburgk 700! Appun 2328! Venezuela, Fendler 1505! Columbia, Lehmann 2140! Flowers in January. Introduced into cultivation in 1820.

\section{Subgenus Omphalissa.}

20. H. aulicum Herb. App. 31. Amaryllis aulica Gawl. in Bot. Mag. t. 3311; Bury, Hexand. t. 19 ; Lindl. in Bot. Reg. t. 444, 1038. - Bulb ovoid, 3 in. diam.; neck short. Leaves 6-8, lorate, bright green, $1 \frac{1}{2} \mathrm{ft}$. long, $1 \frac{1}{2}-2 \mathrm{in}$. broad. Peduncle stout, terete, $1 \frac{1}{2} \mathrm{ft}$. long. Umbel generally 2 -flowered; spathe-valves lanceolate, red-brown, 3-4 in. long; pedicels $1 \frac{1}{2}-2$ in. long. Perianth-limb $5-6$ in. long; tube short, with a distinct incurved green corona at the throat; segments bright crimson, grieen at the base; outer segments and lowest inner about an inch broad above the middle; 2 upper: inner much broader. Stamens shorter than the segments; filaments bright red; anthers $\frac{1}{2}-\frac{3}{4}$ in. long. Style as long as the segments; stigma deeply trifid. Var. stenopetalum Bot. Reg. t. 444, has all the segments much narrower than in the type.

Hab. Central Brazil, Gardner 5210! Regnell 440! Weir 314! Introduced into cultivation in 1819. I cannot distinguish as species H. Heuserianum Karst. Fl. Columb. t. 102, gathered by Dr. Heuser at St. Paulo, H. robustum A. Dietr. or Amaryllis Rougieri Carriere in Rev. Hort. 1882, 312, with coloured figure. A form gathered by Balansa in Paraguay (529) has segments only $\frac{1}{2}-\frac{3}{4}$ in. broad. 
21. H. organense Hook. in Bot. Mag. sub t. 3803. Amaryllis aulica var. glaucophylla Bot. Mag. t. 2983. A. Gardneri Seubert. A. correiensis Bury, Hexand. t. 9.-Bulb large; neck short. Leaves 5-6, lorate, glancous, 1-1 $\frac{1}{2} \mathrm{ft}$. long, $1 \frac{1}{2}$ in. broad, acute. Peduncle stout, $1 \frac{1}{2} \mathrm{ft}$. long. Umbel generally 2 -flowered; spathe-valves lanceolate, 3-4 in. long; pedicels much shorter than the spathe. Perianth-limb 5-6 in. long; tube $\frac{1}{2} \mathrm{in}$. long, funnel-shaped, with a small incurved green corona at the throat; segments bright crimson, with a green keel in the lower half, oblong, acute; outer $1 \frac{1}{2}-1 \frac{3}{4}$ in. broad at the middle; inner lower much narrower. Stamens nearly as long as the scgments; filaments bright red; anthers linear-oblong, $\frac{1}{3} \mathrm{in}$. long. Style as long as the segments; stigma deeply trifid.

Hab. Souch Brazil; Organ Mountains, alt. 4000-5000 ft., Bowie and C'unningham! Gardner 686! 688! Glaziou 8932! Closely allied to II. aulicum.

22. H. psittacinum Herb. App. 31. Amaryllis psittacina Gawl. in Bot. Reg. t. 199 ; Lodd. Bot. Cab. t. 120t; Bury, Hexand. t. 23. - Bulb 3-4 in. diam.; neck produced. Leaves 6-8, lorate,

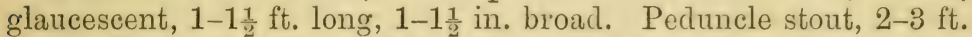
long. Umbel 2-4-flowered; spathe-valves lanceolate, longer than the pedicels. Perianth-limb 4-5 in. long; tube very short, broadly funnel-shaped, with a distinct incurved greenish red corona; segments oblong, acute, undulated, 1-1 $\frac{1}{4}$ in. broad, with a crimsou edge, a green keel, and crimson stripes radiating from the keel. Stamens much shorter than the limb. Style shorter thah the limb; stigma trifid.

Hab. South Brazil, introduced into cultivation in 1814. Flowers in spring. H. Grifjini Herb. (Bot. Mag. tl 3528) is a fine hybrid between psittacinum and Johnsoni.

23. H. calyptratun Herb. App. 31. Amaryllis calyptrata Gawl. in Bot. Reg. t. 164; Lodd. Bot. Cab. t. 864. A. fulvovirens Schott. A. unguiculata Morren.-Bulb globose, 3 in. diam.; tunies brown ; neck short. Leaves 5-6, lorate, acute, bright green, $1 \frac{1}{2}-2 \mathrm{ft}$. long, 2 in. broad. Peduncle terete, green, $2 \mathrm{ft}$. long, $\frac{1}{2}-\frac{3}{4}$ in. diam. Umbel 2-3-flowered; spathe-valves lanceolate, 3 in. long ; pedicels shorter than the spathe. Perianth-limb 4 in. long; tube funnelshaped, $\frac{3}{4} \mathrm{in}$. long, with a distinct incurved corona at the throat; segments oblong-unguiculate, acute, $1 \frac{1}{4}-1 \frac{1}{2}$ in. broad, pale yellow, reticulated on the face with cross-bars of green. Stamens exserted; anthers linear-oblong, $\frac{1}{3}$ in. long. Style exserted; stigma deeply trifid.

Hab. Brazil, Gardner 687! Introduced in 1816. Described from a plant flowered by Messrs. Veitch in May, 1877.

24. H. Cyвister Benth. in Gen. Plant. iii. 725. Sprelielia Cybister Herb. in Bot. Reg. 1840, t. 33 ; Bot. Mag. t. 3872; Flore des Serres, t. 455-6. - Bulb ovoid, brown, 2 in. diam. Leaves produced after the flowers, lorate, green, $1-1 \frac{1}{4} \mathrm{in}$. broad. Peduncle above $2 \mathrm{ft}$. long, glaucescent, subterete, purple downwards. Umbel 4-6-flowered; spathe-valves lanceolate, reddish; pedicels stout. Perianth-limb 3-4 in. long; tube very short, with an incurved 
bearded neck at the throat; segments bright crimson, tinged with green towards the tip and outside, narrowed gradually from near the base to the acute point, the three upper twisted up, the three lower close together. Stamens 1-1 $\frac{1}{2}$ in. longer than the segments; filaments greenish; anthers oblong, $\frac{1}{4}$ in. long. Stigma small, minutely 3 -lobed.

Hab. Andes of Bolivia. Introduced into cultivation about 1840, but now lost. Connects Sprekelia and Hippeastrum.

25. H. Pardinum Dombrain in Floral Mag. t. 344. Amaryllis pardina Hook. fil. in Bot. Mag. t. 5645. - Bulb globose, 2-3 in. diam.; neck short. Leaves 5-7, fully developed after the flowers, lorate, bright green, finally $2 \mathrm{ft}$. long, $2 \mathrm{in}$. broad at the middle, narrowed to 1 in. near the base. Peduncle glaucous, subterete, $1 \frac{1}{2} \mathrm{ft}$. long. Umbel generally 2 -flowered; pedicels $1 \frac{1}{2}-2$ in. long; spathe-valves lanceolate, 2 in. long. Perianth-limb 4 in. long; tube funnel-shaped, under $\frac{1}{2} \mathrm{in}$. long; with a distinct incurved greenish yellow fimbriated corona at the throat; segments oblongunguiculate, acute, $1 \frac{1}{2}-1 \frac{3}{4}$ in. broad above the middle, greenish, more or less flushed and copionsly minutely spötted with red, not vittate, upper broader and lowest inner narrower than the others. Stamens declinate, a little-shorter than the segments; anthers $\frac{1}{2}$ in. long. Style as long as the segments; stigma faintly 3-lobed.

Hab. Andes of Peru; discovered by Pearce; first flowered by Messrs. Veitch in 186\%. Described from a plant that flowered at Kew in February, 1882, and a specimen received from M. André the same year.

\section{Subgenus Aschamia.}

26. H. Andreanum Baker in Gard. Chron. 1880, ii. 424.-Bulb $4-4 \frac{1}{2}$ in. diam., copiously proliferous; tmics brownish grey; neck short. Leaves lorate, developed after the flowers. Peduncle 12-15 in. long, brownish violet, slightly 2-edged. Umbel 4-6-flowered; spathe-valves 2 , rose-red, lanceolate, $1 \frac{1}{2}-2$ in. long; pedicels $1-1 \frac{1}{2}$ in. long. Perianth-limb 4 in. long; tube very short, not coronulate at the throat; segments oblanceolate-oblong, acute, $\frac{1}{2}-\frac{3}{4}$ in. broad above the middle, pale red, with streaks of brighter red, not vittate

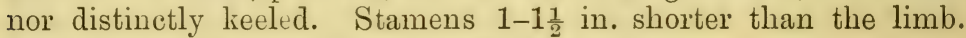
Style longer than the stamens; stigma capitate.

Hab. Central Cordilleras of Nerv Granada, alt. 6000-8000 ft., on the banks of one of the branches of the Rio Cauca. Discovered by M. André in 1876.

27. H. Regrne Herb. App. 31. H. regium Herb. Amaryllis Regince L.; Miller, Ic. t. 24 ; Bot. Mag. t. 453 ; Red. Lil. t. 9 ; Bury, Hexand. t. 24. - Bulb globose, 2-3 in. diam. Leaves fully developed after the flowers, $2 \mathrm{ft}$. long, $1 \frac{1}{2} \mathrm{in}$. broad at the middle, narrowed gradually to $\frac{1}{2}$ in. near the base. Peduncle $1-1 \frac{1}{2} \mathrm{ft}$. long. Umbel 2-4-flowered; spathe-valves lanceolate, 2-3 in. long, equalling the pedicels. Perianth-limb bright red, 4-5 in. long; tube funnelshaped, $\frac{1}{3}-\frac{1}{2}$ in. long; throat with a large greenish white star;

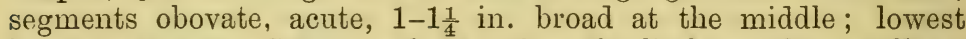
inner narrower. Stamens shorter than the limb; anthers yellow, $\frac{1}{6}-\frac{1}{4} \mathrm{in}$. long. Style as long as the limb; stigma faintly 3 -lobed. 
Hab. Mexico and West Indies to Brazil and Peru. (Native area doubtful). H. africanum Welw. herb., from "aboriginal woods on Prince's Island, alt. $3500 \mathrm{ft}$., "appears to be a form of this species. Amaryllis Alberti Lemaire in Ill. Hort. t. 498, is probably a double-flowered form. Introduced into cultivation in 1728, and called Lilium Regine by Dr. James Douglas in honour of Caroline, the wife of our George II. I have not seen the Venezuelan $I$. promum K. Koch, nor the Peruvian H. stenopetalum A. Dietr., briefly noticed by K. Koch in Wockenschrift, 1874, p. 37.

28. H. miniatum Herb. App. 31. Amaryllis miniata Ruiz \& Pavon. -Bulb ovoid, 2-3 in. diam; neck short. Leaves lorate, $1 \frac{1}{2}-2 \mathrm{ft}$. long, an inch broad above the middle. Peduncle 1-1 $\frac{1}{2} \mathrm{ft}$. loug. Umbel 2-4-flowered; spathe-valves lanceolate, 2 in. long; pedicels 2-3 in. long.: Perianth-limb $3 \frac{1}{2}-4$ in. long, bright red; tube $\frac{1}{4}$ in. long, obscurely coronulate at the throat; segments obovate, subacute, 1-1 $\frac{1}{4}$ in. broad; inner segments narrower than the outer, especially the lowest. Stamens a little shorter than the limb; anthers linear-oblong, $\frac{1}{4}$ in. long. Style reaching to the tip of the segments ; stigma capitate.

Hab. Andes of Peru, Pavon! Quebrada of Pariahuanca, Matthews! Not known in cultivation.

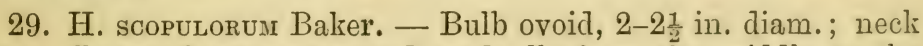
short. Leaves lorate, narrowed gradually from the middle to the base. Peduncle a foot long. Umbel 2-flowered; spathe-valves lanceolate, $1 \frac{1}{2}-2 \mathrm{in.} \mathrm{long;} \mathrm{pedicels} \mathrm{as} \mathrm{long} \mathrm{as} \mathrm{the} \mathrm{spathe.} \mathrm{Periantl-}$ limb bright crimson, $2 \frac{1}{2}-3$ in. long; tube very short, funnel-shaped; upper outer segment $\frac{3}{4}$ in. broad at the middle; lower inner $\frac{1}{2}$ in. Stamens as long as the perianth. Style a little exserted; stigma capitate.

Hab. Andes of Bolivia; Sorata, temperate region, alt. 8000-9000 ft., Mandon 1193 ! Allied to H. Regine and miniatum.

30. H. Mandoni Baker. - Bulb ovoid, 2-3 in. diam. Leaves lorate, $2 \mathrm{ft}$. long, an inch broad at the middle. Peduncle stout, 1-flowered; spathe-valves lanceolate, $3-4$ in. long; pedicel 2 in. long. Flower erecto-patent, bright crimson; perianth-limb 5 in. long; tube greenish, funnel-shaped, $\frac{1}{2} \mathrm{in}$. long; segments obovate, acute; outer $1 \frac{1}{2} \mathrm{in}$. broad; upper the longest; inner all above an inch broad. Stamens much shorter than the limb; anthers yellow; $\frac{1}{4}$ in. long. Style nearly as long as the limb; stigma capitate.

Hab. Andes of Bolivia ; near Sorata, temperate region, alt. 8000-9000 ft., Mandon 1195! Intermediate in general appearance between $H$. Regince and aulicum. It may be identical with H. Warszewiczianum A. Dietr., briefly described by K. Koch, Wochenschrift, 1864, 38.

31. H. Leopoldi Dombrain in Floral Mag. t. 475-6. Amaryllis Leopoldi Moore in Gard. Chron. 1870, 733, fig. 140.-Bulb globose, 2-3 in. diam.; neck short. Leaves lorate, finally $1 \frac{1}{2}-2 \mathrm{ft}$. long. Peduncle stout, subterete. Spathe-valves lanceolate. Perianthlimb the most regular of all the species, 5 in. long, 6-7 in. diam. when fully expanded; tube short, without any distinct incurved corona at the throat; segments obovate, 2 in. broad, white towards the tip, bright red at the middle, with a bifid white keel in the lower half of the red, and a large greenish white throat. Stamens declinate, rather shorter than the segments; filaments white; 
anthers purplish, above $\frac{1}{2} \mathrm{in}$. long. Style longer than the stamens; stigma capitate.

Hab. Andes of Peru, discovered by Pearce. First flowered by Messrs. Veitch in 1869, and named in honour of Leopold, King of the Belgians.

32. H. procerum Lemaire in Ill. Hort. xi. 408. Amaryllis procera Duchartre; Flore des Serres, t. 2077-8. A. Rayneri Hook. fil. in Bot. Mag. t. 5883.-Bulb large, ovoid, with a long neck. Leaves about a dozen, distichous, falcate, ensiform, finally 2-3 ft. long, $1 \frac{1}{2}-2$ in. broad, firm in texture, cartilaginous on the edge. Peduncle $1-1 \frac{1}{2} \mathrm{ft}$. long, much compressed, ancipitous, shorter than the leaves, 1-1 $\frac{1}{4} \mathrm{in}$. diam. Umbel 4-12-flowered; spathe-valves $2-3 \mathrm{in.} \mathrm{long,}$ exceeding the pedicels. Perianth-limb 5-6 in. long, lilac, not starred at the throat; tube very short; segments oblanceolate, acute, under an inch broad. Stamens much shorter than the limb; anthers yellow, $\frac{1}{2}$ in. long. Stigma capitate.

Hab. South Brazil, near Petropolis. Introduced by Binot about 1863, in which year it was described by Duchartre. Very distinct.

33. H. equestre Herb. App. 31. Amaryllis equestris Ait.; Jacq. Hort. Schoen. t. 63 ; Bot. Mag. t. 305 ; Red. Lil. t. 32 . A. punicen Lam. H. occidentale Roem. A. Belladonna Swartz, non Linn.Bulb stoloniferous, globose, 2 in. diam.; tunics brown; neck short. Leaves 6-8, fully developed after the flowers, lorate, bright green, $1 \frac{1}{2} \mathrm{ft}$. long, $1 \frac{1}{2}-1 \frac{3}{4}$ in. broad, narrowed gradually to the point. Peduncle terete, rather glaucous, $1 \frac{1}{2}-2$ ft. long. Umbel 2-4flowered; spathe-valves green, lanceolate; pedicels $2-3 \mathrm{in}$. long. Perianth-limb 4-5-in. long, 4 in. diam. when expanded; tube green, an inch long, obscurely coronulate at the throat; base of the segments yellowish green; upper part bright red; 3 outer $1 \frac{1}{4}-1 \frac{1}{2}$ in. broad ; 3 inner narrower, especially the lowest. Stamens shorter than the segments; anthers small, oblong. Stigma obscurely 3-lobed.

Hab. Throughout Tropical America from Mexico and the West Indies to Chili and Brazil. Var. major Bot. Reg. t. 234; Bury, Hexand. t. 41, is a form with very large flowers. The species was first noticed by Hermann in 1698. Described from plants that flowered at Kew in 1873 and 1879. I cannot find any specific character by which to distinguish A. Roezli Regel in Gartenflora, 1874, 290, t. 809, gathered by Roezl in the Andes of Bolivia. H. barbatum Herb. (Crinum barbatum Linn. herb.) is apparently not more than a whiteflowered variety of this species. H. pyrrochroum Lemaire in Ill. Hort. t. 420, and $H$. spathaceum Sims in Bot. Mag. t. 2315 , are probably both also varieties.

34. H. Reticulatum Herb. in Bot. Mag. sub t. 2475. Amaryllis reticulata L'Herit. Sert. Angl. 12, t. 14; Bot. Nag. t. 657 ; Andr. Bot. Rep. t. 179 ; Red. Lil. t. 424 . Coburgia reticulata Herb. Leopoldia reticuluta Herb. - Bulb subglobose; neck short. Leaves 4-6, thin, oblanceolate, bright green, 2 in. broad above the middle, narrowed gradually to the base. Peduncle nearly terete, a foot long. Umbel 3-5-flowered; spathe-valves lanceolate, 2 in. long; pedicels $1-1 \frac{3}{4}$ in. long. Perianth-limb $3 \frac{1}{2}-4$ in. long; tube $\frac{1}{2}-1$ in. long, not coronulate at the throat; segments obovate-unguiculate, connivent in the lower half, an inch broad at the middle, bright mauve-red, with copious cross-bars of a deeper shade. Stamens 
shorter than the perianth. Stigma faintly 3-lobed. Seeds fewer and less compressed than in the other species.

Var. H. Striatifoliun Herb. Amaryllis reticulata var. strintifolia Herb. in Bot. Mag. t. 2513; Bot. Reg. t. 352 ; Bury, Hexand. t. 48. - Leaves broader, with a distinct white keel. Perianthsegments hardly at all reticulated with cross-bars.

Hab. South Brazil. There is a specimen at the British Museum, dried from the gardens of MIessrs. Lee, of Hammersmith, in 1781. It was introduced in 1777. The only indigenous specimens I have seen were gathered by Burchell in March, 1826, on the shores of Botafogro Bay and near the village of Sao Domingas.

35. H. styuosum Herb. in Bot. Mag. t. 2278. Amaryllis stylosa Bury, Hexand. t. 33. A. maranensis Gawl. in Bot. Reg. t. 719. A. staminea Seub. - Bulb globose, 3 in. diam. Leaves 4-6, bright green, lorate, $1 \frac{1}{4}-1 \frac{1}{2}$ in. broad. Peduncle $1 \frac{1}{2} \mathrm{ft}$. long. Umbel 3-8. flowered; spathe-valves lanceolate; pedicels 1-2 in. long. Perianthlimb 4 in. long, bright flesh-red; tube $\frac{1}{2} \mathrm{in.}$ long, obseurely fimbriate at the throat; segments oblong, acute, under an inch broad. Stamens a little exserted; anthers linear-oblong, $\frac{1}{4} \mathrm{in.}$ long. Style much exserted; stigma capitate.

Hab. Guiana and North Brazil, Burchell 9819! Gardner 1167! Introduced by Lord Carnarvon from Marantham in 1821. Described from a plant flowered by Messrs. Backhouse in May, 1878.

\section{Subgenus LaIs.}

36. H. Rutilum Herb. App. 41. Amaryllis rutila Gawl. in Bot. Reg. t. 23 ; Lodd. Bot. Cab. t. 1449. H. bulbulosum var. rutilum Herb.-Bulb subglobose, stoloniferous, 2-3 in. diam. ; neck short; tunics pale. Leaves 6-8, lorate, bright green, a foot long, above an inch broad. Peduncle glaucous, slightly compressed, a foot long. Umbel 2-4-flowered; spathe-valves lanceolate, $1 \frac{1}{2} \mathrm{in}$. long; pedicels slender, as long as the spathe. Perianth-limb 3-4 in. long; tube green, cylindrical, $\frac{3}{4}$ in. long, obscurely coronulate at the throat; segments oblong, acute, bright crimson, with a green keel extending halfway up, $\frac{3}{4}-1 \mathrm{in}$. broad at the middle, the lower inner narrower. Stamens shorter than the segments ; filaments red; anther's linearoblong, $\frac{1}{4}$ in. long. Style as long as the limb; stigma trifid.

Var. H. Fulgidun Herb. Amaryllis fulgida Gawl. in Bot. Reg. t. 226 ; Bury, Hexand. t.26. A. miniata Sims in Bot. Mag. t. 1943; Bury, Hexand. t. 35, non R. \& P. A. bresiliensis Tratt. Tab. t. 333. H. subbarbatum Herb. in Bot. Mag. t. 2475. H. bulbulosum, vars. subbarbatum, unguiculatum, fulyidum, Simsianum, and equestriforme Herb.--More robust. Bulb 3-4 in. diam. Leaves broader. Perianthlimb 4-5 in. long; tube 1 in. long; segments bright scarlet, with a green base and lieel in the lower half, more ovate, $3-4 \mathrm{in}$. long, outer 1-1 $\frac{1}{4}$ in., inner lower about $\frac{3}{4}$ in. broad.

Var. H. crocatum Herb. Amaryllis crocata Gawl, in Bot. Peg. t. 38. -- Habit as robust and leaves as broad as in fulyidum, but flower smaller, saffron-coloured, with more undulated segments.

Var. citrinun Baker. Amaryllis crocate Bury, Hexand. t. 16.Flower bright yellow. 
Var. H. Acumrnatum Roem. Amaryllis acuminata Gawl. in Bot. Reg. t. 534 \& 1188. A. pulverulenta Lodd. Bot. Cab. t. 184 ; Bury, Hexand. t. 45. H. pulverulentum Herb. in Bot. Mag. t. 2273.-Flowers pale pink; segments very acute.

Hab. South Brazil, especially about Rio Janeiro, Miers 3123 ! 3598! Glaziou 8991! Tweedie! Vauthier! H. Martianum and bahiense Roem., and $H$. glaucescens Herb. appear to be also varieties of this very variable species. Introduced into cultivation about 1810 .

37. H. viтtatum Herb. App. 31. Amaryllis vittata Ait.; Bot. Mag. t. 129 ; L'Herit. Sert. t. 15 ; Red. Lil. t. 10 ; Bury, Hexand. t. 32 \& 40. - Bulb globose, 2-3 in. diam. Leaves 6-8, lorate, bright green, $1 \frac{1}{2}-2 \mathrm{ft}$. long. Peduncle $2-3 \mathrm{ft}$. long. Umbel 2-6flowered; spathe-valves lanceolate, $2-3 \mathrm{in}$. long; pedicels as long as the spathe. Perianth-limb 4-6 in. long; tube funnel-shaped, an inch long, obscurely coronulate at the throat; segments obovateoblong, acute, $1-1 \frac{1}{2}$ in. broad, white towards the edge and distinctly keeled with white, striped with bright mauve-red between the keel and edge; expanded limb 3-5 in. diam. Stamens shorter than the perianth-limb; anthers linear-oblong, $\frac{1}{4}$ in. long. Style as long as the limb ; stigma deeply trifid.

Hab. Andes of Peru, introduced into Europe in 1769. There is a specimen at the British Museum dried from the garden of Mr. Malcolm in 1777. Flowers in April and May. It varies much in the size of the flower and distinctness of the stripes. Var. minor Bury, Hexand. t. 40 , has a perianth 4 in. long. Var. Harrisonice Lindl. Bot. Reg. t. 988, is probably a hybrid between vittatum and solandriflorum (Bury, Hexand. t. 27).

38. H. BReviflorum Herb. Amaryll. 137, t. 21, fig. 4 ; Bot. Mag. t. 3549. - Bulb ovoid, 2-3 in. diam. Leaves lorate, green, $1 \frac{1}{2} \mathrm{ft}$. long, $1 \frac{1}{4}-1 \frac{1}{2}$ in. broad. Peduncle terete, glancous, $2-3 \mathrm{ft}$. long. Umbel 5-6-flowered; spathe-valves lanceolate; pedicels slender, 2-3 in. long. Perianth-limb $2 \frac{1}{2}$ in. long, funnel-shaped; tube very short; segments oblanceolate-oblong, subacute, white, keeled with red, the outer $\frac{3}{4}$ in. broad above the middle, the lowest inner $\frac{1}{2}$ in. Stamens shorter than the limb; anthers small, oblong. Style shorter than the limb; stigma trifid.

Hab. Buenos Ayres, Tweedie! First flowered in cultivation at Glasgow in April, 1836.

\section{Hybrids.}

The broad-leaved species of Hippeastrum hybridise with great facility, and the original hybrids can be easily intercrossed. Since the year 1799, when $H$. Regince was first crossed with $H$. vittatum by a watchmaker of Prescot, in Lancashire, called Johnson, after whom the hybrid was named, a very large number of beautiful types have been produced. About 100 of these, with Latin names, are enumerated, and their parentage given in the second edition of Sweet's 'British Flower Garden,' in 1830.* Up to that time the

* See also Herbert, Amaryll. 335 ; Trans. Hort. Soc. iii. 196, iv. 42 ; Journ. Hort. Soc. ii. 19; Gowen in Trans. Hort. Soc. iv. 498; Lindley in Trans. Hort. Soc. v. 337 ; Kunth, Enum. v. 529 ; Miss Rosenberg's 'Corona Amaryllidacea, published at Bath in 1839, with coloured plates of five hybrids; Dietrich in Berlin Gartenzeit. 1884, 121; K. Koch, Wochenschrift, 1864, 17, 30, 37; Goldring in Garden, 1883, 193; Douglas in Garden, 1887, 250, t. 614; and G. Don in Sweet, Brit. Flow. Gard. ed. 3, pp. 671-675. 
principal species crossed were Rerjinc, reticulatum, vittatum, aulicum, and solundriflorum; and rarely equestre, psittucinum, fulgidum, and stylosum. Since 1870 pardinum and Leopoldi have been largely used, especially the latter. 1 will only attempt here to enumerate a few of the hybrid types which have been figured or to which Latin names have been given.

Forms nearest Rergina : -Johnsoni Bury, Hexand. t. 1; brusiliensis Red. Lil. t. 469; Gravina Melazzo; Carnarvoniu A. DC. Pl. Par. Hort. Genev. t. 9 ; spectabile Lodd. Bot. Cab. t. 159.

Forms nearest aulicum:-Ackermanni; Ackermanni pulcherrima Moore, Mag. 1850, ii. 5; Chelsoni Floral Mag. t. 545; Mendeli Floral Mag. n. s. t. 167; also Floral Mag. t. 97, and new series, tabs. 77,347 , and 359 .

Forms nearest reticulatum:-Sucetii, Colvillei, praclara, formosa, gloriosu, and Goweni. Recent forms, Flore des Serres, t. 2427; Floral Mag. t. 383, and new series, tabs. 22 and 153.

Forms nearest solandriflorum:--Crossed with vittatum it gives ambigun Bot. Mag. t. 3542; also forms figured Bot. Reg. t. 876, and Gartenflora, tabs. 949 and 956 ; also picta Bury, Hexand. t. 5, a fine cross with Johnsoni, figured Bury, Hexand. t. 46, Harrisoni Bury, Hexand. t. 21, and marginata, Croomii, Haylocki, Herberti, and Carnarvoni.

Vittatum has been largely crossed with the four foregoing species.

Pardinum gives the spotted types in Veitch's recent hybrids. A fine cross between this and Leopoldi is figured Gard. Chron. 1877, fig. 136.

Forms near Leopoldi:-A form very near the type is Hendersoni Floral Mag. n. s. t. 117. The best hybrids recently raised by Mr. Heal for Messrs. Veitch at the present day have an open regular flower, with scarcely any tube and much imbricated segments, derived from Leopoldi, combined with a brilliant scarlet colour, probably derived from Regine through Johnsoni.

\section{Vallota Herb.}

Perianth erect, with a long broadly funnel-shaped tube and 6 equal ascending oblong connivent segments, with a pulvinate callus at the base. Stamens inserted below the throat of the perianthtube; filaments filiform; anthers oblong, versatile. Ovary 3-celled; ovules many, superposed; style filiform; stigma capitate. Capsule ovoid-oblong, obtusely angled, loculicidally 3 -valved. Seeds black, compressed, produced into a wing at the base.

1. V. purpurea Herb. App. 29. Amaryllis purpurea Ait.; Gawl. in Bot. Mag. t. 1430. A. speciosa L'Herit. Crinum speciosum Linn. fil. -- Bulb large, ovoid. Leaves subdistichous, lorate, contemporary with the flowers, finally $1 \frac{1}{2}-2 \mathrm{ft}$. long, dying down in autumn. Peduncle hollow, slightly 2-edged, 2-3 ft. long. Umbel 6-9 flowered; spathe-valves oblong-lanceolate, 2-3 in. long; pedicels shorter. Flowers erect, bright scarlet; tube longer than the segments, $\frac{3}{4} \mathrm{in}$. diam. at the throat; segments about $2 \mathrm{in}$. long, 1 in. broad. Stamens reaching halfway up the segments. Style 
reaching to the tip of the segments. $V$. elata Roem. (Amaryllis elata Jacq. Hort. Schoen. i. t. 62) is a form with smaller cherry-red flowers. Var. minor Ker in Bot. Reg. t. 552, is a similar form. Var. magnifica Hort. is a form with large bright scarlet flowers, with a whitish throat.

Hab. Cape Colony; Southern provinces. Introduced into cultivation by Masson in 1774. There is a white-flowered variety. Cyrtanthus hybridus N. E. Brown in Gard. Chron. 1885, vol. xxiv. p. 391, is a hybrid between Vallota and Cyrtanthus sanguineus, most resembling the former.

\section{Cyrtanthus Ait.}

Perianth funnel-shaped, with a narrow tube with a naked throat, two or three times the length of the oblong segments. Stamens inserted below the throat of the perianth-tube; filaments filiform, sometimes very short; anthers oblong, dorsifixed, versatile. Ocury 3-celled; ovules numerous, superposed ; style long, filiform; stigma distinctly or indistinctly 3-lobed. C'apsule oblong, loculicidally 3 -valved. Seeds flat, black, produced into a wing at the base.--liootstock a tunicated bulb. Leares persistent, linear or lorate. Peduncle hollow. Flowers erect or pendulous, usually red or white, with green stripes. Spathe-valves 2-4, green, lanceolate.

Subgenus Cyrtanthus proper. Flowers many in an umbel, pendulous. Leaves lorate. . Sp.1-3.

Subgenus Monelra. Flowers many in an umbel, usually pendulous. Leaves linear.

$\begin{array}{lll}\text { Flowers red } & \cdot & \text { Sp.4-13. } \\ \text { Flowers white } & \text { : } & \text { Sp. 14. } \\ \text { Flowers yellow } & \text {. } & \text { Sp. 15. }\end{array}$

Subgenus Gastronema. Flowers 1 or few in an umbel, erect or slightly decurved. Perianth-tube more open.

$\begin{array}{ll}\text { Leaves linear } & \text { Sp. 16-19. } \\ \text { Leaves lanceolate } \quad & \text { Sp. } 20 .\end{array}$

1. C. obliquus Ait. Hort. Kew. i. 414 ; Jacq. Hort. Schoen. i. t. 75 ; Andr. Bot. Rep. t. 265 ; Bot. Reg. t. 1133 ; Red. Lil. t. 381. Crinum obliquam Linn. fil. Agapanthus Umbrella L'Herit. -- Bulb ovoid, 3-4 in. diam. Leaves 10-12, lorate, distichous, produced after the flower's, $1 \frac{1}{2}-2 \mathrm{ft}$. long. Peduncle stout, subterete, mottled, 1-2 ft. long. Flowers 10-12 in an umbel, very drooping, bright red, with a yellowish base, inodorous, $2-3 \mathrm{in}$. long; pedicels $\frac{1}{2}-1 \mathrm{in}$. ; spathe-valves usually 4 , lanceolate, reflexing. Perianth-tube curved, twice as long as the oblong segments, $\frac{1}{3}-\frac{1}{2}$ in. diam. at the throat. Stamens biseriate; filaments short, an inch long. Style reaching to the tip of the segments; stigma capitate.

Hab. Cape Colony; Southern provinces. Flowers in May and June. Introduced into cultivation by Masson in 1774 .

2. C. carneus Lindl. in Bot. Reg. t. 1462.--Bulb ovoid, 2-3 in. diam. Leaves 8-10, lorate, produced after the flowers, glancous, 
twisted, $1 \frac{1}{2} \mathrm{ft}$. long. Peduncle subterete, glaucous, a foot or more long. Flowers 8-10 in an umbel, very cernuous, bright red,

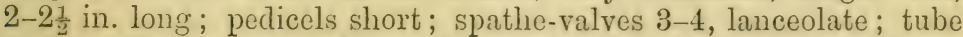
twice as long as the oblong segments, $\frac{1}{3} \mathrm{in}$. diam. at the throat. Stamens inserted in the tube; filaments an inch long. Style reaching to the tip of the segments; stigma capitate.

Hab. Cape Colony; Southern provinces, Drége! Thom! Hacowan 2619! Closely allied to C. obliquus.

3. C. Hutroni Baker. - Leaves lorate, contemporary with the flowers, a foot long, $\frac{1}{2}-\frac{3}{4}$ in. broad. Peduncle moderatcly stout, above a foot long. Umbel 6-8-flowered; spathe-valves 2, oblonglancoolate, $1 \frac{1}{2} \mathrm{in}$. long; pedicels erect, $\frac{1}{2}-1 \mathrm{in}$. long. Perianth pale red, about an inch long including the ovary; tube curved, narrowly fumnel-shaped, $\frac{1}{8}-\frac{1}{6}$ in. diam. at the throat, twice as long as the oblong segments. Stamens biseriate; filaments very short. Style reaching halfway up the limb; stigma tricuspidate.

Hab. Cape Colony; Province of Albany, Hutton! Described from a plant that flowered at Kew in May, 1864.

\section{Subgenus Monelia (Herb.).}

4. C. BRachyscyphus Baker. - Bulb ovoid. Leaves about 3, contemporary with the flowers, linear, 9-10 in. long. Scupe slender, terete, glancous, as long as the leaves. Umbel 6-8flowered; spathe-valves 2, lanceolate, an inch long; peclicels $\frac{1}{2}-\frac{3}{4}$ in. long. Flowers pale red; tube narrowly funnel-shaped, $\frac{1}{6} \mathrm{in}$. diam. at the throat, a little longer than the oblong-lanceolate segments. Stamens inserted near the throat of the tube; filaments $\frac{1}{6}$ in. long. Style overtopping the anthers.

Hab. Port Grosvenor, Pondo-land. Described from a specimen sent by Mr. Tillett, of Sprowston, near Norwich, in July, 1886.

5. C. Welwitschir Hiern; Baker in Journ. Bot. 1878, 197. Bulb ovoid, $1 \mathrm{in}$. diam. Leaves about 4, contemporary with the flowers, linear, glaucous, 1-1 $\frac{1}{2} \mathrm{ft}$. long, $\frac{1}{4}-\frac{1}{3} \mathrm{in}$. broad. Peduncle slender, as long as the leaves. Umbel 3-8-flowered; spathe-valves 2 , lanceolate, $1 \frac{1}{2}-2$ in. long; pedicels slender, erect, $1-1 \frac{1}{2}$ in. long. Perianth red, erect, $1 \frac{1}{4}-1 \frac{1}{2}$ in. long; tube funnel-shaped, $\frac{1}{6}-\frac{1}{4} \mathrm{in}$. diam. at the throat, rather longer than the oblong-lanceolate segments. Stamens biseriate; filaments short; anthers oblong. Style reaching halfway up the limb; stigma tricuspidate. Capsulevalves oblong, $\frac{3}{4}$ in. long.

Hab. Mountains of Angola, subtemperate region, Welwitsch! H. H. Johnston!

6. C. sprratis Burchell; Gawl. in Bot. Reg. t. 167. Monella spiralis Herb. - Bulb ovoid, $1 \frac{1}{2}$ in. diam. Leaves $2-3$, produced after the flowers, linear, weak, spirally-twisted, glancous, 6-9 in. long. Peduncle slender, glaucous, a foot long. Umbel 4-6flowered; spathe-valves 2, lanceolate, an inch long ; pedicels ascending, $\frac{1}{2}-1$ in. Flowers bright red, inodorous, $1 \frac{1}{2}-2$ in. long; tube curved, $\frac{1}{6} \mathrm{in}$. diam. at the throat; segments oblong, $\frac{1}{3} \mathrm{in}$. long. 
Stamens inserted near the throat of the tube; filaments $\frac{1}{4}-\frac{1}{3}$ in. long. Style overtopping the stamens; stigma tricuspidate.

Hab. Cape Colony; Province of Uitenhage, Burchell! Zeyher 347 ! Flowers in November.

7. C. collinus Burchell; Gawl. in Bot. Reg. t. 162. Monella glauca Herb. M. collina Salisb.--Bulb ovoid, $1 \frac{1}{2}$ in. diam. Leaves about 3, produced with the flowers, linear, weak, not twisted, 6-9 in. long. Peduncle slender, terete, a foot long. Umbel 6-10flowered; spathe-valves 2, lanceolate; pedicels slender, suberect, $\frac{1}{2}-1$ in. long. Perianth bright red, $1 \frac{1}{2}-2$ in. long; tube narrowly funnel-shaped, very slender in the lower half, $\frac{1}{4}$ in. diam. at the throat; segments oblong, $\frac{1}{3}$ in. long. Stamens almost uniseriate, inserted near the throat of the tube; filaments very short. Style reaching halfway up the limb; stigma tricuspidete.

Hab. Cape Colony; Uitenhage, Burchell 7783! Zuur-berg, Cooper 3223 ! Flowers in August.

8. C. ReCtiflorus Baker. -- Bulb ovoid, $1 \frac{1}{2}$ in. diam. Leaves 2 , contemporary with the flowers, linear, straight, green. Peduncle

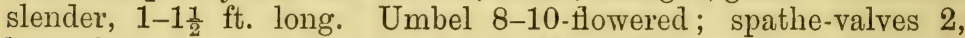
lanceolate; pedicels $\frac{3}{4}-1$ in. long. Perianth straight, red, erect, about an inch long; tube narrowly funnel-shaped, $\frac{1}{6}$ in. diam. at at the throat; segments oblong, half as long as the tube. Stamens biseriate; filaments very short; upper three anthers $\frac{1}{4}$ in. above the others. Style reaching to the tip of the segments; stigma obscurely tricuspidate.

Hab. British Kaffraria; Perie Bush. Discovered by Mr. Tidmarsh, Curator of the Grahamstown Botanic Garden.

9. C. Pallidus Sims in Bot. Mag. t. 2471.-Bulb ovoid, $1 \frac{1}{2}$ in. diam. Leaves 4-5, produced after the flowers, linear, green, not twisted. Peduncles subterete, purplish, $\frac{1}{2} \mathrm{ft}$. long. Umbel 4-5 flowered; spathe-valves 2 , lanceolate; pedicels $\frac{1}{2}-1$ in. long. Perianth pale red, $1 \frac{1}{2} \mathrm{in}$. long; tube narrowly funnel-shaped, $\frac{1}{4} \mathrm{in}$. diam. at the throat: segments oblong, $\frac{1}{2}$ in long. Stamens and style a little exserted from the tube.

Hab. Cape Colony. Known to me only by the figure cited, which was drawn from a garden plant introduced by Villet in 1822 .

10. C. Macowani Baker in Gard. Chron. 1875, 95; Regel Gartenfl. t. 960.-Bulb ovoid, 1 in diam. Leaves 1-3, contemporary with the flowers, linear, green, not twisted, $\frac{1}{2}-1 \mathrm{ft}$. long. Peduncle slender, terete, a foot long. Umbel 6-8 flowered; spathevalves 2, lanceolate, $1-1 \frac{1}{2}$ in. long; pedicels $\frac{1}{8}-\frac{3}{4}$ in. Perianth bright scarlet, $1 \frac{1}{4}-1 \frac{1}{2}$ in. long; tube curved, narrowly funnelshaped, $\frac{1}{6} \mathrm{in}$. diam. at the throat; segments ovate, cuspidate, $\frac{1}{6}-\frac{1}{4} \mathrm{in}$. long. Stamens biseriate; filaments very short. Style just exserted from the perianth-tube: stigma tricuspidate.

Hab. Eastern provinces of Cape Colony, ascending to $5000 \mathrm{ft}$. on the Boschberg. Introduced into cultivation by Prof. Macowan in 1875.

11, C. odorus Gawl. in Bot. Reg. t. 503._Monella odora Herb.

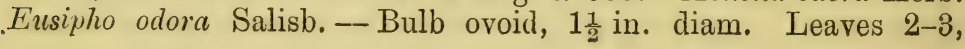


linear, green, straight, a foot long. Peduncle slender, $\frac{1}{2}-1 \mathrm{ft}$. long. Umbel 4-10-flowered; spathe-valves 2, lanceolate, green, $1 \frac{1}{2}-2$ in. long; pedicels shorter. Flowers bright red, fragrant, $2 \mathrm{in}$. long; tube subcylindrical, $\frac{1}{8} \mathrm{in}$. diam. at the throat; segments linearoblong, $\frac{1}{3}-\frac{1}{2}$ in. long. Stamens almost uniseriate, inserted near the throat of the tube; filaments very short. Style sometimes protruded beyond the tip of the perianth-segments; stigma distinctly bicuspidate.

Hab. Cape Colony and Natal. Introduced into cultivation in 1818, by Messr's. Colville, of the King's Road, Chelsea. Flowers in July and August.

12. C. Tuckir Baker in Journ. Bot.1876, 183.--Bulb ovoid, $1 \frac{1}{2} \mathrm{in}$. diam.; neck produced. Leaves 2 , contemporary with the flowers, linear, green, $1-1 \frac{1}{2} \mathrm{ft}$. long. Peduncle as long as the leaves. Umbel 10-12-flowered; spathe-valves 2, lanceolate, green, 3-3 $\frac{1}{2}$ in. long; pedicels $1-2 \frac{1}{2}$ in. Flowers yellowish at the base, fpassing upwards into blood-red, $1 \frac{1}{2}-2$ in. long; tube curved, narrowly funnel-shaped, $\frac{1}{3} \mathrm{in}$. diam. at the throat; segments oblong, $\frac{1}{4}-\frac{1}{3} \mathrm{in}$. long, not spreading. Stamens biseriate, the three lower not exserted from the perianth-tube. Style just overtopping the upper anthers ; stigma tricuspidate.

Hab. Cape Colony; summit of the Boschberg, alt. 4000-5000 ft., Macowan 2133 ! Sent alive from Glasnevin in July, 1884, by Mr. F. Moore.

13. C. Angustifolius Ait. Hort. Kew, i. 414 ; Bot. Mag. t. 271 ; Lodd. Bot. Cab. t. 368 ; Red. Lil. t. 388. Crinum angustifolium Linn. fil. Amaryllis cylindracea L'Herit. Monella anyustifolia Herb. Lissipho angustifolius Salisb. - Bulb ovoid, $1 \frac{1}{2}-2$ in. diam. Leaves $2-3$, contemporary with the flowers, linear, green, straight, $1-1 \frac{1}{2} \mathrm{ft}$. Peduncle as long as the leaves. Umbel 4-10-flowered; spathevalves 2 , lanceolate, $1 \frac{1}{2}-2$ in. long; pedicels $1-1 \frac{1}{2}$ in. long. Perianth bright red, inodorous, $1 \frac{1}{2}-2$ in. long; tube narrowly funnel-shaped, $\frac{1}{6}$ in. diam. at the throat; segments oblong, $\frac{1}{3}-\frac{1}{2}$ in. long. Stamens all exserted from the tube; filaments $\frac{1}{8}-\frac{1}{4}$ in. Style sometimes protruded beyond the tip of the segments; stigma tricuspidate.

Var. GRandiflonus Baker.-Perianth $2 \frac{1}{2}-3$ in. long; throat of the tube $\frac{1}{4}$ in. diam.

Var. C. ventricosus Willd. Sp. Plant. ii. 49. C. angustifolius Jacq. Hort. Schoen. i. t. 76.-Perianth-tube more dilated, ventricose in the middle and contracted at the throat.

Var. C. striatus Herb. in Bot. Mag. t. 2534.-Perianth $2 \frac{1}{2}$ in. long, bright red, with yellow ribs.

Hab. Cape Colony and Natal. Introduced into cultivation by Masson, in 1774. Flowers in autumn.

14. C. Mackenir Hook. fil in Gard. Chron. 1869, 36t1, with figure; Baker in Saund. Ref. Bot. t. 355.-Bulb ovoid, $1 \frac{1}{2}$ in. diam. Leaves $2-6$, contemporary with the flowers, linear, green, straight, a foot long. Peduncle slender, subterete, slightly glaucous, a foot long. Umbel 4-10-flowered; spathe-valves lanceolate, greenish, 1-1 $\frac{1}{2}$ in. long. Flowers pure white, 2 in. long; tube narrowly funnel-shaped, $\frac{1}{6} \mathrm{in}$. diam. at the throat; segments oblong, $\frac{1}{4}-\frac{1}{3} \mathrm{in}$. long. Stamens distinctly biseriate; filaments very short. Style exserted from the tube; stigma tricuspidate. 
Hab, Natal. Introduced by McKen about 1868. Flowers all through winter and spring. Now common in cultivation.

15. C. Lutescens Herb. Amaryll. 129, t. 33, fig. 14. Monella ochroleuca Herb.-Bulb globose, $1 \mathrm{in}$. diam. Leaves 2-4, produced with or after the flowers, linear, green, not twisted, a foot long. Peduncle slender, a foot long. Umbel 2-3-flowered ; spathe-valves lanceolate, green, an inch long ; pedicels shorter. Flowers yellow, 2 in. long; tube slightly curved, very slender in the lower half, $\frac{1}{6}$ in. diam. at the throat; segments oblong, $\frac{1}{4}-\frac{1}{3} \mathrm{in}$. long. Stamens distinetly biseriate; filaments very short. Style exserted from the tube; stigma tricuspidate.

Var. Cooperi Baker. C. lutescens Hook. in Bot. Mag. t. 5374. -Flowers more numerous. Pedicels and spathe-valves longer. Perianth-segments more spreading, ovate, $\frac{1}{8}-\frac{1}{6} \mathrm{in}$. long.

Hab. Cape Colony, Eastern provinces, Natal, and Transvaal. Introduced into cultivation by Mr. T. Cooper in 1863.

\section{Subgenus Gastronema (Herb.)}

16. C. uniflorus Gawl. in Bot. Reg. t. 168. Amaryllis clavata L'Herit. A. humilis Link. Gastronema clavatum Herb. in Bot. Mag. t. 2291.-Bulb globose, $\frac{3}{4}-1$ in. diam.; neck short. Leaves 1-2, linear, contemporary with the flowers, $\frac{1}{2} \mathrm{ft}$. long, not twisted. Peduncle slender, 6-9 in. long. Umbel 1-3-flowered; spathevalves lanceolate, green, 1-1 $\frac{1}{2}$ in. long; pedicel short if the flower be solitary. Flower erect or suberect, $1 \frac{1}{2}-2$ in. long, white, with green or reddish-brown stripes; tube funnel-shaped, $\frac{1}{3}-\frac{1}{2}$ in. diam. at the throat; segments oblong, $\frac{1}{2}-\frac{3}{4}$ in. diam. at the throat. Stamens biseriate; filaments erect or incurved, $\frac{1}{4}$ in. long. Style overtopping the anthers; stigma with 3 falcate branches.

Hab. Throughout Cape Colony and Kaffraria. Flowers from September to January.

17. C. Helictus Lehm. Delect. Sem. Hort. Hamburg, 1839, 7. Cyphonema Loddigesianum Herb.-Differs from the last mainly by its spirally twisted leaves.

Hab. Cape Colony, Eastern provinces.

18. C. vittatus Desf. ; Red. Lil. t. 182.-Bulb globose, $1 \frac{1}{2} \mathrm{in}$. diam. Leaves 5-6, linear, contemporary with the flowers, not twisted. Umbel 5-6-flowered; spathe-valves 2, lanceolate, $1 \frac{1}{2}$ in. long; pedicels very short. Flowers about 3 in. long, white, striped with red-brown; tube slender in the lower half, dilated gradually to a throat $\frac{1}{2} \mathrm{in}$. diam. Stamens exserted from the perianth-tube. Style overtopping the stamens; stigma tricuspidate.

Hab. Cape Colony. Known to me only from the figure cited.

19. C. Surthianus Herb. in Bot. Mag. sub t. 3779.-Bulb ovoid, $1 \frac{1}{2}$ in. diam. Leaves $2-4$, contemporary with the flowers, linear, spirally twisted, rather glaucous, 6-9 in. long. Peduncle slender, terete, $\frac{1}{2} \mathrm{ft}$. long. Umbel 1-2-flowered; spathe-valves 2, lanceolate; pedicels $1-1 \frac{1}{2}$ in. long. Flowers $1-2$, erect, white striped with green or red-brown, $3 \frac{1}{2}-4$ in. long; tube gradually 
dilated from the base to a throat an inch in diameter; segments oblong, an inch long. Stamens biseriate; filaments $\frac{1}{2}$ in. long; stigma tricuspidate.

Hab. Kaffraria. Described from a living plant sent by the late Prof. Balfour from the Edinburgh Botanic Garden, in May, 1876.

20. C. sanguineus Hook. in Bot. Mag. t. 5218. Gastronema sanguinerm Lindl. - Bulb ovoid, 2 in. diain. Leaves 3-4, contemporary with the flowers, bright green, lanceolate, petioled, a foot long, $\frac{1}{2}-\frac{3}{4} \mathrm{in}$. broal. Peduncle slender, terete, 6-9 in. long. Umbel 1-3-flowered; spathe-valves lanceolate, 2-4 in. long; pedi-

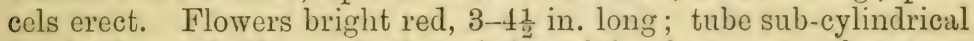
in the lower half, openly funnel-shaped in the upper; throat an inch in diameter; segments ovate, falcate, 1-2 in. long. Stamens nearly uniseriate; filaments incurved, $\frac{1}{2}$ in. long. Style overtopping the anthers; stigma falcate, $\frac{1}{4}$ in. long.

Hab. Kaffraria and Natal, flowering in August. Introduced into cultivation by Messis. Backhouse in 1860. Also Galla Country, East Tropical Africa, gathered by the Rev. T. Wakefield. A very distinct species.

\section{Griffinia Ker.}

Perianth funnel-shaped, horizontal or declinate; tube none or very short, not appendiculate at the throat; segments acute, three lower narrower than the three upper. Stamens declinate, unequal, attached to the base of the segments; anthers small, oblong, versatile. Ovary 3 -celled; ovules 2 in a cell, collateral, basal; style filiform, declinate; stigma capitate, rarely trifid. Capsule loculicidally 3-valved. Seeds often solitary; testa pale.-Rootstock a truncated bulb. Leaves thin, broad, usually petioled. Peduncle solid. Umbel many-flowered; spathe-valves 2, lanceolate; flowers lilac.

Leaves petioled. Stamens 6 . Stigma capitate . . . . . Sp. 1-5. Stigma tricuspidate . . . . Sp. 6. Leaves sessile. Upper stamen suppressed. Sp. 7.

1. G. Dryades Roem. Amarayll. 32 ; Hook. fil in Bot. Mag. t. 5786. Amaryllis dryades Vell. Fl. Flum. iii. t. 117.—Bulb as large as a man's fist. Leaves firmer in texture than in the other species; bright green, above a foot long, 5-6 in. broad, cuneately narrowed to a channelled petiole $6-8$ in. long. Peduncle stout, $1 \frac{1}{2}-2 \mathrm{ft}$. long. Umbel 10-12-flowered; spathe-valves $1 \frac{1}{2}$ in. long; pedicels about an inch long. Perianth-limb $3-4$ in. long; tube subcylindrical, $\frac{3}{4}-1$ in. long, segments oblanceolate, acute, upper $\frac{1}{2}$ in. lower $\frac{1}{4} \frac{1}{3}$ in. broad. Stamens shorter than the segments, one ascending; anthers lilac, $\frac{1}{6}$ in. long. Style as long as the segments; stigma capitate.

Hab. South Brazil, introduced, I believe, by Mr. Wilson Saunders about 1868. Described from a plant flowered by Mrr. William Bull in Sept., 1883.

2. G. onvata, Moore in Gard. Chron. 1876, i. 266, figs. 47-48; Hook. fil in Bot. Mirg. t. 6367.--Bulb ovoid, 3-4 in. diam.; neck 
2-4 in. long. Leaves $6-8$; blade oblong, deep green, above a foot long, 4-5 in. broad, narrowed to a short channelled petiole with a broad clasping base. Peduncle lateral, a foot long, subcompressed, as thick as the finger. Umbel 10-12-flowered, centripetal; spathevalves thin, green, ovate-lanceolate; pedicels $1-1 \frac{1}{2}$ in. long. Perianth $2 \frac{1}{2}-3$ in. long, pale lilac; tube very short; segments oblanceolate, $\frac{1}{3}$ in. broad. Stamens shorter than the segments, one standing up from the others ; filaments white; anthers oblong, pale lilac, $\frac{1}{6}$ in. long. Style nearly as long as the segments; stigma capitate.

Hab. South Brazil, introduced by Mr. Wm. Bull in 1876. Flowers in January and February. Described from a plant that flowered at Kew in February, 1878.

3. G. Hyacinthina Herb. App. 21 Bury Hexand. t. 14. Amaryllis hyacinthina Gawl. in Bot. Reg. t. 163.--Bulb globose, 2-3 in. diam.; neck short. Leaves 4-5, developed after the flowers; blade oblong, acute, 6-9 in. long, 2-3 in. broad, rounded at the base to a channelled petiole as long as the blade. Peduncle 1-2 ft. long, slightly compressed. Umbel 8-10-flowered, centripetal; pedicels none or very short; spathe-valves thin, lanceolate. Perianth-limb 2 in. long, bright lilac; tube very short; segments oblanceolate, acute, upper $\frac{1}{4}-\frac{1}{3} \mathrm{in}$. broad, lower $\frac{1}{6}$ in. Stamens much shorter than the segments. Style declinate; stigma capitate.

Hab. Brazil, introduced in 1815. Described from a living plant sent by Mr. Wm. Bull, Norember, 1880. A variety (micrantha) received from Messrs. Sander $\&$ Co. in the winter of 1880 had flowers scarcely above an inch long.

4. G. intermedia Lindl. in Bot. Reg. t. 990.--Bulb ovoid, longer than in $G$. hyacinthina. Leaves oblong, acute, cuneately narrowed into a long petiole. Peduncle slender, a foot long; Umbel 6-10-flowered; spathe-valves lanceolate, $1 \frac{1}{2} \mathrm{in}$. long; pedicels $1-1 \frac{1}{2}$ long, Perianth pale lilac, $1 \frac{1}{2}-2$ in. long; tube short, funnel-shaped; segments oblanceolate, $\frac{1}{4} \mathrm{in}$. broad above the middle. Stamens shorter than the perianth; 5 declinate, one ascending; anthers linear-oblong, $\frac{1}{6}$ in. long. Style as long as the perianth; stigma capitate.

Hab. Brazil. Described from a plant flowered by Mr. H. J. Elwes.

5. G. parviflora Gawl. in Bot. Reg. t. 511.-Bulb ovoid 2-3 in. diam. Leaves $3-4$ to a bulb, contemporary with the flowers, oblong, acute, half a foot long, $2 \frac{1}{2}-3$ in. broad at the middle, cuneately narrowed to a petiole as long as the blade. Peduncle slender, terete, nearly a foot long. Umbel 10-15-flowered; spathe-valves lanceolate, an inch long; pedicels slender, $\frac{1}{2}-1$ in. Perianth pale lilac, $\frac{3}{4}-1$ in. long; tube short: segments lanceolateunguiculate, 1-12th to 1-8th in. broad, upper broadest. Stamens 6 , shorter than the segments; anthers oblong. Style shorter than the perianth; stigma capitate.

Hab. Province of Bahia, Brazil, Moricand 2305! Described from a plant that flowered at Kew, February, 1877. Introduced in 1815.

6. G. Blumenavia K. Koch et Bonché; Carrière in Rev. Hort. 1867, 32 ; Hook fil. in Bot. Mag. t. 5666.-Bulb ovoid, 2 in. diam. 


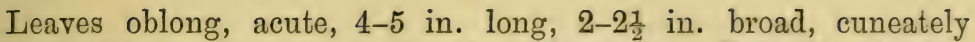
narrowed to a petiole shorter than the blade. Peduncle slender, terete, 6-8 in. long. Umbel 6-8-flowered; outer spathe-valves lanceolate, 1-1 $\frac{1}{2}$ in. long; pedicels $\frac{1}{2}-1$ in. Perianth-limb pale lilac, $1 \frac{1}{2}-2$ in. long; segments oblanceolate, $\frac{1}{4}-\frac{1}{2}$ in. broad, the lower only half as broad as the upper. Stamens 6, unequal, as long as the perianth; anthers yellow, $\frac{1}{8} \mathrm{in.}$ long. Style exserted; stigma distinctly tricuspidate.

Hab. South Brazil; Province of Santa Catherina. Introduced by Dr. Blumenau about 1876. Described from a plant sent from the 'Gardeners' Chronicle,' and another from Mr. Wm. Bull. Flowers February to April.

7. G. Liboniana Morren in Ann. Soc. Roy. Agric. Gand 1845, t. 13 ; Lemaire in Jard. Fleur. t. 290.-Bulb small, 1 in. diam. Leaves $5-6$, contemporary with the flowers, sessile, oblong, acute, 3-4 in. long. Peduncle two-edged, a foot long. Umbel 6-8flowered; spathe-valves lanceolate; pedicels $\frac{1}{2}-\frac{3}{4} \mathrm{in}$. long. Perianth pale lilac, $1-1 \frac{1}{4} \mathrm{in}$. long; tube scarcely any; segments oblanceolate. Stamens shorter than the segments; upper one suppressed. Style shorter than the segments; stigma capitate.

Hab. Central Brazil ; Province of Minas Geraes. Discovered by M. Libon in 1843. Differs from the other species by its sessile leaves and suppressed upper stamen.

\section{Clivita Lindl.}

Perianth funnel-shaped, erect or rather curved; tube short; segments ascending, subequal, oblanceolate or oblanceolate-oblong, obtuse. Stamens inserted at the throat of the perianth-tube; filaments filiform, about as long as the segments; anthers oblong, versatile. Ovary globose; ovules $5-6$ in a cell, fascicled at the centre of the placenta; style long, slender, tricuspidate at the apex. Fruit a bright red pulpy berry. Seeds one or few, large, globose, bulbiform. Bulb imperfect, consisting only of the leafbases; root-fibres very stout. Leares numerous, distichous, persistent. Peduncle stout, solid compressed. Flowers bright redyellow, scentless, many in an umbel, lanceolate.

Subgenns Curvia propeb.-Flower rather curved, narrowly funnelshaped, resembling that of Cyrtanthus , . Sp. 1-2.

Subgenus Imantophyllum. - Flower erect, more broadly fumnelshaped, resembling that of Vallota . . Sp. 3.

1. C. NoBilis Lindl. in Bot. Reg. t. 1182. Imantophyllum Aitoni Hook, in Bot. Mag. t. 2856.-Leaves about a clozen in a

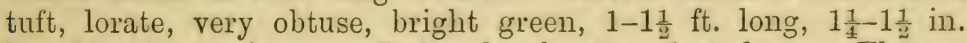
broad; eaige scabrous. Peduncle about a foot long. Flowers 40-60 in an umbel; pedicels $\frac{1}{2}-1$ in ; spathe-valves sereral, unequal, greenish. Perianth curved; tube narrowly funnel-shaped, $\frac{1}{4}-\frac{1}{3}$ in. long; segments oblanceolate, tipped with green, about an inch long. Stamens as long as the segments. Style exserted.

Hab. Cape Colony; South-western provinces. Introduced into cultivation by Bowie in 1828 . 
2. C. Gardneri Hook. in Bot. Mag. t. 4895.-Leaves 10-12 in

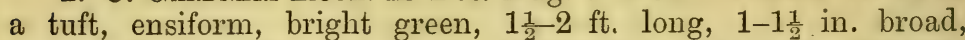
narrowed gradually to the point. Peduncle $1-1 \frac{1}{2} \mathrm{ft}$. long. Flowers

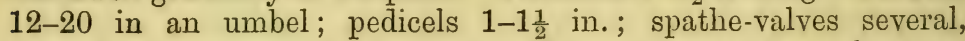
lanceolate, greenish, $1 \frac{1}{2}$ in. long. Perianth eurved; tube narrowly funnel-shaped, $\frac{1}{3} \frac{1}{2} \mathrm{in}$. long; segments connivent, oblanceolate, obtuse, $1 \frac{1}{4}$ in. long. Stamens as long as the segments. Style much exserted.

Hab. Natal and the Transvaal. Introduced into cultivation by ${ }_{i}$ Captain Garden in 1855.

\section{Subgenus Imantophyllum.}

3. C. miniata Regel Gartenflora 1864,131 , t. 434 . Imantophyllum miniatum Hook. in Bot. Mag. t. 4783; Rev. Hort. 1859, 125, t. 29-30; Flore des Serres, t. 949-950, 2373-2374. Leaves 16-20 to a tuft, ensiform, bright green, narrowed to the point, $1 \frac{1}{2}-2 \mathrm{ft}$. long, $1 \frac{1}{2}-2 \mathrm{in}$. broad. Peduncle stout, ancipitous, 1-1 $\frac{1}{2} \mathrm{ft}$. long. Flowers 12-20 in an umbel; pedicels 1-2 in.; spathevalves several, lanceolate or linear. Perianth erect, bright scarlet, with a yellow throat; tube broadly funnel-shaped, $\frac{1}{3}-\frac{1}{2}$ in. long; segments about $2 \mathrm{in}$. long, inner segments broader than the outer. Stamens shorter than the perianth-segments. Style reaching to the tip of the segments. Berry ovoid, bright red, an inch long.

Hab. Natal. Introduced into cultivation by Messrs. Backhouse of York, in 1854. There are many named garden varieties, two of the finest being grandiflora and Lindeni (Ill. Hort. n.s. t. 343). Imantophyllum cyrtanthiflorum, figured Flore des Serres, t. 1877, is a garden hybrid between miniata and nobilis.

\section{Hemanthus Limn.}

Perianth erect; tube subcylindrical; segments equal, linear or lanceolate, spreading or permanently ascending. Stumens inserted at the throat of the perianth-tube; filaments filiform, often longer than the segments; anthers small, oblong, versatile. Ovary globose, 3-celled; ovules sessile or in collateral pairs from the centre of the placenta; style filiform; stigma minutely tricuspidate. Fruit globose, baccate. Seeds often solitary; testa pale, membranous. - Rootstock a tunicated bulb. Leuves broad, obtuse, thin or fleshy. Peduncle stout, solid. Flowers red or white, densely umbellate; spathe-valves more than 2, erect or spreading, membranous.

Subgenus Nerissa (Salisb.). Leaves membranous. and perianth-segments spreading.

Peduncle lateral. Leaves on a produced special stem ; petiole short

Peduncle central. Leaves springing direct from the bulb, with a long petiole.

Subgenus Gyaxis (Salisb.). Leaves membranous. and perianth-segments permanently ascending

Spathe-valves Sp. 1-6.

Sp. 7-9.

Spathe-valves Sp. 10-13. 
Subgenus Metrono (Salisb.). Bulb with thick bifarious tunies. Leaves thick and fleshy. Spathe-valves and perianth-segments spreading . . . . . . . Sp. 14-17.

Subgenus Diacles (Salisb.). Bulb with thick bifarious tunics. Leaves thick and fleshy. Spathe-valves and perianth-segments permanently ascending.

Bracts white, veined with green. Flowers white. Peduncle produced . . . . . Peduncle scarcely any $\quad . \quad$. $\quad$ Sp. 22-23.

Bracts reddish, $\frac{3}{4}-1$ in. long, generally shorter than the flowers

Bracts reddish, $1 \frac{1}{2}-2 \mathrm{in}$. long, equalling or overtopping the flowers

Sp. $18-21$.
Sp. $22-23$.

Sp. 24-31.

Sp. 32-38.

\section{Subgenus Nerissa.}

1. H. nultiflorus Martyn, Monogr. cum icone; Bot. Mag. t. 961 \& 1995; Andr. Bot. Rep. t. 318 ; Red. Lil. t. 204; Lodd. Bot. Cab. t. 912 \& 1948 ; Flore des Serres, t. 52. I1. abyssinicus Herb. H. arabicus Roem. H. delagoensis Herb. H. temuiflonus Herb. in Bot. Mag. t. 3870. H. Kulbreyeri Baker in Gard. Chron. 1878, ii. 202; Flore des Serres, t. 2377 ; Ill. Hort. n. s. t. 354.Bulb globose, $1 \frac{1}{2}-3 \mathrm{in}$. diam. Leaves $3-4$, produced on a short special stem, with an oblong blade $\frac{1}{2}-1 \mathrm{ft}$. long, and short sheathing petioles; main veins $6-8$ on each side of the distinct midrib; transverse veinlets very close, very oblique. Peduncle separate from the leafy stem, slender or stout, plain green or spotted with red. Umbel dense, $3-6$ in. diam.; pedicels $1-1 \frac{1}{2}$ in. long; spathevalves $6-8$, reflexing, green, $1 \frac{1}{2}-2$ in. long. Perianth blood-red; tube cylindrical, $\frac{1}{4} \frac{1}{2}$ in. long; segments linear, 3 -nerved, twice as long as the tube. Filaments bright red, 1-1 $\frac{1}{4}$ in. long. Berry bright scarlet.

Hab. Throughout Tropical Africa from Sierra Leone to Kordofan, Abyssinia, and Delagoa Bay. First published by Vallet in his 'Jardin du Roi ' in 160s. Very variable, but I cannot make out that more than a single species is covered by the above synonyms. There is an authentic specimen of his $H$. coccineus, from Forskhahl, in the Smithian Herbarium.

2. H. filiflorus Hiern MSS.; Baker in Journ. Bot, 1878, 94. - Bulb globose. Leafy stem a foot long, bearing about 6 oblong: leaves on short sheathing petioles; blade membranous, a foot long; main veins $10-12$ between midrib and edge; transverse veinlets close, oblique. Peduncle lateral, a foot long, spotted. Umbel very dense, 5-6 in. diam.; pedicels 1-11 in. long; spathe-valves oblong, 2 in. long, red-brown. Perianth bright red ; tube cylindrical, $\frac{1}{3} \mathrm{in}$. long; segments linear, 1 -nerved, $\frac{1}{2}-\frac{5}{8}$ in. long. Filaments $\frac{3}{4}$ in. long.

Hab. Angola, in the Province of Pungo Andongo, Welwitsch 4009! 4010 ! Flowers in October. Very near H. multiflorus ; perhaps a mere variety.

3. H. Mannir Baker in Bot. Mag. t. 6364. - Bulb small, globose. Leaves $5-6$ at the summit of a short special stem, with an oblong acute membranous blade $\frac{1}{2} \mathrm{ft}$. or more long narrowed to a short channelled petiole; main veins abont 10 on each side of the 
midrib ; transverse veinlets close, oblique. Peduncle 8-12 in. long. Umbel 3-4 in. diam., less dense than in $H$. multiflorus; pedicels $\frac{1}{2}$ in. long; spathe-valves lanceolate, reddish. Perianth bright red; tube cylindrical, $\frac{1}{3}-\frac{1}{2}$ in. long; segments lanceolate, laxly 3 -nerved, $\frac{1}{4}$ in. long. Filaments $\frac{3}{4}-1$ in. long. Style overtopping the anthers.

Hab. West Africa, on the banks of the Bagroo River, gathered by Mann in 1861. Introduced by Mr. Bull from Liberia in 1877.

4. H. Rupestris Baker in Gard. Chron. 1877, 655. - Bulb globose, $1 \mathrm{in}$. diam. Leaves 2 , from the summit of a short slender special stem with slender erect petioles 2 in. long and an oblong membranous blade half a foot long, 4 in. broad, rounded at the base; main veins indistinct, $\frac{1}{4}-\frac{1}{3}$ in. apart ; transverse veinlets very oblique, not so close as in $H$. multiflorus. Peduncle slender, 3-9 in. long, contemporary with the young leaves. Umbel dense, 3 in. diam.; spathe-valves 4-5, narrow oblong, reflexing, red-brown; pedicels $\frac{1}{2}-\frac{3}{4}$ in. long. Perianth bright crimson; tube cylindrical, $\frac{1}{4}$ in. long; segments linear, $\frac{1}{2}$ in. long. Filaments bright red, $\frac{1}{2}$ in. long.

Hab. Guinea, in rocky places near Nupe. Gathered by Barter in the Niger Expedition of 1859.

5. H. Katherine Baker in Gard. Chron. 1877, 655; Hook. fil. in Bot. Mag. t. 6778. - Bulb globose, 2-3 in. diam. Leafy stem $\frac{1}{2} \mathrm{ft}$. long. Leaves $4-5$, contemporary with the flowers, oblong, membranous, 9-12 in. long, narrowed at the base into a short spotted sheathing petiole; main veins $8-10$ on each side of the distinct midrib; transverse veinlets oblique, closer and more distinct than in multiflorus. Peduncle stout, distinct from the leafy stem, spotted low down, a foot long. Umbel dense, 4-9 in. diam.; pedicels 1-2 in. long; spathe 5-6, lanceolate, reflexing, $1 \frac{1}{2}-2$ in. long. Perianth bright red ; tube $\frac{1}{2}-\frac{3}{4}$ in. long; segments lanceolate, reflexing, $\frac{3}{4}-1$ in. long. Filaments ascending, bright red, $1-1 \frac{1}{2}$ in. long. Style erect, 2 in. long. Berry bright red, $\frac{1}{2}$ in. diam.

Hab. Natal. Introduced into cultivation by Mr. Keit in 1877, and named, at his request, after Mrs. Katherine Saunders. Proves to be the finest and most easily cultivated of all the species of this subgenus.

6. H. Grandifolius Balf. fil. Diag. Plant. Nov. Socot. iii. 23.Leaves membranous, ovate, plain green, reaching a length of $12-15$ in. and a breadth of 8-9 in.; main veins $\frac{1}{4}-\frac{1}{2}$ in. apart, with 2-6 finer parallel veins between them; areolæ square; petiole 1-1 $\frac{1}{2}$ in. long. Inflorescence and flower not seen. 1880 .

Hab. Mountains of Socotra, gathered by Dr. I. B. Balfour in the spring of

7. H. cinnabarinus Decaisne in Flore des Serres, t. 1195 ; Hook. in Bot. Mag. t. 5314; Floral Mag. n. s. t. 245.-Bulb globose, $1 \mathrm{in}$. diam., bearing copious fleshy cylindrical root-fibres. Leaves about 4, produced direct from the rootstock, contemporary with the flowers, with an oblong acute membranous blade 6-9 in. long, narrowed gradually into a channelled petiole of about the same length; main veins fine; transverse veinlets close and very 
obtuse. Peduncle slender, a foot long, springing from the centre of the leares. Umbel 3-4 in. diam., much less dense than in $H$. multiflorus; spathe-valves lanceolate, membranous, reflexing; pedicols $\frac{1}{2}-1$ in. long. Perianth bright crimson; tube $\frac{1}{4}-\frac{1}{3}$ in. long; scgments lanecolate, reflexing. $\frac{3}{4}-\frac{7}{8} \mathrm{in}$. long, laxly 5 -nerved. Filaments bright red, a little longer than the segments. Berry globose, often 2-3-seeded.

Hab. Gold Coast and Cameroon Mountains, introduced into cultivation from the Gaboon in 1857, and again by Mann in 1862. Gathered lately by Sir Richard Burton, Capt. Cameron, and Capt. Moloney.

8. H. angolensis Baker in Journ. Bot. 1878, 194. - Bulb elongated. Leaves 3-4, produced direct from the bulb, with an oblong blade $\frac{1}{2}-1 \mathrm{ft}$. long, rounded at the base to a channelled petiole 6-9 in. long; main veins indistinct, $\frac{1}{4}-\frac{1}{3}$ in. apart; transverse veinlets horizontal or: slightly oblique. Peduncle stout, a foot long. Umbel dense, 4-5 in. diam.; pedicels 1-11 in. long; spathevalves deciduous. Perianth bright crimson; tube $\frac{1}{3}$ in. long; segments linear, 3-5-nerved, $\frac{3}{4}$ in. long. Filaments abore an inch long.

Hab. Angola, in the Province of Golungo Alto, alt. 1000-2400 ft., flowering in February, Welwitsch 4008 !

9. H. rotularis Baker in Gard. Chron. 1877, 656. - Bulb globose, $1 \mathrm{in.}$ diam. Leaves springing direct from the rootstock, contemporary with the flowers; blade very thin, oblong, acute, S-9 in. long, narrowed gradually to a chamnelled petiole, about half as long; main veins rery fine, $\frac{1}{4}-\frac{1}{3} \mathrm{in}$. apart; cross reinlets nearly horizontal, not very close. Peduncle rery slender, $\frac{1}{2} \mathrm{ft}$. long. Umbel dense, $3 \mathrm{in}$. diam.; spathe-valves about 8, lanceolate, membranons, $1 \frac{1}{2}-2$ in. long; pecticels $\frac{1}{2}-\frac{3}{4}$ in. long. Perianth bright red, an inch long; tribe half as long as the lanceolate segments. Filaments about as long as the segments.

Hab. Guinea; Forests of Yomba. Gathered by Barter in 1859 .

\section{Subgenus Graxis.}

10. H. puriceus Linn. Sp. Pl. 413 ; Red. Lil. t. 320 ; Bot. Mag. t. 1315. H. Redoutecmus Rocm. - Bulb globose, 2-3 in. diam. Leaty stem short. Leaves $2-4$, oblong, membranous, bright green. 6-9 in. long, narrowed into a short petiole, fully developed with the flowers; main roins about 6 on each side of the distinct midrib; transverse veinlets close, distinct, very oblique. Peduncle lateral, a foot or more long. Umbel dense, $3-4 \mathrm{in}$. diam. ; pedicels $\frac{1}{2}-1 \mathrm{in}$. long; spathe-valres ovate or oblong, imbricated, $1 \frac{1}{2}$ in. long. Perianth pale scarlet, rarely white, an inch long; segments linear, 3-nerved, twice as long as the tube. Filaments bright red, an inch long. Style orertopping the anthers. Berry bright red, the size of a small cherry.

Hab. Southern provinces of Cape Colony, introduced into cultivation before the end of the 17th century, but now almost entirely replaced by natalensis and the varieties of the more showy magnificus. 
11. H. menbranaceus Baker. - Closely allied to $H$. puniconts. Leaty stem not at all produced. Leaves $3-4$ to a bulb, oblong, 4-6 in. long, very thin in texture; petiole slender, 3-6 in. long; main veins $4-5$ on each side of the distinct midrib; cross veinlets not at all oblique and not nearly so close as in H. muicens. Peduncle slender. Umbel $1 \frac{1}{2} \mathrm{in}$. diam.; spathe-valves oblong, reaching to the tip of the flowers; pedicels $\frac{1}{4} \mathrm{in}$. long. Perianth pale red; segments twice as long as the tube. Stamens and style $\frac{1}{4} \mathrm{in.}$ longer than the segments.

Hab. Natal, Gerrard 735! Peddie! Wood 1219 !

12. H. magnificus Herb. in Bot. Reg. 1841, Misc. No. 153. H. meniceus var. magnifica Herb. in Bot. Mag. sub t. 3870. H. Rouperi Floral Mag. 1875, t. 148. - Bulb globose, 3-4 in. diam.; scaleleaves 6-8, suborbicular, green. Leaty stem reaching a length of 1-2 ft., not developed till after the peduncle, spotted with redbrown; produced leaves $6-8$, oblong, membranous, bright green, mndulated, a foot or more long, narrowed to a short sheathing petiole; main veins 8-10 on cach side of the distinct midrib; crossveinlets very close and very oblique. Peduncle lateral, very stout, above a foot long. Umbel globose, very dense, sometimes 5-6 in. diam.; bracts 6-8, bright green, ovate or oblong, ascending, imbricated, $1 \frac{1}{2}-2$ in. long; peclicels $\frac{1}{2}-1$ in. long. Perianth bright pale scarlet, an inch long; segments linear, twice as long as the tube. Filaments bright scarlet, an inch long. Berry bright red, the size of a small cherry.

Var. H. insignis Hook. in Bot. Mag. t. 4745. - Spathe-valves 5-6 in. long, much overtopping the flower's.

Var. Guneletonr Baker.-Leaty stem about a foot long. Leaves orbicular, unspotted, $5-6 \mathrm{in}$. long and broad; main reins $12-15$ on each side of the midrib. Peduncle very stont, 6-8 in. long. Umbel very dense; spathe-valves red-brown.

Var. H. superbus Hort. - Leaty stem not produced. Leaves $5-6$, narrower than in the type, produced directly from the bulb, contemporary with the flowers in spring. Peduncle, bracts, and flower's of the type.

Hab. Natal and Delagoa Bay. Introduced into cultivation in 1841, and now widely spread. For living specimens of var. Gumbletoni I am indebted to Mr. Gumbleton, and of var. superbus to Sir C. W. Strickland and Messrs. Krelage, of Haarlem. Var. insignis was sent alive from Natal to the Rev. Mr. Tooper, of Brighton.

13. H. natalensis Pappe; Hook. in Bot. Mag. t. 5378. - Bulb globose, oblique, 2-3 in. diam.; scale-leaves about 4, round-ovate, pale grcen, tipped and much spotted with red-brown. Leaty stem a foot long; leaves $8-9$, oblong, membranous, bright green, above a foot long, narrowed to a short sheathing petiole, the lower tipped and spotted on the back with red-brown. Peduncle produced from the axis of one of the scale-leaves, compressed, sulcate, about a foot long, $\frac{3}{4}-1$ in. thick. Umbel very dense, globose, 3-4 in. diam.; pedicels $1-1 \frac{1}{2}$ in. long; spathe-valves about 6 , oblong, very obtuse,

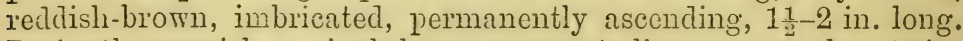
Perianth greenish, an inch long; segments lincar, more than twice 
as long as the cylindrical tubo. Filaments yellowish, above an inch long. Style overtopping the anthers. Berry subglobose, red, 낭 in. diam., usually 1 -seeded.

Hab. Natal, introduced into cultivation by Dr. Sanderson in 1802. Described from living plants in the Kew collection.

\section{Subgenus Melicho.}

14. H. pummro Jacq. Hort. Schoen. i. 32, t. 61. - Bulb subglobose, $1 \mathrm{in.} \mathrm{diam.} \mathrm{Leares} \mathrm{2,} \mathrm{developed} \mathrm{after} \mathrm{the} \mathrm{flowers,} \mathrm{suberect,}$ lorate, subacute, glabrous, 4-5 in. long, $\frac{1}{2}$ in. broad, green, barred and spotted on the back near the base with red-brown. Peduncle slender, spotted, 2-3 in. long. Flower's 5-6 in an umbel; peclicels $\frac{1}{2}-\frac{3}{4}$ in. long. Perianth whitish, $\frac{1}{2}$ in. long; tube short; segments spreading. Stamens and style protruded beyond the tip of the segments.

Hab. Southern provinces of Cape Colony. Known to me only from Jacqúin's figure.

15. H. Lancemfolius Jacq. Hort. Schoen. i. 31, t. 60. - Bulb ovoid, compressed, 1-11 in. diam.; tunics thick, bifarious. Leares 2 , rarely 3 , not developol till after the flowcr's, lancoolate, acute, fleshy, spreading, 6-8 in. long, 2 in. broad, palo green, dotter and barred with red, glibrous on both surfaces, ciliated on the margin with minute deflexed hairs. Peduncle green, slender, compressed, 4-5 in. long. Flowers $6-8$ in an umbel; pedicels $\frac{1}{2}-\frac{3}{4}$ in. long; spathe-ralves lanceolate, about $\frac{1}{2} \mathrm{in}$. long; Perianth white, with a slight pinkish tinge, under $\frac{1}{2}$ in. long; tube short; segments linear, spreading. Stamens and stylo reaching beyond the tip of the segments.

Hab. Southern provinces of Cape Colony. Known to me only from Jacquin's figure.

16. H. Carneus Gawl. in Bot. Reg. t. 509; Hook, in Bot. Mag. t. 3373. H. brevifolius Herb. Amaryll. 234, t. 30, fig. 3. - Bulb compressed, 2-3 in. diam.; tunics thick, green, bifarious. Leares 2 , developed after the flower's, palo green, oblong or obovate, obtuse, narrowed to the base, 4-6 in. long, 2-5 in. broad, softly hairy, especially towards the margin. Peduncle slender, $\frac{1}{2}-1$ ft. long, usually pilose and mottled with purple. Flowers in a dense globose umbel 2-3 in. diam.; pedicels slender, $\frac{1}{3}-1 \mathrm{in}$. long; spathe-valves 5-6, oblong-lanceolate, reflexing, tinged with red. Perianth pink, rarely white, $\frac{1}{2} \mathrm{in}$. long ; tube 1-12th to 1 -8th in. long: segments lanceolate, 1-nerved. Stamens sometimes equalling, sometimes longer than the perianth-segments. mature.

Var. H. strigosus Herb. - Leaves naked on the surface when

Hab. Eastern provinces of Cape Colony, ascending to $4000 \mathrm{ft}$. on the mountains of Kaffraria. It was gathered and sketched by Masson in 1794. Described from a plant flowered by Sir Charles Strickland in August, 1869, and one at Kew in July, 1872. A Natal plant flowered by Herr Leichtin at Baden Baden in August, 1878, with a stouter peduncle, larger oblong, non-reflexing spathe-valves, and a perianth-limb $\frac{3}{\frac{1}{4}}$ in. long, will prebably prove a distinct species, 
17. H. amarylloides Jaeq. Hort. Schoen. iv. t. 408. - Bulb ovoid, not compressed, $1 \frac{1}{2}-2$ in. diam.; tunics thick, bifarious. Leares 2, developed after the flowers, lingulate, obtuse, bright green, fleshy, glabrous, $\frac{1}{2}-1 \mathrm{ft}$. long, $1 \frac{1}{2}-2$ in. broad. Peduncle slender, glabrous, $\frac{1}{2}-1 \mathrm{ft}$. long. Flower's 50 or more in a dense globose umbel 2-3 in. diam.; pedicels $\frac{1}{2}-1 \mathrm{in}$. long; spathe-valves $5-6$, oblong or oblong-lanceolate, spreading. Perianth pinkish or white, $\frac{3}{8}-\frac{1}{2}$ in. long; tube short; segments lanceolate, spreading. Stamens and style overtopping the perianth-segments.

Hab. Eastern provinces of Cape Colony. A plant from Bamboes Spruit, Nelson 24t! with longer pedicels, larger pure white flowers, and shorter subacute leaves, will probably prove a distinct species.

\section{Subgenus Diacles.}

18. H. albiflos Jacq. Hort. Schoen. i. 31, t. 59; Red. Lil. t. 398; Lodd. Bot. Cab. t. 602; Gawl. in Bot. Mag. t. 1239. Diacles ciliaris Salisb. H. intermedins lioem. - Bulb compressed, 2-3 in. diam.; tunics thick, green, bifarious. Leaves $2-4$, contemporary with the flowers, lingulate, suberect, obtuse, 6-8 in. long, $2 \frac{1}{2}-3 \frac{1}{2} \mathrm{in}$. broad above the middle, narrowed gradually to the base, glabrous on the surface when mature, ciliated on the margin. Peduncle pale green, glabrous, 6-9 in. long. Umbel dense, globose, 2 in. diam.; pedicels $\frac{1}{4}$ in. long; spathe-Talves $5-6$, oblong, obtuse, permanently ascending, white, veined with green. Perianth pure white, $\frac{3}{4}$ in. long; tube subcylindrical; segments linear, twice as long as the tube. Filaments white, a little longer than the segments; anthers yellow. Berry globose, bright red, $\frac{1}{2}$ in. diam.

Var. pubescens Herb. H. pubescens Gawl. in Bot. Reg. t. 382 ; Lodd. Bot. Cab. t. 702, non Linn. fil. Diacles pubescens Salisb.Leaves hairy on the face as well as on the margin.

Var. BRAchyphyluus Baker.-Leaves oblong, 3-4 in. long, 2 in. broad, finely ciliated on the edge, glabrous on the surface. Peduncle glabrous, a littie shorter than the leaves.

Var. Burchelin Baker.-Leaves oblong, 3-4 in. long, 2-21 in. broad, hairy on the surface, densely ciliated on the margin. Peduncle hairy, a little longer than the leaves.

Hab. Southern provinces of Cape Colony, ascending to $2500 \mathrm{ft}$. in Graaf Reinet. 1 have seen specimens of the type dried from Kew Gardens in 1800, and of var. pubescens from Kew in 1795, and from Masson's garden in 1794.

19. H. Annotтir Baker in Gard. Chron. 1878, i. 498. - Bulb subglobose, $3 \mathrm{in}$. diam.; tunies thick, green, bifarious. Leaves 2, produced after the flower's, round-oblong, rery obtuse, spreading, 4-5 in. long, 3-4 in. broad, green on the face, hairy towards the margin, ciliated with long soft whitish hairs. Peduncle purplish red, slightly compressed, 4-5 in. long. Umbel dense, $1 \frac{1}{2}-2$ in. diam.; pedicels $\frac{1}{2}-1 \mathrm{in}$. long; spathe-valves $5-6$, oblong-lanceolate, white, with conspicuous veins of green, $11-1 \frac{1}{2} \mathrm{in.} \mathrm{long.} \mathrm{Perianth}$ white, $\frac{5}{8} \mathrm{in}$. long; segments twice as long as the tube. Stamens and style distinctly exserted.

Hab. Cape Colony; Province of Colesberg. Described from a plant sent by Mr. Arnott, that flowered at Kew in June, 1878, and September, 1879. 
20. II. aleonnculatus Baker in Gard. Chron. 1878, i. 202.Bulb 2 in. diam.; tunics thick, green, bifarious. Leaves 2, contemporary with the flowers, lorate, suberect, green spotted with white, above a foot long, $2-3 \mathrm{in}$. broad above the middle, glabrous on the surface, obscurcly ciliated on the margin in an carly stage. Peduncle stont, green, glabrons, 4-6 in. long. Umbel dense, globose, $1 \frac{1}{2}-2$ in. diam.; peclicels $\frac{1}{3}-\frac{1}{1}$ in. long; spatlie-valves $6-7$, oblong, imbricated, ascending, white, with green veins, $1 \frac{1}{2} \mathrm{in}$. long. Perianth white, abore an inch long; segments linear, twice as long as the eylindrical tube. Filaments white, an inch long; anther's oblong, yellow.

Hab. Natal. Flowered by Nessrs. Low at Clapton, November, 1875, Messrs. E. G. Henderson \& Son, Maida Vale, December, 1877, and Mr. F. W. Moore at Glasnevin in 1886. Gathered wild three times lately by Mr. J. M. Wood, of the Durban Botanic Garden.

21. II. Bacrir Baleer in Bot. Mag. t. 6875.-Bulb oblong, compressed, 3-4 in. diam.; tunies thick, green, bifarious. Leaves 2, suborbicular, truncate at the apex, thick, green, fleshy, $\frac{1}{2} \mathrm{ft}$. long, 7-8 in. broad, glabrous on the surface, densely ciliated on the margin. Peduncle stout, green, glabrous, under 2 in. long. Umbel dense, 2 in. diam.; pedicels $\frac{1}{6}-\frac{1}{4}$ in. long; spathe-valves 5-6, oblong, membranous, white reined with green, orertopping the flowers. Perianth pure white, above an inch long; segments linear, twice as long as the tube. Filautents not longer than the perianth-segments; style finally exserted.

Hab. Mountains of Transkeian Kaffraria, discovered by the Rev. R. Baur in 1874. Described from a plant that flowered at Kew, November, 1885. Included amongst the drawings of Natal Plants showed by Miss Large at the Indian and Colonial Exhibition of 1886.

22. H. M[ackexin Baker. - Bulb compressed, 3-4 in. diam.; tunies thick, green, bifarious. Leares 2 , contemporary with the flowers, round-oblong, spreading, 6-8 in. long, 4-5 in. broad, glabrous on the face, clothed on the edge and under surface with soft whitish hairs. Peduncle scarcely any. Umbel few-flowerech, compressed; pedicels very short; bracts oblong; outer greenish, pubescent; inner white, reined with green. Perianth white, nearly an inch long; tube cylindrical, $\frac{\pi}{4}$ in. long; segments linear. Filiments white, longer than the perianth-segments.

Hab. Natal, MIcKen! Described from a plant flowered by Mr. Wm. Bull, November, 1870.

2:3. H. DEFonuis Hook. fil. in Bot. Mag. t. 5903.-Bulb slightly compressed, 3-4 in. diam.; tunies thick, green, bifarious. Leares contemporary with the flowers, spreating, orbienlar, $3 \frac{1}{3}-4$ in. long and broad, evenly pilose over the surfice, not specially ciliated. Peduncle scarcely any. Umbel compressed, $1 \frac{1}{2}$ in. the long diameter; peilicels $\frac{1}{t}$ in. long; spathe-ralves $5-6$, oborate-oblong, $1 \frac{1}{4}-1 \frac{1}{2} \mathrm{in}$. long, white, veined with green. Perianth white, nearly an inch long; segments twice as long as the tube. Filaments white, longer than the segments.

Hab. Natal, MIcKen! Described from a plant that flowered at Kew in March, 1871. 
24. H. потundifolius Gaml. in Bot. Mag. t. 1618. H. orbicularis Domn. - Bulb compressed, 3-4 in. diam. ; tunies thick, bifarious. Leaves 2, spreading, suborbicular, 5-6 in. long and broad, glabrous, scabrous on the margin. Peduncle bright red, $\frac{1}{2} \mathrm{ft}$. long. Umbel dense, compressed, $1 \frac{1}{2}-2$ in. diam.; bracts $4-5$, ovate, bright red, an inch long; pedicels very short. Perianth pale red, an inch long; segments linear, twice as long as the cylindrical tube. Filaments white, longer than the segments.

Hab. Cape Colony; Southern provinces. Described from a specimen gathered by Thumberg and a plant that flowered at Kew, May, 1887. H. Lambertianus R. \& S. is said to differ by its numerous spathe-valves.

25. H. incarnatus Burch.; Herb. Amaryll. 237, tab. 31, fig. 1. -Bulb compressed, 2-3 in. diam.; tunics thick, bifarious. Leaves 2, oblong, spreading, 6-8 in. long, $3 \frac{1}{2}-4 \mathrm{in}$. broad, glabrous and not ciliated, but scabrous on the margin. Peduncle reddish, glabrous, 3-4 in. long. Umbel dense, globose, 2 in. diam.; pedicels short ; spathe-valves 4-5, oblong, ascending, pale red, about an inch long. Perianth pale red, $\frac{3}{4}$ in. long; tube short; segments linear. Stamens slightly exserted.

Hab. Cape Colony; South-eastern district, at Krakamma. Cultivated by Burchell at Fulham in 1817-1819. Nearly allied to H.rotundifolius.

26. H. Coopers Baker.-Bulb compressed, 4 in. diam. Leaves 2, produced in October, spreading, suborbicular, 4-5 in. long, shortly ciliated on the margin. Peduncle much compressed, glabrous, bright red, as long as the leaves. Umbel dense, globose, 2-3 in. diam., produced in July; spathe-valres ovate, bright red, an inch long; peclicels $\frac{1}{4} \mathrm{in}$. long. Perianth bright red, under an inch long; segments twice as long as the tube. Filaments distinctly cxserted; anthers pale yellow.

Hab. Cape Colony. Described from a specimen from Mr. Thos. Cooper, that flowered at Kew in July, 1863.

27. H. Hinsures Baker in Gard. Chron. 1878, 756.-Bulb compressed, $3 \mathrm{in.} \mathrm{diam.;} \mathrm{tunics} \mathrm{thick,} \mathrm{brownish,} \mathrm{bifarious.} \mathrm{Leaves} \mathrm{2,}$ contemporary with the flower's, round-oblong, 5-6 in. long, $3-4$ in. broad, dark green, hairy all orer, especially at and near the edge. Peduncle a little longer than the leaves, densely pilose. Umbel dense, globose, $3-4 \mathrm{in}$. diam.; pedicels $\frac{1}{2} \mathrm{in}$. long; spathe-valves 6 , oblong, membranous, bright red, shorter than the flowers. Perianth white or pinkish, $\frac{3}{4}-1$ in. long; segments linear, twice as long as the tube. Filaments and style much exserted.

Hab. Natal, Cooper 3231! Wood 3443! Transvaal, C. IIudd! Described from a plant flowered by Messrs. Veitch in April, 1878.

28. H. undulatus Herb. Amaryll. 233, tab. 30, fig. 1. - Bulb ovoid, under an inch in diam. Leaves 2 , subcrect, lorate, glabrous, much undulated, 5-6 in. long, $\frac{1}{2}$ in. broad above the middle, narrowed gradually to $\frac{1}{6}$ in. at the base. Peduncle slender, spotted, glabrous, 2-3 in. long. Umbel dense, about 1 in. diam.; pedicels $\frac{1}{4}-\frac{1}{3} \mathrm{in}$. long ; spathe-valves 4, oblong, ascending, bright red, an inch long. Perianth $\frac{1}{2}$ in. long; tube very short. Stamens much exserted, reaching to the tip of the spathe-valves. 
Hab. Cape Colony; Rhinoceros Fontein, near Langralei. Collected by Masson in July, 1793.

29. H. concolor Burch.; Herb. Amaryll. 238, tab. 31, fig. 2.Bulb oblong, compressed; tunies thick, bifarious. Leaves 2, suberect, lorate, about a foot long, $1 \frac{1}{2}-2 \mathrm{in}$. broad at the middle, glabrous, not ciliated. Peduncle slender, rather shorter than the leaves. Umbel dense, glohose, $1 \frac{1}{2} \mathrm{in}$. diam.; pedicels $\frac{1}{1} \mathrm{in.}$ long; spathe-valves 5-6, oblong, membranous, bright red, an inch long. Perianth bright red, $\frac{3}{4}$ in. long; tube very short; segments linear. Stamens exserted, $\frac{1}{4}-\frac{1}{3} \mathrm{in}$.

Hab. Cape Colony; South-western district. Flowered in Burchell's garden, October, 1826. Perhaps not distinct from $H$. sanguineus.

30. H. Sanguneus Jacq. Hort. Schoen. iv. 4, t. 407. Mlelicho sanguineus Salisb. - Bulb compressed, about 3 in. diam.; tunics thick, bifarious. Leaves 2 , suberect, loiate, about a foot long, 2-3 in. broal above the middle, green, glabrous. Peduncle produced before the leaves, slenter, glabrous, 8-9 in. long. Umbel dense, globose, 2 in. diam.; pedicels $\frac{1}{2}-\frac{3}{4}$ in. long; spathe-valves 6-8, oblong or lanceolate, reddish, $1-1 \frac{1}{2}$ in. long. Perianth $\frac{3}{4}$ in. long; segments linear, blood-red, twice as long as the cylindrical tube. Filaments exserted.

Hab. Cape Colony; Southern provinces. The obscure H. Hookerianus Herb. Amaryll. 40.1, tab. 46, fig. 7, may be the same species, but the leaves are not known.

31. H. Humis Jacq. Hort. Schoen. iv. 6, t. 411. MEelicho humilis Salisb. - Bulb ovoid, slightly compressed, 1 in. diam. Leaves 2 , suberect, lorate, produced after the flowers, light green, subacute, $\frac{1}{2}$ ft. long, $1 \frac{1}{2}$ in. broad above the middle, glabrous on the face, minutely ciliated. Peduncle much compressed, $2 \mathrm{in.}$ long. Umbel compressed; pedicels nearly as long as the flowers; spatlievalves about 6 , lanceolate, an inch long. Perianth whitish, $\frac{1}{3}$ in. long; tube very short; segments linear. Filaments exserter. Berry white. figure.

Hab. Cape Colony; Southern provinces. Known to me only from Jacquin's

32. H. callosus Burchell. - Bulb compressed, 3-4 in. diam. ; tunics thick, bifarious. Leaves 2, spreading, orbicular-oblong, glabrons, 9-10 in. long, 6-7 in. broad, not ciliated. Poduncle stout, about 3 in. long. Umbel dense, $1 \frac{1}{2}-2$ in. diam.; pelicels very shor't; spathe-valves about 6 , oblong, mombranous, bright red, ascending, $2 \mathrm{in}$. long, much overtopping the flower's. Perianth pink, $\frac{3}{4}$ in. long; tube very short; segments linear. Stamens exserted.

Hab. Cape Colony; Southern district. Cultivated by Burchell at Fulham in $1818-1819$.

33. H. coccrneus Linn. Sp. Pl.412; Gawl. in Bot. Mag. t. 1075; Red. Lil. t. 139 ; Lodd. Bot. Cab. t. 240. - Bulb compressed, 3-4 in. diam.; tunies thick, bifarious. Leaves 2, fully dereloped in winter, lingulate, subercet, $1 \frac{1}{2}-2 \mathrm{ft}$. 1 ong, $6-8$ in. broad abore the middle, narrowed to $3-4$ in. at the base, green, mspotted, 
glabrous. Peduncle 6-9 in. long, compressed, mottled with minute spots of red-brown. Umbel dense, globose, $2-3 \mathrm{in}$. diam.; pedicels $\frac{1}{1}-\frac{1}{2}$ in. long; spathe-valves $6-8$, oblong, bright red, ascending, imbricated, $2-2 \frac{1}{2} \mathrm{in}$. long. Perianth bright red, about an inch long; tube short; segments linear. Stamens exserted.

Var. H. coarctatus Jacq. Hort. Schoen. i. 30, t. 57 ; Bot. Reg, t. 181.-Fully developed leaves a foot long, 3-4 in. broad. Spathevalves shorter.

Var. H. Carinatus Linn. Sp. P1. 413.-Leaves above a foot long, much narrower and more channelled down the face than in the type.

Hab. Cape Colony; Southern provinces. Introduced into cultivation by Philip Miller in 1731.

34. H. moschatus Jacq. Hort. Schoen. iv. 6, t. 410. - Bulb compressed, $3 \mathrm{in.}$ diam.; tunics thick, bifarious. Leaves 2 , produced after the flowers, lingulate, $1 \frac{1}{2} \mathrm{ft}$. long, $4-4 \frac{1}{2}$ in. broad at the middle, obscurely pubescent when young, naked when mature, marked on the back with transverse bars of dark green on a pale green ground. Peduncle glabrous, much compressed, pale green, $\frac{1}{2} \mathrm{ft}$. long. Umbel dense, globose, $2-3 \mathrm{in}$. diam.; pedicels $\frac{1}{4}-\frac{1}{2} \mathrm{in}$. long; spathe-valves oblong, subacute, ascending, bright red, 2 in. long. Flowers with a strong foxy or musky smell. Perianth bright red, nearly an inch long; segments three times as long as the tube. Stamens distinctly exserted.

Hab. Cape Colony; Southern provinces. Very near H. coccineus.

35. H. tigrinus Jacq. Hort. Schoen. i. 29, t. 56 ; Bot. Mag. t. 1705. - Bulb subglobose, compressed, 3-4 in. diam.; tunics thick, bifarions. Leaves 2 , produced after the flowers, falcate, lingulate, 9-12 in. long, 3-4 in. broad at the middle, glabrous on the surfaces, obscurely ciliated, much spotted with red-brown on the lower part of the back. Peduncle 2-4 ft. long, green, much spotted with red-brown. Umbel dense, globose, $1 \frac{1}{2}-2$ in. diam.; pedicels short; spathe-valves $6-8$, oblong, obtuse, very bright red, permanently ascending, $1 \frac{1}{2}-2$ in. long. Periantl pale red, under an inch long; tube very short. Stamens distinctly exserted.

Hab. Cape Colony; Southern provinces. Gathered and sketched by Masson in 1795. Described from a plant flowered at Kew, November, 1887.

36. H. hyalocarpus Jacq. Hort. Schoen. iv. 5, t. 409. - Bulb ovoid, compressed, $2 \mathrm{in}$. diam. ; tunics thick, bifarious. Leaves 2 , produced after the flowers, lorate, suberect, about a foot long, 2 in. broad, glabrous, not spotted. Peduncle 4-6 in. long, green, mottled with dark red. Umbel dense, globose, 2 in. diam.; pedicels $\frac{1}{4}$ in. long; spathe-valves about 6, oblong, bright red, overtopping the flowers. Perianth red, an inch long; tube short; sogments linear. Stamens slightly exserted. Berry white, containing a single seed.

Hab. Cape Colony; Southern provinces. H. zebrinus Herb., of which the flowers are not known, differs from this by its narrower leaves, densely spotted on the back, and slightly on the face.

37. H. crassipes Jacq. Hort. Schoen. iv. 7, t. 412.-Bulb ovoid, $1 \frac{1}{2}$ in. diam.; tunies thick, bifarious. Leaves 2 , produced after the 
flowers, lorate, suberect, $\frac{1}{2} \mathrm{ft}$. long, $1 \frac{1}{2}-2 \mathrm{in}$. broad, glabrous on the face, softly ciliated, mottled with red on the back towards the base. Peduncle 3 in. long, compressed, green, mottled with red. Umbel dense, globose; pedicels short; spathe-valves 5-6, oblong or oblonglanceolate, reddish, ascending, $1 \frac{1}{2}$ in. long. Perianth pale red, $\frac{3}{4}-\frac{7}{8} \mathrm{in.}$ long; tube short; segments lincar. Stamens exserted. figure.

Hab. Cape Colony; Southern provinees. Known to me only from Jacquin's

38. H. pubescens Limn. fil. Suppl. 193. II, quadriuli is Jacq. Hort. Schoen. i. 30, t. 58; Bot. MIag. t. 1523. - Bulb compressed, 2 in. diam.; tunies thick, bifarious. Leares 2 , produced after the flowers, lorate, suberect, 6-9 in. long, $1 \frac{1}{2}-2$ in. broad above the middle, narrowed to $\frac{1}{4}-\frac{1}{3} \mathrm{in}$. at the base, minutely ciliated, glabrous or finely pilose on the back and face, blotched with red on the back towards the base. Peduncle compressed, dark red, 3-4 in. long. Umbel dense, globose, 1-11 in. diam.; pedicels very short ; spathevalves usually 4, oblong, red, ascending, $1 \frac{1}{2}-2 \mathrm{in}$. long, overtopping the flowers. Perianth bright red, $\frac{3}{4}-\frac{7}{6} \mathrm{in}$. long; tube short; segments linear. Stamens distinctly exserted.

Hab. Cape Colony; Southern provinces. I have seen specimens collected by Thunberg and Masson, and from the garden of Dr. Gryn in 1783. This and not albiflos is the pubescens of the Linnean and Thumbergian herbaria.

\section{Buphane Herb.}

Perianth erect, hypocrateriform; tube short, subcylinclical or campanulate; segments equal, linear or lanceolate. Stamens inserted at the throat of the perianth-tube; filaments straight, filiform; anthers oblong, versatile. Ocary turbinate, 3-celled; ovules 2 in a cell, collateral, sessile at the middle of the placenta; style simple; stigma obscurely 3-lobed. C'upsule turbinate, membranous, loculicidally 3-ralved. Seeds solitary, green, globose.Rootstock a rery large tunicated bulb. Leares coriaceous, ensiform or lingulate. Peduncle short, stout, solid. Flover's in an umbel very numerous, red; spathe of two large ovate valves.

1. B. Disticha Herb. in Bot. Mag. sub t. 2578. Amaryllis disticha Limn. fil. B. toxicaria Herb. Hamanthus toxicarius Thunb.; Jacq. Fragm. t. 39-40; Gawrl. in Bot. MIag. t. 1217. Brunstiqjic toxicaria Gawl. in Bot. Reg. t. 567. - Bulb subglobose, 6-9 in. diam., with many hundreds of thin brown tunics. Leaves 8-16, distichous, ensiform, suberect, not ciliated, finally $1-1 \frac{1}{2} \mathrm{ft}$. long, often undulated. Peduncle stout, compressed, glancous, $\frac{1}{2}-1 \mathrm{ft}$. long. Umbel dense, $\frac{1}{2}-1 \mathrm{ft}$. diam.; pedicels $2-4 \mathrm{in.}$ long; spatheralves ovate, decidnous, $2-3$ in. long. Perianth tube subcylindrical, $\frac{1}{4}-\frac{1}{2}$ in. long; segments linear, $\frac{3}{4}-1$ in. long. Stamens equalling or a little exceeding the perianth-segments. Capsule turbinate, $\frac{3}{4}$ in. long.

Hab. Eastern provinces of Cape Colony northward to Angola, Lake Nyassa, and Lake Tanyanika, where it was found by Lieut. Cameron and Mr. Joseph Thomson. Fruited by Sir C. W. Strickland in August, 1879. 
2. B. cilitaris Herb. in Bot. Mag. sub t. 2573. Amaryllis ciliaris Linn. Hamanthus ciliaris Linn.; Jacq. Fragm. t. 40, fig. 1, \& t. 41, fig. 1. Brunsvigia ciliaris Gawl.; Lindl. in Bot. Reg. t. 1153. Coburgia ciliaris Herb. Crossyne citiaris Salisb. - Bulb globose, 3-4 in. diam. Leaves 4-6, spreading, lingulate, rigidly coriaceous, $\frac{1}{2}-1 \mathrm{ft}$. long, densely ciliated with brown or straw-coloured bristles $\frac{1}{8}-\frac{1}{3}$ in. long. Peduncle stout, $4-6$ in. long. Flower's 50-100 in a dense umbel; pedicels rigid, triquetrous, 3-4 in. long; spathevalves much shorter than the pedicels. Perianth-tube small, campanulate ; segments lanceolate, dull purple, reflexing, $\frac{1}{4}-\frac{1}{3} \mathrm{in}$. long. Capsule $\frac{1}{4}-\frac{1}{3}$ in. diam.

Var. B. guttata Herb. Amaryll. 240, tab. 22, fig. 1. - Leaves narrower; bristles subulate, $\frac{1}{4}-\frac{1}{2}$ in. long.

Hab. Southern provinces of Cape Colony. Sketched by Masson in 1795 (var. guttata), and introduced into cultivation by Burchell.

\section{Crinum Linn.**}

Perianth hypocrateriform or funnel-shaped; tube long, cylindrical, straight or curved; segments linear, lanceolate or oblong, subequal. Stamens inserted at the throat of the perianth-tube; filaments long, filiform; anther's linear, versatile. Ovary 3-celled; ovules few in a cell, sometimes two only, sessile or immersed in the thick placenta; style long, filiform, more or less declinate; stigma minute, capitate. Fruit irregular in shape, finally bursting. Seeds large, green, bulbiform, with very thick albumen. - Rootstock a large bulb, with membranous tunics and a produced neck. Leares persistent, usually broad. Peduncle solid. Floucer's few or many in an umbel, white or reddish; pedicels short; spathe-valves 2 , broad.

Subgenus Stenaster. Perianth erect, hypocrateriform; segments linear. Stamens spreading.

$\begin{array}{clll}\text { Species of Tropical Asia } & & \text { Sp. } 1-8 . \\ \text {, } & \text { Australia and Polynesia } & \text {. } & \text { Sp. } 9-11 . \\ , & \text { Tropical Africa } & \text {. } & \text { Sp. } 12-24, \\ \text {," } & \text { Tropical America } & \text {. } & \text { Sp. } 25-26 .\end{array}$

Subgenus Platyaster. Perianth crect, hypocrateriform; segments lanceolate. Stamens spreading.

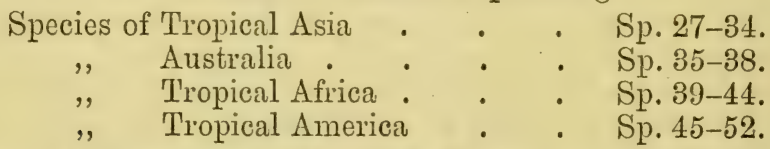

Subgenus Codonocrinuir. Perianth funnel-shaped; tube perma. nently curved; segments oblong, ascending. Stamens and style contiguous, declinate.

Species of Tropical Asia

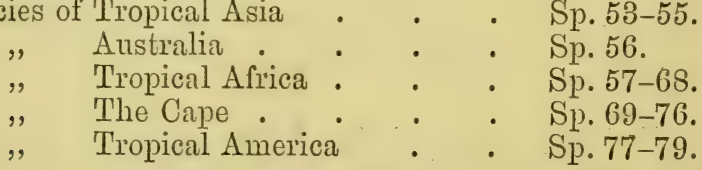

* Reprinted, with additions and alterations, from 'Gardeners' Chronicle,' 1881, i. 763 . 


\section{Subgenus Stenaster.}

1. C. astaticun Limn. Sp. Pl. 419, ex parte; Gawl. in Bot. Mag. t. 1073. C. toxicarium Roxb. C. asiaticum var. toxicarium Herb.; Wight, Ic. t. 2021-2022, - Bulb 4-5 in. diam.; neck 6-9 in. long. Leaves 20-30, lorate, multifarious, thin, bright grecn, 3-4 ft. long, 3-4 in. broad, narrowed gradually to an acute point. Peduncle

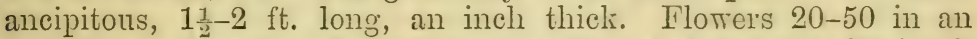
umbel; spathe-valves $3-4 \mathrm{in.} \mathrm{long;} \mathrm{pedicels} \frac{1}{2}-1$ in. long. Perianth white; tube erect, tinged with green, $3-4$ in. long; segments linear, $2 \frac{1}{2}-3 \mathrm{in}$. long. Stamens tinged with red, 2 in. long; anther's $\frac{1}{2}-\frac{3}{4} \mathrm{in}$. long. Ovules solitary. Fruit subglobose, $1 \frac{1}{2}-2$ in. diam., generally 1-seeded.

Var. C. Declinatun Herb. in Bot. Mag.t. 2231; Bury, Hexand. t. 43. - Peduncle assurgent and plicate. Bud slightly ccrnuous; tube and limb longer than in the type, the latter tinged with red.Sillet.

Var. C. sinicuar Roxb. - Leaves 5 in. broad, with a very undulated edge. Peduncle $3 \mathrm{ft}$. long. Tube and segments longer than in the type.-China.

Var. C. procerum Carey; Herb. in Bot. Mag. t. 2684.-Leaves $5 \mathrm{ft}$. long, half a foot broad. Perianth-tube and limb each 5 in. long, the latter tinged red on the outside.--Rangoon.

Var. C. anomalum Herb. C. plicatum Livingstone; Hook. in Bot. Mag. t. 2908. - Leaves expanded suddenly at some distance above the base into a broad membranous plicate variegated wing.China.

Var. Japonicun Baker.-Leaves firmer in texture, 2-21 in. broad.

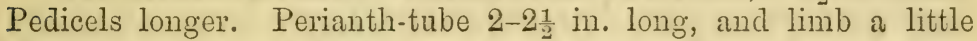
shorter.- Shores of Japan.

Hab. Widely spread in Tropical Asia. Figured by Rumphius in 1750 . There is a specimen at the British Museum sent from Tranquebar by the Moravian brethren in 1784 . The synonyms cited under asiaticum by Linnæeus include erubescens, longifolium, and defixum. It appears to extend eastward to the Aru Islands.

2. C. sumatranun Roxb. Hort. Beng. 23 ; Lindl. in Bot. Reg. t. 1049. C. riyjum Herb. - Bulb ovoid, as large as in asiaticum, but the neck shorter. Leaves ensiform, suberect, 3-4 in. broad, narrowed gradually to the point, firm in texture, dark dull green; edge distinctly serrulate. Peduncle much shorter than the leaves. Umbel 10-20 flowered; spathe-valves lanceolate-deltoid, 3 in. long; pedicels very short. Perianth-tube erect, greenish, 3-4 in. long; segments linear, as long as the tube, not tinged with red outside. Filaments bright red, much shorter than the segments; anther's linear, $\frac{3}{4}$ in. long. Fruit as large as a man's fist, 1-3-seeded.

Hab. Sumatra, Introduced by Dr. Charles Campbell to the Calcutta Botanic Garden in 1801. C. macrocarpum Carey, from Rangoon, is probably a near ally, but it is known only from a brief diagnosis.

3. C. amabtle Domn, Hort. Cantab. ed. vi. 83; Ker in Bot. Mag. t. 1605. C. superbum Roxb.-Bulb small, but with a neck a foot or more long. Leaves 25-30, lorate, 3-4 ft. long, 3-4 in. broad, bright green, tapering gradually to the point, the outer spreading, 
the inner suberect; margin narrow, entire. Peduncle 2-3 ft. long, ancipitous. Flowers 20-30 in an umbel, very fragrant; spathevalves lanceolate-deltoid, tinged red, 4-5, in. long; pedicels $\frac{1}{2}-1$ in. long. Perianth-tube erect, cylindrical, bright red, 3-4 in. long; segments $4-5 \mathrm{in}$. long, $\frac{1}{3}-\frac{1}{2} \mathrm{in}$. broad, red on the outside. Ovules few in a cell. Stamens an inch shorter than the segments.

Hab. Sumatra, introduced into cultivation at the beginning of the century by Dr. Campbell and Sir Stamford Raffles. Described from a plant that flowered at Kew in the winter of 1871. An allied plant with much smaller flowers, collected by Kurz in the Andaman Isles, requires further study.

4. C. Defrum Ker in Joum. Se. iii. 105; Lodd. Bot. Cab. t. 362 ; Herb. in Bot. Mag. t. 2208. C. asiaticum Linn. ex parte; Roxb.; C. Roxburghii Dalz. \& Gibs. Amaryllis vivipara Lam.-Bulb ovoid, 2-3 in. diam.; neck long, cylindrical. Leaves $6-8$ to a bulb, linear, 2-3 ft. long, $\frac{3}{4}-1$ in. broad, deeply channelled down the face, tapering to the point; margin entire. Peduncle moderately stout, $1 \frac{1}{2}-2 \mathrm{ft}$. long. Umbel $6-15$-flowered; spathe-valves ovate-lanceolate, $1 \frac{1}{2}-2$ in. long; pedicels short. Perianth-tube slender, erect, $2 \frac{1}{2}-3$ in. long; segments linear, nearly as long as the tube. Filaments bright red, an inch shorter than the segments; anthers linear, $\frac{1}{2} \mathrm{in}$. long. Capsule subglobose, 2 in. diam.; seeds 1-2 in a cell.

Var. C. exsifolium Roxb.; Herb. in Bot. Mag. t. 2301.-Leaves more acute. Perianth-tube $4 \mathrm{in}$. long; segments as long as the tube, tinged red on the outside.-Pegu.

Hab. Muddy and swampy banks of rivers about Calcutta and through Peninsular India. Flowers in October. Figured by Rheede in 1692.

5. C. Watrir Baker.--Bulb ovoid, 2 in. diam.; neck very short. Leaves ensiform, thin, flaccid, tapering gradually to the point, $1 \frac{1}{2} \mathrm{ft}$. long, 1-1 $1 \frac{1}{\mathrm{t}}$ in. broad; margin entire. Peduncle mederately stout, $1 \frac{1}{2} \mathrm{ft}$. long. Umbel 6-8-flowered; spathe-valves lanceolatedeltoid, $1 \frac{1}{2} \mathrm{in}$. long; pecicels very short. Buds tinged with purple. Perianth-tube slender, erect, $3 \mathrm{in.}$ long; segments linear, half as long as the tube. Stamens as long as the segments; anthers linear, $\frac{1}{3}$ in. long.

Hab. Manipur; Myang Khong Valley, alt. $4000 \mathrm{ft}$., in grassy places, $D r$. G. Watt 7148 ! Allied to C. defixum.

6. C. stenophylum Baker in Gard. Chron. 1881, 786.-Leaves thin, flaccid, linear, $3 \mathrm{ft}$. long, $\frac{1}{t}-\frac{1}{3} \mathrm{in}$. broad. Peduncle slender, ancipitous, about a foot long. Umbel 4 -flowered; spathe-valves lanceolate-acuminate, $2 \mathrm{in}$. long; pedicels $\frac{1}{1} \mathrm{in}$. Perianth-tube slender, erect, 3-4 in. long; segments linear, spreading, half as long as the tube. Stamens shorter than the segments.

Hab. Tavoy, collected by Gomez in October, 1827, Wallich Herb. Ind. 8970 ! Nearest $C$. defixum.

7. C. serrulatum Baker in Gard. Chron. 1881, 786. - Bulb ovoid, 2 in. diam.; tunics thick, dull brown; neck short. Leaves 10-12, suberect, linear, firm in texture, under a foot long, $\frac{1}{4}-\frac{1}{3} \mathrm{in}$. broad, tapering gradually to the point, distinctly serrulate on the margin. Peduncle slender, about a foot long. Umbel ferv-flowered; spathe-valves lanceolate, an inch long; pedicels very short. Perianth- 
tube slender, erect, $3 \frac{1}{2}-4 \mathrm{in}$. long; segments linear, $3 \frac{1}{2}-4 \mathrm{in}$. long, tinged with red on the outside. Stamens nearly as long as the segments ; anther's small, linear.

Hab. Cambodia; Mountains of Pursat, Godefroy-Lebeuf 397 !

8. C. pusilluir Herb. Amaryll. 255, tab. 32, fig. 3.- Bulb very narrow, with a cylindrical neck $4 \mathrm{in}$. long, under $\frac{1}{2} \mathrm{in}$. diam. Leaves few, linear, acute, suberect, under a foot long, $\frac{1}{4}-\frac{1}{3}$ in. broad; margin entire. Flowers few in an umbel; penticels above an inch long. Perianth-tube erect, $3 \mathrm{in.} \mathrm{long;} \mathrm{segments} \mathrm{linear,}$ nearly as long as the tube. Stamens an inch shorter than the segiments; anthers $\frac{1}{3}$ in. long.

Hab. Nicobar Islands. Allied to C. defixum.

9. C. pedunculatum R. Br. Prodr. 297; Ker in Bot. Reg. t. 52; Bury, Hexand. t. 11. C. taitense Red. Lil. t. 408. C. canaliculatum Roxb. C. anstrale and exaltatum Herb. - Bulb 4 in. diam.; neck columnar, $\frac{1}{2} \mathrm{ft}$. long. Leaves 20 to a bulb, lorate, thin, bright green, 3-4 ft. long, 4-5 in. broad; margin entire. Peduncle ancipitous, 2-3 ft. long, $1 \mathrm{in}$. cliam. Flower's 20-30 to an umbel;

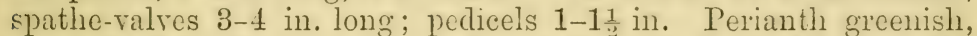
erect, $2 \frac{1}{2}-3 \mathrm{in.}$ long; segments linear, spreaching, shorter than the tube, not tinged with red outside. Filaments bright red, $1 \frac{1}{2}-2$ in. long; anther's linear, $\frac{1}{2}-\frac{3}{4} \mathrm{in}$. long. Style rather longer than the stamens. Ovules 3 in a cell.

Hab. Eastern Australia. Described from a plant that flowered in the Palm-house at Kew in the summer of 1878. Herbert names and describes four varieties. We have what is probably the same species from Timor Laut, Riedel!; Fiji, Seemann 640!; Néw Caledonia, Caldwell!; and New Guinea, Edelfeldt 219 !, the latter received from Baron von Mueller; and Redouté's plant is supposed to have come from Tahiti. $\mathrm{MI}$. Wm. Bull has lately introduced a fine form from Lord Howe's Island.

10. C. nicrantherum Engl. Jahrb. v. 448. - Bulb with a stout produced neck. Leares lorate, $3 \mathrm{ft}$. long, $4 \mathrm{in}$. broad at the middle, narrowed gradually to the point. Spathe-valves 5-6 in. long; pedicels under an inch. Perianth white, with a cylindrical tube above $3 \mathrm{in}$. long, and linear spreading segments $4 \mathrm{in}$. long, $\frac{1}{4}-\frac{1}{3} \mathrm{in}$. broad. Filaments nearly as long as the segments; anther's linear, above an inch long.

Hab. New Mecklenburg and New Hanover, Nunmann. Discovered on the royage of the 'Gazelle,' $187 \tilde{\text {. }}$

11. C. Baseri Schumann in Engl. Jahrb. iv. 194. - Leaves

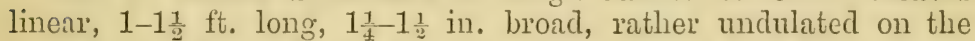
smooth margin. Perianth-tube rather curved, $1 \frac{1}{2}-2$ in. long; segments linear, reddish, $2 \frac{1}{3}-3 \mathrm{in}$. long, $\frac{1}{4}$ in. broad. Filaments rather shortcr than the scgments ; anthers linear, an inch long.

Hab. Marshall's Island, Finsch.

12. C. Bracteatum Willd. Sp. Pl. ii..47; Jacq. Hort. Schoen. iv. t. 495 ; Gawl. in Bot. Reg. t. 179. C. brevifolium Roxb. C. asiaticum var. bracteatum Herb. - Bulb ovoid, 3-4 in. diam.; neck

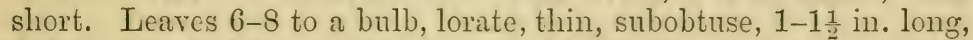
3-4 in. broad at the midlle, narrowed to the base; margin crisped, 
entire. Peduncle a foot long, much compressed, moderately stout. Flowers 10-20 in an umbel; spathe-valves broad, green, $3 \mathrm{in.} \mathrm{long;}$ pedicels very short. Perianth-tubo slender, erect, greenish, $2 \frac{1}{2}-3$ in. long; segments linear, spreading, pure white. Filaments bright red, $1 \frac{1}{2}-2$ in. long ; anthers linear, $\frac{1}{2}-\frac{3}{4}$ in. long. Ovules solitary.

Hab. Wild in the Seychelles, especially on the sandy beaches of the western coast of the Island of Mahé, Home! Introduced from Mauritius long ago to the Calcutta Botanic Garden.

13. C. Welwitschir Baker in Gard. Chron. 1881, ii. 40.-Lonves linear, $1 \frac{1}{2}-2 \mathrm{ft}$. long, $\frac{1}{4}-\frac{1}{3} \mathrm{in}$. broad, moderately firm in texture; cdge slightly scabrous. Perianth-tube curved, 4 in. long; segments linear, ascending, nearly as long as the tube. Stamens short.

Hab. Angola, Welwitsch 4016! This seems very distinct, but the only specimen I have seen is incomplete.

14. C. mauritranum Lodd. Bot. Cab. t. 650. - Leaves ensiform, suberect, about $3 \mathrm{ft}$. long, apparently not more than $2-2 \frac{1}{2}$ in. broad. Peduncle much shorter than the leaves. Flowers 4 in an umbel, sessile. Perianth-tube suberect, 3-4 in. long; segments linear, rather shorter than the tube, tipped with red. Stamens and style shorter than the segments.

Hab. Cultivated by Loddiges at Hackney in 1822, and known now only from the much-reduced figure in their 'Botanical Cabinet.' Nothing like has been sent home from Mauritius of late years.

15. C. Ligulatum Baker in Journ. Linn. Soc. xx. 270.-Leaves aboit $S$ in a tuft, lorate, reaching a length of $2-3 \mathrm{ft} ., 2 \mathrm{in}$. broad at the middle, moderately firm in texture; margin entire. Peduncle stout, a foot or more long. Flowers 20-30 in a dense umbel, sessile; spathe-ralves broad, 2-3 in. long. Perianth-tube slender,

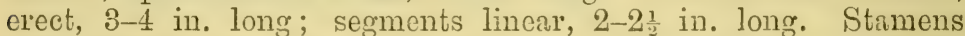
rather shorter than the perianth-segments; anthers linear, $\frac{1}{2}$ in. long. Style as long as the perianth-segments.

Hab. Central Nadagascar, Baron 1982 ! 3575 ! 4389 ! Dr. Parlier! Hildebrandt 3716 ! Native name, Iringatsy. Allied to $C$. asiaticum.

16. C. Firmifoliun Baker in Journ. Linn. Soc. xx. 270.-Leaves narrow, lorate, firm in texture, $3 \mathrm{ft}$. long, $1 \frac{1}{2} \mathrm{in}$. broad at the middle, tapering gradually to the point; margin distinct, entire. Peduncle a foot long. Umbel 6-8-flowered; spathe-valves $1 \frac{1}{2}-2$ in. long: pedicels none: perianth-tube straight, $5-6$ in. long; segments linear, 2-2 $\frac{1}{2}$ in. long. Stamens about as long as the segments; anthers linear, $\frac{1}{2}$ in. long. Style overtopping the anthers.

Hab. East coast of Madagascar, Baron 1638! 4431! Gathered by the Rev. R. Baron, who has discorered about a thousand new plants in Nadagascar, in 1882.

17. C. Leucophyluun Baker in Bot. Mag. t. 6783.-Bulb ovoid, 5-6 in. diam. Leaves 12-15, distichous, lorate-oblong, fleshy,

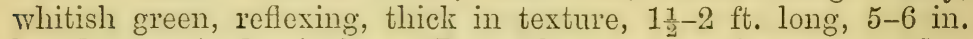
broad; margin denticulate. Peluncle stout, much compressed, a foot long. Flowers 30-40 in a dense centripetal umbel; spathevalves deltoid, $3 \mathrm{in}$. long; pedicels 1-2 in. long. Perianth-tube crect, 3 in. long; limb pale pink; segments linear, patent, $2-2 \frac{1}{4}$ in. 
long. Filaments a little shorter than the segments; anthers linearoblong, $\frac{1}{3} \mathrm{in}$. long. Style as long as the segments.

Hab. Damara-land. Flowered at Kew, Auguist, 18s1, from a bulb purchased from a Danish sea-captain named Thuré Ein.

18. C. Trnneanum Kotschy \& Peyritsch in Plant. Timneanæ, 44, t. 21. - Bulb and leaves unknown. Scape green, compressed. Flowers 12-30 in an umbel; spathe-valves lanceolateddeltoid, 2-3 in. long; pedicels 1-2 in. long. Perianth-tube erect, very slender, 21-3 in. long; limb rose-real; scgments linear, not more than half as long as the tube, $\frac{1}{8}-\frac{1}{6} \mathrm{in}$. broad. Filaments half as long as the perianth-segments; anthers linear-oblong, in. long. Ovules several, superposed.

Hab. East Tropical Africa. First gathered on the banlss of the Bahr-elGhasal by Mdlle. Tinné. Found also by Kotschy in Kordofan, and by Father Tinoblecher in a garden at Gondolioro. The specific name is printed timnece in the text, and indexed by Pritzel as cordofamum.

19. C. Lastri Baker.-Bulb globose, 4-5̃ in. diam.; neck short. Leaves ensiform, distichous, acute, as long as the peduncle, disarticulating near the base, when the flowers fade. Peduncle abore a foot long, stout and much compressed. Umbel many-flowered; spathe-valves broad, membranous; pediecls $\frac{1}{2}-1$ in. Perianth-tube

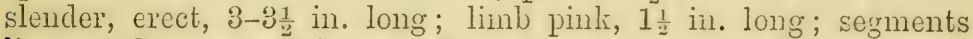
linear. Stamens as long as the segments; anthers linear-oblong, $\frac{1}{4}$ in. long.

Hab. Kongone Mountains, 100 miles inland from Zanzibar, alt. $2000 \mathrm{ft}$. Gathered by Mr. Last. Bulb sent home by Sir Jolnn Kirk in 1Larch, 1881, but we failed to flower it.

20. C. Barnesir Balier in Gard. Chron. 1881, ii. 40.-Bulb and leaves unknown. Peduncle moderately stont. Flowers 20-30 in a dense umbel; spathe-valves ovate, $1 \frac{1}{2}$ in. long; pedicels $\frac{1}{2}-\frac{3}{4} \mathrm{in}$. Perianth with a slender erect tube $2 \frac{1}{2}-3 \mathrm{in.}$ long; limb red, half as long as the tube; segments lincar. Filaments nearly as long as the segments, bright red; anthers lincar-oblong, $\frac{1}{4}$ in. long. Style reaching to the tip of the segments. Orules screral, superposed.

Hab. South-cast Tropical Africa, near Koobie. Known only from a single specimen gathered by Mr. 'T. Baines, the artist, in 1881. Nearly allied to $C$. t'imnectum.

21. C. Thruppir Baker. - Leaves short, lorate, firm in texture, closely veined, $2 \mathrm{in}$. broad; margin denticulate. Pcduncle short, stout. Flower's 20-30 in a dense umbel; spathe-valves broad, membranous; pedicels $\frac{3}{4}-1$ in. Perianth-tube slender, erect, $2 \frac{1}{2}-3$ in. long; limb erect, pink, 2 in. long; segments linear. Stamens nearly as long as the segments; anthers linear, $\frac{1}{4} \mathrm{in}$. long. Style reaching to the tip of the segments.

Hab. Somali-land. Gathered by Messrs. Thrupp and James in April, 1885. Allied to C. Tinneanum.

22. C. amiocharoides Baker in Journ. Bot. 1878, 195. - Bulb large, globose ; neck short. Leaves $6-8$ to a bulb, closely veined, lorate, curved, about a foot long, an inch broad; margin distinctly ciliated. Peduncle stout, much compressed, 3-6 in. long. Flowers 10-20 in an umbel; spathe-valves lanceolate, 2-3 in. long; pedicels 
$\frac{1}{2}-1$ in. Perianth-tube erect, $3-4 \frac{1}{2}$ in. long; segments linear, bright red, 2-3 in. long. Filaments bright red, as long as the segments; anthers linear-oblong, $\frac{1}{4} \mathrm{in}$. long. Style just overtopping the anthers. Ovules several, superposed.

Hab. East Tropical Africa; Djur-land, Dr. Schweinfurth 1370! 1787 ! Kordofan, Dr. Pfund 377 ! 765 !

23. C. BUphanoides Welwitsch MSS.; Baker in Journ. Bot. 1878, 195.-Bulb 5-6 in. diam. Leares ensiform, firm in texture, $1 \frac{1}{4}-1 \frac{1}{2} \mathrm{ft}$. long, $2-2 \frac{1}{2} \mathrm{in}$. broad at the middle, tapering gradually to the point; margin fringed with minute lanceolate scales. Peduncle moderately stout, a foot long. Flower's $30-40$ in an umbel; spathevalves broad, deciduous; pedicels finally $1-1 \frac{1}{2} \mathrm{in}$. long. Perianthtube erect, $3-4 \mathrm{in}$. long ; segments linear, $2-2 \frac{1}{2} \mathrm{in}$. long, $\frac{1}{4} \mathrm{in}$. broad, keeled with red down the back. Filaments mearly as long as the segments; anthers linear, $\frac{1}{3} \mathrm{in}$. long. Style as long as the segments.

Hab. Angola, in sandy woods of the subtemperate region in the Province of Pungo Andongo, Welwitsch 4014!

24. C. angolense Benth. Gen. Plant.iii. 730. Buplane angolensis Baker in Journ. Bot. 1878, 197. - Bulb large, ovoid. Leaves 6-8 to a stem, lorate, much curved, spreading, distichous, 6-8 in. long, $\frac{1}{2}-\frac{3}{4}$ in. broad, glaucous, fimbriate-ciliate. Peduncle stout, not more than 1-2 in. long. Flowers 6-8 in an umbel, dull red; spathevalves lanceolate, $1 \frac{1}{2}-2 \mathrm{in}$. long; pedicels very short. Perianthtube straight, cylindrical, 2 in. long; segments falcate, linear, $1 \frac{1}{4-1} \frac{1}{2}$ in. long. Filaments $\frac{1}{2} \mathrm{in.}$ long; anther's linear-oblong, $\frac{1}{6} \mathrm{in}$. long. Style short.

Hab. Angola, in damp pastures of the Province of Huilla, alt. 3800-5500 ft., flowering in October, Welwitsch 4012! A very distinct and curious plant.

25. C. caribeum Baker in Gard. Chron. 1881, ii. 40. C. fluridumum Griseb. Flora Brit. West Ind. 583, non Fraser.-Leaves loratc-oblong, 9-10 in. long, 3-4 in. broad, narrowe gractually to $\frac{1}{2}$ in. at the base. Flower's $8-4$ in an umbel; pedicels as long as the orary. Perianth-tube nearly straight, $3-4$ in. long; segments linear, spreading, nearly as long as the tube, white, $\frac{1}{8} \mathrm{in}$. broad.

Hab. Gathered in Jamaica by the Rev. Mr. Wullschagel. Known to me only from Grisebach's description. C. foridanum Fraser, founded on a plant brought from Florida, is $C$. asiaticum, according to Herbert.

26. C. cruentuir Gawl. in Bot. Reg. t. 171; Lodd. Bot. Cab. t. 346 ; Bury, Hexand. t. 22. - Bulb large, stoloniferous; neck short. Leaves lorate, glossy, dark bright green, suberect, 2-3 in. broad, 3-4 ft. long, tapering to the point, closely veined; edge cntire. Peduncle stout, compressed, above $2 \mathrm{ft}$. long. Flowers 6-8 in an umbel, subsessile; spathe-valves lanceolate-deltoid, $3 \mathrm{in.}$ long. Perianth-tube erect, 7-8 in. long; segments linear, bright pink, 3 in. long, spreading or reflexing. Filaments bright red, rather shorter than the segments; anthers linear, $\frac{1}{2}$ in. long. Style as long as the segments.

Var. C. Lodbigestanuir Herib. Amaryll. 401. - Pedicels as long as the ovary. Perianth-segments dark purple at the tip.

Hab. Mexico. Introduced into cultivation in Herbert's time, but I have never seen it alive. 


\section{Subgenus Platyaster.}

27. C. Hunile Herb. in Bot. Mag. t. 2636. - Bulb small, globose, greenish; neck very short. Leaves linear, a foot long, spreading, subacute, thicker than in amcmum and pitted over the face. Peduncle slender, subterete, a foot long. Flower's 6-9 in an umbel, cernuous in bud; spathe-valves $2-3$ in. long; pedicels short. Perianth-tube greenish, 3 in. long; segments linearlanceolate, spreading, white, 2 in. long, $\frac{1}{3}$ in. broad. Filaments bright red, rather shorter than the perianth-segments. Style longer than the segments.

Hab. Tropical Asia. Imported alive by Captain Craigie in 1826, and sold to Mr. Cattley, after whom the genus of orchids was named. An imperfect specimen from the collection of Dr. Stocks may perhaps belong here.

28. C. Cuningir Baker in Gard. Chron. 1881, ii. 72.-Leaves linear, a foot long, an inch broad, thin; edge entire. Peduncle slender, a foot long. Flowers 10-12 in an umbel; spathe-valves lanceolate, 2 in. long; pedicels very short. Perianth-tube very slender, $2-2 \frac{1}{2}$ in. long, straight or slightly curved; segments lanceolate, nearly or quite as long as the tube. Filaments bright red, nearly as long as the segments; anthers linear, $\frac{1}{2}$ in. long. Style as long as the segments.

Hab. Philippines; Island of Luzon, province of Albay, Cuming 1832 !

29. C. amenum Roxb. Hort. Beng. 23.-Bulb globose, 2-3 in. diam. ; neck very short. Leaves 10-12 to a bulb, linear, suberect, bright green, $1 \frac{1}{2}-2 \mathrm{ft}$. long, 1-2 in. broad, tapering gradually to the point; edge scabrous. Peduncle slender, subterete, 1-2 ft. long, Flowers 6-12 in an umbel; spathe-valves lanceolate, 2 in. long; pedicels none or very short. Perianth-tube greenish, 3-4 in. long; segments lanceolate, spreading, $2-3$ in. long, $\frac{1}{3}-\frac{1}{2}$ in. broad. Filaments bright red, rather shorter than the segments; anther's linear, $\frac{1}{2}$ in. long. Style as long as the segments. Ovules $4-5$ in a cell.

Var. caudiceum Herb.-Bulb furnished with a cylindrical neck. Ceylon.

Var. C. verecundum Carey. - Leaves more obtuse, spreading, lacunose. Rangoon.

Hab. Eastern Himalayas and Khasia, ascending to $6000 \mathrm{ft}$. in Sikkim. There are good unpublished drawings in the Roxburgh and Cathcart series, both now at Kew. It was in the Calcutta Garden in Wallich's time. (Herb. Ind. 8971, B.).

30. C. Gracile E. Meyer in Presl Rel. Haenk. ii. 120.-Leaves linear, $1 \frac{1}{2} \mathrm{ft}$. long, $1 \frac{1}{2}$ in. broad, narrowed from the middle to both ends. Peduncle slender, about a foot long. Flowers 6-7 in an umbel; spathe-valves lanceolate, $1 \frac{1}{2} \mathrm{in}$. long; pedicels none or very short. Perianth-tube 3 in. long; segments lanceolate, less than half as long as the tube. Filaments shorter than the segments.

Hab. Philippines; Island of Luzon, gathered by Haenke.

31. C. Strachexi Baker in Gard. Chron. 1881, ii. 72.-Leaves lorate, $2 \mathrm{ft}$. long, $1 \frac{1}{2}-2$ in. broad, thin, acute; edge slightly denti- 
culate. Peduncle stout, $1 \frac{1}{2}-2 \mathrm{ft}$. long. Flowers $12-15$ in an umbel; spathe-valves lanceolate, $2 \frac{1}{2}-3$ in. long; pedicels $\frac{1}{2}-1$ in. Perianth-tube slender, $3-3 \frac{1}{2}$ in. long, straight or slightly curved when the flower is fully expanded; segments lanceolate, spreading,

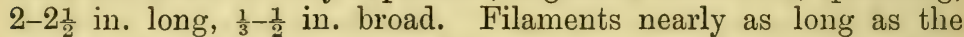
perianth-segments; anthers linear, $\frac{1}{3}$ in. long. Style a little longer than the segments.

Hab. Kumaon, in gardens, Strachey \& Winterbottom!

32. C. Balfourir Baker in Bot. Mag. t. 6570.-Bulb globose, 3 in. diam.; neck short. Leaves 10-12 to a bulb, lorate, spreading, under a foot long, the outer $2-2 \frac{1}{2}$ in. broad, firm; edge entire. Peduncle compressed, longer than the leaves. Flowers 10-12 in a centripetal umbel, very fragrant; spathe-valves lanceolate, 2 in. long; pedicels short, stout. Perianth tube greenish, 2 in. long; segments pure white, lanceolate, as long as the tube, $\frac{1}{2}$ in. broad. Filaments rather shorter than the segments; anthers small, linearoblong. Style red, declinate, as long as the stamens.

Hab. Island of Socotra, discovered by Professor Bayley Balfour. Described from a plant that flowered at Kew in the autumn of 1880 .

33. C. pratense Herb. Amaryll. 256. C. longifolium Roxb. Hort. Beng. 23, non Thunb.-Bulb ovoid, 4-5 in diam.; neck short. Leaves $6-8$ to a bulb, linear, suberect, $1 \frac{1}{2}-2 \mathrm{ft}$. long, $1 \frac{1}{2}-2$ in. broad, narrowed to the point, channelled down the face; margin entire. Peduncle lateral, compressed, a foot or more long, about $\frac{1}{2}$ in. diam. Flowers 6-12 in an umbel; spathe-valves lanceolate-deltoid, 2-3 in. long; pedicels none or very short. Perianth-tube greenish, 3-4 in. long, at first curved; segments lanceolate, white, nearly or quite as long as the tube, $\frac{1}{2} \mathrm{in}$. broad. Filaments bright red, rather shorter than the segments. Ovules 3-4 in each cell.

Var. C. Lorifolium Roxb. Fl. Ind. ii. 131. - Leaves weak, decumbent, 4-5 ft. long. Pegu.

Var. C. elegans Carey; Bot. Mag. t. 2592.-Bulb with a longer neck. Peduncle decumbent. Perianth-tube an inch shorter than the segments. Pegu.

Var. C. venustum Carey. - Flowers about 30 in an umbel. Silhet.

Hab. Plains of India, in low ground liable to inundation. Described from a living plant flowered by Mr. W. Bull in July, 1872.

34. C. Northianum Baker in Gard. Chron. 1882, i. 671.Leaves lorate, resembling those of $C$. asiaticum, 3-4 in. broad, much overtopping the flowers. Peduncle stout, an inch thick. Flowers $30-40$ in a dense centripetal umbel; spathe-valves large, ovate, reflexing. Perianth-tube greenish, $3-4$ in. long; segments lanceolate, white, as long as the tube, $\frac{1}{2}$ in. broad. Filaments bright red, an inch shorter than the segments; anther's linear. Style shorter than the stamens.

Hab. Borneo; common on the edge of streams near Sarawak. Described from a drawing of Miss North's (424). No specimens have yet reached England, so far as I am aware. 
35. C. brachyandrum Herb. Amaryll. 249. - Bulb 3 in. diam.; neck short. Leaves about 20 to a bulb, suberect, ensiform, $3-5 \mathrm{ft}$. long, 2 in. broad, deep green, not tapering much to the point. Peduncle $2 \mathrm{ft}$. long. Flowers above $10-30$ to an umbel, not perfectly erect; pedicels very short. Perianth-tube greenish, nnder 3 in. long; segments lanceolate, $\frac{1}{3}$ in. broad, rather longer than the tube. Filaments scarcely an inch long. Style an inch long. Seeds 2 in a cell.

Hab. North Australia, introduced to the Calcutta Garden by Dr. Carey, and sent by him to Dean Herbert about 1820. I have not seen any specimen, nor has it been figured. In its short stamens and style it agrees with $C$. venosum R. Br.

36. C. venosum R. Br. Prodr. 297.-Bulb and leaves unknown. Peduncle moderately stout, above a foot long. Umbel 6-8-flowered; spathe-valves lanceolate, $3 \mathrm{in}$. long; pedicels very short. Perianthtube very slender, 3-4 in. long, curved in an early stage; segments lanceolate, acute, $1 \frac{1}{2}-2$ in. long, $\frac{1}{2}$ in. broad. Filaments $\frac{1}{2}$ in. long; anthers linear, $\frac{1}{3}$ in. long. Style a little overtopping the anthers.

Hab. North coast of Australia, R. Brown! Siveers Island, Gulf of Carpentaria, Oldfield! Differs in flower from all forms of angustifolium by its short stamens and style.

37. C. uniflorum F. Muell. Fragm. iii. 23.-Bulb small, ovoid; neck short. Leaves $5-6$ to a bulb, narrow linear, arcuate, $1-1 \frac{1}{2} \mathrm{ft}$. long, $\frac{1}{8}-\frac{1}{4}$ in. broad. Peduncle slender, a foot long. Flowers often solitary, sometimes 2 ; spathe-valves linear or lanceolate; pedicels none or very short. Perianth-tube 3-4 in. long, curved in an early stage; segments lanceolate, pure white, $2 \frac{1}{2}-3$ in. long, $\frac{1}{2}$ in. broad at the middle. Filaments bright red, $1 \frac{1}{2}$ in. long; anthers linear, $\frac{1}{2}$ in. long. Style overtopping the stamens. Ovules several in a cell.

Hab. North Australia, in open sandy flats, R. Brown! Macgillivray 482 ! J. G. Veitch! There are specimens in Sir J. E. Smith's herbarium from Loddiges' garden at Hackney, dried in 1879; and from MIr. Hunter, of Perryhill, near Birmingham. I have never seen it alive.

38. C. angustifolium R. Br. Prodr. 297. C. australasicum Herb. C. arenarium Herb. in Bot. Mag. t. 2355.-Bulb subglobose, 3 in. diam.; neck short. Leaves linear, firm in texture, suberect, $1 \frac{1}{2}-2 \mathrm{ft}$. long, $1-1 \frac{1}{2} \mathrm{in}$. broad, tapering to the point; edge scabrous. Peduncle a foot long. Umbel few-flowered; spathevalves lanceolate, 2 in. long; pedicels short. Perianth-tube slender, 3-4 in, long, curved in early stage; segments lanceolate, $2 \frac{1}{2}-3$ in. long, $\frac{1}{2}$ in. broad. Filaments bright red, an inch shorter than the segments; anthers linear, $\frac{1}{2}$ in. long. Style as long as the segments. Ovules $5-6$ in a cell.

Var. C. Confertum Herb. in Bot. Mag, t. 2522. - Flowers sessile; perianth-segments $4 \mathrm{in}$. long, a little exceeding the tube.

Var. C. Blandus Roem. Amaryll. 76 (Bot. Mag. t. 2531).Leaves broader than in type. Perianth-segments broader. Filaments whitish. 
Hab. North Australia. Differs from $C$. asiaticum, with which Mr. Bentham unites it, by the narrow leaves of firmer texture, few-flowered umbels, lanceolate perianth-segments, and numerous superposed ovules.

39. C. modestum Baker in Journ. Linn. Soc. xxii. 528.-Bulb 2 in. diam. ; neck 2 in. long. Leaves $6-8$, linear, a foot long, $\frac{1}{2}$ in. broad low down, tapering to the point, finely ribbed; edge scabrous. Peduncle slender, a foot long. Flowers 5-6 in an umbel, sessile; spathe-valves lanceolate, Perianth-tube slender, erect, 2 in. long; segments lanceolate, patent, $1 \frac{1}{2}$ in. long, $\frac{1}{3}$ in. broad. Stamens rather shorter than the segments; anthers $\frac{1}{3} \mathrm{in}$. long.

Hab. Central Madagascar, Baron 48 ! 4223 !

40. C. purpurascens Herb. Amaryll. 250 ; Baker in Bot. Mag. t. 6525.-Bulb ovoid, 2 in. diam., with a short neck and abundant stolons. Leaves 20 or more to a bulb, linear, thin, much undulated, 1-3 ft. long, an inch broad, sometimes floating. Peduncle slender, a foot or less long. Flowers 5-9 in an umbel; pedicels none or very short; spathe-valves lanceolate, $1 \frac{1}{2}-2$ in. long. Perianth-tube very slender, 5-6 in. long; segments lanceolate, spreading, half as long as the tube, tinged with red on the outside. Filaments bright red, nearly as long as the segments; anther's very narrow, $\frac{1}{2}-\frac{3}{4}$ in. long. Style reaching to the tip of the segments. Ovules $3-4$ in a cell.

Hab. Guinea and Fernando Po, in streams and lakes. Described from a plant that flowered at Kew in June, 1877, sent by the Rev. Hugh Goldie. A variety with linear perianth-segments was gathered in 1884, by Kalbreyer.

41. C. subcernum Baker in Gard. Chron. 1881, ii. 180.-Bulb large. Leaves lorate. Peduncle stout, compressed, lateral, $1 \frac{1}{2}-2 \frac{1}{2} \mathrm{ft}$. long. Flowers 10-15 in an umbel. Spathe-valves broad, reflexing, $2-3$ in. long; pedicels sometimes $1-1 \frac{1}{2}$ in. long. Perianth-tube 4-5 in. long, curved before the flower expands; segments lanceolate, half as long as the tube, $\frac{1}{3} \mathrm{in}$. broad. Filaments bright red, erectopatent, under 2 in. long; anthers linear, $\frac{1}{2}$ in. long. Style overtopping the anthers.

- Hab. Common along the Zambesi from its mouth up to Lake Nyassa. Gathered and sketched by Sir John Kirk in 1861 and 1863. Allied to $C$. Hildebrandtii.

42. C. Hindebrandtir Vatke in Monat. Konig. Acad. Wiss. Berlin, 1876, 863; Baker in Bot. Mag. t. 6709. - Bulb ovoid, 2-3 in. diam.; neck 4-5 in. long. Leaves about 10 to a bulb, lorate, bright green, moderately firm in texture, $1 \frac{1}{2}-2 \mathrm{ft}$. long, $1 \frac{1}{2}-2$ in. broad ; edge entire. Peduncle slender, compressed, a foot long. Flowers 4-8 in an umbel; spathe-valves very long, lanceolate; pedicels very short. Perianth-tube erect, 6-8 in. long; segments lanceolate, spreading, pure white, $2-3$ in. long. Filaments rather shorter than the segments; anthers linear, $\frac{1}{2}$ in. long. Style reaching the tip of the segments.

Hab. Mountains of Johanna Island, alt. $3000 \mathrm{ft}$; d discovered by the late Dr. Hildebrandt in 1875. Described from a plant sent by Sir John Kirk, that flowered at Kew in Sept., 1882. A variety with more numerous flowers is figured Ill. Hort. n.s., t. 615 . 
43. C. crassicaule Baker.-Bulb and leaves unknown. Peduncle very stout, much compressed, above an inch in diameter at the tip. Umbel many-flowered; spathe-valves broad, deciduous; pedicels $\frac{1}{4}-\frac{1}{2}$ in. ; ovary ampullæform, $\frac{1}{2}-\frac{3}{4}$ in. long at the flowering time. Perianth-tube straight, erect, 3-4 in. long; segments lanceolate, as long as the tube, $\frac{1}{2}$ in. broad at the middle. Filaments two-thirds as long as the segments; anthers stout, yellow, $\frac{3}{4}$ in. long.

Hab. South-east Tropical Africa. Described from a single incomplete dried specimen gathered by Mr. T. Baines, the artist, in Oct., 1861. A very fine plant, nearly allied to $C$. augustum.

44. C. augustum Roxb. Hort. Beng. 23 ; Herb. in Bot. Mag. t. 2397, Bury, Hexand. 64. C. amabile var. auınustum Gawl. in Bot. Reg. t. 679.-Bulb regularly conical, $\frac{1}{2} \mathrm{ft}$. diam., sometimes a foot long. Leaves 20-30 to a bulb, lorate, 2-3 ft. long, 3-4 in. broad, bright green, moderately firm in texture, narrowed to the point, closely veined; edge entire. Peduncle lateral, much compressed, 2-3 ft. long, deep claret-red upwards. Flowers 12-30 in an umbel; spathe-valves broad, tinged with red, 3-4 in. long; pedicels sometimes an inch long. Perianth-tube stout, bright red, straight or rather curved, 3-4 in. long; segments lanceolate, erecto-patent, 4-5 in. long, $\frac{1}{2}-\frac{3}{4}$ in. broad, bright red outside, Filaments bright red, half as long as the segments ; anthers linear, an inch long. Style reaching up to the anthers. Seeds solitary in the cells.

Hab. Marshes and streamsides in Mauritius and the Seychelles. Introduced into cultivation in 1819. Described from a plant sent by Mr. Horne, that flowered at Kew in April, 1875.

45. C. erubescens Ait. Hort. Kew, i. 413; Red. Lil. t. 27 ; Jacq. Hort. Schoen. t. 494 ; Lodd. Bot. Cab. t. 31 ; Gawl. in Bot. Mag. t. 1232. - Bulb ovoid, 3-4 in. diam., with a short neck. Leaves numerous, arcuate, lorate, thin, closely veined, 2-3 ft. long, 2-3 in. broad; edge slightly scabrous. Peduncle $2 \mathrm{ft}$. or more long. Flowers 4-12 in an umbel; pedicels none or very short; spathe-valves green, lanceolate-deltoid, 3 in. long. Perianth-tube erect, 5-6 in. long; segments lanceolate, reflexing, half as long as the tube, claret-purple outside. Filaments bright red, 2 in. long; anthers linear, $\frac{1}{2}$ in. long. Ovules $4-5$ in a cell.

Hab. Widely spread throughout Tropical America. Figured in Miller's 'Icones' (tab. 110), and there is a specimen at the British Mruseum dried from a garden at Spring Grove in 1784. Herbert defines and names seven varieties. amongst which are $C$. corantymum and $C$. Gordonianum Roemer.

46. C. americanum Linn. Sp. Plant, 419 ; Gawl. in Bot. Mag. t. 1034. - Bulb ovoid, 3-4 in. diam., with a short neck. Leaves 6-10 to a bulb, lorate, arcuate, $2-3 \mathrm{ft}$. long, $1 \frac{1}{2}-2$ in. broad, moderately firm in texture, closely veined; edge entire. Peduncle moderately stout, $1 \frac{1}{2}-2 \mathrm{ft}$. long. Flowers $3-6$ in an umbel; pedicels none or very short; spathe-valves lanceolate-deltoid, 2-3 in. long. Perianth-tube straight, $4-5$ in. long; segments lanceolate, spreading or ascending, pure white, $3-4$ in. long, $\frac{1}{3}-\frac{1}{2}$ in. broad. Filaments $2-2 \frac{1}{2}$ in. long; anthers linear. Style overtopping the anthers. Ovules $5-6$ in a cell. 
Hab. Southern United States. The type specimen described by Linnæus in 'Hortus Cliffortianus' is at the British Museum.

47. C. Commeryni Jacq. Hort. Schoen. t. 202. C. Commelinianum Herb. C.attenuatum Willd. C. Lindleyanum Herb. C.rero-

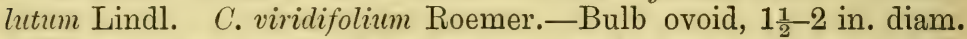
with copious stolons and a short neck. Leaves ensiform, 2-3 ft. long, an inch broad, firm in texture, bright green, closely veined; edge slightly scabrous. Peduncle slender, compressed, 1-2 ft. long. Flowers 4-6 in an umbel; pedicels none or very short; spathevalves lanceolate from a broad base, 2-3 in. long. Perianth-tube slender, erect, 4-6 in. long ; segments lanceolate, reflexing, half as long as the tube. Filaments bright red, about 2 in. long; anthers linear, $\frac{1}{2}$ in. long. Ovules $3-4$ in a cell.

Hab. Guiana and the Amazon Valley, figured by Commelinus from the Amsterdam Garden (tab. 15) in 1706. Scarcely more than a variety of $C$. erubescens.

48. C. strictum Herb. in Bot. Mag. t. 2635. C. Herbertianum Roem. et Schultes.-Bulb small, ovoid, without any distinct neck.

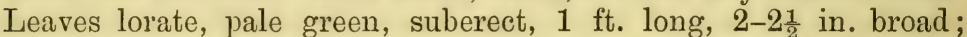
edge entire. Peduncle green, subterete, twice as long as the leaves. Flowers about 4 in an umbel; pedicels none or very short; spathe-valves 2-3 in. long. Perianth-tube pale green, suberect, about 5 in. long; segments lanceolate, white, $3-4$ in. long ; $\frac{1}{2}$ in. broad. Filaments red, an inch shorter than the segments; anthers linear, $\frac{1}{2}$ in. long.

Hab. Described and figured by Dean Herbert from garden specimens of uncertain origin. It has been attributed to Ceylon, but its nearest affinity is with the American Platyasters.

49. C. undulatum Hook. Exot. Flora t. 200.-Bulb small, ovoid, with a long neck. Leaves dark green, ensiform, firm in texture, suberect, $1 \frac{1}{2} \mathrm{ft}$. long, an inch broad; edge entire. Peduncle green, a foot long. Flowers 4 in an umbel; pedicels none or very short; spathe-valves green, linear lanceolate, 3-4 in. long. Perianth-tube greenish, 7-8 in. long, curved before the flower expands; segments lanceolate, undulated, erecto-patent, 3 in. long, not purple outside. Filaments bright red, 2 in. long; anthers linear. Style overtopping the anthers.

Hab. North Brazil; Maranham. Sent alive by Mr. R. Hesketh, about 1827, to the Liverpool Botanic Garden.

50. C. Kunthianum Roem. Amaryll. 80. C. erubescens H. B. K., non Ait.-Bulb ovoid, 3 in. diam., with a short neck. Leaves about 20 to a bulb, lorate, spreading, bright green, 2-3 in. broad, undulated towards the entire margin. Peduncle a foot long. Flower's 4-5 in an umbel; pedicels none or very short; spathevalves lanceolate, 3 in. long. Perianth-tube 7-8 in. long; segments white, lanceolate, $2 \frac{1}{2}$ in. long. Filaments bright red, under 2 in. long; anthers under $\frac{1}{2}$ in. long, Style overtopping the anthers.

Var. nicaraguense Balier. Leaves longer, narrower. Perianthsegments 3 in. long, purple on the outside.

Hab. The type gathered by Humboldt in New Granada, the variety by Mr. Ralph Tate in 1867, near Greytown, in Nicaragua. 
51. C. concinnum Mart. in Roem. et Schultes, Syst. Veg. vii. 857.-Bulb and leaves unknown. Peduncle green, under a foot long. Flowers 12 in an umbel; inner erect; outer curved; pedicels very short; spathe-valves reflexing, lanceolate, $1 \frac{1}{4} \mathrm{in}$. long. Perianth-tube $1 \frac{1}{4}-1 \frac{1}{2} \mathrm{in}$. long; segments lanceolate, $2 \frac{1}{2}-3 \mathrm{in.}$ long, purple outside. Filaments half as long as the segments ; anthers small, oblong. Style reaching to the tip of the segments.

Hab. Central Brazil, gathered long ago by Martius, in the sides of mountains near Villarica, in the province of Minas Geraes.

52. C. Graciliflorum Kunth et Bouché in Ind. Sem. Hort. Berol. 1844.-Bulb 3-4 in. diam.; tunics greenish yellow; neck short. Leaves about 14 to a bulb, lorate, light green, firm in texture, $1 \frac{1}{2}-2 \mathrm{ft}$. long, $1 \frac{1}{2}-2$ in. broad ; edge denticulate. Peduncle much shorter than the leaves. Flowers 6-8 in an umbel; pedicels none or very short; spathe-valves $3-4$ in. long. Perianth-tube erect, 5-6 in. long; segments lanceolate, reflexing, half as long as the tube. Filaments bright red, 2 in. long; anthers linear. Style overtopping the anthers.

Var. Fenderer Baker.-Leaves thinner, 3-4 ft. long, 3-4 in. broad.

Hab. Venezuela, near Maracaibo. MIoritz 1200! Sent alive by Moritz in 1844 to the Berlin Garden. Var. Fendleri; Tovar, Fendler 2169 !

\section{Subgenus Codonocrinum.}

53. C. zeylanicun Linn. Syst. Veg. 263. Amaryllis zeylanica Linn. Sp. Plant. 421. A. ornata Bot. Mag. t. 1171. C. Herbertianum Wall. Pl. Asiat. Rar. t. 145. C. Wallichianum Roem. C. ornatum vars. zeylanicum and Herbertianum Herb.-Bulb globose, 5-6 in. diam.; neck short. Leaves $6-10$ to a bulb, thin, lorate, bright green, 2-3 ft. long, 3-4 in. broad; edge slightly scabrous. Pedincle stout, about as long as the leaves, tinged with red. Flowers $10-20$ in an umbel, fragrant; spathe-valves lanceolatedeltoid, reddish, 3-4 in. long; pedicels very short. Perianth-tube curved, usually 3-4 rarely 5-6 in. long, tinged with red or green ; limb horizontal, 3-4 in. long; segments oblong-lanceolate, acnte, an inch broad, bright red outside in the central third. Stamens declinate, about an inch shorter than the segments; anthers linear, $\frac{1}{2}-\frac{3}{4}$ in. long. Style overtopping the stamens. Ovules $5-6$ in a cell. Fruit subglobose, $1 \frac{1}{2}-2$ in. diam.

Hab. Widely spread in Tropical Asia and Tropical Africa. The commonest species in this section in cultivation, figured first by Commelinus in 1697. Var. reductum Baker in Gard. Chron. 1883, ii. 618, is a variety sent from Zanzibar by Sir John Kirk, with leaves $1-1 \frac{1}{2} \mathrm{ft}$. long, under 2 in. broad low down, and a perianth-tube nearly twice as long as the limb. A plant from the Usagura Mountains (collected by Mr. Last), that flowered at Kew in June, 1887, does not differ materially from the Asiatic type.

54. C. Latifolium Linn. Sp. Plant. 419; Lindl. in Bot. Reg. t. 1297; Wight Ic. t. 2019-2020. C. ornatum var. latifolium Herb. C. Linnai Roem. - Bulb subglobose, 6-8 in. diam. ; neck short. Leaves numerous, thin, lorate, bright green, 2-3 ft. long, 3-4 in. broad; edge slightly scabrous. Peduncle 1-2 ft. long. Flowers 
10-20 in an umbel; spathe-valves deltoid, greenish, 3 in. long; pedicels very short. Perianth-tube curved, greenish, 3-4 in. long; limb horizontal, about as long as the tube; segments oblonglanceolate, acute, an inch broad at the middle, faintly tinged with red in the centre outside. Filaments declinate, $2 \frac{1}{2}-3$ in. long; anthers linear, $\frac{3}{4}-1$ in. Style finally overtopping the anthers. Ovules 5-6 in a cell, superposed.

Hab. Widely spread in Tropical Asia. C. longistylum Herb.; C. moluccanum Roxb., Bot. Mag. t. 2292; C. speciosum Herb. in Bot. Mag. t. 2217; and C. insigne Schultes (Amaryllis insignis Gawl. in Bot. Reg. t. 579) seem all slight varieties of this species.

55. C. Brachynema Herb. in Bot. Reg. 1842, Misc. No. 28 ; Hook. fil. in Bot. Mag. t. 5937; Flore des Serres, t. 2303.-Bulb ovoid, $2 \frac{1}{2}-3 \mathrm{in}$. diam., without a distinct neck. Leaves lorate, not developed till after the flowers, $1 \frac{1}{2}-2 \mathrm{ft}$. long, $3-3 \frac{1}{2}$ in. broad, bright green, moderately firm in texture; edge entire. Peduncle a foot long, subterete. Flowers $15-20$ in an umbel ; spathe-valves lanceolate, $1 \frac{1}{2}-2 \mathrm{in}$. long; pedicels at most as long as the ovary. Perianth-tube not much curved, greenish, $1 \frac{1}{2}-2$ in. long; segments pure white, oblanceolate-oblong, obtuse, cuspidate, 2 in. long, $\frac{3}{4}$ in. broad. Filaments only $\frac{1}{4}-\frac{1}{3}$ in. long; anther's small, oblong. Style shorter than the stamens.

Hab. Bombay Presidency. Described from a plant that flowered at Kew in May, 1877, the bulb of which was sent by Mr. Woodrow. Easily distinguished by its short stamens and style.

56. C. Flaccidum Herb. in Bot. Mag. t. 2133. Amaryllis australasica Ker in Bot. Reg. t. 426.-Bulb ovoid, 3-4 in. diam.; neck very short. Leaves linear, $1 \frac{1}{2}-2 \mathrm{ft}$. long, 1-1 $\frac{1}{2}$ in. broad, closely veined, scabrous on the edge. Peduncle $1 \frac{1}{2}-2 \mathrm{ft}$. long, much compressed. Flowers $6-8$ in an umbel; spathe-valves lanceolate-deltoid, 3-4 in. long; pedicels $1-1 \frac{1}{2}$ in. Perianth-tube 3-4 in. long, usually curved; segments oblong-lanceolate, pure white both inside and out, about as long as the tube, acute, $\frac{3}{4}$ in. broad at the middle. Stamens much shorter than the segments; anthers linear, $\frac{1}{2}$ in. long. Ovules several in each cell, superposed.

Hab. Nerv South Wales and South Australia, first gathered, though not named, by Robert Brown. Introduced into cultivation in 1819, but I have not seen it alive. C. Weinmanni Roem. Amaryll. 90, is probably the same species.

57. C. pauciflorum Baker in Journ. Bot. 1878, 195.-Bulb globose, 2-3 in. diam.; neck very short. Leaves about 6 to a bulb, linear, very firm in texture, stiffly erect, $1-1 \frac{1}{2} \mathrm{ft}$. long, $\frac{1}{4} \mathrm{in}$. broad, closely strongly veined; edge not ciliated. Peduncle slender, 6-8 in. long. Flowers 1-2 to an umbel, sessile; spathe-valves lanceolate, 3 in. long, connate in the 1 -flowered form. Perianthtube curved, 4-5 in. long; limb suberect, rather shorter thân the tube; segments oblong, connivent, obtuse, minutely cuspidate, an inch broad, banded with red-purple. Filaments an inch shorter than the limb; anthers linear, $\frac{1}{2}$ in. long. Style overtopping the anthers.

Hab. Central Africa, in Djur-land, discovered by Dr. Schweinfurth in 1860. We have a sketch of an allied plant, made by Mr. T. Baines in Nov., 
1861, from Koobie, in the Transvaal, and a garden specimen from Sir C. Strickland of a plant from Lake Nyassa, with "broad leaves," two shortly pedicellate flowers and more acute perianth-segments.

58. C. Caleyanum Herb. in Bot. Mag. t. 2466 . C. omatum var. Cureyanum Herb. - Bulb globose, 3-4 in. diam., with reddish brown tunies and a short neck. Leaves 8-10, lorate, spreading, undulated, bright green, thin, 1-2 ft. long, 2-3 in. broad; edge entire. Peluncle a foot long, subterete, green. Flowers $4-6$ in an nmbel; pedicels very short; spathe-valves deltoid, green, $2-3 \mathrm{in}$. long. Perianth-tube curved, greenish, 3-4 in. long; limb horizontal, as long as the tube; segments oblong, acute, an inch broad, faintly tinged with red in the centre. Stamens a little shorter than the segments; anthers linear, $\frac{1}{2} \mathrm{in.} \mathrm{long.} \mathrm{Style}$ reaching to the tip of the segments. Ovules $6-8$ in a cell.

Hab. Mauritius and Seychelles, in marshy ground. Described from a plant that flowered at Kew in Nov., 1877. Scarcely more than a variety of $C$. latifolium.

59. C. abyssinicuar Hochst. in Schimp. Pl. Abyss. No. 1374.Bulb ovoid, 3 in. diam.; neck short. Leaves about six to a bulb, linear, suberect, a foot long, $\frac{1}{2}-1$ in. broad, narrowed gradually to the point, closely veined; edge scabrous. Peduncle moderately stout, 1-2 ft. long. Flowers 4-6 in an umbel; pedicels none or very short; spathe-valves green, ovate-lanceolate, 2 in. long. Perianth-tube slender, curved, $1 \frac{1}{2}-2$ in. long; limb horizontal or suberect, $2-3$ in. long; segments oblong, acute, $\frac{1}{2}-\frac{3}{4}$ in. broad. Filaments $\frac{1}{2}-\frac{3}{4}$ in. long; anthers linear-oblong, $\frac{1}{4}-\frac{1}{2} \mathrm{in}$. long.

Hab. Mountains of Abyssinia, first gathered by Schimper in 1838. Distinguished by its short stamens and short perianth-tube.

60. C. Distrchum Herb. Amaryll. 260. Amaryllis ornata Gawl. in Bot. Mag. t. 1253, excl. syn.-Bulb small, globose. Leaves about 10, distichous, linear, firm in texture, channelled down the face, tapering to the point, a foot long, under an inch broad low down. Peduncle about a foot long. Flower usually solitary, sessile; spathe-valves lanceolate, 2-3 in. long. Perianth-tube curved, 5-6 in. long; limb horizontal, about $4 \mathrm{in.}$ long ; segments oblong, acute, connivent, an inch broad, keeled with bright red. Stamens and style reaching nearly to the tip of the segments.

Hab. Sierra Leone. Differs from C. yucceflorum by its distichous leares. Three different plants are figured as Amaryllis ormata in the 'Botanical Magazine,' viz., C. zeylanicum, giganteum, and the present species.

61. C. yuccæflorum Salisb. Parad. t. 52. C. yucrœoides Herb. C. Broussonetii Herb. in Bot. Mag. t. 2121 ; Lodd. Bot. Cab. t. 668 ; Bury Hexand. t. 21. Amaryllis Broussonetii Red. Lil. t. 62. A. spectubilis Andr. Bot. Rep. t. 390. A. ornata Ait.-Bulb small. globose, purplish, without any distinct neck. Leaves 10-12 to a bulb, multifarious, linear, firm in texture, closely veined, 1-1 $\frac{1}{2} \mathrm{ft}$. long, about an inch broad; edge scabrous. Peduncle slender, a foot long. Flowers 1-2 in an umbel, sessile; spathe-ralves green, lanceolate, 2-3 in. long. Perianth-tube greenish, curved, 4-5 in. long; limb horizontal, 3-4 in. long; segments oblong, acute, connivent, $\frac{3}{4}-1$ in. broad, banded with red on the back. Filaments 
about an inch shorter than the segments; anthers linear-oblong, $\frac{1}{4}$ in. long. Style reaching nearly to the tip of the segments.

Hab. Sierra Leone. There is a specimen at the British Museum from Kew Gardens in 1785 , so that it is no doubt the original ornata of Aiton, who cites the younger Linnæus under his diagnosis, and says it was introduced by Lord Petre in 1740. A plant gathered by Welwitsch in Angola (4015) is probably the same species.

62. C. Sanderianum Baker in Gard. Chron. n. s. xxii. 102; Florist and Pomol. 1784, 157, with woodeut. C. ornatum Bury Hexand. t. 18. C. Broussonetianum var. pluriflorum Herb. - Bulb globose, 2 in. diam. ; neck 2-3 in. long. Leaves 10-12, thin, ensiform, $1 \frac{1}{2}-2 \mathrm{ft}$. long, $1-1 \frac{1}{2} \mathrm{in}$. broad, narrowed from the middle to a long point, much crisped at the denticulate margin. Peduncle a foot long. Flowers 3-6 in an umbel, sessile; spathe-valves 3-4 in. long. Perianth with a curved tube 5-6 in. long; segments oblonglanceolate, acute, connivent, 3-4 in. long, under an inch broad, keeled with bright red. Stamens nearly as long as the limb; anthers linear, $\frac{1}{3} \mathrm{in}$. long. Style reaching to the tip of the segments.

Hab. Corisco Island, Mann 1877! Sierra Leone. Described from a specimen sent from Messrs. Sander and Co., of St. Alban's, in 1884. Nearly allied to C. scabrum Herb.

63. C. scabrum Herb. in Bot. Mag. t. 2180 ; Bury Hexand. t. 32. C. scaberrimum Herb. - Bulb large, ovoid, purplish-brown; neck short. Leaves a dozen or more, lorate, bright green, 2-3 ft. long, $1 \frac{1}{2}-2$ in. broad, firm in texture, closely veined; edge scabrous. Peduncle stout, 1-2 ft. long. Flowers 4-8 in an umbel ; pedicels none or very short; spathe-valves broad, 2-3 in. long. Perianthtube curved, greenish, $3-5$ in. long; limb $2 \frac{1}{2}-3$ in. long; segments oblong, acute, distinctly keeled with bright red. Filaments rather shorter than the perianth-segments; anthers linear, $\frac{1}{2}$ in. long. Style reaching to the tip of the perianth-segments. Ovules 5-6 in a cell.

Hab. Widely spread in Tropical Africa from Guinea across to Abyssinia and Kordofan. It is said to have been imported from the Azores and Brazil, but probably is not native there. I cannot distinguish C. Ruppeliamum. Fresen., except as a mere variety, and this is the plant described by A. Richard in 'Flora Abyssinica' as Hippeastrum vittatum.

64. C. finibriatulun Baker in Journ. Bot. 1878, 196.-Leaves thin, lorate, closely veined, glancous-green, tapering to a point, 2-3 ft. long, 2 in. broad low down; edge ciliated by small membranous scales. Peduncle $2 \mathrm{ft}$. long. Flowers $3-7$ in an umbel; pedicels none or very short; spathe-valves deltoid, 2-3 in. long. Perianth-tube greenish, 4-5 in. long; limb 3 in. long; segments oblong-lanceolate, comnivent, under an inch broad, with a distinct band of red down the middle. Filaments an inch shorter than the segments; anthers linear, $\frac{1}{2} \mathrm{in}$. long. Ovules several in each cell.

Hab. Angola in the province of Loanda, in marshy meadows at a low level, flowering in March, Welwitsch 4018! 4019! Nearly allied to C. scabrum Herb.

65. C. crassipes Baker in Gard. Chron. 1887, ii. 126. - Bulb very large, conical. Leaves lorate, dark green, suberect, 4 in. 
broad. Peduncle stout, compressed, under a foot long. Flowers 15-20 in an umbel; spathe-valves broad, deciduous; pedicels reach 1-1 $\frac{1}{4}$ in. long. Ovules $6-8$ in a cell. Perianth-tube green, nearly straight, 3 in. long; limb suberect, $2 \frac{1}{2}$ in. long; segments lanceolate, $\frac{1}{2}$ in. broad at the middle, white, with a red centre, not distinctly keeled. Filaments purple, nearly as long as the perianthsegments; anthers above $\frac{1}{4}$ in. long.

Hab. Country not known. Flowered by Sir C. W. Strickland, July, 1887, the bulb purchased of Messrs. E. G. Henderson and Co.

66. C. Kırкi Baker in Bot. Mag. t. 6512. - Bulb globose, 6-8 in. diam. ; neck half a foot long. Leaves lorate, acute, reflexing, bright green, $3 \frac{1}{2}-4 \mathrm{ft}$. long, $4-4 \frac{1}{2} \mathrm{in}$. broad, closely veined; edge scabrous. Peduncles stout, compressed, 1-11 $\mathrm{ft}$. long, sometimes 2-3 to a bulb. Flowers $12-15$ in an umbel; pedicels none or very short; spathe-valves broad, reddish brown, 3-4 in. long. Perianth-tube more or less curved, greenish, 4 in. long; limb horizontal, longer than the tube; segments connivent, oblong, acute, above an inch broad, broadly keeled with bright red. Filaments white, $1 \frac{1}{2}$ in. shorter than the segments ; anthers linear, $\frac{1}{2}$ in. long. Style nearly as long as the limb. Ovules several, superposed.

Hab. Zanzibar. Described from a bulb sent by Sir John Kirk, that flowered at Kew in September, 1879. Mombasa Hildebrandt $1228 \mathrm{~b}$ ! Brunsvigia? Massaiana, L. Linden and Rodigas in Ill. Hort. 1887, t. 55, is no doubt a Crinum nearly allied to C. Kirkii. The tube is half a foot long in our type specimen, but the leaves are absent.

67. C. podophyluum Baker in Bot. Mag.t. 6483.-Bulb subglobose, $1 \frac{1}{2}-2$ in. diam., without any distinct neck. Leaves $5-6$ to a bulb, oblanceolate, acute, a foot long, $1 \frac{1}{2}-2$ in. broad at the middle, subpetiolate, thin, laxly veined. Peduncle greenish, compressed, slender, a foot long. Flowers 2 in an umbel, sessile; spathevalves lanceolate, $1 \frac{1}{2}-2$ in. long. Perianth-tube slender, curved, $5-6$ in. long; limb suberect, 3 in. long; segments oblongspathulate, pure white. Filaments nearly as long as the limb; anthers linear, $\frac{1}{4}-\frac{3}{4}$ in. long. Style as long as the stamens.

Hab. Old Calabar. Described from a plant sent by the Rev. Hugh Goldie, which flowered at Kew in Nov., 1879; and another sent by Mr. Kalbreyer, flowered by Messrs. Veitch in 1880 . Closely allied to C. giganteum. I have seen a form with the peduncle entirely suppressed.

68. C. giganteun Andr. Bot. Rep. t. 169; Red. Lil. t. 181; Bury, Hexand. t. 17 . C. petiolatum var. spectabile Herb. C. vanillodornm Welw.; Baker in Journ. Bot. 1878, 196 ; Ill. Hort. n. s. t. 617. Amaryllis gigantea Ait. A. latifolia Lam. A. ornata Gawl. in Bot. Mag. t. 923. A. candida Tratt. Tab. t. 488.-Bulb 5-6 in. diam.; neck short. Leaves a dozen or more, thin, green, 2-3 ft. long, 3-4 in. broad at the middle, acute, much narrowed towards the base, laxly distinctly veined, with distinct cross veinlets. Peduncle stout, green, compressed, sometimes 2-3 ft. long. Flower's generally $4-6$, rarely $8-12$, in an umbel; pedicels none or very short; spathe-valves broad, green, 3-4 in. long. Perianth-tube slender, curved, 4-7 in. long; limb campanulate, 3-4 in. long; sagments oblong, obtuse, pure white, much imbricated. Filaments 
pure white, an inch shorter than the segments; anthers linear, $\frac{1}{2}-\frac{3}{4} \mathrm{in}$. long. Style reaching to the tip of the segments.

Hab. Central and West Tropical Africa, introduced into cultivation by Afzelius about 1780. I have seen it from Jamaica, no doubt introduced.

69. C. lineare Linn. fil. Suppl. 195. C. revolutum Herb. Amaryllis revoluta L'Herit.; Gawl. in Bot. Mag. t. 915. 'A. revolute var. gracilior, Bot. Mag. t. 623. Crinum algoense Herb.Bulb small, ovoid. Leaves linear, $1 \frac{1}{2}-2 \mathrm{ft}$. long, $\frac{1}{2}$ in. broad, glaucous-green, channelled down the face. Peduncle slender, subterete, a foot long. Flowers 5-6 in an umbel; spathe-valves $1 \frac{1}{2}-2$ in. long; pedicels $\frac{1}{2}-\frac{3}{4} \mathrm{in}$. long. Perianth-tube slender, curved, $1 \frac{1}{2}-2 \frac{1}{2} \mathrm{in}$. long; segments oblanceolate, acute, $2-3 \mathrm{in}$, long, $\frac{1}{3}-\frac{1}{2}$ in. broad, tinged with red outside. Filaments bright red, shorter than the segments; anthers linear, $\frac{1}{3}$ in. long. Style reaching to the tip of the segments.

Hab. Cape Colony, Thunberg! Burchell! There is a speeimen at the British Museum, dried from Kew Gardens, in 1779, but it is not in cultivation now.

70. C. variabile Herb. Amaryll. 268, t. 44, fig. 23. Amaryllis variabilis, Jacq. Hort. Schoen. iv. 14, t. 429. A. revoluta var. robustior Gawl. in Bot. Reg. t. 615. Crinum variabile var. roseum Herb. in Bot. Reg. 1844, t. 9. C. crassifolium Herb.-Bulb ovoid, 3-4 in. diam. ; neck short. Leaves $10-12$ to a bulb, linear, green, weak, $1 \frac{1}{2}-2 \mathrm{ft}$. long, 2 in. broad. Peduncle erect, compressed, 1-1 $\frac{1}{2} \mathrm{ft}$. long. Flowers $10-12$ to an umbel; spathe-valves deltoid, 2-3 in. long; pedicels $\frac{1}{2}-1$ in. long. Perianth with a curved greenish tube $1 \frac{1}{2}-2 \mathrm{in}$. long; segments oblong, acute, $2 \frac{1}{2}-3 \frac{1}{2}$ in. long, flushed red down the back. Filaments red, an inch shorter than the segments; anthers linear, $\frac{1}{2} \mathrm{in}$. long. Style as long as the segments. Ovules 3 or more in a cell.

Hab. Cape Colony; Southern Provinces and Kaffraria, Not, I believe, in cultivation now.

71. C. campanulatum Herb. in Bot. Mag. sub t. 2121. C. aquaticum Burchell; Bot. Mag. t. 2352. C. caffrum Herb. Homanthus hydrophilus Thunb.-Bulb small, ovoid. Leaves linear, deeply channelled down the face, reaching a length of 3-4 ft. Peduncle slender, a foot or more long. Flowers $6-8$ in an umbel; spathevalves lanceolate-deltoid, reddish brown, $1 \frac{1}{2}-2$ in. long; pedicels $\frac{1}{2}-1$ in. long. Perianth with a slender curved cylindrical tube $1 \frac{1}{2}-2$ in. long; limb campanulate, about as long as the tube; segments oblong, obtuse, connivent, rose-red. Stamens an inch long; anthers linear-oblong, $\frac{1}{4}$ in. long. Style as long as the perianth. Ovules 6-8 in a cell.

Hab. Cape Colony; Eastern Provinces and Kaffraria, in ponds. Introduced by Burchell, about 1817. A very distinct species, which has been flowered of late years several times by Sir C. W. Strickland.

72. C. mimbricatum Baker in Gard. Chron. 1881, ii. 784. - Bulb very large, globose. Leaves lorate, very thin, $3 \mathrm{ft}$. long, $3 \mathrm{in}$. broad at the middle, narrowed to 2 in. near the base; veins distant, very distinct. Peduncle stout, a foot or more long. Flowers 5-6 in an 
umbel; spathe-valves broad, 3-4 in. long; pedicels an inch long. Perianth pure white, with a slender curved tube 3 in. long, and campanulate limb as long as the tube, with oblong obtuse imbricated segments. Filaments declinate, an inch shorter than the segments; anthers linear, $\frac{3}{4} \mathrm{in}$. long. Style reaching to the tip of the perianth.

Hab. Transkeian Kaffraria ; Butterwick Forest, Macowan 2207! Allied to C. giganteum Andr.

73. C. Moonei Hook. fil. in Bot. Mag. t. 6113; Gard. Chron. 1887, ii. fig. 101. C. Makoyanam Carriere in Rev. Hort, 1877, 417, fig. 75. C. Colensoi, Mackenii, and natalense Hort.-Bulb ovoid, very large, copiously stoloniferous, with a neck sometimes a foot long. Leaves $12-15$ to a bulb, spreading, thin, lorate, bright green, 2-3 ft. long, 3-4 in. broad; laxly distinctly veined; edge entire. Peduncle green, moderately stout, 2-3 ft. long. Flowers $6-10$ in an umbel ; spathe-valves large, thin; pedicels $1 \frac{1}{2}-3$ in. long. Perianth with a curved tube $3-4$ in. long, and a funnel-shaped limb of about the same length, with oblong subacute segments 1-1 $\frac{1}{2}$ in. broad. Filaments pink, an inch shorter than the segments ; anthers linear, $\frac{1}{2} \mathrm{in}$. long. Style reaching to the tip of the perianth. C. Schmidtii Regel Gartenfl. t. 1072, is a form with pure white flowers.

Hab. Natal and Kaffraria, now widely spread in gardens. Our first knowledge of it was from a sketch sent by Bishop Colenso in 1858. It was named by Sir J. D. Hooker after the late Dr. David Moore, of Glasnevin, who was one of the first to grow it succesfully, and who sent the specimen drawn for the 'Botanical Magazine.'

74. C. Fonbesianum Herb. Amaryll. 267; Baker in Bot. Mag. t. 6545. Amaryllis Forbesii Lindl. - Bulb globose, 6-8 in. diam., without a distinct neck. Leaves not fully developed till after the flowers, 10-12 to a bulb, spreading, lorate, obtuse, glancous, closely veined, 3-4 ft. long, 3-4 in. broad; edge conspicuously ciliated. Peduncle stout, compressed, a foot long. Flowers 30-40 in an umbel; spathe-valves deltoid, red-tinted, 3-4 in. long; pedicels stout, $\frac{1}{2}-\frac{3}{4}$ in. long. Perianth-tube about 3 in. long, nearly straight in the central flowers; limb funnel-shaped, $4-4 \frac{1}{2} \mathrm{in}$. long; semments oblong, acute, connivent, $\frac{3}{4}-1$ in. broad, white, with a distinct band of red down the back. Filaments bright red, nearly as long as the segments; anthers linear, $\frac{1}{2}$ in. long. Style as long as the perianth.

Hab. Delagoa Bay, discovered by Forbes about 1824 and regathered by $\mathrm{Mr}$. J. J. Monteiro in 1876. Described from a plant that flowered at Kew in Oct., 1878. Brunsvigia? magnifica, L., Linden and Rodigas in Ill. Hort. n. s. t. 552 , is a Crinum either identical with Forbesianum or near it.

75. C. Longrfolium Thunb. Prodr. 39. Amaryllis longifolia Linn. Sp. Plant. 421; Jacq. Ic. t. 362 ; Red. Lil. t. 347 ; Gawl. in Bot. Mag. t.661. C. capense Herb. Amaryllis capensis Miller. A. bulbisperma Burm. C. riparium Herb.-Bulb ampullæform, narrowed gradually into a long cylindrical neck. Leaves a dozen or more to a bulb, ensiform, acute, glaucous, moderately firm in texture, 2-3 ft. long, 2-3 in. broad; edge scabrous. Peduncle a 
foot or more long, subterete. Flowers 6-12 to an umbel; spathevalves 2-3 in. long; pedicels 1-2 in. Perianth-tube curved, 3-4 in. long; limb about as long; segments oblong, acute, $\frac{3}{4}-1$ in. broad, usually flushed with red down the back, rarely pure white. Stamens nearly as long as the perianth. Style reaching to its tip.

Hab. Universally spread through Cape Colony from the Southern Prorinces to Natal. The most hardy of all the Crinums in England and the only one grown generally out of doors. Var. Farinianum Baker in Gard. Chron. 1887, i. 833, collected by M. Farini in the Kalihari Desert, has pink narrowly funnel-shaped flowers, very long leaves, and a bulb with a verv long neck.

76. C. Macowani Baker in Gard. Chron. 1878, 298; Bot. Mag. t. 6381.-Bulb globose, sometimes 9-10 in. diam., with a neck 6-9 in. long. Leaves $12-15$ to a bulb, spreading, lorate, bright green, thin, 2-3 ft. long, 3-4 in. broad. Peduncle stout, green, 2-3 ft. long. Flowers $10-15$ in an umbel; spathe-valves very large; pedicels 1-2 in. long. Perianth with a curved greenish tube 3-4 in. long, and a funnel-shaped limb of about the same

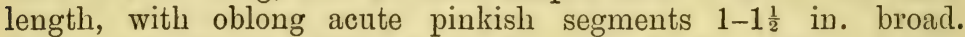
Stamens declinate, a little shorter than the limb; anthers linear, $\frac{1}{2}$ in. long. Style as long as the stamens.

Hab. South-western frontier of Natal, Macowan 2122! Described from a plant that flowered at Kew in Jan., 1878. Closely allied to C. latifolium Linn.

77. C. submersum Herb. in Bot. Mag. t. 2463.-Bulb ovoidoblong, reddish, 3 in. diam. Leaves lorate, acute, pale green; edge scabrous. Peduncle green, compressed, $1 \frac{1}{2} \mathrm{ft}$. long. Flowers about 8 in an umbel, sessile; spathe-valves $3-4$ in. long. Perianthtube curved, greenish, 5 in. long; segments oblong, acute, 4 in. long, white, under an inch broad, with a distinct red keel. Stamens and style nearly as long as the segments.

Hab. Rio Janeiro. Known to me only from the figure and description. It must be very near $C$. scabrum. Herbert finally regarded it as a hybrid between scabrum and erubescens.

78. C. Longiflonum Herb. Amaryll 271. Amaryllis longifolia var. longiflora Ker. in Bot. Reg. t. 303.-Bulb ovoid, 3-4 in. diam., with a distinct neck. Leaves lorate, 4-5 ft. long, 2 in. broad, moderately firm in texture, closely veined, narrowed to the point, not glaucous; edge slightly scabrous. Flowers 6-8 in an umbel; pedicels short; spathe-valves deltoid, 3-4 in. long. Perianth-tube greenish, curved, $3-4 \mathrm{in}$. long; limb funnel-shaped, as long as the tube; segments oblong, acute, connivent, flushed with red in the middle, but without a distinct band. Filaments much shorter than the limb; anthers linear, $\frac{1}{2}$ in. long. Ovules 6-8 in a cell.

Hab. According to Grisebach this is native in Jamaicaa and Antigua. If not true native it is perhaps a large variety of $C$. longifolium. It was figured in 1818, from a plant received by Mr. Griffin from a garden in Jamaica.

79. C. virgineum Mart. in Roem. et Schultes Syst. Veg. vii. 855. C. petiolatum var. virgineum Herb. - Bulb large, brown. Leaves lorate, thin, 2-3 ft. long, 3-4 in. broad at the middle, narrowed to an acute apex and to $1 \mathrm{in}$. above the base; veins as lax as in giganteum and connected by distinct cross veinlets. Flowers about 6 to an umbel; pedicels none or very short; spathe- 
valves 3-4 in. long. Perianth-tube curved, greenish, 3-4 in. long; segments as long as the tube, pure white, connivent, acute. Filaments much shorter than the limb; anthers linear, $\frac{1}{2}$ in. long. Style overtopping the stamens.

Hab. South Brazil, originally described from plants found by Consul Langsdorff between Mandiocea and Porto d'Estrella. We have at Kew three sheets dried by Burchell, from a garden at San Bento in Oct., 1826. It comes about midway between $C$. crubescens and $C$. giganteum. The little-known $C$. Binsii, of Hoffmannsegg, from Rio Janelro, would seem to be like this in leaf, with a flower $4-5$ in. long.

\section{Hybrid Crinums.}

A large number of Crinums were artificially hybridised by Dean Herbert and his contemporaries. The species experimentised upon were principally lonyifolium (capense), americamum, erubescens, asiaticum, scabrum, and zeylanicum. In Kunth's 'Enumeratio,' vol v. p. 582-3, twenty-three hybrids are enumerated under Latin names and their parentage given, and in the second edition of Sweet's 'British Flower Garden,' p. 512, there are thirty-two. Reference should also be made to Herbert's papers in Trans. Hort. Soc. vol. iii. p. 187 (with a figure of C. Govenianum) Amaryll. 272, Journ. Hort. Soc. ii. 14, and to Bury's 'Hexandria,' tab. 30, where a hybrid between pedunculatum and zeylanicum is figured. The only recent hybrid with which I am acquainted is C. Powellii, a cross between longifolium and Moorei.

C. PowelliI Hort.-Bulb globose, with a short neck. Leaves about 20, spreading, ensiform, acuminate, bright green, 3-4 ft. long, 3-4 in. broad low down, smooth on the edge. Peduncle compressed, glaucous, 2 ft. long. Flowers about 8 in an umbel; pedicels $1-1 \frac{1}{2}$ in. long; spathe-valves large, oblong-lanceolate. Perianth-tube curved, greenish, 3 in. long; segments oblonglanceolate, acute, reddish, $4 \mathrm{in}$. long, an inch broad at the middle. Stamens much shorter than the perianth-segments. Style bright red upwards.

Hab. Described from a living plant in the garden of Sir W. Bowman, at Jolwynds, Dorking, July, 1887.

\section{Amarylis Limn. ex parte.}

Perianth funnel-shaped, with a short tube and 6 subequal oblong acute connivent segments. Stamens inserted at the throat of the tube; filaments long, filiform; anthers linear, versatile. Ovary 3 -celled; ovules many in a cell; style filiform, declinate; stigma capitate. Cupsule globose, bursting irregularly. Seels like that of a Crinum.

The name Amaryllis is still universally given in gardens to the species and hybrids of Hippeustrum, which has a flower like that of the present plant, but entirely different capsule and seeds.

1. A. Belladonna Linn. Sp. Pl. 421 ; Bot. Mag. t. 733 ; Red. Lil. t. 180. A. rosea Lam. A. pudica Gawl. Coburgia Belladonna Herb. - Bulb 3-4 in. diam. ; tunics rather fibrous. Leaves 7-9,

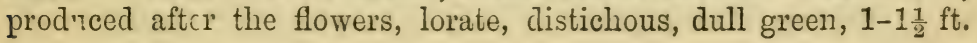


long, under an inch broad. Peduncle solid, compressed, 1-1 $\frac{1}{2} \mathrm{ft}$. long. Flowers 6-12 in an umbel, produced in March and April at

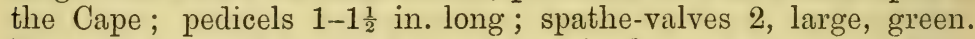
Perianth rose-red in the type; tube $\frac{1}{2}$ in. long; segments $2-3$ in. long, $\frac{1}{2}-\frac{3}{4} \mathrm{in}$. broad above the middle. Capsule globose, $1 \mathrm{in}$. diam. A. pallida Red. Lil. t. 479, differ's only by its pale flowers.

Var. A. Blanda Gawl. in Bot. Mag. t. 1450. Coburgia blanda Herb. - Leaves more sheathing at the base, longer and broader, reaching 2-3 ft. Flowers larger, lighter in colour, and opening wider ; segments $3-4$ in. long, 1-1 $\frac{1}{4}$ in. broad.

Hab. Southern Provinces of Cape Colony. Introduced into cultivation in 1712. Many forms are named in gardens. Sweet calls the genus Belladonna, and admits four species, B. purpurascens, pallida, pudica, and blanda. See also purpurascens, Flore des Serres, t. 911; and rubra, Flore des Serres, t. 1415.

\section{Ammocharis Herb.}

Perianth funnel-shaped, with a stout cylindrical tube and 6 equal ascending oblanceolate-unguiculate segments. Stanens inserted at the throat of the perianth-tube, about as long as the segments; filaments filiform, equally divergent; anthers linear-oblong, versatile. Ovary ampullæform, narrowed into a distinct neck, 3-celled; ovules numerous, superposed, sessile; style filiform, a little longer than the stamens; stigma capitate. Fruit and seeds unknown.

1. A. falcata Herb. App. 17. Amaryllis falcata L'Herit. Hamanthus falcatus Thunb. Crinum falcatum Jacq. Hort. Vindob. iii. 34, t. 60. Ammocharis coranica Herb. Amaryllis coranica Burchell in Bot. Reg. t. 139 \& 1219 (var. pallida). Genus Palinetes Salisb.-Bulb ovoid, reaching a diam. of 6-9 in., not produced into a neck; tunies very numerous, brown, membranous. Leaves bifarious, lorate, spreading; produced before the flowers in summer or autumn, reaching a length of 1-2 ft., an inch broad, green, glabrous. Peduncle stout, lateral, ancipitous, $\frac{1}{2}-1 \mathrm{ft}$. long. Flower's $20-40$ in an umbel, bright red, fragrant, produced in the middle of winter; pedicels $1-1 \frac{1}{2}$ in. long; spathe-valves large, ovate. Perianth-tube $\frac{1}{2} \mathrm{in}$. long; segments $1 \frac{1}{2}-2$ in. long.

Hab. Central and Eastern regions of Cape Colony, from Beaufort and Port Elizabeth, ascending the mountains to $5000 \mathrm{ft}$., northward to Natal. Probably the fruit figured by Gawler in Bot. Mag. t. 1443, is that of a Brunsvigia, mismatched with the flowers.

\section{Brunsvigia Heist.}

Perianth funnel-shaped, erect or slightly curved; tube short; segments lanceolate or oblong-lanceolate, subequal. Stamens long, declinate, inserted at the throat of the perianth-tube, three shorter; filaments filiform; anthers oblong, versatile. Ovary turbinate, 3-celled; ovules numerous, superposed; style filiform, declinate; stigma capitate. Capsule turbinate, acutely triquetrous, narrowed gradually to the base. Seeds green, subglobose, furnished with a distinct funiculus.- Rootstock a large tunicated bulb. Leaves lorate or lingulate, produced after the flowers. Peduncle stout, solid. 
Flouer's bright red, copiously umbelled; spathe 2-valved. A large proportion of the dried specimens I have seen are without leaves, and cannot therefore be determined clearly.

$\begin{array}{lll}\text { Leaves lorate } & \text { Sp.1-4. } \\ \text { Leaves lingulate } & \text { Sp. 5-8. } \\ \text { Flowers unknown } & \text {. } & \text { Sp. 9. }\end{array}$

1. B. Josephin a Gawl. in Bot. Reg. t. 192-193. Amaryllis Josephince Red. Lil. t. 370-372. A. Josephiniana Herb. A. Griffiniana Herb. - Bulb 5-6 in. diam. Leaves 8-10, lorate, glaucous or greenish, suberect, thick, closely ribbed, 2-3 ft. long, $1 \frac{1}{2}-2$ in. broad; edge entire. Peduncle subterete, an inch thick, $1 \frac{1}{2} \mathrm{ft}$. long. Flowers $20-30$, rarely $50-60$, in an umbel; pedicels stout, stiffly erect, $\frac{1}{2}-1 \mathrm{ft}$. long; spathe-valves small, broad, with a large cusp. Perianth bright red, $2 \frac{1}{2}-3$ in. long; tube subcylindrical, $\frac{1}{2}$ in. long; segments lauceolate. Stamens as long as the segments. Capsule smaller, less conical, and not so strongly angled as in $B$. gigantea.

Hab, Central and Eastern districts of Cape Colony, Kaffraria, Orange Free State, and Natal. It was originally described and figured from a plant that flowered in the garden of Malmaison, the bulb of which was purchased in Holland by the Empress Josephine, after whom it was named.

2. B. Grandiflora Lindl. Bot. Reg. t. 1335.-Bulb lirge, ovoid. Leaves lorate, obtuse, suberect, pale green; edge scibrous. Peduncle compressed, slightly glaucous, $1 \frac{1}{2} \mathrm{ft}$. long. Flowers about 30 in an unbel; pedicels 3-6 in. long; spathe-valves deltoid-cuspidate. Perianth pale red, 2 in. long; tube scarcely any; segments oblonglanceolate. Stamens rather shorter than the perianth-segments.

Hab. Cape Colony. Known only from the figure, which was drawn from a plant tlowered in London by Mr. Tate in 1829. Herbert's var. Banksiana is probably founded on a mismatching of leaf and flower.

3. B. Stateriana Benth. Gen. Plant. iii. 727. Ammocharis Slateriana Kunth. Amaryllis Banksiana Lindl. in Bot. Reg. 1842, t. 11. - Bulb globose, 4-5 in. diam. Leaves about 6, lorate, glaucous. Peduncle stout, compressed, $\frac{1}{2} \mathrm{ft}$. long. Flowers $15-20$ in an umbel; pedicels 3-4 in. long; spathe-valves lanceolatedeltoid. Perianth bright rose-red, $1 \frac{1}{2}$ in. long; tube very short; segments lanceolate. Stamens and style shorter than the perianthsegments.

Hab. Cape Colony. Known only from the figure cited, which was drawn from a plant tlowered by J. H. Slater, Esq., at Newick Park, Uckfield, in 1849.

4. B. мrnor Lindl. in Bot. Reg. t. 954. B. humilis Ecklon.Bulb ovoid, 2-3 in. diam. Leaves 3-4, lorate, half a foot long, an inch broad. Peduncle stout, 6-9 in. long. Flowers 12-40 in an umbel ; pedicels comparatively slender, 3-6 in. long; spathe-valves ovate, reflexing, $1 \frac{1}{2}$ in. long. Perianth pale red, $1 \frac{1}{4}-1 \frac{1}{2}$ in. long; tube very short; segments lanceolate. Stamens as long as the perianth-segments; anthers oblong, $\frac{1}{8} \mathrm{in}$. long. Capsule acutely turbinate, 1 in. long. 
Hab. Uitenhage and other South-eastern provinces of Cape Colony. A western plant sketched by Masson about 1795 , and two forms gathered by Drege (8546) in the province of Clanwilliam, are like this in flower, but the leaf is not known.

5. B. gigantea Heist. Monog., with figure. B. multiflora Ait. ; Gawl. in Bot. Mag. t. 1619. Amaryllis orientalis Limn.; Jacq. Hort. Schoen. i. 38, t. 74. Hamanthus orientalis Thunb. Brunsvigia orientalis Ecklon. B. Muricaulis Roem.-Bulb very large. Leaves about 4, spreading, lingulate, closely ribbed, 3-5 in. broad, usually under a foot long. Peduncle red or green, 8-12 in. long, as thick as a man's finger. Flowers 20-30 in an umbel; pedicels stout, strongly ribbed, 4-6 in. long; spathe-valves deltoid. Perianth curved, bright red, $2-2 \frac{1}{2}$ in. long; tube broad, $\frac{1}{4}-\frac{1}{3}$ in. long ; segments lanceolate. Stamens and style rather exserted; anthers $\frac{1}{8}$ in. long. Capsule-acutely triquetrous, $2-3$ in. long.

Hab. South-western provinces of Cape Colony. Introduced into cultivation about 1700, and figured by Siveet, Ferrari, Barrelier, and Morison. The genus was named by Heister in 1753, in compliment to the reigning Duke of Brunswick.

6. B. Cooperi Baker in Saund. Ref. Bot. t. 330. - Bulb ovoid, 3-4 in. diam. Leaves 4-6, lingulate, spreading horizontally, 3-4 in. broan, thick in texture, closely ribbed, minutely granulated; edge scabrous. Peduncle very stout, above a foot long. Flowers 12-16 in an umbel; pedicels stout, 4-6 in. long; spathe-valves broad, ovate. Perianth bright red, 2-21 in. long; tube very short; segments oblong-lanceolate. Stamens as long as the perianthsegments. Capsule turbinate, acutely angled, $1 \frac{1}{2}-2 \mathrm{in.} \mathrm{long.}$

Hab. Cape Colony; mountains of the Eastern provinces, ascending to $5000-6000 \mathrm{ft}$. on the IVitbergen, Drége 3518 !

7. B. striata Ait. Hort. Kew. ed. 2, ii. 231. Amaryllis striata Jacq. Hort. Schoen. i. 36, t. 70. A. nervesa Poir. - Bulb ovoid, the size of a walnut. Leaves 4-6, lingulate, spreading or suberect, 4-6 in. long, $2 \frac{1}{2} \mathrm{in}$. broad, subcoriaceous, closely strongly ribbed; edge scabrous. Peduncle 6-8 in. long, $\frac{1}{2}$ in. diam. Flowers 10-20 in a dense umbel; pedicels slender, 1-3 in. long; spathe-valves ovate, $1-1 \frac{1}{2}$ in. long. Perianth bright red or rose-red, suberect, 1-1 $\frac{1}{4}$ in. long; tube cylindrical, $\frac{1}{4}$ in. long; segments oblong-lanceolate. Stamens and style exserted. Capsule comparatively small.

Hab. Cape Colony; South-western provinces. Sketched by Masson in 1788.

8. B. Radula Ait. Hort. Kew. ed. 2, ii. 230. Amaryllis Liadula Jacq. Hort. Schoen. i. 35, t. 68. C'oburgia Radula Herb. - Bulb globose, larger than a hazel-nut. Leaves 2, spreading, lingulate, obtuse, 2-3 in. long, 1-1 $\frac{1}{4}$ in. broad, covered all over the surface with rough papillæ. Peduncle ancipitous, not more than 2-3 in. long. Flower's $3-5$ in an umbel; pedicels $1-1 \frac{1}{2}$ in. long; spathevalves ovate, reddish, $\frac{1}{2}$ in. long. Perianth $\frac{3}{4}-1 \mathrm{in}$. long; tube very short; segments lanceolate. Stamens as long as the perianthsegments.

Hab. Cape Colony; Karoo, near the Elephant's River. Sketched by Masson in 1790.

9. B. radulosa Herb. Amaryll. 281, t. 22, fig. 2. -- Leaves spreading, lingulate, obtuse, $8-9$ in. long, $3-3 \frac{1}{2}$ in. broad at the 
middle, thick in texture, closely ribbed, rough all over the surface; edge thickened, scabrous. Flowers and fruit unknown.

Hab. Central district of Cape Colony, near the Nu-Gariep, Burchell!

10. B.? Krnкr Baker.-A plant sent home by Sir John Kirk from the Usagura Mountains, in East Tropical Africa, is probably a new genus near Bransvigia. It has a small acutely triquetrous turbinate capsule, just like that of Brmsvigia, but with only a single globose bulbiform green seed sessile near the apex of the placenta. There are very numerous flowers in an umbel, with slender acutely-angled pedicels $\frac{1}{2}-1 \mathrm{ft}$. long. Perianth an inch long, with a short tube and lanceolate segments. Stamens and style exserted; anthers small, oblong. Bulb and leaves unknown.

\section{Nerine Herb.*}

Perianth funnel-shaped, cut down nearly or quite to the ovary, erect or decurved; segments oblanceolate, obtuse, subequal, more or less crisped. Stumens inserted at the base of the perianthsegments; filaments filiform, thickened at the base, suberect or declinate, 3 shorter; anthers oblong, versatile. Oxary globose, 3-lobed; ovules few in a cell, superposed; style filiform, suberect or declinate, obscurely tricuspidate. Corsule globose, deeply 3-lobed, membranous, loculicidally 3 -valved. S'epds 1 or few in a cell, globose, green. - Bulb tunicated, not produced into a neck. Leares long, linear, produced with or a little after the flowers. Peduncle usually slender. Flowers few or many, pale or deep red, arranged in a centripetal or centrifugal umbel; spathe-valves 2, lanceolate.

Peduncle long, slender. Perianth-limb suberect; stamens and style nearly straight

Peduncle long, slender. Perianth limb slightly irregular; stamens and style decliuate.

Umbel centripetal . . . . .

Unbel . Sp. 4-6.

Peduncle short, stout. $\quad . \quad \therefore \quad \therefore \quad \therefore$ Sp. 9-10.

1. N. sarniensis Herb. App. 19. Amuryllis samiensis L.; Curt. in Bot. Mag. t. 294 ; Red. Lil. t. 35 ; Jaeq. Hort. Schoen. t. 66. A. dubia Houtt. A. Jacquinii Tratt. Hemanthus sarmiensis Thunb. N. insignis Hort.-Bulb ovoid, $1 \frac{1}{2}-2$ in. diam.; tunics pale brown. Leaves about 6, bright green, suberect, not curved laterally, developed after the flowers, linear, obtuse, finally a foot long, $\frac{1}{2}-\frac{3}{4}$ in. broad. Peduncle slender, rather compressed, $1-1 \frac{1}{2} \mathrm{ft}$. long. Umbel 10-20-Howered, centripetal ; pedicels 1-2 in. long; spathevalves ovate-lanceolate, $1 \frac{1}{2}$ in. long. Perianth erect, $1 \frac{1}{4}-1 \frac{1}{2} \mathrm{in}$. long, bright crimson; segments oblanceolate, $\frac{1}{4}-\frac{1}{3} \mathrm{in}$. broad, equally faleate, harily at all crisped. Filaments erect, bright red, $\frac{1}{2} \mathrm{in}$.

* Reprinted, with slight alteration, from Gard. Chron. 1885, pp. 779-810. 
longer than the segments; anthers oblong, $\frac{1}{6}$ in. long. Style straight, nearly 2 in. long.

Var. N. Plan'in Hort. - Peduncle longer than in the type. Flower a duller crimson; segments more distinctly unguiculate.

Var. N. venusta Herb. App. 19 ; Ker in Bot. Mag. t. 1090.Leaves pale green. Flowers bright scarlet, produced late in September; segments rather wavy, very falcate.

Var. N. PRofusa Hort. - Leaves dark green. Flowers bright scarlet, produced late in Angust; segments narrower and more acute, less wavy and less falcate than in remusta.

Var. N. rosea Herb. App. 19 ; Bot. Mag. t. 2124. - Leaves darker than in the type. Flowers rose-red. Seeds oblong.

Var. N. conusca Herb. App. 19. Amaryllis cornesca Gawl. A. humilis var., Gawl. in Bot. Mag. t. 1089. - Leaves broader than in the type, bright green, with distinct cross-bars between the main veins. Flowers large, bright scarlet, resembling those of N. curvifolia. A connecting link between species 1 and 2 . N. corusca major Hort. is a form with large flowers, and leaves widening at the middle.

Hab. Southern provinces of Cape Colony. Has been cultivated largely in the Channel Islands for 200 years under the name of the "Guernsey lily," from which the Latin name is derived. It was grown at l'aris in 1634 , and by Gen. Lambert at Wimbledon in 1659. Flowers generally in September and October. Sir Charles Strickland regards Plantii as probably a hybrid between venusta and flexuosa.

2. N. cunvifolia Herb. App. 19. Amaryllis curvifolia Jacq. Hort. Schoen. i. 33, t. 64; Gawl. in Bot. Mag. t. 725 ; Red. Lil. t. 274. - Bulb ovoid, $1 \frac{1}{2}-2$ in. diam.; tunics pale brown. Leaves about 6 , developed after the flowers, linear, obtuse, curved laterally, thicker in texture than in $N$. sumiensis, more or less glaucous, closely veiner, finally a foot long, $\frac{1}{2}-\frac{3}{4}$ in. broad. Umbel 8-12flowered, centripetal; pedicels and spathe-valves as in N. samiensis. Perianth erect, bright scarlet, $1 \frac{1}{4}-1 \frac{1}{2} \mathrm{in}$. long; segments oblanceolate, $\frac{1}{4} \mathrm{in}$. broad, equally falcate, little crisped. Stamens suberect, a little longer than the segments. Style straight, finally 2 in. long.

Var. N. Fотнergilli Roem. Amaryll. 104. Amaryllis Fothergilli Andr. Bot. Rep. t. 163. - More robust in all its parts. Flowers more numerous, between crimson and scarlet.

Hab. Southern provinces of Cape Colony. Introduced in 1788. Flowers in the latter half of September.

3. N. Moorer Leichtlin in Gard. Chron. n. s., vol. xxvi. 681.Leaves produced a little after the flowers, lorate, bright green, much curved, slightly twisted, 9-12 in. long, $\frac{1}{2}-\frac{3}{4}$ in. broad. $\mathrm{Pe}$ duncle compressed, shorter than the leaves. Flowers 6-9 in a centripetal umbel; pedicels $\frac{3}{4}-1$ in. long; spathe-valves longer than the pedicels. Perianth suberect, bright scarlet; segments oblanceolate, crisped, $1 \frac{1}{4} \mathrm{in}$. long, $\frac{1}{4} \mathrm{in}$. broad. Filaments suberect, longer than the perianth-segments. Style straight, $1 \frac{1}{2} \mathrm{in}$. long.

Hab. Cape Colony. Described from a plant sent to Max Leichtlin from Mr. F. W. Moore, of the Glasnevin Garden.

4. N. flexuosa Herb. App. 10. Amaryllis flexuosa Jaeq. Hort. 
Schoen. i. 35, t. 67; Ker in Bot. Reg. t. 172. - Bulb subglobose, $1 \frac{1}{2}$ in. diam. Leaves 4-6, contemporary with the flowers, linear, above a foot long, $\frac{1}{2}-\frac{3}{4}$ in. broad, bright green, sometimes rough with pustules on the face. Peduncle slender, subterete, flexuose, sometimes 2-3 ft. long. Flowers 10-20 in a centripetal umbel; pedicels slender, 1-2 in. long; spathe-valves lanceolate, as long as the pedicels. Perianth declinate, cut down nearly to the ovary; segments oblanceolate, crisped, pale pink, $1-1 \frac{1}{4}$ in. long, $\frac{1}{6}$ in. broad. Stamens declinate, the 3 longer ones rather shorter than the perianth. Style declinate, as long as the stamens.

Var. Sandersoni Baker.-Leaves broader. Peduncle and pediculs more robust. Perianth-segments less crisped, united in a more distinct cup at the base.

Var. N. pulchella Herb. App. 19; Bot. Mag. t. 2107.-Leaves glaucous, firmer in texture than in the type. Peduncle not flexuose. Perianth-segments pale pink, with a rose-red keel. Stamens and style nearly white.

Var. angustifolia Baker. N. pulchella var. angustifolia Baker in Saund. Ref. Bot. t. 329. - Leaves about 8, very narrow, channelled down the face. Pedicels pubescent, 2-3 in. long. Ovary very pubescent.

Hab. Cape Colony, ascending the mountains to $4000-5000 \mathrm{ft}$., and Natal. Var. Sandersoni was sent by Mr. Sanderson from the Transvaal, and var. angustifolia by Mr. Thomas Cooper from Orange Free State. Introduced into cultivation by Masson in 1795 .

5. N. pudica Hook. fil. in Bot. Mag. t. 5901; Flore des Serres, t. 2464.-Bulb globose, 1 in. diam. Leaves 4-6, linear, glaucous, suberect, persistent, 8-9 in. long, $\frac{1}{4}-\frac{1}{2}$ in. broad. Peduncle slender, subterete, 1-1 1 ft. long. Umbel centripetal, 4-6-Howered ; pedicels slender, 1-1 $\frac{1}{2} \mathrm{in.}$ long; spathe-valves lanceolate, tinged with red, as loug as the pedicels. Perianth rather deflexed: segments oblanceolate, scarcely at all crisped, $1 \frac{1}{4}-1 \frac{1}{2}$ in. long, white, keeled upwards with pink. Stamens declinate, shorter than the perianth. Style declinate, reaching to the tip of the perianth. Seeds globose.

Var. N. Elwesir Leichtlin.-Leaves broader, bright green, more persistent; midrib prominent. Umbel more comract. Perianthsegments pale rose, with a darker keel, thicker and more waxy in texture.

Hab. Cape Colony. First described from a plant that flowered at Kew in the autumn of 1868 .

6. N. Filifolla Baker in Bot. Mag. t. 6547. - Bulb globose, under $1 \mathrm{in.}$ diam., with pale tunics produced into a short neck. Leaves $6-10$, contemporary with the flowers, grass green, suberect, very slender, 6-8 in. long. Pecuncle slender, terete, green, finely glandular-pubescent, a foot lung. Flowers 8-10 in a centripetal umbel; pedicels slender, 1-1 $\frac{1}{2} \mathrm{in}$. long; spathe-valves small, green, lanceolate. Perianth deflexed, bright red, an inch long; segments oblanceolate, crisped, only 1-12th to 1-8th in. broad. Stamens declinate, shorter than the perianth-segments. Style equalling the longer stamens. 
Hab. Orange Fuee State, sent to Kew by Mr. Ayres in 1879. Flowers in October and November.

7. N. Humus Herb. App. 19. Amaryllis humilis Jacq. Hort. Schoen. i. 36, t. 629; Bot. Mag. t. 726 ; Red. Lil. t. 449. - Bulb ovoid, 1-1 $\frac{1}{2}$ in. diain. Leaves about 6 , linear, bright green, channelled down the fice, a foot long, $\frac{1}{2} \mathrm{in}$. broad. Peduncle slender, subterete, $\frac{1}{2}-1 \frac{1}{2} \mathrm{ft}$. long. Flowers $10-20$ in a centrifugal umbel; pedicels slender, 1-1 $\frac{1}{2}$ in. long; spathe-valves lanceolate, as long as the pedicels. Periunth deflexed, pink or rose-red, 1-1 $\frac{1}{4}$ in. long ; segments oblanceolate, crisped. Stamens declinate, rather shorter than the perianth. Style decliuate, as long as the perianth.

Hab. Cape Colony. Differs from flexuosa by its dwarfer habit, narrower more deeply channelled leaves, and centrifugal umbel.

8. N. undulata Herb. App. 19. Amaryllis undulata L. ; Mill. Ic. t. 8 ; Bot. Mag. t. 869 ; Red. Lil. t. 115 ; Jacq. Hort. Vind. iii. t. 13. Hemanthus undulutus Thunb. Nerine crispa Hort. - Bulb ovoid, $\frac{3}{4}-1$ in. diam. Leaves $4-6$, linear, bright green, $1-1 \frac{1}{2} \mathrm{ft}$.

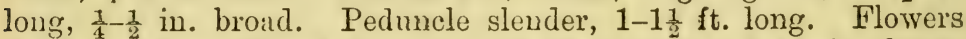
8-12 in a centrifugal umbel; pedicels slender, 1-1 $\frac{1}{2}$ in. long; spathe-valves lanceolate, as long as the pedicels. Perianth-limb pale pink, about $\frac{3}{4} \mathrm{in}$. long; segments oblanceolate, much crisped. Stameus and style declinate, about as long as the perianth. Capsule $\frac{1}{4}$ in. diam.; seeds solitary in the cells, globose.

Var. major Tratt. Tab. t. 394. N. aucta Roem. Amaryllis ancta 'Tratt. - Perianth-segments larger and less crisped. A form intermediate between $N$. unduluta and humilis.

Hab. Cape Colony, northward to the Orange Free State, where it was found by Mr. Thomas Cooper.

9. N. Lucida Herb. Amaryll. 283, tab. 26, fig. 3. Amuryllis hucidu Burchell. A. laticoma Ker in Bot. Mag. t. 497. Brunsvigia lucida Herb. - Bulb 3-4 in. diam., produced into a short neck. Leaves 4-6, contemporary with the flowers, linear, spreading, flaccid, a foot long, $\frac{1}{2}-\frac{3}{4} \mathrm{in}$. broad, scabrous on the edge. Peduncle stont, ancipitous, 4-8 in. long. Flowers 20-40 in a centripetal nmbel; pedicels $3-4$ in. long, straight, moderately stout; spathevalves ovate-lanceolate, much shorter than the pedicels. Perianthlimb $1 \frac{1}{2}-2$ in. long, pale or bright red, ent down to a campanulate tube; segments oblanceolate-unguiculate, $\frac{1}{4} \mathrm{in.} \mathrm{broad,} \mathrm{liardly} \mathrm{at} \mathrm{all}$ crisped. Stamens and style declinate, bright red, nearly as long as the segments. Capsule depresso-globose, $\frac{1}{3}-\frac{1}{2} \mathrm{in}$. diam.

Hab. Central regions of Cape Colony, northward to the Gariep. It was introduced by Burchell, but is not in cultivation at present.

10. N. marginata Herb. Amaryll. 283. Amaryllis marginata Jacq. Hort. Schoen, i. 34, t. 65. Brunsriyia maryinata Ait. Imhofia maryinata Herb. Elisena marginata Roem. - Bulb ovoid, 2-3 in. diam., with imbricated dark brown membranous tunics and very strong root-fibres. Leaves about 4, produced after the flowers, spreading, lingulate, obtuse, 6-9 in. long, 2-2 $\frac{1}{2}$ in. broad, with a reddish crisped cartilaginous edge. Peduncle stout, ancipitous, $\frac{1}{2} \mathrm{ft}$. long. Flowers $12-20$ in a centripetal umbel; pedicels $1 \frac{1}{2}-2$ in. 
long; spathe-valves ovate, shorter than the pedicels. Perianth erect, bright scarlet, $1 \frac{1}{4}$ in. long, cut down to the ovary; segment3 lanceolate, but little crisped, $\frac{1}{4} \mathrm{in}$. broad. Stamens and style sub. erect, a little longer than the perianth.

Hab. South-western districts of Cape Colony. Known to me only from the figure cited.

\section{Hybrid Nerines.}

The following hybrid Nerines were raised long ago by Denn Herbert, viz.:-

1. N. Nitchamia Herb. Amaryll. t. 5, and N. versiculor, between curvifolia and undulata.

2. N. Haylocki, between curvifolia and pulchella.

3. N. pulchello-undulata.

4. N. Spofforthia, between venusta and undulata.

5. N. pulchello-humilis.

6. N. humilis-undulata.

7. N. curvifolio-zenusta.

The following are the principal crosses that have been raised of late years by Messrs. O'Brien, Leichtlin, Cam, and other experimenters :-

8. N. amabilis, between pudica and humilis.

9. N. Cami, between curvifulia and undulata.

10. N. atrosanguinea, between Plàntii and flexuosa.

11. N. cinnabarina, between Fothergilli and flexuosa.

12. N. U'Brieni, of which carminata and carulea are forms, between pudica and Plantii.

13. N. erubescens, between flexunsa and undulata.

14. N. elegans, between flexuosa and rosea.

15. N. Meadowbankii, between sarniensis and Fothergilli.

16. N. Mansellii, between flexwosa and Fothergilli.

17. N. roseo-crispa, between undulata and flexuosa.

18. N. excellens Moore in 'Florist,' 1882, t. 567, between flexuosa and humilis major.

\section{Strumaria Jacq.}

Perianth funnel-shaped, cut down to the ovary; segments equal, spreading, oblanceolate. Stamens inserted at the base of the segments; filaments filiform, usually united with one another and the dilated style towards the base; anthers oblong, versatile. Ovary globose, 3.celled; ovules few, superposed; style swollen and triquetrous towards the base, tricuspidate at the stigmatose apex. C'apsule small, globose, membranous, loculicidally 3-valved. Seeds one or few in a cell, globose, green, bulbiform.-Ruotstuck a tmicated bulb. Leaves lorate or linear, contemporary with the flowers. Peduncle slender, solid, terete. Flovers umbellate, small, whitish or reddish; spathe-valves 2, small, lanceolate. Three out of the four species do not exist in the English herbaria. 
Perianth-segments plane. Filaments connate with one another and the style.

Leaves short, lorate

Leaves longer and narrower.

Perianth-segments crisped. Filaments free

1. S. truncata Jacq. Ic. ii. 47, t. 357. Hamanthus vaginatus Thunb. Hessea raginata Herb. Genus Hymenetron Salisb.-Bulb globose, 1 in. diam.; sheathing tunic brown, funnel-shaped, truncate, $1 \frac{1}{2}-2$ in. long, wrapped round the base of the leaves. Leaves $3-6$, lorate, obtuse, $\frac{1}{2} \mathrm{ft}$. long, $\frac{1}{3}-\frac{1}{2} \mathrm{in}$. broad. Peduncle slender, a

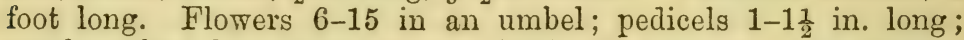
spathe-valves lanceolate, green. Perianth-segments oblanceolate, plain, pinkish, $\frac{1}{3}-\frac{1}{2}$ in. long. Stamens exserted, jointed to one another and the dilated style towards the base.

Hab. Cape Colony. Gathered by Masson at Rhinoceros Fountrin in 1793. There is a specimen from Kew Gardens at the British Museum, dried in the year 1800. S. linguafolia Jacq. Ic. t. 356 (S. Baueriana Herb.) seems a mere variety with more robust habit, broader leaves, and larger flowers. It has been gathered lately by the Rev. H. Whitehead in Namaqua-land.

2. S. angustifolia Jacq. Ic. ii. 47 , t. 359 . Genus Pugionella Salisb. - Bulb ovoid, $\frac{1}{2}$ in. diam. Leaves 2, linear, $\frac{1}{2} \mathrm{ft}$. long, $\frac{1}{8}-\frac{1}{6}$ in. broad, enclosed at the base in a reddish brown cylindrical sheath. Peduncle slender, a foot long. Flowers 8-10 in an umbel, fragrant; pedicels $1-1 \frac{1}{2}$ in. long; spathe-valves lanceolate. Perianthsegments oblanceolate, plain, pale pink, $\frac{1}{2}$ in. long. Stamens exserted, united to the acutely triquetrous style towards the base.

Hab. Southern provinces of Cape Colony. Known to me only from Jacquin's figure and description.

3. S. rubella Jacq. Ic. ii. 46, t. 358. Genus Stylago Salisb.Bulb ovoid, under an inch in diam. Leaves $3-4$, linear, suberect, 6-9 in. long, not enclosed in a funnel-shaped sheath at the base. Peduncle slender, terete, $1-1 \frac{1}{2} \mathrm{ft}$. long. Flowers 6-10 in an umbel. scentless; pedicels an inch long; spathe-valves lanceolate, purplish. Perianth-segments lanceolate, plane, pinkish, $\frac{1}{3}-\frac{1}{2}$ in. long. Stamens exserted; filaments united to the clavate-triquetrous style in the lower third.

Hab. Southern provinces of Cape Colony. Known to me only from Jacquin's figure and description.

4. S. undulata Jacq. Ic. ii. 50, t. 360. Genus Fudolon Salisb. -Bulb ovoid, 1-1 $\frac{1}{2}$ in. diam. Leaves 3-4, suberect, lorate, 6-10 in. long, $\frac{1}{3}-\frac{1}{2}$ in. broad, enclosed at the base in a loose red-brown truncate funnel-shaped sheath. Peduncle slender, terete, $1 \frac{1}{2} \mathrm{ft}$. long.

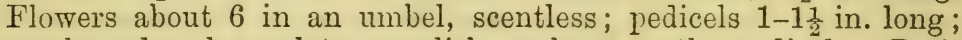
spathe-valves lanceolate, purplish, as long as the pedicels. Perianth-segments pinkish, crisped, lanceolate, $\frac{1}{2}$ in. long. Stamens exserted; filaments free to the base. Style as long as the stamens, clavate-triquetrous in the lower half.

Hab. Southern provinces of Cape Colony. Known to me only from Jacquin's figure and description. 


\section{Tribe 3.-Pancratieæ.}

\section{Eucrosia Ker.}

Perianth funnel-shaped; tube short, campanulate; segments equal, oblanceolate. Stumens much exserted, declinate, inserted at the throat of the perianth-tube; filaments filiform, irregularly united and callose internally at the base; anthers oblong, versatile. ()vary globose, 3-celled; ovules numerous; style filiform, declinate; stigma punctiform. C'apsule deeply 3-lobed. Seedls many, angled by pressure.-Differs from Callipsyche only by its filaments connate towards the base.

1. E. BIColon Ker in Bot. Reg. t. 207 ; Hook. Exot. Flora, t. 209; Herb. in Bot. Mag. t. 2490. - Bulb ovoid, 1 in. diam.; tunies brown, membranous. Leaves several, petioled, contemporary with the flowers; blade thin, lanceolate, $\frac{1}{2} \mathrm{ft}$. long, 1-2 in. brad. Peduncle very slender, a foot long. Flowers about 4 in an umbel; pedicels $\frac{1}{2}-1 \frac{1}{2}$ in. long; spathe-valves about 4 , linear. Perianthlimb an inch long; tube $\frac{1}{6}$ in. long and broad; segments $\frac{1}{4}$ in. broad, reddish yellow, with a laxly 3-5-nerved green keel. Stamens much exserted, and style still longer.

Hab. Andes of Ecuador, Jameson! Seemann! Introduced into cultivation by Lee and Kennedy in 1817 .

\section{Stricklandia Baker.}

Perianth narrowly funnel-shaped; tube short; segments oblanceolate, equal, spreading only at the tip. Stamens not declinate, inserted at the throat of the tube, a little longer than the segments; filaments callose at the base, united halfway up in a cup, lanceolate above it, without any teeth between; anthers linear-oblong, versatile. Ovary globose, 3-lobed, 3-celled; ovules many in a cell, superposed; style filiform; stigma punctiform. Capsule short, deeply 3 -lobed, loculicidally 3 -valved. Seeds many, small.-Differs from Eucrosia by its shorter straight stamens, like those of Stenomesson.

1. S. eucrosiondes Baker. Leperiza encrosivides Baker in Gard. Chron. 1878, i. 170. Stenomesson Stricklandi Balier in Gard. Chron. 1882, ii. 102.-Bulb ovoid, 2 in. diam.; tunics brown, membranous. Leaves 2 to a stem, produced after the flowers; blade thin, green, oblong, 6-9 in. long; petiole shorter than the blade. Peduncle. slender, terete, a foot long. Flowers $3-4$ in an umbel, horizontal or cernuous; pedicels $\frac{1}{2}-1$ in. long; spathe-valves linear. Perianthlimb 1-1 1 in. long; tube green, $\frac{1}{6}-\frac{1}{4}$ in. long; segments $\frac{1}{6}$ in. broad, red, laxly nerved all through, not keeled nor tipped with green. Stamens finally just exserted. Style exserted $\frac{1}{4}$ in.

Hab. Andes of Ecuador. Received alive in the summer of 1882.3 from Sir C. W. Strickland, who pointed out at the time its systematic position; and also from Messrs. E. G. Henderson in 1877, and Dr. Wallace, of Colchester, in 1879. From Phedranassa, under which Mr. Bentham has placed it in 'Genera Plantarum,' it differs by its monadelphous filaments. 


\section{Callipsyche Herb.}

Perianth funnel-shaped; tube short; segments equal, oblanceolate-oblong, laxly nerved down the keel. Stamens much exserted, declinate, inserted at the throat of the perianth-tube, callose at the base, not united; filaments filiform; anthers oblong, versatile. Ovary deeply laterally 3 -lobed; ovules very numerous, superposed; style very long, declinate; stigma punctiform. Capsule deeply laterally 3 -lobed. Seeds crowded, angled by pressure. - Rootstock a tunicated bulb. Leaves thin, oblong, petioled. Peduncle hollow. Flowers many in an umbel ; spathe-valves ovate-lanceolate.

1. C. Eucrosiondes Herb. in Bot. Reg. 1845, t. 45.-Bulb globose, 2 in. diam. Leaves produced after the flowers, petioled, oblong; blade a foot long, about $4 \mathrm{in}$. broad. Peduncle slender, above $2 \mathrm{ft}$. long. Flowers 8-10 in an umbel; pedicels an inch long; outer spathe-valves lanceolate, reflexing. Perianth-limb 1-1 $\frac{1}{4} \mathrm{in}$. long ; segments oblanceolate-oblong, obtuse, greenish yellow, three times as long as the tube. Stameus and style exserted 3 in. beyond the tip of the segments.

Hab. Guayaquil, Sinclair! Given by Herbert as a plant of the West Coast of Mexico, but this is probably a mistake. Introduced in 1844, but I have never seen it alive.

2. C. mrrabilis Baker in Saund. Ref. Bot. t. 168.-Bulb oblong, 2 in. diam.; outer tunics brown, membranous. Leaves $1-2$, produced after the flowers; petiole finally a foot long; blade oblong, acute, thin, a foot long, 5-6 in. broad. Peduncle hollow, $2-3 \mathrm{ft}$. long. Flowers about 30, forming a dense umbel 8-9 in. diam.; pedicels $1-1 \frac{1}{2}$ in. long; outer spathe-valves 2 , ovate-lanceolate, reflexing. Perianth-limb $\frac{5}{8}-\frac{3}{4}$ in. long; segments greenish yellow, twice as long as the campanulate tube. Stamens and style declinate, protruded 3 in. or more from the perianth.

Hab. Andes of Peru. Described first from a plant flowered by Mr. Wilson Saunders at Reigate about 1870 , received from Linden. Since received alive from Sir C. W. Strickland and Messrs. Sander and Horsman. Flowers in July and August.

3. C. aurantiaca Baker in Saund. Ref. Bot. t. 167 ; Bot. Mag. t. 6141. - Bulb ovoid, 1 in. diam.; tunies membranous, brown. Leaves oblong, petioled, developed after the flowers; blade membranous, cordate-oblong, $\frac{1}{2} \mathrm{ft}$. long, $4 \mathrm{in}$. broad. Peduncle subterete, $1 \frac{1}{2}-2 \mathrm{ft}$. long. Flowers $6-8$ in an umbel; pedicels $\frac{1}{2}-1$ in. long;

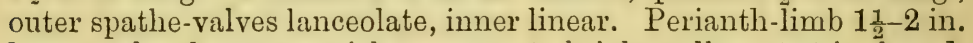
long; tube short, greenish ; segments bright yellow, $\frac{1}{3}-\frac{1}{2}$ in. broad. Stamens exserted, $2 \frac{1}{2}-3 \mathrm{in}$. beyond the tip of the segments; anthers small, oblong.

Hab. Andes of Ecuador, alt. $8000 \mathrm{ft}$., André 4262! First described from a plant flowered by Mr. Wilson Saunders in 1869, received from Linden. I have had it since from Sir C. W. Strickland and Messrs. Bull and Horsman. Flowers in February; leaf not fully developed till June. 


\section{Phedranassa Herb.}

Perianth subcylindrical; tube short or long; segments equal, regular, spreading only at the tip. Stamens inserted at or below the throat of the perianth-tube; filaments straight, filiform, not distinctly appendiculate; anthers oblong, versatile. Ovary globosetrigonous, 3-celled; ovules many, superposed; style filiform; stigma capitate. C'upsule globose, loculicidally 3-valved. Seerls many, small, black.- Liootstock a tunicated bulb. Leaves petioled, oblong or lanceolate, produced after the flowers. Flower's brightcoloured, few or many in an umbel, usually tipped with green; outer spathe-valves lanceolate.

Perianth-tube much shorter than the segments . Sp.1-4.

Perianth-tube much longer than the segments . Sp. 5.

1. P. chloracea Herb. in Bot. Reg. 1845, t. 17. P. obtusa Herb.; Regel, Gartenfl. t. 413. P. multiflura Kunth. Ilcemantius dubius H. B. K. Crinum quitense Spreng. Phycella chloracea Herb. P. ubtusa Lindl.-Bulb globose, 2-3 in. diam. Leaves produced after the flowers; blade oblong-lanceolate, acute, 8-12 in. long, 2-3 in broad at the middle; petiole $\frac{1}{2} \mathrm{ft}$. long, clasping the stem towards the base. Peduncle glaucous, subterete, 2-3 ft. long. Flowers 6-12 in an umbel; pedicels 1-2 in. long; outer spathe-valves acuminate, reflexing. Flowers generally drooping; perianth-limb $1 \frac{1}{2}-2 \mathrm{in.}$ long; tube subcylindrical, $\frac{1}{4}-\frac{1}{3} \mathrm{in.}$ long; segments lanceolate, acute, scarlet, tipped with green, Stamens as long as the perianth-segments. Style finally much exserted.

Hab. Andes of Ecuador. ascending to 12,000 ft., Hartweg! Spruce! Jameson! Often seen in eultivation. P. obtusa, chloracea, and multiflora differ only in the number and size of the flowers. Flowers in summer. On re-examination I fear that P. ventricosa Baker in Engler Jahrb. 1887, 210, founded on Lehmann's 2157 , from Columbia, is also a form of this species.

2. P. viridiflora Baker in Gard. Chron. 1877, ii. 134. - Bulb ovoid, $1 \frac{1}{2}$ in. diam.; outer tunies thin, brown. Leaf single; blade bright green, lanceolate, nearly a foot long, $1 \frac{1}{2}-2$ in. broad at the middle; petiole short. Peduncle terete, a foot long. Flowers about 4 in an umbel, drooping; pedicels $\frac{1}{2}-\frac{3}{4}$ in. long; outer spathe-valves lanceolate. Perianth-limb $1 \frac{1}{4}-1 \frac{1}{2}$ in. long; tube short, greenish yellow; segments oblanceolate-spathulate, green towards the tip, without any red, passing into whitish towards the base. Stamens as long as the segments. Style much exserted.

Hab. Andes of Ecuador. Described from living specimens sent by Mr. H. J. Elwes in June, 1877, and Mr. Wilson Saunders. Perhaps a colour-variety of $P$. chloracea.

3. P. Lehnanxi Regel, Gartenfl. xxxii. 354, t. 1138. - Bulb oroid, 2 in. diam. Leaf oblong-lanceolate, bright green, 6-8 in. long, 2 in. broad at the middle; petiole shorter than the blade. Pechuncle rather compressed. Flowers $3-4$ in an umbel ; pedicels 1-1 $\frac{1}{2}$ in. long; spathe-valves lanceolate, reflexing. Perianth-limb $1 \frac{1}{4}$ in. long; tube green, campanulate; segments oblanceolate, bright red, not tipped with green. Stamens exserted about $\frac{1}{2}$ in. Style $\frac{1}{2}$ in. longer than the stamens. 
Hab. Western slope of the Andes of Columbia, alt. $7000 \mathrm{ft}$., Lehmann. Introduced into cultivation in 1883.

4. P. schizantha Baker in Gard. Chron. 1880, ii. 556. - Bulb ovoid, 1 in. diam. Leaf contemporary with the flower in October, oblong-lanceolate, acute, bright green, 6-8 in. long, 2 in. broad at the middle; petiole short. Peduncle slender, nearly a foot long. Flowers about 5 in an umbel; pedicels $\frac{1}{2}-1$ in. long; outer spathevalves lanceolate. Perianth-limb $1 \frac{1}{2}$ in. long; tube campauulate, green, $\frac{1}{6}$ in. long; segments lanceolate, bright red, with a salmoncoloured obtuse tip $\frac{1}{4}$ in. broad. Stamens exserted $\frac{1}{4}$ in. Style $\frac{1}{4}$ in. longer than the stamens.

Hab. Andes of Ecuador; P'asto, alt. 10,000 ft., André! Discovered in 1876. Described from a living specimen flowered by M. André in October, 1880.

5. P. Carmoli Baker in Saund. Ref. Bot. t. 46.-Bulb globose, 2-3 in. diam., with brown tuuics and a short neck. Iseaves 1-2, as long as the peduncle; blade oblong-lanceolate, acute, bright green, a foot long, $3 \mathrm{in}$. broad at the midale; petiole much shorter than the blade. Peduncle terete, pale glaucous-green, $2 \mathrm{ft}$. long. Flowers 8-10 in an umbel; pedicels an inch long; spathe-valves lanceolate. Perianth-limb 2 in. long; tube bright red, cylindrical, three times as long as the oblong-lanceolate connivent segments, which are green with a pale edge. Stamens exserted, inserted below the throat of the perianth-tube. Style not reaching the tip of the stamens.

Hab. Costa Rica, Carmiol! Described from a plant flowered by Mr. Wilson Saunders in 1867.

\section{Urceolina Rieich.}

Yerianth-tube cylindrical, suddenly dilated; segments equal, oblong or ovate, spreading only at the tip. Stamens inserted at or below the throat of the tube; filaments filiform, indistinctly appendiculate at the base; anthers oblong, versatile. Uiury deeply 3-lobed, 3-celled; ovules many, superposed; style filiform; stigma capitate. C'apsule deeply lobed, loculicidally 3-valved. Seeds many, small. - Roststock a tunicated bulb. Leaves thin, petioled, oblong or lanceolate. Flowers yellow or red, many in an umbel, pendulous.

Flowers yellow, tipped with green; segments long . Flowers bright red, not tipped with green; segments short .

1. U. pendula Herb. Amaryll. 193; Bot. Mag. t. 5464. U. aurea Lindl. Crinum urceolatum Ruiz et Pavon, Fl. Peru, iii. 58, t. 287 в. Collania urceoluta Schult. - Bulb globose, $1 \frac{1}{2}$ in. diam. Leaves $1-2$ to a stem, produced after the flowers; blade thin, oblong, acute, a foot or more long, 4-5 in. broad; petiole much shorter. Peduncle terete, a foot long. Flowers pendulous, bright yellow, tipped with green, 4-6 in an umbel; pedicels slender, 1-2 in. long; outer spathe-valves large, lanceolate. Perianth-tube an inch long, dilated suddenly in the upper third; segments oblong- 
lanceolate, $1 \frac{1}{2}$ in. long, spreading only at the tip. Stamens as long as the perianth-limb. Style shortly exserted.

Var. U. FULVA Herb. Amaryll. 55. - Leaves shorter, more rounded at the base. Flowers much smaller (limb an inch long).

Hab. Andes of Peru. Described from a plant that flowered at Kew, Nov., 1877, and 1887. Var. fulva, Matthews 868 !

2. U. Latifolia Benth. Gen. Plant. iii. 732. Pancratium latifolium Ruiz et Pavon, Fl. Peruv. iii. 54, t. 384. Leperiza latifolia Herb. ; Bot. Mag. t. 4952. Chrysiphiala latifolia Lindl. - Bulb ovoid, 2 in. diam., with brown tunics and a short neck. Leaves 2-4 to a stem; blade oblong, a span long, 4-5 in. broar; petiole much shorter. Peduncle stont, terete, a foot long. Flowers 6-8 iu an umbel, pendulous, bright yellow, tipped with green; pedicels slender, 1-2 in. long; spathe-valves lanceolate. Perianth-tube under an inch long, dilated suddenly into a funnel in the upper third; segments oblong-lanceolate, an iuch long, spreading only at the tip. Stamens slightly exserted. Style overtopping the anthers.

Hab. Andes of Peru. Described from a plant that flowered in Sept. 1856, at Kew, from bulbs sent by Mr. Naclean, of Lima,

3. U. miniata Benth. Gen. Plant. iii. 732. Pentlandia miniata Herb. in Bot. Reg. 1839, t. 68. Spharotele coccinea Link, Otto \&

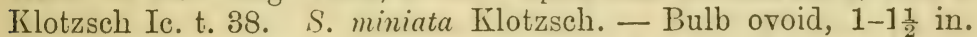
diam.; tunics brown. Leaves produced after the flowers, shortly petioled, a foot long, 1-1 $\frac{1}{2} \mathrm{in}$. broad at the middle, narrowed gradually to the base and apex. Peduncle slender, 1-1 $\frac{1}{2} \mathrm{ft}$. long. Flowers 2-6 in an umbel, pendulous, bright scarlet, not tipped with green; pedicels 1-1 $\frac{1}{2}$ in. long; spathe-valves 2, lanceolate. Perianth-limb $1 \frac{1}{2} \mathrm{in}$. long; tube cylindrical in the lower half, urceolate in the upper half; segments oblong, spreading only at the tip. Stamens inserted below the throat of the tube; anthers sometimes exserted. Style very slender, much exserted.

Hab. Andes of Peru and Bolivia, ascending to $10,000 \mathrm{ft}$., Natthews! Maclean! Pearce! Roezl! Described from a plant that flowered at Kew, Feb., 1877. Also received alive from Mrr. Elwes, Colonel Trevor Clarke, Dr. Wallace, Messrs. Veitch, \&c. Very like Stenomesson croceum in the perianth; differs in stamens and leaf.

\section{Eucharis Plunchon.}

Perianth-tube cylindrical, with a dilated throat, more or less curved; segments oblong, equal, spreading. Stamens inserted at the throat of the perianth-tube, shorter than the segments; filaments variously appendiculate downwards; anthers versatile. Orary globose, 3-celled; ovules many, rarely 2, superposed; style filiform; stigma capitate, 3-lobed. Fruit deeply 3-lobed, finally dehiscent. Seeds large, bulbiform, sometimes solitary. - Rootstuck a tunicated bulb. Leaves petioled, oblong, bright green. Flouters few in an umbel, large, pure white; outer spathe-valves 2 , ovatelanceolate; inner many, linear. 
Quadrate appendage of filaments distinctly protruded from the perianth-tube.

Ovules many in a cell . . . . . . . Sp.1-2. Ovules 2 in a cell . . . . . . . Sp. 3.

Appendage of filaments almost entirely adnate to the perianth-tube. Perianth-segments large, spreading . . . Sp. 4. Perianth-segments small, ascending . . . Sp.5.

1. E. Grandiflora Planch. in Flore des Serres, t. 957 ; Bot. Mag. t. 4971. E. amazmica Hort. Linden; Flore des Serres, t. 1216-1217. - Bulb globose, 2 in. diam. Leaves 2-4 to a stem; petiole about a foot long, semicircular on the back; blade oblong, bright green, a foot or more long, 5-6 in. broad. Pedmcle terete, $1 \frac{1}{2}-2 \mathrm{ft}$. long. Flowers $4-6$ in an umbel; peticels $\frac{1}{2}-1$ in. long; outer spathe-valves ovate-lanceolite; ovules about 20 in a cell. Perianth tube chirved, cylindrical, $2 \mathrm{in}$. long, dilated in the upper third to a throat $\frac{1}{2}$ in. diam. ; segments oblong, obtuse, spreading, $1 \frac{1}{2}-2$ in, long in the cultivated plant. Staminal cup of six quadrate connate segments $\frac{1}{3}$ in. long, with a short filament lanceolate at the base from the centre of each. Style overtopping the anthers.

Hab. Andes of New Granada, Lobb! Jameson! Lehmann! André! Introduced into cultivation in 1854 by M. Triana through M. Linden. The imperfectly-described Hymenocallis Bonplandii Kunth, Enum. v. fici(i, gathered by Bonpland on the banks of the Rio Magdalena, is probably a Euchuris.

2. E. Mastersir Baker in Bot. Mag. t. 6831. - Bulb globose, $1 \frac{1}{2}-2$ in. diam. Leaf-blade oblong, bright green, rounded at the base, 8-9 in. long, 4-5 in. broad; petiole shorter than the blade. Peduncle terete, a foot long. Flowers 2 in an umbel, nearly sessile ; outer spathe-valves lanceolate. Ovules many in a cell. Periunthtube slightly curved, $2 \mathrm{in}$. long, dilated in the upper third to a throat $\frac{1}{2}$ in. diam. ; segments ovate, spreading, above an inch long. Corrona adnate to the tube, except a narrow free border, the connate edge distinctly toothed between the filaments; stipes yellowish green. Style reaching to the tip of the perianth-segments; stigma distinctly 3-lobed. Expanded limb $2 \frac{1}{2}-3 \mathrm{in}$. diam.

Hab. Andes of New Granada. Described from specimens sent by Messrs. Sander \& Co., of St. Albans, in Feb. 1885.

3. E. Candida Planch. in Flore des Serres t. 788.-Bulb globose, stoloniferous, $2 \mathrm{in}$. diam. Leaf-blade bright green, oblong, 9-15 in. long, 4-5 in. broad at the middle, narrowed gradually to the base and acute apex; petiole nearly or quite as long as the blade, rounded on the back. Peduncle subcompressed, glaucous, above a foot long. Flowers $6-10$ in a centripetal umbel; pedicels $\frac{1}{2}-\frac{3}{4}$ in. long; outer spathe-valves lanceolate. Ovary globose, deeply lobed; ovules 2 in a cell. Periantli-tube curved, $1 \frac{1}{2}-2$ in. long, dilated in. the upper third to a throat $\frac{1}{2} \mathrm{in}$. diam, ; segments oblong, 1-1 $\frac{1}{2} \mathrm{in}$. long. Filaments with quadrate appendages $\frac{1}{3}-\frac{1}{2} \mathrm{in}$. long, united at the base only; free part of the filament lanceolate, $\frac{1}{4} \mathrm{in}$. long. Style not reaching to the tip of the segments; stigma small, entire.

Hab. Andes of New Granada, Schlim! Goudot! Described from a plant flowered at Kew in March, 1877, presented by Mr. Wm. Bull. 
4. E. Sanderi Baker in Bot. Mag. t. 6676.-Bulb ovoid, $1 \frac{1}{2}-2$ in. diam.; outer tunics brown. Leaf-blade bright green, oblong, 10-12 in. long, 5-6 in. broad, cordate at the base; petiole half as long as the blade. Peduncle terete, a foot long. Flowers 2-3 in an umbel, nearly sessile; outer spathe-valves lanceolate. Ovules about 20 in a cell. Perianth-tube curved, 2 in. long, dilated in the upper third to a throat $\frac{1}{2}$ in. diam. ; segments ovate, pure white, above an inci long. Corona with a very narrow free collar-like edge; stripes primrose-yellow; free filaments $\frac{1}{3}$ in. long. Style reaching to the tip of the perianth-segments; stigma distinctly 3-lobed.

Var. multiflora Baker in Bot. Mag. t. 6831.-Flowers smaller, 4-6 in an umbel, striped with green.

Hab. New Granada, on the banks of the Rio Dagua and Rio Telembi, Lelunam 2736 ! First described from a living plant sent by MLessrs. Sander \& Co. in March, 1882.

5. E. subedentata Benth. in Gen. Plant. iii. 731. Calliphruriu subedentata Baker in Bot. Mag. t. 6289 ; N. E. Brown in Ill. Hort. n.s. t. 415 . - Bulb ovoid, $1 \frac{1}{2}$ in. diam.; tunies brown, membranous. Leaves about 4 to a bulb, contemporary with the flowers; blade oblong, acute, bright green, deltoid at the base, 6-8 in. long, 3-4 in. broad; petiole as long as the blade, channelled down the face. Peduncle slender, a foot long. Flowers $6-8$ in an umbel; pedicels $\frac{1}{2}-1$ in. long; spathe-valves lanceslate. Ovary globose; ovules 6-8 in a cell. Perianth-tube an inch long, funnel-shaped in the upper half; segments oblong, ascending, $\frac{1}{2} \mathrm{in}$. long. Stamens half as long as the segments; filaments lanceolate, occasionally toothed at the base; anthers linear-oblong. Style as long as the segments. Stigma 3-lobed.

Hab. Andes of New Granada, Lehmann 3374! First described from a plant sent by M. H. Beaufoy, Esq., in Dec. 1876. Since received from Messrs. T. Moore, Veitch, Bull, Linden, \&c.

\section{Plagiolirion Baker.}

l'erianth-tube short, cylindrical; limb oblique, the two lower segments spreading horizontally; segments oblanceolate, equal, twice as long as the tube. Stamens inserted at the throat of the perianth-tube, shorter than the segments; filaments united at the base in a cup, with a tooth between ench of them; anthers oblong, versatile. Oeary globose, 3 -celled; orules $2-3$ in a cell, superposed; style filiform; stigma capitate. ('upsule globose, finally delisiscing. fieeds not more than one in a cell, globose.-Allied to Fincharis and C'alliphuria.

1. P. Honsmann Baker in Gard. Chron. 1883, ii. 38. - Bulb globose, $1 \frac{1}{2}$ in. diam., with a short neck and brown membranous tmics. Leares developed after the flowers; blade thin, oblong, acute, 8-9 in. long, 3-4 in. broad; petiole shorter than the blade. Peduncle 4-6 in. long. Flowers 8-10 in an mubel; pedicels $\frac{1}{2}-\frac{3}{4}$ in. long; outer spathe-valves lanceolate. Perianth-tube green, $\frac{1}{4}$ in. long: segments white, laxly 5-nerved in the central half. Stamens 
half as long as the segments; filaments narrowly winged up to the tip.

Hab. Andes of New Granada. Described from living plants flowered by Mr. F. Horsman, of Colchester, in July, 1883, and Mr. Wm. Bull in May, 1884.

\section{Calimiphruria Herb.}

Perianth-tube funnel-shaped, dilated gradually from the base to the throat; segments equal, oblong, spreading, as long as the tube. Stamens inserted at the throat of the perianth-tube; filaments short, petaloid, with a large lanceolate tooth on each side of the linear-oblong versatile anther. Ovary globose, 3-celled; ovules 2-3 in a cell; style long, filiform, distinctly tricuspidate at the apex. Capsule finally dehiscing. Seeds globose, not more than one in a cell. - Rootstock a tunicated bulb. Leuves oblong, petioled. Flowers white, many in an umbel. Nearly allied to Eucharis.

1. C. Hartwegiana Herb. in Bot. Reg. 1844, Misc. No. 87; Baker in Bot. Mag. t. 6259. - Bulb ovoid, an inch in diam., copiously stoloniferous; tunics brown, membranous. Leaves bright green, firmer in texture and more closely veined than in Fuchuris; blade oblong, acnte, 4-5 in. long, 2 in. broad, cuneate at the base ; petiole shorter than the blade. Peduncle slender, a foot long. Flowers 6-8 in an umbel; pedicels short; outer spathe-valves lanceolate. Perianth an inch long; tube funnel-shaped from the base; throat $\frac{1}{4}$ in. diam. Anthers $\frac{1}{4}$ in. long. Style finally protruded beyond the tip of the segments.

Hab. Andes of Bogota. First gathered by Hartweg in 1842. Described from living plants flowered by Mr. Wm. Bull in July, 1874, and at Kew in November, 1877.

2. C. tenera Baker. - Bulb globose, $\frac{3}{4}$ in. diam. Leaves not seen. Peduncle very slender, $\frac{1}{2} \mathrm{ft}$. long. Flowers $6-8$ in an umbel; pedicels very slender, longer than in C. Hurtwegiana. Perianth $\frac{3}{4}$ in. long; tube subcylindrical in the lower half; segments $\frac{1}{13}$ in. broad, as long as the tube, very thin in texture. Anthers $\frac{1}{8}$ in. long. Capsule $\frac{1}{6}$ in. diam., depresso-globose.

Hab. Andes of New Granada, Goudot!

\section{Eustephia Cav.}

Perianth regular, subcylindrical; tube short, campanulate; segments equal, ascending, oblanceolate, obtuse. Stamens inserted at the throat of the perianth-tube, as long as the segments; filaments free, petaloid in the lower half, toothed on each side at its apex; anthers linear-oblong, versatile. Orary 3-celled; ovules many, superposed; style exserted; stigma capitate. Fruit and seeds unknown.

1. E. coccinea Cav. Ic. iii. 20, t. 238. E. Macleanica Herb. Phadranassu (Odontopus) rubro-viridis Baker. - Bulb ovoid, 1 in. diam., with a cylindrical neck. Leaves $3-4$, developed after the flowers, linear, bright green, a foot or more long. Pecluncle slender, 
ancipitous, a foot long. Flowers 6-8 in an umbel, horizontal or drooping; pedicels $\frac{3}{4}-1$ in. long; outer spathe-valves lanceolate. Perianth $1 \frac{1}{4}-1 \frac{1}{2}$ in. long above the ovary; segments bright red, tipped with green.

Hab. Andes of Peru, Maclean! Received alive from Col. Trevor Clarke, Sir C. W. Strickland, and Messrs. Green and Henderson. Flowers in spring.

\section{Stenomesson Herb.}

Perianth-tube long, fumnel-shaped; segments short, equal, oblong, ascending. Stamens inserted at the throat of the perianthtube ; filaments united towards the base in a distinct cup, which is often toothed between them; anthers oblong, versatile. Ocary 3-celled; ovules many, superposed; style erect, filiform; stigma capitate. Capsule loculicidally 3-valved. Seeds small, crowded, black.-Rootstock a tunicated bulb. Leaies linear, lorate or lanceolate. Flowers few or many in an umbel, generally red or yellow, tipped with green.

Stenomesson proper. Filaments inserted at the edge of the staminal cup. Habit less robust; flowers smaller. Flowers plain yellow . . . . Sp. 1-4. Flowers variegated yellow and red . Sp. 5-6. Flowers plain red . . . . Sp.7-8.

Coburata. Filaments inserted at the edge of the staminal cup. Habit more robust; flowers larger, yellow or red, tipped green . . . . . . Sp. 9-10.

Callithauma. Filaments inserted below the edge of the staminal cup. Flowers green Sp. 11.

1. S. aurantiacun Herb. App. 40. Pancratium aurantiacum H. B. K. Chrysiphiala aurantiaca Roem. et Schultes. S. Hartwegii Lindl. in Bot. Reg. 1844, t. 42. S. eustephioides Herb. - Bulb globose, 1 in. diam., with brown tunics and a short neck. Leaves linear, usually produced after the flowers. Peduncle slender,

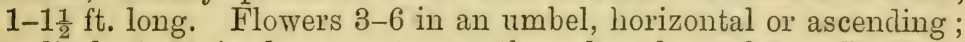
pedicels 1-1 $\frac{1}{2}$ in. long; outer spathe-valves lanceolate. Perianth bright orange, $1 \frac{1}{4}-1 \frac{1}{2}$ in. long; tube funnel-shaped in the upper half; segments oblong-cuspidate, half as long as the tube. Stamens nearly as long as the segments; filaments dilated, united in a cup in the lower half, without any tooth between. Style protruded beyond the tip of the segments.

Hab. Andes of Ecuador, ascending to 13,000 ft., Jameson! Hall! Hartweg! André! Received alive lately from Míessr's. E. G. Henderson and Anderson Henry. Flowers in summer.

2. S. Pearcei Balier in Saund. Ref. Bot. t. 308. - Bulb ovoid, 2 in. diam., with brown tunies and a long neck. Leaves produced after the flowers, lanceolate, bright green, above a foot long, above an inch broad at the middle. Peduncle 2-3 ft. long, subglaucous, slightly compressed. Flowers 6-8 in an umbel; pedicels slender, 2-4 in. long; outer spathe-valves oblong-lanceolate, $1 \frac{1}{2}-2 \mathrm{in.} \mathrm{long.}$ 
Perianth-limb $1 \frac{1}{4}-1 \frac{1}{2}$ in. long; tube tinged with green, funnelshaped in the upper half; segments oblong, pale yellow, $\frac{1}{2}$ in. long. Stamens as long as the segments; filaments united in the lower half in a cup, with a bifid tooth between each of them. Style reaching to the tip of the segments.

Hab. Andes of Peru, Lechler 2138! Andes of Bolivia, alt. 10,000 ft., MIandon 1198! Described from a living plant flowered by Messrs. Veitch in 1871, the bulbs of which were sent home by their collector, Pearce.

3. S. croceum Herb. Amaryll. 199. Pancratium croceum Savigny; Red. Lil. t. 187. S. Ruizianum Kunth. Pancratium flavum Ruiz et Pavon, Fl. Peruv. iii. 54, t. 284 a. - Bulb globose, 1 in. diam. Leaves linear, a foot long, $\frac{1}{4}$ in. broad. Peduncle slender, a foot long. Flowers $4-6$ in an umbel ; pedicels $\frac{1}{2}-1 \frac{1}{4}$ in. long; spathevalves lanceolate. Perianth-limb $1 \frac{1}{2}-2$ in. long; tube slender in the lower half, cylindrical in the upper, suddenly dilated at the middle, pale yellow; segments oblong, $\frac{1}{2}$ in. long. Stamens as long as or a little longer than the segments; cup not distinctly toothed at the edge between the filaments.

Hab. Andes of Peru, Pavon! Dombey! Described from specimens in the Smithian Herbarium and at the British Museum, and a living plant that flowered at Kew in May, 1877.

4. S. flavum Herb. in Bot. Mag. t. 2641. Chrysiphiala flava Gawl. in Bot. Reg. t. 978.-Bulb subglobose, 1 in. diam. Leaves oblanceolate, a foot long, an inch broad, obscurely petioled. Peduncle slender, a foot long. Flowers $4-6$ in an umbel; pedicels slender, an inch long; spathe-valves lanceolate. Perianth-limb bright yellow, $1 \frac{1}{2}-2$ in. long; tube dilated at the middle, cylindrical in the upper half; segments oblong, $\frac{1}{2}$ in. long. Stamens just exserted; staminal cup not distinctly toothed between the filaments. Style overtopping the anthers.

Var. S. Latifoliun Herb. in Bot. Mag. t. 3803. S. vitellinum Lindl. in Bot. Reg. 1843, t. 2. - Edge of the staminal cup with an entire tooth between each filament.

Var. S. curvidentatun Herb. in Bot. Mag. t. 2640. S. panciflorum Herb. Chrysiphiala panciflora Lindl.; Hook. Exot. Flora, t. 132. - Edge of the staminal cup with a bifid tooth between each of the filaments.

Hab. Andes of Peru. Introduced into cultivation by Cowan in 1824. Very likely more than one species is here included, but I have not seen any of the forms alive.

5. S. нuмme Baker in Saund. Ref. Bot. sub t. 308. Coburgia humilis Herb. in Bot. Reg. 1842, t. 46. Clitanthes humilis Herb.Bulb ovoid, under $1 \mathrm{in}$. diam., with brown tunies and a short neck. Leaves linear, bright green, a foot long, developed after the flower. Peduncle very short, bearing one erect flower, with erect membranous spathe-valves, connate in the lower half. Perianth orangered, $2 \frac{1}{2} \mathrm{in}$. long; throat of the tube $\frac{1}{8} \mathrm{in}$. diam.; segments oblong, $\frac{1}{2}$ in. long. Stamens shorter than the segments, united in the ower half in a cup, which is not toothed at the edge. Style finally exserted.

Hab. Andes of Peru; Palcamayo, alt. 10,000 ft., Maclean! Cuzco, $12,000 \mathrm{ft}$., Pearce! Perhaps only a high mountain form of S. recurvatum. 
6. S. Recurvatum Baker in Saund. Ref. Bot. sub t. 308. Pancratium recurvatum Ruiz et Pavon, Fl. Peruv. t. 285a. Coburgia recurvata Herb. Carpodotes recurvatus Herb. Chrysophiala recurvata Lindl.-Bulb ovoid, 1-11 in. diam. Leaves 3-6, linear, a foot long, $\frac{1}{4}-\frac{1}{3}$ in. broad, contemporary with the flowers. Peduncle slender,

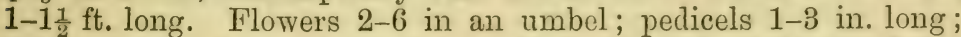

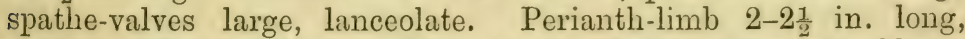
reddish yellow; tube $\frac{1}{6}$ in. diam. at the throat; segments oblong, $\frac{1}{2}-\frac{5}{8}$ in. long. Stamens shorter than the segments; filaments united in a cup obscurely toothed between them. Style finally exserted $\frac{1}{4}$ in. beyond the tip of the segments.

Hab. Andes of Peru, Bolivia, and Northern Chili, Pavon! (British MIuseum) IIaclean! Of Herbert's species I cannot distinguish from this Coburgia discolor, obragillensis, angusta, lutea, and Mracleanica. It was first noticed by Feuillé, under the name of Lilionarcissus bicolor.

7. S. coccineun Herb. App. 40 ; Baker in Ref. Bot. t. 309. S. rubrum Herb. Pancratium coccineum Ruiz et Pavon, Fl. Peruv. t. 285 b. Coburgia coccinea Herb. in Bot. Nag. t. 3865. C. wrecipitata and remusta Herb. - Bulb ovoid, $1 \frac{1}{2}$ in. diam. Leaves 4-5, linear, developed after the flowers, bright green, channelled down the face, a foot long, $\frac{1}{3}-\frac{1}{2}$ in. broad. Peduncle slender, terete, subglaucous, $1-1 \frac{1}{2} \mathrm{ft}$. long. Flowers $4-8$ in an umbel; pedicels $1-1 \frac{1}{2}$ in. long; spathe-valves lanceolate. Perianth-limb bright red, $1 \frac{1}{4}-1 \frac{1}{2}$ in. long; tube $\frac{1}{6} \mathrm{in}$. diam. at the throat; segments oblong, half as long as the tube. Stamens as long as the segments; filaments united in the lower half in a cup with a distinct tooth between each of them. Style finally protruded $\frac{1}{4}-\frac{1}{3}$ in. beyond the tip of the segments.

Var. S. BReviflonum Herb. - Perianth paler red, 1-1 $\frac{1}{4}$ in. long. Leaf lanceolate, indistinctly petioled.

Hab. Andes of Peru, ascending to 10,000 ft., Pavon! Hathews! Pearce! Var. breviflorum; Maclean!

8. S. suspensun Baker in Saund. Ref. Bot. t. 22.-Bulb ovoid, 1-1 $\frac{1}{2}$ in. diam., with brown tunics and a short neck. Leaves 2-3, produced after the flowers, linear or lanceolate, a foot long. Peduncle slender, a foot long. Flowers $4-6$ in an umbel, drooping;

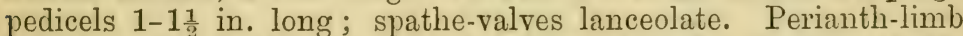

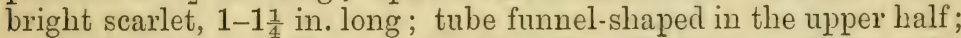
segments oblong, half as long as the tube. Stamens as long as the segments; filaments united in a cup in the lower half; free portion lanceolate at the base, without any tooth between; anthers small, oblong. Style finally exserted beyond the segments.

Hab. Andes of Peru. Described from a plant flowered in 1868 by $\mathrm{Mr}$. Wilson Saunders, the bulbs of which were gathered by Fraser. Received also alive from Messrs. Veitch and Henderson.

9. S. incarnatum Baker in Saund. Ref. Bot. sub. t. 308. Pancratium incarnatum H. B. K. P. quitense Willd. Coburgia incarnata Sweet, Brit. Nlow. Gard. ser. 2, t. 17.-Bulb globose, 2-3 in. diam., with brown tunics and a long neck. Leaves 4-6, contemporary with the flowers, lorate, slightly glaucous, $1-1 \frac{1}{2} \mathrm{ft}$. long, about an inch broad. Peduncle stout, slightly 2 -edged, hollow, $1 \frac{1}{2}-2 \mathrm{ft}$. long, 
Flowers $2-4$ in an umbel; pedicels short; spathe-valves oblong, greenish, $2-3$ in. long. Perianth-tube curved, $2 \frac{1}{2}-3$ in. long, pale or bright red, $\frac{1}{4}$ in. diam. at the throat; segments oblong, cuspidate, $\frac{3}{4}-1$ in. long, conspicuously keeled with green towards the tip. Stamens as long as the segments; filaments united towards the base, with a bifid process between each of them. Style sometimes, but not always, exserted beyond the tip of the segments.

Var. S. Acutum Baker, l.c. Coburgia acuta Herb. - Perianthtube not more than $\frac{1}{6}$ in. diam. at the throat; segments oblonglanceolate.

Hab. Andes of Ecuador, Peru, and Bolivia, alt. $8000-10,000 \mathrm{ft}$. Not infrequent in cultivation. Of the species described by Herbert and Kunth, I look upon C. splendens (Ill. Hort. n. s. t. 285), C. trichroma (Bot. Mag. t. 3807), C. variegata (Pancratium variegatum Ruiz et Pav.), C. chacapoyensis, C. versicolor, C. fulva (Bot. Mag. i. 3221), C. lata, and C. langensis, as mere forms, differing in the size and colouring of the flower.

10. S. Luteoviride Baker in Bot. Mag. t. 6508.-Bulb globose, 3 in. diam., with brown tunics and a cylindrical neck half a foot long. Leaves 3-4 to a bulb, contemporary with the flower's, lorate, bright green, a foot long, 1-1 $\frac{1}{4}$ in. broad. Peduncle above a foot long, stout, ancipitous. Flowers $5-6$ in an umbel; pedicels not more than an inch long; spathe-valves oblong-lanceolate, greenish, 2-3 in. long. Perianth-tube curved, primrose-yellow, 2-2 $\frac{1}{2}$ in. long, $\frac{1}{3}$ in. diam. at the throat; segments oblong-cuspidate, yellow, with a green tip an inch long. Stamens as long as the segments; filaments united in the lower half, with a simple or obscurelytoothed deltoid process between each of them. Style exserted beyond the tip of the segments.

Hab. Andes of Ecuador. Described from a plant that flowered at Kew in the spring of 1879, and another in May, 1887.

11. S. viridiflorum Benth. Gen. Plant. iii. 733. Pancratirm viridiflornm Ruiz et Pav. Callithauma viridiflorum Herb.; Bot. Mag. t. 3866 a. Chrysiphiala viridiflora Schultes.-Bulb ovoid, $1 \frac{1}{2}-2$ in. diam., with brown tunics and a long cylindrical neck. Leaves linear, bright green, $\frac{3}{4}-1 \mathrm{in}$. broad. Peduncle ancipitous, $1 \frac{1}{2}-2 \mathrm{ft}$. long. Flowers about 4 in an umbel; pedicels short; spathe-valves lanceolate, deciduous. Perianth entirely green; tube curved, 2 in. long, $\frac{1}{6}-\frac{1}{4}$ in. diam. at the throat; segments oblong, acute, $\frac{3}{4} \mathrm{in}$. long. Stamens as long as the perianth-segments; filaments inserted below the crenate edge of the cup, rather inflexed. Style not exserted beyond the tip of the segments.

Var. C. angustifoliun Herb. in Bot. Mag. t. 3866 b. - Leaves narrower. Stamens shorter than the perianth-segments. Style exserted.

Var. Elwesrr Baker in Gard. Chron. 1878, 756.-Staminal cup deeply 6-cleft, its lobes quadrate and emarginate.

Hab. Andes of Peru. The type and first variety were introduced into cultivation by Maclean in 1840, and flower in summer. The second variety I had from Mr. Elwes in 1876 and 1878. I know nothing of Herbert's Callithauma spathulatum, which is said to have oblong petioled thick coriaceous leaves, a peduncle $3 \mathrm{ft}$. long, and large green flowers. 


\section{Hyurne Herb.}

Perianth-tube none; segments very long, linear, equal. Stamens attached to the base of the segments; filaments very long, united in a short cup at the base; anthers linear, versatile. Ovary clavate, 3-celled; ovules many, superposed; style filiform; stigma punctate. Immature finit turbinate. Seeds unlinown.- Habit of Hymenocallis, from which it differs by its numerous ovules and free perianthsegments.

1. H. Gardneriana Herb. in Bot. Mag. sub t. 3774. - Bulb ovoid, middle-sized. Leaves lorate, subacute, fleshy, glabrous, contemporary with the flowers in October, a foot long, an inch broad. Peduncle slender, above a foot long. Flowers $3-4$ in an umbel; spathe-valves 2 , ovate, membranous ; pedicels $\frac{3}{4}-1 \mathrm{in}$. long. Perianth-segments 5-6 in. long, $\frac{1}{6}$ in. broad. Filaments nearly as long as the segments, united in a funnel-shaped tube $\frac{1}{4}$ in. long; anthers $\frac{1}{2}$ in. long.

Hab. Brazil ; in dry woods at Ceara. Gathered by Gardner in Oct. 1838. "Bulb used as an emetico-purgative medicine in pectoral complaints."

\section{Pancratium Linn.}

Perianth-tube elongated, cylindrical, dilated into a funnel at the top; segments linear or lanceolate, equal, spreading. Stamens inserted at the throat of the perianth-tube; filaments united in a conspicuous cup with an entire or bifid process between each of them; free portion short; anthers linear, versatile. Uvary 3celled; ovules many in a cell, superposed; style long, filiform; stigma capitate. Capsule loculicidally 3-valved. Seeds black, angled by pressure.-Rootstock a tunicated bulb. Leaves sessile, linear or lorate. Peduncle solid. Flowers pure white, many or few in an umbel; pedicels generally short; outer spathe-valves 2, lanceolate.

Perianth-tube short. Staminal cup small

Perianth-tube short. Staminal cup large

Perianth-tube long. Staminal cup large

Sp. 1-3.

Sp. 4-7.

Sp. 8-12.

1. P. Illyricun Limn. Sp. Pl. 418 ; Red. Lil. t. 153; Bot. Mag. t. 718 (Miller, Ic. t. 197). P. stellare Salisb. Almyra Salisb. Halmyra stellaris Parlat. - Bulb very large. Leaves 5-6, contemporary with the flowers, lorate, glaucous, $1 \frac{1}{2}-2$ in. broad at the middle. Peduncle stout, compressed, a foot or more long. Flowers 6-12 in a centripetal umbel; outer spathe of one large ovate membranous valve; pedicels short, cernuous in fruit. Perianth-tube green, eylindrical, an inch long, dilated only at the very top; segments lanceolate, many-nerved, $1 \frac{1}{2}$ in. long, $\frac{1}{4}-\frac{1}{3}$ in. broad. Staminal cup obconic, $\frac{1}{4}-\frac{1}{3}$ in. long; teeth large, bifid ; free portion of filament $\frac{1}{2}-\frac{3}{4} \mathrm{in}$. long; anthers linear-oblong, $\frac{1}{6} \mathrm{in}$. long. Style reaching to the tip of the segments. Seeds not compressed; raphe white.

Hab. Corsica, Sardinia, Malta, and S. Italy. Flowers in summer. Figured by Besler, Seba, and Parkinson. 
2. P. triflorum Roxb. Fl. Ind. ii. 126. P. malabathricum Herb. Amaryll. 202. Catulli-pola Rheede Malabar. xi. t. 40. - Bulb globose, $1 \frac{1}{2}-2$ in. diam., without any neck. Leaves thin, lanceolate, acute, contemporary with the flowers, $8-12 \mathrm{in}$. long, $\frac{1}{2}-\frac{3}{4} \mathrm{in}$. broad at the middle. Peduncle slender, 6-9 in. long. Flowers 4-8 in an umbel; spathe-valve single, ovate, acute; pedicels very short. Perianth-tube $1 \frac{1}{2}-2$ in. long, dilated in the upper quarter to a throat $\frac{1}{3}$ in. diam.; segments linear, ascending, $\frac{3}{4}-1$ in. long. Staminal cup $\frac{1}{4}$ in. long, with bifid teeth between the short filaments; anthers $\frac{1}{6}$ in. long. Style reaching to the tip of the segments.

Hab. Peninsular India. There is a specimen in the Rottler Herbarium dried from the garden of the Moravian Missionaries in June, 1799. It is included in Hohenacker's 'Plants of Canara' as Crinum pauciflorum Miquel.

3. P. zeylanicum Linn. Sp. Pl. 417 ; Bot. Reg. t. 479 ; Bot. Mag. t. 2548. P. tiar aflorum Salisb. Parad. t. 86.-Bulb globose, $1 \frac{1}{2}-2$ in. diam., not produced into a distinct neck. Leaves 8-12, thin, lanceolate, glossy green, under a foot long, contemporary with the flowers. Peduncle slender, subterete, much shorter than the leaves. Flowers solitary; spathe solitary, lanceolate, tubular at the base; pedicel very short. Perianth-tube 2 in. long, broadly obconic in the upper third; segments lanceolate, as long as the tube. Staminal cup obconic, $\frac{1}{4}$ in. long, with large bifid teeth between the free tips of the filaments, which are $1-1 \frac{1}{4}$ in. long; anthers linear, $\frac{1}{4} \mathrm{in}$. long. Style not overtopping the anthers.

Hab. Tropical Asia. Figured by Rumphius and Commelinus at the beginning of the 17th century, and cultivated in Miller's time. We have it from gardens at Nossi-bé (Hildebrandt 3207!), and a copy of a figure made by Mr. F. W. Burbidge at Labuan.

4. P. Sickenbergir Aschers. et Schwein. in Berlin Gartenzeit. 1883, 345, with figure.-Bulb ovoid, $1 \frac{1}{2}$ in. diam., with a long neck. Leaves 3-6, linear, grey-green, a foot Jong, conspicuously spirally twisted, produced after the flowers. Peduncle much shorter than the leaves. Flowers 3-6 in an umbel; spathe-valves 2, lanceolate. Perianth-tube 1-1 $\frac{1}{2}$ in. long, obconic in the upper third; segments lanceolate, as long as the tube. Staminal cup obconic, under an inch long, with a bifid deltoid tooth between the very short free part of each filament; anthers linear-oblong. Style overtopping the stamens.

Hab. Desert region on the borders of Egypt and Arabia. Our specimens were gathered in the Sinaitic Peninsula in 1883 by Mr. H. C. Hart. It has the leaves of $P$. tortuosum and flower of $P$. maritimum.

5. P. collinum Coss. \& Durieu in Ann. Sc. Nat. ser. 4, i. 238. -Closely allied to P. maritimum, but smaller in all its parts, with a perianth-tube $1 \frac{1}{2}-2$ in., segments an inch, and a more obconic staminal cup $\frac{5}{8}-\frac{3}{4}$ in. long. Pedicels longer, finally $\frac{1}{2}-1$ in. long. Capsule and seeds smaller.

Hab. Algeria, Munby! Durando!

6. P. maritinum Linn. Sp. Pl. 418; Cav. Ic. t. 56 ; Red. Lil. t. 8 ; Bot. Reg. t. 161. - Bulb globose, 2-3 in. diam., with brown tunics and a short neck. Leaves 5-6, linear, glaucous, persistent, finally $2-2 \frac{1}{2} \mathrm{ft}$. long. Peduncle moderately short, compressed, 
1-1 $\frac{1}{2} \mathrm{ft}$. long. Flowers $5-10$ in an umbel; pedicels very short; outer spathe-valves 2 , large, ovate. Perianth-tube greenish, 2-3 in. long, funnel-shaped in the upper quarter; segments linear, ascending. $1 \frac{1}{2}$ in. long. Staminal cup obconie, an inch long, with deltoid teeth between the free tip of the filaments, which is only $\frac{1}{4}$ in. long; anthers linear-oblong. Style reaching to the tip of the segments. Capsule-valves about an inch long and broad.

Hab. Throughout the Mediterranean region from Spain to Syria. Flowers white, very fragrant. P. curolinianum Linn. (Catesby, Carol. iii. t. 5 ; Bot. Reg. t. 927), said to be wild in salt-marshes from Carolina to Florida, does not appear to differ specifically from the European plant. Dr. Sereno Watson doubts its oceurrence in the United States; but Catesby's figure is not a bad representation of this species, and cannot possibly be Hymenocallis rotata, as suggested by Herbert.

7. P. Canariense Ker in Bot. Reg. t. 174. Bollaa canariensis Parlat.-Bulb globose, 2 in. diam. Leaves 4-6, ensiform, glaucous, $1 \frac{1}{2}-2 \mathrm{ft}$. long, $1-1 \frac{1}{2}$ in. broad. Peduncle moderately stout, $1 \frac{1}{2}-2 \mathrm{ft}$. long. Flowers 6-10 in an umbel; pedicels elongated; spathe of 2 oblong-lanceolate valves. Perianth-tube 1-1 $\frac{1}{2}$ in. long, obconic in the upper third; segments lanceolate, an inch long. Staminal cup much shorter than the segments, with bifid teeth between the short free tips of the filaments; anthers $\frac{1}{6}$ in. long. Style reaching to the tip of the segments. Seeds small, turgid.

\section{Hab. Canary Islands. Flowers in October.}

8. P. parven Dalz. in Hook. Journ. ii. 144.-Bulb globose, with a cylindrical neck. Leaves thin, linear or lanceolate, under a foot long, contemporary with the flowers. Peduncle very slender, compressed, $\frac{1}{2}-1 \mathrm{ft}$. long. Flowers $2-4$ in an umbel; pedicels $\frac{1}{2}-\frac{3}{4} \mathrm{in}$. long; spathe-valve 1, sometimes deeply bifid. Perianth-tube 3-4 in. long, obconic in the upper quarter; segments linear, an inch long. Staminal cup fumnel-shaped, half as long as the segments, with a bifid tooth between each of the short free tips of the filaments; anthers linear. Style overtopping the anthers. Seeds few in a cell.

Var. malabaricun Baker. - Leaves linear. Perianth-tube not more than 2 in. Staminal cup smaller.

Hab. Hills of Western Peninsular India, Stocks! Law! Ritchie!

9. P. verecundum Ait. Hort. Kew. i. 412 ; Bot. Reg. t. 413; Wight, Ic. 2023. P. biflorum Roxb. - Bulb globose, 2 in. diam., with a long cylindrical neck. Leaves 6-10, thin, ensiform, contemporary with the flowers, $1-1 \frac{1}{2} \mathrm{ft}$. long, $\frac{1}{2}-\frac{3}{4}$ in. broad. Peduncle moderately stout, compressed, a foot long. Flowers 2-6 in an umbel; spathe-valves 2, lanceolate-acuminate; pedicels short. Perianth-tube 3-4 in. long, obconic in the upper quarter; segments linear, $1 \frac{1}{2}$ in. long. Corona obconic, $\frac{3}{4}-1$ in. long, with a bifid tooth between the free tip of each filament, which is $\frac{1}{2}$ in. long; anthers linear, $\frac{1}{3}$ in. long. Style overtopping the stamens.

Hab. North India, from the Punjaub eastward to the Sikkim Terai. We have a drawing made by Dr. Aitchison in $18 i 8$ and a specimen sent by Messrs. Sander in 1883.

10. P. longiflorum Roxb. Fl. Ind. ii. 125. P. cambayense Herb. -Bulb globose, $1 \frac{1}{2}-2$ in. diam., with a cylindrical neck. Leaves 
thin, ensiform, a foot long, $\frac{1}{2}-1$ in. broad, contemporary with the flowers. Peduncle much shorter than the leaves, compressed. Flowers usually solitary, sessile; spathe-valve single, very acuminate. Perianth-tube greenish, 5-6 in. long, obconic in the upper neck; segments lanceolate, 2 in. long. Staminal cup above an inch long, with a bifid tooth between the free tip of each filament, which is $\frac{1}{2} \mathrm{in}$. long; anther linear. Style reaching to the tip of the segments.

Hab. Central and Peninsular India. Is in the Rottler Herbarium. The description of P. tristylum Rijk in Rev. Hort. 1880, 4t6, from gardens in Java, agrees with this, except that it is said to have three styles. All the Pancratia I have seen have a distinctly capitate stigma, at most faintly 3-lobed.

11. P. тоRтuosum Herb. in Ann. Nat. Hist. iv. 28. P. torti-

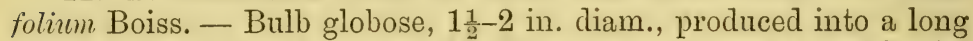
cylindrical neck. Leaves 6-12, linear, contemporary with the flowers, $\frac{1}{2}-1 \mathrm{ft}$. long, conspicuously spirally twisted. Peduncle very short, moderately stout. Flower's $2-4$ in an umbel ; spathevalve single, large, ovate; pedicels very short. Perianth-tube 5-6 in. long, obconic at the apex; segments linear, greenish, ascending, above $2 \mathrm{in}$. long. Staminal cup obconic, above an inch long, distinctly toothed between the short free tips of the filaments; anthers linear, $\frac{1}{4} \mathrm{in}$. long. Style overtopping the anthers. Capsulevalves oblong, an inch long.

Hab. Arabia and Egypt. Discovered by Fischer in 1837. Flowers in late autumn and winter.

12. P. trianthum Herb. in Amn. Nat. Hist. iv. 28. P. tenuifolium Hochst. P. Chapmanni Harvey.-Bulb globose, 1-2 in. diam., with brown tunics and a long cylindrical neck. Leaves $6-8$, narrow linear, a foot or more long, straight. Peduncle short, slender. Flowers 1-3 in an umbel; spathe lanceolate-acuminate, bifid at the tip. Perianth-tube white, $\frac{1}{2} \mathrm{ft}$. long, obconic in the upper inch; segments lanceolate, acute, ascending, 2 in. long. Staminal cup about an inch long, with bifid teeth between the free tips of the filaments, which are $\frac{1}{4}$ in. long; anthers linear, yellow. Style overtopping the anthers; stigma 3 -lobed.

Hab. Throughout Tropical Africa, from Nubia to Senegambia, Guinea, and Damara-land. Flowers in spring and summer. Not yet introduced into cultivation. It may be the imperfectly-described $P$. maximuin Forsk., from Arabia felix.

\section{Hymenocallis Salisb.}

Perianth hypocrateriform; tube cylindrical; segments equal, linear or lanceolate. Stamens united in a distinct cup; free portion of filament filiform; anthers linear, versatile. Ovary 3-celled; ovules 2 in each cell, in a bundle from the base of the axis; style long, filiform; stigma capitate, minute. Capsule large, bulb-like, finally dehiscent. Sceds usually solitary, large, with a thick green spongy testa.-Rootstock a tunicated bulb. Leaves sessile, lorate or petioled, oblong. Pelluncle solid, compressed. Flowers usually pure white, fragrant, many in an umbel. 
Subgenus Hyirenocaldis Proper. Staminal cup comparatively small free part of filaments long.

Leaves petioled. Perianth-tube long .

Leaves petioled. Perianth-tube short Sp.6-9.

Leaves sessile. Perianth-tube long . Sp. 10-16.

Leaves sessile. Perianth-tube short . Sp. 17-24.

Subgenus Ismene (Salisb.) Staminal cup large; free tip of filaments short, incurved.

Flowers white

Sp. 25-30.

Flowers yellow . . Sp. 31 .

1. H. tubiflora Salisb. in Trans. Hort. Soc. i. 341. $H$. guianensis Herb. H. petioluta Roem. Pancratium guianense Gawl. in Bot. Reg. t. 265. P. tubiflorum and petiolatum Schultes.-Bulb ovoid, 3-4 in. diam., with a short neck. Leaves with a thin oblong acute blade 8-12 in. long, 4-5 in. broad at the middle, narrowed gradually to a petiole $\frac{1}{2}-1 \mathrm{ft}$. long; midrib broad, distinct; veins lax. Peduncle compressed, a foot long. Flowers many in an umbel, sessile; spathe-valves membranous, deltoid-cuspidate, reflexing. Perianth with an erect slender tube 6-8 in. long; segments linear, about 4 in. long. Staminal cup a narrow fumnel, an inch long, not toothed between the free part of the filament, which is more than twice as long as the cup; anthers linear, $\frac{1}{2}-\frac{5}{8} \mathrm{in}$. long. Style overtopping the anthers. Ovules 4 or more in a cell, crowded at the base of the axis.

Hab. Guiana, Trinidad, and the Amazon Valley. Introduced into cultivation at Kew about 1803 from bulbs taken in a captured French vessel from Cayenne, and again by Lambert in 1818 .

2. H. undulata Herb. App. 44. H. Borskiana De Vriese, Descript. 10. H. Boschiana Kunth. Pancratium undulatum H.B.K. -Bulb ovoid, 3-4 in. diam. Leaves with a thin oblong acute blade a foot long, 5-6 in. broad, narrowed gradually to a long petiole; veins lax, connected by close oblique cross-bar's. Peduncle compressed, $2 \mathrm{ft}$. long. Flowers $9-10$ in an umbel, sessile; spathevalves 4-5, lanceolate. Perianth-tube 6-7 in. long; segments linear, 3-3 $\frac{1}{2}$ in. long. Staminal cup funnel-shaped, an inch long, toothed between the free part of the filaments, which is $1 \frac{1}{2} \mathrm{in}$. long, tinged with red; anthers linear, $\frac{1}{2}$ in. long. Style much overtopping the anthers.

Hab. Venezuela, Fendler 1501! First gathered by Humboldt. Introduced into the Botanic Garden of Leyden in 1845 by M. Borski.

3. H. Moritziana Kunth, Enum. v. 668. - Bulb as thick as a man's fist. Leaves with an oblong acute blade a foot long, narrowed gradually to a long petiole. Peduncle compressed, $1 \frac{1}{2}-2 \mathrm{ft}$. long. Flowers about 20 in a sessile umbel; outer spathevalves large, reflexed. Perianth-tube $4 \frac{1}{2}$ in. long; segments linear, nearly as long as the tube. Staminal cup finnel-shaped, under an inch long, toothed between the free tips of the filaments, which are $1 \frac{1}{4} \mathrm{in}$. long; anthers linear. Style reaching to the tip of the segments. Ovules 4 in a cell.

Hab. Caracas, Moritz. 
4. H. eucharidifolia Baker in Gard. Chron. 1884, i. 700.Bulb ovoid, 2-3 in. diam. Leaves 4, oblong, acute, shortly petioled, a foot long, 3-4 in. broad at the middle; midrib distinct; veins lax. Peduncle green, acutely angled, under a foot long. Flowers 4-5 in an umbel, subsessile; outer spathe-valves small, lanceolate. Perianth-tube slender, $4-4 \frac{1}{2}$ in. long; segments linear, $3-3 \frac{1}{2}$ in. long. Staminal cup narrowly funnel-shaped, $1 \frac{1}{4} \mathrm{in}$. long, with 1-2 minute cups between the free tips of the filaments, which are not longer than the cup; anthers linear, $\frac{1}{2}$ in. long. Style overtopping the anthers.

Hab. Tropical America. Described from a plant that flowered at Kew, May, 1884. Exact country not known.

5. H. Bistubata Herb. ; Lindl. in Bot. Reg. 1844, Misc. 53.Leaves with a green oblong acute blade, $21 \mathrm{in}$. long, $4 \mathrm{in}$. broad, narrowed to a short petiole. Peduncle compressed, $1 \frac{1}{2} \mathrm{ft}$. long. Flowers about 8 in an umbel, sessile. Perianth-tube above $5 \mathrm{in}$. long; limb recurved, $3 \frac{1}{2}$ in. long. Staminal cup funnel-shaped, rotate at the apex, 2 in. long, with bifid teeth between the free tips of the filaments, which are $\frac{3}{4}-1 \frac{1}{4} \mathrm{in}$. long. Style protruded 2 in. from the staminal cup.

Hab. Known only from Dean Herbert's description. It was received by him from Hartweg. Intermediate between the two subgenera, and perhaps a garden hybrid.

6. H. speciosa Salisb. in Trans. Hort. Soc. i. 340. Pancratium speciosum Salisb. in Trans. Linn. Soc. ii. 73, t. 12; Bot. Mag. t. 1453 ; Red. Lil. t. 412 ; Bury, Hexand. t. 47. - Bulb globose, 3-4 in. diam. Leaves 12-20 to a bulb, oblanceolate-oblong, acute, bright green, closely veined, $1 \frac{1}{2}-2 \mathrm{ft}$. long, narrowed very gradually to a short broad channelled petiole. Peduncle glaucous, compressed, $1 \frac{1}{2} \mathrm{ft}$. long. Flowers $10-15$ in a centripetal umbel; pedicels short; spathe-valves 5-6, lanceolate, green, 3-4 in. long. "Perianth-tube greenish, about 3 in. long; segments $1 \frac{1}{2}-2$ in., as long as the tube. Staminal tube funnel-shaped, $1 \frac{1}{4}-1 \frac{1}{2}$ in. long, $1 \frac{1}{4} \mathrm{in}$. diam. at the throat, toothed between the free tips of the filaments, which are a little longer than the cup; anthers linear, $\frac{1}{2}$ in. long. Style declinate, nearly as long as the segments. Ovules 2 in a cell.

Hab. West Indies. Described from a plant that flowered at Kew, Nov., 1877. Common in cultivation. We have at Kew the originals of the drawings of Salisbury's paper in vol. ii. of the 'Transactions of the Linnean Society,' purchased at Burchell's sale.

7. H. ovata Roem. Amaryll. 169. H. amcena Herb. (but not Pancratium amamum Salisb.). Pancratium ovatum Miller, Dict. No. 9 ; Ker in Bot. Reg. t. 43. P. fragrans Salisb. in Trans. Linn. Soc. ii. 72, t. 11. P. amcenum Ker in Bot. Mag. t. 1467. - Bulb 3-4 in. diam. Leaves with an oblong acute blade a foot or more long, 4-6 in. broad, narrowed gradually to a short broad petiole. Peduncle compressed, about as long as the leaves. Flowers 6-10 in a sessile umbel; spathe-valves ovate. Perianth-tube greenish, $2-2 \frac{1}{2}$ in. long, subterete; segments linear, but little longer than the tube. Staminal cup regularly funnel-shaped, an inch long, toothed or entire between the free tips of the filaments, which are $1 \frac{1}{2}$ in. 
long; anthers linear, $\frac{1}{2}$ in. long. Style much overtopping the anthers. Ovules 2 in a cell.

Hab. West Indies. Nearly allied to $H$. speciosa. It was figured by Ehret (tab. 98), and noticed by Linnæus as a var. of $P$. amboinense. Salisbury's $P$. amconum is a form of $H$. caribca. H. ornata Roem., judging from the description, differs from ovat $\iota$ by its flowers with pedicels $\frac{1}{2}-\frac{3}{4}$ in. long. H. ovalifolia Herb. (Lodd. Bot. Cab. t. 510) is apparently a small slender form of this species.

8. H. Skinneriana Herb. in Bot. Reg. 1843, Misc. No. 59.Bulb middle-sized. Leaves oblong, acute, petioled, a foot long, 5 in. broad. Flowers 6 in a sessile umbel; spathe-valves lanceolate, $1 \frac{1}{2}$ in. long. Perianth-tube $2 \frac{1}{2}$ in. long; segments a little longer than the tuive. Staminal cup narrowly funnel-shaped, toothed between the free tips of the filaments, which are scarcely longer than the cup; anthers linear. Style overtopping the anthers.

Hab. Guatemala, Skinner. Flowered by Dean Herbert at Spofforth in March, 1843.

9. H. glauca Roem. Amaryll. 173. Pancratium glaucum Zuce. Choretis glanca Knowles \& Weste. Floral Cab. ii. 101, with figure. H. Choretis Hemsley. - Bulb globose, middle-sized. Leaves with an oblong acute glaucous lamina $1 \frac{1}{2} \mathrm{ft}$. long, $3-4 \mathrm{in}$. broad, narrowed gradually to a short deeply channelled petiole. Peduncle a foot or more long. Flowers 2-3 in an umbel, subsessile; spathe-valves small, lanceolate. Perianth-tube greenish, 2-3 in. long; segments about as long as the tube. Staminal cup above an inch long, spreading at the throat, toothed between the free tips of the filaments, which are about as long as the cup; anthers linear, $\frac{1}{2}$ in. long. Style overtopping the anthers. Ovules 2 in a cell.

Hab. Mexico, in the Province of Oaxaca. Introduced into cultivation in 1838 , but I have never seen a specimen.

10. H. littoralis Salisb. in Trans. Hort. Soc. i. $338 . H$. adnata Herb. Pancratium littorale Jaeq. Hort. Vind. iii. 41, t. 750; Salisb. in Trans. Linn. Soc. ii. 74, t. 13. P. americanum Miller.Bulb 3-4 in. diam. Leaves 10-12, ensiform, acute, sessile, multifarious, suberect, bright green, $2-2 \frac{1}{2} \mathrm{ft}$. long, $1 \frac{1}{2} \mathrm{in}$. broad at the middle, narrowed to an inch at the base. Peduncle ancipitous, $1 \frac{1}{2}-2 \mathrm{ft}$. long. Flowers $4-8$ in a sessile umbel; outer spathe-valves deltoid, 2-3 in. long. Perianth-tube 6-7 in. long, tinged with green; segments linear, recurved, 4 in. long, adnate to the base of the staminal cup. Staminal cup broadly fumnel-shaped, about an inch long, $1 \frac{1}{2}$ in. diam. at the throat, toothed at the edge between the free tips of the filaments, which are $2 \mathrm{in.}$ long; anthers linear, $\frac{1}{2} \mathrm{in}$. long. Style reaching to the anthers. Ovules 4-6 in a cell.

Hab. Widely spread in Tropical America. It was cultivated by Dr. Richardson at Bierley in 1742. Very variable, the principal named forms being H. Dryandri Roem. (Bot. Mag. t. 825), with tube and segments both much shorter than in the type; $H$. disticha Herb., with leaves rather broader and more distinctly ribbed, and perianth-tube and segments both 4-5 in. long; $H$. acutifolic Herb. (Bot. Mag. 2621), with narrow leaves, and segments an inch longer than the tube, which is under 3 in. long; and H. Staplesiana Roem., with leaves an inch broad, a small staminal cup and perianth-segments an inch shorter than the tube, which is $3-4$ in. long. My description of the type is made mainly from Jacquin's specimen at the British Iruseum, and of $P$. Dryandri from a plant that flowered at Kew in April, 1878, received from the 
Duke of Northumberland's garden at Sion House, and Dryander's plant, dried from Dr. Pitcairn's garden in 1782. There is a good figure by Ehret (Trew. t. 27). I cannot separate $H$. panamensis Lindl. and $H$. insignis Kunth.

11. H. Pedalis Herb. App. 44. Pancratium pedale Lodd. Bot. Cab. t. 809; Lindl. in Bot. Reg. t. 1641.- Leaves lorate, arcuate, bright green, firm in texture, about $2 \mathrm{ft}$. long, 2 in. broad above the middle, narrowed to under an inch at the base. Peduncle about as long as the leaves. Flowers about a dozen in a sessile umbel, with broad spathe-valves. Perianth-tube very slender, 7 in. long; segments very narrow, 5 in. long. Staminal cup fumnel-shaped, about $1 \mathrm{in}$. long, not at all spreading at the throat; free tips of filaments above 2 in. long; anthers linear, $\frac{3}{4}$ in. long. Style reaching up to the anthers. Ovules 5-6 in a cell.

Hab. Introduced from Truxillo about 1820 by Mr. Harrison, of Aigburth. Described from a dried specimen of Dean Herbert's. Doubtfully distinct from H. littoralis.

12. H. tenuiflora Herb. App. 44. - Leaves thinner and more spreading than in $H$. littoralis, acute, $2-2 \frac{1}{2}$ in. broad at the middle, narrowed to an inch at the base. Flowers 10-12 in a sessile umbel. Perianth-tube very slender, 5-6 in. long; segments very narrow, $3-4$ in. long. Staminal cup funnel-shaped, $\frac{3}{4}-1 \mathrm{in.}$ long; free tips of stamens $1 \frac{1}{2}-2 \mathrm{in.}$ long; anthers linear, $\frac{1}{2}$ in. long. Style reaching to the anthers.

Hab. New Granada, Lieut. Holton 143! Deseribed from a plant that flowered at Kew in 1879. Probably a mere variety of $H$. littoralis. It was cultivated by Herbert in 1814. I cannot distinguish from this the Ceylonese plant (C. P. 2339) distributed by Dr. Thwaites as Pancratium malabathricum.

13. H. seneganidica Kunth and Bouché in Ind. Sem. Berol. 1848, 12. - Leaves subdistichous, lorate, acute, arcuate, $2 \mathrm{ft}$. long, $2 \mathrm{in.} \mathrm{broad} \mathrm{above} \mathrm{the} \mathrm{middle,} \mathrm{narrowed} \mathrm{to} \mathrm{an} \mathrm{inch} \mathrm{at} \mathrm{the} \mathrm{base.}$ Peduncle about as long as the leaves. Flowers $6-8$ in a sessile umbel; outer spathe-valves ovate. Perianth-tube slender, 5-6 in. long; segments very narrow, 4 in. long. Staminal cup funnelshaped, about an inch long, $1-1 \frac{1}{4} \mathrm{in}$. diam. at the throat; free tips of filaments $2 \mathrm{in.}$ long; anthers linear. Ovules 6-8 in a cell.

Hab. Sierra Leone, teste Kunth. Congo, on sandy shores betiveen Ambriz and Quizembo, Welwitsch 4029! Scarcely, if at all, distinguishable from $H$. temuiflora.

14. H. caymanensis Herb. Amaryll. 614. Pancratium patens Lindl., non Red. - Leaves thinner, more spreading and more oblanceolate than in $H$. littoralis, $2 \frac{1}{2}-3$ in. broad above the middle, narrowed to an inch at the base. Peduncle stout, above $2 \mathrm{ft}$. long. Flowers 6 or more in a sessile umbel. Perianth-tube 5-6 in. long; segments linear, about 4 in. long, $\frac{1}{4}$ in. broad. Staminal cup obconic, about an inch long; free filaments $2-2 \frac{1}{2} \mathrm{in}$. long; anthers linear, $\frac{1}{2}-\frac{3}{4}$ in. long. Style overtopping the anthers. Ovules 2 in a cell.

Hab. Florida, Curtiss 2830! Cuba, Wright 3245! Jamaica, March 1825! Island of Grand Cayman, Hort. Herbert! Doubtfully distinct specifically from - H. caribaa.

15. H. Harrisiana Herb. in Bot. Reg. 1846, Misc. No. 63 ; Baker in Bot. Mag. t. 6562. - Bulb globose, $1 \frac{1}{2}$ in. diam. Leaves 
3-5, oblanceolate, about a foot long, $2 \mathrm{in}$. broad above the middle; base very narrow. Peduncle slender, rather glaucous, under a foot long. Flowers 2-3 in a sessile umbel; spathe-valves lanceolate. Perianth-tube slender, 3-4 in. long; segments linear, $2 \frac{1}{2}-3$ in. long. Staminal cup funnel-shaped, $\frac{3}{1} \mathrm{in}$. long, very plicate, $\frac{1}{2}-\frac{3}{4} \mathrm{in}$. diam. at the throat, with a small tooth between the free tips of the filaments, which are $1 \frac{1}{2} \mathrm{in}$. long. Style reaching up to the anthers. Ovules 2 in a cell.

Hab. Mexico. Received alive lately from Col. Trevor Clarke and Messrs. Elwes, Bull, and Ware. Described from a plant that flowered at Kew, May, 1879.

16. H. Honsmann Baker. - Bnlb middle-sized. Leaves few,

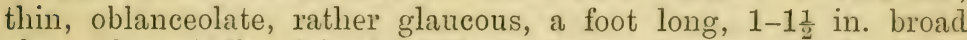
above the middle, deltoid at the apex, very narrow at the base. Peduncle 3-4 in. long. Flowers 1-3 in a sessile umbel; spathevalves small, lanceolate. Perianth-tube $4-5 \frac{1}{2} \mathrm{in}$. long: segments very narrow, $2 \frac{1}{2} \mathrm{in}$. long. Staminal cup rotate, under an inch long, $1 \frac{1}{2}$ in. diam. at the throat; free tips of filaments $1 \frac{1}{4} \mathrm{in}$. long; anthers linear, $\frac{1}{2}$ in. long. Style reaching up to the anthers. Ovules 2 in a cell.

Hab. Mexico. Described from living specimens sent by Mr. F. Horsman, of Colchester, in July, 1883. An allied plant in Gay's Herbarium, dried from the Jardin des Plantes in June, 1860, has an oblong-lanceolate leaf a foot long, 3 in. broad at the middle, and a short pedicel.

17. H. caribea Herb. App. 14. Pancratium caribaum Linn. (Commel. Hort. ii. t. 87); Gawl. in Bot. Mag. t. 826. P. declinatum Jacq. Hort. Vind. iii. 11, t. 10 ; Red. Lil. t. 414 ; Lodd. Bot. Cab. t. 558. P. amcenum Salisb. in Trans. Linn. Soc. ii. 71, t. 11.Bulb globose, 3-4 in. diam. Leaves a dozen or more, multifarious, lorate, acute, $2-3 \mathrm{ft}$. long, $2-3 \mathrm{in}$. broad above the middle, narrowed to an inch at the base, thinner and more spreading than in $H$. littoralis. Peduncle acutely angled, little shorter than the leaves. Flowers 6-12 in a sessile umbel; spathe-valves lanceolate-deltoid.

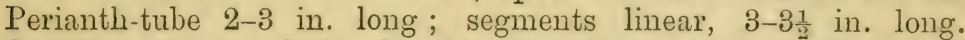
Staminal cup regularly obconic, an inch long, faintly 2 -toothed between the free tips of the filaments, which are $1 \frac{1}{2}-2 \mathrm{in.} \mathrm{long;}$ anthers linear, $\frac{1}{2}$ in. long. Style overtopping the anthers. Ovules 2 in a cell.

Hab. West Indies. Described mainly from a plant that flowered at Kew in June, 1872. Also received alive from Messrs. Veitch and Wilson Saunders. $P$. patens Red, is a form with a tube $3 \mathrm{in}$. and segments 4 in. long. P. lutifolium Miller probably belongs here. I cannot distinguish $H$. angusta Herb. (Pancratium angustum Ker in Bot. Reg. t. 221), except by its narrower leaves. $H$. obtusata Griseb., from Surinam, is said to differ from caribcea by its more obtuse leaves, tube and segments each $3 \mathrm{in}$. long, and sinuses of the staminal cup less produced.

18. H. crasstFolia Herb. App. 44 (misprinted crassiflor in Kunth). I'ancrutium crassifolium R. \& S. Syst. vii. 921 ; Baker in Saund. Ref. Bot. t. 331. P. coronarium and occilentale Leconte.-

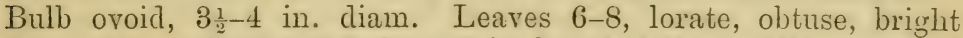
green, firm, suberect, $2 \mathrm{ft}$. long, 2 in. broad at the middle, narrowed to $\frac{3}{4}-1$ in. at thie base. Peduncle compressed, $2 \mathrm{ft}$. long. Flowers about 4 in a sessile umbel; outer spathe-valves large, deltoid. 
Perianth-tube greenish, $2 \frac{1}{2}-3$ in. long; segments linear, $3 \mathrm{in.} \mathrm{long.}$ Staminal cup regularly funnel-shaped, $1 \frac{1}{4} \mathrm{in}$. long, usually toothed between the free tips of the filaments, which are about as long as the cup; anthers linear, $\frac{1}{2}$ in. long. Style overtopping the anthers. Ovules 2 in a cell.

Hab. Southern United States, Chapman! Bahamas, Hort. Saunders! Described from a plant flowered by Mr. Wilson Saunders in 1871, and since received from Messrs. Bull and Ware. First introduced by Fraser about 1816. Very near $H$. caribaa.

19. H. expansa Herb. App. 44. Pancratium expansum Sims in Bot. Mag. t. 1941.-Leaves longer, narrower, and more erect than in H. caribaa. Peduncle ancipitous, $2 \mathrm{ft}$. long. Flowers 9-10 in a sessile umbel; outer spathe-valves large, deltoid. Perianth-tube more slender than in $H$. caribca, $3 \frac{1}{2}-4$ in. long; segments linear, 4 in. long. Staminal cup funnel-shaped, an inch long, with a small tooth between the free tips of the filaments, which are 2 in. long; anthers linear, $\frac{1}{2}$ in. long. Style overtopping the anthers. Ovules 2 in a cell.

Hab. West Indies. Intermediate between $H$. caribcea and littoralis. Described from a plant sent by Mr. Elwes, which flowered at Kew, July, 1878.

20. H. macrostephana Baker in Gard. Chron. 1879, i. 430; Bot. Mag. t. 6436.-Bulb ovoid, 2 in. diam., with brown tunies and a produced neck. Leaves $8-9$, multifarious, oblanceolate, bright green, deltoid at the apex, $2 \frac{1}{2}-3 \mathrm{ft}$. long, $2-3 \mathrm{in}$. broad above the middle, narrowed to an inch above the base. Peduncle shorter than the leaves. Flowers $6-10$ in a centripetal umbel; pedicels very short; spathe-valves lanceolate. Perianth-tube greenish, 3 in. long; segments linear-lanceolate, a little longer than the tube. Staminal cup broadly funnel-shaped, $2 \mathrm{in.} \mathrm{long,} 2 \mathrm{in.} \mathrm{diam.} \mathrm{at} \mathrm{the}$ throat, obscurely 3 -toothed between the areuate-incurved free tips of the filaments, which are an inch long ; anthers linear, $\frac{1}{2}$ in. long. Style overtopping the anthers.

Hab. Described from living plants sent in March, 1879, from Sir Philip Egerton and the Duke of Northumberland. Probably it is the hybrid between H. speciosa and calathina, mentioned by Herbert in Journ. Hort. Soc. ii. 18.

21. H. Galvestonensis Balier. Choretis galvestonensis Herb. Amaryll. 221.-Leaves linear, $1 \frac{1}{2}-2 \mathrm{ft}$. long, $\frac{3}{4}-1$ in. broad. Peduncle 1-1 $\frac{1}{2} \mathrm{ft}$. long. Flowers $4-6$ in a sessile umbel; outer spathe-valves large, ovate. Perianth-tube greenish, $1 \frac{1}{2}-2 \frac{1}{2}$ in. long; segments linear, $2 \frac{1}{2} \mathrm{in}$. long. Staminal cup regularly funnel-shaped, $1-1 \frac{1}{4} \mathrm{in}$. long, not spreading at the edge; free tips of filaments $\frac{5}{8} \mathrm{in}$. long; anthers linear, $\frac{1}{2}$ in. long. Style overtopping the anthers.

Hab. Texas, Drummond 370! 412! Hall 630 !

22. H. Palmeri S. Wats. Cont. ix. 301.-Bulb narrowly oblong, 4-5 lin. diam. Leaves linear, a foot long, $\frac{1}{4}$ in. broad. Peduncle slender, uuder a foot long. Flower solitary, with 3 narrow linear spathe-valves. Perianth-tube $3 \frac{1}{2}-4$ in. long; segments as long as the tube, a line broad. Staminal cup funnel-shaped, $1 \frac{1}{4}$ in. long, acuminately lobed between the free tips of the filaments, which are one-third shorter than the segments.

Hab. Florida; Biscayan Bay, Dr. Palmer 554. Gathered in 1874. 
23. H. Humilis S. Wats. Cont. ix. 301.-Bulb $\frac{3}{4}$ in. diam., upon a thick rootstock. Leaves linear, $4-6$ in. long, $\frac{1}{6}$ in. broad. Peduncle slender, rather shorter than the leaves. Flower solitary; spathe-valves 3, narrow linear, greenish. Perianth $1 \frac{1}{4}$ in. long, dilated at the tip; segments linear, 2 in. long. Staminal cup broadly funnel-shaped, 8 lines long, truncate between the free tips of the filaments, which are one-third shorter than the segments and style.

Hab. Florida; Indian River, Dr. Palmer 555. Gathered in 1874.

24. H. Lacera Salisb. in Trans. Hort. Soc. i. 338. H. rotate Herb. Puncrutium rotatum Ker in Bot. Mag. t. 827 ; Lodd. Bot.

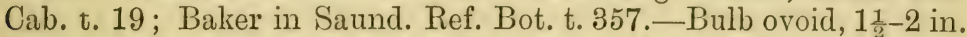
diam., with a produced neck and copious stolons. Leaves 6-8 to a bulb, linear, bright green, 1-1 $\frac{1}{2} \mathrm{ft}$. long, an inch broad. Peduncle slender, compressed, as long as the leaves. Flowers 2-6 in a sessile umbel; spathe-valves small. Perianth-tube greenish, 3-4 in. long; segments linear, as long as the tube. Staminal cup very rotate, $1 \frac{1}{2}-2$ in. diam. at the spreading margin; free tips of filaments $1 \frac{1}{2}$ in. long; anthers linear, $\frac{1}{2}$ in. long. Style much overtopping the anthers. Ovules 2 in a cell.

Var. H. paludosa Salisb. l.c. H. mexicana Herb. H. disciformis and Dillenii Roem. Pancratium mexicanum L. (Dill. Hort. Elth. t. 222). $P$. disciforme Red. Lil. t. 155. - Perianth-tube and segments shorter. Staminal cup about an inch in cliam. at the edge.

Hab. Southern United States. Ismene Knightii Knowles \& West, Floral Cab. ii. 51, appears to be a mere form of this species, with a $10-12$-flowered umbel.

\section{Subgenus Ismene (Salisb.).}

25. H. Quitoensis Herb. App. 44. Ismene temuifolia Baker in Bot. Mag. t. 6397. - Bulb globose, 1 $\frac{1}{2}-2$ in. diam., with brown tunics and a cylindrical neck. Leaves 6-8, tufted, thin, linear, acute, bright green, a foot long, $\frac{1}{2}-\frac{3}{4}$ in. broad at the middle. Peduncle slender, 4-8 in. long. Flower solitary, sessile, with 2 subulate spathe-valves. Perianth-tube slender, greenish, 3-4 in. long, slightly curved at the apex; segments lanceolate, suberect, $2 \frac{1}{2}-3$ in. long, $\frac{1}{2}$ in. broad. Staminal cup obconic, 2 in. long, $1 \frac{1}{2}$ in. diam. at the throat, white ribbed with green, with large quadrate sharply-toothed processes between the inflexed free tips of the filaments, which are $\frac{3}{4}$ in. long; anthers linear, $\frac{1}{3}$ in. long. Style exserted from the staminal cup.

Hab. Mountains of Ecuador, especially the Cerro of Santana, near Guayaquil, flowering in January, Pavon ! Jameson $529 !$ Spruce $6454 !$ Described from a plant flowered in June, 1878, by Messis. E. G. Henderson.

26. H. Andreana Nichols. Dict. Gard. ii. 164. Ismene Andreana Baker in Gard. Chron. 1884, i. 11; Rev. Hort. 1884, 129, 468; 'Garden,' May, 1884.-Bulb as large as an apple. Leaves several, tufted, linear, pale green, weak, $12-15$ in. long, $\frac{3}{4}$ in. broad at the middle. Peduncle slender, shorter than the leaves. Flower solitary; spathe-valves small, linear. Perianth-tube green, cylindrical, curved at the top, $4 \frac{1}{2}$ in. long; segments linear, white, $3 \frac{1}{2}-4$ in. long. 
Staminal cup obconic, nearly $3 \mathrm{in}$. long, $3-4 \mathrm{in}$. broad at the throat, white, striped with green, with rounded entire processes between the abruptly reflexed free tips of the filaments, which are an inch long; anthers linear, $\frac{1}{2}$ in. long. Style exserted from the staminal cup.

Hab. Andes of Ecuador, alt. $8000 \mathrm{ft}$., on the banks of the Rio Ambocas, Andvé 4546 ! Gathered in 1876.

27. H. deflexa Baker. Ismene deflexa Herb. in Bot. Reg. 1839, Misc. No. 142. - Leaves ensiform, acute, a foot long, under 2 in. broad. Peduncle ancipitous. Flowers $3-4$ in a sessile umbel; spathe-valves small. Perianth-tube curved, $1 \frac{1}{2}-2 \mathrm{in}$. long; segments linear, 3-4 in. long. Staminal cup funnel-shaped, 2-3 in. long, with rounded recurved processes between the free tips of the filaments, which are an inch or more long; anthers linear, $\frac{1}{3}$ in. long. Style protruded $1 \frac{1}{2}-2$ in. from the staminal cup.

Hab. A native of the Andes of Peru, at San Mateo, according to Herbert, but Col. Trevor Clarke has recently raised it by crossing $H$. culathina and Elisena longipetala.

28. H. nutans Baker. Ismene mutans Herb. Pancratium mutans Ker (Bot. Mag. t. 1561). - Leaves lorate, obtuse, above 2 ft. long. Peduncle 2-edged. Flowers 3-4 in a sessile umbel. Perianth-tube green, curved, about an inch long; segments linear, white, twice as long as the tube. Staminal cup funnel-shaped, $1 \frac{1}{2} \mathrm{in.} \mathrm{long,}$ irregularly lacerated between the free tips of the filaments, which are $\frac{1}{4}-\frac{1}{3} \mathrm{in}$. long; anther's large, linear. Style reaching nearly to the tip of the segments.

Hab. Supposed to have been imported from Brazil, but more likely Andine. I have not seen a specimen, and my description is made from the Bot. Mag. figure.

29. H. Macleana Nichols. Dict. Gard. ii. 1650. Ismene Macleana Herb. in Bot. Mag. t. 3675. - Bulb ovoid, 2 in. diam., very proliferous. Leaves 6-8, laxly superposed, suberect, bright green, a foot or more long, 18-21 lines broad. Peduncle ancipitous, above a foot long. Flowers $2-8$ in an umbel, sessile or pedicellate; spathe-valves lanceolate. Perianth-tube greenish, straight, $1 \frac{1}{2}-2$ in. long; segments linear, suberect, as long as the tube. Staminal cup obconic, $1 \frac{1}{2}$ in. long, white, banded with green, with rounded spreading sharply-toothed processes between the free inflexed tips of the filaments, which are $\frac{1}{2}$ in. long; anthers linear, $\frac{1}{4}$ in. long. Style protruded from the staminal cup. Ovules 2 in a ceil.

Hab. Andes of Peru, introduced by Maclean in 1834. Described from a plant that flowered at Kew in June, 1881, presented by Col. Trevor Clarke. I cannot separate specifically $I$. pedunculata Herb. or I. virescens Lindl. in Bot. Reg. 1841, t. 12.

30. H. calathina Nichols. Dict. Gard. ii. 165. 1smene calathina Herb. in Bot. Mag. t. 2685. I. cyathiformis, narcissiflora, and Tagliabuei Roem. Pancratium calatrinum Ker in Bot. Reg. t. 215. P. narcissiflorum Jacq. Fragm. t. 138. P. calathiforme Red. Lil. t. 353. - Bulb globose, with a cylindrical neck. Leaves 6-8, subdistichous, superposed, erecto-patent, bright green, lorate, $1 \frac{1}{2}-2 \mathrm{ft}$. long, $1 \frac{1}{2}-2$ in. broad. Peduncle 2 -edged, $1 \frac{1}{2}-2$ ft. long. Flowers $2-5$ in a sessile umbel; outer spathe-valves large, ovate. Perianthtube green, funnel-shaped at the apex, $3-4$ in. long; segments 
white, lanceolate, as long as the tule, $\frac{1}{2} \mathrm{in.}$ liroat. Staminal cup olseonic, white, striped with green, 2 in. long, alwowe 2 in. sliam. at the throat, with rounded spreading toothed proessses between the free tips of the filaments, which are $\frac{1}{2} \mathrm{in.}$ long ; anther's linear, $\frac{1}{2}$ in. long. Style exserted from the staminal cup.

Hab. Andes of Peru and Bolivia. Introduced into eultivation in 1794. We have it also from Guatemala and Buenos Ayres, probably cultivated.

31. H. Amancaes Nichols. Diet. Gard. ii. 165. Nurcissus Amancres Ruiz et Pav. Fl. Peruv. iii. 53, fig. 283. Puncrutiun dimancues Ker in Bot. Mag. t. 1224; Bot. Reg. t. 660. Ismene Amancues Herb. I. crivifolia Salisb.-Bulb globose, $1 \frac{1}{2}-2$ in. diam., with a cylindrical neck half a foot long. Leares $4-5$, laxly superposed, lorate, bright green, suberect, $1 \frac{1}{2} \mathrm{ft}$. long, $1 \frac{1}{2}-2 \mathrm{in}$. broad. P'eduncle ancipitons, 1-2 ft. long. Flowers 3-6, sessile or shortly perlicellate; spathe-valves lanceolate. Perianth-tube greenish yellow, 3 in. long; segments linear, bright jellow, $2-2 \frac{1}{2}$ in. long. Staminal cup obconic, 2 in. long, 2 in. diam. at the throat, bright yellow, striped with green, with incurved bifid toothed deltoid processes between the free tips of the filaments, which are $\frac{1}{2}$ in. long; anther's small, linear-oblong. Style sometimes exserted fin the staminal cup. Ovules 2 in a cell.

Hab. Peru, especially on the Hill of Amancaes, near Lima. Described from plants that flowered at Kew in June-July, 1878-9. Bot. Reg. t. 1665 represents a hybrid between this species and $H$. culıthina.

\section{Elisexa Herb.}

Periunth-tube short, broadly fumel-shaped; segments long, cqual, linear. Stumens as long as the segments, united at the base in a large deffexed funnel-shaped enp); nper part of filament long, filiform; anthers linear, versatile. (Wory 3-celled; ovules 2, basal, collateral; style long, filiform ; stigma capitate. Fruit not seen fully developed, but probably as in Hymenocallis. - Rinotstock a tunicated bulb. Leaves lorate. Pechnele long, solicl. Flowers white, few in an nubcl.

1. E. Ringens Herb. A maryll. 201. Pancrutizm ringens Puiz et Pav. Fl. Peruv. iii. 53, t. 283. Liviope ringy Herb. Liviopsis ringens Reich. -Bulb globose, $1 \frac{1}{2}$ in. diam. Leaves 5-6, linear-lorate, $1 \frac{1}{2} \mathrm{ft}$. long. Peduncle ancipitonis, longer than the leaves. Flower's abont 5 in a nearly sessile umbel; spathe-valves lanceolate. Perianth-tube $\frac{3}{4}$ in. long; segments linear, $1 \frac{1}{2}$ in. long. Staminal eup funnelshaped, $\frac{1}{2} \mathrm{in}$. long ; free tips of filaments $1-1 \frac{1}{4} \mathrm{in.}$ long; anther's linear-oblong. Style overtopping the anthers.

Hab. Andes of Peru.

2. E. sublinis Herb. in Bot. Mag. sub t. 3873. - Habit and leaves of E. rinyms. Flowers about 6 in an umbel; pedicels $\frac{1}{2}-\frac{3}{4}$ in. long; spathe-valves larger. Perianth-tube under $\frac{1}{2}$ in. long; segments linear. 2 in. long. Staminal eup longer; free tips of filaments only $\frac{1}{2} \mathrm{in}$. long.

Hab. Andes of Peru; Caxamarquilla, gathered by Maclean. 
3. E. Longipetala Herb. in Bot. Reg. xxiv. Misc. 79 ; Bot. Mag. t. 3873 ; Baker in Saund. Ref. Bot. t. 264.-Bulb $1 \frac{1}{2}-2$ in. diam., with a long cylindrical neck. Leaves about 6 , lorate, stiffly suberect, light green, $1 \frac{1}{2} \mathrm{ft}$. long, $1 \frac{1}{2}$ in. broad. Peduncle ancipitous, $2-3 \mathrm{ft}$. long. Flowers $5-10$ in a nearly sessile umbel; outer spathe-valves ovate. Perianth-tube $\frac{1}{4}-\frac{1}{3}$ in. long and broad; segments linear, 4 in. long. Staminal cup funnel-shaped, deflexed at a right angle with the tube, $1 \frac{1}{2} \mathrm{in}$. long with the edge reflexed between the free tips of the filaments, which are $2 \frac{1}{2} \mathrm{in}$. long; auther small, linear-oblong. Style overtopping the anthers.

Hab. Andes of Peru and South Ecuador, alt. 6000-8000 ft. Described from a plant that flowered at Kew, May, 1878. Received also alive from Messis. Wilson Saunders, Elwes, Henderson, Veitch, and Colonel Trevor Clarke.

\section{Vagaria Herb.}

Perianth-tube short, funnel-shaped at the apex; segments equal, lanceolate, ascending, with a broad green keel. Stumens inserted at the throat of the tube; filaments quadrate at the base, with a tooth on each side; anthers small, oblong, versatile. Outry globose, 3-celled; ovules $2-3$ in a cell, attached to the middle of the placenta; style filiform; stigma capitate. Capsule deeply 3-lobed, finally dehiscent. Seeds turgid, black.

1. V. parviflora Herb. Amaryll. 226. Pancratium parviflorum Desf.; Delile in Red. Lil. t. 471. Vaginaria Kunth. Almyra Salisb.-Bulb globose, $1 \frac{1}{2} \mathrm{in}$. diam., with brown tunics and a long neck. Leaves 4-6, linear, produced after the flowers, finally $2 \mathrm{ft}$. long. Peduncle slender, ancipitous, 9-12 in. long. Flowers 6-8 in an umbel; pedicels $\frac{1}{2}-\frac{3}{4}$ in. long; spathe-valves linceolate. Perianth-tube $\frac{1}{2} \mathrm{in}$. long; segments rather longer. Stamens much shorter than the segments.

Hab. Syria, about Beyrout and Tripoli. Introduced into cultivation at the Jardin des Plantes in 1815. Flowers in autumn.

\section{Eurycles Sulisb.}

Periunth-tube cylindrical; segments subequal, oblong-lanceolate, ascending. Stumens inserted at the throat of the tube, shorter than the segments; filaments bordered in the lower half, united in a more or less distinct cup; anthers linear-oblong, versatile. Ocary ampullicform, 3-celled; ovules 2 rarely 3 in a cell, medial; style filiform; stigma capitate. Capsule globose, succulent. Seed usually solitary, globose.- Rootstock a tunicated bulb. Leares broad, petioled, with lax arcuate main veins, connected by oblique cross veinlets. F'lowers many in an umbel, white.

1. E. sycvestris Salisb. in Trans. Hort. Soc. i. $337 . \quad$ E. australis Schultes. E. amboinensis and australasica Loud. Pancratinum amboinense Linn.; Ker in Bot. Mag. t. 1419 ; Red. Lil. t. 384. $P$. australasicum. Ker. in Bot. Reg. t. 715. P. nervifolium Sailsb. Parad. t. 84. Crimum nervosum L'Herit. Amaryllis rotundifolia Lam.-Bulb 3-4 in. diam. Leaf with a suborbicular cordate cuspidate blarle, 6-12 in. broad and a long petiole dilated at the 
base; main veins $12-15$ on each side of midrib; basal lobes involute. Peduncle terete, 1-1 $\frac{1}{2} \mathrm{ft}$. long. Flower's $20-30$ in a densie umbel, shortly pedicellate; spathe-valves linceolate. Perianth 2-2 $\frac{1}{2}$ in. long; segments oblanceolate-oblong, as long as the tube. Appendages to filaments $\frac{1}{4}-\frac{1}{3} \mathrm{in}$. long, connate only at the very base, furnished with a tooth on each side of the free apex of the filament, which is $\frac{1}{2} \mathrm{in}$. long.

Hab. Malay I'eninsula and Philippines to North Australia. Flowers in August and September. Figured by Commelinus and Rumphius at the beginning of the 17th century.

2. E. Cunninghani Aiton; Lindl. in Bot. Reg. t. 1506 ; A. Cmningham in Bot. Magr. t. 3399.-Bulb $1 \frac{1}{2}$ in. diam. Leaf thin, with an oblong acute blade 4-9 in. long, not cordate at the base and a long petiole. Peduncle slender, a foot long. Flowers 10-15 in an umbel; pedicels 1-1 $\frac{1}{2}$ in. long; spathe-valves small, lanceolate, Perianth $1 \frac{1}{4}-1 \frac{1}{2}$ in. long; segments much longer than the tube. Staminal cup fumnel-shaped, half as long as the segments, with two large teeth between the free part of each filamcht, which is $\frac{1}{4}$ in. long.

Hab. Queensland and New Sonth Wales; discovered by Allan Cumningham in 1824. Described from a plant that flowered with Messrs. Veitch in the summer of 1874.

\section{Calostemina R. Br.}

Perianth-tube narrowly funnel-shaped; segments oblanceolateoblong, equal, ascending. Stamens inserted at the throat of the perianth-tube; filaments united in a cup in the lower half; anthers small, oblong, versatile. Ovary by abortion 1 -cellud; ovules $2-3$, medial, collateral; style filiform; stigma capitate. Fruit indehiscent, oblique. Seed solitary, globose.-Rootstock a tunicated bulb. I.eurs typically sessile, linear, produced after the flowers. Flovers many in an umbel, white, yellow or red.

Leaves sessile, linear

Leaves thin, oblong, petioled: $\quad$ : $^{\circ}$ Sp. 3.

1. C. purpureum, R. Br. Prodr. 298; Sims in Bot. Mag. t. 2100 ; Bot. Reg. t. 422; Flore des Serres, t. 1135.-Bulb ghlobiose, 2 in. diam. Leaves linear, sessile, $\frac{1}{6}-\frac{1}{4}$ in. broad, produced after the flowers. Peduncle slender, compressed, 1-2 ft. long. Flowers 10-20 in an umbel; pedicels $\frac{1}{2}-1$ in. long; spathe-valves large, lanceolate, membranous. Perianth dark purple, $\frac{1}{3}-\frac{1}{2} \mathrm{in.} \mathrm{long;}$ tube rather shorter than segments. Staminal cup entire or toothed between the free tips of the filaments. Style reaching to the tip of the segments. Seed $\frac{1}{6}$ in. diam.

Var. C. Carneuni Lindl. in Bot. Reg. 1840, t. 26.-Flowers rather larger, pale purple or white. Tubs as long as the limb.

Hab. South Australia and New South Wales.

2. C. Luteum Sims in Bot. Mag. t. 2101; Ker in Bot. Reg. t. 421; Lindl. in Bot. Reg. 1840, t. 19 ; Flore des Serres, t. 1135. 
C. candidum Lindl.- Just like C. purpureum, except that the flower is rather larger and bright yellow. Staminal cup truncate or furnished with deltoid teeth between the free tips of the filaments. Perianth-tube about half as long as the segments. Stamens reaching to the tip of the segments.

Hab. Queensland and New South Wales. Introduced into cultivation with C. purpureum in 1819.

3. C. albua R. Br. Prodr. 298.-Leaves contemporary with the flowers, with a long petiole and a thin oblong acute blade $4-5 \mathrm{in}$.

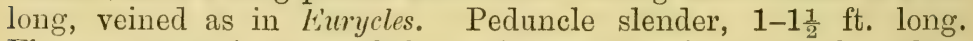
Flowers 12-20 in an umbel; pedicels $\frac{1}{2}-\frac{3}{4} \mathrm{in}$. long; spathe-valves lanceolate. Perianth white, $\frac{1}{2} \mathrm{in}$. long; tube as long as the narrow acute segments. Staminal cup furnished with conspicuous entire or bifid teeth between the free tips of the filaments.

Hab. Gulf of Carpentaria, R. Brown! I have more than once seen garden plants named as this species, but never rightly so. It is most like Eurycles Cunninghami, much reduced in size in flower and leaf.

\section{Suborder 2. Alstrenerieæ.}

\section{Ixiolirion Fisch.}

Perianth regular, without any tube above the ovary; segments subequal, oblanceolate, ascending, acute. Stumens shorter than the segments, attached to their claws; anthers oblong, basifixed. Orary clavate, 3-celled; ovules many, superposed; style filiform; stigma trifid. C'upsule loculicidally 3-valved. Seerls small, angled, with a black testa.-liootstock a tunicated bulb. Leaves linear, mostly aggregated at the base of the slender erect stem. Filuwers in a terminal umbel, with often a few others added. Differs from the typical Alstromerien, which are exclusively American, by its bulbous rootstock.

1. I. montanum Herb. App. 37; Bot. Reg. 1844. t. $66 . \quad$ I. Pallasii F. \& M. Amaryllis montana Labill. Syr. Dec. ii. 5, t. 1; Red. Lil. t. 241. Alstrameria montana Ker. A. triflora Griff. Ic. t. 273.-Bulb ovoid, $1 \mathrm{in}$. diam., with a neek $2-3 \mathrm{in}$. below the basal tuft of lcares. Stem about a foot long, with about 4 long linear persistent ascending leaves agrgregated at its base and several much smaller ones higher up. Flowers about 4 in a terminal mubel, on long unequal pedicels and often one or two solitary flowers below the umbel. Perianth bright lilac, $1 \frac{1}{4}-1 \frac{1}{2}$ in. long; segments oblanceolate, acute, with $3-5$ distinct ribs. Filaments filiform, attached to the base of the segments.

Var. I. tataRicum Herb. App. 37. I. Ledebourii F. \& M.Stems more slender. Leaves subulate. Flowers all in a terminal umbel, smaller than in the type.

Hab. The type; Syria, Lebanon, and the Cilician Taurus, where it ascends to $6000 \mathrm{ft}$., to Central siberia, Afghanistan and Beloochistan. The variety on the Altai and Mountains of Soongaria. I. macranthum Hort. is a form with an unusually large flower. Regel (Descr. vii. 206) calls the collective species I. tataricum, and desoribes five varieties of it. 
2. I. Kolpakowskianum Regel Descr. xii. 208. Kulpaliowstici iximlirioiles Regel Gartenfl. 1878, 294, t. 953.-Bulb 1 in. diam. Leaves ascending, about 4 argregated in a basal tuft and 1 -2 small ones above it. Flower's 2-4, generally all in a terminil nubel. Perianth-segunents $\frac{3}{4}-1 \mathrm{in}$. long, very narrow, colsering loosely in the lower hilf. Filaments very sliort, inserted half-way up the segments.

Hab. Turkestan, alt. 3000-6000 ft. Discovered by Dr. Albert Regel in 1878. Described from a plant flowered by Mr. Elwes in April, 1880.

\section{Alstremeria Lim.}

Perianth-tube none; limb more or less irregular, the lower segment especially of the inner row being different from the otuer two of the same row in size and marking,and the three outer a different shape from the three imner. Stumens slightly declinate, attached to the base of the segments, often unequal; fllaments filiform; anthers small, oblong, basifixed. ()ury turbinate, Зcelled; ovules many, superposed; style filiform; stigma trifid. Cupsule loculicidilly 3-valved, umbonate at the apex. Seeds globose.- Liont of thichened fibres; rootstock none. I.eaves cauline, usually resupinate by the twisting of the base or petiole, more fully developed on the short flowerless stems than on those that produce the flowers, filuers varions in colour, often spotted, arranged in a simple or compound umbel.

Brazilian species.

Leaves rigid, strongly nerved.

Umbel simple . . . . Sp. 1-6.

Umbel compound . . . . Sp. 7-12.

Leaves thin.

Leaves of flower-stem small, linear or lanceolate

Leaves of flower-stem large, oblong or oblong-lanceolite . . . Sp. 17-20.

Chilian species.

Leaves of flowering-stem linear . Sp. 21-31.

Leaves of flowering-stem lanceolate Sp. 32-38.

Leaves of flowering-stem ollong- or obovate-spatulate

Sp. 39-44.

1. A. plantagrnea Mart. in Roem. et Schultes Syst. vii. 739 ; Schenck in Fl. Bras. iii. 178, ta!). 21, fig. 2.-Flowering-stems stiffly erect, $1 \frac{1}{2}-2 \mathrm{ft}$. long. Fully developed leares crowded, sessile, linceolate, erceto-patent, 2-3 in. long, moderately firm in texture; those of the flowering-stem usually much smaller, distant, linear or lancolate. Flowers 5-9 in a simple umbel; bracts 8-12, small, linear; pedicels 1-2 in. long, with linear bracteoles. Perianth 1-1 $1 \frac{1}{1}$ in. long; segments oblanceolate-mnguiculate; inner longer and broader than outer, yellow, spotted with claret-purple. Stamens and style nearly as long as limb. 
Hab. Central Brazil; Provinces of Bahia, Goyaz and Minas Geraes, Martius, Burchell! Gardner !

2. A. isabellina Herb. Amaryll. 86.-Flowering stem $3 \mathrm{ft}$. long; leaves simple, distant, rigid, lanceolate, ascending, at most 4-5 in. long; edges thickened, stramineous. Umbel simple, 10-15-flowered; bracts numerous, minute, lanceolate; pedicels $\frac{1}{2}-1 \frac{1}{2}$ in. long. Perianth $1 \frac{1}{4}$ in. long; segments all oblanceolate, acute, not spotted, $\frac{1}{6}$ in. broad, reddish yellow, conspicuously tipped with green. Stamens as long as the segments.

Hab. Central and Southern Brazil; gathered by Isabelle, Sello, Tweedie and lately by Dr. Glaziou (6734).

3. A. Stenopetala Schenk in Mart. Fl. Bras. iii. 174. Flowering stem 3-3 $\frac{1}{2} \mathrm{ft}$. long. Leaves lanceolate, rigid, sessile, resupinate,

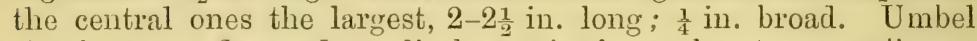
simple, many-flowered; pedicels $\frac{1}{2}-\frac{3}{4} \mathrm{in}$. long; bracts many, linear, sometimes longer than the pedicels. Perianth under an inch long ; segments oblanceolate; inner ones acuminate. Stamens as long as the perianth.

Hab. Central Brazil; Serra de Manuel Gomez, Pohl 1639.

4. A. Schenkiana Baker. A. cunea Schenk in Mart. Fl. Bras. iii. 172, non Vellozo.-Flowering stem $1 \frac{1}{2}-2 \mathrm{ft}$. long. Leaves rumote, linceolate, rigil, not resupinate, the contrai ones an inch

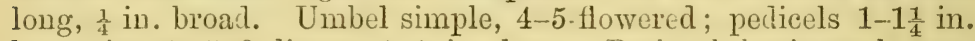
long; bracts 5-6, linear, $\frac{1}{3}-\frac{1}{2}$ in. long. Perianth horizontal; segments reddish, unspotted; outer oblanceolate-spathulate, inner narrow. Stamens included, the three inner lialf as long as the limb.

Hab. Central Brazil; San Joao das Antas, Pohl. Must be very near A. isabellina.

5. A. Gardneri Baker in Journ. Bot. 1877, 261.-Sterile stem a foot long, its leaves spaced out over the upper third, lanceolate, 3 in. long, $\frac{1}{2}-\frac{3}{4}$ in. broad, sharply nibbed. Fertile stem $3 \mathrm{ft}$. long; its leaves few, small, lanceolate, rigid, ascending. Umbel simple, 5-6-flowered; bracts small; pellicels 2 in. long, not bracteolate.

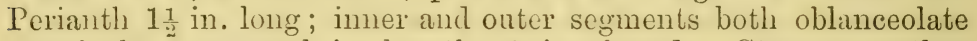
unguiculate, unequal in length, $\frac{1}{4}$ in. broad. Stamens rather shorter than the segments.

Hab. Central Brazil ; I'rovince of Goyaz, Gardner 4369 !

6. A. platyphylda Baker in Journ. Bot. 1877, 261. - Sterile stem $1 \frac{1}{2} \mathrm{ft}$. long; its leaves oblong, subpetiolate, reaching $4 \mathrm{in}$. loug, $1 \frac{1}{2}-1 \frac{3}{4}$ in. broad, firm in texture, strongly ribbed. Flowering stem above $2 \mathrm{ft}$. long, its leaves small, distant, ascending, rigid, lanceolate. Umbel simple, 6-flowered; bracts many, small, lan-

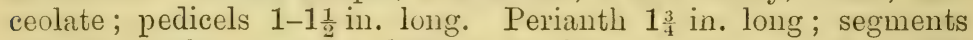
all oblanceolate, acute, about $\frac{1}{4}$ in. broad. Stamens distinctly shorter than the perianth-limb.

Hab. Central Brazil; Province of Goyaz, Gardner 4368!

7. A. Longistyla Schenk in Mart. Fl. Bras. iii. 173.-Flowering stem '2-3 ft. long. Leaves linear, not resupinate, firm in texture, 
the central ones the largest, $4-4 \frac{1}{2}$ in. long, $\frac{1}{6} \mathrm{in}$. broad. Umbel of 5 2-3-flowered rays; bracts 5, linear-lanceolate, $2-4$ in. long. Perianth above an inch long; outer segments oblong-spathulate; inner oblanceolate, spotted with purple. Stamens shorter than segments. Style exserted.

Hab. Minas Geraes, near Barbacena, Pohl.

8. A. apertritora Baker.-Flowering stem above $3 \mathrm{ft}$. long, its luves distant, linear, rigid, lanceolate, acuminate, ascending, at most $1 \frac{1}{2}-2$ in. long. Umbel of $4-5$ long $4-5$-flowered rays; bracts very minute, rigid, lanceolate. Perianth an inch long; segments oblinceolate-minguiculate, reflexing when expanded from half-way down like a Martagon lily, the three inner narrower and more acnte than the three outer. Stamens distinctly shorter than the segments.

Hab. Paraguay, between Villa Rica and Caaguazu, Balansa 528!

9. A. Sellowiana Seubert in Mart. Fl. Bras. iii. 173.-Flowering stem above a foot long. Lcaves linear, rigid, reaching an inch in length on the flowering stem, 3-4 in. on the sterile stem. Umbel of 2-5 2-3-flowered branches; bracts few, linear, rigil, under an inch long. Perianth-segments an inch long, all oblanceolate-unguiculate. Stamens distinctly shorter than the segments.

Hab. South Brazil, Sello, Weir 439 !

10. A. zamioides Balier in Journ. Bot. 1877, 262.-Sterile stem a foot or more long. Leaves lax, erecto-patent, sessile, lanceolate, firm in texture, strongly veined, $4-5 \mathrm{in}$. long, $\frac{3}{4}-1 \mathrm{in}$. broad. Fertile stem 3-4 ft. long. Leaves distant, sessile, lanceolate, ascending, 2-3 in. long. Umbel of about 6 compound rays 6-8 in. long; bracts many, linear, $1 \frac{1}{2} \mathrm{in}$. long. Perianth $1 \frac{1}{4}-1 \frac{1}{2}$ in. long; segments oblanceolate-unguiculate, $\frac{1}{6}-\frac{1}{3}$ in. broad, yellow, much spotted with claret-purple. Stamens an inch long.

Hab. Brazil ; Province of Goyaz, Gardner 4009 !

11. A. Brasiliensis Spreng. Syst. ii. 81.-Flowering stem 3-4 ft. long. Leaves remote, subcoriaceous, not resupinate, the central ones the largest, oblong-lanceolate, 2 in. long, $\frac{1}{3}-\frac{1}{2}$ in. broad. Umbel of 5 1-3-flowered rays; bracts 5, linear. Perianth $1 \frac{1}{4} \mathrm{in}$. long; segments oblong-spathulate, rechlish yellow, inner spotted with brown. Stamens shorter than the segments.

Hab. Central Brazil; Provinces of Goyaz and Minas Geraes; gathered by Pohl and Sello.

12. A. Burchelli Baker in Jom'n. Bot. 1877, 262. - Sterile stcm $2 \mathrm{ft}$. long; its leaves mainly confined to the upper half, linceolate, 3-4 in. long, $\frac{3}{4} \mathrm{in}$. broad, moderately firm in texture, glaucous beneath. Leaves of the fertile stem linear, erectopatent, 3-4 in. long. Umbel of 2-3 simple or forked rays $2-3 \mathrm{in}$. long; bracts about 4, large, linear. Perianth about an inch long ; segments all oblanceolate-unguiculate, $\frac{1}{1}$ in. broad. Stamens about as long as the perianth.

Hab. Central Brazil; Goyaz, Burchell 6883-2! 
13. A. Camyophyllea Jacq. Hort. Śchoen. t. 465. A. Ligtu Curt. in Bot. Mag. t. 125, non Linn.- Sterile stem $\frac{1}{2} \mathrm{ft}$. long, with several thin lanceolite petioled leaves, agregated near its apex, reaching $1 \frac{1}{2}-2 \mathrm{in}$. long, $\frac{1}{2}-\frac{3}{4}$ in. broad. Flowering stem $\frac{1}{2} 1 \frac{1}{2} \mathrm{ft}$. long; its leaves few, linear, ascending, very small. Umbel simple, 3-4-flowered; pedicels $1 \frac{1}{2}-2$ in. long; bracts many, thin, linear, sometimes petioled, 1-1 $\frac{1}{2} \mathrm{in.} \mathrm{long.} \mathrm{Perianth-segments} \mathrm{oblanceolate,}$ with a long claw, very unequal, the longest $1 \frac{1}{2}-1 \frac{3}{4} \mathrm{in}$. long. Stamens shorter than the upper segments.

Hab. Southern Provinces of Brazil, Gardner 844! Nosen 3805! I cannot from the description alone separate definitely A. filipendula Schenck.

14. A. monticola Mart. in Roem. et Schultes Syst. vii. 739 ; Schenck in Fl. Bras. iii. 175 tab. 22, fig. 1.-Flowering stem 2 ft. long, its leaves thin, linear-lanceolate, remote, glabrous, glancons beneath, $2 \frac{1}{2}-3 \mathrm{in}$. long, $\frac{1}{4}-\frac{1}{3} \mathrm{in}$. broud. Umbel 5-6 rays; pedicels usually simple, $1 \frac{1}{4}-1 \frac{1}{2}$ in. long; bracts $6-8$, linear, $1 \frac{1}{2}-2 \mathrm{in}$. long. Perianth horizontal, nearly $2 \mathrm{in.}$ long; segments all oblanceolateunguiculate. Stamens nearly as long as the perianth.

Hab. Brazil; Serra dos Lagos, Province of Bahia, Martius.

15. A. Foliosa Mart. in Roem. et Schultes Syst. vii. 740 ; Schenk in Fl. Bras. iii. 175, tab. 21, fig. 1. - Flowering stem 2 ft. long, its leaves many, thin, ascending, linear, subpetiolate, $3-4$ in. long, $\frac{1}{4}$ in. broad, pubescent beneath. Umbel 3-6-layed; pedicels 2-3 in. lıng, 1-2-flowered; bracts many, thin, linear, as long as the pedicels. Perianth $1 \frac{1}{2}$ in. long; outer segments with a long claw and a cuneate-orbicular limb $\frac{1}{2}$ in. Iroat; the others oblanceolate-unguiculate. Stamens nearly as long as the periantl.

Hab. Central Brazil; Province of Minas Geraes, Martius, Sello! Glaziou 15499! Three varieties are described.

16. A. Pinuhyensis Gardn. MSS. - Flowering stem $3 \mathrm{ft}$. long, its leares fer, distant, linear, erecto patent, not more than an inch long. Sterile stem a foot long, with many thin oblong-spathulate petioled leaves agoregater near its apex, the largest $2-3 \mathrm{in}$. longr, 1-1 $\frac{1}{4}$ in. broad. Umbel simple, 4-6-rayed; pedicels $1-2$ in. long; bracts many, thin, linear or linceolate, about an inch long. Perianth $1 \frac{1}{4}$ in. long; segments oblanccolate-unguiculate, acute, not spotted, the onter $\frac{1}{4}$ in., the inuer $\frac{1}{8}$ in. broad. Stamens shorter than the perianth.

Hab. Brazil ; shady woods near Veiras, Province of l'iauhy, Gardner 2324! Nearly allied to A. pulchella.

17, A. pulchella Linn. fil. Suppl. 206. A. psittacina Lehm.; Hook. in Bot. Mag. t. 3033; Lindl. in Bot. Reg. t. 1540. A. Bankiana Roem. - Sterile stems under a foot long, with a number of thin oblong petioled leaves $2-3$ in. long, $\frac{1}{2}-\frac{3}{4}$ in. broad, aggregated at its apex. Flowering stem 2-3 ft. long; leaves scattered, lanceolate or oblong-spathulate. Umbel simple, 5-6-flowered; pedicels $1-1 \frac{1}{2}$ in. long; bracts many, large, lanceolate, foliaceous. Perianth-segments $1 \frac{1}{2}-1 \frac{3}{4}$ in. long, dark red, tipped with green, all spotted inside with brown, very unequal, the upper with an obovatecuneate limb $\frac{1}{3}-\frac{1}{2}$ in. broad. Stamens nearly as long as the limb. 
Hab. Northern Brazil. This is the only Brazilian species now in cultivation. Several of them are only known from a small number of dried specimens, and need further investigation.

18. A. scaberula Balier in Journ. Bot. 1877, 261. - Flowering stem 4-5 ft. long, with about 30 ascending resmpinite lcaves of thin texture, pubescent all over and rather glancons beneath, the lower oblong-lanceolate, 4-5 in. long, an inch broad at the midhle, the npper growing grimlually smaller. Umbel simple, 5-6-flowered; pedicels $1 \frac{1}{2}$ in. long; bracts $6-9$, lanceolate, shorter than the pedicels. P'erianth $1 \frac{1}{2}$ in. long; segments all oblanceolate-spathulate, subacute, $\frac{1}{6}$ in. broad, copionsly spotted with clinet-brown. Stamens shortcr than the segments.

Hab. Central Brazil ; Province of Goyaz, Gardner 3473 !

19. A. Longistaminea Mart. in Roem. et Schultes Syst. Veg. vii. 739 ; Schenk in Fl. Bris. iii, tab. 20, fig. 2. - Flowering stem under $2 \mathrm{ft}$. long, its leaves distant, lancolate or linear, the largest 2-3 in. long, $\frac{1}{2}-\frac{3}{4}$ in. broad. Umbel 5-1ayed; pedicels short, simple or forked; bracts obsolete, a few large, linear. Perianth an inch long; segments all oblanceolate-spathulate. Stamens as long as the perianth.

Hab. Brazil ; Province of Bahia, Martius.

20. A. inodora Herb. Amaryll. 90, tab. 2, fig. 1. - Flowering stem 2-3 ft. long, its leaves thin, lanceolate or oblong, narrowed into a long winged petiole, reaching $3-4$ in. long, an inch broad. Umbel simple, 2-6-flowered ; pedicels 1-3 in. long; bracts many, large, lanceolate, thin. Perianth $1 \frac{1}{4}-1 \frac{1}{2}$ in. long; segments oblanceolate-unguiculate, the outer $\frac{1}{4}-\frac{1}{3}$ in. broad, the inner narrower, plain or spotted towards the tip with claret-brown. Stamens as long as the segments.

Var. A. Nemorosa Gardn. in Bot. Mag. t. 3958. - Leaves and bracts longer and thinner, the latter sometimes 3-4 in. long, 1-1 $\frac{1}{4}$ in. broad, overtopping the flowers.

Hab. Widely spread in Central and Southern Brazil. Allied to $A$. pulchella, hementha, and aurantiaca.

21. A. pygmea Herb. Amaryll. 100, 397, tab. 8, figs. 4-13.Underground stems $2-4$ in. long. Stem not produced alove the surfuce, bearing a clense tuft of ascending linear or lanceolate leares $\frac{1}{2}-1$ in. long. Flower solitary, sessile in the centre of the tuft of leaves; segments oblanccolate-unguiculate, whitish, unspotted, $\frac{1}{2}-\frac{3}{4}$ in. long, 1-12th to 1-8th in. broad. Stamens nearly as long as the segments.

Hab. Andes of Pasco, Peru, Mathews 865! Gregory Bay, Dr. Cunningham! East P'atagonia, Cupt. King! Andes of Bolivia, alt. 11,000-12,000 ft., MIundon 1207 !

22. A. Revoluta Ruiz et Pav. Fl. Peruv. iii. 59. - Flowering stem a foot or more. Leaves crowded, ascending, linear, the longest 1-1 $\frac{1}{2} \mathrm{in}$. long. Umbel of 6-12 or more simple or forked short rays; bracts many, small, linear. Periantl purplish, $\frac{1}{2}-\frac{3}{1}$ in. long; segments oblanceolate-nuguiculate, 1-12th to 1-sth in. broat, reflexing or spreading from the mildle when exp:mided; inner 
tinged with yellow and spotted. Stamens shorter than the segments; anthers very small.

Hab. Chili; Province of Colchagua, \&c., Pavon! Bridges 1227! C. Gay!

23. A. versicolor Ruiz et Pav. Fl. Peruv. iii. 59. - Flowering stem in the type about $\frac{1}{2} \mathrm{ft}$. long. Leaves many, linear, ascending, the lower about an inch long. Umbel of few simple forks; bracts few, linear. Perianth about an inch long; segments all oblanceolate-unguiculate, acute, yellow spotted with purple; outer $\frac{1}{4}$ in. broad ; inner narrower. Stamens about as long as the segments.

Var. A. Recumbens Herb. Amaryll. 97. - Stem scarcely at all produced above the surface of the ground. Umbel many-rayed; some of the pedicels forked.

Var. A. Cumingrana Herb. Amaryll. 96. - Stems $\frac{1}{2}-1$ ft. long. Leaves scattered, linear, about $\frac{1}{2}$ in. long. Umbel 4-6-rayed, some or all of the pedicels forked. Perianth $1-1 \frac{1}{4}$ in. long.

Hab. Chili, about Valparaiso, Conception, \&c. I cannot, from the material at my command, separate specifically $A$. temuifolia Herb., A. nivalis Meyen, $A$. Kingii Phil., A. xanthina Phil., A. puberula Phil., A. tigrina Phil., and $A$. citrina Phil.

24. A. inconspicua Phil. Descr. Nuev. 1873, 70. - Flowering stem 6-9 in. long. Leaves crowded, linear-subulate, an inch long. Umbel 2-3-rayed; rays 1-7-flowered; flowers racemed, secund, small, purplish.

Hab. Chili; Province of Santiago, Phitippi. Of a large proportion of the Chilian species recently described by Dr. Philippi I have not seen specimens.

25. A. Nivalis Phil. in Linn. xxix. 69, non Meyen.-Flowering stem a span long. Leaves crowded, linear, under an inch long. Umbel of 3 simple rays. Perianth $1 \frac{1}{2}-2$ in. long; outer segments obovate-unguiculate, $\frac{3}{4} \mathrm{in}$. broad; imner longer, narrower, the upper tinged with yellow at the middle and marked with oblique purple lines and spots.

Hab. Chili ; Provinee of Santiago, near the snow-line, Germain. Allied to A. Ligtu.

26. A. paupercula Phil. Fl. Atac. 51, No. 371.-Flowering stem about 2 in. long. Leaves $\frac{1}{4}-\frac{1}{3}$ in. long, undulated at the edge. Umbel 2-3-flowered; pedicels simple or forked, $\frac{1}{2}$ in. long. Perianth pale lilac; outer segments obovate-spathulate, emarginate, with a green mucro, under $1 \frac{1}{2}$ in. long, under $\frac{1}{2}$ in. broad; inner $\frac{1}{4}$ in. longer, acuminate, with a green tip and a yellow oase, inconspicuously spotted.

Hab. Atacama, on a desert coast mountain, called Mejillones, alt. $1200 \mathrm{ft}$, Philippi. Allied to A. violacea.

27. A. rosed Phil. Sert. Mendoc. alt. 43, non Hook.-Flowering stem $1 \frac{1}{2} \mathrm{ft}$. long. Leaves regular, narrow linear, about $\frac{1}{2} \mathrm{in}$. long. Umbel 5-rayed; branches about 3 in. long, usually 3 -flowered. Perianth $1 \frac{1}{2}-1 \frac{3}{4}$ in. long; outer segments rose-red, obovatespathulate, above $\frac{1}{2}$ in. broad; inner narrower, yellow, spotted, with a rose-red cusp.

Hab. Mendoza, Philippi. Allied to A. Ligtu. 
28. A. araucana Plitil. Descr. Nuev. Plant. 1873, 71.-Flowering stem erect, denscly leafy, muder a foot long. Leaves linear, fewnerved, not resupinate, $1 \frac{1}{2}-2 \mathrm{in}$. long, $\frac{1}{6}-\frac{1}{4} \mathrm{in}$. broart. Umbels fewrayed ; rays mostly 2 -flowered. Perianth-segments orange-yellow, nearly 2 in. long; onter ovate-spathulate, with a rounded apex; inner subrhomboid, acute.

Hab. Chili; I'rovince of Araucania, Volckmann. Allied to A. Ligtu.

29. A. Volchinanni Baker. A. stenopetala Phil. Descr. Nuev. Plant. 1873, 71, non Schenck. - Flowering stem 6-15 in. long. Leaves distant, small, linear-lancoulate, the lingest $\frac{3}{1} \mathrm{in.}$ long. Umbel 2-rayed; rays 1-2-flowered. Perianth 2 in. long; outer segments oblanceolate-ungraculate, $\frac{3}{8}$ in. broad; inner narrower, punctate.

Hab. Chili ; Province of Araucania, Volckmann. Allied to A. Ligtu.

30. A. viulacea Phil. Fl. Atac. 51, No. 370. - Leaves of the sterile stem ovate-oblong, petiolei, 5-nerved, with a blade 2 in. long, nearly an inch broad. Flowering stem $1 \frac{1}{2} \mathrm{ft}$. long; leaves distinit, scattcred, erecto patent, linear, under an inch long. Unbel 5-rayed; pedicels forked, 2-3 in. long; bracts about 6, small, ascending, linear. Perianth bright lilac, $1 \frac{1}{2}-2$ in. long; outer segments obovate-mnguiculate, $\frac{3}{4}$ in. broad, truncate, with a small cusp; inner oblong, acute, $\frac{1}{2}$ in. broad, with many small spots. Stamens much shorter than the segments.

Hab. Chili; Desert of Atacama, Philippi! Allied to A. Ligtu.

31. A. Ligtu Linn. Sp. Pl. 462 (Feuill. Obs. ii. 710, t. 4); Lindl. in Bot. Reg. 1839, t. 3. - Flowering stem $1 \frac{1}{2}-2 \mathrm{ft}$. long. Leaves 20-30, thin, ascending, linear or lanceolate, the largest 2-3 in. long, $\frac{1}{4}-\frac{1}{2}$ in. broad. Umbel 3-8-rayed ; rays often forked, 2-3 in. long; bracts several, linear, 1-1 $\frac{1}{2}$ in. long. Perianth about $1 \frac{1}{2}$ in. long; outer segments obovate-ungruiculate, obtuse or cuspidate, $\frac{1}{2}$ in. broad, whitish or pale lilac or pale red, obliquely streaked with purple; inner narrower and more acute. Stamens shorter than the segments.

Var. A. Pulchra Sims in Bot. Mag. t. 2421. A. bicolor Hook. Exot. Flora, t. 65 ; Lodd. Bot. Cab. t. 1147 . A. Flos-Martini Ker in Bot. Reg. t. 731; Sweet, Brit. Flow. Gard. ser. ii. t. 277. A. biculor Lodd. Bot. Cab. t. 1497. - Leaves narrower and longer than in the type. Flower's as large, varionsly coloured, both the outer and inner segments cuspidate or acute.

Hab. Frequent in Chili, and often seen in cultivation in numerous forms. I cannot distinguish specifically $A$. angustifolia Herb., A. Presliana Kunth, A. pallida Graham in Bot. Mag. t. 3040, A. Hookeriana R. \& S. (A. rosea Hook. Exot. Flora, t. 281; A. Hookeri Lodd. Bot. Cab. t. 1272), and A. exserens Meyen. The followlng species recently described by Dr. Philippi must also be near allies:-A. flava, hirtella, Diazi, flava, pallens, inaqualis, and chiloensis.

32. A. Parvula Philippi in Linm. xxxiii. 261.- Flowering stem not more than an inch long above the surface of the ground. Leaves crowded, subrosulate, oblanceolite-sivathulate, about $\frac{1}{2}$ in. long, $\frac{1}{6}$ in. broad. Umbel simple, about 5 -lluwered; pericels $\frac{7}{2}$ in. long; bracts resembling the proper leaves, as long ats the pecticels. 
Perianth rose-red, under an inch long; outer segments obovitespathulate, nearly $\frac{1}{2} \mathrm{in}$. broad; iumer nilrower, linear-oblong.

Hab. Chili; High Andes of Santiago and Aconcagua, Philippi.

33. A. nubigena Philippi in Linn. xxix. 67. - Flowering stem about 4 in. long. Leaves oblanceolate-spathulate, 5-nerved, an iuch long, under $\frac{1}{4}$ in. broad. Umbel simple, 8-9-flowered; pedicels under an inch long. Perianth under an inch long; outer segments rose-red, with a green tip; inner red at the tip, yellow at the middle and dotted, whitish at the base. Stamens much shorter than the segments.

Hab. Chili ; High Andes of the Province of Santiago, Germain.

34. A. Philipri Baker. A. violacea Phil. Descr. Nuev. Plant. 1873, 72, non Fl. Atac. No. 370. - Flowering and sterile stems slender, decumbent, each about a foot long. Leaves of the sterile stem thin, oblong, glabrous, petioled, with a blade about an inch long, above $\frac{1}{2} \mathrm{in}$. broad, those of the fertile stem lanceolatespathulate, $\frac{1}{6}-\frac{1}{4}$ in. broad. Umbel 2-rayeil; pedicels sometimes forked. Perianth bright violet, $1 \frac{1}{2}-2$ in. long; outer segments oblong-unguiculate, obtuse, $\frac{1}{2}$ in. broad ; inner, narrower, acute, spotted. Stamens shorter than the segments.

Hab. Chili ; 20 miles from Carrizal Bajo, King!

35. A. Pelegrina Limn. Sp. Pl. 461 (Feuill. Obs. ii. t. 5); Bot. Mag. t. 139 ; Jacq. Hort. Vind. i. t. 50 ; iii. t. 73 ; Red. Lil. t. 46; Lodd. Bot. Cab. t. 1205. - Flowering stem stout, $\frac{1}{2}-1 \mathrm{ft}$. long. Leaves about 30, thin, lanceolate, ascending, $1 \frac{1}{3}-2$ in. long, $\frac{1}{4}-\frac{1}{2}$ in. broad. Umbel few-rayed and simple in the wild plant, but manyrayed and compound in cultivation; bracts similar in style to the leaves in shape and texture. Perianth lilac, $1 \frac{1}{2}-2$ in. long; outer segments an inch broad, oblong-cordate with a large cusp: inner oblong-spathulate, cuspidate, $\frac{1}{2}$ in. broad, copiously spotted with red-purple. Stamens declinate, much shorter than the segments.

Hab. Chili, near Valparaiso, \&c., introduced into cultivation in 1753. There is a specimen from Lee's garden at Hammersmith in 1774 at the Britisi Museum. A. quillotensis Herb. is a robust cultivated form. A. alba Hort. is a form with unspotted white flowers.

36. A. Gayana Phil. in Linn. xxix. 71.-Flowering stem 2-3 ft. long. Leaves lanceolate, ciliated, not resupinate, the lower 3-4 in. long, $\frac{1}{2}-\frac{3}{4} \mathrm{in}$. broad, the upper growing gradually smaller. Umbel of about 8 forked rays $3 \mathrm{in.} \mathrm{long;} \mathrm{bracts} \mathrm{lanceolate,} \mathrm{an} \mathrm{inch} \mathrm{long.}$ Perianth $1 \frac{3}{4}$ in. long, pale violet; outer segments obovate-emarginate, an inch broad; inner acute, the two upper $\frac{1}{2}$ in. broad, flushecl with yellow and punctate; lower: with an almost orbicular blade $\frac{5}{8} \mathrm{in}$. broad.

Hab. Chili, in shady places, C. Gay. Intermediate between Pelegrina and hemantha.

37. A. hemantha Ruiz et Pav. Fl. Peruv. iii. 60 ; Sweet, Brit. Flow. Gard. ser. ii. t. 158; Regel, Gartenfl. t. 264. A. pulchellu Sims in Bot. Mag. t. 2354; Hook. Exot. Flora, t. 64; Lindl. in Bot. Reg. t. 1008. A. Simsii Spreng. ; Sweet in Brit. Flow. Gard. t. 267. - Flowering stem 2-3 $\mathrm{ft}$. Jong. Leaves crow' 
lanecolate, subpetiolate, glancous beneath, the lower 3-4 in. long, $\frac{1}{2}-\frac{3}{4}$ in. broad, the upper linear. Umbel very compound, manyflowered, with branches 4-6 in. long; bracts thin, lanceolate. Perianth 1 $1 \frac{1}{2}-2$ in. long; onter segments oblong spathulate, acnte, briglit red, timperl with green, $\frac{1}{2}-3$ in. broarl inner oblanceolatemuguiculate, with red-purple spots on a red-yellow ground. Statmens declinate, much shorter than the segments.

Hab. Chili. Common at the present day in European gardens. Var. albida Herb. is a form with whitish flowers.

38. A. aurantiaca D. Don in Sweet Brit. Flow. Gard. ser. 2, t. 205 ; Lindl. in Bot. Reg. t. 1843. A. anren Meyen; Hook. in Jot. Mag. t. 3350. - Flowering stem 2-4 ft. long. Leil es 40-5), thin, lanceolate, subpetiolate, rather glaucous below, the lower 3-4 in. long, $\frac{1}{2}$ in. broad. Flowers $10-30$ in an umbel with long compound rays; bracts like the leares in size and shape. L'erianth bright yellow, $1 \frac{1}{2}-1 \frac{3}{4}$ in. long; onter segments oblong-ungriculate, subobtuse, tipped with grcen, $\frac{1}{2}-\frac{5}{8}$ in. broad; inner narrower, deeper in colour, acute, copiously spotted with claret-brown. Stamens declinate, much shorter than the segments.

Hab. Chili. Common at the present time in European gardens. A. mutabilis Kunze is probably a form either of this or of $A$. hemantha, which are closely allied to one another. $A$. concolor Steud. is a form with pale unspotted Howers.

39. A. venustula Phil. in Linn. xxxiii. 260. - Flowering stem 2-3 in. long, densely leafy only at the apex. Leaves oblongspathulate, $\frac{1}{2}$ in. long, obtuse or subacute, thick in texture, slortly hispid all over both surfaces. Umbel simple, 3 -4-flowered; perticels very short. Perianth $\frac{1}{2}-\frac{5}{8} \mathrm{in}$. long; onter segments with an oblong blade $\frac{1}{3}$ in. broad and a long slender claw; inner oblanceolatemuguiculate, acute, copiously spotted. Stamens as long as the segments.

\section{Hab. Chili, Philippi!}

40. A. Lineatiflora Ruiz et Pav. Fl. Peruv. iii. 60, t. 289.Lerves thin, oblong-spathulate, acute, glabrous, 3-4 in. long, 1-1 $\frac{1}{2}$ in. broad. Umbel with $3-5$ rays reaching 6-8 in. long, bearing each $2-4$ flower's ; bracts about 6 , like the leaves in shape and texture. Perianth lilac, 2 in. long; outer segments obovateumguiculate, acute, an inch broad; inner oblong, acute, under $\frac{1}{2}$ in. broad, much spotterl. Stamens much shorter than the segments.

Hab. Chili, Pavon! (Herb. MIus. Brit.).

41. A. chorillensis Herb. in Bot. Reg. 1843, Misc. No. 95. A. lineatiflora Lindl. in Bot. Rer. 1843, t. 58, non R. \& P.Flowering stem about a foot ling. Leaves thin, oblong-spathulate, bright green, 2-3 in. long, $\frac{3}{4}$ in. broad. Umbel 3-rayed, 8-10-

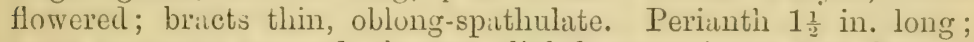
outcr segments rose-recl, oburate, slightly emarginate, $\frac{1}{2}$ in. broul; imner acute, $\frac{3}{8}$ in. broad, flushed with yellow at the middle and dotted. Stamens shorter than the segments.

Hab. Described from a plant cultivated at Chiswick, sent from Lima by Maclean. 
42. A. crocea Phil. in Linn. xxxiii. 262.-Flowering stem $\frac{1}{2} \mathrm{ft}$. long, closely leafy in the upper third. Leaves oblong, acute, firm in texture, abont an inch long, $\frac{1}{3}-\frac{1}{2}$ in. broad. Umbel simple, 2-flowered; pedicels short. Perianth yellow; outer segments obovate-unguiculate, obtuse, $1 \frac{1}{2}$ in. long, $\frac{1}{2}$ in. broad; inner $\frac{1}{4}$ in. longer, narrower, acute. Stamens as loug as the outer segments.

Hab. Chili, Philippi! Allied to A. spathulata.

43. A. spathulata Presl, Rel. Haenk. ii. 122, tab. 22, fig. 2.Flowering stem $\frac{1}{2}-1 \mathrm{ft}$. long. Leaves crowded in the upper part of the stem, oblong-spathulate, thick in texture, glabrous, crisped and scariose at the edge, subobtuse, 1-2 in. long, $\frac{1}{4}-\frac{3}{4}$ in. broad. Umbel simple, ferw-flowered; pedicels short. Perianth reddish, 1-1 $\frac{1}{2}$ in. long ; outer segments obovate-unguiculate, obtuse, $\frac{1}{3}-\frac{1}{2}$ in. broad; inner oblong-unguiculate, acute, $\frac{1}{4}$ in. broad. Stamens usually shorter than the segments.

Hab. Andes of Chili and Mendoza, Gillies! Bridges! C. Gay! A. sericantha Schauer (A. umbellata Meyen) is probably a dwarf form of this species, and A. Neillii Hook, in Bot. Mag. t. 3105, a robust cultivated condition. A. andina Phil. in Linn. xxix. 69, seems to differ mainly by its smaller flowers, but we have a dwarf alpine form of sputhulute from C. Gay with perianth only 7-8 lines long and stamens as long as the segments.

44. A. crispata Phil. in Linn. xxix. 70,-Flowering stem 3-4 in. long, densely leafy only in the upper quarter. Leaves with a suborbicular very much crisped blade $\frac{1}{6}-\frac{1}{4} \mathrm{in}$. long and broad, and a long flat petiole. Flowers $6-12$ in a simple umbel ; pedicels $\frac{1}{2}-\frac{3}{4}$ in. long; bracts many, small, lanceolate. Perianth $\frac{5}{6}$ in. long; seg. ments obovate-unguiculate, obtuse, with a long claw and a small blade $\frac{1}{8}-\frac{1}{6}$ in. broad. Stamens a little longer than the segments.

Hab. Chili, Philippi! A very distinct and curious littte species.

\section{Bomarea Mirb.}

Perianth funnel-shaped; tube none; segments of each row nniform, but those of the two rows dissimilar, the three onter firmer in texture, oblanceolate-oblong, the three inner broadest at the point and narrowed to a distinct grooved clinw. Stamens attached to the base of the segments, about equalling them; filaments filiform; anthers oblong, basifixed. Ovary 3-celled; ovules many, superposed; style filiform; stigma trifid. Ciupsule turbinate, truncate at the apex, 6 -ribbed, finally dehiscing. Seerls subglobose, with a pulpy testa. - Rivot-fibres slender, often thickened towards the tip into large tubers. Stems usually elongated and sarmentose. Leaves usually resupinate, obscurely petioled, usually oblong, acute. Umbels simple or compound. Inner segments of the perianth equalling or exceeding the outer.

Subgenus Spirærine. High mountain types with suberect stems, of which the leaty part is not more than $\frac{1}{2} \mathrm{ft}$. long.

Leaves linear or lanceolate . . . Sp. 1-8. Leaves oblong or oblong-lanceolate - Sp.9-20. 
Sulgenus Wiciurea. High mountain types with suberect stems, much decurved at the top, and crowded ascending non-resupinate leaves

Subgenus Bonarea proper. Stems elongated, sarmentose. Leaves resupinate, usually oblong.

Perianth-segments equal. Umbel simple. Flowers small . . . . .

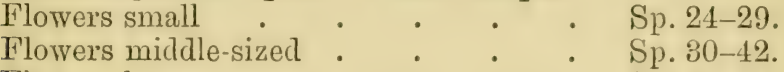
Flowers large . . . . . Sp.43-51.

Perianth-segments equal. Umbel compound. Flowers small • . . . . Sp. 52. Flower's middle-sized : $\quad$. $\quad$ Sp.53-56. Flower's large . • . . . Sp. 57-63.

Inner perianth-segments distinctly longer than the outer. Umbel simple.

Flowers middle-sized . . . . . Sp. 64-65. Flowers large . . • . . . Sp. 66-71.

Inner perianth-segments distinctly longer than the outer. Umbel compound.

Flowers small . . . . . Sp. $72-73$. Flowers large : $\quad . \quad$. $\quad . \quad$ Sp. $74-75$.

\section{Subgenus Sphærine.}

1. B. Linifolia Baker in Journ. Bot. 1882, 201. Alstrameria linifolia H. B. K. A. rosmarinifolia Benth. Spllarine linifolia Kunth. - Stems slender, pubescent upwards, erect, $\frac{1}{2}-1 \frac{1}{2} \mathrm{ft}$. long. Leaves linear or lanceolate, spreading, $1-1 \frac{1}{2} \mathrm{in}$. long, $\frac{1}{6}-\frac{1}{3} \mathrm{in}$. broad, firm in texture, with strongly revolute edges, glaucous and glabrous beneath. Umbel simple, 3-6-flowered, bracteated by a whorl of lanceolate leaves; pedicels $\frac{1}{2}-1 \mathrm{in}$. long, often bracteate. Ovary turbinate, densely pilose. Segments all $\frac{1}{3}-\frac{1}{2} \mathrm{in.}$ long; outer much tinged with red; inner yellow, spotted.

Hab. High Andes of New Granada and Ecuador, 10,000-13,000 ft.

2. B. Leminann Baker in Journ. Dot. 1883, 373. - Stems subcrect, slender, glabrous, 2-3 ft. long. Leaves crowded, ascending, rigid, linear, with recurved edges, glaucous beneath, 3 in. long. Umbel erect, compound; bracts $6-8$, similar to the leaves; ray; 6-8, 4-5 in. long, 2-3-flowered, pubescent npwards; flower-bracts

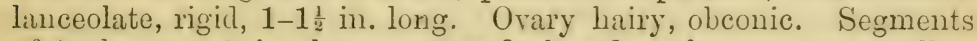
of both rows $\frac{1}{2}$ in. long; outer dark red, pubescent externally; inner light red.

Hab. Andes of Canclimarca, alt. 10,000-11,000 ft., Lehmann 2420!

2. B. cruevia Krand (Chac Leaves lax, linear, crecto-patent, rigid, with revolute edges, strongly ribbed and densely piluse beneath, 4-5 in. long. Unbel erect, compound ; bracts few, just like the leaves ; rays 4, 3-4 in. long, 2-3-1lowered, with large bricts at the forks. Ovary small, obconic, 
glabrous. Perianth-segments all $\frac{3}{4}-\frac{7}{8}$ in. long; outer tinged with red; inner greenish yellow, nearly $\frac{1}{4}$ in. broad at the tip.

Hab. Andes of Columbia, Lobb!

4. B. Hispida Baker in Journ. Bot. 1882, 202. - Stems 1-2 ft. long, decumbent at the base, leaty in the upper half or third. Leaves moderately close, ascending, lanceolate, firm in texture, $1 \frac{1}{2}-2 \mathrm{in}$. long, $\frac{1}{3}-\frac{1}{2} \mathrm{in}$. broad, glaucons and densely hispid on the ribs beneath. Umbel erect; bracts large, lanceolate; rays 2-3, 1-2-flowered, 1 1 - $2 \mathrm{in}$. long, bracteate at the middle. Ovary small, turbinate, pubescent. Segments all $\frac{1}{2}-\frac{5}{3}$ in. long; outer tinged with red; inner yellow, tinged with red.

Hab. New Granada; Paramos of Ocana, 8000-10,000 ft., Schlim 486 ! Goudot! Kalbreyer 563 !

5. B. minima Baker in Journ. Bot. 1882, 202. - Stems slender, $1 \frac{1}{2} \mathrm{ft}$. long, decumbent at the base, leaty and hairy in the rpper third. Leaves close, ascencling, lanceolate, slightly hairy beneath, firm in texture, $1-1 \frac{3}{4} \mathrm{in}$. long; edges narrowly revolute. Umbel simple, 2-flowered ; bracts large, lanceolate; pedicels $1 \frac{1}{2}$ in. long; with a lanceolate bract at the middle. Ovary hemispherical, glabrous. Segments all $\frac{1}{2}$ in. long; outer tinged with red, narrowed in the lower half; inner rather shorter, greenish yellow, spotted.

Hab. New Granada; Paramo of Cuchero, Purdie!

6. B. chmiboracensis Baker in Engl. Jahrb. 1887, 212. - Stem short, suberect, glabrous, cernuous at the apex. Leaves crowded, ascending, lanceolate, rigid, glabrous, closely strongly ribbed, 2-3 in. long, $\frac{1}{3}-\frac{1}{2}$ in. broad. Umbel dense, simple, 6-10 flowered ; bracts 4-5, just like the leaves; pedicels slender, naked, under an inch long. Ovary turbinate, glabrous. Segments all $\frac{5}{8}$ in. long; outer reddish; inner spathulate, yellowish green, $\frac{1}{6}$ in. broad.

Hab. Ecuador; Paramos of Chimborazo, alt. 12,000 ft., Lehmann!

7. B. Brevis Baker in Journ. Bot. 1882, 202. Splucerine breris Iferb.-Stems suberect, glabrous, leaty in the upper half. Leaves oblanceolate, acute, moderately firm in texture, 3-4 in. long, $\frac{1}{2}-\frac{3}{4}$ in. broad at the middle, glabrons beneath. Umbel simple, 3-flowered; bracts one large, the others small; pedicels an inch long, not bracteated. Oviry turbinate, pubescent. Segments all 5 in. long; onter oblanceolate-oblong, tinged with red, emarginate and comnate below the tip.

\section{Hab. Andes of Peru, Mathews 1660!}

8. B. nervosa Baker in Journ. Bot. 1882, 202. Spharine nervosa IIerb.- Stems suberect, glabrous, leaty in the rpper foot. Leaves lanceolate, firm in texture, acuminate, glancous and glabrous beneath, 4-5 in. long, under an inch broad. Umbel simple, erect, 20-30-flowered; bracts 3, large, oblong-lanceolinte; peclicels $1 \frac{1}{2} \mathrm{in}$. long, stiffly erect, pubescent, not bracteated. Ovary turbinate, pubescent. Segments all $\frac{1}{2}$ in. long; outer linear-oblong; inner with a claw as long as the cuneate limb.

Hab. Andes of l'eru, Mlathews 1661! 
9. B. stenopetala Baker in Engl. Bot. Jahrb. 1887, 212.Stems slender, erect, glabrous, slightly flexuose, 2-3 ft. long. Leaves lax, erecto-patent, oblong-lanceolate, very acute, rigid, glabrous, strongly ribbed; lower 3-4 in. long, $\frac{33}{4}$ in. broad. Umbel few-flowered, erect, simple or compound ; bracts $2-3$, large, linear or lanceolate; rays flexuose, 2-3 in. long, naked or bracteolate. Ovary obconic, glabrous. Perianth-segments all $\frac{3}{4} \mathrm{in}$. long; outer dark lake-red; inner orange-red, with a long claw and small cuneate limb.

Hab. New Granada; Woods of Antioquia, alt. 8000-10,000 ft., Lelemann!

10. B. punila Griseb. in Lechl. Pl. Peruv. Exsic. No. 2240.Stems very slender, decumbent at the base, flexuose, leaty only in the top, 1-2 in. Leaves oblong, obtuse, $\frac{3}{1}-1 \frac{1}{4} \mathrm{in}$. long, thin, glaucous and glabrous beneath. Flower solitary, horizontal; pedicel densely pilose, under an inch long. Ovary turbinate, densely pilose. Perianth-segments equal in length, greenish yellow, $\frac{1}{3}$ in. long; outer oblanceolate; inner cuneate.

Hab. Peru; Sachapata, Lechler!

11. B. Biliceul is Branal. CHuth. Plant. Hartweg. 157. - Stems $\frac{1}{2}-1 \frac{1}{2} \mathrm{ft}$. long, decumbent at the base, glabrous, flextose and leafy in the upper third. Leaves 6-8, oblong, firm in texture, obtuse, cuspidate, $1 \frac{1}{2}-2$ in. long, half as broad, glabrous bencath. Umbel 2-3-rayed; bracts 2-3, just like the leaves; pedicels 1-2 in. loug, naked or minutely bracteate. Outer segments oblong; $\frac{1}{2} \mathrm{in.}$ long; inner $\frac{3}{4}$ in. long, cuneate, with a long claw.

Hab. Andes of Peru; Loxa, Hartweg 855 !

12. B. Secundifolia Baker in Journ. Bot. 1882, 202. Alstrameria secundifolia Ruiz et Pav. Fl. Peruv. iii. 60, t. 290 A. Sphcerine secundifolia Herb. - Stems suberect, 2 ft. long, glabrous, leafy in the upper half. Leaves oblong-lanceolate, firm in texture, 3-4 in. long, an inch broad, strongly ribbed, glabrous beneath. Umbel simple; bracts small, lanceolate; pedicels pubescent, an inch long; Segments all $\frac{3}{4}-\frac{7}{8}$ in. long; outer reddish, externally pubescent; inner yellow, spotted.

Hab. Andes of Peru, near Muna, Pavon! (Herb. Mus. Brit.).

13. B. Recurva Baker.-Stems slender, glabrous, 1-1 $\frac{1}{2} \mathrm{ft}$. long, leafy in the upper half, much recurved at the apex. Leaves oblong, acute, glabrous, moderately firm in texture, 3 in. long, an inch broad. Umbel simple, 2-3-flowered; one large bract; pedicels an inch long. Fruit glabrous, turbinate. Inner segments s. obovate, with a narrow claw as long as the blade, yellowish green.

Hab. Andes of Peru; Sachapata, Lechler 2629 !

14. B. angustipetala Baker in Journ. Bot. 1882, 202. Spharine angustipetala Benth. - Stems slender, erect, glabrous, a foot long, leafy in the upper half. Leaves oblong-lanceolate, very acute, $1 \frac{1}{2}-2 \mathrm{in.}$ long, moderately firm in texture, hispid on the raised ribs beneath. Umbel simple, 4-rayed; bracts 5-6, large, lanceolate or oblong-lanceolate; pedicels about 3 in. long, with a lanceolate 
bract at the middle. Ovary obconic, glabrous. Segments all $\frac{3}{4}-1$ in. long, oblanceolate, $\frac{1}{6}-\frac{1}{4}$ in. broad.

Hab. Andes of Bogota, alt. $9000 \mathrm{ft}$., Hartweg!

15. B. Distichophylla Baker in Journ. Bot. 1882, 202. Alstremeria distichophylla Ruiz et Pav. Fl. Peruv. iii. 60, t.287 A. Spharine distichophylla Herb.-Stems suberect, glabrous, $1 \frac{1}{2}-2 \mathrm{ft}$. long, leafy in the upper half, not flexuose. Leaves lax, oblong, acute, moderately firm in texture, $2-3$ in. long, $\frac{3}{4}-\frac{7}{8}$ in. broad, glaucous and slightly pilose beneath. Umbel simple; bracts 2 , similar to the leaves; rays 3-6, slender, curved, glabrous, an inch long, not bracteate. Ovary turbinate, glabrous. Segments all $\frac{1}{3}-\frac{1}{2}$ in. long; outer bright red.

Hab. Peru; Andes of Muna, alt. 10,000-11,000 ft., Pavon! Pearce 159!

16. B. podopetala Baker in Joum. Bot. 1882, 202. - Stems suberect, glabrous, 1-1 $\frac{1}{2} \mathrm{in}$. long, very flexuose in the leafy upper half. Leaves lax, oblong, rigid, glabrous, $2-2 \frac{1}{2} \mathrm{in}$. long, under an inch broad, glaucous beneath. Umbel simple, $2-3$-flowered; bracts 2-3, large, oblong; pedicels slender, curved, 2-3 in. long. Ovary very small. Outer segments oblong, reddish, $\frac{5}{8} \mathrm{in.}$ long; inner $\frac{3}{4}$ in. long, cuneate, with a long claw.

Hab. Andes of Southern Ecuador, alt. 9000-10,000 ft., André 4611 bis !

16. B. polygonatoides Baker in Journ. Bot. 1882, 202.-Stems suberect, glabrous, above a foot long, not flexuose in the leaty upper half. Leaves 12-15, lax, ascending, oblong, acute, firm in texture, 2-3 in. long, $\frac{3}{4}-1$ in. broad. Umbel simple, 2 -flowered; pedicels $\frac{1}{2}$ in. long. Ovary small, glabrous. Segments all $\frac{1}{4}$ in. long, bright yellow.

Hab. Andes of Southern Ecuador, alt. 9000-10,000 ft., André!

18. B. coccinea Baker in Journ. Bot. 1882, 202. Alstrameria coccinea Ruiz et Pav. Fl. Peruv. iii. 62, tab. 291, fig. a. Spharine coccinea Herb.-Stems about $3 \mathrm{ft}$. long, pilose, flexuose and leaty in the upper half. Leaves oblong, acute, $3 \mathrm{in}$. long, $1 \frac{1}{4}-1 \frac{1}{2} \mathrm{in}$. broad at the middle, pilose beneath. Umbels simple; bracts suppressed; rays $2-4$, pilose, $2-2 \frac{1}{2}$ in. long. Ovary turbinate, pubescent. Segments all about $\frac{1}{2} \mathrm{in}$. long; outer bright red; inmer greenish yellow, spotted.

Hab. Andes of Peru, Ruiz \& Pavon. This I have not seen.

19. B. Hartwegir Baker in Journ. Bot. 1882, 203. B. simplex Benth. Pl. Hartweg. 156, non Herb.-Stems suberect, 1-2 ft. long, leaty, densely pubescent and flexuose in the upper half. Leaves lax, petioled, oblong, acute, rounded at the base, 2-3 in. long, moderately firm in texture, strongly nerved and densely pubescent beneath. Umbel simple, 4-8-flowered; bracts suppressed or 2, like the leaves; pedicels curved, densely pilose, 1-1 $1 \frac{1}{2} \mathrm{in}$. long, not bracteolate. Perianth-segments red, equal in length, $\frac{3}{4}$ in. long; outer oblanceolate; inner with a small blade and long claw.

Hab. Peru; Cordilleras of Loxa, Hartweg! South Ecuador, alt. 900010,000 ft., André! 
20. B. Dissitifolia Baker in Journ. Bot. 1882, 203. - Stems suberect, $1-1 \frac{1}{2} \mathrm{ft}$. long, straight, leaty in the upper half. Leaves lax, oblong-lanceolate, acute, 2-3 in. long, firm in texture, green and glabrous beneath, with about 40 close raised veins. Flowers 6-8 in a simple umbel; bracts minute, lanceolate; pedicels curved, densely pubescent, not bracteolate, $1-1 \frac{1}{2}$ in. long. Periantlsegments equal in length, $\frac{3}{4} \mathrm{in}$. long; outer oblanceolate, orangered ; inner narrowly obovate-unguiculate, spotted with violet.

Hab. Andes of South Ecuador, alt. $9000 \mathrm{ft} .$, André !

zOA Bisquasulosa Krivazil. (Colombiáor Ecundor)

Subgenus Wichuræa.

21. B. glaudescens Baker in Journ. Bot. 1882, 201. Alstrameria glancescens H. B. K. Collania glaucescens Herb. Wichurce glancescens Roem.--Stems 1-2 ft. long, stiffly erect, decurved at the apex. Leaves rigid, linear, with very revolute edges, very ascending, I-2 in. long. Umbel simple, 3-6-flowered; pedicels about $\frac{1}{2} \mathrm{in.} \mathrm{long;} \mathrm{bracts} \mathrm{rigid,} \mathrm{lanceolate,} \mathrm{an} \mathrm{inch} \mathrm{long.} \mathrm{Ovary} \mathrm{glabrous.}$ Perianth $\frac{3}{4} \mathrm{in}$. long; segments equal in length; outer tinged with red; inner spotted with claret-red.

Var. Dulcis Baker. Alstrameria dulcis Hook. Bot. Musc. ii. 237, t. 95. Collania dulcis Herb. ; Lindl. in Bot. Reg. 1837, t. 34. Wichurca dulcis Roem.-A depauperated form, with slender less rigid stems, smaller leaves and bracts, and only 1-2 flower's.

Var. pUberula Baker. Collania puberula Herb. Wichuraa puberula Roem.-Umbel much laxer, many-flowered, compound, with pedicels $2-3$ in. long, with a large lanceolate bract at the fork. Flowers larger.

Hab. High Andes of Ecuador, Bolivia and Peru, ascending to 13,000 ft. on Pichincha and 14,000 on Sorata. Collania nutans Herbert MSS. is a form with an elongated slender sarmentose stem.

22. B. Andinarcana Balier in Journ. Bot. 1882, 201. Collania andimarcana Herb.; Hook. in Bot. Nag. t. 4247. Wichurca andimarcana Roem.-Stems stout, suberect, glabrous or pubesecent, much decurved at the top. Leaves crowded, sessile, erectopatent, glossy, lanceolate, moderately firm in texture, $3-5$ in. long, $\frac{1}{4}-\frac{1}{2}$ in. broad, glaucous and pubescent beneath. Umbel of few simple or forked rays about an inch long; bracts like the leaves or broader. Perianth $1 \frac{3}{4}-2$ in. long; segments equal in length; outer linear-oblong, much tinged with red; inner yellowish green, $\frac{1}{3}-\frac{1}{2}$ in. broad at the tip. Stamens exserted.

Hab. High Andes of Peru, MIathews 1164! MIaclean! The plant figured in the 'Botanical Magazine,' which was flowered by Messrs. Veitch in 18t6, from seeds collected by Lobb, has a lax umbel, with pediccls $3-4$ in. long, with large bracts at the fork.

23. B. intolucrosa Baker in Journ. Bot. 1882, 201. Collania involucrosa Herb. Amaryll. 103, t. 9. Wichurca inrolucrosa Roem. - Stems stout, suberect, 3-4 ft. long, very cermuous at the apex. Leaves crowded, ascending, linear, with revolute edges, firm in texture, erecto-patent, 4-5 in. long, glaucous and densely pilose beneath. Flowers 6-20 in a dense simple umbel, surrounded by 
numerous oblung glossy bracts $1 \frac{1}{2}-2$ in. long; pedicels very short. Perianth 2 in. long; all the segments oblanceolate, $\frac{1}{4}-\frac{1}{3}$ in. broad.

Hab. High Andes of Peru and Bolivia.

23.A 8 macyocephela Prox (Angeretiva)

23 B B. Fitsig $=$ Kribzl. (Boline. Subgenus Bomarea proper.

23 C B. macrouthera kinuzl.

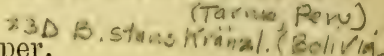

24. B. тоRта Herb. Amaryll. 115. Alstrameria torta H. B. K. B. cumbrensis Herb. - Stems elongated, slender, sarmentose, glabrous. Leaves crowded upwards, linear or lanceolate, $1 \frac{1}{2}-2$ in. long, moderately firm in texture, glabrous beneath. Flowers 6-10 in a simple umbel; bracts large, lanceolate, pedicels very slender, $\frac{1}{2}-\frac{3}{4}$ in. long. Ovary hemisplerical, glabrous. Perianth-segments equal in length, $\frac{5}{8}-\frac{3}{4} \mathrm{in}$. long ; outer oblanceolate, tinged red; inner cuneate-unguiculate, yellowish green, spotted.

Hab. Andes of Ecuador and Peru, gathered by Humboldt, Jameson, and Mathews.

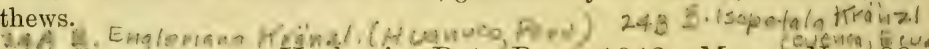

25. B. Uncifolia Herb. in Bot. ${ }^{2}$ eg. 1842, Musc. No. 88. B. platypetalu Benth. Stems slender, glabrons, elongated, sarmentose. Leaves lax, linear or lanceolate, $2-3$ in. long, moderately firm in texture, glabrous and glaucous beneath. Flowers 4-10 in a simple umbel; bracts several, large, lanceolate; pedicels slender, 1-2 in. long, not bracteolate. Perianth-segments equal in length, $\frac{3}{4}$ in. long; outer oblong; innes cuneate-unguiculate, with a blade $\frac{1}{4}$ in. broad.

Hab. Andes of Ecuador, ascending to $12,000 \mathrm{ft}$. Gathered by Jameson, Hartweg, Spruce, and André.

26. B. angustifolia Benth. Pl. Hartweg, 156. - Stems elongated, sarmentose, strongly angled, glabrous. Leaves spreading, lanceolate, 3-4 in. long, $\frac{1}{4}-\frac{1}{3} \mathrm{in}$. broad, moderately firm in texture, green, glabrous and closely ribbed beneath. Flowers 20-30 in a simple umbel; bracts many, just like the leaves; pedicels 1-2 in. long, very slender, glabrous, not bracteolate. Perianth-segments equal in length, $\frac{3}{4} \mathrm{in}$. long; outer ublanceolate; inner with a small blade and very long claw.

Hab. Peru ; Cordilleras of Loxa, Hartweg 853 !

27. B. glomerata Herb. Amaryll. 115, tab. 15, fig. 1.-Stems elongated, slender, sarmentose, pubescent upwards. Leaves lax, oblong-lanceolate, $2-3 \mathrm{in}$. long, moderately firm in texture, glabrous or pubescent beneath. Flowers a dozen or more in a dense simple umbel; bracts minute, linear; pedicels slender, downy, $\frac{1}{2}-\frac{3}{4}$ in. long. Ovary pilose. Perianth-segments equal in length, $\frac{1}{2}$ in. long; outer oblanceolate; inner oblanceolate-unguiculate.

Hab. Andes of Columbia and Peru, II athews 1662! Lobb 256!

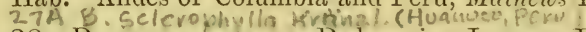

28. B. PACHYPhLEBIA Baker in Journ. Bot. 1882, 204.--Stems elongated. sarmentose, glabrous. Leaves lax, shortly petioled, oblong-lanceolate, acute, firm in texture, $2-2 \frac{1}{2} \mathrm{in}$. long, $\frac{1}{2}-\frac{5}{8} \mathrm{in}$. broad, obscurely pilose beneath, with about 40 crowded raised veins. Umbel simple, 6-8-flowered; bracts small, lanceolate; pedicels densely pubescent, ebracteolate, under an inch long. 
Perianth-segments equal in length, s. in. long; outer oblanceolate, tinged with red; inner cuneate-unguiculate, yellow.

Hab. Andes of Southern Ecuador, alt. 10,000 ft., André! Allied to B. tomentosa.

29. B. tonentosa Herb Amaryll. 117. Alstrameria tomentosa Ruiz et Pav. Fl. Peruv. iii. 62, t. 293 в. B. setacea Herb. Alstremeria setacer Ruiz et Pav. Fl. Peruv. t. 262 в. B. densiflora Herb.; Bot. Mag. t. 5531. - Stems elongated, sarmentose, pubescent. Leaves lax, petioled, oblong, acute, 2-4 in. long, moderately firm in texture, densely pubescent beneath. Umbel simple, deuse, manyflowered; bracts many, small, lanceolate; pedicels 1-2 in. long, pubescent, not bracteolate. Perianth-segments equal, $\frac{1}{3}-\frac{3}{4}$ in. long; outer oblanceolate, tinged with red; inner cuneate-unguiculate, yellow.

Hab. Andes of New Granada, Ecuador and Peru, 6000-11,000 ft. Introduced into cultivation in 1865 by Messrs. Veitch.

30. B. LANcifolia Baker in Journ. Bot. 1882. 202. - Stems elongated, stout, sarmentose, finely pubescent. Leaves lax, ascending, lanceolate, acuminate, $3-4$ in. long, $\frac{1}{3}-\frac{1}{2}$ in. broad low down, green and glabrous on both surfaces. Flowers 30-40 in a simple umbel; bracts small, lanceolate; pedicels ebracteolate, about an inch long, Ovary turbinate, pubescent. Perianth-segments equal in length, $\frac{3}{4}-\frac{7}{8}$ in. long; outer oblanceolate, tinged with red; inner golden yellow, with a long distinct claw.

Hab. Andes of Quito, alt. 6000-9000 ft., André !

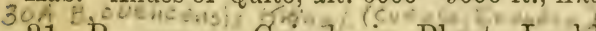

31. B. CERnua Griseb. in Plant. Lechler, No. 2597. - Stems elongated, very slender, sarmentose, finely pubescent. Leaves lax, lanceolate, $1 \frac{1}{2}-2 \mathrm{in}$. long, $\frac{1}{2} \mathrm{in}$. broad, thin in texture, glaucous and pubescent beneath. Flowers $3-4$ in a simple umbel, very cernuous ; bracts $3-4$, just like the leaves ; pedicels $1-1 \frac{1}{2}$ in. long, densely pubescent, not bracteolate. Ovary hemispherical, densely pubescent. Perianth-segments equal in length, an inch long; outer oblanceolate-spathulate; inner obovate-unguiculate, $\frac{1}{3} \mathrm{in}$. broad.

Hab. Peru; Andes of Sachapata, Lechler !

32. B. Finbriata Herb. Amaryll. 116. Alstrcemeria fimbriata Ruiz et Pav. Fl. Peruv. iii. 63, t. 293 A.-Stems elongated, sarmentose, glabrous. Leaves lax, lanceolate, $3-5$ in. long, $\frac{1}{2}-\frac{3}{4} \mathrm{in}$. broad, firm in texture, closely ribbed, glabrous or slightly pubescent beneath. Flowers many in a dense simple umbel; bracts small,

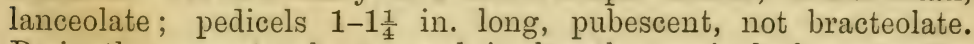
Perianth-segments about equal in length, an inch long; outer dark-coloured, oblanceolate-spathulate; inner obovate-unguiculate, $\frac{1}{3}$ in. broad, yellow, copiously spotted.

Hab. Andes of Peru and Bolivia, Nathews 867! MIandon 1202! I cannot distinguish specifically $B$. subglobosa, floribunda and anceps Herb.

33. B. stenopetala Balier. - Stems elongated, sarmentose, acutely angled, pubescent. Leaves lax, petioled, oblong, acute, 3-4 in. long, about an inch broad, very thick and rigid in texture, densely pubescent on the thick crowded veins beneath. Flowers 
many in a dense simple umbel; bracts minute; pedicels densely

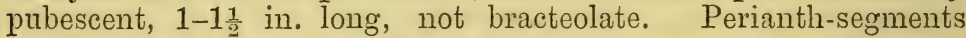
equal in length, an inch long; outer oblanceolate, red-brown; inner bright yellow, oblanceolate-unguiculate, under $\frac{1}{4} \mathrm{in}$. broad. 2783 !

Hab. Andes of New Granada; Ocana and Cauca. Kalbreyer! Lehmann

34. B. CRassifolia Baker.-Stems elongated, sarmentose, very flexuose, persistent, shortly pubescent. Leaves lax, lanceolate, 2-3 in. long, $\frac{1}{2}-\frac{3}{4}$ in broad, very thick, rigid, pubescent beneath, strongly ribbed. Flowers $12-15$ in a simple umbel; bracts minute, linear; pedicels an inch long, densely pubescent, not bracteolate. Ovary small, pubescent. Perianth-segments equal in length, under an inch long; outer oblanceolate, red-brown; inner cuneate-unguiculate, $\frac{1}{3}$ in. broad, yellowish green, spotted.

Hab. New Granada; Andes of Antioquia, alt. 8000 -9000 ft., Lohmmann ! Near B. fimbriata Herb.

35. B. Halliana Herb. Amaryll. 112, tab. 10, fig. 3.-Stems elongated, slender, sarmentose, glabrous. Leaves lax, petioled, lanceolate, 3-4 in. long, $\frac{3}{4}$ in. broad, thin in texture, distantly ciliated on the ribs beneath. Flowers about 6 in a simple umbel; bracts small; pedicels 1-1 $\frac{1}{2}$ in. long, puboscent, not bracteolate. Ovary densely pubescent. Perianth-segments equal in length, an inch long; outer oblanceolate; inner cuneate-unguiculate, yellow, spotted with claret-brown, $\frac{1}{3}$ in. broad.

Hab. Andes of Ecuador; Patacocha, Col. Hall!

36. B. aurantiaca Herb. Amaryll. 399, t. 46, fig. 1. B. Macleanica Herb.-Stems stout, elongated, sarmentose, densely pubes-

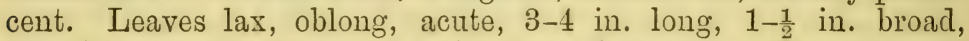
densely matted with grey pubescence beneath. Flowers very numerous, arranged in a dense globose umbel; bracts small, numerous; pedicels $1 \frac{1}{2}-2$ in. long; pubescent, not bracteolate. Perianth-segments equal in length, an inch long; outer brownish, oblanceolate-spathulate; inner obovate-unguiculate, bright yellow, not spotted, $\frac{1}{2}$ in. broad.

Hab. Andes of Peru and Bolivia, MLathews 1160 ! MIandon 1203!

37. B. angulata Benth. Pl. Hartiveg, 156.-Stems elongated, sarmentose, glabrous, acntely angled. Leaves lax, petioled, oblong, acute, 3-4 in. long, 1-1 $\frac{1}{4}$ in. broad, moderately firm in texture, glaucous and slightly pubescent beneath. Flowers about 20 in a simple umbel; bracts many, large oblong, leaf-like; pedicels 1-1 $\frac{1}{2}$ in. long, glabrous, not bracteolate. Ovary glabrous. Perianthsegments equal in length, an inch long; outer oblanceolate; inner a little longer, obovate-unguiculate, $\frac{1}{3} \mathrm{in}$. broad.

Hab. Peru; Andes of Loxa, Hartweg! Very near B. multiflora Mirbel.

38. B. multiflora Mirb. in Roem. Amaryll. 276. Alstremeria multiflora Linn. fil. B. Bredemeyeriana Herb.; Flore des Serres, t. 2316. A. Bredemeyeriana Villd. B. Fanningiana Herb.-Stems elongated, sarmentose, finely pubescent. Leaves lax, petioled, oblong, acute, $3-4 \mathrm{in}$. long, thin in texture, glabrous or pubescent 
beneath. Flowers $20-40$ in a dense simple umbel; bracts many, oblong, foliaceous ; pedicels $\frac{3}{4}-1 \mathrm{in}$. long, pubescent, not bracteolate. Perianth-segments nearly equal in length; outer oblanceolate, an inch long, tinged with red; inner a little longer, obovate-unguiculate, $\frac{1}{2}$ in. broad, reddish yellow, copiously spotted with claretbrown.

Hab. Mountains of Venezuela and New Granada. Description mainly taken from the original specimen gathered by Mutis, in the Linnean Herbarium.

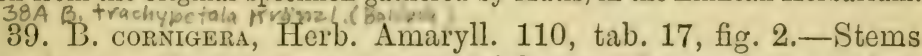
very slender, clongated, sarmentose, glabrous. Leaves lax, petioled, oblong-lanceolate, $1 \frac{1}{2}-2$ in. long, $\frac{1}{2} \mathrm{in}$, broad, thin in texture, glabrous beneatl. Flower's 1-3 in a simple umbel; bracts unequal, sometimes large; pedicels $1 \frac{1}{2}$ in. long, with small bracteoles near the base. Perianth-segments equal in length, an inch long; outer oblong-spathulate, emarginate, with a distinct apical spur; inner obovate-unguiculate.

Hab. Andes of Peru, Mathews 1659 !

40. B. Rosea Herb. Amaryll. 118. Alstrameria rosea Ruiz. et Pav. B. variabilis Herb. B. simplex Herb. in Bot. Mag, t. 3863. - Stems elongated, sarmentose, glabrous. Leaves lax, petioled, oblong, acute, 3-4 in. long, thin in texture, glaucous and pubescent bencath. Umbel usually simple; flower's ferw or many; bracts small; pedicels slender, glabrous, $1 \frac{1}{2}-2$ in. long, often bracteolate at the middle. Perianth-segments equal, an inch long; outer oblanceolate, pale red tipped with green; inner obovate-unguiculate, greenish yellow, spotted.

Hab. Andes of Peru, Bolivia and Tucuman. Herbert's two varieties, placed under $B$. purpurea, are apparently many-flowered forms of this species.

41. B. oligantha Baker in Gard. Chron. 1877, ii. 648.-Stems slender, elongated, sarmentose, glabrous. Leaves lax, oblong, acute, 3-4 in. long, thin in texture, densely pubescent beneath. Flowers $6-8$ in a simple umbel; bracts large, foliaceous; pedicels pubescent, 1-1 $\frac{1}{2}$ in. long, often bracteolate. Ovary densely pubescent.

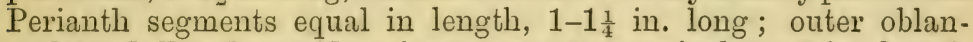
ceolate, dull red outside; inner cuneate-unguiculate, $\frac{1}{3}$ in. broad, bright yellow, with claret-brown spots.

Hab. Andes of Peru; introduced by Leichlin in 1877. The specimens from which the original description was made are very poor and weak.

42. B. purpurea Herb. Amaryll. 118. Alstrameria purpurea Ruiz et Pav. Fl. Peruv. iii. 63, t. 294 A. - Stems elongated, sarmentose, pubescent. Leaves lax, oblong-lanceolate, acute, 3-4 in. long, an inch broad, pubescent beneath. Flowers 20-60 in a dense simple umbel; bracts small, linear-lanceolate; pedicels $1 \frac{1}{2}$ in. long, often furnished with a small lanceolate bracteole at the middle. Perianth-segments equal, purple, an inch long; outer oblanceolate; inner obovate-unguiculate.

Hab. Woods of the Peruvian Andes, Pavon!

43. B. multipes Benth. Pl. Hartweg, 156.-Stems elongated, sarmentose, glabrous. Leaves lax, lanceolate, acuminate, 4-5 in. long, $\frac{3}{4}$ in. broad, moderately firm in texture, glabrous beneath. 
Flowers 40-50 in a lix irregular simple umbel ; outer bracts large, leafy; pedicels $3-4$ in. long, glabrous, not bracteolate. Ovary glabrous. Perianth-segments equal in length, $1 \frac{1}{2}-1 \frac{3}{4}$ in. long; outer oblanceolate, tinged with red, scarcely $\frac{1}{4}$ in. broad; inner rather longer, obovate, with a very long narrow claw.

4. Hab. Andes of Peru, Hartweg 854!

44. B. CRINITA Her̂b. Ámaryll. 119, t. 15, fig. 4. - Stems elongated, sarmentose, finely pubescent.-Leaves distinctly petioled, lanceolate, acuminate, $3-4 \mathrm{in}$. long, $\frac{1}{2}-\frac{3}{4} \mathrm{in}$. broad, firm in texture, glaucous and slightly pubescent beneath. Flowers 6-10 in a simple umbel; bracts large, lanceolate; pedicels 5-6 in. long. densely pubescent, not bracteolate. Ovary turbinate, densely pubescent. Perianth-segments equal in length, $1 \frac{3}{4} \mathrm{in}$. long; outer oblanceolate-spathulate, $\frac{1}{3}$ in. broad ; inner oblong, with a claw as long as the blade.

Hab. Andes of Peru, Matheros 1664!

45. B. goniocaulon Baker in Journ. Bot. 1882, 204.-Stems elongated, sarmentose, stout, acutely angled. Leaves lax, subsessile, lanceolate, acuminate, moderately firm in texture, 4-6 in. long, $\frac{3}{4}-\frac{1}{2}$ in. broad low down, green and glabrous beneath. Flowers 30 or more in a simple umbel; bracts numerous, unequal, linceolate, foliaceous; pedicels 2-3 in. long, not bracteolate. Perianth-segments equal in length, $1 \frac{3}{4}-2$ in. long; outer oblong, lanceolate, acute, red towards the base, green at the tip; inner obovate-unguiculate, greenish, spotted with violet.

Hab. Mount Corazon, Andes of Quito, alt. $8000 \mathrm{ft} .$, Andrê 3646 !

46. B. crocea Herb. Amaryll. 119. Alstrameria crocea Ruiz et Pav. Fl. Peruv. iii. 61.- Stems elongated, sarmentose, glabrous. Leaves linear, lanceolate, very acute, $4-5$ in. long, $\frac{1}{3}$ in. broad, pubescent beneath. Flowers many, arranged in a simple umbel;

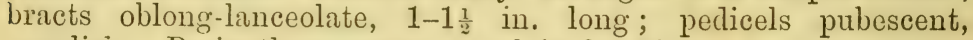
purplish. Perianth-segments equal in length, $1 \frac{1}{2}$ in. long; inner segments crocus-yellow.

Hab. Andes of Peru, Pavon (not seen).

Hab. Andes of Peru, Pavon (not seen). Ac 85 saloyana sadire (scunder)

47. B. acunirnata Baker in Engl. Jahrb. 1887, 212. - Stems slender, elongated, sarmentose, glabrous. Leaves lax, petioled, oblong-lanceolate, acuminate, 4-5 in. long, an inch broad, moderately firm in texture, glabrous beneath. Flowers $4-5$ in a very lax simple umbel; bracts small, lanceolate; pedicels $2-3$ in. long, with a small lancolate bracteole at the middle. Perianth-segments equal in length, $1 \frac{3}{4} \mathrm{in}$. long; outer oblanceolate, $\frac{1}{3}$ in. broad; inner not much broader, yellow, with purple spots.

Hab. New Granada; Province of Antioquia, alt. 5000-6000 ft. Lehmann!

48. B. Longipes Baker in Journ. Bot. 188, 204. - Stems clongated, sarmentose, glabrous. Leaves lax, distinctly petioled, oblong, acute, rounded at the base, 4-5 in. long, $1 \frac{1}{2}-1 \frac{3}{4} \mathrm{in}$. broad low down, moderately firm in texture, shortly pubescent beneath. Flowers abont 8 in a lax simple umbel; bracts few, unequal, one lirge and leaf-like; pedicels 5-6 in. long, obscurely bracteolate. 
Perianth-segments equal in length, 15-16 lines long; outer oblanceolate, purplish, $\frac{1}{3}$ in. broad, inner not much broader, yellowish.

Hab. Andes of South Ecuador, alt. 9000 ft. André, 4614 !

49. B. superba Herb. Amaryll. 117, tab. 6, fig. 1. - Stems elongated, sarmentose, glabrous. Leaves lax, spreading, lanceolate, 4-5 in. long, $\frac{3}{4} \mathrm{in}$. broad, moderately firm in texture, green and glabrous beneath. Flowers $40-50$ in a dense simple umbel; outer bracts large, leaty; pedicels pubescent, 1-1 $\frac{1}{2} \mathrm{in}$. long, not bracteolate. Ovary densely pubescent. Perianth-segments equal in length, $\mathbf{1}_{\frac{3}{4}}$ in. long; outer oblanceolate-spathulate, $\frac{1}{3} \mathrm{in}$. broader; inner unguiculate, scarcely broader.

Hab. Andes of Peru; Province of Chacapoyas, Mathews 1663 !

50. B. formosissmia Griseb. in Pl. Lechl. No. 2141, non Herb. Alstrameria formosissima Ruiz et Pav. Fl. Peruv. t. 296. - Stems stout, elongated, sarmentose. Leaves lax, oblong, acute, distinctly

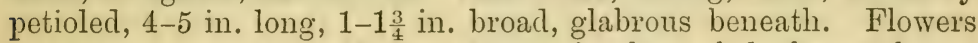
very numerous, arranged in a dense simple umbel; bracts large, foliaceous; pedicels $1 \frac{1}{2}-2$ in. long, pubescent, not bracteolate. Perianth-segments equal in length, $1 \frac{1}{2} \mathrm{in}$. long; outer oblanceolate, reddish; inner a little longer, twice as broad, cuneate-unguiculate, yellow.

Hab. Andes of Peru, Pavon! The above description is from Pavon's type-specimen. Lechler's 2141 differs by its lanceolate leaves, and agrees with Herbert's description of 13 . T'urneriana from Santa Fé de Bogota. Columbian specimens from Lobb and Bolivian from Pearce agree substantially with Pavon's.

51. B. vestita Baker in Engl. Jahrb. 1887, 213. - Stems elongated, sarmentose, very stout, acutely angled, pubescent. Leaves lax, distinctly petioled, oblong, acute, 5-6 in. long, $1 \frac{1}{2}$ in. broad, firm in texture, pubescent beneath. Flowers very numerous, arranged in a dense simple umbel 4-5 in. diam.; bracts about 8 , oblanceolate, resembling the outer perianth-segments in shape and texture; pedicels pubescent, an inch long, not bracteolate. Peri-

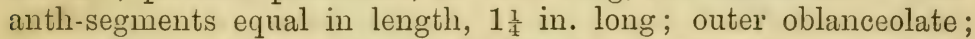
inner obovate-unguiculate, $\frac{1}{2}-\frac{3}{4}$ in. broad, yellowish red, not spotted.

Hab. New Granada; Paramo of Ruiz, Antioquia, 8000-10,000 ft., Lehmangn b. we ber buveriana Kränzal. (Sandià Pen),

52. B. Salsilla Herb. Amaryll. 110. Alstrameria Salsilla Linn., non Gawl. A. oculata Lodd. Bot. Cab. t. 1851; Bot. Mag. t. 3341.- Stems elongated, sarmentose, slender, glabrous. Leaves lax, spreading, petioled, lanceolate or oblong-lanceolate, 2-4 in. long, $\frac{1}{2}-1 \mathrm{in}$. broad, moderately firm in texture, glabrous beneath. Umbel 4-15-rayed, compound; bracts small; rays $1-3$ in. long, 1-3-flowered; bracteoles small, lanceolate; lower pedicels ascending, $\frac{1}{2}-\frac{3}{4}$ in. long. Ovary turbinate, glabrous. Perianth-segments equal in length, $\frac{1}{2}$ in. long, all manve-purple; outer oblanceolate-spathulate; imner broader, obovite-unguiculate, with a horse-shoe shaped dark zone at the base of the blade.

Hab. Chili, near Valparaiso, dc. Received alive recently from Mr. Wilson Saunders and Herr Leichtlin. Lechler's plant, named " $B$. multiflora, n. sp." by Grisebach, is not Mirbel's multiflora, but a form of this species.

52. A B. Tarmerisis Fränal, (Junin, Peru) 
53. B. parvifolia Baker. - Stems elongated, sarmentose, pubescent. Leaves sessile, linear, glabrous, $1-1 \frac{1}{2}$ in. long, $\frac{1}{6}$ in. broad, moderately firm in texture. Umbel of 10-12 2-3-flowered rays $3-4$ in. long; bracts many, just like the leaves; lower pedicels ascending, 1-1 $\frac{1}{2}$ in. long; bracteoles nearly as large as the bract. Ovary turbinate, glabrous. Perianth-segments equal in length, $1 \frac{1}{4}$ in. long; both rows oblanceolate, bright pink, with a dark purple tip. Stamens and style exserted.

Hab. Andes of Peru, Maclean!

54. B. Hookeriana Herb. Amaryll. 398, tab. 46, fig. 2.-Stems elongated, sarmentose, pubescent. Leaves lax, distinctly petioled, oblong, acute, 5-6 in. long, under 2 in. broad, firm in texture, strongly ribbed and pubescent beneath. Umbel very dense; bracts minute; rays very numerous, 2 in. long, densely pubescent, 1-2-flowered. Ovary densely pubescent. Perianth-segments equal in length, under an inch long; outer oblanceolate, $\frac{1}{4}$ in. broader ; inner not broader, oblanceolate-unguiculate.

Hab. Andes of Peru; Province of Chacapoyas, Mathews !

55. B. Acutrfolia Herb. Amaryll. 112. Alstrameria acutifolia Link \& Otto, Ic. i. 5, t. 29 ; Bot. Mag. t. 3050, 3871, 6444 ; Sweet, Brit. Flow. Gard. ser. 2, t. 77.-Habit and leaves of B. edulis, from which it differs by its short simple or at most 2 -flowered peduncles and more brightly-coloured (yellow) inner perianth-segments.

Hab. Mexico and Guatemala, ascending to $10,000 \mathrm{ft}$. on the Peak of Orizaba. Received alive lately from Mr. Elwes. Intermediate between $B$. edulis and multiflora.

56. B. edulis Herb. Amaryll. 111. Alstrameria edulis Tussac, Fl. Antill. i. 109, t. 14; Andr. Bot. Rep. t. 649. A. Salsilla Gawl. in Bot. Mag. t. 1613, non Linn. - Stems elongated, sarmentose, slender, glabrous. Leaves lax, petioled, oblong or oblong-lanceolate, acute, $3-4 \mathrm{in}$. long, 1-1 $\frac{1}{2} \mathrm{in}$. broad, thin in texture, glabrous beneath. Umbel compound, few or many- (4-20) rayed; bracts large, foliaceous; branches 3-6 in. long, 1-4-flowered; bracteoles small, lanceolate ; lower pedicels $1-1 \frac{1}{2}$ in.long. Ovary turbinate, glabrous. Perianth-segments equal in length, about an inch long; outer oblanceolate-oblong, $\frac{1}{3}$ in. broad, pink, with a green tip; inner cuneate-unguiculate, retuse, mucronate, $\frac{1}{2}$ in. broad, greenish, copiously spotted with claret brown. Capsule 1 in. diam.

Var. B. chontalensis Seem. in Gard. Chron. 1871, 479 ; Hook. fil. in Bot. Mag. t. 5927.-A fine variety with large thin leaves, an umbel with few long branches, larger flowers, more obovate outer segments, and pale yellowish green inner segments.

Var. B. ovata Mirbel. Alstrameria ovata Cav. Ic. i. 54, t. 76 ; Hook. in Bot. Mag. t. 2846. B. hirtella Herb. Alstrameria hirtella H. B. K. - Leaves broader, more rounded at the base, pubescent beneath. Flowers larger.

Var. B. connuta Herb. Amaryll. 114, t. 17, fig. 4. - Outer segments of the perianth furnished with a distinet spur at the apex.

Hab. Throughout Tropical America from Cuba and Mexico to Peru and the South of Brazil. Very variable. Besides those placed above as varieties, I 
cannot distinguish specifically $B$. caraccensis, paucifora, bracteata, obovata, MIoritziana, latifolia, Irandifolia, macrocarpa, and punctatn of Herbert, $B$. AIoritzianu Klotzsch, B. miniatu and afjnis Kunth, and B. Brunnianu, specter-s bilis, Schenkium, ILurtiuna, and salsilloides Seubert.

57. B. JacQuesiana Kunth, Enum. v. 800. Shstrimerir Jucquesiana Van Houtte Flore des Serres, t. 182. - Stems elongated, glabrous, sarmentose, dark brown. Leaves distinctly petioled, oblong, acute, 4-6 in. long, 2 in. broad, moderately firm in texture, glabrous beneath. Umbel drooping, 6-12-rayed; bracts large, leaf-like; rays reach a foot or more long, 1-3-flowered; bracteoles small, lanceolate. Ovary turbinate, glabrous. Perianth-segments equal in length, 13-2 in. long; outer oblong-spathulate, bright pink, spotted only towards the edge; inner not broader, unguiculate in the lower half, greenish white, spotted all over the blade. Capsule turbinate, $2 \frac{1}{2}$ in. long, with 6 strong ribs.

Hab. Brazil. Described from a plant that flowered at Kew in 1875 . Allied to $B$. edulis.

58. B. Diffracta Baker in Journ. Bot. 1882, 206. - Stems elongated, sarmentose, slender, glabrous. Leaves lax, distinctly petioled, oblong, acuminate, 6-8 in. long, 2 in. broad, thin in texture, green and glabrous beneath. Umbel of two racemose forks a foot long, bearing each 3-5 flower's on short or long ascending pedicels; bracteoles small, lanceolate. Perianth-segments equal in length, $1 \frac{3}{4}$ in. long; outer oblanceolate, pink, tipped with green; inner greenish, oblong, with a long claw, spotted all over the face.

Hab. Central Cordillera of New Granada, André 2310! Candinamarca, alt. $6000-7000 \mathrm{ft.}$, Lehmann 2499 !

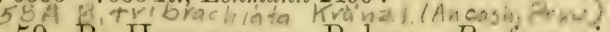

59. B. Herbertiana Balier. B. formosissima Herb. et Benth. excl. syn. Ruiz et Pav. - Stems stout, elongated, sarmentose, glabrous. Leaves lax, petioled, oblong, acuminate, 5-6 in. long, moderately firm in texture, green and glabrous beneath. Umbel of 12-16 rays half a foot long, bearing each 2-3 flowers near the end; bracts many, small, foliaceous; pedicels short, ascending, pubescent.

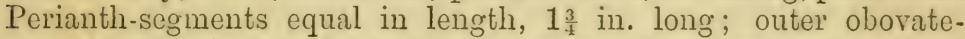
cuneate, 3 in. broad; inner obovate-unguiculate, copiously spotted with claret- brown.

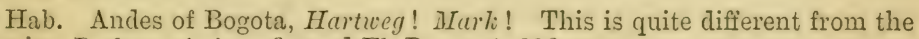
Peruvian B. formosissima, figured Fl. Peruv. t. 296.

60. B. Kranzlini Baker in Engl. Jahrb. 1887, 213. - Stems elongated, slender, sarmentose, terete, glabrous. Leaves las, petioled, oblong-lanceolate, glabrous, $4-5 \mathrm{in}$. long. Umbel of 3-4 slender areuate rays 4-9 in. long, bearing usually 2 flowers each; bracts small. Ovary deepiy sulcate, glabrous. Perianthsegments equal in length, $1 \frac{1}{2}-1 \frac{3}{4}$ in. long; outer segmants oblanceolate, reddish, $\frac{1}{2}$ in. broad; inner obovate-unguiculate, greenish yellow, copiously spotted with claret-brown.

Hab. Andes of Nerv Granada; Antioquia and Cauca, alt. 7000-8000 ft., Lehmann 2921 ! Kalbreyer 1462 !

61. B. Carderi Masters in Gard. Chron. 1876, i. 795, fig. 143; Floral Mag. n. s. t. 239. - Stems elongated, sarmentose, glabrous. 
Leaves lax, petioled, oblong, acute, 4-6 in. long, $1 \frac{1}{2}-3$ in. broad, moderately firm in texture, glabrous. Umbel compound, a foot long; rays 6-9, simple or 2-4-flowered; bracts large, leaf-like; bracteoles lanceolate, an inch long. Ovary turbinate, glabrous. Perianth-segments equal in length, 2 in. long; outer oblanceolate, $\frac{1}{2}$ in. broad, pale pink, spotted with claret-brown towards the tip; inner greenish white, cuneate-unguiculate, $\frac{1}{2}$ in. broad, much spotted. Capsule turbinate, 2 in. long, 1 in. diam., with 6 strong ribs.

Hab. Andes of New Granada. Introduced into cultivation by Mr. Carder, through Mr. W. Bull, in 1876. Described from plants in flower at Kew, November, 1887.

62. B. Shutrleworthim Masters in Gard. Chron. 1882, i. 76, tabs. $77 \& 85$. - Stems slender, elongated, sarmentose, glabrous. Leaves petioled, oblong, acute, 5-6 in. long. Umbel of 5-10 rays reaching a foot in length, bearing about 3 flower's each on long ascending pedicels ; bracts large, leaty. Ovary turbinate, glabrous. Perianthsegments equal in length, 2 in. long; outer oblanceolate, $\frac{1}{3}$ in. broad, tinged with red; inner not broader, unguiculate in the lower half, yellow tinged with green, copiously spotted with redbrown. Capsule turbinate, 2 in. long, with 6 strong ribs.

Hab. Andes of New Granada; Province of Ocana, alt. $5000 \mathrm{ft}$., Lehmann 3351 ! Introduced into cultivation by Carder in 1882. Pearce 727, with $20-30$ rays to the umbel, is probably the same species.

63. B. Wildiamsie Masters in Gard. Chron. 1882, ii. 553.Stems elongated, sarmentose, slender, glabrous. Leaves oblong, acuminate, membranous, glabrous. Umbel few-rayed, compound, about 12 -flowered; rays $\frac{1}{2} \mathrm{ft}$. long. Ovary pubescent. Perianthsegments equal in length, 2 in. long; outer oblanceolate, bright pink, white inside, copiously spotted with dark purple; inner obovate-unguiculate, whitish green, copiously spotted on the face. Capsule turbinate, 2 in. long.

Hab. New Granada; Mt. Quindio. Introduced by Mrs. Rosa Williams in 1882, through Messrs. Shuttleworth and Carder. Flowered in 1884 by Mr. Richardson at the Liverpool Botanic Garden.

64. B. Caldasiana Herb. Amaryll. 119. Alstrameria Caldasii H. B. K. ; Bot. Mag. t. 5442. - Stems elongated, sarmentose, glabrous or slightly pubescent. Leaves thin, spreading, oblong, acute, distinctly petioled, 3-6 in. long, 1-1 $\frac{1}{2}$ in. broad, rather glaucous, glabrous or pubescent beneath. Umble simple, 6-30flowered; bracts many, oblong-lanceolate; pedicels 1-2 in. long, pilose. Ovary hemispherical, pubescent. Perianth-segments unequal; outer oblanceolate, reddish brown, $\frac{3}{4}-1 \mathrm{in}$. long; inner $\frac{1}{2}$ in. longer, cuneate-unguiculate, bright yellow.

Hab. Andes of Ecuador and New Granada, alt. 8000-11,000 ft. Introduced into cultivation by Messrs. Veitch in 1865. A high mountain form recently received from Messrs. Sander from the Andes of Pasto, in New Granada, has leaves not more than an inch and flowers only $\frac{3}{4}$ in. long, and we have a similar plant from Costa Rica from Mr. Sherring.

$64 A$. Costaricensis Kränzl. (costa Rica)

65. B. Kalbreyeri Baker in Journ. Bot. 1882, 204; André in Rev. Hort. 1883, 516, with figure. -- Stems elongated, sarmentose, 
pubescent. Leaves lax, shortly petioled, oblong, acute, 2-3 in. long, densely pubescent beneath. Umbel simple, 10-15-rayed; bracts many, small ; pedicels about an inch long, densely pubescent. Ovary hemispherical, densely pubescent. Perianth-segments unequal; outer segments $\frac{3}{4}$ in. long, oblanceolate, red-brown; inner $\frac{1}{2}$ in. longer, cuncate-unguiculate, bright yellow, with claret-brown spots.

Hab. Andes of New Granada, alt. 9000-10,000 ft. Doubtfully distinct from $B$. Caldasiana.

66. B. frondea Mast. in Gard. Chron. n. s. xvii. 669, fig. 102. Stems elongated, sarmentose, pubescent. Leaves lax, spreading, oblong, acute, moderately firm in texture, 4-5 in. long, pubescent, beneath. Umbel dense, simple, many-flowered; bracts many, oblong-lanceolate, foliaceous; pedicels pubescent, $1 \frac{1}{2}-2$ in. long. Ovary pubescent. Perianth-segments unequal in length; outer oblanceolate, reddish brown, 1-1 $\frac{1}{4} \mathrm{in}$. long; inner $\frac{1}{2} \mathrm{in}$. long, cuneate-unguiculate, bright yellow, with copious spots.

$\mathrm{Hab}$. Andes of New Granada, 8000-10,000 ft. Introduced into cultivation in 1882 by Miessirs. Shuttleworth and Carder. Nearly allied to B. Caldasiana.

67. B. ANDreana Baker in Journ. Bot. 1882, 205. - Stems elongated, sarmentose, pubescent. Leaves oblong-lanceolate, acute, $3-5$ in. long, $\frac{3}{4}-1$ in. broad, thin in texture, finely pubescent beneath. Umbel simple, 10-15-rayed; bracts small; pedicels $1 \frac{1}{2}-2$ in. long. Perianth-segmente unequal in length; outer oblanceolate, $1 \frac{1}{4}$ in. long, reddish brown; inner $\frac{1}{2}$ in. longer, bright yellow, spotted with claret-brown.

Hab. Andes of New Granada, André 675!2756! Kalbreyer 1502! Nearly allied to $B$. frondea.

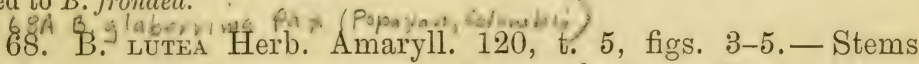
slender, elongated, sarmentose. Leaves lax, spreading, oblonglanceolate, 3-4 in. long, moderately firm in texture, glabrous beneath. Umbel simple, 5-6-rayed; bracts small, linear ; pedicels $1 \frac{1}{2}-2$ in. long, bracteolate, densely pubescent. Perianth-segments unequal ; outer $1 \frac{1}{2} \mathrm{in}$. long, oblanceolate, brown, densely pubescent; inner 2 in. long, cuneate-unguiculate, bright yellow, unspotted.

Hab. Andes of Ecuador; western slope of Pichincha, Jameson! Hall!

69. B. Patini Baker. - Stems elongated, sarmentose, pubescent. Leaves lax, drooping, petioled, oblong-lanceolate, 3-4 in. long, moderately firm in texture, pubescent beneath. Flowers very numerous, forming a simple umbel; bracts large, foliaceous ; pedicels $1 \frac{1}{2}-2$ in. long, pubescent, not bracteolate. Perianthsegments unequal; outer oblanceolate, brownish; inner plain yellow, 2 in. long, $\frac{1}{2}$ in. broad, cuneate-unguiculate.

Hab. Andes of New Granada; Province of Antioquia, Patin! Jervoise! Nearly allied to $B$. patacoensis Herb.

70. B. patacoensis Herb. Amaryll. 120, t. 14, fig. 3 ; Hook. fil. in Bot. Mag. t. 6692. B. conferta Benth.; Masters in Gard. Chron. 1882, 186, t. 31. - Stems elongated, sarmentose, purple-tinted, pubescent. Leaves lax, oblong-lanceclate, 5-6 in. long, moderately firm in texture, pubescent beneath. Flower's 20-30 in a simple 
umbel ; bracts large, foliaceous ; pedicels pubescent, $1 \frac{1}{2}-2 \mathrm{in.} \mathrm{long,}$ not bracteolate. Perianth-segments unequal; outer oblanceolate, bright red, $1 \frac{1}{2}$ in. long ; inner cuneate-unguiculate, 2 in. long, $\frac{1}{2}$ in. broad, bright red, with a yellow keel, with a few spots.

Hab. Andes of Ecuador and New Granada. Described from a plant that flowered at Kew in October, 1882, from Messrs. Shuttleworth and Carder.

71. B. pardina Herb. Amaryll. 120, t. 14, fig. 1.-Stems stout, elongated, glabrous, sarmentose. Leaves lax, petioled, oblong, acute, 4-6 in. long, $1 \frac{1}{2}-2$ in. broad, thin in texture, glabrous beneath. Flowers 20 or more in a dense simple umbel; bracts foliaceous; pedicels $\frac{1}{2}-1 \mathrm{in}$. long, densely pubescent. Perianthsegments unequal; outer oblanceolate, $1 \frac{1}{2}-2$ in. long, brown tinged with red; inner nearly an inch longer, $\frac{1}{2} \mathrm{in}$. broad, white, copiously spotted with violet-purple. Fruit bright red.

Hab. Andes of Nerv Granada and Ecuador, gathered recently by Lobb, Spruce, Pearce, and André.

72. B. dispar Herb. Amaryll. 115, t. 17, fig. 1. B. declinata Klotzsch. Alstrameria declinata Popp. \& Endl. Nov. Gen. ii. 44, t. 160.-Stems slender, sarmentose, glabrous. Leaves thin, oblong, acute, 6-8 in. long, 2 in. broad, green and glabrous on both surfaces. Umbel 3-5 rayed; bracts almost suppressed; pedicels 4-5 in. long, 2-3-flowered, with small bracts at the forks. Ovary turbinate, glabrous. Perianth-segments nnequal; outer reddish, $\frac{3}{4}$ in. long; inner yellowish green, an inch long.

Hab. Andes of Peru, Mathewos 1658! Poppig.

73. B. HIRsuta Herb. Amaryll. 114. Alstrameria hirsuta H.B.K. - Stems 10-15 ft. long, sarmentose, strongly angled. Leaves lax,

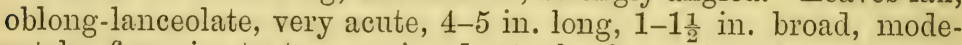
rately firm in texture, crisped at the base, densely pubescent beneath. Umbel 6-8-rayed; bracts few, large or altogether suppressed ; pedicels 5-6 in. long, 2-3-flowered, bearing small lanceolate bracts at the forks. Ovary turbinate, pubescent. Perianthsegments unequal in length; outer reddish brown, $\frac{1}{2}$ in. long; inner obovate-unguiculate, $\frac{3}{4} \mathrm{in}$. long, yellow, spotted with claretbrown.

Hab. Andes of New Granada. Gathered originally by Humboldt; regathered lately by Kalbreyer.

74. B. Lyncina Herb. Amaryll. 398, tab. 46, fig. 2. - Stems elongated, sarmentose, glabrous. Leaves lax, drooping, distinctly petioled, oblong, acute, $2-3$ in. long, 1-1 $\frac{1}{4}$ in. broad, moderately firm in texture, green and glabrous on both surfaces. Umbel dense, 20-30-rayed; bracts many, small, unequal; pedicels an inch long, densely pubescent, simple or forked. Ovary densely pubescent. Perianth-segments unequal in length; outer brownish, oblanceolate, pubescent, $1 \frac{1}{4}$ in. long; inner $\frac{1}{2}$ in. longer, cuneate with a narrow claw, yellowish, very much spotted with claret-red.

Hab. Andes of Peru, Mathews 1668!

75. B. vitellina Mast. in Gard. Chron. 1882, 143, t. 151.Stems elongated, sarmentose, glabrous. Leaves lax, ovate-oblong, 
acute, 3-4 in. long. Umbel about 12-rayed; bracts 4-5, large, leaf-like; pedicels 5-6 in. long, usually once forked above the middle. Perianth-segments unequal, bright yellow; outer linearoblong, $1 \frac{1}{4}-1 \frac{1}{2}$ in. long; inner obovate-unguiculate, retuse, apiculate, 2 in. long, $\frac{3}{4}$ in. broad.

Hab. New Granada; Province of Ocana. Introduced into cultivation by Carder in 1882.

\section{Leontochir Phil.}

Perianth-tube none; segments all alike, cuneate with a long slender claw. Stcumens shorter than the segments, attached to their base; filaments filiform; anthers oblong, basifixed. Oxary turbinate, 1-celled, with 3 parietal placentas; style filiform; stigmas 3 , linear, spreading. Fruit a strongly-ribbed capsule dehiscing at the apex. Seeds small, globose.

1. L. Orallei Phil. Descr. Nuev. Plant. 69; Hook. Ic. t. 1389. - Stems sarmentose, reaching a length of several feet. Leares numerous, sessile, resupinate, oblong, acute, lower 3-4 in. long, upper gradually smaller. Umbel very dense, simple, many-flowered; pedicels very short; bracts small. Perianth-segments an inch long, reddish, not spotted, with an orbicular-cuneate blade $\frac{1}{3} \mathrm{in}$. diam. Style shorter than the stamens. Capsule $\frac{1}{2}$ in. long.

Hab. Chili, at Conception, Bridges 1377! Carrizal Bajo, King! Mr. Goldring showed me it living in February, 1883, from Kelly gardens.

\section{Suborder III.-AGAVEÆ.}

\section{Polianthes Limn:}

Perianth with a long narrowly funnel-shaped curved tube and short subequal segments. Stamens inserted at the middle of the tube, not exserted from its throat; filaments filiform, very short; anthers linear, erect, dorsifixed. Ocary 3 -celled, free at the apex; orules many, superposed; style filiform; stigmas 3, orate, falcate. Fruit ovoid, crowned by the persistent perianth. Seeds flat, with a lax testa.

1. P. tuberosa Linn. Sp. P1. 453 ; Red. Lil. t. 147 ; Bot. Mag. 1817 ; Bot. Reg. t. 63. - Rootstock tuberous. Basal leares 6-9 to a stem, thin, linear, bright green, 1-1 $\frac{1}{2} \mathrm{ft}$. long, deeply channelled in the lower half, spotted with red-brown on the back. Stem 2-3 ft. long, with 8-12 abbreviated leares. Flowers in pairs in a lax spike; bracts green, lanceolate. Perianth pure waxy white. $1 \frac{1}{2}-2 \frac{1}{2}$ in. long; segments oblong-lanceolate, spreading, $\frac{1}{2}-\frac{3}{4} \mathrm{in}$. long.

Var. P. Gracilis Link \& Otto, Ic. t. 24. - Habit more slender. Leaves narrower. Perianth with a long slender tube and linear segments.

Hab. Mexico. Long cultivated in all parts of the world for its fragrant flowers. We flowered $P$. gracilis at Kew in August, 1880. 


\section{Prochnyanthes S. Wats.}

Perianth subpersistent, its tube subcylindrical at the base, then abruptly geniculate and dilated; segments broad, short, equal, erect. Stamens inserted below the throat of the perianth; filaments filiform; anthers linear, versatile. Ovary 3 -celled; ovules numerous, superposed; style filiform; stigmas oblong. Capsule globose, loculicidally 3 -valved. Seeds many, flattened, with a close dark testa.

1. P. viridescens S. Wats. Cont. xiv. 457. - Stem erect from a short thick bracteated caudex, simple, leafy below, sparsely bracteate above, 4-6 ft. long. Leaves linear-lanceolate, subcoriaceous,

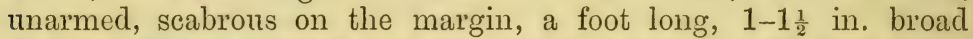
at the middle, narrowed to a long winged petiole. Flowers laxly racemose, greenish yellow, tinged with brown; bracts lanceolate, $\frac{1}{2}$ in. long ; pedicels $1-1 \frac{1}{2}$ in. long, not jointed. Ovary $\frac{1}{4}$ in. long, equalling the cylindrical base of the tube; throat $\frac{1}{2}$ in. long; segments $\frac{1}{4}$ in. long, broadly ovate. Capsule $\frac{1}{2} \mathrm{in}$. long.

Hab. Mexico, in the Province of Jalisco, Dr. Palmer 9! Discovered in 1886.

\section{Bravoa Llav, et Lex.}

Perianth with a long subcylindrical tube and short ovate or oblong subequal segments. Stamens inserted about the middle of the perianth-tube; filaments short, filiform; anther's linear, dorsifixed. Ovary ovoid, umbonate at the apex, 3-celled; ovules many, superposed; style filiform; stigma trifid. Capsule loculicidally 3-valved. Seeds flattened, with a black testa.- Rootstock tuberous. Basal leaves few, long, lanceolate or linear, thin, entire-edged; stem-leaves much reduced. Flowers red or whitish, usually in distant pairs; bracts small, scariose; pedicels articulated at the apex.

$\begin{array}{lll}\text { Flowers bright red } & \text { Sp. } 1 . \\ \text { Flowers whitish } & \text { - } & \text { Sp. } 2-4 .\end{array}$

1. B. Geminiflora Llave et Lex. Descr. i. 6. Catocamia geminiflora Link \& Otto, Abbild. 35, t. 18. - Tuber globose, 1-1 $\frac{1}{2}$ in. diam.; tunics copiously fibrous at the apex. Basal leaves 5-6, ensiform, 1-1 $\frac{1}{2} \mathrm{ft}$. long, $\frac{1}{2}-\frac{3}{4}$ in. broad. Peduncle 1-1 $\frac{1}{2} \mathrm{ft}$. long, bearing about 4 reduced leaves. Raceme 3-12 in. long, with flowers in distant pans; pedicels $\frac{1}{4}-\frac{1}{2}$ in. long ; bracts scariose, lower lanceolate, upper ovate. Perianth bright red, $\frac{3}{4}-1$ in. long; segments ovate, greenish, $\frac{7}{8}$ in. long. Anthers reaching to the throat of the tube. Capsule small, globose.

Hab. Mountains of Central Mexico, ascending to $7000 \mathrm{ft}$. Introduced into cultivation in 1838. It is almost hardy in the neighbourhood of London.

2. B. sessiliflora Hemsl. in Biol. Cent. Amer. Bot. iii. 338, t. 86.-Tuber oblong, with tunics slitting into fine fibres at the top. Basal leaves linear, acuminate. Peduncle including inflorescence

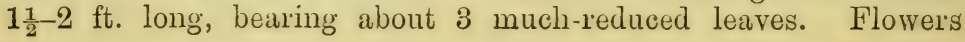


whitish, sessile in about 3 distant pairs; outer bracts small, ovate. Perianth-tube 1-1 $1 \frac{1}{4}$ in. long; segments oblong, $\frac{1}{4}$ in. long. Anther's a little protruded from the tube.

Hab. Mexico ; San Luis Potosi, alt. 6000-8000 ft., Parry \& Palmer 867!

3. B. singuliflora S. Wats. in Proc. Amer. Acad. xxii. 479.Tuber $1 \frac{1}{2}$ in. diam. Basal leaves numerous, linear, a foot or less long, $\frac{1}{6}-\frac{1}{3} \mathrm{in}$. broad, undulate on the edges. Peduncle including the inflorescence $3 \mathrm{ft}$. long. Flowers usually or always solitary; pedicels very short; outer bracts deltoid. Flowers greenish white; tube with the ovary $1 \frac{1}{4} \mathrm{in}$. long, tinged with purple; segments oblong, $\frac{1}{x-\frac{1}{3}} \mathrm{in}$. long. Anthers reaching nearly to the tip of the segments. Capsule oblong, under an inch long.

Hab. Mexico; mountains near Chihuahua, Pringle. Discovered in 1886.

4. B. Búlltana Balier in Gard. Chron. 1884, ii. 328. - Tuber ovoid, above $1 \mathrm{in}$. diam., the outer tunies slit into copious fibres at the top. Basal leaves lanceolate, acuminate, bright green, $\frac{1}{2} \mathrm{ft}$. long, 1-1 $\frac{1}{2}$ in. broad. Peduncle $2-3 \mathrm{ft}$. long, flexuose, bearing only a single much-reduced leaf. Raceme of 5-6 pairs of whitish nearly sessile flower's; bracts minute, ovate. Perianth $1 \frac{1}{4} \mathrm{in}$. long; tube $\frac{1}{3}$ in. diam. at the top; segments ovate, $\frac{1}{6}$ in. long and broad. Stamens reaching to the tip of the segments.

Hab. Mexico. Described from a plant flowered by Mr. Wm. Bull in 1884 .

\section{Beschorneria Kunth.}

Perianth with a very short funnel-shaped tube and subequal ascending lanceolate segments. Stamens inserted at the base of the segments and about equalling them; filaments filiform; anthers linear-oblong, versatile. Ovary clavate, 3-celled; ovules many, superposed; style thickened at the base; stigma capitate. Capsule subglobose, loculicidally 3-valved. Seeds crowded, flattened, brownish black.-Rootstock short, tuberous. Basal leares rosulate, ascending, lanceolate, glaucous, scabrous on the margin; stem-leaves bractlike. Flowers clustered, greenish or reddish, arranged in simple or panicled racemes; pedicels articulated at the apex; bracts ovate, scariose. The species are all very closely allied to one another.

1. B. tubiflora Kunth, Enum. v. 844; Hook. in Bot. Mag. t. 4642; Regel, Gartenfl. t. 851. - Leaves a dozen or more in a rosette, about a foot long, $\frac{1}{2} \mathrm{in}$. broad in the wild, an inch broad in the cultivated plant, very scabrous on both surfaces. Peduncle 2-3 ft. long including the simple raceme; bract-leaves about a dozen, lanceolate; flowers $2-3$ in a cluster, with unequal pedicels and a cluster of unequal ovate scariose bracts. Whole Hower $1 \frac{1}{2}$ in. long; ovary $\frac{1}{2}$ in. long; segments reddish green, an inch long, $\frac{1}{6}$ in. broad below the tip. Stamens a little shorter than the segments.

Hab. Mountains of Central Mexico, ascending to $6000-8000 \mathrm{ft}$. Introduced into cultivation by Ehrenberg in 18t5, and by Roezl in February, 1857. See Belg. Hort. 1883, p. 133. I cannot separate specifically B. Cohniana Jacobi inedit, which flowered at Kew, April, 1877. 
2. B. Toneliana Jacobi, Index, 11 (name only); Hook. fil. in Bot. Mag. t. 6091 .-Leaves $15-20$ in a rosette, $1 \frac{1}{2}-2 \mathrm{ft}$. long, 2 in. broad above the middle, narrowed to an inch above the base, very glatcous, scabrous on the margin and under surface. Peduncle $4 \mathrm{ft}$. long including the long simple raceme, reddish purple; flowers 2-5-nate; bracts and pedicels reaching an inch long. Whole flower $2 \mathrm{in}$. long; ovary cylindrical, $\frac{3}{4} \mathrm{in}$. long; limb greenish; segments $\frac{1}{6}$ in. long.

Hab. Mexico. Described from a plant flowered by Mr. Wilson Saunders at Reigate in 1874.

3. B. yuccoides Hook. in Bot. Mag. t. 5203.-Leaves about 20 in a basal rosette, $1 \frac{1}{2} \mathrm{ft}$. long, 2 in. broad at the middle, narrowed to $\frac{1}{2}$ in. above the dilated base, moderately glaucous when mature, scabrous on the edge and under surface. Peduncle $4 \mathrm{ft}$. long including the panicle, bright red; lower branches $\frac{1}{2} \mathrm{ft}$. long, spreading. Whole flower $2-2 \frac{1}{2}$ in. long; ovary cylindrical, an inch long; segments entirely green, above an inch long, $\frac{1}{6}$ in. broad.

Hab. Mexico. Flowered in 1860 by Mr. Wilson Saunders at Reigate, and at Kew in April, 1875.

4. B. bracteata Jacobi, Index, 11 (name only); Baker in Bot. Mag. t. 6641.-Leaves 20-30 in a basal rosette, $1 \frac{1}{2}-2 \mathrm{ft}$. long, 2 in. broad above the middle, contracted to less than an inch above the base, glaucous, scabrous on the edge and under surface. Peduncle 4-5 ft. long including the panicle, reddish brown; bract-leaves 3-4, lanceolate, erect. Panicle rhomboid, 2 ft. long; central branches 8-9 in. long; pedicels $\frac{3}{4}-1$ in. long; bracts ovate, scariose, bright red. Whole flower $2 \mathrm{in}$. long; ovary cylindrical; segments an inch long, at first red, finally tinged with red.

Hab. Mexico. Described from a plant flowered at Kew, March, 1882.

5. B. Decosterina Balier in Bot. Mag. t. 6768.-Leaves 15-20 in a basal rosette, $2-2 \frac{1}{2} \mathrm{ft}$. long, $2-2 \frac{1}{2} \mathrm{in}$. broad above the middle, narrowed to an inch above the dilated base, firm in texture for the genus, glaucous, smooth on the face, scabrous on the margin and under surface. Peduncle 7-8 ft. long including the lax panicle; lower branches a foot long, subtended by large lanceolate bracts;

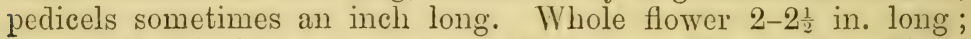
ovary cylindrical; segments reach $1 \frac{1}{2} \mathrm{in.long}$. Capsule $1 \mathrm{in}$. diam.

Hab. Mexico. Flowered at Kew, February, 1884. Received from Max Leichtlin.

\section{Imperfectly-known Species.}

I know nothing of B. Galcottei, pumila, Schlechtendulii, and Terlindeniana, mentioned by name alone in Jacobi's 'Index.' We grow a plant at Kiew under the name of $B$. superbu, received from Mr. Thomas Hanbury, of Mentone, with greener leaves than any of the foregoing, but have not as yet flowered it.

\section{Doryanthes Correcl.}

Perianth with scarcely any tube above the ovary; segments long, equal, falcate. Stamens inserted at the base of the perianth- 
segments; filaments filiform, thicker downwards; anthers oblong or linear-oblong, erect, basifixed. (Wvary clavate or cylindrical, 3-celled; ovules many, superposed; style elongated, trisulcate; stigma capitate. Capsule turbinate, with a woody endocarp, loculicidally 3-valved. Seeds flattened, reniform, with a brown testa.Rootstock none. Leaves ensiform, forming a dense basal rosette. Stem with thyrsoid or congested inflorescence attaining a height of $20 \mathrm{ft}$. or more. Stem-leaves much reduced. Flowers large, bright red, often replaced by bulbillæ, as in Furcraa. - A very curious and distinct genus, and all the other Agavece are American.

1. D. excelsa Correa in Trans. Linn. Soc. vi. 213, t. 23-24; Bauer, Illust. t. 13-15; Bot. Mag. t. 1685; Regel, Gartenfl. t. 421; Flore des Serres, t. 1912. - Leaves 50-100 in a rosette, ensiform, falcate, $5-6 \mathrm{ft}$. long, 3-4 in. broad at the middle, narrowed gradually to a winged petiole an inch broad, with a cylindrical point 2-3 in. long. Stem 10-20 ft. long, with numerous ascending bract-leaves. Inflorescence a terminal capitulum a foot in diam.; final bracts oblong-lanceolate, subcoriaceous, bright red, $3 \mathrm{in.} \mathrm{long.}$ Ovary cylindrical-triquetrous, $1 \frac{1}{2}$ in. long; segments linear, $2 \frac{1}{2}-3$ in. long. Stamens nearly as long as the segments; anther's linear, an inch long.

Hab. New South Wales. First properly flowered in cultivation by the Right Hon. C. Long in 1815.

2. D. Palmeri W. Hill; Benth. Fl. Austral. vi. 452 ; Hook. fil. in Bot. Mag. t. 6665; Gard. Chron. 1874, t. 44-45; Flore des Serres, t. 2097-8.-Leaves 100 or more, ensiform, strongly ribbed, 6-8 ft. long, 4-6 in. broad, narrowed downwards to a winged petiole an inch broad and furnished with a cylindrical point 4-6 in. long. Peduncle 6-10 ft. long, with copious short ascending leaves. Inflorescence a dense thyrsoid panicle $3 \mathrm{ft}$. long; final bracts ovate, bright red, $2 \mathrm{in}$. long. Ovary clavate, $1 \frac{1}{2} \mathrm{in}$. long; segments lanceolate, not longer than the ovary. Stamens a little shorter than the segments; anthers linear-oblong, $\frac{1}{2}$ in. long.

Hab. Queensland. Flowered at Brisbane, 1870; at Kew, April, 1882. Mr. Charles Moore, of the Sydney Botanic Garden, sends photographs of two marked varieties, one with a compact inflorescence and long leaves, the other with a laxer panicle and shorter leaves.

\section{Agave Limn.*}

Perianth funnel-shaped; tube short; segments subequal, oblanceolate, falcate. Stamens inserted at or below the throat of the tube; filaments filiform, generally much longer than the segments;

* Reprinted, with alterations, from the 'Gardeners' Chronicle' in 1877. The paper was translated into Italian by Baron Ricasoli, and appeared, with the original woodcuts, in vol. iv. (1879) of the 'Report of the Tuscan Horticultural Society.' For fuller details see Jacobi's elaborate Monograph, which originally appeared in the 'Hamburg Gartenzeitung,' 1861-1867, and its two Nachtrages ; Engelmann's paper' in vol. iii. of the 'Transactions of the Academy of Science of St. Louis'; Salmdyck in 'Hortus Dyckianus,' 1834, and Bonplandia, 1859,' pp. 85-96; K. Koch in 'Tochenschrift,' 1869; Todaro's recent 
anthers linear, versatile. Ovary oblong-cylindrical, rostrate, 3celled; ovules many, superposed; style subulate; stigma capitate, 3-lobed. Fruit an oblong capsule, loculicidally 3 -valved. Seeds discoid, with a thin black testa. - Monocarpic and acaulescent, rarely polycarpic with a produced trunk. Leaves densely rosulate, more or less fleshy and usually firm in texture, with a pungent end-spine and copious horny marginal prickles. Inflorescence densely subspicate or a thyrsoid panicle; peduncle with only reduced leaves; flowers greenish yellow, proterandrous.

\section{Key to Subgenera founded on inflorescence.}

Euagave. Flower's in clusters, which are placed at the end of the branches of a deltoid thyrsoid panicle.

Liттжа (Tagl.). Flowers in pairs, forming a dense cylindrical subspicate inflorescence.

Manfreda (Salisb.). Flowers solitary, forming a lax simple subspicate raceme or spike.

Key to Series and Groups founded on the shape, size and texture of the leaves.

Series I. Coriaceo-carnose. Leaves persistent, both rigid and thick in texture, not at all flexible. End-spine large and pungent.

Group 1. Filiferæ. Edge of the leaf splitting off into distinct threads . . . . . . Sp. 1-5.

Group 2. Marginate. Edge of the leaf furnished with a continuous toothed horny border from top to bottom.

Leaves ensiform.

Grandifoliæ . . . . Sp. 6-10.

Parvifolir . . . . Sp.11-16.

Leaves oblong-or oblanceolate-spathulate.

Grandifoliæ . . . . Sp. 17-20.

Parvifolize . . . . Sp. 21-23.

Group 3. Subnarginatæ. Edge of the leaf furnished with a continuous toothed horny border in the upper half or third, but not down to the base.

$$
\begin{aligned}
& \text { Parvifoliæ . . . . Sp. 24-30. } \\
& \text { Grandifoliæ : } \quad \text {. } \quad \text { Sp. 31-34. }
\end{aligned}
$$

figures and descriptions of new species in 'Hort. Bot. Panorm.'; and Terraciano's Synopsis (1885) of the species cultivated at Naples. My own descriptions were mostly drawn up from the living plants at Kew, and in the collections of $\mathrm{Mr}$. Wilson Saunders at Reigate and Mr. J. T. Peacock at Hammersmith. Besides the published figures, there are at Kew sets of photographs made from the collections of Mr. Wilson Saunders, Baron van Ellemeet, and Ir. van Bemmele. 
Group 4. Americane. Edge of the leaf without any continuous horny border below the tip; marginal teeth large, with the edge repand between them.

Leaves oblong-spathulate . . Sp. 35-45.

Leaves oblanceolate-spathulate.

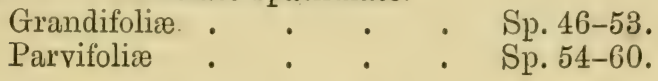

Group 5. Rigide. Edge of the leaf without any continuous horny border below the tip; teeth small, with the edge not repand between them.

Leaves oblong-spathulate . . Sp. 61-64.

Leaves oblanceolate or ensiform . Sp.65-75.

Group 6. Striate. Edge of the leaf minutely serrulate; surfaces strongly ribbed . . . . . Sp.76-79.

Group 7. Integrifolise. Edge of the leaf entire; surfaces not ribbed . . . . . Sp. 80-82.

Series II. Carnoso-coriacee. Leaves persistent, more fleshy and less rigid than in the last series; end-spine smaller and less pungent.

Group 8. Geminiflore. Edge of the leaf splitting off into threads . . . . . . Sp. 83.

Group 9. Aloides. Edge of the leaf furnished with small distinct horny teeth.

Leaves oblong-spathulate • - S Sp. 84-92.

Leaves oblanceolate or ensiform.

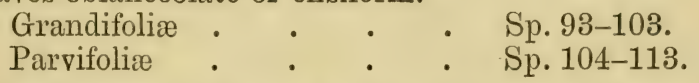

Group 10. Serrulate. Edge of leaf minutely serrulate. Sp. 114-115.

Group 11. Atrenuate. Edge of leaf entire. Sp. 116-117.

Series III. Fuexiles. Leaves persistent, but thinner and more flexible than in the two previous series. End-spine small, scarcely pungent.

Group 12. Viviparæ. Leaves distinctly toothed.
Leaves linear-ensiform
Sp. 118-119.
Leaves lanceolate . . . . Sp. 120-123.
Leaves oblanceolate-oblong . . Sp. 124-125.

Group 13. Yuccæfolia. Leaves subentire or obscurely serrulate Sp. 126. 
Series IV. Herbaceæe (= Manfreda). Leaves dying down annually, almost herbaceous. End-spine not at all pungent.

Stamens short . . . . Sp. 127.

Stamens much longer than the perianth-segments.

Perianth-segments at least as long as the tube . .

Perianth-segments longer than the tube

Sp. 128-134.

Sp. 135-138.

\section{Group 1.-FiLIFERÆ.}

1. A. (Littca) filifera Salmdyck, Hort. Dyck. 8, 309 ; Lemaire, Ill. Hort. t. 243; Baker in Gard. Chron. 1877, fig. 49; Berl. Monat. 1887, t. 5. - Acaulescent. Leaves $60-100$ in a dense rosette, stiff, straight, ensiform, 6-9 in. long, an inch broad, narrowed gradually to a grey pungent tip, pale green, the continuous edge splitting off into grey wiry threads, the back marked with grey lines where the edges of other leaves have pressed against it. Peduncle 3-4 ft. long; bract-leaves subulate, the upper squarrose. Flower's in a dense spilie 2-4 ft. long; bracts purplish brown, linear. Perianth 2 in. long including the ovary; ovary with a long beak; tube an inch long; segments linear, greenish brown, $\frac{1}{2}$ in. long. Filaments purple, $1 \frac{1}{2}$ in. long.

Var. A. Filanientosa Salmdyck in Bonpland. vii. 94 ; Baker in Saund. Ref. Bot. t. 164. - Leaves larger, reaching a length of 18-21 in. Peduncle including 5-6 ft. spike 10-12 ft. long.

Hab. Mexico, first described by Prince Salmdyck in 1834. Flowered at Kew in 1875 and 1887. A. Romani Hort. De Smet, is said to be a hybrid between this species and $A$. xalapensis.

2. A. (Littea) schidigera Lemaire, Ill. Hort. t. 330 ; Hook. fil. in Bot. Mag. t. 5641. - Habit of A. filifera, from which it differs by the white marginal file being flattened, not subulate.

Hab. Mexico, introduced into cultivation by Verschaffelt in 1861. Flowered at Kew, 1878, 1879, 1881. According to Roezl, in Belg. Hort. 1883, the leaves of the wild plant are sometimes bright red and sometimes dull purple. $A$. Ortgiesiana Hort. is a dwarf form, with a pale central band down the face. It flowered at the Palermo Botanic Garden in 1882.

3. A. (Littca) Sснотті Engelm. Notes, 17. A. yeminiflora var. Sonore Torrey. - Acaulescent. Leaves linear, $\frac{1}{2}-1 \mathrm{ft}$. long, $\frac{1}{4}-\frac{1}{3} \mathrm{in}$. broad, very rigid in texture, flat or concave on the face, triquetrous on the back, very pungent at the tip, the margin splitting off into copious fine white threads. Peduncle with inflorescence 5-6 ft. long. Flowers in lax ascending pairs; pedicels very short. Perianth with ovary $1 \frac{1}{2} \mathrm{in}$. long; segments equalling the narrowly funnel-shaped tube. Filaments twice as long as the segments.

Hab. Sierras of Southern Arizona, Pringle! Discovered by the late Dr. Arthur Schott in 1855. We have a form from the Missouri Botanic Garden without any marginal threads.

4. A. (Littan) partiflora Torrey in Bot. Mex. Bound. 214.Acaulescent. Leaves linear-lanceolate from a deltoid base, rigid in texture, $2 \frac{1}{2}-3 \mathrm{in}$. long, $\frac{1}{3} \mathrm{in}$. broad, ending in a pungent grey 
spine, the edge furnished with minute brown cartilaginous teeth below the middle, above it splitting off into a ferw short stout white threads. Peduncle with inflorescence 4-5 ft. long. Flowers not more than $\frac{1}{2}$ in. long; ovary oblong, $\frac{1}{6} \mathrm{in.}$. long; tube campanulate, a little longer than the ovary. Filaments $\frac{1}{3}$ in. long, inserted low down in the tube, scarcely protruded beyond the tip of the segments.

Hab. Sierras of Southern Arizona, also discovered by Dr. Schott during the expedition sent to explore the Mexican boundary in 1855 .

5. A. (Littaa) Angustissina Engelm. Notes, 18.-Leaves narrow linear, rigid, 2-3 ft. long, $\frac{1}{4}$ in. broad, convex on the back, filamentose on the edges, ending in a short pungent brown spine. Peduncle with spilie 5-6 ft. long.

Hab. Western Mexico, near Ocotillo, gathered by Dr. Gregg.

\section{Group 2.-Marginate.}

6. A. Karatto Miller, Gard. Dict. No. 6, non Salmdyck.-Leaves ensiform, dark green, $2 \frac{1}{3}-3 \mathrm{ft}$. loing, $3 \mathrm{in}$. broad, the end spine black, the border reddish brown and slightly serrated. Inflorescence unknown.

Hab. West Indies; Island of St. Kitts. A plant lately received at Kew from St. Kitts, from the Hon. J. H. H. Berkeley, is probably Miller's species in a young state. It has bright green leaves, a little narrowed below the middle and a very narrow red-brown edge, with very small hooked deltoid-cuspidate teeth.

7. A. (Littaa) Lophantha Schiełe in Linnæa, iv. 582.-Acaulescent. Leaves 30-40 in a rosette, rigid, ensiform, 2-3 ft. long, $1 \frac{1}{2}$ in. broad at the middle, dull green in the typical form, $\frac{1}{4}$ in. thick in the centre, rather concave down the face, rounded on the back, ending in a pungent brown spine an inch long, margined by a narrow grey continuous horny line, furnished with distant grey falcate teeth about a line long. Peduncle with spike reaching a length of 15-20 ft. Flowers dense, $1 \frac{1}{4}$ in. long; tube very short; segments linear-oblong, pale green, tinged with brown, as long as the ovary. Stamens twice as long as the perianth-segments.

Hab. Mexico, introduced by Schiede about 1840. Now common in collections, with many named varieties. Flowered at Kew in the autumn of 1887. A. ccrulescens. Salmdyck is a variety with very glaucous leaves, which runs into the type through vars. subcanescens and grisea. A. Funliana K. Koch \& Bouché appears to be a variety with vittate leaves.

8. A. (Littau) univittata Haw. in Phil. Mag. x. 414 ; Balier in Saund. Ref. Bot. t. 215 ; Gard. Chron. 1877, fig. 58 ; Bot. Mag. t. 6655 .- Acaulescent. Leaves 50 or more in a rosette, ensiform, very rigid in texture, $2-2 \frac{1}{2} \mathrm{ft}$. long, $2-3 \mathrm{in}$. broad at the middle, narrowed very slightly downwards and gradually to a pungent endspine an inch long, the face very slightly concave, dull dark green, with a broad pale band down the middle, the edge furnished with a continuous narrow brown margin, with distant small falcate prickles. Peduncle 3-4 ft. long, with dense squarrose bract-leaves. Spike dense, 7-8 ft. long, 4 in. diam. Ovary cylindrical, glaucousgreen, an inch long; tube very short; segments yellowish, $\frac{1}{2}$ in. 
long. Stamens inserted at the throat of the tube, more than twice as long as the segments.

Hab. Mexico, introduced into cultivation about 1830. Flowered at Kew in 1880, with Mr. Peacock about the same time, and with Mr. Wilson Saunders in 1869. I cannot, from the description, separate $A$. ensifera Jacobi, Nacht. 14.

9. A. (Littca) splendens Jacobi, Nacht. ii. 63.- Shortly caulescent. Leaves 50-60 in a rosette, ensiform, very rigid, above $2 \mathrm{ft}$. long, 2 in. broad at the middle, subopaque olive-green, not vittate, narrowed to a pungent point an inch long, margined with a very broad border, brown, fading to grey, the teeth very large crowded irregular subdeltoid hooked, sometimes confluent.

Hab. Described by Jacobi in 1870 from the collections of Muilman at Utrecht and Baron de Jonge van Elemeet. Allied to A. xylonacantha. It flowered at the Missouri Botanic Garden in January, 1885, and Mr. Shaw sent us a leaf for the Kew Herbarium.

10. A. (Littar ) xylonacantha Salmdyck in Bompland. vii. 92; Hook. fil. in Bot. Mag. t. 5660 ; Gard. Chron. 1877, fig. 81.Shortly caulescent. Leaves not more than 20 in a rosette, ensiform, $1 \frac{1}{2}-3$ ft. long, $2-3$ or even $4 \mathrm{in}$. broad at the middle, a slightly glancous dead green, narrowed gradually to a pungent brown point an inch long, pale green, marked with a few darker green lines on the back, furnished with a broad continuous horny border and a few very large irregular deltoid hooked often geminate teeth. Peduncle 5-6 ft. long; bract-leares subulate, ascending. Spike longer than the peduncle. Flowers $1 \frac{1}{4}-1 \frac{1}{2}$ in. long; ovary cylindrical; tube very short; segments lanceolate, greenish yellow, $\frac{1}{2}-\frac{5}{8} \mathrm{in}$. long. Stamens three times as long as the segments.

Hab. Mexico, introduced from Real del Monte by Mr. Repper in 1846. Flowered at Kew in 1867, and with Mr. Wilson Saunders in 1866 \& 1867. Vars. perbella (Gard. Chron. 1877, fig. 22) and hybrida (fig. 80) are dwarf forms with vittate leaves. A. amurensis Jacobi, Monog. 46 (A. Kochii Jacobi, Monog. 211) is apparently a similar divarf form.

11. A. (Littan) multilineata Balier. A. heteracantha Hort. Angl., non Zucc.-Acaulescent. Leaves 30-40 in a dense rosette, ensiform, a foot long, an inch broad at the middle, dark green, neither glaucous nor vittate, narrowed gradually to a pungent apex, with a narrow continuous grey edge with irregular distant small lanceolate uncinate teeth, rounded on the back, pale green, with copious interrupted darker green lines. Peduncle $3 \mathrm{ft}$. long. Spike slender, not dense, finally $5 \mathrm{ft}$. long. Perianth $1 \frac{1}{2} \mathrm{in.}$ long; tube very short; segments linear, $\frac{1}{2}$ in. long. Stamens twice as long as the segments. Capsule oblong-trigonous, $\frac{3}{4}$ in. long.

Hab. Probably Mexico. Described from a plant that flowered at Kew in the autumn of 1887 . We have received it lately from Leichtlin as "A. tetragona."

12. A. (Littca) heteracantha Zuccal. in Nova Acta, xvi. 2, 675 ; Regel, Gartenfl. t. 639. A. Poselgerii Salmdyck. A. Lechuguilla Torrey.-Acaulescent. Leaves 20 or 30 in a dense rosette, ensiform, rigid, $1-1 \frac{1}{2} \mathrm{ft}$. long, $1 \frac{1}{2}-2 \mathrm{in}$. broad at the middle, dull green, with a broad pale band down the face, rounded and marlied with distinct green lines down the back, the margin furnished with a distinct moderately broad grey or brown edge, with numerous middle-sized 
or large hooked brown teeth. Peduncle including the dense spike reaching a length of $6-10 \mathrm{ft}$. Flower $1 \frac{1}{2} \mathrm{in}$. long; tube very short; segments lanceolate, above $\frac{1}{2}$ in. long. Stamens twice as long as the segments.

Hab. Texas and Northern Mexico, Wright 1907! Palmer 1311! Pringle 157 ! We have a specimen from Mr. Shaw of a plant that flowered at the Missouri Botanic Garden in January, 1885. The strong short fibres of the leaves is used, Mr. Morris tells me, in the manufacture of brushes.

13. A. (Littaa) Kenchover Lemaire in Ill. Hort. 1864, 64 ; Gard. Chron. 1877, fig. 78. A. Beancamei Lemaire.-Acanlescent. Leaves 20-30 in a rosette, cusiform, rigid, 6-12 in. long, $1 \frac{1}{2}-2 \mathrm{in}$. broad low down, dull green, with a pale central band on the face, rounded on the back without any darker green lines, the pungent end-spine an inch long, the continuous grey or brown border moderately broad, the irregular grey lanceolate curved teeth $\frac{1}{6}-\frac{1}{4}$ in. long. Inflorescence a dense spike. Flowers $1 \frac{1}{2}$ in. long; segments linear-oblong, twice as long as the broadly funnel-shaped tube. Stamens twice as long as the perianth-segments. Capsule an inch long.

Hab. Mexico ; Chihuahua, alt. 7000-8000 ft., Pringle 802! Introduced by Verschaffelt about 1864, and named by Lemaire in compliment to the Baron Kerchore von Oussclghem. Widely spread now in gardens with many varieties: inermis is dwarf, without any spines; pectinata has a broader leaf than in the type, without any central band; macrodunta has leaves $1 \frac{1}{2} \mathrm{ft}$., with copious irregular grey lanceolate prickles; and diplacantha few distant smaller often geminate teeth. A. rigidissima Jacobi, Nacht. ii. 66 , seems to be also a form with few very remote deltoid teeth, sometimes entirely obsolete.

14. A. Nissoni Baker in Gard. Chron. 1874, i. 529. - Acaulescent. Leaves 30-40 in a rosette, ensiform, rigid, 5-6 in. long, $\frac{3}{4}-\frac{7}{8}$ in. broad above the dilated base, glaucous green on the face, with a distinct pale central band, the pungent end-spine $\frac{1}{2} \mathrm{in}$. long, the margin with a very narrow continuous grey edge, with copious lanceolate spines $\frac{1}{8}$ in. long. Inflorescence unknown.

Hab. Mexico, introduced lately by Verschaffelt. Differs from all forms of Kerchovei by its more numerous thinner leaves with a narrotver border.

15. A. Roezliana Baker in Gard. Chron. 1877, i. 529, fig. 79.Acaulescent. Leaves 20-30 to a rosette, ensiform, rigid, 6-7 in. long, 1-1 $\frac{1}{2}$ in. broad at the middle, bright glossy green on the face, with a distinct pale central band, rounded on the back without any darker green lines, narrowed to a bright reddish brown pungent spine $\frac{1}{2}-\frac{3}{4} \mathrm{in}$. long, continuously margined with a moderately broad border of red-brown fading to grey, furnished with copious spreading lanceolate little-curved teeth $\frac{1}{4}-\frac{1}{3} \mathrm{in}$. long. Inflorescence unlmown.

Var. Inghami Balier l.c.-Leaves $1 \frac{1}{2}-2$ in. broad at the middle, slightly narrowed downwards, $1-1 \frac{1}{4} \mathrm{in}$. broad above the base.

Hab. Mexico, introduced by Roezl.

16. A. (Littaa) Victoriz-Regine T. Moore in Gard. Chron. 1875, ii. 485, with wooleut; Engelm. in Gard. Chron. 18s2, ii. 841, figs. 148, 149 ; Ill. Hort. n. s. t. 413. A. Consideranti Carriere in Rev. Hort. 1875, 429, fig. 68. - Acaulescent. Leaves 100-200, forming a dense rosette a foot in diameter, densely imbricated, 
lanceolate, 6-8 in. long, 18-21 lines broad above the dilated base, narrowed gradually to a rather obtuse point, which is tipped by a pungent black spine $\frac{1}{2} \mathrm{in}$. long, which has usually 1-2 small deltoid teeth on each side of it, dead green, margined with a continuous white border which leaves distinct vertical bands where it is pressed against the neighbouring leaves. Peduncle $4 \mathrm{ft}$. long. Spike dense, cylindrical, $6 \mathrm{ft}$. long. Flower greenish-yellow, $1 \frac{1}{4}$ in. long; tube very short; segments oblong-lanceolate, $\frac{1}{2}$ in. long. Stamens three times the length of the segments.

Hab. Mexico, near Monterey, first brought to Europe by M. Considerant in 1872. Flowered for the first time at the Cambridge Botanic Garden, Boston, U.S.A., in the autumn of 1882, the plant having been brought from Monterey by Dr. Palmer. A most distinct and remarkable species.

17. A. Vanderminneni Jacobi, Nacht. 19.-Acaulescent. Rosette $5 \mathrm{ft}$. broad and nearly $3 \mathrm{ft}$. high. Leaves numerous, oblongspathulate, $2-2 \frac{1}{2} \mathrm{ft}$. long, 6-7 in. broad at the middle, dull opaque, green, not vittate, banded and glancescent on the back, with a long pungent end-spine and a continuous straight grey-brown edge, and remote regular large deltoid-uncinate brown teeth. Inflorescence unknown.

Hab. Probably Mexico. Described from the Belgian collections in 1868.

18. A. Demeesteriana Jacobi, Monogi. 218. - Shortly caulescent. Leaves very rigid, lanceolate-spathulate, nearly $2 \mathrm{ft}$. long, $3 \frac{1}{2}$ in. broad at the middle, narrowed to $2 \frac{3}{4}$ in. above the base, opaque, glancous green, not vittate, furnished with broad transver'se deeper-coloured and paler bands, the end-spine short but pungent, the margin distinct, narrow, horny, repand, with broad small teeth. Inflorescence unknown. in 1865 .

Hab. Probably MIexico. Described by Jacobi from the Belgian collections

19. A. (Littcea) Henriquesir Baker in Gard. Chron. 1887, i. 732, fig. 70.-Acaulescent. Leaves oblong-lanceolate, rigid, bright green, $2 \mathrm{ft}$. long, $5 \mathrm{in}$. broad at the middle, pungent at the apex, with a continuous broad brown edge, with copious deltoid-cuspidate prickles $\frac{1}{4}$ in. long, with a very broad base, which are sometimes geminate. Peduncle including infloreseence 13-14 ft. long. Spike dense, longer than the peduncle. Ovary an inch long; tubs very short; segments linear, dark brown. Stamens more than twice as long as the narrow segments.

Hab. Probably Mexico. Described from a plant that flowered at the Botanic Garden of Coimbra, May, 1887, from material supplied by its Director, Prof. Henriques.

20. A. (Littca) Haynaldi Todaro, Hort. Bot. Panorm. 88, t. 24. Leaves 30-40 in a dense rosette, rigidly coriaceous, dark green, a yard long, 4-5 in. broad at the middle, narrowed to $2 \frac{1}{2}-3 \mathrm{in}$. above the base, with a pungent brown end-spine an inch long, margined continuously with grey brown, furnished with copious irregular middle-sized much-hooked prickles. Peduncle including the spike about $25 \mathrm{ft}$. long, the former short. Flower green, 2 in. long; tube scarcely any; segments oblong, an inch long. Filaments $2 \frac{1}{2}-3$ in. long. 
Hab. Probably Mexico. Described by Dr. Todaro in 1878 , from a plant that flowered near Palermo. Named after Archbishop Haynald.

21. A. Gheisbreghti Lemaire; Jacobi, Monogi. 42. - Acaulescent. Leaves $30-60$ in a dense rosette, lanceolate-spathulate, rigid, bright glossy green, not vittate, $9-12 \mathrm{in.}$ long, $2 \frac{1}{2}-3 \mathrm{in}$. broad at the middle, nar'rowed to $2-2 \frac{1}{2}$ in. above the dilated base, the pungent end-spine $\frac{1}{2}$ in. long, the back not striated with green lines, the border red-brown till a late-stage, the copious irregular lanceolate-deltoid teeth $\frac{1}{6}-\frac{1}{4}$ in. long. Inflorescence unlinown.

Var. A. Rohani Jacobi, Monogr. 43. - Leaves about $\frac{1}{2} \mathrm{ft}$. long. deader green, vittate down the face.

Var. A. Leguarana Hort. - Leaves a foot long, $1 \frac{1}{2} \mathrm{in}$. broad at the middle, with a narrower edge.

Hab. Mexico, sent by Gheisbreght in 1862 to Verschaffelt.

22. A. Peacocirn Croucher in Gard. Chron. 1873, 1400, tab. 283. -Acaulescent. Leaves 40-60 in a rosette, rigid, oblanceolatespathulate, 9-12 in. long, 2 in. broad above the middle, narrowed to $1 \frac{1}{2}$ in. above the clilated base, dull green, with a pale central band down the face, the pungent end-spine an inch long, the moderately broad continuous horny border at first red-brown, then grey, the large subdistant deltoid-cuspidate prickles $\frac{1}{4}-\frac{1}{3} \mathrm{in}$. long. Inflorescence unknown.

Hab. Central Mexico; Province of Tehuacan, imported by Roezl. Described from a plant seen at Mr. J. T. Peacock's in November, 1872.

23. A. (Littea) Horrida Lemaire; Jacobi, Monogr. 43 ; Baker in Bot. Mag. t. 6511. A. Desmetiana and Regeliana Hort.Acaulescent. Leaves 30-50 in a dense rosette, rigid, lanceolate-

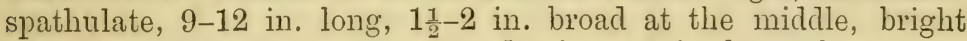
green, not vittate, the pungent end-spine $\frac{3}{4}-1$ in. long, the margin furnished with a continuous broad grey border, with copious large deltoid-cuspidate teeth $\frac{1}{3}-\frac{1}{2}$ in. long. Peduncle stout, 3-4 times as long as the leaves; bract-leaves copious, subulate, squarrose. Spilie very dense, as long as the peduncle. Flower's $1 \frac{3}{4} \mathrm{in}$. long; tube funnel-shaped, $\frac{1}{3}$ in. long; segments lanceolate, yellowish green, as long as the ovary. Stamens under three times the length of the segments.

Var. macrodonta Balier in Gard. Chron. 1877, 623. - Leaves 50-60, broader than in the type ( $2 \frac{1}{2}$ in.). Spines larger.

Var. micracantha Baker in Gard. Chron. l. c. fig. 98. A. grandidentata Jacobi, Nonogr. 207. - Border of the leaf narrower, and spines smaller than in the typical form. A. Morganii Hort. differ's from this by its larger teeth.

Var. A. Gilbeyi Hort.; Gard. Chron. 1873, 1305, fig. 270 ; 1877, fig. 101 ; Regel, Gartenfl. 1874, 89, with woodcut. - Leaves about 30 , not more than $3-4$ in. long, 2 in. broad at the middle, dark green, with a pale stripe down the centre, the border as broad as in the type, with 3-4 large spines on each side.- Introduced by Roezl from Tehuacan.

Var. A. Triangularis Jacobi in K. Koch Wochen. 1869, 178.Leaves obovate, glatcous grey, about \pm in. long by 3 in. broach, the border very broad, the teeth very large and curved. 
Hab. Mexico, introduced by Verschaffelt in 1862. The type is described from a plant of Mr. J. T. Peacock's that flowered at Kew in April, 1880. We have a photograph from Dr. Todaro of a tuft that bore 10-12 spikes simultaneously in the Palermo Botanic Garden in 1885. I cannot, by the description, separate A. Maigretiana Jacobi, Monogr. 215.

\section{Group 3.-Subiarginate.}

24. A. Pumin Hort. De Smet.-Acaulescent. Leaves 7-8 in a dense rosette, an inch high, $2 \frac{1}{4}-2 \frac{1}{2}$ in. diam., ovate, thick, rigid, more or less ascending, 1-1 $\frac{1}{4}$ in. broad, $\frac{1}{2}-\frac{3}{4}$ in. long, narrowed suddenly to a weak dark end-spine $\frac{1}{4} \mathrm{in}$. long, which is decurved as a narrow line half-way down the blade; marginal prickles distant, lanceolate, hooked, deflexed, $\frac{3}{4}-\frac{1}{6} \mathrm{in}$. long. Inflorescence unknornn.

Hab. Probably Mexico. Our Kew plant of this curious very dwarf species was received from De Smet in 1879, and in eight years has not increased in size materially. It produces offsets freely about the base.

25. A. (Euargave) Shawir Engelm. Notes, 26, tabs. 2 and 3. -Acaulescent. Leaves 50-60 or more, oblong-spathulate, 8-10 in. long, $3 \frac{1}{2}-4 \frac{1}{2} \mathrm{in}$. broad at the middle, dull green, slightly glaucous, narrowed to a brown pungent end-spine an inch long, the horny border decurrent, the edge below it furnished with copious upcurved lanceolate brown teeth $\frac{1}{4}-\frac{1}{2} \mathrm{in}$. long. Peduncle 8-12 ft. Panicle thyrsoid, about $2 \mathrm{ft}$. long and broad; branches stout, 4-9 in. long. Flowers $3-3 \frac{1}{2}$ in. long, greenish yellow; tube broadly funnel-shaped, $\frac{1}{2}-\frac{3}{4}$ in. long; segments an inch or more. Stamens half as long again as the segments. Capsule oblong-trigonous, cuspidate, $2 \frac{1}{2}-2 \frac{3}{4}$ in. long.

Hab. Dry hills bordering the Pacific at the south-west corner of California, discovered by Dr. Parry in 1850. Named by Dr. Engelmann after Mr. Henry Shaw, who founded and endowed the Botanic Garden at St. Louis, Missouri. In $1885 \mathrm{Mr}$. Shaw kindly sent us a set for the Kew Herbarium of the leaves of all the Agaves he had in cultivation. Introduced into cultivation about 1875.

26. A. (Euagave) Deserti Engelm. Notes, 22.-Acaulescent. Leaves few in a rosette, oblanceolate, $\frac{1}{2}-1 \mathrm{ft}$. long, $1 \frac{1}{2}-2 \mathrm{in}$. broad above the middle, very glaucous, deeply concave on the face, with a long slender brown end-spine decurrent to about the middle of the edge, both this and the unbordered lower half of the leaf being furnished with crowded strong hooked horny lanceolate prickles $\frac{1}{6}-\frac{1}{4}$ in. long. Peduncle slender, reaching 6-10 ft. Panicle thyrsoid; branches very short; lower horizontal. Flower yellow, under 2 in. long; tube $\frac{1}{8}-\frac{1}{6} \mathrm{in}$. long and broad; segments oblong, $\frac{3}{4} \mathrm{in}$. long. Stamens twice as long as the segments.

Hab. Eastern base of the mountains of Southern California, discovered by Lieut. Emory in 1846. Introduced into cultivation about 1875.

27. A. (Fuagare) Huachucensis Baker.-Leaves very thick and rigid, oblong, 15-16 in. long, $\frac{1}{2} \mathrm{ft}$. broad at the middle, the brown pungent end-spine above an inch long, decurrent as a horny border to the middle of the blade, both it and the rest furnished with copious deflexed brown prickles, the upper ones lanceolate-deltoid, $\frac{1}{3}-\frac{1}{2}$ in. long, the lower growing regularly gradually smaller. Flower $2 \frac{1}{2}$ in. long; tube funnel-shaped, $\frac{1}{3}-\frac{1}{2}$ in. long and broad; 
segments 3 in. long, yellow, lanceolate from a deltoid base. Stamens 2-3 times the length of the segments.

Hab. Arizona ; IIuachuca MLountains, alt. 5000-8000, Pringle! Receired in 1885. Nearly allied to $A$. Shavii, Engelm.

28. A. (Euagave) applanata Lemaire; Jacobi, Monogr. 48; Sodaro Hort. Bot. Panam. ii. 29, t. 30.-Acaulesent. Leaves sometimes 150 , oblong-spatlunlate, $8-12 \mathrm{in}$. long, 3-3.3. in. broad at the middle, narrowed to $2-2 \frac{1}{3} \mathrm{in}$. above the base, intensely persistently glaucous, the lower half of the face flat, the upper half concave, the pungent end-spine an inch long, decurrent as a brown border the upper third or half of the blade, the bright brown deflexed lanceolate prickles $\frac{1}{4}-\frac{1}{3}$ in. long. Peduncle $3-4$ times as long as the leaves. Panicle thyrsoid, as long as the peduncle; lower branches patent. Flowers greenish yellow, $2 \frac{1}{2}-3$ in. long; tube short; segments lanceolate, an inch long. Stamens 2-3 times the length of the segments.

Hab. Mexico, introduced into cultivation about 1862. Flowered for the first time lately with Dr. Todaro at the Palermo Botanic Garden. I cannot, from the description, clearly separate $A$, cinerascens, Jacobi Monogr. 51.

29. A. (Euagure) Asperrinia Jacobi Monogr. 61.-Acaulescent. Leares few, oblanceolate, $1 \frac{1}{2}-2 \mathrm{ft}$. long, $3-4$ in. broad at the middle, dull green when mature, glaucous when young, scabrous on both surfaces, with a very large pungent end-spine decurrent for half a foot or more, the prickles very large and deltoid-cuspictate. Flower's $2 \frac{1}{2}$ in. long; tube broadly fumnel-shaped $\frac{1}{2}$ in. long; segments yellowish, under an inch long. Stamens more than twice as long as the segments. Capsule oblong, $1 \frac{1}{2}-2$ in. long.

Hab. Mexico ; State of Coahuila, Palmer 1309! Pringle 158! Described by Jacobi in 1864 , from plants sent by Lindheimer to the Botanic Garden of Munich. Dr. Engelmann sent out seeds under the name of A. longispina.

30. A. Toneliana Baker in Gard. Chron. 1881, i. 362.Acanlescenit. Leares $40-50$ in a dense rosette, lanceolate, rigid, $1 \frac{1}{2}-2 \mathrm{ft}$. long, $3-4 \mathrm{in}$. broad at the middle, narrowed to $2 \frac{1}{2}-3 \mathrm{in}$. abore the base, flat in the lower half, green, glaucous only when young, $\frac{1}{8} \mathrm{in}$. thick in the centre; the pungent brown end-spine an inch long, decurrent for 3-4 in., the rest of the border margined with chesnut-brown cuspidate prickles $1-8$ th to $1-12$ th in. long with a very broad base, which is confluent except for a short space above the middle of the blade. Inflorescence unknown.

Hab. Probably Mexicar Described from a plant of Mr. J. T. Peacock's, when his collection was exhibited at Kew in 1881. Named after M. Tonel, of Ghent.

31. A. (Eunyace) Hookeri Jacobi, Monogr. 219 ; Baker in Bot. Mag. t. 6589.-Acaulescent. Leaves $30-40$ in a rosette, oblanceolate, $4 \mathrm{ft}$. long, 6-9 in. broad at the middle, marrowed to 4-5 in. above the base, green, only slightly glaucous when young and towards the base, marrowed gradually to a pungent end-spine $1 \frac{1}{2}-2$ in. long, which is decurrent as a narrow brown edge for 4-6 in., the prickles deltoid-cuspidate from a broad base $\frac{1}{4}-\frac{1}{3}$ in. long. Peduncle $30 \mathrm{ft}$. long including the panicle, $4-5$ in. thick at the base. Panicle thyrsoid, 4-5 ft. long, the lower branches a 
foot long. Flower's greenish yellow, $3 \mathrm{in.}$ long; tube broadly funnelshaped, $\frac{1}{2}$ in. long; segments $1 \frac{1}{4}$ in. Stamens more than twice as long as the segments.

Hab. Mexico. Described by Jacobi in 1865 from plants at Kew and Reigate. At Kew it flowered for the first time in October, 1880. A. Fenzliana Jacobi Monogr. 221 differs from typical Hookeri (see N. E. Brown in Gard. Chron. 1883 i. 507) by its smaller prickles. I cannot from the description separate $A$. incequidens $K$. Koch in Wochen. 1860,28 , and if this be the same that name is the earliest.

32. A. (Euayare) atrovirens Karw.; Salmdyck, Hort. Dyck. 1834, 302. A. tehuacensis, Karw. A. Salmiana Otto ; Rev. Hort. 1873, 373, tabs. 40-41; Gard. Chron. 1871 ii. 141, t. 31, 1877, 2, fig. 33. - Acaulescent. Leaves 12-30, oblanceolate-spathulate, 2-4 ft. long in cultivation, 4-6 in. broad above the middle, narrowed to 3-4 in. above the base, a dull slightly glancous green, the face often very concave, the pungent end-spine $1 \frac{1}{2}-2$ in. long and decurrent for 6-12 in., the large deltoid-cuspidate teeth hooked either up or down, with the edge repand between them. Peduncle with inflorescence reaching a length of 25-30 ft. Panicle 6-8 ft. long; flowers $4 \mathrm{in}$. long; tube short; segments $1 \frac{1}{2}$ in. long. Stamens 3 in. long. I cannot from the descriptions definitely separate A. Jacobianu, Salmdyck, A. Canartiuna, Schlechtendalii, deflexispina, Ottonis and gracilis Jacobi.

Var. A. Latissina Jacobi, Monogr. 41.-Leaves broader, oblongspathulate, $2-3 \mathrm{ft}$. long by 8-9 in. broad above the middle. From this I camnot separate A. Lehmanni, mitraformis and coarctata Jacobi.

Hab. Mexico, introduced into cultivation by Karwinski, who says that the leaves of the wild plant reach a length of 12 feet. It must be borne in mind that the dimensions of the leaves in these descriptions are almost invariably taken from plants cultivated in pots under glass, and that, therefore, no doubt they are often far short of what the plant reaches in its native stations. This is said to be the species specially used in the manufacture of pulque. It has flowered at Paris, Antibes, and on the shores of the Lago Naggiore, and is now doing so at Kerv.

33. A. (Euayace) cochlearis Jacobi, Nacht. ii. 67.-Acaulescent. Leaves few in a rosette, oblong-spathulate, 5-6 ft. long, above a foot broad, opaque green, with a deeply excavated face, the very stout pungent end-spine decurrent for some distance, the middlesized deltoid-cuspidate brown prickles variously curved. Peduncle with inflorescence reaching a length of 26 feet. Flowers 4 in. long; tube short; segments yellowish green above $1 \frac{1}{2} \mathrm{in.long.}$ Stamens 3 in. long.

Hab. Mexico. Described by Jacobi from a plant that flowered at Stuttgart in 1867. Perhaps not distinct specifically from A. atrovirens.

34. A. (Fuagave) spectabilis Todaro, Hort. Bot. Panorm. ii. 4, t. 25.-Acaulescent. Leaves 180 in a rosette, lanceolate, very glaucous, 6-7 ft. lovg, 5 in. broad at the middle, with a large pungent spine decurrent for half a foot and middle-sized lanceolatedeltoid brown teeth, with the edge not repand between them. Panicle thyrsoid; branches erecto-patent, the lower above a foot long. Flowers greenish yellow, $2 \frac{1}{2}$ in. long; tube very short; segments above an inch long. Stamens twice as long as the segments. 
Hab. Probably Mexico. Flowered in 1879 with Dr. Todaro at the Palermo Botanic Garden.

\section{Group 5.-Americane.}

35. A. cucullata Lemaire; Jacobi, Monogr. 89.-Acaulescent. Leaves about 20 in a dense rosette, oblong-spathulate, very

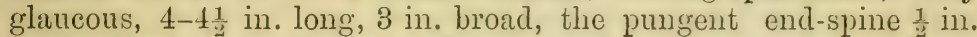
long, the close horny deltoid-cuspidate teeth $\frac{1}{6} \mathrm{in.}$ long. Inflorescence unknown.

Hab. Mexico, introduced into cultivation by Verschaffelt about 1860 . Perhaps only a dwarf variety of A. Scolymus. A. Simsii, Croucheri and rotundifolia, Hort. are closely allied forms.

36. A. (Eucugave) megalacantha Hemsl. Diag. iii. 55; Biol. Cent. Amer iii. t. 88 A.-Leaves oblong, 4 in. long, 3 in. broad, with a pungent end-spine above an inch long and 5-6 very large prickles on each side with a horny deltoid-cuspidate apex. Flower $1 \frac{3}{4}$ in. long; tube very short; segments lanceolate, yellow, $\frac{3}{4}$ in. long. Filaments $1-1 \frac{1}{4}$ in. long.

Hab. Mexico, at Pedregat, near the city of Mexico. Bourgean 1020 bis! Collected during the French expedition of 1863-1866.

37. A. (Fuugure) Seemanniana Jacobi, Nacht. 29.-Acaulescent. Leaves about 20 in a rosette, oblong-spathulate, 6-9 in. long, $3-3 \frac{1}{2} \mathrm{in}$. broad at the middle, narrowed to $2 \mathrm{in}$. above the base, slightly glaucous, the face flat except near the tip, the dark brown pnngent end-spine $\frac{1}{2}$ in. long, the teeth small, moderately close, deltoid-cuspidate, decurved. Peduncle with panicle reaching a length of $6 \mathrm{ft}$.

Hab. Guatemala, introduced into cultivation by Dr. Seemann through Mr. W. Bull in 1868.

38. A. (Euarace) Parryi, Engelm. Notes, 23.-Acaulescent. Leaves 20-30 in a rosette, oblong-spathulate, 10-12 in. long, $3-3 \frac{1}{2} \mathrm{in}$. broad at the middle, narrowed to $2 \frac{1}{2} \mathrm{in}$. above the base, the brown pungent end-spine an inch long, the slender brown horny teeth not more than $\frac{1}{6} \mathrm{in}$. long in the upper part of the blade. Peduncle 8-12 ft. long. Panicle about 3 ft. long. Flower 2 in. long; tube broadly fumnel-shaped, $\frac{1}{3} \mathrm{in}$. long ; segments lanceolate, $\frac{3}{4}$ in. long. Stamens more than twice as long as the segments. Capsule oblong-trigonous, $1 \frac{3}{4} \mathrm{in}$. long.

Hab. Arizona and New Mexico, discovered by Lieut. Emory in 1846. Distributed in European gardens by Dr. Engelmann in 1868 from seeds Gathered by Dr. Parry. Flowered at the Missouri Garden in 1879.

39. A. (Euagave) Wistizeni Engelm. Notes 32. A. scabra Salmdyck in Bonpland. vii. 89.-Acaulescent. Leaves about 30 in a rosette, oblong, a foot long, 3-5 in. broad at the middle, very rigid, very glaucous, the end-spine hard and pungent, shortly decurrent, the subdistant middle-sized spines deltoid-cuspidate, straight or hooked. Peduncle with panicle reaching 10-12 feet. Flower $2 \frac{1}{2} \mathrm{in.}$ long; tube short, obconic ; segments yellowish, $\frac{3}{4} \mathrm{in}$. long. Stamens more than twice as long as the segments. Capsule 2 in. long.

Hab. Northern Mexico; province of Chihuahua, \&c., Palmer 1310! Pringle 22! Discovered by Dr. Wislizenus in 1847. 
40. A. FEROX K. Koch in Wochen. 1860, 23.-Acaulescent. Leaves 20-30 in a rosette, oblong-spathulate $1 \frac{1}{2}-2 \mathrm{ft}$. long, 6-9 in. broad at the middle, narrowed to $4 \frac{1}{2}-5 \mathrm{in}$. above the dilated base, a dull slightly glancous green, the face flat except at the top, the slightly decurrent pungent point above an inch long, the very large deltoid-cuspidate brown teeth $\frac{1}{3}-\frac{1}{2} \mathrm{in}$. long, with the edge deeply repand between them. Inflorescence unknown.

Hab. Mexico, not unfrequent in cultivation. A. Bomnetiana of the Belgian Gardens is scarcely different.

41. A. Galeottei Baker in Gard. Chron. 1877, ii. 41.Acaulescent. Leaves $30-40$ in a dense rosette, oblong-spathulate, 1-1 $\frac{1}{2} \mathrm{ft}$. long, 4-6 in. broad above the dilated base, the face flat or rather concave, green, hardly at all glaucous when mature, the pungent end-spine $\frac{3}{4}-1$ in. long, the close deltoid-cuspidate purplish black prickles $\frac{1}{6}-\frac{1}{4} \mathrm{in}$. long, straight or slightly hooked. Inflorescence unknown.

Hab. Mexico. Described from plants seen in the Saunders and Peacock collections in 1872 .

42. A. (Enayare) Guedenerri Houllet in Rev. Hort. 1875, 466. -Acaulescent. Leaves about 30 in a rosette, oblong-spathulate, $2 \frac{1}{2} \mathrm{ft}$. long, 4-5 in. broad above the middle, dull glaucous green, with a pungent end-spine an inch long and small brown deltoidcuspidate prickles $\frac{1}{8}-\frac{1}{6} \mathrm{in}$. long. Flowering stem 10-12 ft. long. Panicle thyrsoid, with about 20 branches. Flowers yellowish green. Stamens much exserted.

Hab. Mexico. Of this I have seen only a young plant in the collection of Mr. J. T. Peacock. It flowered in the collection of MI. Guedeney at Vesinet, in 1875.

43. A. (Euagare) Longisepala Todaro, Hort. Bot. Panorm. t. 31. -Acaulescent. Leaves moderately numerous, oblong-spathulate, glaucous green, 7-8 in. broad at the middle, narrowed to 3-4 in. above the base, the pungent end-spine an inch long, the edge slightly repand between the large broad-based deltoid-cuspidate teeth. Peduncle about 5 times as long as the leaves. Panicle shorter than the peduncle; branches ascending. Flower $2 \frac{1}{2}-3$ in. long; tube short ; segments yellowish green, $1 \frac{1}{2} \mathrm{in.} \mathrm{long.} \mathrm{Stamens}$ very long.

Hab. Probably Mexico. Flowered lately with Dr. Todaro at the Palermo Botanic Garden.

44. A. (Euagave) Scolynus Karw.; Salmdyck Hort. Dyck. 307 ; Baker in Saund. Ref. Bot. t. 328.-Acaulescent. Leaves 20-40 in a dense rosette, oblong-spathulate, 9-18 in. long, 3-6 in. broad above the middle, very glaucous, the pungent end-spine an inch or more long, the large liorny deltoid-cuspidate teeth $\frac{1}{4}-\frac{1}{3} \mathrm{in}$. long. in the upper half of the blade, with the edge distinctly repand between them. Peduncle including the thyrsoid panicle 14-16 ft. long. Flower 2-3 in. long; tube short, broadly funnel-shaped; segments greenish-yellow, $\frac{3}{4}-1$ in. long. Stamens twice as long as the segments.

Hab. Mexico, introduced into cultivation about 1880, and now common, with numerous varieties. Under this I place A. Schnittsphani Jacobi, A. 
amona Lemaire (smaller than typical Scolymus), A. Verschaffeltii Lemaire in Ill. Hort. t. 564, Baker in Saund. Ref. Bot. t. 306, A. S'uundersii Hook. in Bot. Mag. t. 5493 (leaves about a foot long; teeth very large), $A$. crenata Jacobi, $A$. Mescal K. Koch (less glaucous than the type), and A. auricantha Hort. (leaves thinner and more numerous than in the type, moderately glaucous, with smaller prickles). A. Verschaffeltii medio-picta Hort. De Smet is a form with variegated leaves. A plant which, so far as leaf goes, might be a form of Scolymus, flowered at Kew in 1887 with panicle branches quite suppressed, thus furnishing a link of transition between the subgenera Euagave and Littcea.

45. A. (Euagare) ротатопun Zuccar. in Nova Acta xvi. 2. 674.Acaulescent. Leaves about 20 in a rosette, oblong-spathulate, 2-2 $\frac{1}{2} \mathrm{ft}$. long, 7-9 in. broad at the middle, narrowed to $4-5 \mathrm{in}$. above the base, a clull glaucous green, the face slightly concave, the slightly decurrent pungent end-spine $1 \frac{1}{2}-2 \mathrm{in.}$ long, the horny deltoid-cuspidate prickles $\frac{1}{4}-\frac{1}{3}$ in. long, with the edge repand between them. Peduncle 10-12 ft. long, including the thyrsoid panicle, which is $4-5 \mathrm{ft}$. long. Flowers $3 \mathrm{in.}$ long; tube short; segments greenish yellow, an inch long. Stamens twice as long as the segments.

Hab. Mexico, introduced into cultivation about 1830. Doubtfully distinct specifically from $A$. Scolymus.

46. A. oligophylla Baker in Gard. Chron. 1878, 492. A. parcifolia Baker non Todaro.-Acaulescent, densely crspitose and soboliferous. Leaves $6-8$ in a rosette, lanceolate, 3-4 in. long, $\frac{1}{2}-\frac{5}{3}$ in. broad, slightly glaucescent, broadly channelled all down the face, narrowed gradually to a weak end-spine $\frac{1}{4}-\frac{1}{3}$ in. long, the pricliles lanceolate, horny, decurved, the central ones $\frac{1}{8}$ in. long, the upper and lower smaller. Inflorescence unknown.

Hab. Probably Mexico. Described from a plant in the possession of Mr. Justus Corderoy, of Blewbury, near Didcot, in 1878.

47. A. (Littca) utahensis Engelm. Notes, 20.-Acaulescent. Leaves ensiform, $\frac{1}{2}-1 \mathrm{ft}$. long, 12-21 lines broad, thick, glaucous, rigid, the pungent end-spine an incl long, the deltoid teeth $\frac{1}{8}-\frac{1}{6}$ in. long, white with a darlier base. Peduncle 5-7 ft. long including the 1-2 ft. spike. Flower's about an inch long; tube very short; segments $\frac{1}{3}$ in. long. Stamens little exserted. Capsule oblong, an inch long.

Hab. Southern Utah and Arizona. Introduced into cultivation about 1880. This reaches the farthest north of all Agaves.

48. A. (Littaa) maCRACANThA Zuccar. in Nova Acta xvi. 2, 676 ; Baker in Gard. Chron. 1877, ii. tab. 27. A. flarescens Salmdyck. A. Bessereriana Jacobi ; Bot. Mag. t. 5940.-Acaulescent or shortly caulescent. Leares $30-50$ in a rosette, lanceolate, $\frac{1}{2}-1 \mathrm{ft}$. long, 1-1 $\frac{1}{2}$ in. broad above the middle, very rigid, very glaucous, the face rather turgid in the lower half, the end-spine nearly black, very pungent, $\frac{1}{2}-\frac{3}{4}$ in. long, the purplish-black small subdeltoidcuspidate prickles $\frac{1}{3}-\frac{1}{6}$ in. long. Peduncle $2-3 \mathrm{ft}$. long. Flowers 10-12 in a lax raceme, all solitary on ascending pedicels $\frac{1}{4}-\frac{1}{2} \mathrm{in}$. long. Perianth $2 \mathrm{in.}$ long; segments greenish, three times as long as the tube. Stamens exserted about half an inch.

$\mathrm{Hab}$. Mountains of Central Mexico, ascending to 5000-6000 ft. Introduced into cultivation about 1830. Flowered with MIr. Saunders in the spring of 1871. I cannot separate specifically $A$. subjalcata and linearis Jacobi. 
49. A. concinna Baker in Gard. Chron. 1877, ii. 137.Acaulescent. Leaves about 30 in a rosette, oblanceolate, rigid, 7-8 in. long, 2 in. broad at the middle, narrowed to $1 \frac{1}{2}$ in. above the base, the face flat, slightly glaucous, the pungent end-spine nearly an inch long, the subdistant much-hooked deltoid-cuspidate prickles $\frac{1}{4}$ in. long. Inflorescence unknown.

Hab. Probably Mexico. Described from the Peacock collection in 1872.

50. A. Flaccida Jacobi, Monogr. 226 ; Baker in Gard. Chron. 1877, fig. 26.-Acaulescent. Leaves 40-50 in a rosette, oblanceolate, a foot long, $3 \mathrm{in}$. broad above the middle, narrowed to $1 \frac{1}{2} \mathrm{in}$. above the dilated base, glaucous-green, the face flat throughout, the slightly decurrent pungent end-spine an inch long, the crowded deltoid-cuspidate slightly-hooked prickles 1-6th to 1-5th in. long. Inflorescence unknown.

Hab. Probably Mexico. Described from a plant seen in the Saunders collection in 1872. Intermediate between Scolymus and macracantha.

51. A viridissima Baker in Gard. Chron. 1877, ii. 137.Acaulescent. Leaves about 30 in a rosette, oblanceolate, a foot long, $3 \mathrm{in}$. broad above the mildle, narrowed to $2 \frac{1}{2} \mathrm{in}$. above the base, very rigid, bright green, the face flat, the end-spine hard and pungent, nearly an inch long, the close grey spreading lanceolate unequal prickles $\frac{1}{6}-\frac{1}{4}$ in. long, those of the upper half of the blade slightly curved upwards. Inflorescence unknown.

Hab. Probably Mexico. Described from a plant seen in the Peacock collection, Nov., 1872.

52. A. (Euagave) weissenburgensis Wittm. in Berl. Gartenzeit, 1885, 14, fig. 5.-Acaulescent. Leaves 30-40, oblanceolate, 8-9 in. long, $2-2 \frac{1}{2} \mathrm{in}$. broad above the middle, rigid, green, scarcely at all glaucous, the pungent end-spine $\frac{1}{2}$ in. long, the hooked distant deltoid-cuspidate prickles $\frac{1}{8}-\frac{1}{6}$ in. Peduncle with panicle $7-8 \mathrm{ft}$. long, the latter of few very short ascending branches. Flower above $2 \mathrm{in.}$ long; tube $\frac{1}{2} \mathrm{in}$. ; segments greenish yellow, lanceolate, $\frac{3}{4} \mathrm{in}$. long. Stamens twice as long as the segments. Capsule $1 \frac{1}{2}$ in. long.

Hab. Probably Mexico. Described by Dr. Wittmack from a plant that flowered at Weissenburg, in the province of Brandenburg, in 1885.

53. A. (Euagave) Baxteri Baker.-Acaulescent. Leaves about 30 in a dense rosette, oblanceolate-spathulate, $3 \mathrm{in}$. broad above the middle, narrowed to 2 in. above the face, flat on the face, moderately glaucous, the pungent end-spine about an inch long, the marginal teeth subdistant, lanceolate, hoolied, horny to the base, at most $\frac{1}{6} \mathrm{in}$. long. Peduncle glaucous, $4 \mathrm{ft}$. long, an inch thick. Panicle thyrsoid, $4 \mathrm{ft}$. long; branches erecto-patent, the central ones 4-5 in. long, with flowers up to 20 in a dense cluster at the end. Flowers about 2 in. long; ovary $\frac{3}{4}$ in. ; tube short.

Hab. Probably Mexico. Described from a plant that flowered at Kew in the spring of 1888, received from the Oxford Botanic Garden, named after its late Curator.

54. A. (Euagare) Palmeri Engelm. Notes, 31.-Acaulescent.

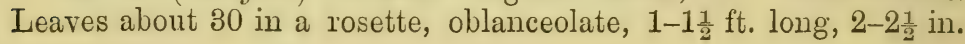


broad above the middle, narrowed to $1 \frac{1}{2}$ in. above the base,

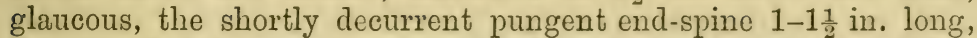
the edge slightly repand between the large deltoid-cuspidate prickles, of which those of the upper half of the blade are $\frac{1}{4}-\frac{1}{3}$ in. long. Peduncle with panicle 8-12 ft. long. Flowers $13-2$ in. long; tube very short; segments yellowish, oblong-lanceolate, $\frac{3}{4} \mathrm{in}$. long. Stamens more than twice as long as the segments. Capsule $1 \frac{1}{2}-2$ in. long.

Hab. Mountains of Southern Arizona, ascending to $6300 \mathrm{ft}$. Vasey! Pringle! Discovered by Dr. Schott in 1855. Introduced into cultivation in Europe about 1880 .

55. A. (Euagave) marmorata Roezl in Belg. Hort. 1883, 238.Acaulescent. Leaves $12-15$ in a rosette, spreading, oblanceolate. 2-3 ft. long, 4-5 in. broad above the middle, narrowed to $2-2 \frac{1}{2}$ in. above the base, glancous, concave in the upper half of the face, very rough on both sides, the pungent end-spine an inch long, the margin very repand between the close irregular large deltoidcuspidate prickles, which are $\frac{1}{4}-\frac{1}{3}$ in. long and broad with a curved brown horny tip. Peduncle with panicle 10-16 ft. long.

Hab. Mexico; Province of Tehuacan. Introduced into cultivation by Roezl. Described from two plants in the Kew collection in 1887. Between $A$. Scolymus and americana. Used by the Indians for abrasions of the skin of their horses and mules.

56. A. (Euagave) Thennetel Zuccar. in Roem. Collect. 138, t. 3.-Acaulescent. Leaves about 30 , oblanceolate-spathulate, $1 \frac{1}{2}-2 \mathrm{ft}$. long, $4 \frac{1}{2}-5 \mathrm{in}$. broad above the middle, narrowed to $3 \mathrm{in}$. above the dilated base, the face nearly flat, green, only slightly glaucous when young, the dark brown pungent end-spine an inch long, the distant deltoid-cuspidate prickles not more than $\frac{1}{8} \mathrm{in.}$ long. Peduncle 10-12 ft. long including the thyrsoid panicle. Flower's yellowish green, 3 in. long. Stamens twice as long as the perianth-segments.

Hab. Mexico. Described from a plant in the Peacock collection in 1872, and the inflorescence from Zuccagni. The name Theometel goes back to Morison, and Kunth cites for it figures by Munting and Ray. I cannot distinguish from this what I have seen in English gardens under the name of A. Beauleuriana Jacobi.

57. A. coccinea Roezl; Jacobi, Monogr. 76. - Acaulescent. Leaves $20-30$ in a dense rosette, oblanceolate-spathulate, $1 \frac{1}{2}-2 \mathrm{ft}$. long, 4-6 in. broad two-thirds of the way up, narrowed to $3 \mathrm{in.}$ above the dilated base, dark green, only slightly glancous when young, the hard pungent end-spine $1 \frac{1}{2} \mathrm{in}$. long, the edge repand between the close irregular deltoid-cuspidate prickles, which are $\frac{1}{6}-\frac{1}{4}$ in. long. Inflorescence unknown.

Hab. Mexico; introduced into cultivation by Roezl in 1859. Described from plants seen at Kew, Reigate, and Hammersmith. I cannot distinguish specifically a plant received at Kew in 1883 from Leichtlin, labelled $\mathrm{A}$. gracilispina. Var. brevifolia Hort., is a dwarf form.

58. A. Maxiniliana Baker in Gard. Chron. 1877, ii. 202. A. Gustariana Hort.-Acaulescent. Leares about 20 in a rosette, oblanceolate-spathulate, $1 \frac{1}{2}-2 \mathrm{ft}$. long, $2 \frac{1}{2}-3$ in. broad above the middle, narrowed to $1 \frac{1}{2}-2$ in. above the base, a slightly glancous 
green, the pungent brown-black end-spine an inch long, the bright chestnut-brown prickles larger and more irregular than in americana, with longer and sharper eusps, at most $\frac{1}{4} \mathrm{in}$. long. Inflorescence unknown.

Hab. Probably Mexico. Described from specimens seen at Kew and Reigate, the former sent by Mr. Justus Corderoy.

59. A. (Euagave) mexicana Lam. Encyc. i. 52 ; Ricasoli in Gard. Chron. 1883, i. fig. 22.-Acaulescent. Leaves 20-30 in a rosette, oblanceolate-spathulate, $2-3 \mathrm{ft}$. long, 5-6 in. broad above the middle, narrowed to $3-4$ in. above the base, very glaucous, the brown pungent point an inch long, the subdistant deltoid-cuspidate prickles $\frac{1}{8}-\frac{1}{6}$ in. long. Peduncle $18 \mathrm{ft}$. long, including the $7-8 \mathrm{ft}$. thyrsoid panicle. Flowers $2 \frac{1}{2}-3$ in. long; tube $\frac{1}{2}-\frac{3}{4}$ in.; segments greenish yellow, under an inch long. Capsule $2 \mathrm{in.} \mathrm{long.}$

Hab. Mexico. Frequent in European gardens. The above description is made from specimens at Kew and Reigate, and of the inflorescence from a plant that flowered in 1855 at Brussels. Baron Ricasoli's plant, grown in the open air at Florence, had above 100 leaves reaching a length of $4 \mathrm{ft}$. and a peduncle $23 \mathrm{ft}$. long, with 46 branches. I cannot distinguish specifically $A$. cyanophylla Jacobi.

60. A. (Euagave) anericana Limn. Sp. Plant. 461 ; Andr. Bot. Rep. t. 438 ; Bot. Mag. t. 3654.-Acaulescent. Leaves usually 30-40, sometimes 50-60 in a rosette, oblanceolate-spathulate, 3-6 ft. long, 6-9 in. broad above the middle, narrowed to 4-5 in. above the base, glaucous green, the pungent brown end-spine, $1 \frac{1}{2}-2 \mathrm{in}$. long, the edge repand between the distant unequal middlesized deltoid-cuspidate prickles. Peduncle with panicle 24-36 ft. long, the latter with 20-40 branches, the lower a foot long. Flower reaching a length of $3-3 \frac{1}{2}$ in.; tube funnel-shaped, $\frac{1}{2} \mathrm{in.} \mathrm{long;}$ segments yellowish, 1-1 $1 \frac{1}{4}$ in. long. Stamens twice as long as the segments. Capsule oblong, 2 in. long.

Hab. Widely spread in Tropical America and now introduced in many parts of the Old World. It is said to have been introduced into Europe about the middle of the 16th century, and to have first flowered in England at Hampton Court in 1714. For a full account of its history see a paper by. Danielli in Nuov. Giorn. Bot. Ital. xvii. p. 49-138, tabs. 5-10. Martius (Fl. Bras. iii. 185) enumerates fifty books in which it is mentioned between 1554 and 1748. A. Milleri Haw. (A. virginica Miller non Linn.) is a dwarf variety, and $A$. picta Salmdyck and A. ornata Jacobi forms with variegated leaves. I cannot from the descriptions distinguish clearly A. Fuerstenbergii and expansa Jacobi.

\section{Group 5. Rigid.s.}

61. A. Decaisneana Jacobi, Nacht. 28.-Acanlescent. Leaves oblong-spathulate, about 14 in. long, 3 in. broad at the middle, narrowed to 2 in. above the base, a light rather shining green, the face concave, the end-spine strong and nearly black, the edge margined by crowded minute deltoid black teeth, which are rather recurved at the tip. Inflorescence unknown.

Hab. Mexico. Introduced about 1869. Described by Jacobi from a specimen in the Jardin des Plantes at Paris.

62. A. Warelliana Baker in Gard. Chron. 1877, ii. 264, fig. 53.-Acaulescent. Leares about 30 in a rosette, oblong-spathulate, 
9-10 in. long, $3 \mathrm{in.} \mathrm{broad} \mathrm{above} \mathrm{the} \mathrm{middle,} \mathrm{narrowed} \mathrm{to} 2 \mathrm{in.}$ alove the base, nearly flat on the face, green, searcely at all glancous, tipped with a strong brown encl-spine an inch long, margined with close very small deltoid prickles, which are redbrown when young and nearly black when old. Inflorescence unknown.

Hab. Probably Mexico. Described from the Saunders collection at Reigate, in 1872.

63. A. (Iittea macrantma Todaro, Hort. Bot. Panorm. ii. 11, t. 27.-Acaulescent. Leaves $40-50$, oblong-spathulate, 5-6 in. broad at the middle, $2-3$ in. above the base, dull glaucous green, the face concave, the pungent end-spine an inch long, the young leaves thinly edged with brown, the teeth small, deltoid-cuspidate, moderately close. Peduncle with dense spike 4-5 ft. long. Flowers $3 \mathrm{in.} \mathrm{long;} \mathrm{tube} \mathrm{fumnel-shaped,} \frac{1}{2} \mathrm{in}$. long. Stamens about three times the length of the segments.

Hab. Probably Mexico. Flowered with Dr. Todaro at the Palermo Botanic Garden, in 1879.

64. A. (Littaca) Botterir Baker in Bot. Mag. t. 6248; Gard. Chron. 1877, ii. fig. 54.-Acanlescent. Leaves about 50 in a rosette, oblong-spathulate, $2 \mathrm{ft}$. long, $6 \mathrm{in}$. broad above the middle, narrowed to $4-1 \frac{1}{2} \mathrm{in}$. above the base, pale green, hardly at all glaucous, the pungent end-spine $\frac{1}{2}$ in. long, the crowded nearly black deltoid teeth not more than $\frac{1}{8} \mathrm{in}$. long. Peduncle with dense 2-3 ft. spilie 7-8 ft. long. Flowers $2 \frac{1}{2}$ in. long; tube $\frac{1}{4}-\frac{1}{3} \mathrm{in}$. long. Stamens more than twice as long as the segments.

Hab. Mexico. Sent by Botteri by Mr. Wilson Saunders. Flowered with Mr. J. T. Peacock, in the spring of 1875.

65. A. (Euagave) RIGIDA Miller, Gard. Dict. No. 8; Engelm. Notes, 28. A. Ixtli Karw. A. Karwinstiii Zuccar. A. ixtlioides Hook. in Bot. Mag. t. 5893. Fourcroya rigida Haw.-Acaulescent or' shortly caulescent. Leaves $30-40$ in a rosette, ensiform, $1 \frac{1}{2}-2 \mathrm{ft}$. long, $1 \frac{1}{2}-2$ in. broad at the middle, narrowed to an inch above the base, rigidly erecto-patent, glaucous, the pungent end-spine an inch long, the subdistant dark brown or nearly black deltoid teeth not more than $\frac{1}{8}$ in. long. Peduncle, including thyrsoid panicle, 12-15 ft. long. Flowers $1 \frac{1}{2}-2$ in. long; tube very short; segments narrow, greenish, an inch long. Stamens twice as long as the segments. Capsule $1 \frac{1}{2}-2$ in. long.

Var. A. elongata Jacobi, Monogr. 108. A. fourcroyoides Jacobi. A. ixtlioides Lemaire. A. rigida var. longifolia Engelm. A. Candelubrum Todaro, Hort. Bot. Panorm. i. 66, t. 15.-Leaves 100 to a rosette, 3-4 ft. long, 4-5 in. broad. Peduncle including ample thyr'soid panicle 20-25 ft. long.

- Var. sisalana Engelm. Notes, 28.-Trunk short.-Leaves 4-6 ft. long, 4-6 in. broad, generally without teeth. Peduncle including panicle 25-30 ft. long.

Hab. South Mexico; Provinces of Vera Cruz, Yucatan, \&c. This is the species which yields the most valuable fibre, for a full account of which see Morris in ' Kew Bulletin,' No. 3. The export from Yucatan in 1883 was worth $£ 658,000$. A. rigida Miller was named from a dwarf form with entire leaves. 
What is probably the same is amongst the unpublished drawings at the British Museum made from the Syrhagen Garden in 1720, under the name of "Aloe pita foliis non spinosis." My description of the typical form refers to the plant as commonly grown in English and Belgian Gardens. The little-known $A$. angustifolia Haworth is probably a form of this species. We have received it lately in flower from Demerara and Central Madagascar. We have a photograph from Dr. Todaro of a plant in flower which is probably sisalana grown as A. brevis at the Palermo Garden.

66. A. Corderoy Baker in Gard. Chron. 1877, ii. 399, fig. 79. -Acaulescent. Leaves 40-50 in a dense rosette, ensiform, rigidly erecto-patent, $1 \frac{1}{2} \mathrm{ft}$. long, an inch broad above the middle, narrowed to $\frac{3}{4} \mathrm{in}$. above the base, slightly channelled down the face, bright green, the pungent end-spine an inch long, the subdistant erecto-patent, deltoid-cuspidate dark brown spines of the edge $\frac{1}{8}$ in. long. Inflorescence unknown.

Hab. Mexico, introduced by Roezl. Named after Mr. Corderoy by De Smet, from whose establishment at Ledeberg-lez-Gand, in Belgium, a great many of the plants in the Saunders and Peacock collections were purchased.

67. A. (Euagave) Pringlei Engelm.-Leaves ensiform, very rigid, $15-18$ in. long, the dilated base $3-3 \frac{1}{2}$ in. broad, narrowed gradually from 2 in. above the base to the pungent apex, the distant marginal prickles small, brown, deltoid-cuspidate, hooked. Flower $1 \frac{1}{2}$ in. long; tube short, subcylindrical ; segments narrow, yellow, $\frac{1}{2}$ in. long, Stamens twice as long as the segments. Capsule oblong, 1-1 $\frac{1}{2}$ in. long.

Hab. Central mountains of Lower California, alt. $6000 \mathrm{ft}$, Orcutt! Described from a dried specimen sent to Kew by Mr. C. G. Pringle. We have a specimen of an allied plant that flowered with Mr. J. T. Peacock in 1881, that was labelled $A$. scaberrima.

68. A. (Euagave) excelsa Jacobi, Monogr. 238. - Shortly caulescent. Leaves about 30 in a rosette, ensiform, rigid, 2 ft. long, $2 \mathrm{in}$. broad at the middle, green when fully mature, slightly glancous when young, the pungent end-spine, $\frac{1}{2}$ in. long, the prickles small, nearly black, deltoid-cuspidate, distant. Peduncle with thyrsoid panicle $12-15 \mathrm{ft}$. long. Flowers like those of $A$. rigida.

Hab. Mexico. Described from a plant flowered at the Glasgow Botanic Garden in August, 1884, by Mr. Bullen.

69. A. Regeliana Jacobi, Monogr. 236.-Acaulescent. Leaves oblanceolate, $1 \frac{1}{2} \mathrm{ft}$. long, $2 \frac{3}{4}$ in. broad above the middle, narrowed to $1 \frac{3}{4}$ in. above the base, a light pruinose green, the face slightly concave, the end-spine pungent, the marginal teeth very minute, crowded, colourless. Inflorescence unknown.

Hab. Mexico. Described by Jacobi in 1865, from a plant shown by Messrs. Glynn, of Utrecht, at the Amsterdam Exhibition. I cannot clearly separate A. ananassoides De Jonghe and Jacobi, Nacht. 32, of which we have a photograph in the Elemeet series. The plant which usually does duty under the name of Regeliana in gardens is A. horrida Lemaire.

70. A. (Euagave) miradorensis Jacobi, Nacht. 31.-Acaulescent. Leaves about 30 in a rosette, oblanceolate, $2 \frac{1}{2}-3 \mathrm{ft}$. long, $2 \frac{1}{2} \mathrm{in}$. broad above the middle, narrowed to $1 \frac{1}{2}-2$ in. above the base, bright pale green, glaucous when young, the pungent chestnut- 
brown end-spine an inch long, the prickles very minute, deltoid, hardly at all horny. Peduncle including 5-6 ft. thyr'soid panicle $23 \mathrm{ft}$. long. Flowers $2 \mathrm{in}$. long; tube very short; segments under an inch long. Stamens twice ås long as the segments.

Hab. Mexico. Described by Jacobi from the Belgian Gardens in 1867. The above description and three sketches, now in the Kew Herbarium, were made from a plant that flowered with MIr. J. T. Peacock, at Hammersmith, in December, 1877. I cannot by the description separate the earlier-named $A$. Desmetiana Jacobi Monog. 241.

71. A. (Littca) polyacantha Haw. Revis. Succ. 35. A. xalapensis Roezl. A. uncinata and chiripensis Jacobi.-Acaulescent. Leaves about 30 in a rosette, oblanceolate, 1-2 ft. long, 3-5 in. broad above the middle, narrowed to $2-3$ in. above the base, bright green, only slightly glaucous in an early stage, the dark brown shortly decurrent end-spine $\frac{1}{2}-\frac{3}{4}$ in. long, the crowded dark brown irregular patent deltoid prickles not more than 1-12th to 1-8th in. long. Peduncle 8-12 ft. long, including the dense 3-4 ft. spike. Flower $1 \frac{1}{2}-2$ in. long; tube subcylindrical, $\frac{1}{3}$ in. long; segments $\frac{3}{4}$ in. long, yellowish brown. Filaments more than twice as long as the segments.

Hab. Mexico. Introduced into cultivation about 1820. We have lately received it from Trinidad, from $\mathrm{MI}_{2}$. Hart. A plant from the Saunders collection flowered with Mr. F. Pawle, at Reigate, in 1875.

72. A. (Littca) Densiflora Hook. in Bot. Mag. t. 5006.Acaulescent. Leaves $30-40$ in a rosette, oblanceolate-spathulate, $2-3 \mathrm{ft}$. long, 3-5 in. broad above the middle, narrowed to $2 \frac{1}{2}-4$ in. above the base, bright green when mature, only slightly glancous when young, the pungent shortly decurrent end-spine $\frac{1}{2} \mathrm{in}$. long, the irregular crowded bright brown spreading deltoid prickles $\frac{1}{2}-1$ line long. Peduncle including the dense spike $6-8 \mathrm{ft}$. long. Flowers $1 \frac{1}{2}-2$ in. long; tubegfunnel-shaped, $\frac{1}{4}-\frac{1}{3} \mathrm{in}$. long; segments lanceolate, greenish brown, $\frac{1}{2}-\frac{3}{4}$ in. long. Stamens 2 in. long. Capsule $\frac{3}{4}-1$ in. long.

Hab. Mexico. First described by Sir W. J. Hooker, from a plant that flowered at Kew in 1857. It has since often flowered, both at Kew and Reigate.

73. A. (Euagave) LuRIDA Ait. Hort. Kew, i. 472; Gawl. in Bot. Mag. t. 1522 ; Baker in Saund. Ref. Bot. t. 307. A. vercl-cruz Miller, an earlier name, altered by Haworth to vera-crucis. Acaulescent or shortly caulescent. Leaves $30-40$ in a rosette, oblanceolate, $2-3 \mathrm{ft}$. long, $2 \frac{1}{2}-3 \frac{1}{2}$ in. broad above the middle, narrowed to 2 in. above the base, very glaucous, the pungent endspine an inch long, the subdistant deltoid prickles $\frac{1}{8}$ in. long, at first red-brown, finally nearly black. Peduncle including the 3-6 ft. thyrsoid panicle 12-16 ft. long. Flowers 3 in. long; tube broadly funnel-shaped, $\frac{1}{2}$ in. long; segments greenish yellow, narrow, an inch long. Stamens twice as long as the segments. Capsule $1 \frac{3}{4}-2$ in. long.

Var. A. Jacquiniana Schult. Syst. Veg. vii. 727 ; Hook. in Bot. Mag. t. 5097 ; Belg. Hort. ix. t. 25. A. hurida Jacq. Collect. iv.

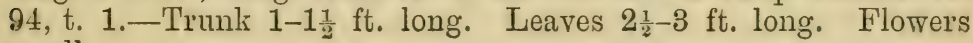
simall. 
Hab. Mexico, the most widely-spread species next to $A$. americana. It was figured by Commelinus in 1706 . The above description was made from a plant that flowered with $\mathrm{Mr}$. Wilson Saunders in 1870. We have it in flower from Madras (1810), Coimbra (1881), and Hong-Kong (1882). A leaf, $6 \mathrm{ft}$. long and 7 in. broad, sent from the Bahamas by the Colonial Secretary in 1887, apparently belongs to this species.

74. A. Salmoyckir Baker in Gard. Chron. 1877, ii. 490. $A$. Keratto Salmdyck et Jacobi non Miller.-Acaulescent. Leaves 40-50 in a rosette, oblanceolate, $4-5 \mathrm{ft}$. long, $5-6 \mathrm{in}$. broad above the middle, narrowed to $4-5$ in. above the base, bright green, the end-spine scarcely pungent, the crowded minute deltoid-cuspidate dark-brown spines not more than 1-12th in. long. Inflorescence unknown.

Hab. Mexico. Described from living plants at Kew and Reigate in 1872.

75. A. (Euagave) Morrisir Baker in Gar'd. Chron. 1887, i. 643, fig. 105.-Acaulescent. Leaves 20-30 in a rosette, oblanceolate-spathulate, 4-6 ft. long, $\frac{1}{2}-1 \mathrm{ft}$. broad above the middle, narrowed to $4-6$ in. above the base, green, hardly at all glaucous, quite smooth on both surfaces, the pungent end-spine an inch long, the subdistant deltoid-cuspidate dark brown prickles $\frac{1}{3}-\frac{1}{6}$ in. long. Peduncle including the thyrsoid panicle 15-20 ft. long; branches 30-50, the lower horizontal, above a foot long. Flowers 2-23 in. long; tube short; segments bright yellow, an inch long. Stamens nearly twice as long as the segments. Capsule an inch long.

Hab. Jamaica, confused by Grisebach and others with A. americana. The data for describing it have been collected by Mr. Morris, now AssistantDirector of Kew Gardens, during his residence in the island, and he has also introduced into cultivation at Kew both the type and a fine form with variegated leaves.

\section{Group 6.-Striate.}

76. A. (Littæa) striata Zuccar. in Nova Acta xvi. 2, 678 ; Hook. in Bot. Mag. t. 4950.-Acaulescent or shortly caulescent. Leaves 150-200 in a dense rosette, linear from a very dilated base,

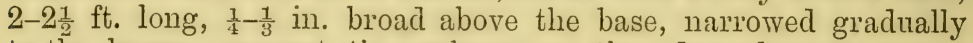
to the brown pungent tip, scabrous on the edge, glaucous green, the face rather raised, the back subtriquetrous, both surfaces marked with close vertical ribs. Peduncle including the dense 2-3 ft. spike 6-8 ft. long. Flowers $1-1 \frac{1}{2}$ in. long; tube broadly funnel-shaped, about equalling the brownish-green oblong segments. Stamens purple, $1 \frac{1}{2} \mathrm{in}$. long, inserted low down in the tube. Capsule oblong-trigonous, $\frac{1}{2}$ in. long.

Var. A. Recurva Zuccar. loc. cit.-Leaves larger and more falcate than in the type, reaching 3-4 ft. End-spine not pungent.

Var. A. Stricta Salmdyck. A. Hystrix Hort.-Leaves very stiff, about a foot long, more convex on the face.

Var. A. eCHrNordes Jacobi, Nacht. 48. A. ensiformis and Iichurdsii Hort.-Still dwarfer and stiffer than var. stricta, the leaves only half a foot long, $\frac{1}{3} \mathrm{in}$. broad at the middle.

Hab. Mountains of Mexico, now common in cultivation under a large number of forms. It was figured in the 'Botanical Nagazine' from a plant that flowered at Kew in 1856, sent from Real del Monte by Mr. Repper. We have two photographs of a plant that flowered with Signor Fenzi at Florence in 
October, 1876. Dr. Palmer got it lately in Coahuila. It sometimes passes muster in gardens as Yuece hystrix, and sometimes as Dasylirion junceum. A quadrilocular capsule has lately been figured by Terracino in Nuov. Giorn. Bot. Ital. xvii. t. 19.

77. A. (Littaca) falcata Engelm. Notes, 16. A. califormica Jacobi.-Acaulescent. Leaves $20-30$ in a rosette, linear, $1 \frac{1}{2}-2 \mathrm{ft}$. long, $\frac{1}{2}-\frac{3}{4}$ in. broad above the dilated base, rigid, glaucous, narrowed gradually to the horny brown pungent tip, scabrous on the margin, distinctly lieeled on the face, subtriquetrous on the back, distinctly striated on both surfaces. Peduncle 4-8 ft. long, including the lax spilic. Flowers 1-11 in. long; tube broadly fumnel-shaped, nearly as long as the oblong segments. Stamens $1 \frac{1}{2}-2$ in. long, inserted at the middle of the tube. Capsule oblongtrigonous, $\frac{1}{2}-\frac{3}{4}$ in. long.

Hab. Mexico; mountains of Coahuila. Palmer 1314, Pringle! Discovered by Drs. Wislizenus and Gregg in 184f-1848. Introduced into cultivation about 1867. It was first described by Jacobi from a living plant at Kew. It is not known to grow in California.

78. A. (Littea) Paucifolin Todaro, Hort. Bot. Panorm. i. 77, t. 19.-Acaulescent. Leaves few, rigid, linear, $1 \frac{1}{2} \mathrm{ft}$. long, $\frac{1}{2} \mathrm{in}$. broad, finely striated, convex on the face, scabrous on the margin, pungent at the apex, the base suddenly dilated. Peduncle slender, about 4 ft. long. Flowers few, subspicate, greenish, $1 \frac{1}{2}$ in. long; limb as long as the ovary; tube equalling the oblong segments. Stamens purplish, 1-1 $\frac{1}{2}$ in. long.

Hab. Probably Mexico. Described by Dr. Todaro from a plant that flowered at the Palermo Botanic Garden in 1877.

79. A. (Littca) Dasylirioides Jacobi and Bouché, Monogr. 150; Hook. in Bot. Mag. t. 5716 ; Baker in Gard. Chron. 1877, 2, fig. 111. A. dealbata Lemaire.-Acaulescent. Leaves 80-100 in a dense rosette, linear, very glaucous, $1 \frac{1}{2}-3 \mathrm{ft}$. long, $\frac{3}{4}-1 \mathrm{in}$. broad above the dilated base, stiffly erecto-patent or falcate, flat on the face and hardly at all convex on the back, narrowed gradually from the middle to a short pungent point, serrulate on the margin, finely striated vertically on both surfaces. Peduncle 10-12 ft. long, including the long dense often cernuous spilse. Flowers $1 \frac{1}{2}-1 \frac{3}{4}$ in. long; tube broadly funnel-shaped, $\frac{1}{3}$ in. long; segments yellow, twice as long as the tube. Stamens $1 \frac{1}{2} \mathrm{in}$. long.

Hab. Mexico. Figured in the 'Botanical Magazine' from a plant that flowered at the Regent's Park in January, 1868. It has since flowered several times both at Reigate and Kew, the last time in 1887.

\section{Group 7.-INtegrifoliæ.}

80. A. integrifolia Baker.-Acaulescent. Leaves about 30 in a dense rosette, rigid, oblanceolate, recurving, very glaucous, entire, $5-6$ in. long, 1-1 $\frac{1}{2} \mathrm{in}$. broad above the middle, narrowed gradnally to the base and suddenly to a brown pungent end-spine $\frac{1}{4} \mathrm{in}$. long, the margin entire. Inflorescence unknown.

Hab. Mexico. Described from a plant received at Kew from the Missouri Botanic Garden in 1885. 
81. A. (Euagave) Netwberryi Engelm. Notes, 21.-Acaulescent. Leaves ensiform, 7-10 in. long, $\frac{3}{4}$ in. broad above the dilated base, rigid, entire, narrowed gradually to a pungent brown end-spine $\frac{1}{2}$ in. long. Peduncle slender, $8 \mathrm{ft}$. long. Panicle narrow, lax; branches 1-3 in. apart, 1-2 in. long, bearing each 2-5 flowers, which are only an inch long, including the ovary, with a short tube and oblong segments. Stamens but little exserted, inserted low down in the tube.

Hab. Mountains of North-West Arizona, alt. $4000 \mathrm{ft}$., discovered by Dr. J. S. Newberry in March, 1848.

82. A. Houlletir Jacobi, Monogr. 256.-Acaulescent. Leaves $30-40$ in a rosette, oblanceolate, $1-1 \frac{1}{2} \mathrm{ft}$. long, 2 in. broad above the middle, narrowed to an inch above the dilated base, bright green, glaucous on the back towards the base, quite entire on the margin, the pungent end-spine $\frac{1}{2} \mathrm{in}$. long. Inflorescence unknown.

Hab. Probably Mexico. Described ${ }_{4}^{5} b y$ Jacobi from the Belgian Gardens in 1865. I have seen it alive both at Kew and Reigate. It may be an extreme variety of $A$. rigida.

\section{Group 8.-Geniniflore.}

83. A. (Littea) geminiflora Gawl. in Brandes Journ. iii. t. 1; Bot. Reg. t. 1145 ; Reich. Ic. Exot. t. 209-210 ; Spin. in Cat. Hort. Sebast. 1823, 3, with figure. Littaa geminiflora Tagl.Acaulescent. Leaves 200-300 in a dense rosette, recurved, linear, $1 \frac{1}{2}-2 \mathrm{ft}$. long, $\frac{1}{8}-\frac{1}{4}$ in. broad at the middle, bright green, convex on both sides, not striated, the pale edge splitting off into fine threads, the tip slightly pungent. Peduncle 18-24 ft. long, including the dense spilie. Flowers $1 \frac{3}{4}-2$ in. long; tube subcylindrical, $\frac{1}{3}$ in. long; segments linear, greenish brown, twice as long as the tube. Filaments twice as long as the segments.

Hab. Mexico, introduced into cultivation in 1797. It first flowered in 1815 in the garden of Count Von Litta, after whom the genus Littcea was named. It is often found in English gardens under the name of Bonapartea juncea, and has also been called Draccena Boscii and Yucca Boscii. A. Taylori Hort. Williams (Gard. Chron. 1877 ii. 125) is a garden hybrid, of which geminiflora is one parent and filamentosa (not densiflora, as has been stated) probably the other.

\section{Group 9.-ALOIDEe.}

84. A regia Baker in Gard. Chron. 1877, ii. 620, fig. 124. A. revoluta Hort. Peacock.-Acaulescent. Leaves 12-15 in a rosette oblong-spathulate, $1 \frac{1}{4}-1 \frac{1}{2} \mathrm{ft}$. long, $4-5 \mathrm{in}$. broad at the middle, narrowed to 2-3 in. above the base, bright green on the flat face, the subpungent brown tip $\frac{1}{2}$ in. long, the prickles moderately close, brown, deltoid, not more than 1-12th inch long, the upper ascending, the lower deflexed. Inflorescence unknown.

Hab. Probably Mexico. Seen alive in the Kew, Reigate, and Hammersmith collections.

85. A. melanacantha Lemaire; Jacobi, Monogr. 117.-Acaulescent. Leaves few in a rosette, oblong-spathulate, about a foot 
long, $4 \mathrm{in}$. broad at the middle, narrowed to $2 \mathrm{in}$. above the base, a light opaque green, the end-spine short and brown, the teeth subdistant, minute, brown, deltoid-cuspidate. Inflorescence unlinown.

Hab. Probably Mexico. Described by Jacobi from a plant exhibited at the Ghent Exhibition of 1863.

86. A. (Euagare) Wildingrn Todaro, Hort. Bot. Panorm. t. 32.Acaulescent. Leaves few, oblong-spathulate, bright green, 6-7 in. broad at the middle; end-spine short, not pungent; teeth small, close, deltoid-cuspidate, dark brown. Peduncle 4-5 times the length of the leaves. Panicle lax, about as long as the peduncle. Flower's $1 \frac{1}{2}$ in. long; tube very short; segments yellowish, as long as the ovary. Stamens twice as long as the segments.

Hab. Probably Mexico. Figured lately by Dr. Todaro from the Palermo Botanic Garden.

87. A. Rudis Lemaire; Jacobi, Monogr. 118. A. Malinezii K. Koch.-Whortly caulescent. Leaves few, oblong-spathulate, 15 in. long, 5-6 in. broad at the middle, narrowed to 2 in. above the base, a light opaque green on the concave face, the end-spine short, brown, the teeth moderately distant, minute, brown, deltoidcuspidate, recurved. Inflorescence unknown.

Hab. Probably Mexico. Described by Jacobi in 1864 from a living plant in the garden of Herr Tonel, at Ghent.

88. A. Laurentiana Jacobi, Monogr. 254.-Acaulescent. Leaves moderately numerous, oblong-spathulate, $\frac{1}{2}-2 \mathrm{ft}$. long, 5-6 in. broad above the middle, narrowed to $3 \mathrm{in}$. above the base, the face opaque green and deeply concave, the end-spine short, stout and brown, the edge slightly repand between the minute straight brown deltoid teeth. Inflorescence unknown.

Hab. Probably Mexico. Described by Jacobi in 1865 from a plant in the collection of Herr Laurentius, at Leipsic.

89. A. Offorana Jacobi, Monogr. 116.-Acaulescent. Leaves 25-30 in a rosette, oblong-spathulate, $1 \frac{1}{2}-2 \mathrm{ft}$. long, $4-5$ in. broad above the middle, narrowed to $3 \mathrm{in}$. above the base, deeply concave on the bright-green face, the subpungent end-spine $\frac{1}{2}$ in. long, the teeth moderately close, brown, deltoid, 1-12th to 1-8th in. long. Inflorescence unknown.

Hab. Cuba. My notes are taken from a plant seen at Reigate in August, 1872. It was described by Jacobi from the collection of Madame Legrelle d'Hanis at Antwerp, in 1862.

90. A. (Littca) Celsiana Hook. in Bot. Mag. t. 4934.Acauloscent. Leaves 20-30 in a rosette, oblong-spathulate, $1 \frac{1}{2}-2 \mathrm{ft}$. long, 4-5 in. broad, the middle narrowed to $2 \frac{1}{2}-3$ in. above the base, the persistently glaucous face flat in the middle, the endspine slightly pungent, the crowded lanceolate spines very unequal both in shape and size, 1-12th to 1-8th in. long, only the largest brown and horny at the tip, those below the middle of the blade deflexed. Peduncle 5-6 ft. long, including the short dense spike. Flowers $1 \frac{1}{2}-2$ in. long; tube very short; segments purplish green, lanceolate, $\frac{5}{8}-\frac{3}{4}$ in. long. Filaments $1 \frac{1}{2}-2$ in. long. 
Hab. Mexico. Described by Sir W. J. Hooker from a plant that flowered at Kew in May, 1856, received from M. Cels, of Paris. It flowered again in the summer of 1879 , and a small variety with leaves only 8-9 in. long, with $\mathrm{Mr}$. Corderoy in July, 1883.

91. A. (Littac Ehrenberai Jacobi, Monogr.136.-Acaulescent. Leaves moderately numerous, oblong-spathulate, $1 \frac{1}{2}-2 \mathrm{ft}$. long, 5 in. broarl above the middle, narrowed to $2 \frac{1}{2}$ in. above the base, an opaque rather glaucous green on the concave face, the brown endspine short, the crowded minute deltoid marginal teeth brown at the tip only. Peduncle 4-5 ft. long. Flowers $1 \frac{1}{2}$ in. long; tube short; segments linear-oblong, above $\frac{1}{2} \mathrm{in}$. long. Filaments above 2 in. long.

Hab. Mexico. Described by Jacobi from plants seen at Berlin and Erfurt in 1864. It flowered with Herr Allardt at Berlin in 1867. I cannot from the description separate specifically A. Legrelliana Jacobi, Monogr. 253.

92. A. Lindleyi Jacobi, Nacht. 37.-Trunk $1 \frac{1}{2} \mathrm{ft}$. long below the rosette of leaves. Leaves numerous, oblong-spathulate, $6-7 \mathrm{in}$. broad at the middle, narrowed to $3-3 \frac{1}{2}$ in. above the base, very thick, flat in the middle, glancous, the end-spine dark brown, the marginal prickles close, deltoid, with a horny black tip. Inflorescence unknown.

Hab. Mexico, described by Jacobi from a plant seen in the collection of Mr. Wilson Saunders in 1867.

93. A. (Littca) Goeppertiana Jacobi, Monogr. 243.-Stem reaching a length of half a foot. Leaves 20-30 in a rosette, oblanceolate-oblong, 4-5 in. broad at the middle, narrowed to $3-3 \frac{1}{2}$ in. above the base, bright green, the short brown tip scarcely pungent, the crowded spreading brown deltoid teeth under a line long. Peduncle including the dense $4-5 \mathrm{ft}$. spike 8-9 $\mathrm{ft}$. long. Flower nearly $2 \mathrm{in.}$ long; tube as long as the oblong segments. Stamens 2 in. long. Capsule $\frac{3}{4}$ in. long.

Hab. Probably Mexico. Described by Jacobi in 1865 from plants seen at Breslau and Reigate, the former of which flowered in 1874, and is figured in the 'Index Seminum ' for that year of the Breslau Garden, of which Dr. Goeppert was Director.

94. A. (Littca) HoRizontinalis Jacobi, Nacht. 33.-Caulescent. Leaves few in a rosette, oblanceolate-oblong, $2 \mathrm{ft}$. long, 4-5 in. broad at the middle, narrowed to $2 \frac{1}{2}$ in. above the base, the broad channelled face bright light green, glaucous when young, the subpungent brown end-spine short, the marginal teeth crowded, minute, brown, deltoid. Peduncle including the dense $2-2 \frac{1}{2}$ in. spike 6-7 ft. long. Flowers under 2 in. long; segments oblong, reddish brown, about as long as the broadly fumnel-shaped tube. Stamens 2-21 in. long.

Hab. Probably Mexico. Described by Jacobi in 1865 from a plant that flowered in the collection of Von Elemeet, of which we have a photograph.

95. A. Snirthiana Jacobi, Monogr. 250.-Acaulescent. Leaves about 30 in a rosette, oblanceolate-oblong, $2-2 \frac{1}{2} \mathrm{ft}$. long, $4-5 \mathrm{in}$. broad at the middle, narrowed to $2-2 \frac{1}{2}$ in. above the base, bright green on the flat face, the subpungent brown tip $\frac{1}{2}$ in. long, the close deltoid brown marginal prickles 1-12th in. long. Inflorescence unknown. 
Hab. Mexico; San Luis, Potosi. Described by Jacobi from a plant seen at Kew in 186;), which is still there and has never flowered. I cannot clearly separate from the descriptions A. lamprochlor $a$ and A. perlucida Jacobi.

96. A. Humbomtina Jacubi, Monorr. 251. - Acanlescent. Leaves 30-10 in a rosette, oblanccolate-oblong, $2 \frac{1}{2}-3 \mathrm{ft}$. long, $5-6$ in. broal above the midlle, narrowed to 3 in. above the base, bright green, slightly glaucous when young, the sulppungent brown end-spine $\frac{1}{2} \mathrm{in.}$ long, the close very minute deltoid marginal prickles tipped with brown. Inflorescence unknown.

Hab. Mexico; San Luis, Potosi. Described by Jacobi from a plant seen at Kew in 1865, which is still there and has never flowered.

97. A. Kewensis Jacobi, Monogr. 242.-Trunk $\frac{1}{2} \mathrm{ft}$. long below the rosette of leaves. Leaves $30-40$ in a rosette, oblanceolate-

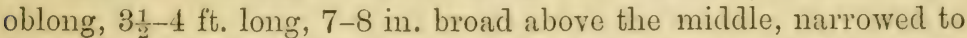
4 in. above the base, bright green, the subpungent end-spine short and brown, the face concare in the middle, the marginal prickles small, close, brown, deltoid. Inflorescence unknown.

Hab. Mexico. Described by Jacobi from a plant seen at Kew in 1865 , which is still there.

98. A. (Littecu) Sartorm K. Koch Wochen.1860, 37; Bot. Mag. t. 6292. A. Nonctiii and rufocincta Jacobi. A. pendulu Schmitt. A. cespritusa Todaro, Hort. Bot. Panorm.t. 8.-Trunk 1-2 ft. long, sometimes forked. Leaves $30-40$, spaced out in a lax rosette, ensiform, $1 \frac{1}{2}-2 \mathrm{ft}$. long, $3 \mathrm{in}$. broad at the middle, narrowed to $2-2 \frac{1}{2} \mathrm{in}$. above the base, bright green, with a pale band down the centre, the face flat, the ond-spine small and not pungent, the minute, crowded deltoid spreading tecth tipped with red-brown. Peduncle lateral, including the 2-3 ft. often cermuous spilie 6-8 ft. long. Flowers grcenish, $1 \frac{1}{4}-1 \frac{1}{2}$ in. long; tube $\frac{1}{3}$ in. long; segments lanceolate, $\frac{1}{2} \mathrm{in}$. long. Stamens about three times as long as the segments, inserted at their base.

Hab. Mexico and Guatemala. Introduced about 1863. Frequent in cultivation. This is distinctly polycarpic, and flowers at Kew usually every year.

99. A. (Littru) oblongata Jacobi, Nacht. 40.-Acaulescent. Leares $20-30$ in a rosette, lanceolate, $2 \mathrm{ft}$. long, $3 \frac{1}{2} \mathrm{in}$. broad at the middle, narrowed to $3 \mathrm{in}$. above the base, light glancous green, the face nearly flat in the centre, the cud-spine small and weak, the marginal prickles close, minute, brown, deltoid. Peduncle $4 \mathrm{ft}$. long. Spilic dense, twice as long as the pectuncle, Flowers $1 \frac{1}{2} \mathrm{in}$. long; tube short. Stamens $2 \frac{1}{2}$ in. long. Capsule oblong, $1 \frac{1}{4}$ in. long.

Hab. Probably Mexico. Described by Jacobi in 1868, from a plant in the collection of Herr Tonel at Ghent. Perhaps a mere variety of micrucuntha; the name is not appropriate.

100. A. (Littea) Haselofrir Jacobi, Monogr. 244. - Shortly canlescent. Leares about $20 \mathrm{in}$ a rosette, lanceolate, $1 \frac{1}{2}-2 \mathrm{ft}$. long, $3 \mathrm{in}$. broad at the middle, narrowed to $2 \mathrm{in}$. abore the base, bright light green, the subpungent brown end-spine $\frac{1}{2}$ in. long, the marginal teeth close and brown, the central ones lanceolate, $\frac{1}{8}$ in. 
long, those of the lower two-thirds of the edge more or less deflexed. Peduncle $7 \mathrm{ft}$. long including the dense $2 \mathrm{ft}$. spike. Flowers green, $1 \frac{1}{2}$ in. long; tube short; segments $\frac{1}{2}$ in. long. Filaments $2-2 \frac{1}{2}$ in. long.

Hab. Probably Mexico. Described by Jacobi in 1864, from a plant in the garden of the gentleman after whom it is named. I have seen it both at Kew and Reigate.

101. A. (Littau) Mumlunnni Jacobi, Nacht. ii. 76. - Shortly caulescent. Leaves about 30 in a rosette, lanceolate, $2 \mathrm{ft}$. or moro long, $2-2 \frac{1}{2}$ in. broad at the middle, bright green on the concave face, the end-spine subpungent and reddish brown, the marginal prickles crowded, minute, deltoid, red-brown. Peduncle including

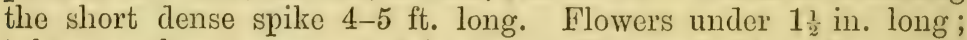
tube very short; segments $\frac{1}{2} \mathrm{in}$. long. Filaments $1 \frac{1}{4} \mathrm{in}$. long.

Hab. Probably Mexico. Deseribed by Jacobi in 1871, from a plant in the collection of Herr Muilmann at Utrecht.

102. A. Martiana K. Koch, Wochen. 1860, 38.-Acaulescent. Leaves lanceolate, reaching a length of $2-2 \frac{1}{2} \mathrm{ft} ., 3-3 \frac{1}{2} \mathrm{in}$. broad at the middle, narrowed to $2 \frac{1}{2} \mathrm{in}$. above the base, a light opaque green, the face nearly flat, the end-spine short, the edge in the upper part furnished with a continuous brown line and minutely toothed, lower down furnished with irregular small deltoid brown teeth.

Hab. Probably Mexico. Described by Dr. Karl Koch from a plant in the Berlin Botanic Garden.

103. A. (Euagjave) CARIBes Baker in Gard. Chron. 1877, ii. 683.

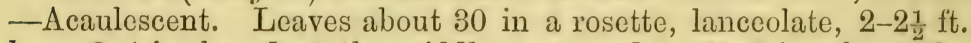
long, 3-4 in. broad at the middle, narrowed to $2 \frac{1}{2}-3$ in. above the base, bright green, the face nearly flat, the weak brown end-spine $\frac{1}{2}$ in. long, the marginal teeth close, very minute, all pale or only tinged with brown at the very tip. Infloresecnee a thyrsoid panicle. Flowers 2 in. long; tube very short; segments lanceolate, yellowish, $\frac{3}{4}$ in. long. Filaments scarcely longer than the segments.

Hab. Martinique, Hahn 114! Inflorescence described from a dried specimen, received from Dr. Cosson in 1873 . We have what I suppose to be the same species alive at Kew, but it has never flowered. The only other species of this group known to have a thyrsoid panicle is $A$. Wildingii.

104. A. Bernhardi Jacobi, Nacht. 38. - Shortly caulescent. Leaves oblanceolate, 7-8 in. long, 3 in. broad at the middlc, narrowed to $2 \frac{1}{4} \mathrm{in}$. above the base, light bright green, the face rather concave, the chestnut end-spine short and slender, the tecth rather crowded, deltoid, cuspidate, castaneous, fragile, unequal. Inflorescence unknown.

Hab. Probably Mexico. Described by Jacobi about 1868, from a plant in the Leipsic Botanic Garden.

105. A. (Littaa) Rupicola Regel in Gartenfl. vii. 312.- Shortly caulescent. Leaves about 20 in a rosette, oblanceolate, 12-15 in. long, $3 \frac{1}{2}-4 \mathrm{in}$. above the middle, narrowed to $2 \frac{1}{2}-3 \mathrm{in}$. above the base, bright green, the end-spine small and weak, the edge irregrularly jagged rather than toothed, the tips castaneous. Peduncle 
7-8 ft. long including the dense $2 \mathrm{ft}$. spike. Flower under $2 \mathrm{in}$. long, segments oblong, yellowish, equalling the funnel-shaped tube. Stamens $2 \mathrm{in.}$ long.

Hab. Mexico. Sent by Karwinski to the Petersburg Botanic Garden, where it flowered in 1863.

106. A. (Littaa) Boucher Jacobi, Monogr. 120.-Trunk reaching a foot in length. Leaves $20-30$ in a rosette, oblanceolate, $1-1 \frac{1}{2} \mathrm{ft}$. long, $3 \frac{1}{2}-4 \frac{1}{2} \mathrm{in}$. broad at the middle, narrowed to $2 \frac{1}{2}-3 \mathrm{in}$. above the base, bright light green, rather glaucous when young, the darkbrown subpungent end-spine $\frac{1}{2}$ in. long, the brown deltoid teeth crowded and very minute. Peduncle about $6 \mathrm{ft}$. long. Flowers under 2 in. long, yellowish green; segments oblong, as long as the tubes. Stamens under 2 in. long.

Hab. Probably Mexico. Introduced to the Berlin Botanic Garden in 1861, and flowered there in 1864. I have seen it both at Kew and Reigate.

107. A. (Littaa) micracantha Salmdyck in Bompland. vii. 93 ; Baker in Saund. Ref. Bot. t. 327.-Shortly caulescent. Leaves 20-30 in a rosette, oblanceolate, 15-18 in. long, 3-5 in. broad above the middle, narrowed to 2-3 in. above the base, bright green, the face flattish, the end-spine red-brown and moderately firm, the copious close reddish-brown deltoid teeth 1-12th in. long. Peduncle including the dense $3-4 \mathrm{ft}$. spike 6-7 ft. long. Flowers $1 \frac{1}{2}-1 \frac{3}{4}$ in. long; segments oblong, yellowish, as long as the funnelshaped tube. Stamens 2 in. long.

Hab. Mexico. Introduced about 1860, now frequent in cultivation. Described from a plant that flowered in 1870 with Mr. Wilson Saunders at Reigate. Flowered at Kew in 1867 and 1878.

108. A. (Littaa) misis Salmdyck in Bonpland. vii. 93; Baker in Gard. Chron. 1877, ii. 717, fig. 137.-Shortly caulescent. Leaves about 30 in a rosette, oblanceolate, 12-15 in. long, 3 in. broad above the middle, narrowed to $2 \mathrm{in}$. above the base, bright green, flat in the middle, the end-spine weak, the crowded deltoid teeth very small, ontirely green, or obscurely tipped with redbrown. Peduncle including the dense 3-4 ft. spike 9-10 ft. long, Flower about $2 \mathrm{in}$. long; segments oblong, about as long as the tube. Stamens above 2 in. long.

Hab. Mexico. Introduced about 1860. Flowered at Berlin in 1869, and by MIr. Thomas Hanbury, at Mortola, in 1877. Seen alive both at Kew and Hammersmith. Scarcely more than a variety of A. micracantha.

109. A. (Littca) albicans Jacobi, Monogr. 137; Balier in Gard. Chron. 1877, ii. 717, fig. 138. A. Ousselghemiana Jacobi. Acaulescent. Leaves about 30 in a rosette, oblanceolate, $12-15$ in. long, 3-4 in. broad at the middle, narrowed to $2-2 \frac{1}{2}$ in. above the base, persistently glaucous, with a small weak end-spine, the close deltoid brown horny teeth under a line long. Peduncle, including the dense $1 \frac{1}{2}-2 \mathrm{ft}$ spilie $5-6 \mathrm{ft}$. long. Flower $1 \frac{1}{2} \mathrm{in}$. long; segments greenish yellow, linear-oblong, twice as long as the fumnelshaped tube. Stamens under 2 in. long.

Hab. Mexico. Introduced above 1860. Flowered in 1867, by Count Kerchove d'Ousselghem, and in 1882 by Mr. Justus Corderoy, at Blewbury. Scarcely more than a variety of micracantha. There is a form with variegated leaves. 
110. A. Thonsoniana Jacobi, Monogr. 240.-Acaulescent. Leaves $30-40$ in a rosette, oblanceolate-oblong, 12-15 in. long, $3 \frac{1}{2}-4 \frac{1}{2} \mathrm{in}$. broad above the middle, narrowed to $2 \frac{1}{2}-3 \mathrm{in}$. above the base, very bright green, the subpungent brown end-spine $\frac{1}{2}$ in. long, the teeth close, red-brown, very irregular, the largest 1-12th in. long. Inflorescence unknown.

Hab. Mexico; San Luis Potosi. Described by Jacobi from a plant seen at Kew in 1865, and named in compliment to Dr. Thomson.

111. A. WaLLISII Jacobi, Nacht. ii. 78.-Acanlescent. Leaves few, lanceolate, 9-10 in. long, 2 in. broad at the middle, narrowed to $1 \frac{1}{2}$ above the base, bright green, the short end-spine brown, the teeth crowded, minute, brown, deltoid. Inflorescence unknown.

Hab. Columbia, sent by Wallis to Linden in 1867.

112. A. (Littac) chloracantha Salmdyck in Bompland. vii. 93. - Trunk sometimes $\frac{1}{2} \mathrm{ft}$. long. Leaves about 30 in a rosette, oblanceolate-oblong, 18-20 in. long, 4-5 in. broad above the middle, narrowed to $2 \frac{1}{2}-3$ in. above the base, bright green, the end-spine small and weak, the very small close deltoid marginal teeth scarcely tipped with brown. Peduncle 5-6 ft. long, including the dense $2 \mathrm{ft}$. spike. Flowers $1 \frac{1}{2} \mathrm{in}$. long, bright green. Stamens above 2 in. long.

Hab. Nexico, introduced about 1860. Described from a plant of Mr. J. T. Peacock's, which flowered at Kew, March, 1882.

113. A. Brauniana Jacobi, Monogr. 240.-Nearly acaulescent. Leaves $30-40$ in a rosette, lanceolate, 15-18 in. long, $2 \frac{1}{4}-2 \frac{1}{2}$ in. broad at the middle, narrowed to $1 \frac{1}{2}-1 \frac{3}{4} \mathrm{in}$. above the base, bright green, the face flat in the centre, the subpungent brown end-spine $\frac{1}{2}$ in. long, the moderately close deltoid-cuspidate brown teeth $\frac{1}{2}-1$ line long, sometimes confluent into a continuous brown border, the upper ones curved up and the lower down. Inflorescence unknown.

Hab. Mexico; San Luis Potosi. Described by Jacobi from a plant seen at Kew in 1865 , which is still there and has never flowered.

\section{Group 10.-Serrulate.}

114. A. pruinosa Lemaire; Jacobi, Monogr. 168. A. Debaryana and Kellockii Jacobi. A. Gheisbrerghtii and dentata Hort.-Shortly caulescent. Leaves 10-20 in a rosette, spreading oblanceolateoblong, $1 \frac{1}{2}-2 \mathrm{ft}$. long, 4-5 in. broad above the middle, narrowed to $2-2 \frac{1}{2}$ in. above the base, the face flat, pale glaucous green, the texture soft and fleshy, the end-spine not at all pungent, the edge furnished with irregular minute deltoid spreading pale green teeth not tipped with brown. Inflorescence unknown.

Hab. Mexico. Introduced by De Smet of Ghent in 1863. Habit of attenuata, from which it differs by its serrulate leaves.

115. A. (Littaca) bracteosa S. Wats. in Proc. Amer. Acad. xi. 162 ; Engelm. in Gard. Chron. 1882, ii. 776, figs. 138-139.Acaulescent. Leaves about 15 in a rosette, linear, $1 \frac{1}{2}-2 \mathrm{ft}$. long, $1 \frac{1}{2} \mathrm{in}$. broad low down, narrowed gradually to the non-pungent tip, 
minutely scrulate. Peduncle 3-4 ft. long, with numerous subulate recurved bract-leaves 4-6 in. long; flowers in a dense spilie about $2 \mathrm{ft}$. long. Flower about an inch long; tube very short; segments oblong, $\frac{1}{3}$ in. long. Stamens 2 in. long. Capsule oblong, $\frac{1}{2}$ in. long.

Hab. Northern Mexico, near Monterey. Introduced by Dr. Palmer to the Cambridge (Harvard) Botanic Garden, where it flowered in 1ss1. Habit of A. yuccefolia.

\section{Group 11.-Atrenuat.玉.}

116. A. ( Littra) Ermaremtana Jacobi, Monogr. 178, 313 ; Baker in Saund. Ref. Bot. t. 163 ; Gard. Chron. 1876, ii. fig. 145.Acanlescent. Leares $20-25$ in a rosette, oblinceolate-oblong,

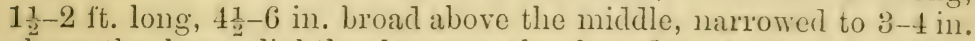
above the base, slightly glaucous, the face flat above the middle, the tip not at all pungent, the margin pale and quite entire. Peduncle, including the dense $3-4$ ft. spilie, $12-13 \mathrm{ft}$. long. Flowers $1 \frac{1}{4}-1 \frac{1}{2} \mathrm{ft}$. long; tube scarcely any; segments grcenish yellow, oblong, $\frac{1}{2}-\frac{3}{4}$ in. long. Stamens 2 in. long.

Hab. Mexico, introduced about 1864 and named by Jacobi after his friend M. de Jonge Van Elemeet, whose fine collection was dispersed in 1873. It was first flowered by Mr. Wilson Saunders at lieigaie in 1s67. It tlowered at Kew in 1877 and 1883.

117. A. (Littea) attenuata Salmdyck, Hort. Dyck. 303 ; Rev. Hort. 1875, 149, figs. 31-32. A. yluneeseens Hook. in Bot. Marg. t. 5833 ; Gard. Chron. 1887 ii. 219, fig. 55. A. spectubilis Hort. Trunk reaching a length of 4-5 ft. below the rosette of leaves. Leaves 10-20 in a dense spreading rosette, oblong, 2-21 ft. lontr, $8-9$ in. broad above the middle, narrowed to 2 ? -3 in. above the base, persistently glancous, the face flat, the tip not at all pungent, the edge pale and quite entire. Peduncle twice as long as the leares; bract-leaves adpressed, lanceolate. Spilic dense, cermuous, 6-8 ft. long. Flower 2 in. long; segments greenish-yellow, oblong, longer than the fumnel-shaped tube. Stamens under 2 in. long.

Hab. Mexico, introduced into cultivation about 1834. It has flowered several times at Kew, beginning with 1861, and was figured lately in the 'Gardener's Chronicle' from a plant that bloomed with Dr. Henriques at Coimbra.

\section{Group 12.- Viripar.e.}

118. A. pugionirorins Zuccal. in Nova Acta xvi. 2, 676. Acaulescent. Leaves linear, $1 \frac{1}{2}-2 \mathrm{ft}$. long, 6-8 lines broad, glaucescent, narrowed griadually to a firm dirts brown end-spine $\frac{1}{2}-3$ in. long, slightly concave on the face, the tceth small, distant, deltoid-cuspidate, dirk brown, straight or uncinate. Inflorescence unknown.

Hab. Mexico, introduced about 1830. I have never seen this species.

119. A. Serrulata Karw. in Otto Gartenzeit. 1842, 51.Acaulcscent. Leares cnsiform, 2-21 ft. long, an inch broad at the middle, narrowed to ${ }_{4}^{3} \mathrm{in}$. above the base, glitucescent, the face 
slightly concave, the end-spine very small, black, the small teeth crowded in the lower part of the margin, at first greenish, finally brown. Inflorescence unknown.

Hab. Iexico. Introduced into cultivation about 1842. This species also I have never seen.

120. A. (Euggave) vivipara Linn. Sp. Plant. 461 (Rumph. Amboin. v. 273, tab. 94); Wight, Ic. t. 202t, non Salmdyck. A. Cantula Roxb. A. Rumpliii Hassk. Fourcroyju Cuntula Haw.-Shortly caulescent. Leaves 20-50 in a dense rosette, ensiform, 2-3 ft. long, $1 \frac{1}{2}-2 \mathrm{in}$. broad at the middle, narrowed to $1-1 \frac{1}{4} \mathrm{in}$. above the base, dull green when mature, glaucous in an early stage, thin but firm in texture, the subpungent brown end-spine $\frac{1}{2} \mathrm{in}$. long, the deltoid subdistant brown hooked teeth $\frac{1}{2}-1$ line long. Inflorescence reaching a length of 12-20 ft.; thyrsoid panicle much shorter than the peduncle. Flowers $1 \frac{1}{2}-2$ in. long, often turned into bulbillæ like those of Furcraa; tube very short; segments greenish yellow, $\frac{3}{4}-1 \mathrm{in}$. long. Filaments twice as long as the segments.

Hab. Mexico and Honduras. Introduced early and now spread widely in the Old World. It is common in India, and we have it also from Fernando Po. It has been twice flowered lately by Mr. Thos. Hanbury at Mortola. It is fully described by Jacobi under the name of $A$. Cantula Galeotti, in his first Nachtrage, p. 45-47. I cannot from the deseriptions separate $A$. bulbifera Salmdyck and A. stenophylla Jacobi.

121. A. Rubescens Salmdyck, Hort. 1834, 306. A. flaccida

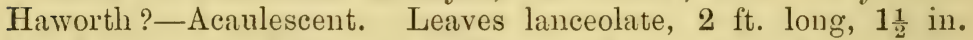
broad, glancescent, turning reddish in bright sunlight or when fading, subflaccidly recurved, the upper part deeply channelled, the end-spine slender and brownish, the minute crowded deltoid teeth whitish with a pale brown tip. Inflorescence unknown. 1834.

Hab. Mexico. Described by Prince Salmdyek from his own collection in

122. A. Laxa Zucear. in Salmdyck, Hort. 1834, 8 ; Baker in Gard. Chron. 1877, ii. fig. 151.-Shortly caulescent. Leaves 50-60 in a rosette, ensiform, $2-2 \frac{1}{4} \mathrm{ft}$. long, $1 \frac{1}{2}-2 \mathrm{in}$. broad at the middle, narrowed to an inch above the base, and very gradually from the middle to the small dark brown subpungent tip, bright green, slightly glaucous towards the base in an early stage, the distant hooked brown marginal prickles about a line long. Inflorescence unknown.

Hab. Mexico. First described by Prince Salmdyck from his own collection in 1834. It may be a variety of $A$. vivipara.

123. A. Broneliæfolia Salmdyck, Hort. 1834, 303 . A. teox muliana Karw.-Acaulescent. Leaves ensiform, resembling those

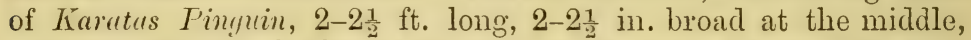
narrowed to an inch above the base, rather shining green, the endspine weak, the moderately crowded deltoid hooked red-brown teeth 1-12th to 1-8th in. long. Inflorescence unknown.

Hab. Mexico. Introduced into cultivation by Karwinski about 1834.

124. A. (Euayave) sobolifera Salmdyck, Hort. 1834, 307 (Herm. Lugd. 16-17, with figure). A. antillarum Dese.-Shortly caulescent. Leaves 20-40 in a rosette, oblong, 2-3 ft. long, 
3-5 in. broad at the middle, narrowed to $2-3 \mathrm{in}$. above the base, very bright green, the face deeply concave, the subpungent brown end-spine $\frac{1}{2} \mathrm{in}$. long, the distant brown deltoid-uncinate marginal prickles 1-12th to 1-8th in. long. Peduncle 8-10 ft. long; inflorescence a deltoid panicle, the lower branches 9-12 in. long.

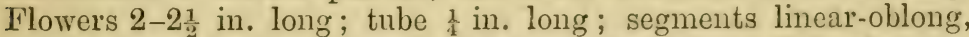
bright yellow, $\frac{3}{4}-1$ in. long. Stamens less than twice as long as the segments. Capsule oblong, $1 \frac{1}{2}-1 \frac{3}{k}$ in. long.

Hab. West Indies. First noticed as a cultivated plant by Hermann in 1678. My description is taken from living plants at Kew and Reigate, and of the inflorescence from Dr. Engelmann, whose notes were made on plants collected by Dr. Parry and Mrr. C. Wright on San Domingo. It resembles Furcrea cubensis in leaf and habit. It is often called A. viripura in English gardens, and is figured under that name in Gard. Chron. 1877, ii. fig. 150.

125. A. Todaror Balier.-Acaulescent. Leaves oblong, 6-7 ft. long, $18 \mathrm{in}$. broad at the middle, narrowed to $9 \mathrm{in}$. above the base, bright green, much undulated, the face very concave, the endspine scarcely pungent, the edge much undulated between the very large deltoid hooked brown marginal pricliles. Inflorescence unknown.

Hab. Probably Mexico. Described from a leaf and photograph sent by Dr. Todaro in January, 1886. It has been cultivated in the Palermo Botanic Gardens under the name of $A$. undulata. It is a magnificent plant, with the leaves like those of $A$. sobolifera in colour and texture, but with the undulated edge and large teeth of $A$. Scolymus and potatorum.

\section{Group 13. Yuccefolia.}

126. A. (Littaa) yuCCæFolia DC. in Red. Lil. t. 328-329; Ilook. in Bot. Mag. t. 5213. A. Cohniena Jacobi. - Shortly caulescent. Leaves $20-40$ in a dense rosette, linear, much recurved, $1 \frac{1}{2}-2 \frac{1}{2} \mathrm{ft}$. long, $\frac{3}{4}-1 \mathrm{in}$. broad at the middle, dilated to $1 \frac{1}{2} \mathrm{in}$. at the base, deeply channelled all down the face, a dull rather glaucous green, with a pale band down the contre, the tip not at all pungent, the back broadly rounded, the edge with a narrow brown scariose line, entire or obscurely serrulate. Peduncle $6-8 \mathrm{ft}$. long, including the short lax spike. Flower $1 \frac{1}{2}$ in. long; tube $\frac{1}{4} \mathrm{in}$. long; segments linear-oblong, greenish yellow, $\frac{5}{8}-\frac{3}{4}$ in. long. Stamens twice as long as the segments.

Hab. Mexico. Introduced into cultivation about the beginning of the century. It flowered at Kew in 1829, from a plant brought by Richard Cumningham from Paris, and again in 1861 and 1s74, and with Mr. Thomas Hanbury at Mortola in 1887. The flowers are sometimes single and sometimes in pairs, so it connects the subgenera Littea and Henfieda.

127. A. (Lilteca) spicata Cav. Descr. 454, non DC.-Leaves spreading, ensiform, above $2 \mathrm{ft}$. long, nearly 3 in. broad at the base where it is widest, ehannelled down the face, serrulate on the margin. Peduucle $15 \mathrm{ft}$. long, including the $6 \mathrm{ft}$. spilie. Perianth greenish yellow; tube short; segments linear-oblong. Stamens twice as long as the segments.

Hab. Described by Caranilles in 1502 , from a plant that flowered in the Madrid Botanic Carden, brought from Mavana. No other botanist seems to have seen it. 


\section{Group 14. Herbacee.}

127. A. (Manfieda) iraculata Regel, Ind. Sem. Hort. Petrop. 1856, 16. A. maculosa Hook. in Bot. Mag. t. 5122 ; Fenzi in Gard. Chron. 1872, 1194, fig. 273.-Acaulescent. Leaves 12-20 in a rosette, lanceolate, spreading, $\frac{1}{2}-1 \mathrm{ft}$. long, $\frac{3}{4}-1$ in. broad at the middle, glaucous green, mottled on both sides with irregularly brownish blotches, the point not at all pungent, the edge distinctly rather distantly serrulate. Peluncle $1 \frac{1}{2}-3 \mathrm{ft}$. long; bract-leaves few and much reduced. Flowers in a lax subspicate raceme $\frac{1}{2}-1 \mathrm{ft}$. long; lower pedicels finally $\frac{1}{3}$ in. long. Perianth $1 \frac{1}{2} \mathrm{in}$. long; tube subcylindrical, curved, $\frac{3}{4}$ in. long; seyments linear-oblong, purplish green, not longer than the tube. Stamens scarcely longer than the segments. Capsule $\frac{3}{4}-1$ in. long. 1307 !

Hab. Texas and the north of Mexico, C. Wright 183! 1905! Pulmer 1306 !

128. A. (Manfieda) sessiflona Hemsl. Bot. Cent. Amer. iii. 350, tab. 88 в.-Acaulescent. Rootstock $2 \frac{1}{2}$ in. diam. Leaves linear or ensiform, $1-1 \frac{1}{2} \mathrm{ft}$. long, $\frac{1}{2}-\frac{3}{4}$ in. broad at the middle, tapering gradually to a long point, closely serrulate on the margin. Peduncle $2 \mathrm{ft}$. or more long. Spike short, lax. Flowers $1 \frac{1}{4}-1 \frac{1}{2}$ in. long; tube narrowly fumnel-shaped, as long as the linear-oblong brownish segments. Stamens much exserted.

Hab. Mountains of Central Mexico, Bourgeau 412 ! 3003 !

129. A. (Manfireda) Revoluta Klotzsch in Otto \& Dietr. Gartenzeit. 1870, 274.-Acaulescent. Leaves a dozen or more, lanceolate, 6-8 in. long, $\frac{1}{2}-\frac{3}{4}$ in. broad low down, plain green, pruinose beneath, falcate, channelled down the face, entire on the margin. Peduncle $4 \mathrm{ft}$. long, including the dense spilie. Perianth $1 \frac{1}{4}-1 \frac{1}{2}$ in. long; tube equalling in length the greenish linear-oblong segments. Stamens exserted.

Hab. Mexico. Introduced to the Berlin Botanic Garden in 1840.

130. A. (Munfiella) variegata Jacobi, Monogr. 180; Balier in Saund. Ref. Bot.t. 326.-Acaulescent. Leaves 15-18 in a rosette, spreading, lanceolate, 12-15 in. long, 1-2 in. broad, deeply channelled down the face, copiously spotted with brown, a green ground, the narrow cartilaginous edge very obscurely serrulate. Peduncle $3 \mathrm{ft}$. long, including the 12-15-flowered lix spilie. Flowers $1 \frac{1}{4}-1 \frac{1}{2}$ in. long; tube subcylindrical, equalling the linearoblong greenish-brown sogments. Stamens much exserted. Capsule oblong, under an inch long.

Hab. Northern Mexico; valley of the Rio Grande. Discovered by Dr. Gregg in 1847. Described from a plant that flowered with Mr. Wilson Saunders in 1870.

131. A. (Munfreda) Alibertir Baker in Gard. Chron. 1883, i. 176. Allibertia intermedic Marion.-Rootstock sheathed by several fleshy scalc-leaves. Leaves 10-12 in a rosette, lauceolate, 12-16 in. long, narrowed gradually from a little above the base to an acute channelled tip, serrulate on the margin. Peduncle including the inflorescence 1-5 ft. long. Flowers subspicate; pedicels very short. 
Perianth a little over an inch long; tube subcylindrical; segments very short. Stamens exserted above an inch.

Hab. Probably Nexico. Figured and described by M. Marion in the ' Revue Horticole des Bonches du Khone,' S'pt. and Nov., 18.42. Tre received a living plant in 1884 from M. Deleuil labelled Alliberthiera intermedia.

132. A. (Manfireda) pebescress Regel \& Ortgies in Gartenfl. 1874, 227, tab. 804.-Leaves $12-15$ in a rosette, spreading, lan-

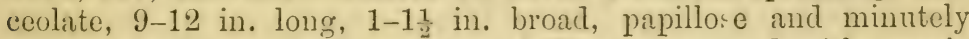
pubescent all over both surfaces, dull green spotted with purple towards the base, not serrulate. Peduncle $3 \mathrm{ft}$. long. Spile $\frac{1}{2} \mathrm{ft}$. long, laxly 12-15-flowered. Perianth $1 \frac{1}{4}$ in. long; tube subeylindrical, longer than the linear-oblong greenish segments, which are $\frac{1}{4}-\frac{1}{3}$ in. long. Stamens much exserted.

Hab. Mexico. Introduced by Roezl about 1870. Seen at Mr. J. T. Peacock's, December, 1877, but not in Hower.

133. A. (ILunfiedu) virgnica Limn. Sp. Plant. 416 ; Jacq. Ic. t. 378; Bot. Mag, t. 1157, non Miller.-Acaulescent. Leaves 10-15 in a rosette, spreading, lanceolate, $\frac{1}{2}-1 \frac{1}{2} \mathrm{ft}$. long, 1-3 in. broad at the middle, plain green or mottled with brown spots, the narrow white edge very obseurely scrrulate. Peduncle $2-3 \mathrm{ft}$. long. Flower's brownish green, arranged in a lax raceme 1-1 $\frac{1}{2} \mathrm{ft}$. long;

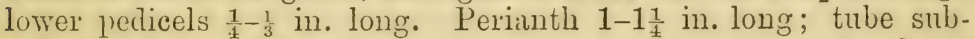
cylindrical, $\frac{1}{2}$ in. long; segments linear oblong, $\frac{1}{3}-\frac{1}{2}$ in. long. Stamens 2-3 times the length of the segments. Capsule $\frac{1}{2}-\frac{3}{4}$ in. long.

Hab. Southern United States.

134. A. (Manfreda) brachystachys Cav. Descr. 453. A. spicatı DC. in Red. Lil. t. 485, non Cav. A. polyanthoides Cham. et Schlecht. A. saponaria Lindl. in Bot. Reg. xxv. t. 55. A. humilis Rocm.-Acaulescent. Leaves $\mathbf{1 2 - 1 5}$ in a rosette, spreading, lan-

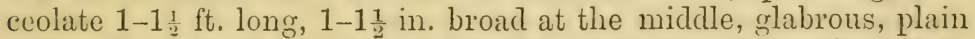
green, the pale edge very indistinctly serrulate. Peduncle $3-4 \mathrm{ft}$. long; bract-leares distant, small. Spike lax, $1 \mathrm{ft}$. or more long. Flowers $2 \mathrm{in.} \mathrm{long;} \mathrm{tube} \mathrm{subcylindrical,} \frac{3}{t}-1$ in. long; segments linear, greenish yellow, $\frac{1}{2} \mathrm{in}$. long. Stamens twice as long as the segments. Capsule $\frac{3}{4}$ in. long.

Hal. Mexico. Introduced into cultivation at the beginning of the century. Coulter 1555! Andrieux 61! We had it alive in 1877, from the Rev. H. N. Ellacombe. The native name is Mole, and the root is used as soap.

135. A (Manfieda) planifolia S. Wats. Contrib. xiv. 479.Rootstock persistent for three or four years. Leaves lanceolate, flat or nearly so, 8-12 in. long, 1-2 in. broad at the middle, not spotted, minutely denticulate. Peduncle 4-5 ft. long. Perianth $\frac{3}{4} \mathrm{in}$. long exclusive of the ovary; segments $3-4$ times the length of the tube. Stamens much exserted. 1886.

Hab. Hexico; province of Chihuahua, gathered by Mr. C. G. Pringle in

136. A. (Manfreda) protuberans Engelm. inedit. A. guttata Hemsl. Biol. Cent. Amer. Bot. iii. t. 87-Acaulescent. Leaves 8-12 in a rosette, spreading, lanceolate, above a foot long when 
mature, $1-1 \frac{1}{4} \mathrm{in}$. broad at the middle, narrowed to $\frac{1}{2}$ in. above the base, shallowly channelled down the face, dull green copiously mottled with confluent brown spots, closely denticulate on the cartilaginous margin. Peduncle 3-4 ft. long. Flowers laxly or densely spicate. Perianth 1-1 $\frac{1}{4}$ in. long; tube $\frac{1}{6}-\frac{1}{4}$ in. long, broadly fumel-shaped; segments linear-oblong, 2-3 times the length of the tube. Filaments twice as long as the segments. Capsule oblong, under an inch long.

Hab. Mexico ; Mountains of San Luis Potosi, alt. 6000-8000 ft., Schaffner 505 ! 506! Parry \& Palmer 865! Described partly from living plants at Kew, received from Max Leichtlin.

137. A. (Manfiedı) guttata Jacobi and Bouché, Monogr. 190; Nacht. ii. 87.-Acanlescent. Leaves few, lanceolate, spreading, 15-16 in. long, $2 \mathrm{in}$. broad below the middle, deeply channelled down the green face, paler beneath with subpruinose streaks, with reddish-brown blotches on both surfaces, subentire on the edge. Flowers $1 \frac{1}{2} \mathrm{in}$. long; segments linear oblong, twice as loug as the short funnel-shaped tube. Stamens $2 \mathrm{in.} \mathrm{long.}$

Hab. Mexico. Introduced to the Berlin Botanic Garden about 1860, by Ehrenberg, and flowered there in 1870.

138. A. (Manfirela) undulata Kilotzsch in Otto \& Dietr. Gartenzeit, 1840, 274. A. drimiafolia Hort. - Acaulescent. Leaves a dozen or more in a rosette, lanceolate, $1 \frac{1}{2} \mathrm{ft}$. long, $1 \frac{1}{1} \mathrm{in}$. broad, deeply channelled down the face, dull glaucons green, not spotted, much undulated, the narrow cartilaginous edge obscurely serrulate.

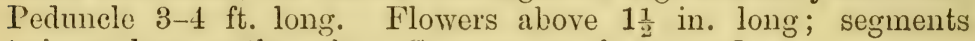
twice as long as the tube. Stamens much exserted. in 1869 .

Hab. Mexico. Introduced to the Berlin Garden in 1840 and flowered there

\section{Furcrea Vent.** \\ (Fourcroya R. \& S.).}

Perianth rotate; tube short, cylindrical; segments oblong, subequal, spreading horizontally. Stumens short, attached to the throat of the perianth-tube; filaments erect, very strumose in the lower half; anthers oblong, versatile. Ocury oblong, 3-celled; ovules many, superposed; style erect, strumose, with three prominent angles towards the base ; stigma capitate. Capsule oblong, loculicidally 3 -valved. Seeds flat, with a thin black testa.-Acaulescent or caulescent. Leuves densely rosulate, usually rigid, spinepointed and spine-edged. F'lowers laxly panicled, greenish white, 1-3-nate, often replaced by bulbillie, from which the plant can be readily reproduced; pedicels articulated; bracts small, membranous.

Subgenus Furcrea proper.-Leaves firm in texture, usually edged with deltoid spines, entire betreen them.

Group of gigantea.-Trunk long below the rosette of leaves . . . . . Sp. 1.

* Reprinted, with slight alteration, from Gard. Chron. 1879, i. 623, 656 . 
Group of cubensis.-Trunk none or short.

Inner leaves rigidly suberect; marginal prickles larger . . . . . .

Inner leaves thimner and more or less wavy; marginal prickles smaller .

Subgenus Roezlia. - Leaves more flexible, closely, minutely denticulate, not spiny on the edge. Trunk produced

Sp. 2-10.

Sp. 11-15.

1. F. Gigantea Vent. in Ust. Ann. xix. 54; Bot. Mag. t. 2250 ; DC. Pl. Grasses, t. 126 ; Wight, Ic. t. 2025. Ayme fieticla Limn. (Commel. Hort. ii. t. 18). F. futida Haw. Funium pitiferum Willemet.-Trunk reaching a length of 3-4 ft. Leaves 40-50 in a dense rosette, ensiform, 4-6 ft. long, 4-6 in. broad at the middle, narrowed to $2 \frac{1}{2}-3 \mathrm{in}$. above the base, rigid, but the outer recurving, bright green, channelled down to the face, narrowed gradually to a pungent tip, usually without marginal spines, rarely (var. Willemetiuna Roem.) with a few near the base. Peduncle, including inflorescence, 20-40 ft. long. Panicle about as long as the peduncle; central brauches copiously compound; pedicels $\frac{1}{4}-\frac{1}{2}$ in. long, lower 2-3-11ate. Ovary $\frac{3}{4}$ in. long, glabrous; segments greenish white, oblong, an inch long. Scent of flower's strong.

Hab. Widely spread in Tropical America and naturalised in Mauritius, Madagascar, and India. Introduced, into cultivation at Hampton Court in 1690. The leaves yield an abundant supply of excellent fibre (See Morris in Kew Bulletin, iii. 8). We have a specimen in flower from Kew Gardens, dried by I). Goodenough in November, 1793 . I cannot separate definitely $F$. atroviridis Jacobi and Goeppert, Monog. 273; Nachtrage, ii. 90.

2. F. cubensis Haw. Syn. 73. Ayare cubensis Jacq. A. odorata Pers.-Trunk very short below the rosette of leaves, 3-4 in. thick. Leaves about 30 in a rosette, lanceolate, bright green, firm in texture, shallowly channelled down the face, $2-2 \frac{1}{2} \mathrm{ft}$. long, $3-4 \mathrm{in}$. broad above the middle, narrowed to $1 \frac{1}{2} \mathrm{in}$. above the base, gencrally scabrous on the back, scarcely pungent at the convolute brown tip, margined with large distint deltoid hooked brown prickles. Peduncle 5-6 ft. long, with several ascending lanceolate bract-leaves. Panicle lax, rhomboid, 5-6 ft. long, $1 \frac{1}{2}-2 \mathrm{ft}$. diam.; lower branches slightly compound; pedicels short, articulated at the tip, lower 2-3-nate. Ovary with short tube $\frac{3}{4}$ in. long; segments oblanceolate-oblong, an inch long, mills-white, green outside, Scent faint.

Hab. Widely spread in Tropical America, and often cultivated in the Old World. Described from a plant that flowered at Kew, November, 1877. Var. inermis Baker, in Bot. MIag. t. 6.573, is a form with the leaves entirely destitute of spines, from the collection of Mr. Wilson Saunders, that flowered at Kew in November, 1879. I cannot separate definitely $F$. Aitoni and rulleculuta Jacobi, Nacht. 59-60. F. Lindeni Jacobi in Ill. Hort, n. s., t. 186, differs mainly by its handsomely variegated leaves. For an elaborate account of its pre-Linnean synonymy see Martius in Fl. Bras. iii. 188.

3. F. tuberosa "Ait."; Jacobi, Monoogr. 276; Hassk. Retz. ii. 16. -lyace tuberosa "Miller"; Salmdyck, Hort. Dyck. 302.-Trunk 
6-8 in. long below the rosette of lenves, 2-3 in. diam. Leaves about 30 in a rosette, lanceolate, bright green, firm in texture, 2-3 ft. long, 2-3 in. broad at the middle, smooth on the face, scabrous on the back, scarcely pungent at the tip, armed on the margin with remote horny uncinate prickles. Panicle with peduncle (according to Hassliarl) reaching a height of $30 \mathrm{ft}$. or more; branches copiously compound, the central ones 6-9 long. Flower's greenish white, sweet-seented; segments oblong, an inch long.

Hab. Tropical America. The descriptions of Niller and Aiton are very brief. In the absence of reliable specimens I have simply copied Jacobi and Hasskarl. See also Carriere in Rev. Hort. 1877, 234, figs. 39-40. We have a photograph fram Prof. Miquel's collection, of a young plant of F. interrupta Hort. Van Houtte, which, according to Jacobi, is the genuine tuberosa. All the species of the cubensis group seem to come very near to one another, and I much doubt their being all really distinct specifically.

4. F. Geninispind Jacobi, Nonogr. 282.-Trunk reaching a font long, 5-6 in. diam. below the rosette of leaves. Leaves $40-50 \mathrm{in}$ a dense rosette, lanceolate, $3-4 \mathrm{ft}$. long, $6-8$ in. broad at the middle, narrowed to $3 \frac{1}{2}-4$ in. above the liase, bright green, smooth on the shallowly chammelled face, very scabrous on the back, the short brown point subpungent, the edge armed with distant delto:duncinate brown spines $\frac{1}{6}$ in. long, many, especially about the micdle of the leaf, confluent, so as to have a hook pointing both ways. Inflorescence unlnown.

Hab. Tropical America. Described from a fine plant which has been in the Cactus House at Kew for many years, but has never flowered. Probably this is the plant placed as a variety of tuberosa by Willdenow and Aiton.

5. F. Selloa K. Koch; Jacobi, Monog. 289; Hook. fil. in Bot. Mag. t. 6148.-Trunk none or very short, 4-5 in. thick. Leaves 30-40 in a dense rosette, lanceolate, very rigid in texture, bright green, 3-4 ft. long, $4 \mathrm{in}$. broad at the middle, narrowed to $1 \frac{1}{2}-2 \mathrm{in}$. above the base, subpungent at the tip, the margin armed with distant hooked large brown horny prickles. Peduncle 8-10 ft. long below the panicle; bract-leaves distant, lanceolate, 3-4 in. long. Panicle 5-6 ft. long, $3 \mathrm{ft}$. broad; branches simple; lower flowers 2-3 nate; pedicels $\frac{1}{2} \mathrm{in}$. long. Ovary including the short tube an inch long; segments oblong-lanceolate, $1 \frac{1}{2}-1 \frac{3}{4}$ in. long, $\frac{1}{2}-\frac{3}{4}$ in. broad, much tinged with green. Scent faint.

Hab. Mexico and Guatemala. Introduced into cultivation by Warcervicz. Described from a plant that flowered at Kew, November, 1877.

6. F. Commelini Kunth, Enum. v. 842. Agave Commelyni Salmdyck, Hort. 301 (Commel. Hort. Amstel. ii. t. 19). Subacaulescent. Leaves about 30 in a rosette, lanceolate, bright green, $2 \frac{1}{2} \mathrm{ft}$. long, $3 \frac{1}{2}-4$ in. broad at the middle, narrowed to $1 \frac{1}{2} \mathrm{in}$. above the base, coriaceous in texture, bright green and very glossy on the face, the point scarcely pungent, the edge smooth except a few obscure spines near the base. Panicle with peduncle $25 \mathrm{ft}$. long, the former rhomboid, 11-12 ft. long, $14 \mathrm{ft}$. diam. Periantlssegments an inch long.

Hab. Tropical America. Described from plants at Kew and in the Saunder's collection. 
7. F. sтricts Jacoli, Nacht. 56.-Acaulescent. Leaves about 30 in a rosette, lanceolate, bright green, wot so firm in texture as

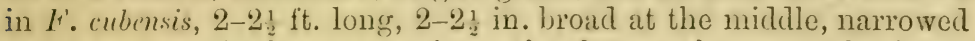
to $1 \frac{1}{2} \mathrm{in}$. near the base, smooth on the face, scabrous on the back, subacutely leeled, so deeply channelled as to be almost triquetrons in section above the middle, margined with distant large deltoid uncinate prickles. Peduncle with panicle 8-9 ft. long. Perianthsegments an inch long.

Hab. Tropical America. First described by Jacobi from a plant that flowered with MI. Demoulin, at Mons, in 1868. We received it lately at Kew, from the Berlin Botanic Giarden.

8. F. Flavoviridis Hook. in. Bot. Mag. t. 5163. - Acanlescent.

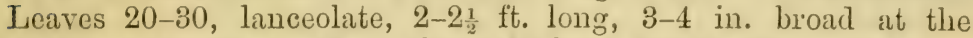
middlle, narrowed to $1 \frac{1}{2} \mathrm{in}$. above the base, bright green, similar to those of cubensis in texture, smooth on the face, scibrous on the back, margined with middle-sized horny deltoid hooked prickles. Peduncle with the panicle 12-15 ft. long, the latter shorter than the barren portion. Expanded flower 3 in. diam. ; ovary glabrous, an inch long. Segments greenish white, oblong-lanceolate, $\frac{1}{2}-\frac{5}{8}$ in. broad.

Hab. Mexico. Sent from Real del Monte by Mr. Repper to Kew, where it flowered for the first time in 1859 . Described from a plant that flowered at Kew, November, 1887.

9. F. pubescens Todaro, Sopra Nuov. sp. Foucr. 1879. Acaulescent. Leaves about 30, lanceolate, rigid in texture, not at all wary, $2 \mathrm{ft}$. long, $2 \frac{1}{2} \mathrm{in}$. broad at the middle, pungent at the tip and armed with distant deltoid-uncinate middle-sized prickles. Peduncle rather longer than the leaves. Panicle five times as long as the peduncle; branches ascending, arcuate, copiously compound. Ovary densely pubescent. Perianth-segments greenish white, above an inch long, $\frac{1}{2}-\frac{3}{4}$ in. broad.

Hab. Tropical America. Described from dratwings sent by Prof. Todaro.

10. F. flegans Todaro, Hort. Panorm. 13, t. 4. F. Gheisbreythii and mujumiformis Hort.-Trunk none or very short below the rosette of leaves. Leaves $40-50$ in a rosette, lanceolate, 5-6 ft. long, 4-5 in. broad at the middle, narrowed to $3 \mathrm{in}$. above the base, bright green, smooth on the face, scabrons on the back, with a short brown end-spine and large brown horny marginal prickles. Peduncle 20-25 ft. long, panicled nearly down to the base; inflorescence $9 \mathrm{ft}$. diam.; branches copiously compound, the lower as long as the central ones. Ovary with short tube an inch long; segments greenish white, $1 \frac{1}{2} \mathrm{in}$. long, $\frac{1}{2}-\frac{3}{4} \mathrm{in}$. broad.

Hab. Mexico. Described and figured by Professor Todaro, from a plant that flowered in the Palermo Botanic Garden in 1875.

11. F. uxdulata Jacobi, Nacht. 55; Hook. fil. in Bot. Mag. t. 6160.-Acaulescent. Leaves $20-30$ in a rosette, lanceolate, $1 \frac{1}{2} \mathrm{ft}$. long, $1 \frac{1}{2}-2$ in. broad at the middle, narrowed to $\frac{3}{4}-1$ in. above the base, dull green, wavy, all recurring, deeply chamnelled down the face, scabrous on the back, almost pungent at the tip, armed on the ellge with hooked deltoid brown prickles 1-12th in. long. Peduncle $3 \mathrm{ft}$. 
long. Panicle 7-8 ft. long; branches short, erecto-patent, simple, ccrnuous. Ovary glabrous, $\frac{3}{4}-1$ in. long. Perianth-segments greenish white, $1 \frac{1}{4}$ in. long.

Hab. Mexico; Chiapas and Tabasco. Sent by Gheisbreght to Verschaffelt. It was described by Jacobi in 1867, and first flowered at Kew in October, 1874. A fine drawing sent by Dr. Fenzl to Kew in 1863, under the name of $F$. tuberosa, apparently represents this species. We have a similar plant with smaller very thin leaves, received from Bermuda by $\mathrm{Mr}$. Wm. Bull in 1878. F. Roezlii atropurpurea, exhibited by De Smet at Brussels in 1876, is said to have thin leaves a foot long, of a pale bronzy purplish tint.

12. F. Barilletr Jacobi, Nacht. 51.-Trunk $\frac{1}{2} \mathrm{ft}$. long, $2-3 \mathrm{in}$. diam. below the rosette of leaves. Leaves many in a rosette, lanceolate, $2 \frac{1}{2}-3 \mathrm{ft}$. long, $4-5 \mathrm{in}$. broad at the middle, narrowed to $2 \mathrm{in}$. above the base, a subopaque deep green with strealis of darker green, wavy and subangulate concave down the face, not pungent at the point, the margin with only a few minute deltoid teeth similar to the blade in substance. Inflorescence unknown.

Hab. Tropical America. Described by Jacobi from specimens in the Parc Monceau at Paris, in 1867.

13. F. Demouliniana Jacobi, Monogr. 297. - Acaulescent. Leaves numerons, lanceolate, $2 \mathrm{ft}$. long, $2 \frac{1}{4} \mathrm{in}$. broad at the middle, narrowed to an incli above the base, firm in texture, opaque green, very convex on the back, the apex not pungent, the margin armed only with a few minute deltoid brown teeth. Peduncle 9-10 ft. long, including the panicle, which begins $3 \mathrm{ft}$. from its base. Flowers unknown.

Hab. Mexico. Introduced by Galeotti to the Botanic Garden at Brussels. Described in 1866.

14. F. Lipsiensis Jacobi, Nacht. 54.-Acaulescent. Leaves $20-30$ in a rosette, lanceolate, $2-2 \frac{1}{2} \mathrm{ft}$. long, $3 \mathrm{in}$. broad at the middle, narrowed to $1 \mathrm{in}$. above the base, moderately firm in texture, all recurved, an intense opaque light green, with pruinose streaks on the upper side when young, the end-spine short, the minute deltoid teeth horny at the tip. Peduncle $3 \mathrm{ft}$. long. Panicle $9 \mathrm{ft}$. long. Perianth-segments oblong-lanceolate, $1 \frac{1}{4} \mathrm{in}$. long, $\frac{1}{3}-\frac{1}{2}$ in. broad.

Hab. Tropical America. Described by Jacobi in 1868, from plants received from the Leipsic Botanic Garden.

15. F. Depauperata Jacobi, Monogr. 293.-Acaulescent. Leaves ferw, lanceolate, about $1-1 \frac{1}{2} \mathrm{ft}$. long, $1 \frac{1}{2}-2 \mathrm{in}$. broad at the middle, narrowed to half-an-inch above the base, very thin, bright green, the tip not pungent, the minute teeth deltoid and patent, scarcely at all horny. Yeduncle $3 \mathrm{ft}$. long, the lowest branch of the panicle arising half-a-foot from its base. Flowers all solitary. Perianthsegments oblong-lanceolate, above an inch long, $\frac{1}{3}-\frac{1}{2}$ in. broad.

Hab. Tropical America. Described by Jacobi from a plant received in 1865 from M. Bedinghaus, of Mons. We received a plant at Kew in 1882, from the Botanic Garden of Berlin. 


\section{Subgenus Roezlia.}

16. F. Bemnghausi K. Koch, Wochen. 1863, 233 ; Belg. Hort. 1863, 327, with fig. Yucre P'urmentieri Roezl. Iioezlia bulbifera, Ii. resjie, Yucca argyjropleylla, and Y. T'oneliana Hort. F. Roezlii André in Rev. Hort. 1887, 353, fig. 71.-Trunk 5-6 ft. long below the rosette of leaves, 6-9 in. diam. Leaves 50 or more in a dense rosette, ensiform, 3-4 ft. long, 3-4 in. broad at the middle, narrowed gradually to the point and to an inch above the base, permanently glaucous on both sides, smooth on the face, very scabrous on the back, the margin minutely denticulate, as in Beschorneria. Inflorescence reaching a height of 15-20 ft.; peduncle much shorter than the pyramidal panicle, the branches of which are long and drooping; lower flowers 2-3-nate; pedicols $\frac{1}{4}-\frac{1}{3}$ in., articulated at the tip. Ovary pubescent, an inch long; perianth-segments oblong, an inch long, tinged green nutside.

Hab. Mexico. Introduced by Roezl about 1860. (For a full account of its discovery see Belg. Hort. 1883, 133.) First flowered by M. Bedinghaus, of Mons, after whom it was named by Karl Koch in 1863, and lately (1875 and 1881) by Mr. Dorien Smith, in Scilly; by Mr. J. Spull, in 1887; and at the Jardin d'Acclimatation, Hyeres, in 1887.

17. F. Long.eva Karw. et Zuce. in Nova Acta, xvi. 2, 606, t. 48; Hook. in Bot. Mag. t. 5519.-Trunk reaching a length of 40-50 ft., 1-1 $\frac{1}{2} \mathrm{ft}$. diam. Leaves 100 or more in a dense rosette, ensiform, 4-5 ft. long, 4-5 in. broad, narrowed gradually to the point and to 2 in. above the base, opaque green, not glaucous, nearly all recurving, the face flat in the centre, the back with only a scabrous lieel, the edge minutely denticulate. Peduncle with panicle reaching a length of $40 \mathrm{ft}$. ; branches spreading or drooping, copiously compound, reaching a length of $12-15 \mathrm{ft}$. ; lower flower's 2-3-nate. Ovary very pubescent. Perianth-segments oblong, an inch long, $\frac{1}{2}$ in. broad.

Hab. Mexico. Discovered by Karwinski about 1829, in the province of Oaxaca, alt. 10,000, and found also by Skinner in Guatemala. (See Bateman's Monograph of Odontoglossum, sub t. 17.) Was flowered at the Regrent's Park Botanic Garden in 1864, and at the Wellington Botanic Garden, in New Zealand, in 1885. There is a very fine specimen planted out in the Temperate House at Kew. 



\section{N D E X.}

(Vantetres and Sraosyas in Italics.)

\section{Acis}

autumnalis, 20

Broteri, 19

cephalonica, 20

grandiflora, 19

hiemalis, 20

longifolia, 20

oporantha, 20

pulchella, 2.

rovea, 20

trichophylla, 19

Agapanthus

Umbrella, 54

Acive, 163

albicans, 191

Alibertii, 1:16

amona, 177

americana, 180

amurensis, 168

ananussoides, 182

angustifolia, 182

angustissima, 167

antillarum, 195

applanata, 173

asperrima, 173

attenuata, 193

atrovirens, 174

auricantha, 177

Baxteri, 178

Beauleuriana, 179

Bernhardii, 19 ।

liessereriana, 177

Bonnetiana, 176

Botterii, 181

Bouchei, 191

brachystachys, 197

bracteosa, 192

Brauniana, 192

brevis, 182

bromelisefolia, 194

bulbifera, 194

cespitova, 189

californica, 185
Agave

C'anartiana, 174

Candelabrum, 181

Cantula, 19.t

caribrea, 190

Celsiana, 187

chiapensis, 183

chloracantha, 192

cinerascens, 173

coaretata, 174

coccinea, 179

cochlearis, 174

ccerulescens, 167

Cohniana, 195

Commelyni, 200

concinna, 178

Consideranti, 169

Corderoyi, 182

crenata, 177

Croucheri, 175

cubensis, 1999

cucullata, 175

cyaniophylla, 180

dasylinioides, 185

dealbata, 185

Debaryana, 192

Decaisneana, 180

deflexispina, 174

Demeesteriana, 170

densitlora, 183

dentata, 192

Deserti, 17.2

Desmetiana, 188

diplacantha, 169

drimicefolia, 198

echinoides, 184

Ehrenbergii, 188

Elemeetiana, 193

elongata, 181

ensifera, 168

ensiformis, 184

excelsa, 182

expansa, 180
Agave

falcata, 185

Fenzliana, 174

ferox, 176

filamentosa, 166

filifera, 166

flaccida, 178

flaccida, 194

flavescens, 177

jotida, 199

fourcroyoides, 181

Fuerstenbergii, 180

Funkiana, 167

Galeottei, 176

geminitlora, 186

geminiflora Sonore, 166

Gheisbreghtii, 172

Gheisbreghtii, 192

Gilbeyi, 171

glaucescens, 193

Goeppertiana, 188

gracilis, 174

gracilispina, 179

grandidentata, 171

grisea, 167

Guedeneyri, 176

Gustaviana, 179

guttata, 198

Haselofii, 189

Haynaldi, 170

Henriquesii, 170

heteracantha, 168

Hookeri, 173

horizontinalis, 188

horrida, 171

Houlletii, 186

huachucensis, 172

Humboldtiana, 189

humilis, 197

hybrida, 168

hystrix, 184 .

incequidens, 174

inermis, 169 
Ag.ave

Inghamii, 169

integrifolia, 185

Ixtli, 181,

ixtlioides, 181

Jacobiana, 174

Jacquiniana, 183

Karatto, 167

Karwinskii, 181

Kellockii, 192

Keratto, 184

Kerchovei, 169

Kewensis, 189

Kochii, 168

lamprochlora, 189

latissima, 174

Laurentiana, 187

laxa, 194

Lechuguilla, 168

Legrelleana, 188

Leguayana, 171

Lehmanni, 174

Lindleyi, 188

longisepala, 176

longispina, 173

lophantha, 167

lurida, 183

macracantha, 177

macrantha, 181

macrodonta, 169, 171

maculata, 196

maculosa, 196

Maigretiana, 172

marmorata, 179

Martiana, 190

Maximiliana, 179

megalacantha, 175

melanacantha, 186

Mescal, 177

mexicana, 180

micrantha, 191

micracantha, 171

IIIlleri, 180

miradorensis, 182

mitis, 191

mitraformis, 174

Morganii, 171

Morrisii, 184

Muilmanni, 190

multilineata, 168

Newberryi, 186

Nissoni, 169

Noackii, 189

oblongata, 189

odorata, 199

Offoyana, 187

oligophylla, 177

ornata, 180

Ortyiesiana, 166

Ottonis, 174

Ousselghemiana, 191

Palmeri, 178

Parryi, 175
Agave

parviflora, 166

paucifolia, 186

paucifolia, 177

Peacockii, 171

pectinata, 169.

pendula, 189

perbella, 168

perlucida, 189

picta, 180

planifolia, 197

polyacantha, 183

polyanthoides, 197

Poselgeerii, 168

potatorum, 177

Pringlei, 182

protuberans, 197

pruinosa, 192

pubescens, 197

pugioniformis, 193

pumila, 172

vecurva, 184

Regeliana, 182

Regeliana, 171

regia, 186

revoluta, 196

revoluta, 186

Richard ii, 184

rigida, 181

rigidissima, 169

Roezliana, 169

Rohanii, 171

Romani, 166

rotundifolia, 175

rubescens, 194

rudis, 187

rufocincta, 189

Rumphii, 194

rupicola, 190

Salmdyckii, 184

Salmiana, 174

Saponaria, 197

Sartorii, 189

Saundersii, 177

scaberrima, 182

scabra, 175

schidigera, 166

Schlechtendahlii, 174

Schnittsphani, 176

Schottii, 166

Scolymus, 176

Seemanniana, 175

serrulata, 193

sessilitiora, 196

Shawii, 172

Simsii, 175

sisalana, 181

Smithiana, 188

sobolifera, 195

spectabilis, 174

spectabilis, 193

spicata, 195

spicata, 197
Agave

splendens, 168

stenophylla, 194

striata, 184

stricta, 184

subcanescens, 167

Taylori, 186

tehuacanensis, 174

teoxamuliana, 194

tetragona, 168

Theometel, 179

Thomsoniana, 192

Todaroi, 195

Toneliana, 173

triangularis, 171

tuberosa, 199

uncinata, 183

undulata, 198

univittata, 167

utahensis, 177

Vanderwinneni, 170

variegata, 196

vercerucis, 183

Verschaffeltii, 177

Victoria-reginx, 169

virginica, 197

virginica, 180

viridissima, 178

vivipara, 194

Wallisii, 192

IVarelliana, 180

weissenburgensis, 178

Wildingii, 187

Wislizeni, 175

xalapensis, 183

xylonacantha, 168

yucciefolia, 195

Alliberthiera

intermedia, 197

Allibertia

intermedia, 196

AJAx

albicans, 5

breviflos, 4

cambricus, 3

cеrmuиs, 5

cyclamineus, 4

lobularis, 3

lorifolius, 4

maximus, 4

minimus, 4

muticus, 3

nanus, 4

nobilis, 3

obvallaris, 3

pallidus preco $x, 3$

propinquus, 4

pumilus, 4

rugilobus, 3

serratus, 3

spurius, 4

T'elamonius, 4

tubeflorus, 4 
AJdx

variiformis, 3

Almyra, 117, 130

Alstremánia, 133

acutifolia, 154

alba, 140

albida, 141

andina, 142

angustifolia, 1:39

apertiflora, 135

araucana, 139

aurantiaca, 141

bicolor, 139

brasiliensis, 135

Bredemeyeriana, 150

Burchellii, 135

Caldasii, 156

caryophyllea, 136

chiloensis, 139

chorillensis, 141

citrina, 138

coccinea, 146

crispata, 142

crocea, 142

crocea, 152

Cumingiana, 138

declinata, 158

Diazi, 139

distichophylla, 146

dulcis, 147

edulis, 154

exserens, 139

filipendula, 136

fimbriata, 149

flava, 139

Flos Martini, 139

foliosa, 136

formosissima, 153

Gardneri, 134

Gayana, 140

glaucescens, 147

hremantha, 140

hirsuta, 158

hirtella, 139, 154

Hookeri, 139

Hookeriana, 139

incequalis, 139

inconspicua, 138

inodora, 137

isabellina, 134

Jacquesiana, 155

Kingii, 138

longistaminea, 137

Ligtu, 139

lineatiflora, 141

lineatiflora, 141

linifolia, 143

longistyla, 134

montana, 132

monticola, 136

multitlora, 150

Neillii, 142

nemorosa, 137
Alstromenta -

nivalis, 138

nubigena, 140

oculata, 153

ovata, 154

pallens, 139

pallida, 139

parvula, 139

paupercula, 138

P'elegrina, 140

Philippii, 140

piauhyensis, 136

plantaginea, 133

platyphylla, 134

Presliana, 139

pulserula, 138

pulchella, 136

pulchella, 140

pulchra, 139

purpurea, 151

pygmaa, 137

recumbens, 138

revoluta, 137

rosea, 138

rosea, 139, 151

rosmarinifolia, 143

Salsilla, 153, 154

scaberula, 137

Schenkiana, 134

secundifolia, 145

Sellowiana, 135

sericantha, 142

setacea, 149

Simsii, 140

spathulata, 142

stenopetala, 134

stenopetala, 139

tenuifolia, 138

tigrina, 138

tomentosa, 149

torta, 148

tricolor, 139

triftora, 132

umbellata, 142

venustula, 141

versicolor, 138

violacea, 139

violacea, 140

Volckmanni, 139

xanthina, 138

zamioides, 135

Amaryulis, 95

Ackermanni, 53

acuminata, 5.2

advena, 43

Alberti, 49

Andersoni, 37

andicola, 36

Atamasco, 31

Atamasco minor, 33

aucta, 102

aulica, 46

aurea, 37, 46
Amartmits

australasica, 88

Banksiana, 97

Belladonna, 95

Belladonna, 50

Berterii, 35

bicolor, 44

bifolia, 32

blanda, 96

brasiliensis, 51, 53

Broussonetii, 89

bulbisperma, 93

calyptrata, 47

candida, 34, 91

capensis, 43

carinata, 31

Carnarvonia, 53

carnea, 32

Chelsoni, 53

chilensis, 42

ciliaris, 74

cinnamomea, 22

citrina, 28

clavata, 58

carulea, 37

colchiciflora, 28

coranica, 96

correiensis, 47

corusca, 100

crispa, 22

crocata, 51

Croomii, 53

curvifolia, 100

cylindracea, 57

depauperata, 33

disticha, 73

dryades, 59

dubia, 99

entreriana, 32

equestris, 50

exigua, 15

falcata, 96

flammea, 37

flexuosa, 100

Forbesii, 93

formosa, 53

formosissima, 38

Fothergilli, 100

fulgida, 51

fulvorirens, 47

Gardneri, 47

gigantea, 91

glaucophylla, 47

gloriosa, 53

Goweni, 53

gracifolia, 36

Harrisoni, 53

Haylocki, 53

Hendersoni, 53

Herberti, 53

humilis, 58, 100, 102

myacinthina, 60

ignea, 44 
Asaryluis

insignis, 88

Jacquinii, 99

Johnsoni 53

Josephine, 97

Josephiniana, 97

laticoma, 102

latifolia, 91

Leopoldi, 49

longifolia, 93, 94

lucida, 102

lutea, 29

maranensis, 51

marginata, 102

Mendeli, 53

mesochloa, 32

miniata, 49, 51

minima, 34

minuta, 34

nervosa, 31, 98

nivea, 34

orientalis, 98

ornata, 87, 89, 91

pallida, 96

pardina, 48

parvula, 34

picta, 53

preclara, 53

procera, 50

psittacina, 47

pudica, 95

pulverulenta, 52

punicea, 50

purpurascens, 96

purpurea, 53

radiata, 40

Rálula, 98

Rayneri, 50

Regince, 48

reticulata, 50

revoluta, 92

robusta, 35

Roezli, 50

rosea, 32, 95

Rougieri, 46

rubra, 96,

rutila, 51

sarniensis, 40, 99

speciosa, 53

spectabilis, 53, 89

staminea, 51

stellaris, 21

stricita, 98

striatifolia, 51

striatula, כै4

stylosa, 51

sylvatica, 35

Sweetii, 53

tubiflora, 37

tubispatha, 31, 35

undulata, 100

unguiculata, 47

variabilis, 92
Amarylis

verecunda, 34

versicelor, 35

vittata, 52

vivipara, 76

zeylanica, 87

Ammocharis, 96

coranica, 96

falcata, 96

Slateriana, 97

Axoiganthus, 27

breviflorus, 27

luteus, 28

minor, 28

Apodolirion, 25

Bolusii, 26

Buchanani, 26

Ettx, 26

lanceolatum, 26

Mackenii, 26

Macowani, 26

Argenope, 10

Aschamia, 41

Assaracus, 5

capax, 5

reflexus, 5

Aurelia, 12

Broussonetii, 12

Belladonna, 96

blanda, 96

pallida, 96

pudica, 96

purpurascens, 96

Brschoryeria, 161

bracteata, 162

Colmiana, 161

Decosteriana, 162

Guleottei, 162

pumila, 162

Schlechtendahlii, 162

supertu, 162

Toneliana, 162

tubittora, 161

Verlindeniana, 162

yuccoides, 162

Bollea, 119

canariensis, 119

BoM.MEA, 142

acuminata, 152

afjinis, 155

anceps, 149

andimarcana, 147

Andreana, 157

angulata, 150

angustifolia, 148

angustipetala, 145

aurantiaca, 150

brachysepala, 145

bracteata, 155

Brauniana, 155

Bredemeyeriana, 150

brevis, 144

Caldasiana, 156
BoMIIREA

caraccensis, 155

Carderi, 155

cernua, 149

chimboracensis, 144

chontalensis, 15.4

coccinea, 146

conferta, 157

cornigera, 151

cormuta, 1554

crassifolia, 150

crinita, 152

crocea, 152

cumbrensis, 148

declinata, 158

densiflora, 149

diffracta, 155

dissitifolia, 147

dispar, 158

distichophylla, 146

duleis, 147

edulis, 154

Fann ngiana, 150

fimbriata, 149

floribunda, 149

formosissima, 153

formosissima, 155

frondea, 157

glaucescens, 147

glomerata, 148

goniocaulon, 152

grandifolia, 155

Halliana, 150

Hartwegii, 146

Herbertiana, 155

hirsuta, 158

hivtella, 154

hispida, 144

Hookeriana, 154

involucrosa, 147

Jacquesiana, 155

Kalbreyeri, 156

Kranzlinii, 155

lancifolia, 149

latifolia, 155

Lehmanni, 143

linifolia, 143

longipes, 152

lutea, 157

lyncina, 158

IIacleanica, 150

macrocarpa, 155

Martiana, 155

miniata, 155

minima, 144

Moritziana, 155

multiflora, 150

multiflora, 153

multipes, 151

nervosa, 144

obovata, 155

oligantha, 151

ovata, 154 
Bomarea

pachyphlebia, 148

pardina, 158

parviflora, 154

parviflora, 155

patacoensis, 157

Patini, 157

phyllostachya, 143

platypetala, 148

podopetala, 146

polygonatoides, 146

puberula, 147

pumila, 145

punctata, 155

purpurea, 151

recurva, 145

rosea, 151

salsilloides, 155

Schenkiana, 155

secundifolia, 145

setacea, 149

Shuttleworthii, 156

simplex, 146, 151

spectabilis, 155

stenopetala, 145, 149

subglobosa, 149

superba, 153

tomentosa, 149

torta, 148

'Turneriana, 153

uncifolia, 148

variabilis, 151

vestita, 153

vitellina, 158

Williamsiæ, 156

Bravoa, 160

Bulliana, 161

geminiflora, 160

sessilitiora, 160

singuliflora, 161

Brunsvigia, 96

Banksiana, 97

ciliaris, 74

Cooperi, 98

gigantea, 98

granditlora, 97

humilis, 97

Josephinr, 97

Kirkii, 99

lucida, 102

magnifica, 93

marginata, 102

Massaiana, 91

minor, 97

multiflora, 98

orientalis, 98

Radula, 98

radulosa, 98

rubricaulis, 98

Slateriana, 97

striata, 98

toxicuria, 73
Buphane, 73

angolensis, 80

ciliaris, 74

disticha, 73.

guttata, 94

toxicaria, 73

Coctocapnia geminiflora, 160

Calliphruria, 112

Hartwegiana, 112

subedentula, 111

tenera, 112

Callipsyche, 106 aurantiaca, 106 eucrosioides, 106 mirabilis, 106

Callithauma, 113 angustifolium, 116

Elwesii, 116

viridiflorum, 116

Calostemana, 131

album, 132

candidum, 132

carneum, 131

luteum, 131

purpureum, 131

CARPolyza, 23

spiralis, 23

Chione, 7, 8

Chuidanthos, 28

Cumingii, 43

Ehrhenbergii, 28

fragrans, 28

Chloraster.

fissus, 10

integer, 10

Choretis

galvstonensis, 126

glauca, 123

Chrysipliala

aurantiaca, 113

fava, 114

latifolia, 109

pauciflora, 114

recurvata, 115

viridiflora, 116

Clitanthes

humilis, 114

Clivia, 61

Gardneri, 62

grandiflora, 62

Lindeni, 62

miniata, 62

nobilis, 61

Coburgia, 50, 113

acuta, 116

angusta, 115

Belladonna, 95

blanda, 96

chacapoyensis, 116

coccinea, 115

discolor, 115

fulva, 116
Coburgia

humilis, 114

incarnata, 115

leta, 116

langensis, 116

lutea, 115

macleanica, 115

obragillensis, 115

pracipitata, 115

Radula, 98

recurvata, 115

reticulata, 50

splendens, 116

trichroma, 116

variegata, 116

venusta, 115

versicolor, 116

Codonocrimum, 74, 87

Coleophyllum, 88

Collania

andimarcana, 147

dulcis, 147

glaucescens, 147

involucrosa, 147

nutans, 147

puberula, 147

urceolata, 108

Cooperia, 27

chlorosolen, 27

Drummondii, 27

pedunculata, 27

Corbularia, 2

albicans, 3

Bulbocodium, 2

cantabrica, 3

hedrcantha, 3

lobulata, 2

monophylla, 3

Schultesii, 2

serotina, 2

Crindir, 74 -

abyssinicum, 89

amabile, 95

amœnum, 81

americanum, 85

ammocharoides, 79

angolense, 80

angustifolium, 83

angustifolium, 57

anomalum, 75

aquaticum, 92

arenarium, 83

asiaticum, 75

asiaticum, 76, 77

attenuatum, 86

augustum, 85

austrulasicum, 83

australe, 77

Bainesii, 79

Bakeri, 77

Balfourii, 82

blundum, 83

brachyandrum, 83 


\section{Crinua}

brachynema, 88

bracteatum, 77

brevifolium, 77

Broussonetii, 89

buphanoides, 80

canaliculatum, 77

capense, 93

Careyanum, 89

caribæum, 80

caudiceum, 81

C'olensoi, 93

Commelinianum, $86^{\circ}$

Commelyni, 86

concinnum, 87

confertum, 83

corantynum, 85

crassic uule, 85

crassifolium, 92

crassipes, 90

cruentrim, 80

Cumingii, 81

declinatum, 75

slefixum, 76

distichum, 89

elegans, 82

ensifolium, 76

erubescens, 85

erubescens, 86

exaltatum, 77

falcatum, 96

Harinianum, 94

Fiendleri, 87

fimbriatulum, 90

firmifolium, 78

flaccidum, 88

floridanum, 80

Forbesianum, 93

Gordonianum, 85

Govenianum, 95

gracile, 81

graciflorum, 87

Herbertiantm, 86, 87

Hildebrandtii, 84

humile, 81

imbricatum, 92

insigne, 88

japonicum, 75

Kirkii, 91

Kunthiannm, 86

Lastii, 79

latifolium, 87

leucophyllum, 78

ligulatum, 78

Lindleyanum, 86

lineare, 92

I,innoei, 87

Loddigesianum, 80

longifolium, 93

lonrifolium, 82

longitlorum, 94

longistylum, 88

Muckenii, 93

\section{Criveri}

Macowani, 94

macrantherum, 77

Malioyamum, 93

Martinezii, 21

Massaianum, 91

mauritianum, 78

modestum, 84

moluccamum, 88

Moorei, 93

natalense, 93

nervosum, 130

Northianum, 82

obliquum, 54

ornatmm, 87, 89, 90

paucitorum, 88

pauciflorum, 118

pedunculatum, 77

petiolatum, 91, 94

podophyllum, 91

Powellii, 95

pratense, 82

purpuraseens, 84

pusillum, 77

quitense, 107

reductum, 87

revolutum, 86, 92

riparium, 93

Roxbughii, 76

Ruppellinпum, 90

Sanderianum, 90

scaber rimum, 90

scabrum, 90

Schmidtii, 93

serrulatum, 76

sinicum, 75

speciosum, 53, 88

spirate, 23

stenophyllum, 76

Stracheyi, 81

strictum, 86

subcernuum, 84

sumatranum, 75

superbum, 75

tuitense, 77

tenellum, 22, 23

'linneanum, 72

Thruppii, 79

undulatum, 86

unitlorum, 83

urceolatum, 108

vanillodorum, 91

variabile, 92

venosum, 83

venustum, 82

verecundum, 81

virgineum, 94

viridifolium, 86

Wallichiamum, 87

Wattii, 76

IVeinmanni, 88

Welwitschii, 78

yuccrtlorum, 89
Chisum

yucceroides, 89

zeylanicum, 87

C'rossyne, 74 ciliaris, 74

Cryptostephayus, 1 densitforus, 1

Cydenis, 13

Cyphonema Loddigesiamm, $5 \mathrm{~S}$

Crrtaxthus, 54 angustifolius, 57

brachyscyphus, 55

breviflorus, 27

carneus, 54

collinus, 56

Cooperi, 58

gramdiflorus, 57

helictus, 58

Huttoni, 55

liybridu: $5 \pm$

lutescens, 58

Mackenii, 57

Macowani, 56

obliquus, $5 \pm$

odorus, $\check{0} 6$

pallidus, 56

rectillorns, $5 \mathrm{f}$

sanguineus, 5!)

Smithianus, 59

spiralis, 55

striatus, 57

'I'uckii, 57

unitilorus, 58

ventricosus, 57

vittatus, 58

VVelwitschii, 55

Diacles, 63, 68

ciliaris, 68

pubescems, 68

Diomedes, 13

major, 13

minor, 13

Parkinsoni, 13

Donsanthes, 162

excelsa, 163

Palmeri, 163

Elisena, 129

longipetala, 130

marginata, 102

ringens, 129

sublimis, 129

Erinosma, 19

carpathicum, 13

vernum, 19

EucharIs, 109

anıazonica, 110

candida, 110

granditlora, 110

Mastersii, 110

multiflora, 111

Sanderi, 111

subedentata, 111 
Eucnosia, 10:

bicolor, 105

Eudolon, $10 t$

Eurycles, 130 amboinensis, 130 australasica, 130 australis, 130

Cunninghami, 131 sylvestris, 130

Eusipho angustifolia, 57 odora, 56

Etstepmi, 112 coccinea, 112 macleanica, 43, 112

Fourcroya, 198 fatida, 199 rigida, 181

Funium pitiferum, 199

Furacrisa, 198 Aitoni, 199 atroviridis, 199 barilleti, 202 Bedinghausii, 203 Commelyni, 200 cubensis, 199 Demouliniana, 202 depauperata, 202 elegans, 201 flavo-viridis, 201 geminispina, 200 Gheisbreghtii, 201 gigantea, 199 Lindeni, 199 lipsiensis, 202 longreva, 203 pubescens, 201 pugioniformis, 201 Roezlii, 202, 203

Selloa, 200 stricta, 201 tuberosa, 199 undulata, 201 valleculata, 199 Willemetiana, 199

Galantuus, 16 caspius, 17 cancasicus, 17 Clusii, 17 corcyrensis, 17 Elwesii, 17 globosus, 17 græcus, 17 Imperati, 17 latifolius, 17 latifolius, 18 lutescens, 17 major, 17 Melvillei, 17 nivalis, 16 octobrensis, 17 Olgre, 18
Gamantues

plicatus, 18

poculiformis, 17

precox, 17

liedontei, 17

veflexus, 17

Scharloki, 17

Gamymedes, 5

allus, 5

cernuus, 5

concolor, 5

nutans, 5

pulchellus, 5

Ciastronema, 54, 58

clavatum, 58

sanguineum, 59

Getirlusis, 23

afra, 24

Britteniana, 24

ciliaris, 25

cuspidata, 25

lanceolata, 26

latifolia, 25

longistyla, 24

polyanthera, 25

spiralis, 24

undulata, 25

verticillata, 24

villosa, 24

Grinfixid, 59

Blumenavia, 60

dryades, 59

hyacinthina, 60

intermedia, 60

Liboniana, 61

micrantha, 60

ornata, 59

parvitlora, 60

Gyaxis, 62, 65

Habranthus, 41

Andersoni, 37

Andersoni texanus, 33

andicola, 36

angustus, 43

Bammoldi, 43

bifidus, 43

cearensis, 36

chilensis, 42

caruleus, 37

concolor, 35

Gilliesianus, 43

gracilifolius, 36

hesperius, 43

kermesinus, 43

lineatus, 42

mendocimus, 43

miniatus, 43

montanus, 45

nemoralis, 43

nobilis, 43

pedunculosus, 43

pratensis, 46

pulcher, 43
Habrantmes

pumilus, 42

punctatus, 43

robustus, 35

roseus, 42

spathaceus, 43

speciosus, 46

sylvaticus, 35

versicolor, 35

H. mantues, 62

abyssinicus, 63

albiflos, 68

albomaculatus, 69

amarylloides, 68

angolensis, 65

arabicus, 63

Arnottii, 68

Baurii, 69

brachyphyzllus, 68

brevifolius, 67

Burchellii, 6s

callosus, 71

carinatus, 72

carneus, 67

ciliaris, 74

cinnabarinus, $6 t$

coarctatus., 72

coceineus, 71

concolor, 71

Cooperi, 70

crassipes, 72

deformis, 69

delagoensis, 63

dubius, 107

falcatus, 96

filittorus, 63

grandifolius, 64

Gumbletoni, 66

hirsutus, 70

humilis, 71

hyalocarpus, 72

hyydrophilus, 92

incarnatus, 70

insignis, 66

intermedius, 68

Kalbreyeri, 63

Katherinæ, 6.4

Lambertiamus, 70

lanceæfolius, 67

Mackenii, 69

magnificus, 66

Mannii, 63

nembranaceus, 66

moschatus, 72

multiflorus, 63

natalensis, 66

orbicularis, 90

orientalis, 98

pubescens, 73

pubescens, 68

pumilio, 67

puniceus, 65

quadrivalvis, 73 
Hemanthus

Redouteanus, 65

rotularis, 65

rotundifolius, 70

Rouperi, 66

rupestris, 64

sanguineus, 71

samiensis, 99

spiralis, 23

strigosus, 67

superbus, 66

tenuiflorus, 63

tigrinus, 72

toxicarius, 73

undulatus, 70

undulatus, 102

vaginatus, 104

Halmyra

stellaris, 117

Haylockia, 29

pusilla, 30

Helena, 9

gracilis, 9

planicorona, 10

Hermione

aquilimba, 7

alba, 9

amona, 9

ambigua, 14

antipolensis, 7

aperticorona, 9

auranticorona, 7

Bertolonii, 8

bifrons, 9

biscrenata, 9

breviflora, 8

callichroa, 9

calliopsis, 9

cerina, 8

cheiranthea, 9

chlorotica, 9

citrina, 7

compressa, 9

contorta, 7

corcyrensis, 7

corrugata, 7

crenata, 7

crispicorona, 7

cupularis, 9

Cypri, 7

debilis, 7

decora, 7

discreta, 7

elegans, 11

erodora, 9

fistulosa, 8

flaveola, 9

flexiflora, 7

floribunda, 7

formosa, 7

fulgida, 9

ganymedoides, 7

hololeuca, 8
Hermone

intermedia, 9

jasminea, 8

jucunda, 8

lacticolor, 7

latifolia, 9

littoralis, 7

lobata, 7

Luna, 8

luteola, 9

mediterranea, 7

micrantha, 8

modesta, 8

monspeliensis, 7

multiflora, 9

neglecta, 7

nobilis, 9

obliterata, 12

obsoleta, 11

perlutea, 9

pratensis, 7

primulina, 9

reflexicaulis, 9

Sequentia, 8

serotina, 10

sertulosa, 9

solaris, 9

splendens, 9

subcrenata, 7

sublutea, 9

sulcicaulis, 7

tenuiflora, 8

tereticaulis, 8

Trewiana, 7

trifida, 9

virginea, 8

viridiflora, 10

xanthea, 9

Hessea, 21

crispa, 22

Dregeana, 22

filifolia, 22

gemmata, 23

Rehmanni, 22

spiralis, 22

stellaris, 21

undulata, 104

Zeyheri, 22,

Himantophyllum, 61

Hippeastrum, 61

Ackermanni, 53

acuminatum, 52

advenum, 43

africanum, 49

ambiguum, 53

andinum, 45

Andreanum, 48

Bagnoldi, 43

bahiense, 52

barbatum, 50

bicolor, 44

bifidum, 43

brachyandrum, 42
Hippeastrum

breviflorum, 52

bulbosum, 51

calyptratum, 47

Carnarvonii, 53

Chelsoni, 35

chilense, 42

citrinum, 51

Colvillei, 53

crocatum, 51

Croomii, 53

Cybister, 47

equestre, 50

equestriforme, 51

formosum, 53

fulgidum, 51

Gilliesianum, 43

glaucescens, 52

gloriosum, 53

Goveni, 53

Gravina, 53

Griftini, 47

Harrisonice 52

IIarisoni, 53

Hendersoni, 53

Herbertianum, 45

Herberti, 53

Heuserianum, 46

Jamesoni, 44

Jolnsoni, 53

Leopoldi, 49

lineatum, 42

Mandoni, 49

marginatum, 53

Martianum, 52

Mendeli, 53

miniatum, 49

modestum, 45

montanum 45

occidentale, 50

organense, 47

pardinum, 48

phycelloides, 44

pictum, 53

proclarum, 53

pratense, 46

procerum, 50

pronum, 49

pulverulentum, 52

pyrrochroum, 50

Reginæ, 48

regium, 48

reticulatum, 50

Rhodolirion, 45

robustum, 46 .

roseum, 42

rutilum, 51

scopulorum, 49

Simsianum, 51

solandriflorum, 46

soratense, 42

spathaceum, 50

spectabile', 53 
Hippeastruy

stenopetalum, 49

striatifolium, 51

stylosum, 51

subbarbatum, 51

Sweetii, 53

uniflorum, 45

unguiculatum, 51

vittatum, 52

vittutum, 90

Warcewiczianum, 49

HyLine, 117

Gardneriana, 117

IIymenetron, 104

Hymenocalisis, 120 .

acutifolia, 123

adnata, 123

Amancaes, 129

атюия, 122

Andreana, 127

angusta, 125

bistubata. 122

Bouplandi, 110

Borskiana, 121

Boschiana, 121

calathina, 128

caribara, 125

caymanensis, 124

Choretis, 123

crassifolia, 125

deflexa, 128

Dillenii, 127

disciformis, 127

disticha, 123

Dryandri, 123

eucharidifolia, 122

expansa, 126

galvstonensis, 126

glauca, 123

guianensis, 121

Harrisiana, 124

Horsmanni, 125

humilis, 127

insignis, 124

lacera, 127

littoralis, 123

Macleana, 128

macrostephana, 126

mexicana, 127

Moritziana, 121

nutans, 128

obtusata, 125

ornata, 123

ovalifolia, 123

ovata, 122

Palmeri, 126

paludosa, 127

panamensis, 124

pedalis, 124

petiolata, 1:1

quitoensis, 127

senegambica, 124

Skinneriana, 123
Hrarenocalitis

speciosa, 122

Staplesiana, 123

tenuiflora, 124

tubiflora, 121

undulata, 121

Illus, 5

Imantophyllum, 61

Aitoni, 61

cyrtanthiflorum, 62

grandiflorum, 62

Lindeni, 62

miniatum, 62

Imhofia, 22

Burchelliana, 23

crispa, 22

filifolia, 22

gemmata, 22

marginata, 102

Ismene, 121, 127

Amancaes, 129

Andreana, 127

calathina, 128

crinifolia, 129

cyathiformis, 128

deflexa, 128,

Knightii, 127

Macleana, 128

narcissiflora, 128

nutans, 128

pedunculata, 128

I'agliabuei, 128

temuifolia, 127

virescens, 128

IxIoLIRION, 132

Kolpakowskianum, 133

Ledebourii, 132

macranthum, 132

montanum, 132

Pallasii, 132

tataricum, 132

Jonquilla, 10

major, 10

media, 10

minor, 10

Kolpakowstia, 133

ixiolirioides, 133

Lais, 41

LAPIEDRA, 21 gracillima, 15

Martinezii, 21

Placiana, 21

LEONTOCHIR, 159

Ovallei, 159

Leopoldia reticulata, 50

Leperiza eucrosioides, 105 latifolia, 109

Leucojun, 18

astivum, 19

autumnale, 20

autumnale, 19
LEUCOJUM

carpathicum, 19

grandiflorum, 19

Hernandezii, 19

hyemale, 20

longifolium, 20

niccense, 20

pulchellum, 19

roseum, 20

strumosum, 22

tingitanum, 20

trichophyllum, 12

Vagneri, 19

vernum, 19

Liriope

ringens, 129

Liriopsis ringens, 129

Littaa, 164 geminiflora, 186

Lxconis, 39

aurea, 40

radiata, 40

sanguinea, 4 ?

Sewerzowii, 39

squamigera, 40

straminea, 40

Macropodastrum, 41

Manfireda, 164

Melicho, 63, 67

humilis, 71

sanguineus, 71

Monella, 54

angustifolia, 57

collina, 56

glauca, 56

ochrolenca, 58

odora, 56

spiralis, 55

Narcissus, 1

albus, 11

Amances, 129

angustifolius, 12

apodanthus, 7

Aschersonii, 7

Assoanus, 6

aureus, 2

autumnalis, 11

Backhousei, 12

Barle, 8

Barrii, 14

Bernardi, 13

Bertolonii, 8

Biance, 7

Bicchianus, 7

bicolor, 4

biflorus, 11

biflorus hybridus, 14

Broussonetii, 12

Bulbocodio-pseudonarcissus, 21

Burbidgei, 14

calcuthinus, 5, 6 


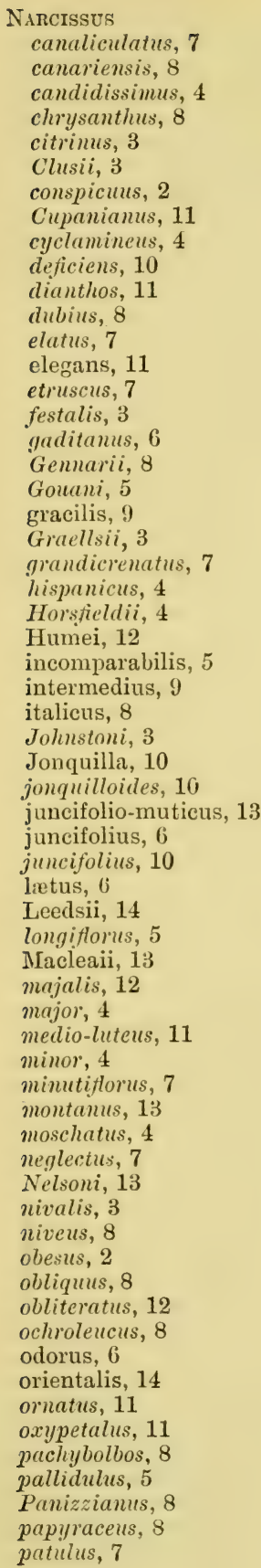

Nancissus

persicus, 29

poculiformis, 13

polyanthos, 8

precox, 8

P'seudo-narcissus, 3

rudiatus, 9

radiiflorus, 12

recurvus, 11

reflexus, 5

Requienii, 6

remopolensis, 7

Ricasoliamus, 7

rupicola, 7

Sabini, 13

serotinus, 10

siculus, 8

spathulatus, 11

spiralis, 11

stellaris, 11

subalbidus, 8

syriacus, 7

Tazetta, 7

Tazetto-poeticus, 14

Tenorii, 7

temuifolius, 2

temuior, 9

triandrus, 5

trilobus, 5,6

tripodalis, 11

turgidus, 2

unicolor, 8

varians, 7

verbanensis, 12

vergellensis, 8

viridiflorus, 10

IVebbii, 10

Nerive

amabilis, 103

angustifolia, 101

atrosanguinea, 103

aurea, 40

Cami, 103

carminata, 103

cimnabarina, 103

cerulea, 103

cornsca, 100

curvifolia, 100

elegans, 103

Elwesii, 101

erubescens, 103

excellens, 103

filifolia, 101

flexuosa, 100

Fothergilli, 100

Haylocki, 103

humilis, 102

insignis, 99

japonica, 40

lucida, 102

Mansellii, 103

marginata, 102

Meadowbankii, 103
Nerine

Mitchamia, 103

Moorei, 100

O'Brienii, 103

Plantii, 100

profusa, 100

pudica, 101

pulchella, 101

rosea, 100

roseo-crispa, 103

Sandersoni, 101

sarniensis, 99

Spofforthice, 103

undulata, 102

venusta, 100

Nerissa, 62, 63

Nivaria

astivalis, 19

Oileus, 3

abscissus, 3

albus, 4

hexangularis, 4

minor, 4

pumilus, 4

Omphatissa, 41

Oporanthus.

Fischeriamus, 29

luteus, 29

Orexis, 40

Palinetes, 96

Pancratium, 117

апкиит, 122, 123, 125

Amancaes, 129

amboinense, 130

americanum, 123

angustum, 125

aurantiacum, 113

australasicum, 130

biflorum, 119

culathiforme, 128

calathinum, 128

cambayense, 119

canariense, 119

caribeum, 125

carolinianum, 119

Chapmanni, 1:0

coccineum, 115

collinum, 118

coronarium, 125

crassifolium, 125

croceum, 114

declinatum, 125

disciforme, 127

Dryandri, 123

expansum, 126

flavum, 114

fiagrans, 122

glaucum, 123

guianense, 121

humile, 15

illyricum, 117

incarnatum, 115

latifolium, 109, 125 
Paxcratium

littorale, 123

longiflorum, 119

malabaricum, 119

maritimum, 118

maximum, 120

mexicamum, 127

narcissiflorum, 128

nervifolium, 130

mutans, 128

occidentale, 125

ovatum, 122

parviflorum, 130

parvum, 119

putens, 124, 125

pedale, 124

petiolatum, 121

quitense, 115

recurvatum, 115

ringens, 129

rotatum, 127

Sickenbergii, 118

speciosum, 122

stellare, 117

tenuifolium, 120

tiareflom, 118

tortifolium, 120

tortuosum, 120

trianthum, 120

triflorum, 118

tristylum, 120

tubiflorum, 121

undulatum, 121

variegatum, 116

verecundum, 119

vividiflorum, 116

zeylanicum, 118

Panza

bicolor, 13

Papiria

lanceolata, 26

spiralis, $2 t$

villosa, 24

Patrocles, 14

Pentlandia

miniata, 109

Pinadranassa, 107

Canmioli, 108

chloracea, 107

Lehmanni, 107

multiflora, 107

obtusa, 107

v"ubro-virialis, 112

schizantha, 108

ventricosa, 107

viridiflora, 107

Philogyne, 6

calathina, 6

C'ampernelli, 6

Curtisii, 6

heminalis, 6

interjecta, 6
Philogyne

minor, 6

odora, 6

rugyulosa, 6

118, 124 Phycella, 41, 44

angustifolia, $\$ 1$

attenuata, $4 t$

bicolor, 44

biflora, 44

bievituba, 44

chloracea, 107

cyrtanthoides, 4.4

graciliflora, 44

Herbertiana, 45

ignea, $4 t$

magnifica, 44

obtusa, 44

PLACEA, 15

Arzæ, 16

Germainii, 16

grandiflora 15

lutea, 16

ornata, 15

pratensis, 46

Plagiolirion, 111

Horsmanni, 111

Plateana, 7

Platyaster, 74, 18

Polianthes, 159

gracilis, 159

tuberosa, 159

Prasiteles, 10

Prochnyanthes, 160

viridescens, 160

Pugionella, 104

Pyrolivion, 30, 37

albicans:, 38

aureum, 37

flammeum, 37

flavum, 37

Queltia, 5

alba, 6

apodantha, 7

aurantia, 6

concolor, 5

fotida, 5

Gouani, 6

Jonquilla, 10

juncifolia, 6

Leedsii, 6

nivea, 6

orientalis, 14

semipartita, 5

Rhodolivion, 45

andinum, 45

montanum, 45

Rhodophiala, 41, 45

amarylloides, 46

andina, 45

lecta, 46

mudesta, 45

Volckmanni, 16

Roezlia, 203
Roezlia

bulbifer'a, 203

regia, 203

Ruminia, 20

lyyemalis, 20

nicaensis, 20

Sceptranthus

Drummondii, 27

Schizanthes

orientalis, 14

Spharine, 142, 143

brevis, 144

coccinea, 146

distichophylla, 116

linifolia, 143

nervosa, 144

secundifolia, 145

Sphcrotele

coccinea, 109

miniata, 109

SHIFKELIA, 38

C'ybister, 47

formosissima, 38

glanca, 38

Heisteri, 38

Karwinskii, 38

ringens, 38

Stenaster, 74, 75

S'Texodesson, 113

acutum, 116

angustifolium, 116

aurantiacum, 113

breviflorum, 115

coccineum, 115

croceum, 114

curvidentatum, 114

Elwesii, 116

eustephioides, 113

flavum, 114

Hartwerii, 113

humile, $1 \mathrm{I} 4$

incarnatum, 115

latifolium, 114

luteoviride, 116

pauciflorum, 104

Pearcei, 113

recurvatum, 115

rubrum, 115

Ruizianum, 114

Stricklandi, 105

suspensum, 115

viridiflorum, 116

vitellinum, 114

Stephanoma

elegans, 46

Sternbergid, 28

etnensis, 28

americana, 30

Clusiana, 29

colchiciflora, 28

dalmatica, 29

Fischeriana, 29

grecea, 29 
Sternberaia

latifolia, 29

lutea, 29

macrantha, 29

pulchella, 29

Schuberti, 28

sicula, 29

Stricklandia, 105

eucrosioides, 105

Strummaria, 103

angustifolia, 104

Baueriana, 104

crispa, 22

filifolia, 22

gemmata, 23

lngucefolia, 104

rubella, 104

spiralis, 23

stellaris, 21

truncata, 104

undulata, 104

Tityrus, 9, 10

Tros, 13

galanthifolia, 13

montana, 13

UNGERNIA, 39

Oldhami, 39

Sewerzowi, 39

trisphæra, 39

URCEOLINA, 108

aurea, 108

fulva, 109

latifolia, 109

miniata, 109

pendula, 109
Vagarta, 130

parviflora, 130

Vaginaria, 130

Vallota, 53

elata, 54

hybrida, 54

magnifica, 54

minor, 54

purpurea, 53

Wichurea, 143, 147

andimarcana, 147

dulcis, 147

glaucescens, 147

involucrosa, 147

puberula, 147

Yucca

argyrophylla, 203

Parmentieri, 203

Toneliana, 203

Zephyranthes

acuminata, 32

albicans, 38

Andersoni, 37

andicola, 36

Atamasco, 31

aurea, 37

aurea, 33

boliviensis, 38

candida, 34

carinata, 31

cearensis, 36

citrina, 34

cœrulea, 37

Commersoniana, 33

concolor, 36
Zephyranthes

depauperata, 33

Drummondii, 27

filifolia, 33

flammea, 37

flava, 37

flavescens, 32

franciscana, 36

gracilifolia, 36

gracilis, 33

Grahamiana, 34

grandiflora, 31

lilacina, 31

Lindleyana, 32

longifolia, 33

macrosiphon, 35

mendocensis, 36

mesochloa, 32

minima, 34

nervosa, 31, 32

pallida, 34

purpurea, 42

pusilla, 30

robusta, 35

rosea, 32

sessilis, 34

Spofforthiana, 32

sylvatice, 35

texana, 33

Treatiæ, 31

tubispatha, 31

verecunda, 34

versicolor, 35

Wrightii, 32

Zepluyrites, 30, 35

WEST, NEWMAN \& CO., PRINTERS, HATTON GARDEN, LONDON, E.C. 





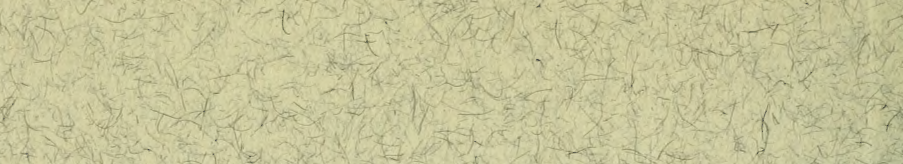

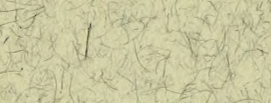

b.

4)

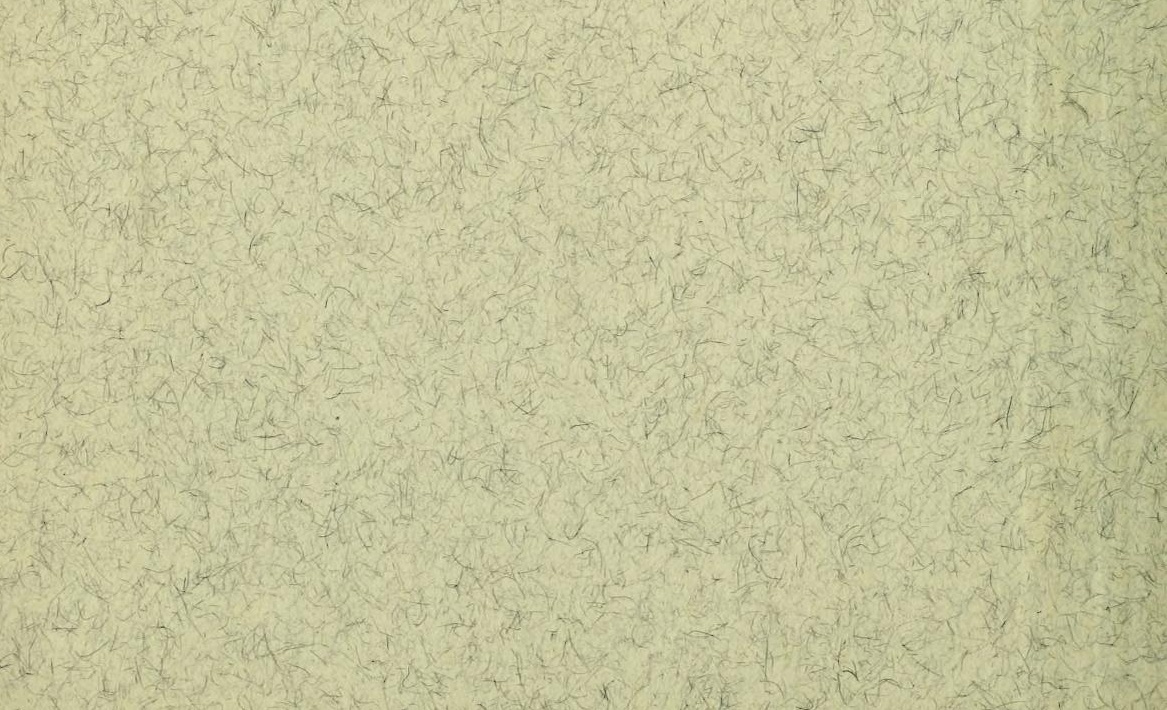


